1.9.

for 

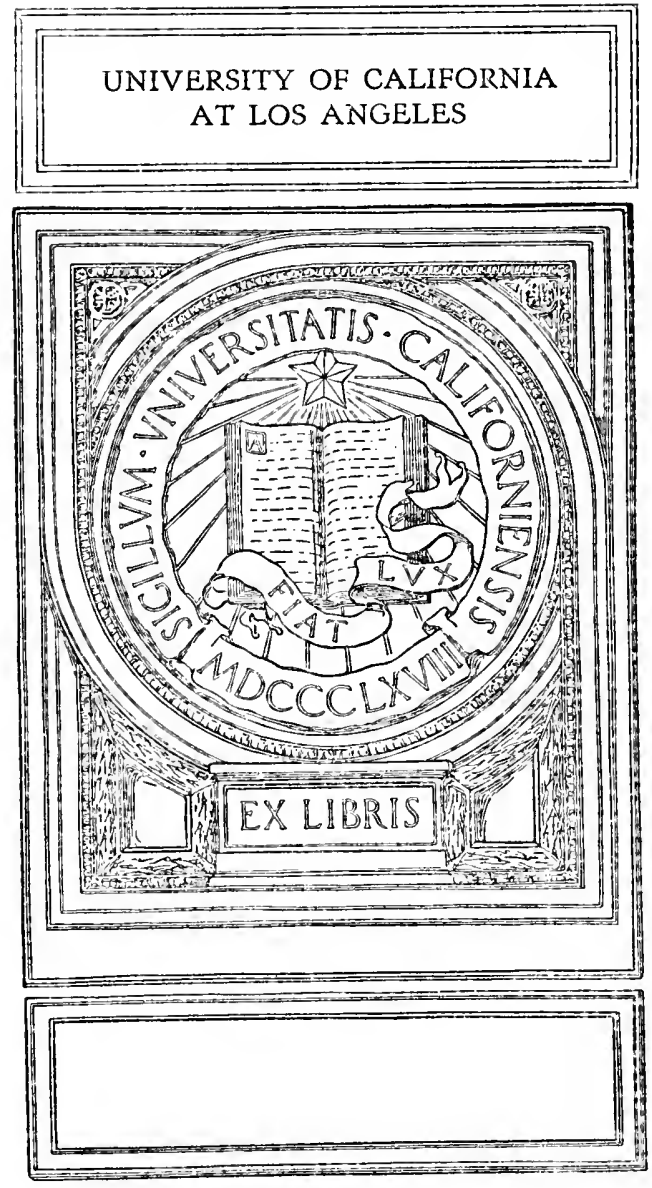




\section{THE}

\section{DEVELOPMENT OF TRANSPORTATION IN}

\section{MODERN ENGLAND}

IN TWO VOLUMES

VOLUME II 
CAMBRIDGE UNIVERSITY PRESS

C. F. CLAY, MANAGER

ILOnDon: FETTER LANE, E.C.

jeinburgh: roo PRINCES STREET

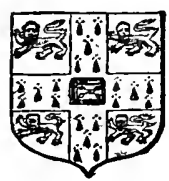

Prew Hark: G. P. PUTNAM'S SONS

bomban, Calcutta and ftadras: MACMILIAN AND CO., Lrd.

Toronto: J. M. DENT AND SONS, LtD.

Tokpg: THE MARUZEN-KABUSHIKI-KAISHA 
THE

\title{
DEVELOPMENT OF TRANSPORTATION
}

IN

\section{MODERN ENGLAND}

\author{
BY \\ W. T. JACKMAN \\ Lecturer in Political Economy, University of Toronto
}

VOLUME II

Cambridge :

at the University Press

I 9 I 6 
*. 


\section{TABLE OF CONTENTS}

\section{VOLUME II}

\section{CHAPTER VII}

\section{DEVELOPMENT OF RAILWAYS}

Early tramroads for mines and quarries

Surrey Iron Railway for general merchandise . . . . . . . 465

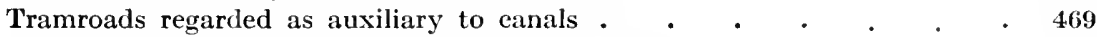

Effectiveness of traction by rail over that by road . . . . . . . 472

Development of steam as a motive power . . . . . . . . . 473

Stockton and Darlington Railway. . . . . . . . 4 47

Organization of goods and passenger trade on that line . . . . 481

Discussion of relative importance of canals and railways . . . . . 485

Reasons for and prospective advantages of railways . . . . . . 485

Claims made in favour of the canals . . . . . . . . 494

Nature of the opposition to railways . . . . . . . . . . 497

Early advocates in favour of railways . . . . . . . . . $\quad . \quad 507$

Work of Thomas Gray . . . . . . . . . . . . $\quad . \quad 507$

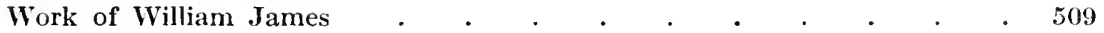

Various plans for formation and operation of railways . . . . $\quad 510$

Liverpool and Manchester Railway . . . . . . . . 514

Modern railway era began with Liverpool and Manchester line . . . 526

Success of this line was immediate . . . . . . . . . . 526

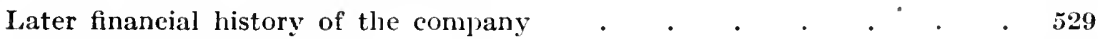

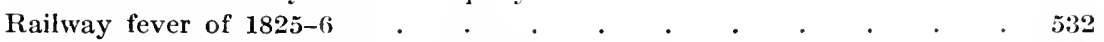

Public were greatly stirred by possibilities of railways _ . . . . $\quad$. $\quad 533$

Liverpool and Birmingham Railway . . . . . . . . . 535

London and Birmingham Railway . . . . . . . . . $\quad . \quad 543$

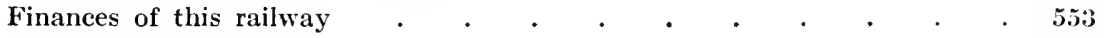

Great Western Railway . . . . . . . . . . . 554

Other railways . . . . . . . . . . . . . . 564

Railway panic of $1835-\tau$ showed need of systenatization . . . . . 570

Parliament applied same principles to railways as to eanals . . . 572

Continuance of this impossible; railways essentially monopolistie . . 573

Changes in legislation witlı recognition of monopolistic nature of railways $5 \mathbf{5 7 4}$

Destructive competition prevented by working agreements . . . . 577

Recognition of failure of competition among railways where combination or

working agreement is possible . . . . . . . . 578

Economy of amalgamation . . . . . . . . . . . $\quad . \quad 580$ 
"Railway mania" of 1844-6 . . . . . . . . . . . . . . . 583

Mlania brought vast amounts of amalgamation . . . . . . . . $\quad$. 586

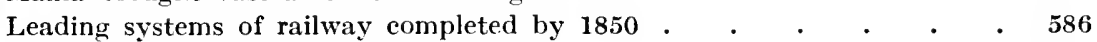

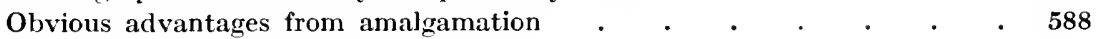

Formation of Railway Clearing House . . . . . . . . $\quad .588$

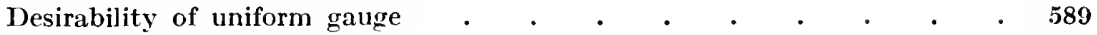

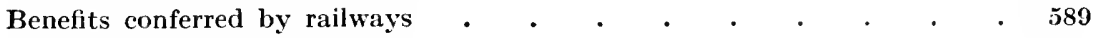

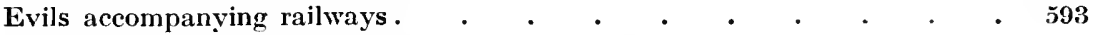

Some reasons why many railways were unprofitable . . . . . . 601

Amalgamation of railways differed from that of canals or roads $\quad . \quad 602$

\section{CHAPTER VIII}

\section{EFFECTS OF STEAM UPON ROAD TRANSPORTATION}

Railway fares slightly lower than those of stage coaches . . . . $\quad$. 604

Railway had also advantages of greater comfort and speed . . . $\quad 605$

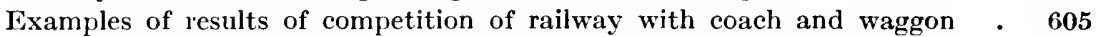

Almost immediate decrease of coaching and posting along lines of road adjacent

to and parallel with the railways . . . . . . . . 608

Effect upon coaching and carrying establishments . . . . . 610

Decreased revenues of some turnpike trusts and increase of trusts' debts $\quad \mathbf{6 1 2}$

Compecition of steam vessels in rivers and around coast reduced business and

revenues of some trusts. . . . . . . . . . . . . 614

Examples of reduction of trust revenues by railways . . . . . $\quad$ \$16

Reasons why railways attained ascendancy over stage coaches . $\quad . \quad 619$

\section{CHAPTER IX \\ COMPETITION OF RAILWAYS AND CANALS}

Description of the various carrying systems on railways . . . . $\quad 624$

Railways working to exclude private carriers from their lines . . . 626

Pros and cons of the carrying question a . . . . . . . . $\quad$. 626

Means used to drive the carriers off the railway lines a . . . $\quad 630$

Canals had to lower rates under railway competition . . . . . . . 633

Decreased revenues of canals shown in decreased prices of shares . $\quad$. $\quad 634$

Working agreements formed between railways and canals after competition

had reduced their revenues and profits . . . . . . . 636

Act of 1845 to enable canals to compete with railways . . . . $\quad$. 638

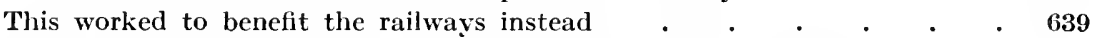

Great movement in 1841-6 to amalgamate canals with railways . $\quad 640$

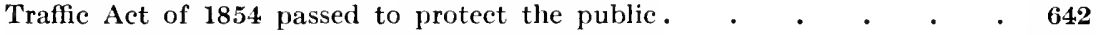

Additional amalgamation and working agreements . . . . . . $\quad$. 643

When canals merged with railways their rates usually increased . . 646

Railway policy to take the trade from canals . . . . . . 647

Reasons for failure of canals to successfully compete with railways . . $\quad 649$

Plans devised to enable canals to keep their trade-usually unsuccessful . 661

Coasting trade also threatened by railway . . . . . . . . . 665 


\section{APPENDICES}

PAGE

1. River Weaver Navigation . . . . . . . . . . . . . $\quad .666$

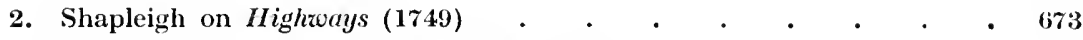

3. Hawkins on the Laws of Highways (1763) . . . . . . . $\quad 677$

4. On Letting the Tolls . . . . . . . . . . . $\quad$ 681

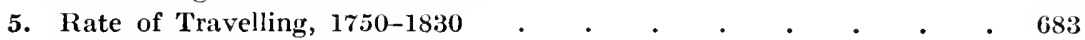

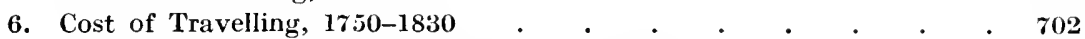

7. Cost of Carriage of Goods by Land, 1750-18:30 . . . . . $\quad 716$

8. Statistics of Comparative Cost of Carriage by Road and Inland Navigation. . . . . . . . . . . . . 724

9. Table of Canal and Railway Amalgamations, 1846-72 . $\quad . \quad 730$

10. Statistics showing Effects of Railways in reducing Canal Freight Rates 731

11. Statistics showing Extent to which Freight Rates were raised through Amalgamations of Canals and Railways . . . . . . 736

12. Illustrations of the Way in which Canals sometines maintained Competition against the Railways . . . . . . . . . 738

13. Statistical View of Highway and Canal Legislation . . . . $\quad 742$

14. Pickford et al. v. The Grand Junction Railway Company . . . 744

Bibliography

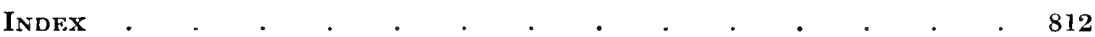

\section{MAP}

Collins' Railway Map of England . . . . . . . . . in pocket of Vol. II 
• 


\section{CHAPTER VII}

\section{DEVELOPMENT OF RAILWAYS}

IT is not easy to trace the origin of railways, but the earliest approximation to the modern railway was, doubtless, the wooden tramroad, the existence and use of which dates far anterior to the modern railway era. The earliest system for the conveyance of eoal from inland collieries was by the use of pack-horses, mules or asses, over the backs of which were slung the bags filled with eoal; and this method prevailed down to the close of the eighteenth eentury ${ }^{1}$. m Of course, with the gradual improvement of the roads, some earts had come into use; and the amount of load that could be drawn upon these roads had inereased. There still remained, however, the difficulty of bringing the eoal from the pit's mouth down to the river or to the road; and to effeet this end, wooden tramroads came in time to be laid down.

We are informed that, as early as $\mathbf{1 5 5 5}$, there was a tram from the west end of the Bridge Gate in Barnard Castle, for the repairing of which the proprietor of the eastle left the sum of $20 \mathrm{~s}$. The word "tram," at that time, seems to have been used in the north of England and the south of Scotland to describe the special track or road and the truck that ran on it. The truek was drawn along this way by men or horses ${ }^{2}$. The use of the tramroad in the coal distriets, however, for facilitating the conveyanee of that heavy eommodity, does not seem to have come into public attention until half a century or a century after that time; for a reeord in the books of one of the free companies in Neweastle, dated 1602, states that from time immemorial the eoal earts had been aeeustomed to earrying eight "baulls" of eoal from the pits to the river", but recently that amount had been redueed

1 Jeans, Jubilee Memorial of the Railzeay System, p. 5. Jeans says of his work that the facts and figures were all "compiled from official and accredited sources, so that their accuracy may be accepted as nnimpeachable."

2 Gordon, Our Ilome Railzays: Ilow they began and Ilow they are zorked, 1, p. 4. Gordon says that his work has been drawn from the original sources, and has been ollicially approved by the railway anthorities as authentic.

3 Iight bolls of coal were equal to $17 \mathrm{cwt}$.

J. T. II. 
to seven "baulls." The expense of carrying such heavy loads on poor roads would naturally cause them to seek some other means of conveyance than by cart; but it would seem as if no great change had been made before the middle of the seventeenth century, for a gentleman, writing in 1649, said that many thousand people were employed in the coal trade, some by working in the pit, and others by carrying in waggons and wains to the river Tyne ${ }^{2}$. Some change, however, had been made, for shortly before that time, perhaps about 1630, a man by the name of Beaumont went north to Newcastle with new kinds of implements for mining the coal, and he it was who introduced the "wooden way" and waggons for carrying the coal from the pits down to the river. He, apparently, had thirty thousand pounds in money with which to begin his improved system of mining the coal and sending it on its way toward the market; but in a few years he had used up all his money and "rode home upon his light horse," having lost all his capital ${ }^{3}$. By the old system, it was not uncommon for these northern mine-owners to employ five or six hundred horses and carts in this traffic; and hence it was of vast importance to reduce the great expense incurred in keeping so many horses and drivers, in the wear and tear of earts, and in the making and repairing of roads 4 It was recognized that the difficulties of the soft roads would be overcome by the adoption and use of the wooden rails upon which to draw the loaded waggons; so that, although Beaumont lost all that he had, others took up his ideas and put them successfully into operation. About 1670 the use of wooden ways seemed to be a common method for conveying the coal from the pits to the river, and those who had lands between the collieries and the river would lease or sell strips of these lands to the mine-owners, upon which the latter would lay their rails from the mines to the bank of the river. Rails of timber were laid down and bulky four-wheeled waggons were made to fit these timbers; so that a keen observer, in 1676, asserted that by this means the carriage was made so easy that one horse would draw down as much as four or five chaldrons of coal at one time, which was an immense benefit to the coal merchants ${ }^{5}$.

1 Wood, Practical Treatisc on Railroads (1825), p. 34.

2 Gray, Chorographia, or a Survey of Nezcastle upon Tine (1649), pp. 24-25.

3 Ibid., pp. 24-25; Wood, Practical Treatisc on Railroads (1825), p. 35, quoting from Gray; Stretton, A Fezv Notes on Early Railicay II istory, p. 3.

4 .Jeans, op. cit., p. 5.

5 North, Lifc of the Right IIonourable Francis North, Baron of Guilford, Lord Keeper of the Great Seal, pp. 136-7. See also Wood, Practical Treatise on Railroads (1825), p. 36, and Cumming, Rail and Tram Roads (1824), p. 7. In Transactions of the IIighland Society, vi, p. 6 et seq., Scott gives an account of the origin and 
In constructing such a road an effort was usually made to have it on a slight decline from the pit's mouth to the place where the coal was to be discharged from the waggons, so that heavy loads might be easily conveyed without a great expenditure of encrgy by the horses employed in hauling. The rails were not always laid so as to give a uniform declivity throughout the whole length; but they followed more or less the surface of the ground. Where, on part of the road, there was a steep declivity, the speed of the waggon was regulated by a brake attached to the vehicle and managed by the driver. The waggons used had low wheels, for the smoothness of the rails made high wheels unnecessary; and upon the roads of ordinary declination it was easy for a horse to draw three tons of coal from the pit to the river ${ }^{1}$, although the ordinary load for one horse was nineteen bolls or about forty-two hundredweight ${ }^{2}$. The economy of the waggon-way over the old way of carrying coal may be noted from the fact that, upon the common roads, the regular load for a horse with a cart was only about seventeen hundredweight ${ }^{3}$. Of course, the empty waggons had to be drawn back up the incline and the road was made so that horses could meet and pass at certain places.

In time the wooden rail had its upper surface worn away; and it is probable that at first such repairs were made by fastening another rail or plank upon the top of the one that was worn' ${ }^{4}$ But on some parts of the road where occasional acclivities oceurred which could not be levelled, or where sudden windings of the road had to be made, and where, therefore, there would be an unusual amount of friction with the wheels, thin plates of wrought-iron were laid on the wooden rails and fastened to them. The advantages secured by this means in diminishing friction and keeping the rails from wearing would suggest the obvious advantage of having the wooden rails plated throughout with sheet-iron, or covered with iron plates or bars nailed on them. These were called "plateways." When these rails were first faced with iron, we do not know; but the use of such plated rails development of railways, and says that from the records of Ravensworth Castle it would appear that railways came into use there in 1671. See also the petition of Charles Brandling, Lord of the manor of Middleton, owner of coal mines there, and several other owners and occupiers of grounds in Leeds, asking Parliament for permission to lay a waggon-way, from the coal mines, through the grounds of the other petitioners, to Leeds, where Brandling agreed to deliver coal at reduced prices $(J ., H$. of $C$., xxvil, p. 57).

${ }^{1}$ Cumming, op. cit., p. 9, and Wood, op. cit., pp. 36-41, give full details as to the construction of the road.

2 Cumming, op. cit., p. 8; Wood, op. cit., p. 41.

3 Wood, op. eit., p. 41.

4 Stretton, A Few Notes on Early Railway History, p. 3. 
soon caused much wear to the wooden wheels of the waggons, and the next improvement was to replace the wooden wheels by those made of cast-iron ${ }^{1}$. From one source we are informed that as early as 1734 cast-iron wheels with an inner flange were in use near Bath ${ }^{2}$; and another who has looked carefully into the history of some early railways gives the introduction of cast-iron wheels as having taken place about $1753^{3}$. Which of these dates is more nearly correct we shall not undertake to say.

The use of the plated rail did not seem to be very much extended. Probably the chief reason for this was that the nails, which were intended to securely hold the plates on the rails, would be continually working loose and demanding constant expense in effecting repairs. Instead of this method being continued, the plated rails were displaced and cast-iron rails were adopted. At what time the introduction of the latter occurred we are unable to definitely ascertain; the year 1738 has been given as the time when cast-iron took the place of wooden rails ${ }^{4}$, but we have not found anything to substantiate this, and regard the date given as too early. Probably the year $\mathbf{1 7 6 7}$ more nearly marks the date when the cast-iron rail superseded the old plated rail; for the books of the great Coalbrookdale Iron Works in Shropshire show that on November 13, 1767, there were between five and six tons of such rails cast there and tried as an experiment ${ }^{5}$. These rails were made with a flange on the inside, and they were so long and without any support in the centre that the heavy waggons frequently caused them to break; but, later, that was remedied by making the waggons smaller and the loads lighter, and coupling the cars together so as to distribute the weight over a greater length of road $^{6}$. In 1776 a similar cast-iron railway was laid down by John

1 Stretton, op. cit., p. 3 ; Gordon, Our Home Railways, p. 4.

2 Gordon, op. cit., p. $4 . \quad{ }^{3}$ Stretton, op. cit., p. 3.

4 Wood, op. cit., p. 44, quoting from an anonymous writer. See also Cumming, Rail and Tram Roads, p. 10, and Francis, History of the English Railway, I, p. 45.

5 Stretton, op. cit., p. 4; also Wood, op. cit., pp. 44-45, who quotes the statement of Robert Stephenson to substantiate this assertion. See also Gordon, op. cit., p. 4. Scott, in Transactions of the IIighland Society, vi, p. 7, said that below ground, in the pits, cast-iron rails did not begin to replace wooden ones till 1776 .

6 Stretton, op. cit., p. 4; Wood, op. cit., p. 44. In Communications to the Board of Agriculture, I, p. 203, there is given the description of a tramroad from the coal-pit to Alloa, Scotland. The sleepers were eighteen inches apart; the wooden rails were covered by iron on top; and the waggons would each hold one and onehalf ton of coal. Two, and sometimes three, waggons werc linked together; so that, under the latter circumstances, one horse would draw four and one-half tons of coal and three tons weight of carriages. The first cost of construction was $\$ 900$ to $£ 1000$ per mile. 
Curr at the Nunnery Colliery, near Sheffield ${ }^{1}$; but it was not until about 1794 that cast-iron rails were first used in the collierics of Durham and Northumberland ${ }^{2}$.

One of the greatest improvements was made in 1789, when, at the suggestion of Smeaton, William Jessop, in constructing a railway from Nanpantan to the Loughborough Canal, used narrow, cast-iron "edge rails," three feet long, and removed the flange from the rail to the inner side of the wheel ${ }^{3}$. This form of rail and of wheel has been the model upon which the construction of rails and wheels has proceeded during most of the time since that day.

Up to this time wooden sleepers had been in use and the rails had been bolted or pinned to them. But in 1797, when laying a railroad at the Lawson Colliery, near Newcastle-upon-Tyne, Barns introduced stone blocks instead of wooden sleepers, the inducement, doubtless, being that the stonc supports would be more suitable for a road which had to carry loads of such heavy material as coal ${ }^{4}$. This was also applied by Benjamin Outram, in 1799, in the construction of a line from Ticknall to the Ashby Canal; the rails used here were of the same form as those used in $\mathbf{1 7 7 6}$ by Curr on the Sheffield line, namely, with the flange on the outside of the rails, and the latter had both ends fastened securely to the stone supports. It is evident, therefore, that Outram was not the first to employ stones as the foundation of the railway, although some have supposed that his name, shortened by the maintenance of only the last part of it, has been perpetuated by calling these "tram-ways 5 ."

In 1799 there was a proposal to build a line from London to Portsmouth and in 1801 the Surrey Iron Railway Company obtained an Act for accomplishing the first part of this road, from Wandsworth to Croydon. This was the first railway company, the first public railway, and the first so-called railway Act, although it was not the first Act in which a railway was authorized. The line was opened in 1804 between these two places and traction was effected by horsepower; and the rails, resting on stone block sleepers, were four inches

1 Wood, op. cit., p. 45, quoting from Carr's Coal Viewer and Engine Builder; Stretton, op. eit., p. 4 ; Gordon, op. cit., p. 4.

2 Jeans, Jubilee Meneorial of the Railway System, p. 6.

3 Wood, op. cit., p. 48 ; Stretton, op. cit., p. 4; Gordon, op. cit., p. 5. The Jessop rail may now be seen in the South Kensington Muscum, London.

4 Wood, op. cit., p. 46 ; Stretton, op. cit., p. 5.

5 Wood, op. cit., p. 46; Stretton, op. eit., p. 5 ; Gordon, op. cit.. p. 5. The name "tram" was in use much earlier than this, for in 1555 Ambrose Middleton bequeathed $20 \mathrm{~s}$. "to the amendinge of the highwaye or tram from the weste ende of Bridgegait, in Barnard Castle." (Surtees Society Publieations, xxxvil, p. 37 notc.) 
wide, one inch thick, and with an arched flange one inch thick and three and one-half inches high. The delight of a certain nobleman in witnessing the economy of horse-power on this railway caused him to think that such lines should be extended from London to Edinburgh, Glasgow, Holyhead, Milford, Falmouth, Yarmouth, Dover and Portsmouth; but the idea of the general extension of railways over the country was at that time considered as absurd ${ }^{1}$.

Between this Act of 1801 and that of 1821 sanctioning the construction of the Stockton and Darlington Railway, there were not less than nineteen railway Acts passed, five of which were allowed to lapse. Among the plate-ways which were constructed at this time were some of great significance, such as the Peak Forest line over the Derbyshire hills ${ }^{2}$; a line at Ashby-de-la-Zouch in Leicestershire ${ }^{2}$; the Forest of Dean line; the Glouccster and Cheltenham; the Dartmoor Railway to connect with the port of Plymouth ${ }^{3}$; and others, such as the proposed railways from Stortford to Cambridge and from Liverpool to Manchester, had been under consideration but had not been authorized ${ }^{4}$. As early as $\mathbf{1 8 1 0}$ there was a movement for the construction of a railway or canal from Stockton, via Darlington, to Winston, in order to provide an outlet for the mineral wealth of that district ${ }^{5}$. We are justified in saying that the first quarter of the nineteenth century was a time when, gradually, the claim of the railways upon public attention was becoming accentuated and the mechanical advances were showing that this was to be the coming means of locomotion.

The constant breaking of the cast-iron rails induced interested individuals to attempt to find a better substitute for them; and the results of experiment seemed to indicate that malleable iron rails, if properly supported so that they could not bend too much in the centre, would be more durable than cast-iron. Nicholas Wood, whose knowledge of early railway development was unsurpassed, informs us that malleable iron rails were tried at the Wallbottle Colliery, near Newcastleupon-Tyne, about 1805, but because their narrow surface cut the periphery of the wheels they were superseded by cast-iron rails of wider surface ${ }^{6}$. Robert Stephenson's assertion was that this kind of

1 Stretton, op. cit., p. 5 ; Gordon, op. cit., p. 6.

2 Stretton, op. cit., p. 5.

3 The Times, Nov. 21, 1823, p. 4. The road was just completed at this time after four years of construction work. For others that were constructed at this time see Francis, IIistory of the English Railway.

4 Cambridge Chronicle and Journal, Aug. 30, 1811, p. 2; The Times, July 29, 1822, p. 3.

5 Jeans, Jubilee Memorial of the Railway System, p. 14.

${ }^{6}$ Wood, Practical Treatise on Railroads, pp. 60-61; Stretton, op. cit., p. 5. 
rail was first introduced about 1815, at Lord Carlisle's coal works, on Tindale Fell, in Cumberland ${ }^{1}$, and Jeans seems to have followed Stephenson in his acceptance of this date ${ }^{2}$; but Wood shows that, by the statement of the agent of these coal works, the date given by these two men was erroneous, for malleable iron rails were laid down on this tramroad in $1808^{3}$. We may say, apparently with truthfulness, therefore, that east-iron rails began to be replaced by those of malleable iron in the first years of the nineteenth century; and although the wooden plated rails and the cast-iron rails were not immediately displaced by the malleable iron rails, the results obtained from the gradual adoption of the latter showed the wisdom of their increasing use $^{4}$.

The construction of the tramroads, or iron railways ${ }^{5}$, varied according to the nature of the ground and the traffic to be carried upon them. If most of the traffic went in one direction, as in the carriage of coal from the mines, the road was made to slope slightly in that direction; and the degree of declivity was determined by the traffic and its extent, the object being to equalize the draught each way as nearly as possible. The road was sometimes made single and sometimes double, according to the expected amount of carrying upon the line and the way in which this was to be done $e^{6}$. As a rule, the track was not double, but the single track was made more serviceable by having turnouts, where waggons might meet and pass. The width of the rails apart was largely decided by the shape of the waggons and by the physical characteristics of the country through which the road passed; it usually varied between three and four and one-half feet. Where stone sleepers were in use, they were generally embedded about three feet apart from centre to eentre, so as to accommodate the fastening of the rails which were generally three feet in length; and the space between the sleepers was filled up with gravel or other material to make a good hard $\operatorname{road}^{7}$. The rails were then laid end to end and fixed in position by having an iron spike driven through

1 Wood, op. cit., p. 61.

2 Jeans, op. cit., p. 12.

3 Wood, op. cit., p. 61.

4 Wood, op. cit., pp. 61-70, enters into a long discussion of the advantages and disadvantages of the malleable iron rail.

5 In the early Acts, no difference is made between the terms tramroad and railway in regard to their meaning.

6 If the descent of loaded waggons by gravity were to be used to draw up the waggons when unloaded, it was, of course, necessary to have a double track. So too, when one track was not sufficient to accommodatc the amount of the carrying.

7 On the tramroad from the coal-pits to Alloa (Scotland) the sleepers were only eighteen inches apart. See description of this road in Communications to the Board of Agriculture, I, P. 203. 
each end into a wooden plug in the centre of the stone sleeper, or else by driving the spike through the rail into a cavity in the stone sleeper and fixing this securely in position by means of molten lead ${ }^{1}$. Of course, after malleable iron rails were substituted for those of castiron, it was not necessary to have the sleepers set so close together. We must not form the picture of these tramroads from what we know of our modern railways; it was rare, indeed, that the former demanded the cuttings and the embankments that we see on railway lines to-day, for instead of cutting through a hill in order to get a more or less straight course, they easily wound around the sides of the hills, preferring the circuitous rather than the straighter but more expensive road. In the same way, they avoided the filling up of large concavities along the line, and sought a more devious route in order to avoid the hcavy costs of filling and embanking. The line of rail followed the great inequalities of the surface of the route chosen; and was not, as the present railways, laid upon as nearly a uniform, straight and level road as possible ${ }^{2}$.

1 Scott, in Transactions of the IIighland Society, vi, pp. 8-10, gives the method of constructing the railway between Kilmarnock and Troon harbour. It was a doubletrack line, laid with flat or plate rails, although he says that at that time the edgerail was generally introduced.

2 Wood, op. cit., pp. 36-37, quotes a description of these tramways as given in Jaa's Voyages Métallurgiques, I, p. 199, in 1765; and he amplifies this description of the early railways on pp. 38-40 of his book. I have thought that the account of such a tramway, as given by Coxe, in his IIstorical Tour through Monmouthshire (1904), p. 202, would be illuminating, and would show what they were like in the year 1801, when his book was first published. As much as possible his own words are preserved in the narration of the process of making such a railroad: "The ground being excavated about six feet in breadth, and two in depth, is strewed over with broken pieces of stone, and the frame laid down. It is composed of rails, sleepers, or cross bars, and under sleepers. The rail is a bar of cast-iron, four feet in length, three inches thick, and one and a half broad; its extremities are respectively concave and convex, or in other words are morticed and tenanted into each other and fastened at the ends by two wooden pegs to a cross bar called the sleeper. This sleeper was originally of iron, but experience having shown that iron was liable to snap or bend, it is now made of wood, which is considerably cheaper, and requires less repair. Under each extremity of the sleeper is a square piece of wood, called the under sleeper, to which it is attached by a peg. The frame being thus laid down and filled with stones, gravel, and earth, the iron rails form a ridge above the surface, over which the wheels of the cars glide by means of iron grooved rims three inches and a half broad." At the junction of two roads, and to facilitate the passage of two cars in opposite directions, movable rails, called turn rails, are occasionally used, which are fastened with screws instead of pegs, and may be pushed sideways. "The declivity is in general so gentle as to be almost imperceptible: the road, sometimes conveyed in a straight line, sometimes winding round the sides of precipices, is a picturesque object, and the cars filled with coals or iron, and gliding along occasionally without horses, impress the traveller, who is unaccustomed to such spectacles, with 
Another particular in which the tramroads differed from the railways of to-day is that the latter are the principal means for the land conveyance of goods, whereas the tramroads were regarded not as principal but as auxiliary agencies for transportation. In the later years of the eighteenth century, when the early tramroads were coming into notice in certain localities, the canals and the ordinary roads were claiming more and more attention, since these were considered as the permanent routes along which the conveyance of goods should be effected. It was but natural, therefore, that the new facilities of transport should be thought of, not as displacing in any sense the existing modes of conveyance, but as accessories to them. Canal companies considered the tramroads as valuable additions to their facilities, for by means of them trade and communications could be effected with districts that would otherwise be inaccessible. There were canals that were constructed through territory to tap the coal resources of that region; but either because they could not economically reach the source of the coal on account of its height above a water supply, or because, if they did reach it, the operation of the canal was too expensive to be remunerative, these canals were impotent to supply the necessary facilities for the development of this mineral wealth. In such places, the use of a tramway would enable such materials as coal, stone and iron-ore to be brought down to a lower level, where the canals could do the effective service that they were designed to fulfil in carrying these things thence to the places of manufacture. In fact, at the end of the eighteenth century, and even during the carly part of the nineteenth century, tramways were regarded as strictly tributary to the canals; for in many petitions to Parliament, asking for authority to construct canals, there were also requests for the privilege of making collateral cuts, "with proper railways and other roads to communicate with these canals ${ }^{1} . "$ In most of these cases, the tramway was to reach some

pleasing astonishment." The expense of construction of these roads varies according to circumstances. It is seldom less than one thousand pounds per mile, and sometimes exceeds that sum. The cars weigh not less than three and a half tons. They are drawn by a single horse, and the driver stands on a kind of footboard behind, and can instantaneously stop the car by means of a lever and a drop, which falls between the wheels, and suspends their motion. In places where the declivity is more rapid than usual, the horse is taken out, and the car impelled forward by its own weight. For description of the waggons used, see Wood, op. cit., pp. 76-80; and other data regarding the formation and operation of these roads are given in Cumming, Rail and Tram Roads.

1 See, for example, $J ., I I$. of $C$., Mar. 11, 1789, regarding railways and roads to lead to the Cromford Canal; $J$., $I$. of $C$., Feb. 9, 1791, regarding railways and roads to connect with the Hereford and Gloucester Canal ; J., II. of C., Dec. 20, 1792, for railways and roads to connect with the proposed Grand Junction Canal ; J., H. of C., 
high and broken land where there were eonsiderable amounts of mineral resources and where a canal would have been impossible or unprofitable ${ }^{1}$. From the above we can see that the tramways and roads were elosely associated in their relation with the canals; but the fact that tramways were oecasionally eonstrueted to terminate at a certain bridge or a certain turnpike road is still stronger evidenee that the iron roads were closely assoeiated with the ordinary roads and subsidiary to them ${ }^{2}$,-in other words, the tramways were collecting and distributing agencies for products earried along the great highways of the kingdom.

In England, Wales and Seotland, these tramroads were in some parts fairly numerous, and most of them were only short lines, branching off from the navigable rivers and canals to the different mines. The majority of those in the United Kingdom were in the extensive mining districts south of the Severn, including South Wales; in the eoal districts near Neweastle and Sunderland along the rivers Tyne and Wear; in the coal and other mining areas of Lancashire and Yorkshire, as well as of Derbyshire and Staffordshire; in the mining regions of the eounty of Salop and adjaeent parts of the Severn valley; in the mining sections near Glasgow, and in the coalfields of Midlothian and

Jan. 31, 1793, regarding railways and roads to connect with the Stratford-on-Avon Canal; $J$., II. of $C$. F Fb. 1$], 1793$, for railways and roads to connect with the Birmingham and Fazeley Canal. See also Pitt, Agriculture of Leicester (1809), p. 313, and Diekson, Agriculturc of Lancashire (1815), p. 613, both of which show that by means of these iron roads coal and iron were brought down from the pits to the canals by a cheap and very convenient way, and that the tramways were primarily regarded as subservient to the canals, even down to the first quarter of the nineteenth century. That railways were not much thought of apart from eanals, is shown also by Communications to the Board of Agriculture, $\mathrm{n}, \mathrm{p} .478$, and Transactions of the Highland Society, vi, pp. 10-11. For details of this close relation between tramroads and canals, see the pamphlets of C. E. Stretton given in bibliography.

1 There were many of these early tramroads in southern Wales, where there are mines of coal and iron; also in Lancashire, Derbyshire and the Newcastle region, as well as in Scotland. Anderson, Recreations in Agriculture, Iv, p. 198, urged the eonstruction of railways where canals were not possible, and showed (ibid., IV, pp. 199-201) to what extent railways had already been constructed in the Midlands of England and what a great inerease in earriage had been effected by them. Communications to the Board of Agriculture, I, p. 477, shows the utility of the railways in extending the influenee of canals for ten to twenty miles on each side of the latter, and also into the mountainous sections where canals were almost impracticable. See also Hassall, Agriculture of Monmouth (1812), p. 105, containing an aecount of the iron railways of that county and their effects.

${ }^{2} J ., I I$. of $C$., Feb. 15, 1826, petition for a railway or tramroad from the Grosmont railway at Llangua (co. Monmouth) to Wye Bridge, in the eity of Hereford; $J$., II. of C., lxxxv, p. 59, petition for the Leicester and Swannington railway or tramroad. 
Fife, where they were found in great numbers but on a small scale'. These roads in South Wales, and in the countics along the Severn valley, were chiefly inclined planes with various slopes, on which one horse could easily take down thirty to forty tons together with the weight of the waggons, but it required three or four horses to bring the empty waggons up again, and cven then the up-grade work was the heavier. There were, however, a few inclined planes on which the loaded waggons in descending brought up the empty oncs, but this method was employed only in cases where the declivities were very great ${ }^{2}$. In the county of Salop and adjoining mineral areas of the west of England, and in Wales, these iron roads increased considerably in number in the first quarter of the nineteenth century ${ }^{3}$; and it can be justly claimed that this district may boast of being the place where the inclined plane was first used to introduce railways in aid of inland navigation and for the development of the wealth of the country ${ }^{4}$. The tramroads in the coalfields of Northumberland and

1 Scott, in Transactions of the IIighland Society, vi, pp. 11-15, gives the names of the many tramways or railways, in $\mathbf{1 8 2 4}$, in the Severn valley, in Yorkshire, Derbyshire, Leieestershire, Staffordshire, Ianeashire, and in the eoal eounties of Northumberland and Durham, as well as those in Scotland. Regarding the difficulties and dangers connected with carriages moving up and down these inclined planes, see Wood, Practical Treatise on Railroads, pp. 86-103.

2 That is, from six to eighteen inches in the yard. The lengths of these inclined planes varied from 100 to 600 vards at one place. On inclined planes, see Seott, in Transactions of the II ighland Society, v1, pp. 15-30, who gocs into this subject very fully. This double railway was in use in Shropshire, for instance, in the railway connexions of the Ketley and Shropshire Canals (Plynley, Agriculture of Shropshire (1803), pp. 291 ff.). See also Scott, op. cit., vi, pp. 8-9.

3 As late as 1790, there was hardly a single railway in all South Wales; while in 1824 the aggregate extent of rail and tramroads in the eounties of Monmouth, Glamorgan and Carmarthen alone was thought to exceed 400 niles (Cumming, Rail and Tram Roads, p. 27).

4 The history of the great Sirhowy tramway, in the eounty of Monmouth, may enable us to see more clearly the relation of these early roads to the development of the wealth of the eountry through whieh they passed; and we have chosen this one because, in point of magnitude, it was one of the greatest. It extended from Pilgwelly, near Newport, to the Sirhowy and Tredegar Iron Works (24 miles), whence it was eontinued five miles further to the Trevil Lime Works, in Brecknockshire, along with a branch westward to the Rumney and Union iron works. This railway was eonstrueted at the suggestion of Mr Outram. On being eonsulted by the Monmouthshire Canal Company, as to the best means of supplying that eanal with water, of whieh there was sueh a great scareity that trade was suffering severely, Outram reeommended a few reservoirs to be made, but more partieularly a tramroad, to run parallel with the Crumlin line for eight or nine miles out from the town of Newport. In order to ease or take away part of the trade from the canal, this line was to pass through Tredegar park, the property of Sir Charles Morgan; and it was finally arranged between Sir Charles, the Monmouthshire Canal Co., and the 
Durham were many and important, and were used not only in carrying the coal from the mouth of the mine to the river, but in bringing it from the interior of the mine to the entrance. It is in connexion with these colliery roads that we get some very important advances in the practical application of steam to locomotion on rails. Apart from these tramroads leading to coal and other mineral supplies, the only important tramroad made during these first two decades of the nineteenth century was the Surrey Iron Railway, from Croydon to Wandsworth' which was authorized in 1801. It was to be of advantage to a very populous agricultural country through which it was to be built, by opening up cheap and easy communication for carrying coal, corn, merchandise, and, in fact, commodities of all kinds; in other words, as we have already noted, this was doubtless the first attempt to construct a public railway for the carrying of miscellaneous products.

In all these cases the introduction of the tramway was for the purpose of facilitating the carriage of commodities, especially of heavy commodities like coal, and thereby reducing the cost of carrying these along the highways that were then and there available. Experiments

Tredegar Iron Works Co., that he should make one mile, which was in his park, the Monmouthshire Canal Company to make eight miles, and the Tredegar Iron Works Company to make the remaining fifteen miles, each to take tonnage on its respective part of the road. The road was completed about 1804, and also a turnpike by the side of it for about seventeen miles, at a total cost of about $\$ 74,000$, or about $\$ 3000$ per mile. About $£ 40,000$ of this sum was spent by the Canal Company in building a bridge and making some very deep and expensive cuttings; while the Tredegar Iron Co. completed ncarly double the distance at a cost of $\$ 30,000$. Sir Charles Morgan spent $\mathfrak{E} 1000$ upon one mile, but he too had some deep cuttings and a double road to make. Notwithstanding the expense, this road. in 1824, paid the proprietors thirty per cent., by reason of having a considerable trade upon it in coal and iron, which paid the same tonnage as upon the canal. For the first nine miles out of Newport (the parts made by the Canal Company and Sir Charles Morgan) it was a double road: one for the loaded waggons to come down, and the other for the empty ones to return; and on the Tredegar Iron Company's part (fifteen miles) it was a single road, with frequent places for teams to turn out and pass. The whole length of the road for twenty-four miles was an inclined plane, averaging about one. eighth of an inch in the yard, or a little morc; but the Tredegar Iron Company's part was of somewhat greater dcclivity than the rest. The coal and iron were conveyed on it in waggons, each carrying about forty-five to fifty hundredweight, exclusive of the waggon; and a team of four or five horses would draw about fifteen of these waggons down with ease. The waggons were variously constructed, according to the fancy of the parties, some of wood, some wholly of iron. The width of the road was four feet two inches, and it was laid down with cast-iron plates, three feet long, fastened to the slcepers by a pin passing through the rail, and into a hole bored in the stone block four to five inches deep, and there secured with lead (Cumming, Rail and Tram Roads, pp. 25, 26, 28-30).

1 J., II. of C., Feb. 27 and Mar. 5, 1801, Lvi, pp. 112-13. 
had been conducted to show how much more effective was the work of a horse when drawing upon a railway than upon the ordinary roads, and important results had been obtained. For example, in 1799, on a railway at Measham, the declivity of whieh was five-sixteenths of an inch in the yard, one horse drew nineteen waggons, which with their loading anounted to thirty tons, and was not subjected to extraordinary work in doing so. At a later time, on the same road, one horse drew down a load amounting in all to thirty-five tons; while up the grade or aseent he drew five tons with ease ${ }^{1}$. From the facts which were being demonstrated, it was becoming more evident that there were possibilities in this method of conveyance whieh were not fully realized; that, instead of being confined to the operations of mining, it was also fitted to take an important place in the conveyanee of all kinds of produets and merchandise, and to faeilitate the interchange of traffic from one centre to another. But it was reeognized that if tramways were to be used for general traffic, where there was carriage of goods each way, the more the line approximated to a perfect level the better it would serve the purposes for whieh it was intended ${ }^{2}$. While most people regarded the railways as useful in the limited sphere in which they had been employed, there was but an oecasional individual, at the beginning of the nineteenth century, who contemplated a broader field of service for them. There were at that time at least two who foresaw the general extension of railways over England; and one of these proposed that all the railroads eonstructed should be owned by the state and free to all so that eaeh eould use his own waggons upon them ${ }^{3}$.

But tramroads or railways for general purposes could have but partial suceess until some other than horse-power could be employed ${ }^{4}$;

1 Communications to the Board of Agriculture, II, pp. 475-6.

2 Statement of Robert Stephenson, in Transactions of the Highland Society, vi, p. 136.

${ }^{3}$ Sir Richard Phillips, after witnessing the economy of horse-labour on the Surrey Iron Railway, thought that sueh lines should be extended from London to the prineipal places of the kingdom (Stretton, A Few Notes on Early Railzay IIistory, p. 5). Dr James Anderson, in his Recreations in Agriculture, 1v, pp. $204 \mathrm{ff} ., 214$, pointed out the advantages of earrying railroads from London to every other part of the country and reeommended that they be owned by the publie. In 1818, the scientifie men of the country were offered a reward for the advaneement of the railway system; and a picee of plate of fifty guineas value was to be given for the best essay on the construction of railroads for the conveyanee of ordinary eommodities. See this advertisement in Transactions of the IIighland Society, vi, pp. 3-1; and the essays sent in are printed immediately following these pages.

4 Cumming, Rail and Tram Roads, p. 33, in speaking of the Surrey I ron Railway, says: "But it must be observed, that rail-ways, as hitherto worked by horses, generally speaking possess very little, if any, advantage over eanals." The fact is, 
and the perfeeting of the steam-engine by Watt turned the attention of many to the application of steam-power to locomotion on common roads, and of a few others to the possibility of its use on the tramways. We have already seen that the limited use of steam for navigation was a practical reality before the beginning of the nineteenth eentury; and we have also noted the introduction of the steam-carriage in the early years of that century, to take the place, to some extent, of the stage eoach. While experiments were being conducted with the steamengine, with a view to its use on the common roads, the possible application of stcam for traction purposes on railway lines was also a subject of interest; and in 1804, for the first time, a steam-engine, constructed by Richard Trevithick, was employed on the railroad at the Merthyr Tydvil coal mines in South Wales. It was very imperfect but was used for a short time.

As early as $\mathbf{1 8 0 0}$ the possibilities of the use of steam on railways were foreseen by some and were loudly proclaimed ${ }^{\mathbf{1}}$; but the public mind failed to grasp the real importanee of this new power in its wider applieations. Many beeame engaged in its investigation whose names and results have not come much into publie notice; but of these we do not propose to treat in detail here ${ }^{2}$. One of the most important

that railways were not eonstructed as a rival conveyanee to the canals, but merely as supplementary to them. Yet railways certainly had advantages that were not possessed by canals, else there would not have been so many of them authorized during the first quarter of the nineteenth century. Note the perfeet rage for raikways, in 1825, when horse-power alone was in general use in connexion with them. For example, the prospeetus of the Surrey, Sussex, Hants, Wilts and Somerset Rail-Road Company [Brit. Mus. 8223. e. 10 (148)], issued in 1825, says: "The necessity of using loeomotive engines is not contemplated, every calculation being made on the use of horses only, although seientific improvement, when fully confirmed, will be availed of."

1 Anderson, Recreations in Agriculurc, iv, pp. 198-214.

${ }^{2}$ On the historical development of the steam-engine and the loeomotive, see Gordon, A II istorical and Practical Treatise upon Elemental Locomotion; Areher, William Itedley, Inventor of Railivay Locomotion; Gordon, Our IIome Railways, pp. 7-19. A few facts regarding one of the most ingenious inventors, William Murdoek, whose name has been largely obseured by the glory attached to others, may help to place this man in his true light. As a Seotch boy, he came down to Boulton and Watt's works at Soho to secure employment and after some hesitation Watt engaged him. The boy soon showed his ability and began working during his spare time to produce an engine that could be used for locomotion. Watt discouraged this and the firm, in order to withdraw him from his purpose, sent him to Redruth, in Cornwall, about 1780 , as engineer, to look after some of their engines that were in use in the mines there. Away from Watt, Murdoek had a freer hand, and he again took up the problem of making a locomotive earriage, whieh he brought to a successful issue. In 1786 Murdoek was on his way to London to take out a patent on his steam-carriage when he was met by Boulton who prevailed on him to 
men to devote time and ability to the study of this new power was Richard Trevithick, and we are disposed to mention him in particular, not only because of the good results which he secured, but also because some have arrogated to themselves what was really accomplished by Trevithick. We have alrcady learned of his success with the steamcarriage in the first threc years of the century; but he was convinced that better results could be obtained on a smooth than on a rough road and he lost no time in applying his locomotive engine to tramways. In February, 1804, his locomotive was working on a tramroad at Penderyn, near Merthyr Tydvil in Wales, and rumning with facility up and down inclines of one in fifty ${ }^{1}$. The ten tons which the locomotive drew were soon increased to twenty-five tons, on this same road, with its unevenness and sharp curves ${ }^{2}$, and this load was drawn at the rate of four miles per hour ${ }^{3}$. After Trevithick had made some further improvements in his engine and had constructed several of them for various purposes ${ }^{4}$, he demonstrated in London for several months of the year 1808 that the locomotive with smooth wheels on smooth rails could draw heavy loads with no other assistance than the force of adhesion or gravity ${ }^{5}$. This is a fact which is supported by such apparently incontrovertible evidence that we wonder that any subsequent worker in this field should have attempted to take away the honour which belongs to Trevithick as the "father of the loeomotive engine6." For some reason, which is not very clear, Trevithick's results were obscured by the partial suceess of Blenkinsop, who in 1811 patented his device of the rackrail and $\operatorname{cog}$-wheel which was in use in his colliery. Under this arrangement the whecls were prevented from slipping on the rails by having the toothed wheels of the locomotive fit into the corresponding notches of the rails. But in 1813 and 1814 both William Hedley and George Stephenson again demonstrated the possibility of drawing loads by using locomotive engines with smooth wheels on smooth rails by the mere action of the friction of the wheels

come back, which he did. The Soho firm did not want to lose Murdock, and, loyal to them, he was deprived of the honour of introducing the locomotive. On Murdock's work, see Samuel 'Timmins's essay on him and his accomplishments, in the Birmingham Free Reference Library; also Gordon, Our IIome Railivays, pp. 7-9; Smiles, Lives of the Engineers; Wood, op. eit., pp. 123-57.

1 Trevithick, Life of Trevithick, I, p. 160.

2 Ibid., I, pp. 164, 167, 182.

4 Ibid., 1, pp. 191-2.

3 Ibid., I, p. 182.

5 Ibid., I, pp. 192, 201.

6 Ibid., I, pp. 193-4; ibid., I, p. 206, testimony of Luke Hebert, in his Railroads and Locomotion, p. 30 ; illid., I, pp. 201-3. To this we may add the confirmation given by Wood, Practical Treatise on Railroads (1825), p. 124; Stretton, A Few Notes on Early Railway History, p. 6; Gordon, Our IIome Railways, pp. 11-16. 
on the rails'. From that time on, there was a gradual increase in the employment of the loeomotive, at first on eolliery railroads, and, later, on the railways built for general purposes.

It is not our province to enter into details concerning the development of the loeomotive, nor to traee the successive changes in the application of this power on the colliery roads in the north of England. Some good results had been secured by such men as Hedley, Stephenson and Wood, proving conelusively the great superiority of the locomotive engine over all other kinds of power. For example, on the Killingworth Colliery railroad, in 1814, an engine was tried on a line the steepest gradient of which was one in four hundred and fifty; and the locomotive aseended this with eight loaded waggons, weighing altogether about thirty tons, at the rate of four miles per hour ${ }^{2}$. In the years whieh followed these initial suecesses, improvements were made by Stephenson both in the locomotive itself and in the mode of construeting and laying down the rails; and these results were attracting attention all over the eountry.

1 Both Hedley and Stephenson claimed the priority of this discovery; but, as we have seen above, Trevithiek was some years ahead of either of them. In a letter written by William Hedley, he says: "I beg to say that I am the individual who established the principle of loeomotion by the friction or adhesion of the wheels upon the rails." Trevithiek, Life of Trevithick, I, p. 203; Archer, William Iledley, Inventor of Railway Locomotion, pp. 4-6. How false this statement is, we have already noted. But as between Hedley and Stephenson, a disputc has arisen as to their claim for preedenee. Smiles, in his Lives of the Engineers, III, p. 142, clearly admits that Hedley discovered and demonstrated the sufficiency for traction of the smooth wheel and rail, but he fails to give him very ample eredit; on the eontrary, he reserves this for Stephenson. Archer, op. cit., pp. 4-6, in taking up the case for Hedley, gives a letter from the latter to Dr Lardner, to show that Hedley was really earlier than Stephenson in the application of this principle; and Archer says that this letter and the complete absenee of denial from any souree whatever is the elearest possible proof that Hedley's elaim was considered incontrovertible. He says, moreover, that this faet has never been ehallenged nor answered by Stephenson or anyone else. This last statement of his does not seem to accord with what we find in the report of the Proceedings of the Grcat Western Railway Company, p. 27, for in this case when George Stephenson was asked: "You are the first person who suggested the using of locomotive engines, and applying them to the purposes to whieh they are now applied?" his answer was, "Yes." Evidently, then, Stephenson did claim priority in this matter. While there is a deeided probability that Hedley's elaim to priority is the stronger, we have not sufficient data to prove it conclusively. But the point to be emphasized is that Trevithiek was ahead of either of them. The claim of the latter inventor is substantiated also by Sir John Rennie, in his Autobiography, pp. 230, 232. He says (ibid., p. 233) that 'Trevithiek's prineiple had been forgotten by later experimenters. Stretton says that Trevithiek's prineiple of the adhesion of the wheels to the rails was apparently not understood at that time (A Feze Notes on Early Railway II istory, p. 6). See also Gordon, Our Home Railivays, p. 18. 
One of the most important of the eoal-roads, which was construeted after the traetion power of the locomotive had been demonstrated, was the Stoekton and Darlington; and as the history of this enterprise is instructive from several standpoints it is desirable that we should consider it minutely.

A protracted controversy had been taking place as to the easiest and most advantageous way of improving the earrying facilities from the Durham coalfield. In those times, Stoekton was the port of the river Tees, but the winding of the river from its mouth up to that town made the time required for sailing this distance sometimes as long as that oceupied in the journey from London to the Tees ${ }^{1}$. In the year 1805 it was deeided to shorten the ehannel of the river by a "cut" at Portrack, near Stockton; the Act for this purpose was passed in 1808, and by 1810 the work was eompleted by which that part of the river was shortened two miles'. In the same year began a movement for construeting a railway or canal from Stockton, by way of Darlington, to Winston, in order to provide a better outlet for the mineral and other traffie of South Durham and North Yorkshire. A committee in 1811 confirmed the great advantage of sueh a railway or canal, and reported this to a meeting of those desirous of promoting this undertaking, held at Darlington in the beginning of 1812. Those who were present at this meeting resolved to engage Rennic to make a survey before any further measures were taken ${ }^{3}$.

For some years there was diversity of opinion, some favouring a railway and some a canal; and this is not to be wondered at, for up to that time no loeomotive had been made that could attain a greater speed than four or five miles per hour, whereas steam navigation had many years before reached the rate of seven miles per hour ${ }^{4}$. Apparently, therefore, the railway offered no advantage over a eanal in the matter of speed. Nor was there yet any widespread or generally accepted idea in favour of making railways take the place of the stage coach for passenger travel. In the public mind, railways seemed to be designed ehiefly for the better and faster earriage of minerals and goods, and only a few saw the latent possibilities in the locomotive engine. Whatever the eause, this project was allowed to rest until in 1818 it was aetively revived by the advocates of the eanal. These

1 Pcase, Diaries of Edzeard Pease, p. 83.

2 Ibid., p. 83; Jeans, op. cit., p. 14.

3 .Jeans, op. cit., pp. 14-15; Pease, Diaries of Edzeard Pease. 1). 8:3-84. From Jeans has been obtained much of the historical account of this railway that is here given.

${ }^{4}$.Icans, op. cit., p. 15, quoting from John Willox, The steam Fled of Liverpool (1865). 
recommended that the contemplated canal, according to the suggestion of Rennie in 1813 and Whitworth in 1768, should begin at Stockton and take its course by way of Darlington to Winston, where, perhaps by the aid of a railway, it could secure a rich harvest from the coalfield. Or, if that were not deemed advisable, the end sought might be accomplished by the construetion of a railway at one-half the expense of a eanal; and according to Rennie's opinion the railway would be satisfactory in eases like this where the principal carriage must proceed from one end only ${ }^{1}$. The only result of this meeting was the appointment of a committee to investigate the comparative merits of the two schemes; but later in the year another meeting was held to consider the whole subject and at that time most of those who were present advoeated the adoption of a railway in preference to a canal. That meeting decided in favour of a railway, and drew up a prospectus showing the estimated cost and anticipated revenue from the railway, as well as its advantages to the country ${ }^{2}$.

The road had been surveyed by Overton, but as there was much doubt as to the best route and the probable cost Robert Stephenson was called in to report on the proposed line. His survey was not very satisfaetory to the committee that had the work in charge; and the latter, retaining Overton as engineer, proseeuted their work aecording to his directions. A Bill was brought into Parliament to secure the required authority for the construetion of the road; but the opposition offered, espeeially by some of the landowners, was so formidable that it became necessary to employ every means to coneiliate them, by the promoters using all authority and influenee they eould command in Parliament; and even then some of the most pertinaeious opponents, like Lord Darlington, remained implacable and the Bill was lost ${ }^{3}$.

But the eommittee that had the work in charge were undaunted by this defeat and it was determined to bring the measure before Parliament again in the next session. The former route lay through one of the Duke of Cleveland's fox-eovers, which, to the nobility of those days, were of greater importance than public highways; so it was agreed that a new survey should be made to get another route and the committee wisely decided to lose no time in conciliating opposition. After making this survey, Overton made a report to the directors on September 29, 1820. This report gave little that was new $^{4}$; and on the basis of that report the committee, in November,

1 Jeans, op. eit., pp. 16-17.

2 Pease, Diaries of Edreard Pease, p. 84; Jeans, op. eit., Pp. 23-24. Jeans gives the prospeetus on pp. 24-26.
3 Jeans, op. eit., pp. 28-31.
4 Jeans, op. cit., pp. 32-34. 
1820 , issued a manifesto showing the advantages of the railway in the conveyance of coal. They declared that everything had been done to conciliate those who hitherto opposed the railway and to avoid any injury to private property; that, because one horse on the railway could draw as much as ten on the common road, a vast reduction in the price of carriage would take place; that easier aceess to markets would be of great benefit to the farmers in enabling them to procure coal, as well as lime and manure for their land, while permitting them more conveniently to dispose of their surplus produce; that the commercial, mining and manufacturing interests would secure important benefits from the reduced rate of carriage for their respective products; and that the population at large would partake of beneficent results in the reduced price of fuel. In the matter of revenue it was shown that, from data already presented, there was reasonable expectation of the subscribers receiving fifteen per cent. a year, without anticipating any increased consumption, which was invariably the consequence of a reduced cost of conveyance. A very significant statement of the committee was to the effect that public opinion toward the railway had changed, as shown by the fact that there were very few who objected to the railway crossing their property ${ }^{1}$. Under these conditions application was again made to Parliament for a Bill in 1820; but on account of the circumstances due to the death of the King it was determined to defer proceedings until the session of 1820-21. For this second Bill, as for the first, they had to make a great fight, in which they were led by their Quaker promoter, Edward Pease, whose name is indissolubly associated with the Stockton and Darlington railway. "Every member of Parliament that could be influenced, directly or indirectly, was pressed into the service of the promoters. Every peer that was known to have any doubt or hesitation was seized upon and interviewed until he became a convert, while those who locked upon the measure with favour were confirmed in the faith. Nay, more, the promoters and their friends even carried their influence as far as the hustings, and spared neither trouble nor expense in endeavouring to secure--especially in the north of England-the return of candidates known to be partial to their eause?". This second Bill was passed in April, 18213.

After legislation had been seeured, George Stephenson was appointed engineer of the Stockton and Darlington railway. This first Act comprises sixty-seven closely printed pages, embodying the whole of the law relating to railways; it was the earliest and probably the longest

$$
\begin{aligned}
& 1 \text { Jeans, op. eit., pp. 31-35. } \\
& { }_{3}^{2} \text { Act } 1 \text { \& } 2 \text { Geo. IV, c. 44. }
\end{aligned}
$$


railway Act that received the sanction of Parliament. No mention was made of the employment of engines, for it was intended to work the line entirely by horse-power; although a general provision was made that the company should "appoint their roads and ways convenient for the hauling or drawing of waggons and other carriages passing upon the said railways or tramroads, with men or horses, or otherwise." The adoption of steam-power was, apparently, not seriously considered until the construction of the roadway was far advanced. Then Edward Pease went to Killingworth Colliery to see Stephenson's engine working, and from that time he had implicit faith in the locomotive engine. Through his influence the amended Stockton and Darlington Railway Act of 1823 gave the company authority to erect one stationary steam-engine in a suitable position and to make and use locomotives or movable engines for the conveyance of goods and passengers along the line ${ }^{1}$. In this there was a wide departure from the first Act, which said nothing about passenger traffic and made no mention of locomotives. According to the statute, the road was to be free to all persons who chose to place their waggons and horses upon it for the hauling of coal and merchandise, provided they paid the tolls fixed by the Act; and the gauge of the railway, four feet eight and one-half inches, was taken from the width of the road waggons.

On the success or failure of Stephenson's locomotive engines on this "Quaker line" very much depended; if failure, a check would be given to railway enterprise; if success, a new era would dawn which would show a complete revolution in the means of communication. The first cngine used on this railway was built by Stephenson; and in comparison with later results its performance was very modest. The best it could do was to travel at the rate of four to six miles per hour; and an engine and tender of fifteen tons could draw on a level nearly forty-eight tons gross load at the rate of five miles per hour ${ }^{2}$. Stationary engines were used for drawing the waggons up the incline. But even this result was enough to cause many a speculative mind to become enthusiastic over the prospects and to predict the time when high rates of speed would be attained. To them it seemed as if the vision were already within their grasp as a reality and they lost no occasion to communicate to the public, in glowing terms, the picture of the

1 Jeans, op. cit., p. 43; Pease, Diaries of Edrard Pease, pp. 85-87. This second Act was 4 Geo. IV, c. 33 .

2 Jeans, op. cit., pp. 53-54. On the early life and training of Stephenson, see Autobiography of Sir John Remie, p. 235 et seq.; also the life of Stephenson in Smiles' Lives of the Engineers, which gives full details. 
near future. Concerning railroads and other speculative schemes of that day, Lord Eldon said that Englishmen, who were wont to be sober, had grown mad; and to aid in forming a more reasonable view, Nicholas Wood, who was recognized as an expert in railway affairs, declared: "It is far from my wish to promulgate to the world that the ridiculous expectations, or rather professions, of the enthusiastic speculist will be realized, and that we shall see them travelling at the rate of twelve, sixteen, eighteen, or twenty miles an hour. Nothing could do more harm towards their adoption or general improvement than the promulgation of such nonsense ${ }^{1}$."

But people did not have to wait long before they found that some of the dreams of the enthusiasts were already accomplished facts. On Sept. 27, 1825, when the railway was opened amid great demonstration of splendour ${ }^{2}$, it was shown that, on an incline, one engine could draw a whole train, with a weight of at least eighty tons, at the rate of ten to fifteen miles per hour ${ }^{3}$. The success of the railway was immediate but not startling ${ }^{4}$; and soon the line was extended back to Witton Park Colliery, about 125 miles from Stockton, so that Darlington was just about half-way along the line. In 1827, the first year in which the coal and merchandise traffic was fully worked, the revenuc from coal was $£ 14,455$, while the receipts from lime, merchandise and sundries was only £3285. The chief source of revenue was the coal, the tolls on which in 1830 were six or seven times the amount of revenue derived from all other sources combined ${ }^{5}$. Both in the amount of revenue that accrued to the company and the speed at which the traffic was carried, it was evident that this line of road was a paying investment.

The Stockton and Darlington promoters did not at first count upon any revenue worth speaking of from passengers. Between these two places there was only one coach, which went three or four times a week,

1 Jeans, op. cit., p. 66.

2 Concerning the opening, see Pease, Diaries of Edward Pease, p. 88; Nervcastle Courant, Oct. 1, 1825, which gives an account of that great occasion. Smiles, Lives of the Engineers, III, pt. 2, ch. viii, gives an extremely interesting account of the arrangements for this railway. Tweddell's History of the Stockton and Darlington Raitray was well intended, but it does not get far enough to even touch the subject of which it proposed to treat.

3 .Jeans, op. cit.. p. 70 .

4 The success of the railway is shown in a statement signed by S. P. (probably Samuel Pease, one of the directors of the railway), showing the facts for the railway as on Mar. 23, 1829 (Collection of Prospectuses, etc., pp. 121-4). Note also Remarks upon Pamphlet by Inzestigator on the Proposed Birmingham and London Railzeay, p. 4 , showing that by 1831 the shares of the company had risen in value from $\$ 100$ to $\$ 200$ each.

5 Booth, II istory of the Liverpool and Manchester Railivay, p. 2. 
on the turnpike road; and the amount of passenger travel scarcely paid a reasonable profit to the coach proprietor. Nor was there much likelihood that there would be any increase of passenger traffic on the rail unless greater speed could be developed in order to encourage the desire to travel. The railway made no special provision for this aspect of the business. It was originally intended to allow proprietors of stage coaches or other vehicles to use the line under ccrtain specified conditions for the conveyance of passengers, and on similar terms to allow carriers to make use of the line for the carriage of goods, so that both these phases of enterprise might be carried on independently of the railway company. After the railway had been opened two weeks, the company put on a coach of their own for the conveyance of passengers ${ }^{1}$; but shortly alter, a contract was made with Pickersgill, who leased the railway company's coach and operated it on the railway. Up to 1830 the two or three coach proprietors on the line carried on the passenger and merchandise business; they used horses to draw the coaches along the line, paying the tolls for the use of the line and receiving the amounts paid for these services ${ }^{2}$. They seem to have had their own way, in large measure, as to regulating hours and traffic; and it appears certain that their arrangements must have clashed, for on Jan. 22, 1830, the company began to regulate the times of arrival and departure at each end so as to give them equality of advantages ${ }^{3}$. The early organization of the passenger and goods traffic on the line shows us, then, several coach proprietors each of whom took out a licence for himself and paid his tax to the state, but gave no account to the railway company except the total number of journeys each coach had made per month, on the basis of which they paid the company for the use of the line. Anyone was at liberty to put his horse and carriage on the railway and draw for himself or others, provided he complied with the company's by-laws. The growth of the passenger traffic was slow, for before 1832 the number of passengers travelling between Stockton and Darlington did not average more than 520 per week ${ }^{4}$, although the number of coaches had increased from two or three in 1830 to seven in $1832^{5}$. About 1833, the company found that, instead of having so many different interests

1 Jeans, op. cit., p. 81, gives in full their hand-bill concerning the passenger service. This is also given in Layson, Life of George Stephenson, p. 93, advertising the passenger coach between Stockton and Darlington. It gives the times of departure and arrival at each place along the line for cach day of the week. It is interesting as the first railway passenger time-table.

2 Jeans, op. cit., pp. 81-82; Booth, History of the Liverpool and Manchester Railzeay, p. 2.

3 Jeans, op. cit., p. 84.

4 Details are given in Jeans, op. cit., pp. 85-86. $\quad 5$ Ibid., pp. 84, 86. 


\section{vII] Organization of Carriage on Early Railways}

represented on their line, it would be more convenient and advantageous if they should take the whole carrying trade into their own hands and displaee horses by steam-power ${ }^{1}$. The respeetive interests of the different proprietors were acquired by purehase and arrangements were made for more eomfortable and speedy carriage of passengers; and on April 7, 1834, the company announced that they had eommeneed to run eoaehes and carriages by locomotives for the eonveyanee of passengers and goods between Stockton and Middlesborough "six times per day at present fares, thus forming a regular line of communication via Stoekton and Darlington with Shildon, Auekland," ete. ${ }^{2}$

We have given somewhat fully the eonditions regarding the operation of this railway, to show the way in whieh the carrying trade was organized on it, for, since this line was an intermediate between the colliery roads and the modern railway designed for both passenger and freight carriage, it is instruetive to see the steps through whieh the orderly process of development has taken place. It will help us to appreciate the circumstances under which the enterprise was carried on if we picture to ourselves what two noted railway engineers observed on this road in 1829; between Stockton and Darlington there were several locomotive engines of different forms and power and horses also were employed upon the same part of the line; while, toward the upper end of it, there were two inelined planes with stationary engines ${ }^{3}$. When the declivity was such that the waggons would run down without the horse drawing, the animal was detaehed and took his place in his own carriage behind the train of waggons until his services were again required ${ }^{4}$. With this aggregation of the different kinds of power in

1 Competition among the rival coacli proprietors using the single line of roadway led to confusion and eollisions among them; their merehandise trains sometimes got so heavily loaded that they had to be helped by the locomotive engine in order that other traffic might not be held up or delayed. This method, of eourse, was simply carrying out the same conditions that existed in the carrying tradc on the canals. Even before the railway was opened, the eommittee in charge of the work, after careful investigation, had declared that it would "greatly eonduce to the interest of the company that they should become the prineipal carriers on the line." They had been asked by a certain individual for permission to use his locomotive engine on the railway, but the eommittee thought that it would be improper to grant this applieation (Jeans, op. cit., p. (63).

2 Jeans, op. eit., pp. $87-89$.

3 Walker and Rastrick, Report to the Direetors of the Liverpool and Manchester Railway, on the Comparative Merits of Loco-motive and Fixed Engines, as a Moving Power, p. 3. On the application of stationary engines on some railroads, sec Wood, Practical T'reatise on Railroads, pp. 110-23.

${ }^{4}$ Macturk, IIistory of Railways into IInll, p. 29, quoting from Walker's observations eoneerning the operation of the Stockton and Darlington Railway. 
use upon the line, together with the facts already noted in regard to the diversity of interests in the passenger and merchandise traffic, we can see how difficult it would be to maintain harmony among the different carriers and to fix the responsibility for any breach of the company's regulations or any misuse of its property.

From our present-day standpoint, we would imagine that the question as to whether locomotive engines should be employed, or whether horse power should be used for traction purposes, could be easily settled; but it does not seem that the former was immediately accepted as the motive power that was soon to displace all other. Even after the Liverpool and Manchester Railway had been in full operation for some years and the utility of the locomotive engine had been completely demonstrated, there were still those, and some of them engineers, who clung tenaciously to the idea that, under certain conditions, horses or stationary engines might be profitably employed. In 1833 when the agitation was going on for a railway to connect London with the west, one writer urged the employment of horses because they would be more eeonomical than steam power ${ }^{1}$. In 1825 when George Stephenson had surveyed the line of the proposed Leeds and Selby Railway, he recommended three inclined planes for part of the line and loeomotive engines for the rest ${ }^{2}$; but as the committee in charge of the work did not agree with him they asked James Walker, another famous railway engineer, to make another survey. He opposed the use of stationary engines recommended by Stephenson; but said that, if the road as then designed were to be constructed, he would favour the employment of horses, as on the Stockton and Darlington, instead of stationary engines. If they were used, the inclination from Leeds toward Selby was such that the horse might ride six to seven miles, in the proposed distance of about thirty miles, and in the opposite direction it might ride about three miles. Walker's report seems to imply that the committee had decided to use horses on the railway ${ }^{3}$; to this he agreed if speed were not desired; but, taking everything into consideration, he strongly favoured the uniform level, without inclined planes, and the employment of locomotive engines upon it ${ }^{4}$. His

1 Bristol Mercury, Oct. 5, 1833, p. 4, letter of "A Well Wisher."

2 Macturk, History of the IIull Raikeays, pp. 18-32.

3 Ibid., pp. 18-32, gives in full Walker's report to the committee of the proposed Leeds and Selby Railway Co.

4 Walker said that on the Darlington line the horse-power amounted to about one halfpenny per ton per mile on the coal conveyed down to Stockton, and, all things considered, the cost of hauling by locomotives was not less; but at the rate of eight or ten miles per hour the engine-power would be very much cheaper if there were enough traffic to form full loads for the engines. Macturk, op. cit., p. 32. 
calculations, however, were made with a view to the use of rails that would be strong enough to support locomotive engines, although he expected that at first horse-power chicfly would be used. It is evident, therefore, that public attention did not turn away immcdiatcly and entirely from the time-honoured motive power as soon as the locomotive engine had demonstrated its possibilities.

From the results that had been accomplished on the coal-roads, it was apparent that the ultimate triumph of steam locomotion on rails was certain; but the efforts toward its actual realization did not wait until the success of the Stockton and Darlington had been shown. In the meantime, other roads were in process of construction, such as the Moreton and the Liverpool and Manchester; and here, too, the decision had been made in favour of the employment of locomotive engines ${ }^{1}$. When, therefore, it was obvious, beyond all doubt, that it was practicable to use the locomotive engine for hauling heavy loads on rails, the canal proprietors found that their waterways had a powerful rival in bidding for traffic; and in the decade beginning with 1820, when the railway propaganda was being vigorously pushed, a very active discussion was going on as to the relative merits of steam railways, canals and turnpike roads. Such periods of change, when the social and industrial world must be adapted to some new development in commercial life, necessarily elicit much controversy and bring to light the underlying current of public thought in regard to existing conditions and proposed improvements. Under the circumstances, during the above decade, one of the great questions was as to the relative importance of the railways and the canals, since it was the competition between these two agencies that was likely to produce the most pronounced effects. It may help us to understand the situation more perfectly, therefore, if we can sce the way in which the friends of each regarded them just at the time before the railway came to assume such great importance.

One of the great reasons put forward for the construction of railways was the reduced cost of carriage that would thereby ensue. In many cases a considerable part of the prices of articles of necessity consisted of the cost of transporting them from producer to consumer, and therefore it was recognized that every saving in this cost would produce a corresponding reduction in the prices of the articles. The decreased cost of commodities would redound to the benefit of the consumer, by giving him command over a larger supply of the necessaries of life, and this larger supply at lower prices would stimulate consumption, both at home and abroad. The inereased consumption would, in turn, call for

1 Cumming, Rail and Tram Roads, p. 33. 
increased production of both manufactured and agricultural products; and so the whole fabrie of rural and urban industry would be strengthened and developed ${ }^{I}$. In addition to seeuring their food supplies eheaper, they would also be able to obtain a cheaper and more regular supply of eoal. During severe frosts, when the canals were frozen for some weeks, the price of eoal sometimes went up to exorbitant figures and even the supply was inadequate to the need; but during the most inelement weather the railroad would be able to eontinue the bringing of the usual amount of this much needed article the same as at other times, so that the possibility of scarcity or high prices would not cause any alarm². The same thing applies with regard to the provision of abundant supplies of coal and other raw materials for manufacturing; and the eities that eould draw upon wider and wider arcas for these neeessaries of manufacture would flourish all the more abundantly ${ }^{3}$. What was true of the necessity of regularity and certainty, as well as eheapness, in supplying eonsumption goods was equally true in regard to goods intended for export; if the goods did not reach port from the interior in time for the sailing dates of the vessels the shipper lost the orders and the shipowner the amount of the freight. This was no infrequent oeeurrenee. But eheapness of carriage, in addition to benefiting eonsumers, would be equally profitable to producers, both in industry and agriculture. By reducing the cost of transport there would remain to the producer a greater surphus to reward his labour; lands more distant from markets could be eultivated beeause of being more nearly on a parity with those nearer the markets, and in this way also the margin of eultivation could be extended; land that had hitherto lain waste could now become productive, and, therefore, while there would be much inerease in the food supplies of the country, there would also be a larger return to the landlords as well as to the farmers. By making possible the application of more eapital to traets already under eultivation and increasing the

1 Cundy, Inland Transit, 2nd ed. (1834), pp. 19-21; Godwin, An Appeal to the Public on the subject of Railways, pp. 8-18; The Times, Mar. 16, 1836, p. 7 .

2 Manchester Guardian, Jan. 1, 1831, p. 4, letter from "W. N. R." on the "Liverpool and Leeds Railway;" ibid., Jan. 29, 1831, p. 1, prospectus or "report" on the Manchester and Leeds Railway: Mudge, Observations on Railways, p. 2.

3 Manchester Guardian, Jan. 29, 1881, p. 1; The Times, Oct. 28, 1837, p. 3, on the first general meeting of the Sheffield and Nanchester Railway; Sheffield Iris, July 29, 1834, p. 2, on the "New Railroad ;" ibid., Oct. 7, 1834, p. 1, prospectus of the proposed railway from Sheffield to Rotherham.

4 London and Birmingham Railway Bill. Extracts from Minutes of Evidence given before the Committee of the Lords on this Bill, pp. 1-12, evidence of Messrs Barry, Hemsley, Barnes, Dillon, Mason, Moore; Mudge, Observations on Railiays, p. 3 . 
extent of tillable land, the population of the kingdom would be provided with a more ample and less expensive food supply and the amount of labour would be incrcased, thus reducing the poor rates ${ }^{1}$. The extension of the markets for the product of any section would tend to maintain uniformity of price, so that the farmer would not be subjected to the occasional alternations of over-abundance and scarcity and the price fluctuations which accompanied such changes. The more equal distribution of goods throughout the country would result in benefit to the consumer also, by making his food cheaper and less precarious. What we have said as to the prospective advantages to the consumers and producers of agricultural produce applicd with equal force in the case of manufactured products; to maintain and enlarge both the home and the foreign market, the articles supplied must be cheaper and better than could be produced elsewhere, and that necessitated cheaper communication and facility in executing orders. The opening up of new and larger markets would infuse a new spirit into industry as well as agriculture, and the material resources of the realm would no longer lie waste ${ }^{2}$.

Increased speed in the conveyance of passengers and goods was another great desideratum which was anticipated as the outcome of the introduction of railways. As a consequence of this, both producers and consumers expected that new and morc distant markets would be opened for commodities of a perishable nature, such as vegetables, dairy produce and meat. In order that these should be most successfully marketed they would have to be sent as quickly as possible from the producer to the consumer; and as the railway speed would be six or seven times as great as that of the carts or waggons the railway would cause the area of production of these things to be thirty-six to forty-nine times greater than its present extent ${ }^{3}$. Butter, cream, vegetables and similar commodities would not stand transportation by the slow-going canal or road-waggon, and, therefore, were confined to the markets at a very limited distance from the grower or feeder;

1 Cundy, Inland Transit, 2nd ed. (1834), pp. 19-20; Cundy, Observations on Railways, 2nd ed. (1835), pp. 23-24; Manchester Guardian, Jan. 1, 1831, p. 4, letter from “W. N. R.;" Mudge, Observations on Railways, p. 3.

2 Ilerepath's Railway Magazine, N.S., I, pp. 96-100, "A Few Words on Railways," by "Delta." He said that the cost of conveyance in the case of coal was a large element of the price; that coal was sold at the pit's mouth for five to ten shillings per ton. and at the distance of fourtcen miles it cost double that amount, so that for lack of cheap transportation facilities the natural resources of the country were lying waste. He regarded this as an unanswerable argument for railroads.

3 Cundy, Observations on Railways, 2nd ed. (1835), pp. 21-23; Cundy, Inland Transit, 2nd ed. (1834), pp. 22-23. 
but with the faster conveyance by rail they would secure an enlarged market that would make them profitable for production. Similar conditions would enlarge the area for the remunerative rearing of animals to provide the meat supply of the large centres. Before the railway, if animals were transported alive from the growers to the consumers' market, the market was limited by the power of the animals to travel and the cost of their support on the road; or if they had to be carried by waggons the cost was still greater by reason of the added expense of horses and waggons. But, by the railway, lambs, calves and other animals could be sent easily and cheaply to the metropolitan markets to meet the requirements of these large centres. In this way the urban population would be able to draw upon wider and wider sources of supply and thus eliminate any peculiarities of local conditions; while the rural producers would find a more extended market for their surplus and a more stable equilibrium of prices and of demand ${ }^{1}$. The improvement of the marketing would enhance the value of the land which produced these things, and so both the tenant and the owner would derive advantage from being made independent of merely local circumstances. Along with accelerated speed in the conveyance of agricultural and industrial products, there would be a similar advance in the rate of passenger travel. Towns under existing conditions some stages distant from London or other large city would become its suburbs; men cloing business in the greater centres would be able to reside at considerable distances from the places of their employment, and thus not only enjoy a more healthful environment for themselves but also help to prevent the overcrowding of population within confined $\operatorname{areas}^{2}$; and time that had been spent on the slow journeys of the coaches could now be saved, in great measure, and devoted to remunerative employment. This saving of time that would accompany the frequency of communication between places of great commercial intcrcourse would be a considerable economy in enabling them to expedite the transaction

1 Cundy, Iuland Transit, p. 23; London and Birmingham Raikway Bill. Extracts from the Mimutes of Evidence given before the Lords Committee, pp. 13-21, evidence of Messrs Warner, Whitworth, Sharp, Attenborough, and Kay; The Times, Mar. 16, 1836, p. 7, concerning the South Eastern Railway; Macturk, History of Railways into Iull, p. 44, original prospectus of the Hull and Selby Railway; Boyle, Hope for the Canals, p. 19; Hampshire Adiertiser and Salisbury Guardian, Mar. 29, 1834, p. 2, on the "Southampton Railway;" Parkes, Claim of the Subscribers, pp. 4-17.

2 Cundy, Inland Transit, p. 24. A notable instance of this is observed to-day when we see business men, who carry on thcir occupation in smoke-begrimed Glasgow, going to and from their residences in the royal city of Edinburgh. On the saving of time and expense in travelling, see London and Birmingham Railway Bill. Extracts from the Minutes of Evidence given before the Lords Committee, pp. 22-24, evidence of Messrs Mason and Cheetham. 
of business both by personal visits and through the medium of correspondence ${ }^{1}$. Then, too, in the transportation of troops and of military and naval supplies the railway would be of vast importance over the former slow and expensive means of conveyance ${ }^{2}$.

Railways were desired also because they would bring increased facilities and introduce certainty and regularity of conveyance. The lack of accommodation and equipment on the part of the canal companies was, in some instances, notorious, especially on the routes conneeting the great industrial and distributing markets, like Manehester, Liverpool, Birmingham and London ${ }^{3}$. The inadequaey of the canals between Manchester and Leeds for the eonveyance of general merchandise was so strongly felt that even with the earriage of a large part of the traffic by waggons the need for a railway was keenly appreciated ${ }^{4}$. But, supposing the carrying faeilities of a canal chain to be sufficient for all ordinary purposes, there were other elements which affected the desirable uniformity of the flow of traffic. The droughts of summer or the frosts of winter frequently eaused delays of several weeks; and these were attended with serious results to those who were affected to the greatest extent by them ${ }^{5}$. The eessation of trade on a eanal that served a particular town would, at times, cause the price of coal to increase as much as 100 per eent., on account of the seareity of that commodity at that special time. ${ }^{6}$. Exporters who were depending upon goods from the interior reaching the port by a eertain sailing day were sometimes disappointed, and the goods, when delivered, were rejected beeause out of time. Orders were frequently lost because the goods could not be

1 Cundy, Observations on Railieays, 2nd ed. (1835), pp. 29-32.

2 This was especially emphasized in the case of the London and Southampton Railway. See summary of evidence on this railway Bill in IIampshire Advertiscr and Salisbury Guardian, Mar. 29, 1834, p. 2.

${ }^{3}$ To each of these we shall refer in more detail when we come to consider the railways connecting these places.

4 Manchester Guardian, Jan. 29, 1831, p. 1, prospectus of the Manchester and Leeds Railway.

5 Manchester Guardian, Jan. 29, 1831, p. 1, prospectus of the Manchester and Leeds Railway; Sandars' pamphlet on the Liverpool and Manehester Railway; Parkes, Claim of the Subseribers to the Birmingham and Liverpool Railroad, pp. 46-51; Brit. Mus. 8223. e. 10 (70), 'Prospectus of Kentish Railway Company,' 'Prospectus of the Birmingham and Liverpool Rail Road Company;' Brit. Mus. 8223. e. 10 (149), 'Prospectus of the Taunton Great Western Railroad;' Vallance, Sinking Capital in Railways, p. 9; Macturk, IIistory of Railways into IIull, pp. 48-41.

6 Hamchester Gasette, Jan. 1, 1831, p. .4, letter from "W. N. R." refers to the fact that in .January and February 1830, the canals were frozen for some weeks, and during that time "the price of coals in Liverpool rose, in many instances, npwards of onc hmored per cent.," and the daily demand for the town was more than the supply. 
got to the seaport in time for shipment by certain vessels ${ }^{1}$. All such vexations would be avoided by having railways upon which to carry the goods and the public thought turned to the desirability of this new aecession to the agencies of conveyance. Furthermore, many of the canals took a circuitous route, which added grcatly to the length of the journey; and while this cnabled them to get access to all those places that would be likely to have most traffic to offer, it was very inconvenient for those who wished the transport of their goods with the least possible delay.

Another prospective advantage of railways was that there would be a saving in the amount of capital required to be invested in business. It was expected that capital would not need to be locked up in warehouses where individual merchants had to keep on hand large supplies of stock because of the uneertainty and difficulty of renewing their supply. Under the cxisting circunstances, for example, coal was unable to stand the expense of land carriage, and so every dealer had to lay in an immense stock before winter, lest the canals should freeze, and before summer, lest they should be deficient in water supply. To remunerate the extra capital that was thus unproductively tied up something had to be added to the price of the coal. But it was a foregone conclusion that the railway would be able to operate without reference to these accidents of time or season, so as to bring a uniform supply throughout the year; and, therefore, dealers would not need to have a large capital lying barren for months at a time. The retail merchants of the country could go or send to London in the morning and have their purchases in the evening; this would obviate the necessity of their keeping an expensive and redundant stock, and in their eountry establishments, which would cost less than in the town, they would be enabled to enter advantageously into competition with the London dealers ${ }^{2}$.

The coming of the railway was eagerly awaited in other cases because it was thought that this would emaneipate the people from the thraldom of a canal monopoly that had beeome oppressive, sometimes almost beyond endurance. The canals between London and the Midland metropolis long cnjoyed a monopoly and reimbursed their capital with

1 London and Birmingham Railway Bill. Extracts from the Minutes of Evidence given before the Lords Committee, pp. 6-11, evidence of Messrs Barnes, Dillon, Mason, Moore and Westall. Sometimes when there was an insistent demand for the goods by a eertain time the dealer paid the heavy eost of land carriage, rather than depend upon the slow movement of freight by water.

${ }^{2}$ Cundy, Observations on Railways, 2nd ed. (1835), p. 50; Mudge, Observations on Railways, p. 2; Shaen, Revierv of Railways and Raitway Lcgislation, p. 33; The Times, Mar. 16, 1836, p. 7, on the "South Eastern Railway." 
great profit; and one of the objects of projecting a railway to connect these two places was to get rid of the high charges which the canals continued to impose'. Among the chief reasons for the construction of the proposed railway between Sheffield and Rotherham, in 1834, was the desire to break down the monopoly in coal that then existed, and to supply these cities, especially the former, with coal brought from greater distance. The unfortunate condition of the navigation along this six and one-half miles, particularly of the Sheffield and Tinsley Canal, precluded all hope of reduction of eharges on this waterway; and the people turned to the proposed railway as the only means of affording relief ${ }^{2}$. The conditions in the county of Monmouth at the time the plan was formed for a railway from Newport, through Pontypool, to Blaen Avon and Nant-y-glo, exemplify a situation which called loudly for and warranted the construction of the railway along this valley. The carrying traffic of the extensive mineral country there was almost monopolized by "The Company of Proprietors of the Monmouthshire Canal Navigation," which had been incorporated in $1792^{3}$ and had been given most arbitrary powers for making canals and railways. Its Act exempted the tolls receivable by the company from the payment of any rates, and the lands purchased by them were to be rated at their original, not their improved value. Within a few years the company had completed two lines of canal, one from Newport to a little above Pontypool, and the other from Newport through another valley to Crumlin. From these canals a variety of ill-constructed railways and tramways had been made in order to open communication with new works. For lack of water the Crumlin branch could not be operated, and necessity compelled the construction of a tramroad which almost superseded the canal. The other branch of the canal, because of the numerous locks and continual impediments and cessation from one cause and another, was almost uscless ${ }^{4}$. Yet notwithstanding the unsatisfactory state of their works, the company charged such exorbitant rates and provided such poor facilities that many of the iron-masters of that section preferred to send their products

${ }^{1}$ Birmingham Joumal, Feb. 5, 1831, p. 3, letter from "A Subseriber to the London and Birmingham Railway."

2 Sheffield Iris, Oet. 7, 1831, p. 1, 'Prospeetus of the Proposed Railway from Sheffield to Rotherham.

3 Aet :32 Geo. III, c. 102.

4 Blewitt, New Monmouthshire Railway, p. 6, informs us that, in 18.4, a boat from the Pontypool works could make only five journeys in a fortnight between that town and Newport, a distanee of not over ten miles; and coal taken down the canal about five and one-half miles did not, on the average, reach Newport in less than eight hours. 
around by a more circuitous route, sometimes at great expense, than to utilize this shorter waterway ${ }^{1}$. Then, too, the iron-masters of Merthyr, by means of the Taff Vale Railway, were able to send down and ship their iron from Cardiff, in first-class condition, without rust, just as it came from the rolling mills. This led to the desire for a better quality of material among the iron merchants of Liverpool and elsewhere; and they demurred to receive iron from the Monmouthshire district which, on account of having been so long on the eanal and waiting so long at the doeks at Newport, exposed to air, had become badly rusted ${ }^{2}$. Cardiff, the adjoining port and great rival of Newport in the iron trade, had always had the advantage of lower rates by canal, and, after the construction of the Taff Vale Railway, its trade had markedly increased ${ }^{3}$. From the foregoing facts we can judge how oppressive was the Monmouthshire Canal Company's monopoly upon the iron-masters of that portion of the country, and with what eagerness the industrial community contemplated, and actively set to work to seeure, the advantages of a railway ${ }^{4}$. But the greatest canal monopolies, from which release was earnestly sought by the projecting of railways, were probably those between Liverpool and Manchester and between Liverpool and Birmingham : these we shall consider in detail when we come to diseuss the formation of railway lines along these routes ${ }^{5}$.

1 Blewitt, Nero Monmouthshire Railway, pp. 7-9. The Ebbw Vale Iron Works had made, at their own expense, a tumnel a mile long, to communicate with the Sirhowy Tramroad, by which their iron reached Newport much cheaper, although the route was four miles longer. 'The Bailey Iron Works bronght their iron from Beaufort to Nant-y-glo by a tunnel about a mile long, at the end of which it was raised by a water balance, and then sent via Abergavenny to Newport, 31 miles, though the canal company's road was convenient to their works and the distance by that route to Newport was only 22 miles. The greater part of the Blaen Avon iron was sent at heavy cost, via Abergavenny, to Newport, about 28 miles, when by the canal routc it was only about 16 miles.

2 Ibid., pp. 7-8.

3 Ibid., p. 10. In 1829 the amoumt of coal sent to Cardiff was only about one-sixth of that sent to Newport; while in 1840 the amount sent to Cardiff was more than one-half of that sent to Newport.

4 The canal company had turned a deaf car to all complaints of the traders, as to the excessive charges, bad construction and indifferent repair of their canals and tramroads, until the wholesome fear of threatened competition compelled them to take the first step toward amelioration by reducing their tonnage rates on iron and coal (ibid., pp. 12-14).

5 On the canal monopoly between Liverpool and Manchester, see Sandars' pamphlet on the Liverpool and Manchester Railway, and The Times, April $\mathbf{7 , 1 8 2 6}$, p. 2, on the Liverpool and Manchester Railway Bill in the House of Commons. On the conditions that prevailed between Liverpool and Birmingham, see Parkes, Claim of the Subscribcrs to the Birmingham and Liverpool Railroad. 
Of the other reasons which were given as incentives to railway construction we shall give but brief mention, because they did not assume such importance in the estimation of the public. Railways were urged by some because it was thought that they would reduee the number of horses required for the transportation service, and that land which had been devoted to the keeping of horses for the carriage of freight and passengers along the highways could now be used for growing food supplies for the families of the kingdom. Adam Smith had said that to support each horse required, on the average, as much land as would support eight men; and if there were, as was estimated, over $\mathbf{1 , 0 0 0 , 0 0 0}$ horses engaged on the roads, the land required to provide for them would be able to support an additional 8,000,000 people, or else it would largely increase the means of subsistence of the existing population ${ }^{1}$. This same argument was used, as we have seen, in favour of the canals when their introduction was the subject of public interest; but in neither case did the contemplated decrease of horses employed on the highways materialize, for increasing facilitics of conveyance brought an increasing demand for horses in collecting and distributing traffic ${ }^{2}$. Another circumstance favourable to the new means of conveyance was that the introduction of the railway would furnish a more efficient method of handling large quantities of freight than was possible on the canals. In the ports of the north of England from which coal was shipped machinery was used for lifting a loaded car and suspending it over the hold of the vessel, after which the bottom of the car was displaced and the coal was allowed to fall easily into the vessel. But no such service was possible with eanal barges and so the cost of unloading them was much greater. Of course, this system was not known until after the tramways were found in effective operation ${ }^{3}$. Of other inducements for the formation of railways, there was the expectation that thereby the pilfering from canal barges, which in some cases seems to have been an organized business systematically pursued, would be for ever abolished ${ }^{4}$; the ordinary roads would be greatly relieved of the transport of coal, lime and other heavy articles, so that the expense of their maintenance would be much less than under

1 Cundy, Inland Transit, 2nd ed. (1834), pp. 20-21; Bristol Mercury, Sept. 1, 1832 , p. 2, letter from "J. O." Suppose the coaches on the road from London to Edinburgh changed horses twenty-five times; that would require one hindred horses for one journey of each coach, besides the supernumerary ones kept in ease of aceident. But the work of a great many coaches might be performed by the expense of one steam-engine and this would result in great ceonomy.

2 Cundy, Inland Transit, 2nd ed. (1834), p. 21 ; Cundy, Observations on Railways, 2nd ed. (1835), p. 47.

3 Blewitt, New Monmouthshire Railway, p. 11.4 Ibid., pp. 9-10.

J. T. II. 
existing eonditions; and, in faet, no limit could be assigned to the wealth that would be saved and the inerease of wealth that would be produeed by this ehange in inland conveyance.

In contrast to the elaims made for the railways, those made for the eanals seem decidedly laeking in many features of eeonomie significance. The two enterprises were entirely different in eharaeter. The railway had an air of parade and display that dazzled and tended to deceive the superfieial observer. Its general aspeet was that of vitality, energy and efficieney: the large trains, their promptitude of arrival and departure and the speed of the engines were all subjeets of admiration, and stood out in great relief when viewed alongside the quiet, unseen canal and its slowly plodding barges. In consequenee of this there were few who ventured to lift up their voiees in favour of the eanals as an effective competitor of the railways. There were, indeed, some who, despite the unfortunate system of construetion and maintenance of the canals, argued in favour of them and urged their claim from the standpoint of cheapness and faeility of earriage. For example, a writer, in $\mathbf{1 8 2 5}$, after showing the relative advantages of rivers and eanals in the matter of ease and specd of earriage, finally eoneluded that, at a given rate of speed, a horse could move four times the weight on a canal or river that he eould on a railroad ${ }^{x}$. Others who looked into this subjeet carefully and with seientifie precision were convineed that, up to a certain low rate of specd, a horse could draw more on a canal than on the railway; but this rate of traction was so mueh less than what was possible on the rails that the waterway would be thought of only in eonnexion with the conveyance of commodities for the carriage of which speed was of little aeeount ${ }^{2}$. Occasionally, other reasons were addueed to prove that railways were inferior to canals as means for the earriage of freight ${ }^{3}$;

1 Brit. Mus. 08,235. f. 77, 'Observations on the Comparative Merits of Inland Navigations and Railroads,' pp. 22-23.

2 Wood, Practical Treatise on Railroads (1825), p. 157 et seq., and Thomas Tredgold on Railroads.

3 Brit. Mus. 08,235. f. 77 , 'Observations on the Comparative Merits of Inland Navigations and Railroads,' pp. 28-38, gives arguments against the locomotive and in favour of canals; and the writer finally says: "But I certainly think sufficient proofs appear, that in competition with a long line of canal or river navigation, enjoying a gencral trade, and affording the means of free and open competition, any project of a railroad would prove ruinous to the adventurers, and useless to the public" (p. 43). To the same effect were the words of another in 1832, after the Liverpool and Manchester Railway had been in operation for two years. He showed that for passenger traftic the railway was superior to any other mode of travelling; but, in regard to the freight traftic, his conelusion was that, mile for mile, goods were not earried so cheaply on the Liverpool and Manchester Railway as on the great lines of canals, and could neither remunerate the carrier as to his 
but the number of people who laid any cmphasis upon this possible outcome of the competition seemed to be very small.

The facts appear to indicate that the canal companies, instead of becoming morc active and endeavouring to secure more of the traffic in the field which was now being invaded by a rival, usually acted on the defensive in trying to protect their alleged rights ${ }^{1}$. The great argument put forth by those who favoured the canals was the constant plea of vested interests: that Parliament had, by statutory provision, authorized the construction of and investment in canals, and, therefore, nothing should be done to destroy such facilities, under which the trade of the country was said to be flourishing ${ }^{2}$. Canal property, in many cases. was the only basis of seeurity for wills, settlements and family incomes; and to destroy them would ruin thousands of familics. If the canal were not sufficient for the increased traffic, why should the canal companies not be allowed to enlarge their works to meet the needs of an expanding commerce ${ }^{3}$ To interfere with private property was to overthrow the stability which was fundamental to social life and the protection which the individual might justly claim from the government; and this appeal of protection to individual rights seldom failed of response when addressed to any class of the English people ${ }^{4}$. In

freight nor the proprietor as to his tolls in the same manner as eanals did (P., Letter to a Friend, containing Observations on the Comparative Merits of Canals and Railways, pp. 2, 3, 8). His inference was "that the level railway 30 miles long between Liverpool and Manehester eannot put down two navigations, between the same points the first of which is fifty and the other forty-five miles long" (ibir., pp. 12-13); and in this opinion he seems to have been entirely sineere, sinee his pamphlet shows the utmost candour in giving the railway its full share of praise. See also Birmingham Journal, Mar. 5, 1831, p. 3, "On Railways."

1 There were, of eourse, some exceptions to this. At Manchester, for example, in 1825, the aetivity of the railroads in earrying on their plans exeited the feeling of eompetition among the proprietors of inland navigation; and the latter (ealled the fourth estate of the realm, beeause of their immense parliamentary interest) determined to prove that the speed on inland navigation was mueh greater than it had been represented. To establish their point, a flat left Nanehester on the Mersey and Irwell Navigation in the morning and reaehed Liverpool by one o'elock. There she loaded a full load of cotton and started back for Manchester whieh was reached at 10.30 that night. This was repeated the following day (Manchester Gazette, Jan. 15, 1825, p. 3, on "Effeet of Competition"). It is possible that sueh sporadic attempts as this were found elsewhere; but that does not disprove the statement we have made.

2 Hansard's Parliamentary Debates, N.S., xiI (1825), pp. 845-9; ibid., xv (1826), pp. 89 ff.; Brit. Mus. T. 1371 (18), pp. 9-11.

3 "J. C." in Gentleman's Magazine, xcv, Pt. 1, pp. 113-15, showing the "advan" tages of canals over railways."

4 Hansard's Parliamentary Debates, N.S., XII (1825), p. 847, debate on the Liverpool and Manehester Railway 13ill. Jeaffreson, Life of Robert Stephenson, I, 1. 268, 
answer to this plea of vested rights it was said that Parliament, by sanctioning the building of railways, would not be breaking faith with the eanal proprietors, for it was never contemplated that monopolies should be protected nor that further impetus to the development of commerce should be denied. The carriers by waggon had, in vain, urged the same consideration against the development of water conveyance, when the latter had become absolutely essential to the material advance of the country ${ }^{1}$. The canals had becn given an opportunity to meet the increasing demands of commerce, and even those which were best situated had not done so, but had raised their charges and treated the demand with insolence ${ }^{2}$. It had never been the function of government to protect such injustice at the expense of the public good.

To recapitulate: the chief arguments advanced in favour of the railways were their speed and cheapness of carriage as contrasted with the canals, and the insufficiency of water carriage to serve the necessary purposes of the rapidly growing trade and industry of the country; the fact that they did provide good investments in some cases was not one of the primary inducements to their formation ${ }^{3}$. Additional facilities for the carriage of goods were essential, a sine qua non for the material advance of the country's interests. Some of the canals had not been improved at all, others very little, since their construction;

tells us that among all classes of society so universal was the antagonism to railways, from a fear that they would be injurious to vested interests, that gentle and simple with equal complacency viewed the constitution of tribunals which necessarily sympathised in a very high degree with the prevailing prejudice. See also Parkes, Claim of the Subseribers to the Birmingham and Lizerpool Railroad, pp. iv-v, 3-4, $63-66,72-74$.

1 Gentleman's Magazine, xcy, Pt. 1, pp. 199-200.

2 See Sandars' pamphlet on the Liverpool and Manchester Railway, pp. 3-9.

3 Gentleman's Magazine, xcv, Pt. 1, pp. 199-200; Remark's upon Pamphlet by "Investigator" on the Proposed Birmingham and London Railway, pp. 10-12, 24 ff.; Brit. Mus. 8223. e. 10 (70), 'Prospectus of Kentish Raiłway Company;' Brit. Mus. 8223. e. 10 (148), 'Prospectus of the Surrey, Sussex, Hants, Wilts, and Somerset Rail-Road Company;' 'Collection of Prospectuses, Maps, etc., of Railways and Canals,' pp. 13-14, giving the prospectus (dated May 10, 1830) of the two companies, the Liverpool and Birmingham Railway Company and the Birmingham and Liverpool Railway Company, whose interests were identical for the construction of a railway between thesc two cities; ibid., p. 65, giving the announcement of the Directors of the London and Birmingham Railway, 1833, and showing that the railway would more than double the specd of the stage coach, that the cost of passenger travel would be less than half that by coach, and that merchandise would be earried for only two-thirds of what was formerly paid on the canals. See also iljid., p. 74, 'Statement of the Case of the Liverpool and Birmingham Railway Bill (1831),' and pp. 139-40, $159-60,169-70,176$, which give other prospectuses of railways; also Railway Times, v, pp. 639, 711, 973 . 
and this in the face of an incessant demand from industrial and eommercial interests. In some eases, where the trade was heavy, navigation companies had refused to incur the extra expense of maintaining a sufficient number of barges to provide for emergeneies, but had made only meagre provision for even the usual requirements ${ }^{\mathbf{1}}$. Then, too, on some eanals the charges had been raised by the exorbitant demands of the proprietors ${ }^{2}$, until this increased cost, along with the inadequacy of the serviec ${ }^{3}$, led to the promotion of railway enterprise. Private interests and individual advantage had already too long dominated in matters of transportation; neessity required added equipment for, and new life imparted to, the service; the public must not be sacrificed to the individual benefit; and the railway system was the result of the operation of these imperative ealls for the national advanee along this line.

It will be fitting at this point to consider the nature of the opposition which was encountered by the railways in their efforts to bceome established along the highways of trade. In the first place, opposition arose from many of the landowners, who stubbornly resisted the encroachment upon their domains of these black monsters, the locomotive engines, with their trailing clouds of smoke, disfiguring the landscape, destroying the privacy and seclusion of their estates, and causing a great decrease in the value of their lands. As a rule, the landlords thought much more of the peacefulness of their own estates and mansions than of the public good; and the mental picture of a railway with its tail of smoke eurling aeross the country, blackening everything even to the fleeces of wool on the sheep, reckless of the aesthetic rural conditions and of the seemrity of individual or public property, was to them the symbol of all that was disagrecable, vulgarizing and mereenary 4 . The introduction of such "infernal machines," as the

1 Sandars on the Liverpool and Manchester Railway, p. 16.

2 Ibid.; Cumming, Rail and Tram Roads, p. 33; Geutleman's Magazine, xciv, Pt. 1, pp. 415-17; 'Prospeetus of the Birmingham and Liverpool Railroad Company:'

3 On aecount of delays on the waterways from Liverpool to Manchester, more time had sometimes been consumed in the earriage of goods that short distance than in the transatlantic voyage (Gentleman's Magazine, xcrv, Pt. 2, p. 5.56).

"See leter from "No Railer at the Present System," in Aris's Birmingham Gazcte, Jan. 10, 182.5, p. 1, acknowledging that railroads were superior to the canals in the matter of speed, but opposing them ehiefly from the aesthetie standpoint: he would not like to see the country disfigured by the elouds of smoke. His letter ends by saying: "Do, good Mr Editor, lend your potent aid, at the commencement of the eoming year, to avert this mass of evils, and help by advice, by entreaty, by warnings, by ridicule, by anything, to thwart the designs of these iron-hearted speculators, who would take from the people of this free country all hopes of another 
locomotives were sometimes called, must be stoutly resisted. The destruction of the unity of the farm by having part of it eut off from the homestead; the dividing of eloses that were convenient in form and size into "ill-shaped fragments;" the formation of deep cuttings across the hills and of large embankments aeross the low lands, thus preventing the natural flow and drainage of water; the inconvenience and danger to the public on account of the railway crossing the highways on the same level; these, along with the declaration that there was no necessity for greater speed of travelling nor faeilities for conveyance, added pretext upon pretext for the opposition of the landholding classes $^{1}$. Others were aroused to hostility lest a projected railway might pass through their fox-covers, or in some other way interfere

merry Christmas. If we must be slaves let it not be to iron-masters-let us open our eyes before the accumulation of smoke renders it impossible for us to see, and let us, above all things, heware lest Rail-roads, like party, prove 'the madness of many for the gain of few.' "A similar Ictter is found in ibid., Jan. 17, 1825, p. 2, from one who subscribes himself" as "Common Sense." See also IIansard's Parliamentary Debates, N.S., XiI (1825), pp. 845-9; ibid., xv (1826), p. 89 et seq.; Booth, Liverpool and Manchester Railzay, p. 31 et seq.; Brit. Mus. T. 1371 (18), pp. 5-9; The Times, May 4, 1824, p. 2 and Mar. 5, 1825, p. 5, on the "Tees and Weardale Railroad;" ibid., Nov. 18, 1830, p. 3, letter from "A Landowner;" ibid., July 17, 1832, p. 3. As an cxample of utter lack of sanity in the treatment of such a subject, perhaps the letter of Georgc Jones in The Times, May 3, 1834, p. 6, stands unrivalled. See also his petition against the London and Southampton Railway, in IIampshire Advertiser, Mar. 22, 1834, p. 2. A farmer in Northamptonshire refused his assent to the proposed London and Birmingham Railway on the ground that the smoke would injure the fleeces of his sheep (Birmingham Journal, Jan. 29, 1831, p. 2). As to the landlords' opposition to the Stockton and Darlington Railway, see Jeans, Jubile Memorial of the Raikeay System, pp. 28, 29, 32. A writer, signing himself "Ebcnezer," evidently a Quaker, in a letter to the Leeds Intclligencer, Jan. 13, 1825, p. 3, while admitting that the engines on the rail were much faster than the canal barges, cxpresses the evil connceted with the railway as follows: "On the very line of this railway, I have built a comfortablc house; it enjoys a pleasing view of the country. Now judge, my friend, of my mortification, whilst I am sitting comfortably at breakfast with my family, cnjoying the purity of the summer air, in a moment my dwelling, once consccrated to peace and retirement, is filled with dense smoke or foetid gas; my homely, though clcanly, table covered with dirt; and the features of my wife and family almost obscured by a polluted atmosphere. Nothing is heard but the clanking iron, the blasphemous song, or the appalling curses of the directors of these infernal machines." This was not the sentiment of one but of a multitude, and references conld bc added at great length. See also Leeds Intelligencer, Mar. 4, 1830, p. 3, and Mar. 11, 1830, p. 3, on the Leeds and Selby Railway; Sheffeld Iris, Mar. 3,1835, p. 2 , and Scpt. 22,1835 , p. 4 , on a landlord's opposition to the proposed Sheffield and Rotherham Railway; Birmingham Journal, Mar. 11, 1826, p. 1; Manehester Courier, Feb. 4, 1832, p. 3, on the London and Birmingham Railway.

1 Birmingham Journal, Jan. 22, 1831, p. 1, on the London and Birmingham Railway. 
with their anusement of hunting; and the great landholders were not to be expected to make any coneession, or to be cocreed into anything, even although their estates would thereby become more valuable and great benefit result to the public ${ }^{1}$. Many were averse because it seemed to them that a railway, with its force of men who were by no means serupulous of others' property and property-rights, would be an unmitigated evil; for it would permit the passage along the line of men of the worst class who would be ready to cause much annoyance to landowners on account of the nuisances which they would commit upon private property adjacent to the railway. Vast sums of money were required at first, under the plea of "compensation," to buy off the opposition of property holders and to pay for the strips of land that were necessary for these public enterprises; and when it was found that the money would be fortheoming for this purpose, some impecunious peers enriched themselves by demanding exorbitant prices for their land, under the specious pretence of injury to their estates". "Any amount that could by any means be squeezed from the funds of a railway company under the name of compensation, public opinion decided to

1 Jeans, Jubilee Memorial of the Railway System, p. 32; Sheffield Iris, Sept. 22, 1835, p. 4.

2 Jeaffreson, Life of Robert Stephenson, x, chap. ix, tells about the opposition to railways and shows that "in some cases enormous sums of money were paid for the acres of obstinate landowners" (p. 180). See also, Remarks upon Pamphlet by "Investigator" on the Proposed Birmingham and London Railway, p. 6; :Great Western Railway. Evidence on the London and Birmingham Railway Bill,' pp. 12, 14, 34-37; Railway and Canal Cases, 1, pp. 326 ff., 347 ff., 416 ff., 462 ff., show how often it was necessary to buy off the opposition of landowners. Parkes, Claim of the Subscribers to the Birmingham and Liverpool Railroad, p. vi, shows that ecrtain landowners were incited by the canal companies to oppose railways. See also ibid., p. 70. Jeaffreson, op. cit., 1, pl). 268-70, gives us an instance: "An impoverished nobleman, owning a house and park of the value of $£ 30,000$, in a county through which one of the earliest railways was carried, for a small strip of his park, occupied by the railway, which ran quite beyond the sight range of his windows, obtained no less a sum than $£ 30,000$ - or the entire value of the estate which the line was supposed only to depreciate. A few years afterwards this same peer sold another corner of the same park for another line for a second $£ 30,000$, and when he had thus extracted from two companies $£ 60,000$ as compensation for damage done to his estate, the original property was greatly augmented in value by the lines which, it was represented, would inflict upon it serious injury." He tells us that similar cases were of constant occurrence; and far from rousing public indignation, they met with public approval. The way in which compensation for lands was determined is fully set forth in Parl. Papers, 1845 (420), x, 417, 'Theport of Select Conmittee of the House of Lords on Compensation for Lands taken for or injured by Railwatys ;' see especially the evidence of Messrs Duncan, Clutton, Driver and Cramp. They show the way in which "extravagant sums," often far greater than the lands were worth, were paid in order to get rid of opposition. 
be legally and honourably acquired ${ }^{1} . " \quad$ Later, when the public benefits of the railway were known, this was ehanged; and those who had protested against this means of earriage beeame strong supporters of it $^{2}$. Parliament went cven so far as to pass a resolution excluding from the eommittee sitting on any railway bill any member who either held land through which the line was to run or was otherwise commereially interested in the rejection or passing of the bill ${ }^{3}$.

Other great opponents of the railways were the canal companies, which in some instanees had beeome strongly entrenehed in the eommereial life and aetivities of the kingdom. Their hostility was naturally to be looked for where the railway was to be construeted parallel to the eanal, for in that ease it was possible that the revenue of the canal company would be decreased on account of the railway competition ${ }^{4}$. The motives of opposition were sometimes eoneealed or thinly veiled; but underneath them all there was the one pervading objeet, namely, to keep the monetary returns from the canals as high as possible. Sometimes it was said that the railway could not carry heavy goods as

1 Jcaffreson, op. cit., 1, pp. 269-70. As compensation for "severance" of his estate, a proprictor, after requiring that bridges should be built at so many points along the line that the "severance" would practically cease to exist, would demand two, three, or four thousand pounds, in addition to the extortionate price already paid for the land actually given up to the line. It was useless for the agents of the railway company to show that this "severance" was merely an imaginary grievance, which effccted no real injury to the estate. Refusing to see it in this light, the owner remained steady in his demand and gained his "severance" compensation. Having thus sold a strip of land at four, five, or six times its value, as recompense for a purely imaginary damage, the owner would then candidly avow that this severance caused lim so little discomfort, that he could do with only half or quarter of the stipulated bridges, and that, for a further sum, he would free the company from the obligation to build the unnecessary bridges. In these early days railway companies were powerless to resist such extortions. They had to buy the goodwill of the community by hard cash. Sec also The Economist, Weekly Commercial Times, and Banlicrs' Gazette, $18+5$, p. 758 .

2 In 1844, Mr Croker wrote: "I know persons who were adverse to railroads, and who would now give $\$ 500$ a mile to have them nearer their residences." (Croker Papers, 11, p. 25.) Mr Earle, before the Committee on the London and Birmingham Railway Bill, testified that he would no longer oppose any railway, as he had determinedly opposed the construction of the Liverpool and Manchester Railway ('Great Western Railway. Evidence on the London and Birmingham Railway Bill,' p. 12). Other great estate-owners had also changed front in this way (ibid., pp. 34-37).

3 Jeaffreson, op. cit., т, p. 2 r1.

4 Teisserenc, Études sur les roies de communication, pp. 21, 31: Whishaw, Analysis of Railways, p. 164, showing that the Manchcster and Leeds Railway was opposed by the Rochdale Canal, Calder and Hebble and Aire and Calder Navigations until restrictive clauses in their favour were inserted in the railway Act; Leeds Intelligeneer, Mar. 11, 1830, p. 3, Jan. 23, 1836, p. 3, and April 23, 1836, p. 3. 
eeonomically as the canals could ${ }^{1}$; in other cases the canal companies declared that there was not enough traffic to warrant the additional facilities of carriage 2 . The commissioners of river navigations opposed railways that would probably take away some of their traffic, for the same reasons as they opposed the construction of eanals parallel to or out of the river over which they had control, namely, that the river would rapidly fill up on account of disuse and, therefore, the lands and towns along the river would be materially injured and in danger of inundation; that the tolls from the traffic remaining on the river would not be sufficient to defray the interest of the debt and expenses of maintenance; and that the value of adjacent estates and of the mercantile property connected with the river and its trade would serionsly deeline ${ }^{3}$. Perhaps the canals and canal carricrs were the most indefatigable of all the opponents of the railway. They would inevitably lose more than most other interested parties by the entrance of this new and effective rival into a realm which they had thought was pre-empted by themselves; and in proportion to their probable loss was their effort to save themselves from the impending disaster ${ }^{4}$.

But if the freight carriers by water were vigorous in their animosity to railways, we should expect that the coaching establishments would also be hostile to them, because of invading their field for the conveyance of passengers. And, of course, ranged with the coach proprietors we should expeet to find others whose interests were closely bound up with the prosperity of the coaching and the carrying trade on the roads. Whether it is because our information along this line is not so complete, or because there was less capital embarked in road carriage than in canal carriage-from whatever cause, we do not find the same volume of complaint and the same keenness of antagonism from the representatives of the carriers along the highways that we find from those interested in the waterways. It would be wholly unnatural for those large conecrns that had from 700 to 1300 horses, or even those which had a much smaller business, to allow their enterprise to be disintegrated withont making efforts to save it; but while they petitioned Parliament to care for their interests, they did not, apparently, endeavour to arouse such a storm of opposition as did the canal forces. It must not be understood,

I A Few General Obserwations on the Prineipal Railways, pp. ix. x, 9.

2 Leeds Intelligeneer, Маг. 4, 1830, p. 3, Mar. 11, 1830, p. 3, and Mar. 18, 1830, p. :3; Sheffield Iris, April 7,1835, p. 4, on the Sheffield and Rotherham Railway Bill.

3 See, for example, Felix Farley's Bristol Jourual, Feb. 22, 1834, p. 1, and Mar. 15, 1884, p. 1.

${ }^{4}$ See also Railway Chronicie, Sept. 20, 1845, pp. 1299-1300; Sheffield Iris, April 7, 1835, p. 4, and June 2, 1835, p. 2; Manehester Guardian, April 2, 1831, p. 3, on Manchester and Leels Railway Bill. 
however, that their claims upon public consideration were not strongly presented; but, in seeking favourable action, they did not stir up disaffection among other classes of the community in order to secure their co-operation. The character of their opposition, in trying to uphold their own stability and permanence, is well exemplified by a petition to the House of Lords from coaeh proprietors, post-masters and waggonmasters on the lines of road between London, Worcester, Hereford and Gloucester, asking for protection of their interest by the rejection of all applications for railways in general, and, particularly, for the Liverpool and Birmingham, and Birmingham and London raikways ${ }^{1}$.

Of a similar nature to the foregoing was the opposition of trustees of tumpike roads and of those who had loaned them money on the security of the tolls. They were averse to the building of a railway which would take traffie from that high way and thereby reduce the amount of toll that would be collected at the gates; for if the tolls were to become lessened, the seeurity for the money loaned would be correspondingly lessened ${ }^{2}$, while the revenues for the maintenance of the road and the payment of interest on the debt would be depleted. When it was known in advance that a railway was to be constructed which would probably have this effect upon a certain turnpike, very few persons were ready to bid for the gates at the time they were put up at auction; and, reasoning from analogy with those eases where railways had already made themselves felt, the few bidders who did come forward would not assume the risk of taking the gates except at greatly redneed rentals. When trustees found such difficulties in the financing of their roads after the eompletion of a railway, it is little wonder that they objeeted to the introduction of the latter knowing that their difficulties would increase with the passage of the years.

Some towns rejeeted the boon that was offered them, and opposed the railways so strongly that they would not allow the company to build their line within the eity linits. For instance, to satisfy the people of Northampton and to meet their objections, the London and Birmingham Railway Company carried their roadway a considerable distance from the town, and built their works and shops at Wolverton, instead of, as originally intended, at Northampton ${ }^{3}$. The town of

1 IIampshire Adīertiser and S'alisbury Guardian, May 11, 1838, p. 2; see also Proceedings of the Great Western Railway Company, p. 10.

2 Brit. Mus. T. $18 \pi 1$ (18), p. 14; 'Great Western Railway. Evidence on the London and Birmingham Railway Bill,' p. 15, evidence of Joseph Pease ; Birmingham Journal, Feb. 12, 1831, p. 2, on the London and Birmingham Railway; Cundy, Observations on Railways, p. 15.

3 Stretton, History of the London and Birmingham Railicay, p. 1. See also Markham and Cox, Northampton Borough Records, II, pp. 543-4. 
Maidstone in Kent assailed the South Eastern Railway so vigorously that the Dover line was carried far away from them ${ }^{1}$. Owing to representation from Windsor, a clause was inserted in the Great Western Railway Aet forbidding any station at that important town ${ }^{2}$. It was not till after repeated applications that a braneh of the Great Western was allowed to be eonstructed to $\mathrm{Oxford}^{3}$; and then the authorities of the university had a clanse inserted by which the station at Oxford was to be ereeted at a spot as remote as possible from the colleges. ${ }^{4}$. Perhaps the opposition of Oxford University and of Eton College was the most vehement that the Great Western Railway eneountered. The latter institution refused to allow the railway to eone within three miles of the school; and in the railway Act Eton College obtained the insertion of a elause forbidding the erection of a station at Slough and requiring the company to provide policemen to patrol the line for a certain distance on each side of Slough so as to safeguard the Eton boys from danger. But although the Act forbade the building of a station at Slough, yet the railway trains, from the very first, stopped there to set down and take up passengers, and as an offiee the company used two roons in an adjoining public-house. On aceount of this supposed breach of the law, the Eton College offieials entered suit against the railway eompany; but it was shown that the latter had observed the terms of the Act of incorporation and eonsequently the suit was dismissed ${ }^{5}$.

Loeal jealousies of one kind and another aroused opposition to railways that were highly advantageous from the point of view of public benefit. Farmers near a large centre of population were found to objeet to the eonstruetion of a railway back from that centre into the more distant eountry, lest their monopoly in a luerative market would thereby be broken up, beeause produee grown at a much greater distance from that market could come into eompetition with that grown in the nearer areas. As an illustration of this, we note that the

1 Railway Times, Ix, p. 961.

2 Shaen, Review of Railzays and Railway Legislation, p. 29.

3 Ibid., p. 29.

4 Sekon, History of the Great W'estern Railway, p. 8.

5 Railway and Canal Cases, 1, pp. 200-10, gives this ease in full. See also Sekon, II istory of the Great Western Railzay, pp. 6-8; Markham and Cox, Northampton Borough Reeords, II, pp. 543-4; Felix Farley's Bristol Journal, Mar. 15, 1834, p. 4. The Great Western Railway was a rival seheme of the London and Southampton Railway; and the latter joined with Eton College and with many landowners in opposing the Great Western (Fay, A Royal Road, p. 20). Brit. Mus. 8235. bb. 87 (1), 'Speech of Counsel on the 30th May, 1848, before a Seleet Committee of the Ilouse of Commons, on behalf of the Head, Lower and Assistant Masters of Eton against the Great Western Railway Extension from Slough to Windsor,' shows how strong was Eton's opposition to the railway eoming within easy aceess to that eollege. 
Great Western Railway was opposed by the Middlesex, Berkshire and Buckinghamshire farmers beeause they feared that London would be able by this means to get food supplies from a distance at cheaper prices than those at which they had been accustomed to selling ${ }^{1}$. Of the same nature, apparently, was the opposition to the proposed Tees and Weardale Railway, in 1824, the opponents of the line asserting that the outlet for North Durham coal by the rivers Tyne and Wear was sufficient, while its advocates desired additional facilities of outlet by the river Tees ${ }^{2}$. Some were averse to railways because they feared that thereby trade would be transferred from one place to another. For example, the eontemplated Great Western Railway stirred up some of the people of Bristol because of their alarm lest a large part of the trade then transacted at that city should be afterward centred at London. If the products which were brought into Bristol from Ireland were to be taken to London immediately upon their arrival at the quay, it was thought that the mercantile interests of the former city would be injuriously affected; and if the shipping and the West India trade should subsequently locate at London, instead of remaining at Bristol, this western emporium of commerce would be sacrificed and the "ancient and once-flourishing eity of the splendid name" would probably be dismantled ${ }^{3}$. Sometimes the owners of coal mines at a certain place opposed the introduction of a railway that would enable other coal mines to compete with theirs, and this local monopolistic spirit characterized much of the antagonism that railway promoters realized ${ }^{4}$.

1 Proecedings of the Great Western Railway Company, pp. 7,13 . We observed the same objection to the cxtension of the turnpike system from London to the remote parts of the kingdom. See Railway Times, vi, p. 242, article entitled "Railways and the Agricultural Interests," showing that the prices formerly received by the farmers of Southall and Perivale, co. Middlesex, for their cattle when sold in the London market had been forced down by reason of the great numbers of cattle and sheep that had been brought by the Great Western Railway from the West of England to London. But, of course, there were compensating advantages that the farmers enjoyed, even if they had forgotten them.

2 The Times, Nay 4, 1824, p. 2.

${ }^{3}$ Bristol Mercury, Feb. 16, 1833, p. 2, and Mar. 2, 1833, p. 2, letters from "Scrutator." It seens strange that this man should have been showing how Bristol would decline after the railway was constructed, when another man, signing himself "A Burgess," was, at the same time, writing a series of thirty letters on the trade of Bristol, showing the causes which had brought about its decline and the means necessary for its revival (Bristol Mereury, Feb. 2, 1833, p. 2; Feb. 9, 1833, p. 2; Feb. 16, 1833, p. 2; Feb. 23, 1833, p. 2 ; etc.).

4 Manchester Guardian, Feb. 26, 1831, p. 3, concerning the Oldham Railway; Sheffield Iris, Oct. 7,1834, p. 1, prospectus of the proposed railway from Sheffield to Rotherham; ibid., Mar. 31, 1835, p. 2, editorial on the Sheffield and Rotherham 
Upon the other forms of, or reasons for, opposition to railways we shall dwell but briefly. Some turned against them as enterprises in which money would be sunk without any adequate return, eonsidering them as a new and dangerous form of speeulation ${ }^{1}$. It was contended that the actual amount invested in them would greatly exeeed the estimates that had been made for the purpose of inducing capital to embark therein ${ }^{1}$, and hence there would soon be financial embarrassment when interest could not be paid on the great investment. Moreover, the absorption of the national capital to such a vast extent would divert it from more legitimate ehannels; and the fact that railways were not regarded by some as legitimate enterprises would seem to have been chiefly due to branding the whole system with the same characteristics that had been displayed in the case of some crude and other dishonest ventures ${ }^{2}$. When many plans were being formed for railways, it was inevitable that some ill-devised and delusive sehemes were encouraged, which ended in the ruin or injury of those eoneerned in them; and also some dealers in shares who profited in one case but lost in another used unworthy means of aecrediting or disparaging particular undertakings. Thus, no matter how good and substantial the enterprise, it might be given a wrong character, at least for a time, and in this way be subjected to popular condemnation.

Railway; ibid., April 7, 1835, p. 2, on the Sheffield and Rotherham Railway; ibid., Sept. 15, 1835, p. 4, letter from W. Ibbotson. See also The Times, June 17, 1836, p. 3.

1 Aris's Birmingham Gasette, Oet. 4, 1824, p. 3, letter signed "Common Sense ;" Remarks upon Pamphlet by "Investigator" on the Proposed Birmingham and London Railway, pp. 4, 6; Parkes, Claim of the Subscribers to the Birmingham and Liverpool Railroad, pp. 3-4, 64-67. Vallance, Sinking Capital in Railways, pp. 6-23, warned against investing in railways the $£ 30,000,000$ which at that time (1825) it was proposed to lay out upon them. His opinion was that it was doubtful whether the railway could travel with safety at more than six miles an hour (p. 18), i.e., about half the rate of the coach (p. 30); that, at that rate, the railway could not travel regularly and uniformly from the beginning to the end of the journey (pp. 19-20); and that, because it had to earry so much coal and water, the locomotive would not be able to do its work at the least possible expense. Since railway operation was therefore defective in all these essentials, the people should beware of sinking capital in this new mode of transit.

2 IIerepath's Railway Magazine, N.S., III, pp. 24-27, "On Railways as Investments." This writer says that it was very obvious that the greater number of capitalists were not friendly to railways and generally stood aloof until the profit of the work was known. The great fundholders and the landed proprietors, with few exceptions, hung back from enterprises which were ultimatcly very successful; while the commercial elasses, who were accustomed to tracing out results from the operation of eertain principles, were the men who had been chiefly responsible for the devclopment of national improvements. 
Railways were at times prevented from, or delayed in, obtaining legislative sanction on account of the political expedients that were resorted to. Not infrequently the House of Lords blocked measures that had passed the House of Commons after careful inquiry and close scrutiny. Some members of a committee to which a particular bill had been referred, were known to absent themselves from all hearings upon the bill because they either had no interest in or were opposed to it, and to walk into the committce room just before the time for the decision in order to give their vote adversely ${ }^{1}$. In other cases, some of the supporters of a bill, from motives of delicacy, abstained from attending at all and this left the measure in the hands of an opposing majority, so that after all the expense of time and money involved in hearing witnesses and paying parliamentary agents, the measure was foredoumed to rejection. With the committees upon private bills constituted as they were, it was not always the best line that secured favourablc consideration; but that line was likely to be carried whieh could excrt the greatest influence in commanding public attention and obtaining the predominance in the committee ${ }^{2}$.

Some very trivial reasons were occasionally given for the opposition that was manifested to railway projects. Sometimes they were opposed for the same reason that stage coaches in early days were opposed, namely, because they would induce people to go flying about the country, instead of attending to their work at home ${ }^{3}$. Some were afraid that the velocity at which the trains would travel would occasion great accidents and the suggestion was made that it might be desirable to establish every five or six miles along the line what would be practically well-equipped hospitals to take care of the injured ${ }^{4}$. At other times railway bills failed to pass bccause of insignificant breaches of the Standing Orders when the measure was brought before the committee $^{5}$. Even where a noble landowner knew that the projected railway would not injure, but rather inmensely benefit, his property, he still opposed it, without being able to assign any valid reason for

1 Sheffield Iris, Sept. 22, 1835, p. 4, letter from W. Ibbotson.

2 Parl. Papers, $1836(0.96)$, xxs, 235, 'Minutes of Evidenee before the Select Committee on Railway Bills,' evidenee of James Walker, C.E., Q. 178.

3 Fay, A Royal Road, pp. 23-24, gives some of the contemporary statements; for example, one of the great canal proprietors said: "I foresee what the effect will be-it will set all the world a-gadding. Twenty miles an hour! why, you will not be alle to keep an apprentice boy at work... . Grave plodding eitizens will be flying about like comets."

4 Leeds Intelligeneer, Jan. 13, 1825, p. 3, letter on "Railways."

5 Shaen, Review of Railways and Railway Legislation, pp. 36-40. He cites his cases from the parliamentary reports. 
this deeision ${ }^{1}$. In fact, until the railways had fully demonstrated their utility there was active opposition to every scheme that was brought forward; railways, apparently, were treated as nuisances and every impediment was thrown in their way to cause the promoters to desist from sueh activity ${ }^{2}$. We do not wonder, however, at the rooted prejudice to the railways, when such a great engineer as Thomas 'Telford was strongly opposed to them ${ }^{3}$.

Among those who took a prominent part in the discussion in favour of railways were George Stephenson and his son Robert, Nieholas Wood (who was intimately associated with George Stephenson), William James and Thomas Gray. Perhaps the last-named, more than any other, kept this subject before the public, not only by his contributions to the current press, but by a work of considerable magnitude on what he called a "general iron railway"." His mind was full of this one idea, and he gave it expression on all oceasions. The locomotive engine was sure to supersede all other kinds of conveyance, and even to do away with the necessity of horses. He would, therefore, leave the turnpike roads as they were, and perfect steam railways as a system more in keeping with the time and with the inereasing traffic of a commercial nation ${ }^{5}$. And, as for canals, he deplored the fact of engineers still wasting, as he thought, their time and the public money in these clelusive speculations ${ }^{6}$. He warned the public against subscribing to canal schemes, "for the time is fast approaching when railways must, from their manifest superiority in every respect, supersede the neeessity both of canals and turnpike-roads, so far as the general commerce of the

1 Sheffield Iris, Sept. 22, 1835, p. 4, letter of W. Ibbotson.

2 Observations on the Comparative Merits of Navigations and Railloads, pp. $43 \mathrm{ff}$.; Shaen, op. cit., pp. 29-30.

3 Autobiography of Sir John Rennie, p. 244.

4 The complete title is Observations on a General Iron Rail-zeay, or Land Steam Conveyance; to supersede the Neeessity of IIorses in all Public Vehicles; showing its vast Superiority in every respect, over all the present Pitiful Methods of Conveyance by Turnpike Roads, Canals, and Coasting-Traders. Containing every Species of Information relative to Rail-roads and Loco-motive Engines. The first edition was published in 1821 and the fifth in $\mathbf{1 8 2 5 .}$

5 See letter of T. Gray in Gentleman's Magazine, xclv, Pt. 2, pp. 313-16; also Gray, General Iron Railzay, pp. vii, xx-xxi, 2, 6, etc. He speaks of the many complaints as to the state of the roads and of the impossibility of finding an effectual remedy: of the accumulating delot on the turnpike roads, as shown by their annual statements; of the waste in trying to keep them up, for they had "nothing, save folly and extravagance, to recommend them." He favoured the "general introduetion of meehanie power, so as completely to supersede the necessity of horse power in all publie waggons, stage and mail-coaehes, and post-ehaises" (p. xi).

${ }^{6}$ Gentleman's Magazine, xav, Pt. 2, pp. 313-16. 
country is concerned ${ }^{1}$." The cxpense of making a canal and canal boats, the expense of men's wages, of horses' kcep, etc., he thought, must render the transport of merehandise much dearer by eanal than by an improved railway which eombined eeonomy of time and of labour.

Gray's scheme is an interesting one. He would have the railway system undertaken as a national work; for unless the nation took up the matter it would not be earried out on proper principles ${ }^{2}$. He would have a national board appointed to introduce the most simple and general principle of uniform connexion throughout the eountry; there should be facility of national communication by having uniformity of rails and vehieles and provision should be made for the easy interchange of traffic. The central feature of his plan was to have a general iron railway eentring at London, with one main trunk line running from London to Edinburgh and another trunk line from London to Falmouth ${ }^{3}$. From these, branehes should be constructed to run to all the important places in the kingdom, so that London might be eonnected with all the industrial and commercial eentres. By having these roads laid out in straight lines and on perfeet levels, the distances between the chief places would be greatly redueed and thus the time and the cost of carriage and travelling would be much lessened ${ }^{4}$. On these great through routes there should be different roadways for trains going to and those departing from London; and as London was approached these should be increased in number ${ }^{5}$.

By such a plan, Gray thought to see extended into every part of the country the advantages which would lead to permanent prosperity; and so confident was he of the ultimate trimph of the steam railway, that he used every possible endeavour to secure its accomplishment. In 1820 and 1821 he submitted two addresses to His Majesty's Ministers

1 Gentleman's Magazine, xciv, Pt. 2, pp. 313-16. He says: "Were canal proprietors sensible how much their respective shares would be inproved in value, by converting all the canals into rail-ways, there would not, perhaps, in the space of ten or twenty years, remain a single canal in the country." (Gray, General Iron Railway, p. 9.)

2 Letter of 'T. Gray on "Railway Advantages," in Gentleman's Magazine, xcvi, Pt. 1, pp. 126-8; also ibid., xcv, Pt. 2, pp. 310-12.

${ }^{3}$ Gentleman's Magazine, xcv, Pt. 1, p. 205. For his general plan for the railways of Great Britain, see his diagram in General Iron Railway.

${ }^{4}$ Gentleman's Magazine, xcv, Pt. 1, p. 205; also ibid., xcv1, Pt. 1, pp. 126-8; Gray, General Iron Railway, p. 10.

5 Gray, Generul Iron Railway, p. 12. He says: "In order to establish a general iron railway, it will be necessary to lay down two or three railways for the ascending and an equal number for the descending vehicles. In the inmediate neighbourhood of London, the trafhic might demand six railways." With the constantly increasing traffic between Liverpool and Manchester, he would lay down between these two places also six lines. Similarly for other towns, according to their importance. 
of State, showing the great national importance of his scheme; and again, in 1822, he urged its importance upon then by giving a detailed account of its advantages ${ }^{1}$. In 1823 he renewed his petition to the Ministers of State and asked for the appointment of a Select Committee of the House of Commons to investigate his plan'2. He likewise petitioned the Board of Agriculture and tried to show them that the many important advantages which his proposed system of railways would afford to the public must overcome every prejudice and finally prevail over every other means of conveyance ${ }^{3}$. In a petition to the Lord Mayor and Corporation of the city of London, he reiterated the advantages that would result from the adoption of this new system of carriage; and asked them, in the intcrests of the whole country, to favour the establishment of railways ${ }^{4}$. But, whatever the reason may have been, Gray's national railway project was not taken seriously, for nothing was done towards its accomplishment ${ }^{5}$.

The name of William James seems to have been given a place secondary in importance to that of Thomas Gray and the two Stephensons; and yet he was among the earliest, if not the earliest, of the originators and promoters of the system of passenger transit on railways. It appears that, as early as 1799 , he was engaged in laying out plans for railways, some details of which he gives in his memoranda ${ }^{6}$. This work was continued at least down to 1808 when his diary ends; and during that time he surveycd and completed many sections of railroad that were to be used for the conveyance of coal to navigable waterways?. In a paper addressed to the Grand Surrey Canal Company,

1 Gray, General Iron Railway, pp. xvii-xviii.

2 Ibid., p. xix. ${ }^{3}$ Ibid., pp. xx-xxi.

4 Ibid., pp. xxi-xxiii. He shows that by the railway the people of London might be regularly supplied with coal on comparatively reasonable terms, instead of "suffering under abominable extortion," under the existing conditions.

5 Anyone who will read Gray's book through will find some things which are visionary and even the more serious part of the book contains much that would antagonize the public and turn them away from the writer of it. In the Raikeay Record, 11, pp. 401, 568, 595, 628, 658, 692, there are a series of articles dealing with "The Railway System and its Author," giving the chief facts in connexion with the work of Thomas Gray for the introduction of railways into England. He was at that time (1845) in destitute circumstances; and there was an agitation in favour of raising a sum of money that would put hin beyond the necessity of hard manual work in those days of his old age. See also Wilson, The Raikvay System and its Author, Thomas Gray, now of Exeter. A Letter to the Right Honourable Sir Robert Pcel, Bart. 'This was an appeal to Peel, by a friend of Gray's, that the latter might be relieved, and that his name might have the honourable place it deserved anong England's great men in connexion with the railways.

${ }^{6}$ P., The Tro James's and Two Stepliensons, p. 18; Mining Journal, Dec. 5, 1857, in which is found James's diary down to 1808.

$?$ Ilbid. 
he spoke of himself as an experienced engineer, "in railroads especially;" and other expressions of similar import are given in this same document ${ }^{1}$. But the most remarkable part of his diary refers to his plan for the formation of a general railroad company, with a capital of $£ 1,000,000$, "to take lands for ever to form railroads," and to fulfil other designated purposes ${ }^{2}$. We need not here follow his career and the testimony which was borne to his accomplishments; it will be sufficient to say that his wide experience and his ability were recognized at that time, but we have been unable to aseertain why his work has been overshadowed by that of his compeers ${ }^{3}$.

At this formative stage in the history of railways it was to be expected that a considerable variety of plans would be suggested for their construction and operation; they were an entirely new feature in the industrial and commercial world, and those who were most interested in them were groping their way in the endeavour to ascertain the conditions of the greatest economy for this new instrument of conveyance. It will, therefore, not be amiss to note some of the proposals that were made, with the intention of securing this object, in the early years of the railway development. Before the success of the locomotive engine had been fully assured, the use of the inclined plane on the coalcarrying railways was, as we have seen, a feature of common occurrence; and even after the tractive power of steam had been demonstrated there were still some roads which were planned by engineers of repute, partly as inclined planes to be worked by stationary engines and partly level to be worked by locomotive engines ${ }^{4}$. Instead of steam power, it was

1 P., The Tro James's and Tro Stephensons, p. 22. For instance, he says in that paper: "... and that the said railroads and all person or persons, and their servants, carriages, and cattle passing thereon, shall be under the control and management of the said William James and his co-partners...."

2 Ibid., p. 23; also his diary referred to above.

3 For the rest of his work, and his connexion with George Stephenson, see ibid., pp. 23-105. He advocated the possibility of attaining on railways a speed of twenty or thirty miles per hour-contrary to the opinions of George Stephenson and Nicholas Wood, who thought that railway travelling could never exceed eight or ten miles an hour (pp. $40 \mathrm{ff}$.). Even Robert Stephenson acknowledged that it was not his father, but William .Tames, who was the "Father of Railways" (ibid., p. 105). See also Autobiography of Sir John Rennie, pp. 234-6.

4 The Cromford and High Peak Railway, from the Cromford Canal to the Peak Forest Canal in Derbyshire, was made to rise by inclined planes to the summit level of one thousand feet above the former canal and then descend seven hundred and sixty feet to the latter canal. The rough country there made it necessary to propose the construction of both level parts and inclined planes, on the former of which locomotive engines were to be used and on the latter stationary engines (Manehester Gazette, Nov. 13, 1824, p. 3). On the Stockton and Darlington Railway they had both levcls and inclined planes and both kinds of engine. They also used horse-power 
not infrequently planned to use horse power, cither on the incline or on the level ${ }^{1}$. As late as 1829, when the Leeds and Selby Railway was in prospect, it was decided to make the operation of the line possible by either horse power or loeomotive engines, or to permit the company to use locomotive carriages if this were thought desirable ${ }^{2}$. George Stephenson, who had surveyed that line in 1825 , had recommended for part of the line three inclined planes which could be worked by horse power or stationary engines, and for the remainder of it level reaches upon which locomotive engines could be employed. But in 1829 , after Stephenson's suggestions had been rejected by the eommittec that had the work in charge, James Walker, who had also come into great prominence as a railway engineer, was asked to re-survey the line; and his opinion was decidedly in favour of the uniform system without inclined planes. Under these circumstances each shipper could utilize the line most favourably; and he calculated the strength of the rails, so that although at first horses would, in all probability, be the principal power used, yet locomotive engines might be used then or at a later time $^{3}$. With accumulated experience of the results secured on railways, it became evident that for all ordinary purposes, where there would probably be traffic in both directions, the more nearly the line approximated to a perfect level the more cononically eould it be operated and the more efficient would be its service.

Another suggestion that seemed to find some favour was that railways might very acceptably be laid down at the sides of the ordinary highways and might be worked by either steam or horse-power. By this plan, the eost of the roadway would be greatly reduced, for the utilization of the land at the sides of the public roads for such a public purpose would not call for the enormous expenditures that were made by existing railways for the right of eminent domain. The carrying of

(Jeans, Jubilee Memorial of the Railway System, pp. 33-35, 43, 53-54). See also Walker and Rastrick, Liverpool and Manchester Railway. Report to the Directors on the Comparative Merits of Locomotive and Fixed Engines, pp. 3, 4, showing that there were inelined planes and stationary engines on other eolliery roads, such as those of the Ifetton Colliery and the Brunton and Shields. See also Wood, Practical Treatise on Railroads (1825), pp. 93-123, and A Few General Obserations on the Principal Railways, pp. ix, 19-20, showing that in 1838, on the stockton and Darlington and on the Leieester and Swannington, there were both self-acting and stationary-engine inelined planes, and these abrupt inelines were great drawbaeks on all railways.

1 Walker and Rastriek, op. eit., p. 49. Rastriek here shows the great advantage of the locomotive over horse-power.

2 Leeds Intelligencer, Nov. 5, 1829, p. 3, on the Leeds and Selby Railway.

3 Maeturk, IIistory of the Mull Railways, Pp. 18-32, gives Walker's report to the eommittee of the proposed Leeds and Selly Railway Company. 
railways along the course of the highways would not cause the dislocation of the usual currents of trade; the inns along the roads would not suffer, the various establishments that had grown up as links in the customary trade circulation would not be endangered, the diverse interests that had grown up around the system of road carriage would not be threatened with annihilation, and consequently the change from the old régime to the new would be accomplished with as little adrerse effect as possible. So hopeful were some in regard to the applieation of this method that a writer in 1829 observed that "it is thercfore nothing problematical to expect in the course of the next ten years to see railways by the roadsides extending from London, Liverpool, Hull, Edinburgh," etc. ${ }^{1}$ He asserted that by having railroads laid down on the high road from London to Liverpool, the mails drawn by a light locomotive engine might go this distance, 204 miles, casily in twelve hours, carrying twice their usual number of passengers and at much lower cost ${ }^{2}$. Another, in 1833, considered horse-power more economical than steam, and he would have this applied on tram or railways, constructed as nearly as possible along the sides of the turnpike roads ${ }^{3}$. This suggestion was not the product of visionary minds, for even such a competent engineer as Fairbairn adrocated the plan ${ }^{4}$. In addition to securing the advantages already mentioned, of reducing the cost of construction and perpetuating the existing trade routes with all their appointments for commercial purposes, railways located in this way would cause no invasion of estates, against which there was much complaint at that time. The decreased cost of construction would result in lower freight rates; and the increased traffic along the roads would ensure the receipt of tolls sufficient to repay the debts upon the various turnpike trusts. If the railways were built and owned by the state, as was suggested by Fairbairn, all revenues therefrom would accrue to the state. We see, therefore, that there were several reasons why this would appeal to the publie; but when we remember that the locomotive engine works most economically on long lines of straight road we can see one physical reason why this method was not adopted ${ }^{5}$. The fact, too, that some

1 The Times, Oct. 19, 1829, p. 3, on "Locomotive Carriages."

2 The Times, Oct. 19,1829 , p. 3 .

3 Bristol Mercury, Oct. 5, 1833, p. 4, letter from "A Well Wisher," on the comparative advantages of horse and steam-power on railways.

4 Henry Fairbairn's Trcatise on the Political Economy of Railroads (1836).

5 Ibid. He gives a full description of this plan and the benefits that would result from it. In his chap. iv, he shows that steam-power is too expensive for use in conveving merchandise; horse-power is best for that purpose. This sounds grotesque in view of the present circumstances. Many other of his statements are ludicrous; for instance, he says that all the great navigable rivers, like the Shannon, 
apparently impractical conceptions were associated with this scheme, must have militated against its serious consideration.

Another plan for the improvement of railways has the name of Henry R. Palmer associated with it ${ }^{1}$. He proposed that where substances were likely to get on the rails, as was eustomary when they were so close to the surface of the ground, the rails should be clevated; but to elevate two lines of rail would cost too much, and, therefore, he would endeavour to arrange the form of a carriage so that it would travel upon a single line of rail without overturning. His method was to have the carriage so constructed that the two parts of it would balance upon the rail, irrespective of whether the number of passengers or the amount of freight were the same in each compartment ${ }^{2}$. A line of railway on this suspension principle was constructed for practical purposes of demonstration at Cheshunt, in Hertfordshire; apparently, it did its work successfully and answered the design in every respect ${ }^{3}$, but it was intended more to exemplify the prineiple upon which it worked than to actually engage in the general carriage of all kinds of traffic. Why it was not employed as a regular means of conveyance, we have not the means of determining, although it was probably because of mechanical defects; and from that time onward all efforts at sceuring a workable monorail system were unsuccessful, until within the last few years when the gyroscope seems to have exhibited its practicability for the earriage of passengers at a high rate of speed.

We must now return from this digression as to the attitude of the public at this early time toward the railways, and the consideration of some of the proposals for seeuring their greatest effectiveness, to resume the historical development of the network of lines which was soon spread over the country. Through the discussion which was going on anong engineers and the public generally, it was becoming evident that, not only from a mechanical standpoint ${ }^{4}$, but also eeonomically, the railway

Mississippi, St Lawrenee, Thames, ete., will now be deserted for land conveyanee, when his system is put into effect. See his chapters vi and viii for sueh ethereal projeets.

1 Palmer, Description of a Raikcay on a New Principle.

2 The details of the plan may be found in the work last referred to.

3 A full description of this railway and its method of operation is very elearly given in The Times, June $2 \%, 1825$, p. 3.

4 On the relative meehanieal advantages of railways, eanals and turnpike roads, espeeially the two former, see Sylvester's Report on Railroads; Macharen, Raikways as compared with Canals and Common Roads, p. 58 et seq.; Tredgohl on Railroads; Nieholas Wood, Practical Treatise on Railroads; and contrast these with Gordon, Observations on Railways and Turnpilie Rouds, pp. 4-11, who thought that the meehanieal advantage of an edge railway was small when eompared with a good turnpike road. Of these meehanical features we shall not treat herr. 
was to largely supersede both the canal and the highway as a means for the facilitation of the earriage of goods and passengers. Besides, the suceess of the coal-roads, and especially of the Stockton and Darlington, on whieh loeomotive engines were being used with admirable results, made widely known the benefits to be oltained from the new means of locomotion. But we must not suppose that the suceess of the Stoekton and Darlington was the reason for the eonstruction of the other roads which were opened a few years afterward; on the contrary, at least two of the most important roads were projected before the Stoekton and Darlington line was opened, namely, the Liverpool and Manchester and the Liverpool and Birmingham. As we have already seen, the chief reason why the railways came into existence was because of the need of more adequate facilities for conveyance than the canals could give. The enormous profits which some canals were making were also an inducement for railways to come in and secure a share of these benefits ${ }^{1}$, and the success of existing railroads, giving additional encouragement to the projectors of new lines, had an important effect in initiating these enterprises along routes where they were much needed.

What we have just said applies with special force to the transportation conditions and requirements between Liverpool and Manchester. Under the stimulus of the Industrial Revohution, which assumed its greatest prominence in the cotton industry of Lancashire, villages had grown into towns and towns into large eities. Since the year 1760 Manchester and Salford, which are separated by only a small river, and which are eonsidered as one, had probably increased in population at least eight-fold before $1830^{2}$. The increase in the amount and value of

1 The great profits of the navigations between Liverpool and Manchester are considered when we come to take up the neeessity for the Liverpool and Manchester Railway. Regarding the profits of the Bridgewater Canal, see also Parkes, Claim of the Subseribers, p. 24. As to the amount of the profits of the Birmingham, Grand Trunk and other canal companies, see Parkes, op. cit., pp. 16-20, 24, 43-44, 61. See also the cxamples given in 'Prospectus of the Birmingham and Liverpool Rail Road Company.' In Aris's Birmingham Gazette, Dec. 13. 1824, p. 1, a letter from F. Finch regarding the proposed Birmingham and Liverpool Railway spcaks of the "inordinate profits" that the canals had enjoyed long enough.

2 Sandars' pamphlet on the Liverpool and Mianchester Raikvay gives us the following figures for the population of Manchester and Salford:

$$
\text { in } \begin{aligned}
1757 & =19,837 \text { (estimated) } \\
1773 & =27,246 \text { (estimated) } \\
1821 & =133,788 \text { (census figures) } \\
1824 & =163,858 \text { (estimated). }
\end{aligned}
$$

Booth's figures were:

$$
\left.\begin{array}{cc}
\text { in } 1760 \text { about } 22,000 \\
, 1824, & 150,000
\end{array}\right\} \text { Booth, Liverpool and Manchester Railway, p. } 6 .
$$


the cotton manufactured there had becn very great, amounting to fifty per eent. in the eight years following the close of the Napoleonie war. So great had been the ehange, that, while in 1814 there was not one power loom in Manchester, in 1824 there were nearly 30,000 of them ${ }^{2}$. Manchester had become the focus of a large manufacturing population, from whieh large quantities of eotton goods were sent to Liverpool and thenee to all parts of the world. Liverpool also was rapidly attaining commercial importance and as a seaport was second only to London. Her population had almost doubled between 1800 and $1825^{3}$; and her colonial and foreign trade had been making great progress, as is shown by the tonnage and eustoms statistics ${ }^{4}$. Foreign produee of all kinds

1 The following figures show this fact:

\section{Cotton manufactured at Manchester}

$\begin{array}{ccr}\text { Year } & (a) \text { Quantity } & (b) \text { Value } \\ 1815 & 110,000,000 \mathrm{lbs} . & £ 7,487,562 . \\ 1823 & 160,000,000 \mathrm{lbs} . & £ 10,875,000 .\end{array}$

2 Booth, Liverpool and Manchester Railway, p. 6. In 1790 there was only one steam-engine in use in Manchester while in 1824 there were over two hundred.

3 Sandars gives the following figures for the population of Liverpool:

in $1720=11,833$ (estimated)

„1760=25,787 (estimated). Same figure given by [Corry], History of Liverpool, p. 119.

$, 1801=77,708$ (census)

$, 1811=94,376$ (eensus)

$, 1821=118,972$ (eensus)

", 1824=135,000 (estimated).

4 On the imports, exports and shipping of Liverpool, sec Brit. Doe. 1825 (182), II, 409, and 1825 (206), II, 413.

According to Sandars (p. 44), the statistics of tonnage and dock duties at Liverpool were as follows:

\begin{tabular}{cccccl} 
Year & No. of ships & Tonnage & \multicolumn{3}{c}{ Dock duties } \\
& & & $\mathcal{E}$ & $s$. & $d$. \\
1752 & - & - & 1,776 & 8 & 2 \\
1760 & 1,245 & - & 2,830 & 6 & 7 \\
1770 & 2,073 & - & 4,142 & 17 & 2 \\
1780 & 2261 & - & 3,528 & 7 & 9 \\
1790 & 4,223 & - & 10,037 & 6 & 21 \\
1800 & 4,746 & 450,060 & 23,379 & 13 & 6 \\
1805 & 4,618 & 463,482 & 33,364 & 13 & 1 \\
1815 & 6,440 & 709,849 & 76,915 & 8 & 8 \\
1822 & 8,136 & 892902 & 102,403 & 17 & 4 \\
1824 & 10,001 & $1,180,914$ & 130,911 & 11 & 6
\end{tabular}

From these figures it is evident that the tonnage of this port had much more than doubled between 1800 and 1821 , while the dock duties in 1824 were almost six times as much as in 1800 . Sandars gives these figures for each year, but his figures 
passed daily from Liverpool to Manchester and manufactured goods went from Manchester to Liverpool, whence they reached the world's markets. The amount of this interchange of commodities between these two cities was conservatively estimated at 1000 tons a day and it was constantly increasing ${ }^{\mathbf{1}}$. This great advance in population and in industry meant a greatly incrcased demand in the facilities for handling both in-coming and out-going freight.

How had this increasing demand for earrying faeilities been met by the existing transportation ageneies? The cost of carriage by land was $40 s$. per ton, which was so high as to be almost prohibitory for all goods cxcept those of the finest quality and highest value. In reality, land carriage was more largely coneerned with the carrying of passengers than of goods, although, on account of delays by water carriage, it frequently oceurred that waggons and earts had to be resorted to for taking cotton up to Manehester and manufactured goods back to Liverpool $^{2}$. This was done in the face of a freight rate that was three times that on the eanal, in order to sceure speedy and certain delivery of goods that were required for immediate shipment from Liverpool ${ }^{3}$. But the carriage of most of the heavy goods was done by the navigation companies, whieh felt themselves sccure in the possession of a monopoly that they had long enjoyed to the public detriment. To the consideration of this monopoly we now turn our attention in order that we may see how their work had been carried on.

By various devices, both the Mersey and Irwell (or "Old Quay") Navigation Company and the Bridgewater Canal Trustees had contrived to raise their rates above what they were legally allowed to charge ${ }^{4}$.

for the earlier years do not exaetly eorrespond with those of Enfield, Essay towards Ilistory of Lezerpool, Pl. 6i-69.

In 1770 the custons receipts at the port of Liverpool were $£ 231,994.12 s .5 d$. In 1822 they were $£ 1,591,123$, and in $1823, £ 1,808,402$, which shows how rapidly they were increasing. (In addition to above referenees, see Baines, Ilistory of Liverpool, p. 492.)

ln 1784 there were eight bags of American eotton imported into Liverpool; in 1824 there were 409,6ro bags. Of this, the great bulk went to Manchester (Booth, Liverpool and Manehester Iarilway, P. 5). In the footnote to pages 6 and 7 , Booth shows the progress of the port of Liverpool from 1824 to 1830 .

1 Booth, Liverpool and Manchester Railway, p. 4; Sandars, Liverpool and Manchester Railway, p. 13: also 'Prospeetus of the Liverpool and Wanchester Railway Company,' as given in Booth, p. 11.

2 Sandars, op. cit., p 17.

3 Ibid., p. 17. He says that goods going from Manehester for immediate shipment from Liverpool. often paid $£ 2$ or $£ 3$ per ton for carriage.

4 Coneerning the eonditions of carriage by these two routes between Liverpool and Manchester, we shall follow Sandars, Liverpool aud Manehester Railkeay, p. 4 et seq., in his deseription of their methods. His statements were uncontradicted, were based upon documentary evidence and lore the sanction of authority. 
The Old Quay Navigation Company, by their Aet of 1\%33:, were allowed to levy a tonnage duty of $3 s$. $4 d$. per ton, but were not restricted as to the rate of charge for freight. They adhered faithfully to this rate of tonnage; but as they owned nearly all the warchouses in Manchester on the banks of their navigation they were able to make much more revenue by freight, sinee for the use of these warchouses they could charge what they pleased and without the warehouses the navigation would be useless. In this way they were able to put their charges up so high as to drive all the other carricrs off the navigation, and thus almost monopolize the carrying trade on their route. It will be observed that, in inereasing their charges, this company did not violate their own laws. But this eannot be said of the Bridgewater Trustees, who, apparently, transgressed in several ways the statutory authority under which they were expected to operate, as we shall now show. The proprietor of the Bridgewater Canal was bound by his Acts not to charge more than $2 s .6 d$. per ton for eanal dues; and for this charge the Duke was required to provide, for all persons earrying goods on his canal, wharfage or warehouse room for a certain period of time. He also bound himself not to charge more than $6 s$. a ton (tonnage included) for any goods which he might earry by his own vessels ${ }^{1}$. How was this fulfilled?

On the suggestion of Brindley, who surveyed the Trent and Mersey Canal, the Duke arrangcd with the Trent and Mersey Canal Company to unite the two canals at Preston Brook in order to faciitate the transfer of goods from one canal to the other; and His Grace contraeted to cut the canal from there to Runcom at his own expense. By this means the two canals would have a common outlet to the Mersey tideway and thus the communication would be more convenient and eomplete ${ }^{2}$. In consideration of his expenses in making and maintaining the eanal from Preston Brook to Runcom and the neeessary locks and other works to accompany the eanal, the Duke was empowered to reecive a tonnage duty of $6 d . p \leftrightarrow r$ ton on all goods destined to enter the Trent and Mersey Canal $^{3}$. This sum was exaeted by the Duke on all goods that were conveyed between Liverpool and Manchester. in addition to the 2s. od. allowed by his own Aets, although he would have had to bring his canal to Runcorn and eharge no more than the $2 s$. $6 d$. if he had not arranged with the Trent and Mersey Canal Company. This made the tonnage duty between Liverpool and Manchester $3 s$.

1 Aets 32 Geo. II, c. 2 (1759), sec. 29; 2 Geo. III, e. 11 (1761), sec. 11.

2 Aet 6 Geo. III, e. 96 (176is), sec. 8t.

3 Trent and Nersey Canal Act, pp. ?00-4: Act fi Geo. III, e. 9ti (1765), secs. $86 i-87$. 
But this was not all. His Grace bound himself to the Trent and Mersey Canal Company that if he ever found it necessary to make inereased accommodation at Runcorn, the tonnage charge should still not be more than $6 d$. He soon found it necessary to construct a large reservoir there into which vessels destined to enter his canal were admitted at tide time. He pretended to construct this for his own ressels, but he kindly permitted those of other carriers to enter on condition that they paid $1 s$. per ton for the privilege, which was almost a necessity. This amount he collected on all goods passing along his own canal, as well as on those destined for places along the Trent and Mersey. This raised the tonnage to $4 s$. per ton.

A third means of increasing this tonnage rate remains to be pointed out. When the Rochdale Canal Company obtained its Act for cutting a line from Rochdale to Manchester, the Duke of Bridgewater obtained permission to make the lock to connect his canal with the Rochdale; and for this he was empowered to levy $1 s .2 d$. per ton on all goods which passed his lock, as indemnification for the loss which his warehouse property might sustain by this junction. In return for this payment he was bound to find warehouse room, gratis, for the goods for a certain limited time. Instcad of this legal charge, he exacted the $1 s .2 d$. per ton on all goods that were carried on his canal between Liverpool and Manchester, whether they passed the junction lock or not. In this way he managed to secure $5 s$. $2 d$. per ton on all goods carried on his line, while the Legislature never intended him to have more than $2 s .6 d$.

In addition to this unduly high charge, another extortion of the Bridgewater Trustees was that all goods which passed from Liverpool to Runcorn to enter the Trent and Mersey Canal had to pay about twice the amount of freight which they should have paid, owing to the fact that these Trustees had monopolized nearly the whole of the land and warehouses at Runcorn. They would not allow the goods to be landed at all without paying what they asked.

It is evident, therefore, that each of the existing navigations between these two great cities was acting so as to get the greatest possible amount from the service rendered; each was operating as a virtual monopoly. The Duke was strongly advised to buy the Mersey and Irwell Navigation at the price for which it was offered, about $£ 10,000$; but he was confident of the superiority of his canal and rejected the offer ${ }^{1}$. But

1 On his refusal, it was bought by some Manchester merchants and in the years prceeding 1825 it was producing an avcrage annual revenue of about $£ 15,000$; in otler words, the yearly receipts were one and one-half times the total cost. Brit. Mus. 08,235. f. 77 , 'Observations on the General Comparative Merits of Inland Communieation by Navigations or Railroads,' pp. 6-7. 
although the Duke declined to purchase this Old River Navigation, it seems that the two companies found it advantageous to share the monopoly with each other. The alliance of their interests was effected by an agreement made in 1810; and in that year the two concerns publicly advertised that they had mutually agreed upon an advanee of freight rates ${ }^{1}$. The rates of 1810 were nearly three times those of 1795 and about one-third more than those of $1824^{2}$. Of course, by the latter year it was becoming evident that there was the possibility of putting down a railway between these two places; and, apparently to placate those who wanted the railway, the navigation companies reduced their rates, but even the reduced rates were twice as much as those of $1795^{3}$. Until this possibility came before them there was an unqualified refusal to make any reduction ${ }^{4}$, and any objections made by shippers were met with insolence on the part of the navigation companies ${ }^{5}$.

Not only were the charges for transportation high, but the delays in the carriage of goods were often long and vexatious. These were occasioned, sometimes because of the entire stoppage of the waterways by frost or drought, and at other times by their being blocked up on account of the pressure of traffic. At times, storms and adverse winds prevented the navigation of the tideway of the Mersey, for it frequently occurred that when the wind blew very strong either south or north, the vessels could not move against it. Merchandise was often brought across the Atlantic to Liverpool in twenty-one days; while, owing to the various causes of delay above mentioned, goods were in some instances longer than this on their passage from Liverpool to Manchester ${ }^{6}$.

1 Brit. Mus. 08,235. f. 77, 'Observations on the General Comparative Merits of ... Navigations or Railroads,' p. 7. The advertisement of this change is given in Liverpool Adiertiser, Sept. 29, 1810. Each company gave public notice of the change of rates over the signature of its own agent and the two advertisements are exactly alike.

2 Sandars, op. cit., pp. 11-13.

3 Ibid., p. 13. Their rates in that year (1824) were: on heavy goods, such as corn, 12s. 6d. per ton, and on light goods, like cotton, 15s. per ton.

4 See letter of Captain Bradshaw, who had eharge of the Bridgewater Canal interests, in reply to a Memorial from the Corn Merchants of Liverpool asking for a reduction of freight. He refused to make any move toward such lowering of rates. Bradshaw's letter is given in full by Sandars, p. 12.

5 If the merchant complained of delay, he was told to do better if he could. If he objeeted to the rates, he was warned that if he did not pay promptly lis goods might not be earried at all.

${ }^{6}$ Sce 'Prospeetus of the Liverpool and Manchester Railway' as given in Booth, op. cit., p. 13. In regard to this lack of carrying facilities and the delays, see also 'Collection of Prospcetuses, Maps, ete., of Railways and Canals,' 1. 14, and Brit. Mus. 08,235. f. 77, 'Olsservations on the General Comparative Merits of... Navigations or Railroads,' p. $\tau$. 
Even the opponents of the railway did not deny that this had occasionally been the case ${ }^{1}$. But the causes of delay were mostly of such a nature that the navigation companies were powerless to effect mueh change in them, for the forces of nature were beyond their control; and, therefore, in the eomplaints as to the inadequate service, more emphasis was laid upon the extortionate charges whieh were voluntarily imposed than upon the impediments which eould not be avoided ${ }^{2}$.

The results of this monopolistic policy pursued by the two navigations were highly satisfactory to them, but not to the public generally. For nearly half a century, the thirty-nine original proprietors of the Mersey and Irwell Navigation had been paid ercry other year the total amount of their investment ${ }^{3}$ : and shares in that narigation company,

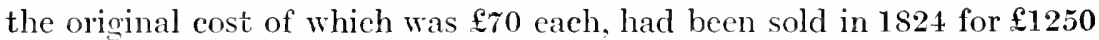
each $^{4}$. In the ease of the Bridgewater Canal, the results were similar; and one who knew the finaneial position of that coneern as fully as anyone could know it without being a trustee had good reason to believe that, since about $180^{\circ}$, the net ineome of this eanal had averaged nearly $£ 100,000$ a year ${ }^{5}$. Remembering that the cost of this canal was $£ 200,000$ to $£ 220,000$, we see that, at the above rate, the whole cost of the undertaking would be repaid erery two years or a little more. These statements are in aceord with that made by another in 1826, who. speaking upon this point. said that because the canals had recently raised their rates they were then making more than 100 per cent. profit ${ }^{6}$.

1 Booth, op. eit., p. 16.

2 It was "the enormous eharge for the freight of goods" between Liverpool and Manchester that had "become quite insufierable" (Sandars, p. 3). Of course, some delays were direetly traceable to the navigation companies, for it was a well-known fact, especially among corn and timber dealers, that great difficulty had been found in getting vessels or barges to convey these things to Manehester. Timber had frequently been detained in Liverpool a month for want of barges to earry it inland, and eorn and other commodities had been delayed eight or ten days for lack of a vessel for their conveyance. This was a serious evil, for men would not go to a market from which they had such diffieulty in getting their goods (Sandars, p. 16). The delays on the eanals also made it possible for mueh pilfering of goods to be carried on. On this monopolistie poliey, see asso Brit. Mus. 08,235. f. 7 \%, 'Observations on the General Comparative Merits of... Navigations or Railroads,' pp. 6- $\tau$; Aris's Birmingham Gazette, Dee. 18, 1824, p. 1, letter fron F. Finch; P., Letter to a Friend on the Comparatize Merits of Canals and liailicays, pp. 29-30, speaking of the overgrown monopolies between Liverpool and Manchester.

3 Sandars, op. eit., p. 21.

4 Ibicl., p. 21; also 'Prospectus of the Liverpool and Manchester Railway,' as given in Booth, p. 12.

5 Ibid., p. 21. The faet that no one ventured to deny what Sandars said seems to point pretty conelusively to the aceuracy of it. See also Parkes, op. cit., p. 24.

${ }^{6}$ IIansard's Parl. Debates, xv (1826), p. 93. 
From these facts, it is apparent that the monopolizing policy of the two navigation companies was, for the time being, highly advantageous to them, although their bencfit was secured by means that were derogatory to the best interests of industry 1 .

In the light of what we have here presented it is clear that a new line of conveyance was essential if adequate provision were to be made for the growing needs of that district. The proprietors of the navigations said that, by allowing time for increasing the number of thcir boats and the facilities for loading and unloading, they would be able to take care of the increase of trade; but this would not put an end to the delays or reduce the expenses of transport, against which there were such persistent complaints. Another canal was out of the question for the existing navigation had possession of all the water that was available; and it never seemed to occur to them that by lowering their rates they might perpetuate their business and also their profits ${ }^{2}$. Canal navigation had failed to meet the conditions of an expanding trade and a developing industry; and therefore the only thing to do was to obtain parliamentary authority for laying down a railway, which would combine the requisites of speed ${ }^{3}$, economy ${ }^{4}$, and safety ${ }^{5}$.

In 1822 a project was formed for constructing a railway between these two cities, on which carriages driven by steam should carry both merchandise and passengers at the rate of ten miles per hour. The expenses of a survey were contributed, and in the autumn of that year

1 It was not the desire of the Duke of Bridgewater that his canal should thus be used for the personal enriehment of the one individual who eontrolled it. On the contrary, his will (which gave R. H. Bradshaw the position of "superintendent" of the Duke"s possessions) showed that he intended the eanal for the publie good, for it says that the almost unlimited authority conferred on the superintendent was "to the intent that the public may reap from the same those advantages which I hope and trust the plan adopted in this my will is ealeulated to produce for their benefit" (Brit. Mus. 10,815. c. 35, 'Will of the Duke of Bridgewater,' p. 50).

2 Brit. Mus. 08,235. f. 77, 'Olsservations on the General Comparative Merits of... Navigations or Railroads,' p. 7.

3 In the passage from Liverpool to Manchester, goods going by eanal took, on the average, about 30 hours (Sandars, p. 17). But by a railway it would not take more than one-sixth of that time. The railway would not be hindered by chrought or frost, or any of the other impediments and dangers of water earriage. The railway would have extra earriages ready to meet any emergencies of business and thus prevent delay from that source.

4 The rates by the railway would be greatly redueed and competition would prevent their becoming exorbitant. Thus coal and other neessaries would be proeured cheaper than at present. Goods shipped by railway from either terminus for the other would not have to break bulk and be transhipped at the tideway.

5 When goods were sent by railway there would be no losses in the Mersey tideway due to storms. There would be no breaking open of packages and pillaging of contents if the goods were in the railway car (Sandars, p. 17). 
William James completed the survey and suggested a line of road. Public notices were given of the intention to apply to Parliament for authority to execute this line; but, probably owing to the fear of opposition from the whole body of inland navigation proprietors throughout the kingdom and for other causes, the measure was not followed $u \mathrm{p}^{1}$. The enterprise, however, was not allowed to sleep; men were sent to investigate the Stockton and Darlington and other coalroads in the north, especially near Newcastle and Sunderland, where both locomotive and stationary engines were in use for the conveyance of coal, and after their return it was decided to form a company for building a double railway between Liverpool and Manchester. The promoters were men of the highest standing and influence in these two cities. On Oct. 29, 1824, the company issued its prospectus, which detailed the reasons why the railway was desired and the benefits to be secured by it ${ }^{2}$. In the early part of 1825 application was made to Parliament for an Act to authorize the construction of this road.

Strong opposition was aroused against this Bill. The proprietors of the three navigations which connected Liverpool and Manchester forgot their former jealousy and disagreements and made common cause against the proposed railway. Their chief argument was that of vested interests: that their canals had been brought into existence under the authority of a former Act of Parliament and that now Parliament could not consistently pass a Bill which would destroy that property ${ }^{3}$. But this pretext was taken away when it was shown that there was a great difference between superseding an old machine that had paid its owners thirty times over, and superseding one that had not paid its owners the amount of its first cost. As these navigations belonged to the first class, there could be nothing against their being displaced by more advanced means of carriage. In league with the navigation companies were the large landholders, like the Earls of Derby and Sefton, a part of whose estates would be crossed by the railroad. They opposed the railway because they believed the sanctity of their domains would be invaded and the privaey of their residences destroyed by thus bringing into their neighbourhood a public highway, with its varied traffic of coal, merchandise and passengers ${ }^{4}$. The canal companies that were interested in the traffic of this region issued circulars calling upon" every

1 Manchester Gazette, Oct. 16, 1824, p. 3.

2 The full text of the prospectus is given in Booth, Lizerpool and Manehester liailway, p. 9 et seq. This first railway prospectus is an interesting document.

3 See report of the committee of the House of Commons on the Liverpool and Manchester Railway Bill, 1825, which gives full details as to the character of the opposition. See also Sandars, op. cit., p. 21.

4 Hansard's Parl. Debates, N.S., XII, p. 8.8; Booth, op. cit., p. 15. 
canal and navigation eompany in the kingdom " to oppose to the utmost, and by a united effort, the establishment of railways wherever contemplated ${ }^{1}$; and these must have had great influence when the cause was aided by Bradshaw, the superintendent of the Bridgewater Canal, whose authority was almost as good as law ${ }^{2}$. So intense was this opposition of the eanal interests that, in their opinion, it was impossible for a man to hold any of these railway shares and still be loyal to the canal company of whose shares he held any considerable amount ${ }^{3}$. The hostility of the estate-owners was also vigorous: they had used every means to prevent the making of a survey for the proposed railroad. They had blockaded their grounds on every side and had men employed to watch them. Bradshaw even fired guns through his grounds in the course of the night to prevent the surveyor coming on in the dark ${ }^{4}$. Both the navigation companies and the large landowners employed parliamentary representatives to work in their behalf, so as to put down such an intolerable innovation in established modes and vested rights ${ }^{5}$. The railway company likewise sent down a committee

1 See postscript attached to the prospectus that was distributed to memlers of Parliament and others, as given verbatim in Baines, History of Liverpool, p. 603.

2 According to Sandars (pp. $31,32,34$ ) no bill eould be brought forward in Parliament for a canal in any part of the kingdon but Bradshaw interfered to give full direetions. He made the trade of the eountry tributary to him in all directions. Santars, pp. 31-33, gives examples of this: "Every man, every Corporate Body, seems spell-bound the moment Mr Bradshaw interposes his authority."

"At a meeting of delegates from different parts of the kingdom, to eonsult as to canal interests in general, one of the delegates was turned out because he had five shares in the railway. The faet that he held canal property of the valuc of $£ 40,000$ was no protection to him. Sandars, p. 34 .

1 See letter of George Stephenson to Joseph Pease, dated Oct. 19, 1824, giving details of this opposition. This letter is reprodueed in Jeans, Jubilee Memorial of the Railway System, pp. 55-56, to show that the railway promoters had "sad work with Lord Derby, Lord Sefton, and Bradshaw."

${ }^{5}$ Of course, those members of Parliament who aeted in this way were not acting in any judicial frame of mind, but as those who were biased in favour of their friends. Mr Creevey, who represented Lords Sefton and Derby, was a member of the parliamentary committee to deal with the Liverpool and Manchester Railway Bill: and the attitude of some is well exemplified in Mr Creevey's letters (Maxwell, Creevey Papers, II, pp. 87-88). Under date of Mar. 16, 1825, he writes: "...Sefton and I have come to the conelusion that our Ferguson is insaue. He quite foamed at the mouth with rage in our Railway Conmittee in support of this infernal nuisance-the loeomotive Monster, earrying 80 tons of goods, and navigated by a tail of smoke and suphur, coming through every man's grounds between Manchester and Liverpool." On Mar. 25, 1825, he writes: "...I get daily more interested about this railroad-on its own grounds, to begin with, and the infernal, impudent, lying jobbing by its promoters." See also under dates of IIay 31 and June 1 , of the same year. 
to London to watch and aid the progress of the Bill through the House of Commons ${ }^{1}$. After a eontest of about three months, during which the neeessity of additional means of eonveyance was emphasized and thoroughly aceeded to, some errors were diseovered in the survey that had been made and this ereated so unfavourable an impression on the committee that the Bill was withdrawn'2. Before the next year an aceurate survey had been made; the line of way was changed so as to be less objectionable to the Earls of Sefton and Derby ; the Marquis of Stafford, representing the Bridgewater Canal, had been indueed to subscribe for 1000 shares of stoek in the railway; and a new prospectus was issued, explaining the eauses of the former unsuecessful applieation, how these had been overeome, and the benefits that would aecrue from the railway ${ }^{3}$. Early in 1826 the Bill was introdueed a seeond time, and in that session it passed both Houses ${ }^{4}$. Various estimates are given as to the eost of obtaining the Aet, varying from $£ 40,000^{5}$ to $£ 70,000^{6}$, but, of course, either of these estimates may be far from the actual amount. Gcorge Stephenson was then appointed resident engineer, and under his direetion the work was pushed to eompletion as rapidly as possible.

Of the diffieulties eonnected with the construction of the line we

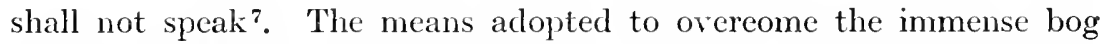
ealled Chat Moss, which the railway erossed as if it were dry and firm land, when at any point a pieee of metal would sink out of sight by its own weight, forms a ehapter in engineering whieh is of great interest. But while we shall not diseuss the physical and meehanieal features eonneeted with the formation of the road, there is one aspeet of its development whieh we may profitably refer to, namely, the ehoice of motive power. The line was nearing eompletion at the end of the year 1828, but no agreement had been reaehed as to whether stationary or locomotive engines should be employed ${ }^{8}$. In order to settle this

1 Booth, p. 14; Baines, IIistory of Lizerpool, p. 603.

2 Booth, p. 18.

3 Booth, pp. 25-31, gives this prospectus also in full.

4 The new survey put the line so that it did not touch the Earl of Sefton's estate and crossed only a few detached fields of the Earl of Derby's estate. The opposition of the Bridgewater Navigation, the most powerful of the two direct routes, was disarmed by the Narquis of Stafford taking such a large interest in the railway (see second prospectus as given by Booth).

5 Birmingham Journal, Nay 2\%, 1826, p. 3.

6 Ibid., Feb. 5, 1831, p. :3, letter from "A Subscriber to the London and Birmingham Railway." Compare these estimates with that of Booth in the Appendix of liis work.

7 On this aspect of the work, see Smiles, Lizes of the Engincers, George Stephenson.

8 Chattaway, Raikeajs, p. 2, tells us that even horse-power was considered. 
important matter, two celebrated engineers, James Walker and John Urpeth Rastrick, were asked to investigate this question and report their results to the directors of the railway. They visited the important places where steam-engines were used, notably the Stockton and Darlington and other coal roads in the north; and afterward each made out his own report showing his conclusions, in which there was almost entire harmony between the two engineers. In their reports, they were agreed that, having regard for the present and prospective interests of the company, locomotive engines would be found the more satisfactory. These should travel at the rate of ten to fifteen miles per hour ${ }^{1}$. In addition, they would employ two stationary engines upon the Rainhill and Sutton inclined planes to draw up the locomotive engines along with the carriages and goods. Their view, that on the line as a whole locomotive engines should be used, found acceptance with the directors; but the locomotive engines that had been used for some years in connexion with a few of the large collieries for the conveyance of coal were utterly unsuited to the requirements of passenger traffic. Knowing the vital importance of the character of the motive power, the directors offered a premium of $\mathfrak{£ 5 0 0}$ for the best locomotive adapted to the purposes of their line, two of the conditions being that it should be capable of drawing at least three times its own weight, at a speed of not less than ten miles per hour, and that it should consume its own smoke ${ }^{2}$. Several competitors entered this contest, and in October, 1829 , the various designers of the engines brought their locomotives for trial on the railway. On the first day, the engine made by Braithwaitc and Erickson, of London, exceeded all others in speed; but when the competition had continued for some days, in order to have a good test of all the engines, the prize was finally awarded to George Stepheuson's engine, the "Rocket"." After the expiration of almost another year,

1 Walker and Rastrick, Liverpool and Manchester Railway, Report to the Directors on the Comparative Merits of Loco-motive and Fixed Engines, as a Mozing Power. Nicholas Wood thought that the locomotive engine ought not to travel more than eight miles an hour; but these two engineers believed it could go at the rate of ten miles per hour with perfect safety, provided it did not exceed eight tons gross weight, exclusive of the tender (ibid., pp. 49,76 ).

2 Chattaway, Railcays, p. 2. For the conditions of this competition, sec Jeaffreson, Life of Robert Stephensou, 1, pp. 124-5. The Liverpool and Manchester Railway Act, 7 Geo. IV, e. 49 , required the engine to "effectually consunc its own smoke."

${ }^{3}$ Full details of the trial of the engines are given in The Times, Oct. 8,1829, p. 3; Oct. 9, 1829, p. 3 ; Oct. 12, 1829, p. 3; Oct. 16, 1829, p. 3; Oct. 24, 1829, p. 4; Oct. 31, 1829, p. 2. See also Smiles, Life of George Stephenson. These experiments, and others later, showed that the locomotive engine could easily attain a speed of 24 to 30 miles an hour. An account of this trial of the engines is given also in 
during which the construction of the roadway and its accessories procceded toward completion, the line was formally opened with great éclat and enthusiasm, on Scptember 15, $1830^{1}$.

With the Liverpool and Manchester line, the railway era really began. It was the first railway that was constructed for the express purpose of carrying passengers as well as freight; and no other power was ever used on it but that of locomotive engines. Up to this time, all others, except the Surrey Iron Railway, had contemplated the carriage of one commodity (usually coal, iron, or stone) and were operated as adjuncts to a colliery, quarry, or the like; while the Surrey Iron Railway employed only horse-power in the work of conveyance. The Lirerpool and Manchester, on the contrary, was constructed for the public welfare, rather than for private profit, as we can readily judge by the fact that no person could subscribe for more than ten shares, and the profit on these would not aggregate very much for any individual2. Indeed, under the Act of Parliament by which it was authorized $^{3}$, the profits or dividends were limited to ten per cent. ${ }^{4}$; and the undertakers werc so anxious to encourage industry and commerce that they declared they would be satisfied with even five per cent. ${ }^{5}$ It is very evident, then, that there was a wide difference between the Liverpool and Manchester Railway and any of those which had preceded it.

The immediate success of the Liverpool and Manchester Railway was the occasion of universal admiration and satisfaction. The rate

Lizerpool Times, Oct. 13, 1829, p. 328, and Oct. 20, 1829, p. 333 . The facts connected with this contest are also given in Jeaffreson, Life of Robert Stephenson, 1 , ehap. ix.

1 A full account of the opening is given in Lizerpool Times, Sept. 21, 1830, p. 298; Manehester Guardian, Sept. 18, 1830, p. 3; and Smiles' Life of George Stephenson. See also the history of the Liverpool and Manchester Railway written by Walker, pp. 42-48, for a description of the "Grand Opening of the Railway." The rejoicing of the day was saddened by the death of Mr Huskisson, M.P., which occurred because of an accident on the line. Booth, who was treasurer of the company, gives us an accomt of the construction of the line and the expenditures connected therewith in his second chapter. His third chapter is an account of the railway itself. His fourth chapter shows the mechanical principles applicable to railways, and how the directors finally decided to adopt the locomotive engine. In the Appendix he gives the details of the cost of the railway, which, including stations, warehouses, etc., amounted to $£ 820,000$.

2 II ansards Parliamentary Debates, N.S., xn (1525), p. 848; The Times, Mar. 3, 1825, p. 2, statcment of Mr Huskisson in the debate in the House of Commons on this Bill.

3 Act 7 Geo. IV, c. 49 .

4 See also The Times, Mar. 3, 1825, p. 2, and April $\%, 1826$, p. 2, statements of Mr Huskisson.

5 The Times, Mar. 3, 1825, p. 2. 
of speed on passenger trains was twice that of the fastest stage coaches and the cost of travelling was redueed about one-half ${ }^{1}$, while the amount of travelling increased fourfold ${ }^{2}$. Under these cireumstances many of the old stage eoaches ran almost empty for a short time and several were immediately withdrawn. Soon all the stage coaehes disappeared from regular service along this route and the railway absorbed all the passenger traffic ${ }^{3}$. The freight rates also were reduced by the railway by about one-third; and in order to enable the carriers on the navigations to meet this reduction the tolls on the Bridgewater Canal and on the Mersey and Irwell were reduced by about thirty per cent. ${ }^{4}$ The effect of the railway, therefore, was beneficial to the public by reducing overgrown monopolies within reasonable bounds, and it also stimulated these opulent canal companies to think of something else than their own pecuniary interests ${ }^{5}$. The value of land along the line of railway invariably increased, which was advantageous both to landowners and tenants, for the tenants had wider and better markets opened up to receive their produce and because of this enhancement of the value of the land the landowners could receive higher rents. This was observable also in cases where the railway eompany wanted to buy land in addition to that which they already held; their second purehase was invariably

1 Proecedings of the Great Western Railweay Company, p. 6; Ammal Registcr, 1832, p.445; 'Great Western Railway. Evidence on the London and Birmingham Railway Bill,' testimony of Henry Booth, p. 8. Aeeording to Mr Booth's statement, the fare between Liverpool and Manchester, by stage eoaeh, had varied a good deal, but was about $10 s$. inside and $6 s$. outside. On the railway, first elass fare was $5 s$. and second class $3 s .6 d$. The statement of a writer in the Manchester Guardian, Sept. 25, 1830, p. 2, makes the railway fares a little higher than those given by Booth, placing first elass at $7 s$. and seeond class at $4 s$. On the reduetion of rates see also 'Collection of Prospectuses, ete.,' p. 65, whieh is in elose accord with Booth's assertion.

2 Before the railway, there were about twenty coaehes per day between Liverpool and Manchester. Supposing these to be full every trip, carrying eighteen passengers each and pursuing their daily rounds for three hundred days in the year, there would be 108,000 people earried between these plaees in the course of the year. But in the twelve months after the opening of the railway about 460,000 persons were carried between these two termini (The Times, Oet. 19, 1831, p. 4).

${ }^{3}$ Manchester Guardian, Sept. 25, 1830, p. 2, on "Railway Coaches."

4 P., Letter to a Friend, containing Observations on the Comparatize Nerits of Canals and Railiays, p. 12. The freight rate between Liverpool and Manehester was reduced from 15s. to $10 \mathrm{~s}$. The tolls on the Bridgewater Canal were redueed from $3 s .8 d$. to $2 s .8 d$, and on the Mersey and Irwell from 3s. $4 d$. to $2 s .4 d$. See also 'Collection of Prospeetuses, Naps, etc., of Railways and Cauals,' pp. 13,65 .

5 P., op. cit., pp. 29-30; The Times, April 7, 1826, p. 2. For eanals which were paying one hundred per cent. every year or every two years there was need of some new factor to reduce their charges. 
made at a higher price than that paid for the first ${ }^{1}$. Not only did the public benefit from the railway, but the company itself also realized that the enterprise was a corporate snccess. In the first half of the year 1831 the net receipts wcre such that, after large expenditures for warehouses, carriages, etc., the company was able to declare a half-

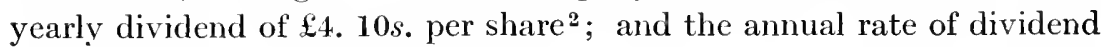
continued to range between eight and ten per cent. during the years following ${ }^{3}$. The value of the shares in the market may also be

1 See evidence before the committee on the London and Birmingham Railway Bill, as summarised in Birmingham Journal, May 19, 1832, p. 3, e.g., evidenee of Messrs Earle, Lee, Unsworth, Pease. See also Proceedings of the Great Western Railway Compamy, p. 6. The prospectus of the Liverpool and Birmingham Railway Company and the Birmingham and Liverpool Railway Company, whose interests were practically identical, showed that land which, from its vicinity to the Liverpool and Manchester Railway had been expected to deteriorate in value, and the owners of which had consequently claimed compensation, had, on the contrary, become more valuable than before. See especially the testimony of Mr Lee before the committee on the London and Birmingham Railway Bill, to the effect that some property along the linc of the Liverpool and Manchester Railway had been sold for building purposes at three to five times the sum it would have brought before the establishment of the railway. The almost universal testimony of those who gave evidenee before the committee on the London and Birmingham Railway Bill in 1832 was that lands along the route of the L. \& M. Ry had increased in value. Even land formerly waste had been bronght into cultivation and yielded a good rent. See also Ammual Register, 1832, p. 445; 'Collection of Prospectuses, Maps, ete. of Railways and Canals,' p. 65; 'Great Western Railway. Evidence on the London and Birmingham Railway Bill, pp. 34-37; and the notable case of increased land valucs given in Railway Times, iv, p. 215 .

${ }^{2}$ The receipts from Jan. 1 to June 30, 1831, as given by the Annual Register, 1831 , p. 169, were:

\begin{tabular}{|c|c|c|c|c|}
\hline & $\mathfrak{E}$ & $s$. & $d$. \\
\hline \multicolumn{2}{|c|}{ From conveyance of passengers } & 43,600 & 7 & \\
\hline , & merchandise & 21,875 & 0 & \\
\hline$"$ & coal & 218 & 16 & \\
\hline & Gross receipts & $\overline{65,693}$ & 13 & \\
\hline \multicolumn{2}{|c|}{ Expenses for repairs, salaries, ete. } & 35,379 & 0 & 0 \\
\hline & Net reccipts & 30,314 & 13 & \\
\hline
\end{tabular}

The net receipts divided among 7012 shares allowed a dividend of $£ 4$. $10 \mathrm{~s}$. per sliare for the half year. (lt will be noted that there is a slight error here in summing up the gross receipts.) See also Brit. Mus. 8235. ee. 12 (1), p. 2.

3 In 'Collection of Prospectuses, Maps, etc. of Railways and Canals,' p. 173, there is given an 'Extract of the Report of the Liverpool and Manchester Railway,' for the half year ending Dee. 31, 1833, with a comparison of the results for this six months with the results for previous half years since the railway began operation. The half-yearly dividend thus far had ranged from four to four and one-half per cent. This financial ștatement was also attached to the prospectus of the Great Western Raikway, 1834 (ibid. p. 176). In Brit. Mus. 8235. ee. 12 (1). 'Reasons in favour of a Direct Line of Railroad from London to Manchester,' p. 2, we have a comparison 
taken as an index of the measure of the success of the railway. Even before the experiments of October, 1829, to find the best engine for use on the line, the railway shares had been selling at a premium; but after that time their value rose very rapidly, until, within a month after the success of the locomotive engine had been demonstrated the shares were

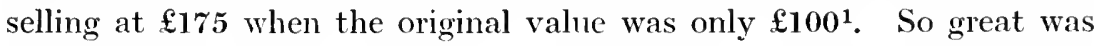
the demand for these shares, and so highly were they valued, that it was difficult to procure them on any terms. By 1832 the value of the shares had risen 100 per cent. ${ }^{2}$, and by 1836 almost 200 per cent. ${ }^{3}$, above their original value. All the important railways that were taken up immediately after 1830 put forth the success of the Liverpool and Manchester Railway as an attestation and guarantee of the success of their own enterprises ${ }^{4}$.

But we must follow the finances of this company a little farther if we would obtain a correct idea as to its operations. Let it be said, first of all, that by its Act the company was limited in the payment of dividends to a maximum of ten per cent. a year; and it was the only railway company that was restricted in this way. As we have seen, the company early paid the full amount of the dividend that was allowed and continued to pay this for many years. When the company sought authority from Parliament to construct the road it was declared that $£ 510,000$ would be ample for all purposes ${ }^{5}$; and according to their Act of incorporation the capital was fixed at that amount. But it would appear that this amount proved insufficient to complete the road and its equipment, and by the Acts of 1829 and 1830 the company was allowed to increase its capital by the issuance of shares to the amount of $£ 127,500$ and $£ 159,375$ respectively, all of which was said to have

of the above receipts of 1831 with those of the year 1836, showing that the dividend in the latter year was ten per cent. In 1834 it was paying nine per cent. (Proceedings of the Great Western Railway Company, p. 52), and in 1842 it was paying ten per cent. (Railways: Their Uses and Management, p. 7).

1 The Liverpool Times, Nov. 24, 1829, p. 376, informs us that before these experiments the shares were selling for $£ 118$ each, but at this date they were now selling for $£ 75$ premium, and could scarcely be had even at that price.

2 Proceedings of the Great Westem Railway Comprmy, p. 52; also evidence on the London and Birmingham Railway Bill, 1832, testimony of Henry Booth. The shares in 1831 were selling for $\$ 196$ (Remarks upon Pamphlet by Investigator on the Proposed Birmingham and London Railway, p. 4; 'Collection of Prospectuses, etc.,' p. 65).

3 Gentleman's Magazine, 1836, v1, p. 421. The Liverpool and Manchester shares, the par value of which was $£ 100$, were selling in 1836 for $£ 280$.

4 See prospectuses of the Birmingham and Liverpool, London and Birmingham, and Great Western railways.

5 Sce the company's prospectus, as given in Booth's history of the railway. 
been expended and yet the works were not completed. Under subsequent Aets, they were allowed to raise by sale of shares or to obtain on loan a further sum amounting to $£ 427,500$, thus bringing the total capital up to $£ 1,224,375$, of which the share capital was $£ 808,025$ and

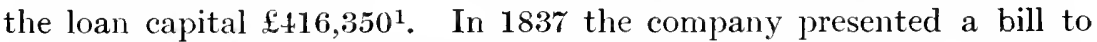
Parliament, stating that although the above amount had been spent "on or about the undertaking," its works had not yet been completed; and accordingly it was desired to obtain authority to borrow an additional sum of $£ 400,000$, which, if authorized, would raise the capital to $£ 1,624,375$. This extra amount was to be asked as a loan from the Government, that is, from the Exchequer Loan Commissioners, and in case the Government advanced the moncy it was to have the prior claim upon the revennes of the company ${ }^{2}$. In the six years up to 1837 , the company had paid in dividends $£ 442,504.7 s .6 d$; ; but during the same time the amount obtained on loan and by the sale of shares was much in excess of this amount, and, therefore, the company would seem to be obtaining money from others to pay dividends, while all the time becoming more embarrassed ${ }^{3}$. But when seen in another light, these sevcral accessions to capital presented facts which led to an entirely different conclusion. Their expenditure upon additional works was said to have brought additional revenue; so that after paying the interest on these increasing amounts obtained from creditors the company was still able to pay the maximum dividend of ten per cent. ${ }^{4}$ Instead, therefore, of the company becoming more hopelessly embarrassed financially, it was ostensibly getting upon a more secure foundation. We prefer to think that this was the explanation of the above-mentioned great increase of capital. But there is another way in which it can be, and was, accounted for, namely, as a device for overeoming the restriction of their profits to ten per cent. It was held by some that if Parliament had rigidly enforeed this provision of the Act and steadfastly refused to allow the distribution of additional profits under any other guise, the company would have been compelled time and again to reduce the fares and charges to the public; but since this provision was not enforced the railway company, under the semblance of increasing the "public accommodation," created a pretext for the issuance of new shares, and thus extra profits were divided out in

1 These facts appear in the Bill presented to Parliament in 1837, asking for further authority (The Times, Hay 9, 1837, p. 6, letter from “'T.G."), and are confirmed by IV. S. Moorsom, C.E., in ibid., Nay 23, 1837, p. 6.

2 The Times, May 9,1837 , p. 6, letter of "T. G."

3 Ilid., May 9, 1837, p. 6. This was the contention of "T. G."

4 Ibid., May 23, 1837, p. 6, letter of W. S. Moorsom giving quotations from the company's semi-annual finaneial statements. 
the form of new stock ${ }^{1}$. If this were the explanation of the great increase of eapital from time to time, the road must have been suffieiently profitable to pay at least forty to fifty per eent. It seems to be more consonant with the facts to aecept the first solution of this problem ; for if the eompany's business were so flourishing that surplus profits could be divided out in this way, there would have been no need of applying to Parliament for a Government loan. And yet, in the face of these facts, several persons, by their publications, attempted to prove to the public that this railway was nothing but an unprofitable speculation ${ }^{2}$.

We have now brought our subject down to the time of the initiation of the modern railway; but in order that we may consider in detail the effect of this new means of transportation we must see it in a more advaneed stage of development, for it is impossible to form any correct estimate of its value and influence from a single example apart from a system. It will, therefore, be neeessary for us to outline the history of railways to about the middle of the eentury in order to see the forces which were at work throughout this early period when the railway was attaining a position of importance as a public earrier.

During the third decade, when the railway had not yet demonstrated its great superiority, but was in the tentative evolutionary stage, and when the locomotive engine was still in the experimental period of its development, there was uncertainty and instability of the public mind concerning the utility of this newcomer in the field of transportation. Some expected that the railway would only add another means of conveyance to those already existing, in the same way as the introduction of canals had done sixty years before, but that every facility given to the carriage of materials, while adding to the general carrying trade, would eause no injury to canal property ${ }^{3}$. It seems, however,

1 The Times, Oct. 1, 1846, p. 5, letter from "Cato."

2 Gordon, Treatise upon Elemental Locomotion, 2 nd ed., p. 225 et seq.; Gordon, The Fatness of Turupike Roads and Highways, p. 28; Cort, Railroad Impositions Deteeted, or Facts and Arguments to prove that the Liverpool and Manehester Raitivaly has not paid One per ceut. Nett Profit, etc. These based thcir opinion upon the probability that nothing had been set aside for depreciation. See also Remarks upon Pamphlet by Investigator on the Proposed Birmingham and London Railicay, p. b. Grahame, Treatise on Internal Intercourse and Communieation (1834), p. 159, in summing up his statistics and arguments regarding the Liverpool and Manchester Railway, said: "No one, who fairly considers these results, but must acknowledge that the whole is a failure, at least, as presently conducted. The cxpenses are so enormous, as completely to absorb every advantage of speed, and each year these expenses increase." He would have the road open to all, so that, upon payment of the tolls, anyone could use the road as freely as they did the turnpikes.

3 Manchester Gazette, Jan. 15, 1825, p. 3, editorial comment. 
that there were few who regarded railways in this way. Many people foresaw in them very decided advantages, and, while fairly assured in their own minds that a new era was dawning in the transport service, they had not yet received complete proof that its successful establishment was at hand. But whatever were the prospects of the railways, whether favourable or unfavourable, there was a large amount of capital in the country seeking investment and this superabundance of capital introduced the rage for speculation ${ }^{1}$, in which the railways shared. The years 1825 and 1826 seem to have been the climax of this speculative fever. All kinds of projects were promoted by men who were eager to take advantage of the circumstances of the time to reap large returns from credulous and unsophisticated prospective investors. Men were induced to believe that they had only to embark in one of these schemes to ensure themselves a life of affluence and ease; labour and eare were to be at an end and the golden harvest would soon appear. In February, 1825, there were at least five railway companies and thirty dock companies, loan companies, insurance companies, and other kinds of undertaking, that were being floated ${ }^{2}$. Railways were being planned to connect the most important mercantile and manufacturing towns in the kingdom, and the success of the Stockton and Darlington line gave added impetus to this movement ${ }^{3}$, not withstanding the secret opposition which was very active on behalf of interested bodies for their own private good. This fever was instituted mostly for purely speculative purposes, in order that projectors and their attorneys and other assistants might profit to a large extent through trafficking in shares ${ }^{4}$. The latter were brought into the market at a premium and pushed to as high a price as possible; then they were unloaded upon unsuspecting and unfortunate individuals who were duped and left stranded "after the waters of delusion had ebbed away ${ }^{5}$ " Of the great number of these sehemes that were brought forward, but few ever cane to completion; of the others, no vestige remained except in the disaster which

1 Brit. Mus. 08,235. f. 77, 'Observations on the Comparative Merits of Inland Navigations and Railroads; pp. 8, 10.

2 Coumty Chronicle and lleelily Adzertiser, Feb. 1, 1825, p. 2, gives a list of thirtyfive such eompanies then afioat.

3 The London Magazine, I, N.S. (1825), p. 33, on "Railways;" Grinling, The II istory of the Great Northern Railicay, p. 1. Among these railways may be mentioned the London and Birmingham, the Great Northern from London to Cambridge, and the Liverpool and Birminghm. Aris's Birmingham Gasette for the year 1825 (note, for example, the issue of Jan. 31, 1825) shows a grcat many projects for railroads that were then occupying publie attention.

4 The Times, July 17, 1832, p. 3, statement of Lord Wharncliffe; Mudge, Obserrations on Raitica!s. 1. 35.

5 Investigator, Bercare the Bubbles, p. 10 ; Nudge, op. cit., p. 35. 
overtook those who had been deceived by the wiles of the mereenary speculators. How much eapital was lost from legitimate productive industry we have no means of ascertaining; but if we were to receive the statements of contemporaries ${ }^{1}$, and then make much allowance for exaggeration, we should still be required to believe that this panic assumed proportions of considerable magnitude. Fortunately, however, only a few of these projeets which were brought forward were authorized by Act of Parliament to proceed to execution, for most of them were ventures of such a nature that their success could not be definitely foretold ${ }^{2}$. But when the success of the Stockton and Darlington was assured the year 1826 saw the authorization of eighteen new railways, among them the Liverpool and Manchester.

Following the poliey that had been pursued with great benefit to the country for three-quarters of a century, in allowing private enterprise to develop and manage inland communication, the Legislature considered each of the schemes brought forward according to its own merits; and for each one that met with approval a private Act was passed, which contained the entire statutory provisions applicable to the undertaking.

After the utility of the locomotive had been shown on the Stockton and Darlington line, and especially after the results of the trials of the locomotives on the Liverpool and Manchester, in the autumn of the year 1829, had been made known, interest was aroused anew in the prospects of railways. The vast range of possibility which opened up when it was seen that loeomotive engines could travel at rates of speed from twenty-five to thirty miles an hour, seemed to fire the imagination of many. By this means, places then considerable distances apart would be brought very close to one another; the capitals of Scotland and Ireland would be within twenty-four hours' journey of London; facility in the communication of intelligence would enable the pcople in all corners of three kingdoms to keep in direct touch with the measures

1 Investigator, Bercare the Bubbles, p. 1, speaks of the "uncontrollable exereise of the spirit of speculation, which, in 1825 and 1826 , brought about so fatal a crisis, involved so many in ruin," ete.; and again (p. 10) he refers to the "melaneholy wrecks of men of important station." In Felix Farley's Bristol Joumal, Oet. 5, 1833, p. 2, a letter from John IVeedon spcaks of the "rash and improvident speculations which led to the frightful commereial eatastrophe of 1826." Mudge, Obscritions on Railways, p. 35, deplores allowing the "delusive and ruinous speeulations" of 182.5 to go on uncheeked, and says that this "injury to the wealth and prosperity of the country" was felt for nearly ten years.

2 On the details of this panie, see Franeis, History of the English Railiay. Jeaffreson, Life of Robert Stephenson, I, pp. 272 et seq., shows the difference between the railway crises of 1825 and 1836 and the railway mania of 184t-6. 
that were before the Government for consideration, and public opinion would acquire a strength and concentration that it never possessed before. By the rapidity and cheapness of travel, workers in any part of the country could readily go to any other part, and the inevitable consequence would be that sooner or later there would be only one rate of wages throughout the United Kingdom. The ease and celerity with which markets could be reached would cause land to be brought into eultivation that had hitherto been required to lie waste because of the expense of transporting the produce to a suitable market. By means of steam, it was thought, the produce of land twenty or thirty miles from the market would be brought to the place of sale in as short a time, and at as small a cost, as the produce of land five or six miles distant had been by waggon; and, therefore, while the consuming public would profit by this increased supply, the landlords would also derive advantage because of the increased value and rentals of their lands and the farmers would receive greater net returns from the sale of their surplus ${ }^{1}$. With such vast national benefits as these and many others presented to an admiring world, it would have been strange, indeed, if there had not been an outburst of sentiment in favour of an expansion of railway construction; and the statement in 1829 that within ten or twenty years the whole country would be united by railways which would convey passengers and goods at twice the speed and one-third of the cxpense that then prevailed ${ }^{2}$, was abundantly fulfilled in strict literalness of detail. With the accustomed tendency to exaggeration, people had been talking of travelling in the near future at fifty or sixty miles per hour ${ }^{3}$; but more conservative minds were counselling moderation. It was thought that the rate of thirty miles an hour of actual progress would be as great a velocity as would be compatible with safety. In any ease, railway promoters should wait until the Liverpool and Manchester Railway was opened before making a survey, since a few months' operation of that line would teach many things of which people were then ignorant $t^{4}$ Even as late as 1831 there were some who, after the Liverpool and Manchester Railway had been in operation for a half year, still advised to go slowly in the further establishment of railways; it was said that the greater economy of this new means of carriage had

1 See, for example, Liverpool Times, Nov. 17, 1829, p. 362, on "Future Changes." So great would be the advantages seeured in the way of linking up elosely the great towns of the kingdom, that the writer thought the country would become like Sir Thomas More's Utopia, where "iota insula velut una familia est." He was partieularly interested in the great benefits which would accrue to Liverpool in making it the most important port of England.

2 Ibid.

${ }^{3}$ Birmingham Journal, Dec. 5, 1829, p. 4, on "Steam Coaches and Locomotive Engines."

4 Ibid., Dec. 12, 1829, p. 4, on "Steam Travelling" (editorial). 
not yet been proved, and that experience alone would show whether railways could carry cheaper than canals ${ }^{1}$. But, while urging the necessity of caution and the desirability of avoiding undue haste, it was felt that the locomotive on the rails was to be the coming means of transportation, and, therefore, consideration should be given to making the road as nearly level as possible and to preventing all chances of obstruction, so that the engines might develop the greatest power and the highest rate of speed ${ }^{2}$.

The first lines that were actually constructed after the opening of the Liverpool and Manchester were in connexion with it, and chiefly in Lancashire. A branch was formed from Bolton to Leigh, and another from Leigh to Kenyon, where it formed a junction with the main line. Other branches were made from Newton, on the main line, to Wigan on the north and Warrington on the south, and still another from the main line, near St Helens, to Runcorn. It is not our purpose, however, to enter into details as to the filling in of the shorter lines; rather do we consider it as consonant with our object to describe the laying down of only the foundations of the railway system, and to the greater lines only shall we devote our attention.

Following the year 1824, an active campaign had been pursued to secure a railway between Liverpool and Birmingham. A large traffic was carried on along this route between the midland metropolis and the great port on the Irish Sea; yet the carrying facilities of these two places, like those of Liverpool and Manchester, were uncertain, expensive and totally inadequate to their necessities. We have already detailed the conditions which existed between the two latter places for the carriage of goods before the railway was constructed; but, according to the prospectus of the two companies which were desirous of having the railway between Liverpool and Birmingham, the conditions attending water carriage between these two cities were "infinitely worse" in regard to delays, charges and impediments ${ }^{3}$. It would almost seem as if this statement were exaggerated; and in order that the reader may see the relative conditions along the two routes we shall present a few facts concerning the conveyance of merchandise by the waterways between Liverpool and the Midlands ${ }^{4}$.

As in the case between Liverpool and Manchester, so also between

1 Birmingham Journal, Mar. 5, 1831, p. 3, on "Railways."

2 Ibid., Dec. 12, 1829, p. 4.

3 'Collection of Prospectuses, Maps, etc., of Railways and Canals,' Pp. 13-14, gives the prospcctus in full. It is also given in Birmingham Journal, Mar. 11, 1826, p. 1, and in Liverpool Times, May 11, 1830, p. 149.

4 For the facts pertaining to water carriage between Liverpool and Birmingham, we shall refer much to Parkes, Claim of the Subseribers to the Birmingham and Liverpool 
Liverpool and Birmingham, the canal companies eonstituted probably the strongest opposition to the construction of a railway. Their monopolistic policy was not to be overthrown without a struggle to save it. For many years the canals along this route had made inordinate profits: one of the canals connecting with Birmingham paid an annual dividend of $£ 100$ on the original cost of $£ 140$ per share, so that the annual profits divided among the shareholders closely approximated the first cost of the canal ${ }^{1}$. It would appear that some canals profited still more largely from their trade, for we learn that one of them passing through this midland district paid an amnual dividend of $£ 140$ upon an original share of $£ 140$, and the value of such shares had been increased from $£ 140$ to $£ 3200$; while another in the same district had paid an annual dividend of $£ 160$ upon the original shares of $£ 200$, and the shares had been enhanced in value until they had reached $£ 4600$ each $^{2}$. Impediments of one kind and another caused delays to the transit of merchandise; for example, all goods that arrived at Runcorn had taken three or four hours, and occasionally as many days, in the Mersey estuary; then at Runcorn every ton of goods had to be transhipped and the loaded barges had to be elevated through the locks to a height of serenty-five to ninety feet before they could proceed on their way; after that they set out along the canal for Birmingham, which they reached four to six days after leaving Liverpool ${ }^{3}$. Similar delays and barriers had to be endured by the finished products of the Midlands on their way to the port, whence they could be shipped to the great markets. In addition, the cost of conveyance along the canals, together with the great amount of compensation tolls imposed when

Railray. His statements were not contradicted, and may therefore be taken as accurate.

1 Parkes, Claim of the Subscribers, pp. 19-20; West, History of Warwickshire (1830), p. 100.

${ }^{2}$ See Prospectus of the Birmingham and Liverpool Railroad Company. This statement was not controverted by any other evidence, not even before the parliamentary committee to which the Bill was referred, and it may therefore be considered as true. Had it been possible to contradict it, the denial would certainly have been made, since every effort was being used at this time to discredit the railways. See confirmation in Parkes, op. cit., p. 24; also Aris's Birmingham Gazette, Dec. 13, 1824, p. 1, letter from F. Finch, in whieh he speaks of the "inordinate profits" which these canals had long enough enjoyed. Cumming, Rail and Tram Roads (1824), p. 47, evidently quotes from the Prospectus of the Birmingham and Liverpool Railroad Company. See also Birmingham Journal, Sept. 2, 1826, p. 1, Prospectus of the Proposed Railway from Birmingham to Wolverhampton.

${ }^{3}$ Prospectus of the Liverpool and Birmingham Railway, as given in the Liverpool Times, May 11, 1830, p. 149. The delays, charges and impediments of the navigation were felt as early as $17 \tau 1$ by Brindley, who projected an aqueduct bridge over the Mersey as a remedy. 
a barge passed from one eanal into another, were serious obstaeles to the development of traffic ${ }^{1}$. But, despite these restrictions upon the system of transit in that part of the eountry, there had been a great inerease in the amount of, and revenue from, the tonnage which centred in the Midlands ${ }^{2}$; so great, in fact, that the existing facilities eould not accommodate the traffie, and, therefore, there was a persistent demand for new means of conveyance. To rely upon water carriage for atxiliary facilities would be to invite disaster, and this for several reasons. In the first place, no more water was available for an extra canal throughout that seetion ${ }^{3}$; and even had there been abundance of water for an additional canal, there were eireumstances that were decidedly opposed to the formation of such a waterway. The conveyance by eanal, under the best conditions, was altogether too slow for the carriage of meat, butter and other agricultural produce, since these might be spoiled before they reached the market for which they were intended ${ }^{4}$; and the transport of manufactured commodities from the interior to the coast was frequently so uneertain that shippers sometimes suffered considerable loss through their inability to ship goods by a pre-arranged vessel. During the drought of summer and early autumn, the boats often had to go with a light load and wait their turns in passing the locks, so as to economize in the use of water ${ }^{5}$. Moreover, some of the castings and apparatus, then sent at great expense by land earriage, could not be sent by eanal, because their size would not permit them to pass through canal locks, and, oceasionally, because their weight exceeded the tonnage of a single barge ${ }^{6}$. The stoppages of traffic on the canals along this course were frequent and sometimes prolonged, for floods damaged the navigation works, repairs consumed much time, and frost was sometimes a still more serious barrier. All these suspensions deranged the aceustomed production, distribution and eonsumption of products, and eonsequently the price, so that both producer and consumer suffered thereby ${ }^{7}$. Considerable delays occurred also from the lack of a sufficient number of boats to convey the accumulation

1 Parkes, op. cit., pp. 42-43.

2 Ibid., p. 44.

3 Ibid., p. 45.

4 Aris's Birmingham Gazette, Feb. 2, 1829, p. 2, letter of "A Looker-On," says that the average speed of a boat passing along a canal, with a full load, and without the interruption of locks, was two and one-half miles per hour. In Mr Lee's letter (ibid., Feb. 9, 1829, p. 1), replying to the foregoing, while he contradicts some things mentioned by "A Looker-On," he does not deny this statement as to the rate of speed. For further confirmation of this, see also ibid., Dee. 17, 1827, p. 3, letter from Mr Lee containing some facts as to canal tralfic rates.

5 Parkes, op. cit., p. 47.

6 Ibid., p. 45.

7 Ibid., pp. 47-52. 
of goods ${ }^{1}$; and on various occasions goods had been in transit from four to six weeks ${ }^{2}$. Because of these circumstances, namely, the vast increase of trade in the districts between Birmingham and Liverpool, the increasing importance of cheap and rapid transport, and the glaring fact that, although the profits of water carriage had increased beyond those of any other branch of enterprise, no reduction had been made in the charges of conveyance, the commercial and industrial classes proposed to construct a railway that would furnish adequate facilities to meet the enlarged needs of trade.

The first efforts toward securing such a line were made in the year 1824, when two companies were formed to undertake this work: one, the Liverpool and Birmingham Railway Company to construct the portion of the line from Liverpool, and the other the Birmingham and Liverpool Railway Company to construct the portion of the line from Birmingham. Their interests were identical, and they worked together to secure separate acts of incorporation and to frame regulations under which they could collaborate for their mutual good and the public advantage. Each company issued its prospectus in 1824, showing the existing conditions and the changes which would be effected should they be successful in securing parliamentary authorization to construct their line; and in this announcement they promised to carry "by day and night, at all times of the year, in periods of frost or of drought, at the rate of at least eight miles an hour," and at an expense "less by onethird, probably by one-half," than the existing rate by canal ${ }^{3}$. Immediately the opposition was aroused, led by those who were interested in maintaining the monstrous monopoly of the navigation interests; and owing to the hostility of the combined opponents, and to some inexplicable causes, the railway companies were powerless to secure the passage of their Bill. The advantages to be obtained from the proposed railway, however, were too great to allow the project to permanently fail; and a quiet agitation was continued in its favour. The companies endeavoured to placate opposition and to solicit the concurrence of those whom they had been able to win over from their attitude of dissent ${ }^{5}$. Early in the year 1826, the Birmingham and Liverpool Railway Company issned an address and appeal to the public, explaining their motives and the principal grounds upon which

1 Parkes, op. cit., p. 53.

2 Ibid., p. 54.

3 Parkes, op. cit., pp. 57-60, gives the prospectus.

4 Birmingham Journal, Dec. 12, 1829, p. 3.

5 See, for example, Birmingham Journal, Jan. 21, 1826, p. 3, showing that the railway companies sent representatives to attend at the meetings of the commissioners of the turnpike roads along and near the route, in order to get them to favour the railway. In this, they seemed to have poor results. 
they based their case ${ }^{1}$. They showed that beeause there was only one canal eonnecting Birmingham with Liverpool there was no competition in the conveyance of goods; hence the need of a railway to introduce that element in the life of trade. The distanee between Birmingham and Liverpool by canal and the Mersey river was approximately 120 miles, but by the proposed railway it would be only ninety miles. Moreover, the time required by fly boats to follow this waterway between the two termini would be at least sixty hours, but by the proposed railway it would not exeeed fifteen hours. The freight rate for merchandise would be redueed from $45 s$. per ton by the above waterway to not more than $30 \mathrm{~s}$. per ton on the rails. The stoppages on the canals, due to frost, drought and other eauses, which oeeasioned great inconveniences and frequent losses to shippers, would be unknown with the railway; and the injury to corn, merchandise and other goods, on aecount of the leakage and sinking of boats, could not occur on the railway. In the previous session of Parliament the canal proprietors had strenuously denied that there was any need for additional means of conveyance; but in the session following there was a Bill before Parliament for a canal from Autherley to Nantwich, along the line of the intended railway, which was a virtual admission that there was need of greater accommodation for the publie. This being granted, it was a question whether parliamentary sanetion should be given to a railway or to a sceond canal. The railway line had been lately resurveyed by Jessop and Rennie and the greatest care had been taken to render the route as satisfactory as possible to the largest number of the landed proprietors, although there were some whom they had not been able to conciliate. Having detailed some of the local advantages that would result from the railway, its promoters also showed its importance from the national point of view, as forming part of one great line of direet communication between London and Ireland, and they concluded by requesting Parliament and the publie to consider it impartially and to obtain for the country the benefits it held out to agriculture, commerce, manufactures and the political seeurity of the realm. This appeal was signed by Robert Peel, the ehairman of the company, and doubtless earried much weight exeept with those who were personally interested in opposing the railway.

For some months we are unable to follow the company's history, but in Angust of that year (1826) there was held at Birmingham a general meeting of the subseribers to the railway, at which an unexpeeted turn was given to their affairs. Those present at this meeting, while fully satisfied regarding the advantages of a railway between Birmingham

1 Birmingham Journal, Mar. 11, 1826, p. 1, gives this address in full. 
and Liverpool, yet decided that, taking into consideration "the existing pecuniary embarrassments of the country," and the present difficulties in the way of obtaining an Act for a line upon the extensive scale originally proposed, it would be prudent to confine their efforts to the establishment of a railway between Birmingham and Wolverhampton, with such branches as might be thought necessary to the neighbouring towns and works. This line would not cxceed fourteen miles in length and could be exceuted for $£ 150,000$; it would pass through the heart of the mining district of Staffordshire, and thus provide another means of supplying Birmingham, Wolverhampton and intermediate places with coal, iron, lime and other materials for their manufacturing industries. Those subscribers who preferred to retire rather than cooperate in this limited enterprise would be allowed to do so under reasonable terms, and those who wished to continue as subscribers would be retained, but in no case could a subscriber hold more than fifty shares of fifty pounds each ${ }^{1}$. At the same meeting there was read a prospectus of this proposed shorter line of railway, showing the large population and business interests of this locality, the need of additional means of conveyance to compete with the monopolistic canals and reduce the freight charges, and the desirability of eliminating longexisting grievances ${ }^{2}$. It would seem that this project did not materialize, probably on account of opposition that was aroused through party squabbling; for at a meeting of the subscribers to the undertaking in the early part of the year 1831 it was agreed, with only one dissenting voice, to suspend further prosecution of the work for a year ${ }^{3}$. Evidently they had not got much, if any, nearer to the execution of the proposed undertaking.

But although this partial enterprise was devoid of results, the earlier plan for a line between Birmingham and Liverpool had, in the meantime, been resumed. Toward the end of the year 1829, when the people had seen the probable, if not the positive, success of the Liverpool and Manchester Raihway, a large and enthusiastic meeting of the wealthy merchants and manufacturers of Birmingham was held, to promote the construction of the line to Liverpool ${ }^{4}$. About the same time, a meeting was held in Liverpool, at which it was determined to form a company for constructing a railway from that city along the same course as that projected by the Birmingham people; and, in order to further this plan,

1 Birmingham Journal, Sept. 2, 1826, p. 1, gives the exact words of the resolutions accepted at that general meeting.

2 Ibid. The prospectus is here given verbatim.

3 Ibid., Feb. 12, 1831, p. 2, on the "Wolverhampton and Birmingham Railroad."

4 Ibid., Dec. 12, 1829, p. 3, on the "Birmingham and Liverpool Railway." 
and to reduce the opposition as much as possible, the interests of the navigation companies were to be given attention. To remuncrate canal proprietors for the losses which they would probably sustain from impending competition, extraordinary inducements and privileges were held out for them to become shareholders in the railway ${ }^{1}$. Before the middle of the year 1830 this line had been surveyed by Stephenson and Rastrick on the same double-track plan as that of the Liverpool and Manchester ${ }^{2}$; and a new prospectus had been issued detailing the reasons for the proposed railway and the advantages which would be secured by it ${ }^{3}$. As in 1824 , the work was to be carried out under the superintendence of two companies, onc beginning at each end of the line; their interests were to be identical, in making application to Parliament for separate Acts of incorporation, in framing their laws and regulations, and in fixing their tolls, the object being to sccure unity of design and harmony of operation. In the session of 1831 application was made to Parliament for a Bill to authorize the construction of this road; but after a little time it was decided not to proceed with the measure in that session of Parliment and consequently the Bill was withdrawn. But although the Bill for the whole line was withdrawn, the Birmingham committee resolved to apply for the part of the intended line between Birmingham and Wolverhampton. The House of Commons, however, refused to entertain their application under such circumstances and the committee abandoned, for the time being, their legislative activity ${ }^{4}$. In November of that year, the subscribers to the proposed Liverpool and Birmingham Railway met to consider a report from the committee which had been appointed to determine the best course to be pursued to further their object. This report showed what had already been done, the opposition encountered and the difficulties overcome; and recommended that, instead of beginning at Liverpool, the railway should join with the Warrington and Newton line at Warrington and proceed southward from there, thus forming a

1 Birmingham Journal, Dec. 26, 1829, p. 2.

2 Ibid., June 5, 1830, p. 2; Manchester Gazette, June 5, 1830, p. 3. The line was to be 100 miles long.

${ }^{3}$ Literpool Times, May 11, 1830, p. 149, gives the prospectus in full. In brief, the advantages of the proposed railway, as given in the prospcetus, were as follows: (1) avojding the dangerous and uncertain navigation of the Mersey; (2) much greater speed in the carriage of goots; (3) reduetion of the cost of carriage; (4) passengers would then be conveyed in one-half the timc and at one-half the cost; (5) hence, great saving to the agricultural, commercial and manufacturing classes; (6) Ireland would be benefited by a wider market for her produce. The prospectus is also given in 'Collection of Prospectuses, Maps, ctc., of Railways and Canals,' PI. 13-14.

4 Manchester Guardian, July 16, 1831, p. 3.

J. T. II. 
continuation of that short road. The committee also reconmmended that the line stop at Wolverhampton, instead of being carried all the way to Birmingham, in order to placate the strong opposition among the canal proprietors who were antagonistic to the formation of a railway between Wolverhampton and Birmingham; but a deputation from Birmingham showed that if this course were followed most of the subscribers of that city would withdraw their names ${ }^{1}$. Early in 1832 the Liverpool and Birmingham Railway Company, with which the Birmingham and Liverpool Railway Company had consolidated ${ }^{2}$, decided that the railway should commence at Warrington, where it would virtuaily join the Liverpool and Manchester, and terminate at Birmingham, the distance between these two points being seventy-four miles ${ }^{3}$.

In the latter part of the year 1832, it was found expedient for these two consolidated companies to unite under one head, forming the Grand Junction Railway Company. This company revived the undertaking which had been previously postponed, and planned to connect Birmingham with Warrington, whence connexion would be secured through Newton with Liverpool and Manchester by means of the lines that were already in operation. The road was to be made through the mining and manufacturing sections of Warwickshire and Staffordshire, with branches finally to the Pottery districts; and the prospectus which the company issued expressed the conviction that the traffic would be sufficicntly great to yield a net return of fifteen per cent. upon capital ${ }^{4}$. Application was made to Parliament for authority to give effect to the company's purposes ${ }^{5}$, and on May 3, 1833, the Grand Junction Railway Act received the sanction of the House of Lords ${ }^{6}$. In 1835, these two

1 Manchester Guardian, Nov. 19, 1831, p. 3.

2 Birmingham Journal, Dec. 10, 1831, p. 3. It would seem that the Birmingham and Liverpool Railway Company eame in for some seathing censure, because that after acting as a self-constituted body and "fattening from the deep subscription purse," they had incurred expenses of about $\$ 17,000$ in connexion with their threefold application to Parliament. and yet had accomplished nothing. Ibid., Dec. 24, 1831, p. 3, letter from "A Sufferer."

3 Ibid., Jan. 14, 1832, p. 2; $M$ : chesier Guardian, Jan. 14, 1832, p. 2; The Times, Jan. 13, 18:32, p. 4. It was expected that this road would pay a clear profit of about fourteen per eent. on the capital expended.

4 The Grand Junction Railway prospeetus is given in full in the Manchester Guardian, Oct. 27, 1832, p. 1. It was dated Oct. 15, 1832. The estimated cost of the road between Birmingham and Warrington, 75 miles, was $\$ 1,000,000$, which was thought to be in excess of the amount that would be actually needed. By using the Liverpool and Manehester and Warrington and Newton connexions, the distance between Liverpool and Birmingham would be 95 miles, and between Manchester and Birmingham 96 miles.

5 Birmingham Joumal, Nov. 17, 1832, p. $1 . \quad{ }^{6}$ Ibid., Nay 4, 1833, p. 3. 
divisions, from Newton to Warrington and from Warrington to Birmingham, were incorporated into one line, thus forming continuous rail communication for over eighty miles. This was a very important road, not only because it was the longest line at that time, but because it brought the Midlands and the intervening commercial and manufacturing district into close connexion with Liverpool, the second largest port of the kingdom.

Contemporaneous with the efforts to secure a railway between Liverpool and Birmingham, there was corresponding activity to obtain rail connexion between Birmingham and London. The need of this was greatly felt at that time. The commercial and industrial classes were prevented from reaping the full reward of their activities, because of the impediments to the carriage of goods on the canals. The latter were frequently stopped, sometimes for considerable periods, on account of frost, drought, or the necessity of repairs ${ }^{1}$; and at such times shippers, who had arranged to send goods on a particular vessel, were unable to fulfil their orders, while the shipowner also lost by being deprived of the revenue from this freight ${ }^{2}$. Even if the canals were not stopped, the rates of conveyance were so slow that merchants lost orders because they could not get their goods in time to ship by a certain sailing. By "fly boats" on the canal, the fastest water conveyance of the time, it took four days to bring such products as glass from Birmingham to London ${ }^{3}$, and then there were losses to be borne on account of breakage and pilferage, which, on the great amount of traffic along that route, amounted to a large toll annually ${ }^{4}$. In addition to these barriers, the freight rates were so high that the monopoly of the canal companies had long been recompensed by a great profit on their capital ${ }^{5}$. Some commodities, such as linens, silks and others, for the carriage of which speed was a desideratum, had to be brought by coach and pay charges which were two, three, or four times as much

1 'London and Birmingham Railway Bill. Extracts from the Minutes of Evidence given before the Committee of the Lords on this Bill,' pp. 3, 8, 10, etc., evidence of Messrs Barry, Dillon, Moore. The latter, who was a Birmingham merchant, said that some of his goods had been delayed in transit on account of the canal being frozen from Dec. 24 till Feb. 20, and then part of the goods were rejected because out of time. Mr Barry had known the canals closed by frost for six or seven weeks.

2 Ibid., pp. 1, 2, 3, 4, 6, etc., evidence of Messrs Barry, Hemsley, Barnes, etc.

${ }^{3}$ Ibid., p. 4, evidence of Mr Hemsley; Birmingham Journal, Dec. 1, 1832, p. 3, "Advantages of a London and Birmingham Railway."

- 'London and Birmingham Railway Bill. Extracts from Minutes of Evidence before Lords Committee,' p. 5, evidence of Mr Hemsley; Birmingham Journal, Dec. 1, 1832, p. 3.

5 Birmingham Journal, Feb. 5, 1831, p. 3, letter from "A Subseriber to the London and Birmingham Railway." 
as canal carriage would have $\operatorname{cost}^{1}$; and as the mercantile classes were conducting their business more and more from-hand-to-mouth, they were feeling the necessity of having some means by which rapidity of communication could be effected. If this eould be secured they would be able to carry on their enterprises without having so much capital locked up in unproductive forms ${ }^{2}$.

The necessity of a railway was felt also by the agricultural interests, especially the farmers. The supplying of the London market with vegetables, dairy produce, etc., from the country demanded accelerated transit; otherwise these perishable commodities could not be carried any great distance. To meet the requirements of that market for meat, cattle and sheep in vast numbers were taken from the country; but the road expenses connected with taking these animals on the hoof were considerable and the eattle were much injured by the long journey. At times they travelled till their feet were sore, and they had to be sold at the towns along the road for what they would bring. This was true also of the sheep. If the animals were slaughtered in the country and the meat carried to the metropolis, it would sometimes be spoiled before it reaehed its destination. So that, whether the one method or the other were adopted, it was uneconomical, for both the weight was lessened and the quality deteriorated ${ }^{3}$. But by means of a railway, animals, meat, dairy products, vegetables and all other necessaries of life could be sent to the London market and be received there almost as fresh as when they left the country; and, at the same time, the expense of reaching the metropolis and the loss or injury suffered on the way would be either lessened or prevented ${ }^{4}$.

While these classes were not being provided with suitable facilities for the transportation of their products, the inevitable tendency was to retard all the best interests of the community. Deficiencies in the means of conveyance reacted upon the cost of the goods and commodities to the consumers, and the burden which was felt by the producing classes pressed with equal or greater weight upon those who had to

1 'London and Birmingham Railway Bill. Extracts from Minutes of Evidence before Lords Committee,' pp. 6, 7-8, 11, evidence of Messrs Barnes, Dillon and Westall.

2 Ibid.. pp. 5, 12, evidencc of Messrs Hemsley and Westall.

3 Ibid., pp. 13-20, evidence of Messrs Warner, Whitworth, Sharp and Attenborough.

4 Ibid., evidence of Messrs Warner and Attenborough. It was estimated that cattle going from Braybrooke to London, 80 miles, lost $10 \mathrm{~s}$. a head in walking that distance upon the common roads; and the cost of driving them that distance was about $7 s$. a hcad in summer and $8 s$. in winter. See also Birmingham Journai, Dec. 1 , 18:32, p. 3, "Advantages of a London and Birmingham Railway." 
purchase these things. Not only was the expense of the carriage of freight unduly high, but the cost of travelling was also felt to be too great for the advantages in regard to speed and comfort that were offered by the coaches; and this barrier to trade, it was certain, would be removed by a railway, which would save both time and expense ${ }^{1}$.

Perhaps the only interest to profit from the existing conditions was the body of canal proprietors, who reaped large returns from their high charges and impositions. The increasing traffic on the canals in this chain, especially on the Grand Junction and Oxford canals, was not accompanied by any disposition on their part to reduce their rates; but they exacted all that they could lawfully charge and endeavoured to swell their receipts to the utmost extent ${ }^{2}$.

During the railway fever of $\mathbf{1 8 2 5}$, among many projects that were brought forward was one for the connecting of Birmingham and London by a railway; but this scheme, like several others, failed to materialize at that time ${ }^{3}$. It was revived in 1827 , but without any success; and in 1829 , when the results of the trials of the locomotive engines on the Liverpool and Manchester line had demonstrated the vast possibilities of mechanical traction, the plan was taken up with greater vigour. The possibility of a railway as a competitor of the canals induced those interested in the waterways to get together in 1827 and propose the formation of a new canal, to be called the London and Birmingham Canal, which, it was hoped, would render such great aid in the carriage of the traffic that there would be no need for a railway. It appears from contemporary evidence that the promoters of this canal, or one of their officials, notoriously falsified the subscription list; but there were other reasons also which helped to decide the issue against the proposed canal4, especially the necessity of increased speed in the

1 'London and Birmingham Railway Bill. Extracts from Minutes of Evidence before Lords Committee,' pp. 22-24, evidenee of Messrs Mason and Cheetham.

2 Parkes, Claim of the Subseribers, pp. 42-43. Parkes gives (op. cit., p. 44) a table of the "Tonnage Receipts on the Grand Junetion Canal" from 1795-1824, which shows that in little more than twenty ycars (1800-1823) there had been a more than tenfold inerease in the tomage receipts on this eanal. See also Collection of Prospeetuses, ete.' p. 19, which gives the distanee and tonnage rates on the eanals between Birmingham and London.

${ }^{3}$ Grinling, History of the Great Northern Railway, p. 1.

4 The agitation for this eanal is given in Aris's Birmingham Gazette; see, for example, the issues of Dee. 17, 182\%, and Feb. 2, 1829. 'Collection of Prospectuses, etc..' pp. 31-33, gives the complete prospectus of this proposed eanal. See also Birmingham Journal, Nov. 17, 1827, p. 1 : Dee. 15, 1827, p. 3; Dec. 19, 1829, p. 2; Dee. 26,1829 , p. 2 ; April 10, 1830, p. 3. There was nuch fraud connected with this project, and the unabashed jobbing is shown also in Parl. Papers, 1830 (251), $\mathrm{x}, 719$, Report from the Committee on the Birmingham and London Junction Canal Petitions.' 
conveyance of both goods and passengers. But the agitation for the railway continued and its adrocates used the results obtained from the locomotive tests on the Liverpool and Manchester, in October, 1829, as an inducement to secure support for this new enterprise. It was asserted that this railway would be of great national benefit for forwarding troops and military stores; that by it the manufactures of Birmingham and its neighbourhood would be conveyed to London in much less time and at less expense than by canal; that the agricultural produce of all the intervening section would be able, on account of the faster speed and redueed cost of conveyance, to find wider markets and better prices; that the coal of Staffordshire could be taken to satisfy the needs of the consumers at the metropolis and along the railway; and that the expense of maintaining the turnpike roads adjacent to the proposed railway would be almost all saved, amounting on the average to about $\$ 250$ per mile anmually ${ }^{1}$. Throughout the year 1830 there was a deeper interest manifested in the project and this continued to intensify until application was made to Parliament to secure authority to carry out this enterprise.

It will be appropriate here to examine the naturc of the opposition to the proposed railway, and, first, we shall consider that of the landed interest. The landlords feared that the railway would injure the property through which it would pass, by destroying the privacy and unity of the farms; that the closes which were now convenient in form and size might be divided into ill-shaped fragments; that the deep cuttings across the slopes of the hills might intereept the supply of water to the wells and grounds below; that the large embankments across the low lands would interfere with the natural drainage of the parts above them; and that, where the railway erossed the highways on the same level, it would be inconvenient and dangerous to the public. It was said that the existing means of land and water carriage were greater than had ever been required; that no necessity had been shown for accelerated communication; and that the absence of the support of the landowners was undeniable proof that the undertaking was uncalled for

1 Birmingham Journal, Nov. 28. 1829, p. 3, letter from “T. B.," entitled "Observations on the Advantages of a Railway Communication between Birmingham and London." The writer shows that at a very moderate calculation the returns from passengers who now patronized the existing seventeen coaches each way daily between London and Birmingham, would be enough to pay large profits on the cost of the railway. As a matter of fact, his calculation of the cost of construction was much too low, being only about one-fifth of the actual cost. His figure for the expense of building the road was $£ 963,000$, whereas the actual cost was over $£ 4,500,000$. See IIerepath's Railzay Magazine, N.S., vi, pp. 16-17. On the advantages of this railway, see also Birmingham Journal, July 17, 1830, p. 3, on "Railroads." 
by the wants or wishes of the country ${ }^{1}$. The promoters of the railway answered these objections by an array of facts which, to an unbiased mind, should have been convincing. Regarding the plea that the privacy of the estates would be destroyed and the homesteads severed, the answer was made that privacy was one of the worst features of a farm; that a farm on a great public thoroughfare was worth much more than one in a country lane; and that the construction of bridges over and arches under the railway would give facility of communication between the divided portions of the farms. The objection that the railway cuttings would prevent the circulation of water to the lower grounds was answered by showing that, if the water eollected in the ditches on each side of the railway, it could be drawn off and used for irrigation and that the railway would act as a drain to those lands that had too much water, and therefore would do for the farmer what he had long wanted but had not the money to do for himself. The claim that large embankments across the low lands would interfere with the natural drainage was met by the assertion that the railway would cross streams and watercourses by means of viaducts so as to leave these outlets as open as before. The supposed interference with traffic on the highways was shown to be without foundation, because the railway would pass either over or under all great thoroughfares and every precaution would be taken to protect the public from risk. The alleged sufficiency of the existing facilities of carriage provoked acrimonious reply: it was true that the roads and canals could convey more goods and passengers than had passed on them, and for the obvious reason that a narrow limit was imposed by the expense and delay in each case; but by lowering the charge of conveyance and by quickening the return on capital through increased speed and regularity the amount of the traffic would be greatly augmented. It was very clear that, when the canals were frozen, and the people, especially the labouring classes, of the Midlands could not get coal, there was much need of some additional means of conveyance. The wealth of some mineral districts was, to a great extent, exeluded from the London markets on account of the heavy expense of canal transport. Moreover, every man's time was part of his capital: it made considerable difference whether a person had to spend six hours or twelve hours upon the road, for in the former case there was a greater use of time and less expense involved than in the latter. A few landowners might not be put to any inconvenience by reason of the slow and expensive transit of passengers and goods,

1 Birmingham Journal, Jan. 22, 1831, p. 1, on the "London and Birmingham Railway;" The Times, Nov. 18. 1830, p. 3, letter from "A Landowner," concerning the London and Birmingham Railway. 
but the public were the best judges as to the loss oceasioned by the present impediments to everyday business. And, finally, the declaration that the absence of the support of the landowners was undeniable proof that the railway was unealled for by the wants or wishes of the country, was of absolutely no validity. The wants of the country gentlemen were no index of the wants of the country generally. The fact that the Liverpool and Manchester line had benefited both landowners and tenants was conclusive evidence that corresponding benefits would acerne to the landed classes in this case ${ }^{1}$.

The other great elass that were opposed to the formation of the railway included the canal interests between the Midlands and London. It was indubitable that the railway would take part of the traffie which had been accustomed to going on the canals; and the revenues of the canal companies would probably be redueed, at least relatively if not absolutely. There was no doubt but that some of the canals along this route, like the Grand Junction and the Oxford, had remunerated their proprietors handsomely and it was but natıral that they should seek to perpetuate these conditions of their own prosperity; but, on the other hand, the freight charges were high, and, judging from the results which had been attained by the Liverpool and Manchester Railway in reducing the rates along its line, there was every reason to believe that comparable results would be secured in this case. There was, apparently, no remedy for the injury whieh canal proprietors would sustain, unless they would join and make common cause with the railway company. Persevering hostility, conducted at great sacrifice of property, might delay the railway, but could not prevent it, since it was for the public benefit. The canal companies should not expect the progress of improvement to be halted to secure the continuance of their enjoyment of monopoly. They had remunerated their capital for a long time with immense profits; and they should not now complain at the introduction of a cheaper and faster means of conveyance 2 . The Marquis of Stafford, the greatest canal proprietor in the world, had formerly opposed the Liverpool and Manchester Railway, but later he became convinced of its usefulness and in 1831 he owned 1000 shares of its stock $^{3}$. But all the owners of canal shares were not so readily convinced

1 Birmingham Journal, Jan. 22, 1831, p. 1, on the "London and Birmingham Railway;" ibid., Feb. 5, 1831, p. 3, letter from "A Subscriber to the London and Birmingham Railway."

2 Birmingham Journal, Jan. 22, 1831, p. 1, on the "London and Birmingham Railway ;" ibid., Feb. 5, 1831, p. 3, letter from "A subscriber to the London and Birningham Railway;" ibid., Mar. 5, 1881, p. 3, "Public Meeting to Support Railways."

${ }^{3}$ Birmingham Journal, Feb. 5, 1831, p. 3. 
that the greater economy of railways had been proved. Because the Liverpool and Manchester Railway was considered as a brilliant success was no reason to conclude that experience would confirm this result in every other instance; and, partly in support of this vaguc hope of being able to compete with the railways, and partly in the expectation that Parliament would protect them from ruin, the canals offered strenuous resistance to the anthorization of the railway ${ }^{1}$.

The third elass from which opposition was encountered by the railway included the coach proprietors, waggon masters and postmasters, the amount of whose business was likely to be seriously reduced by the new means of conveyance. Before the line had been put in operation between Liverpool and Manchester, there were about twenty-two regular coaches on that road; but, by the beginning of the ycar 1831, almost all these stage coaches had been laid aside, and soon the railway was carrying about three times as many passengers as had formerly patronized the coaches ${ }^{2}$. This apparently inevitable decline of road carriage of passengers and goods induced the proprictors engaged in this business to resist the establishment of the new enterprise which was destined to destroy their means of support; but, probably because they were not backed by the large amount of wealth that was available for the landowners and the canal proprietors, their claims seem to have commanded but little public attention. An interesting case of such opposition, in 1833, comes to us in the form of a petition to the House of Lords from those who were carrying on these undertakings on the lines of road between London, Worcester, Hereford and Gloucester; they requested the Lords to protect their interests by rejecting all applications for railroads in general, and particularly the Liverpool and Birmingham and Birmingham and London railways ${ }^{3}$. It would be but natural that the owners of these vehicles along the same or parallel lines of road should oppose the formation of a railway which would take away their business; but why those should oppose it whose line of activity was more or less in the opposite direction, is by no means so clear.

In addition to neutralizing the arguments of their enemies, the railway company put forward some other strong reasons in favour of their

1 Birmingham Journal, Mar. 5, 1831, p. 3, "On Railways."

2 Birmingham Journal, Feb. 5, 1831, p. 2, letter from "A Railway Subseriber," on the London and Birmingham Railway; 'London and Birmingham Railway Bill. Extracts from the Minutes of Evillenee given before the Committee of the Lords on this Bill,' evidence of Ilenry Booth (treasurer of the Liverpool and Manchester Railway Company), pp. 54-5.5.

"IIampshire Advertiser and Salisbury Guardian, May 11, 18:33, p. 2, "Coaches v. Railway." 
project. As the landowners had profited from the construction of the Liverpool and Manchester line, and some who formerly were very active against that enterprise were now as strongly in favour of it, so it would be to the advantage of estate owners in this other section to have the midland metropolis connected with London. The hostility of the landlords was, therefore, ill-advised. Not only would the railway add to the value of their property, but the proximity of larger and better markets for farm produce would give the tenants higher prices for what they had to sell, and thus render them more prosperous. A few hours at the most would suffice to carry fatted animals from their pastures to Smithfield, without their losing in weight or being injured, as at present, by drovers. The railway would supply the metropolis market better, and with more facility and regularity, from a distance of eighty miles, than at present from the neighbouring districts; and the steady market would be a boon for agriculture, while providing steadier employment for labour. The expenditure of millions upon this work would lighten the burden of poor rates and prove beneficial to the country through which the railway would be carried ${ }^{1}$. The passenger fares would be reduced from the eoach fares of $4 d$. per mile inside and $2 \frac{1}{4} d$. per mile outside, to $2 d$. and $1 \frac{1}{4} d$. per mile respectively on the railway; and this would be the accompaniment of a rate of speed double that of the average speed of eaaches. Corresponding reduction in the iime and expense of the earriage of goods was anticipated ${ }^{2}$. To placate the owners of eoaching establishments, it was shown that, instead of there being less work for eoaches, there would be more after the railway were put in operation. Doubtless, the construction of the railway would cause the eoaehes along that line to be set aside; but throughout a belt of many miles in width on each side of it, numerous cross coaches would be immediately established to meet the railway at important stations according to the eonvenience of passengers. For example, the many steamboats conneeting London, Dover and Calais had increased, rather than diminished, the number of post-horses on the Dover road $^{3}$; and evidence was given before a committee of the House of Commons to the effect that while, before the opening of the Liverpool and Manchester Railway, the coaching business on the main

'Birmingham Journal, Feb. 5, 1831, p. 3, letter from "A Subscriber to the London and Birmingham Railway."

${ }^{2}$ Birmingham Journal, Jan. 22, 1831, p. 1, on the London and Birmingham Railway. According to this writer the carrying of goods by the fly vans was done at the rate of five miles per hour and at a cost of at least $9 d$. per ton per mile, while the railway would carry them at fifteen or more miles per hour.

3 Birmingham Joumal, Feb. 5, 1831, p. 2, letter from "A Railway Subscriber," on the London and Birmingham Railway. 
road between these two termini was carried on by 400 horses belonging to Liverpool proprietors and 400 to Manchester proprietors, after the opening of that line, although coaches soon ceased to run on the direct road, there was such a great inerease on the cross roads that the proprietors at Manchester, by 1834, had 800 horses employed and the demand was still increasing ${ }^{1}$. The safety, certainty and rapidity of conveyance were of themselves sufficient to recommend the railway in preference to any other means of carriage 2 .

In 1830 a Bill was introduced into Parliament seeking authority to construct a railway between these two termini; but the strong opposition which was manifested against this measure, especially by several of the great landowners ${ }^{3}$ and the canal companies along the route ${ }^{4}$, but also by proprietors of coaching establishments and turnpike trustees ${ }^{5}$, caused the failure of the Bill to pass in the session of 1831-2. As was the case in the promotion of the railway from Birmingham to Liverpool, so also in this case, there was the existence of two separate companies which were later merged into one before the Act of Parliament was passed to sanction the undertaking ${ }^{6}$. The defeat in 1832 was made the occasion of greater earnestness and the supporters of this scheme got together to inquire into the reasons for their failure and to devise more effective measures for securing their ends. In addition to foes without, the company had to meet and harmonize internal dissension. Some of the subscribers to the undertaking had made their subscriptions and signed the contract deed, in 1830 , on the assumption that this line would connect with the projected

1 See summary of this evidence in IIampshire Advertiser and Salisbury Guardian, Mar. 29, 1834, p. 2.

2 Birmingham Journal, Mar. 5, 1831, p. 3, "Public Meeting to Support Railways."

3 In addition to foregoing references, see also Brit. Mus. 1890. c. 9 (5). Stretton, IIistory of the London and Birmingham Railway, shows the opposition of the Earl of Clarendon and the Earl of Esscx.

4 In addition to previously-mentioned references, see Remarks upon Pamphlet by Investigator on the Proposed Birmingham and London Railway. "Investigator" evidently represented the canal interests and he had tried to show the evils that would be caused by the railway. See also Brit. Mus. T. 1371. (18), the writer of which was apparently a canal proprietor, since the pamphlet presents that side of the case. It was entitled, "The Probable Effects of the London and Birminghim Railway.' Since it is impossible to get too clear a view of the way in which railways were regarded at the time of thcir introduction, the contents of this pamplilet are worthy of perusal.

5 Birmingham Journal, Feb. 12, 1831, p. 2, for example, shows the opposition of the trustees of the Dunchurch and Stonebridge road to the proposed railway.

${ }^{6}$ Birmingham Journal, Sept. 21, 1833, p. 3, on "London and Birminghan Railway;" Manelester Guardian, April 7, 1832, p. 1, on "London and Birmingham Railway." 
Liverpool and Birmingham Railway; but the latter had been abandoned, and, therefore, the whole situation was changed. It would seem, too, that the directors of the company that was formed by a union of the former two eoncerns had ehanged the plans for the railway and increaser the estimated cost of the line without submitting these plans to a general meeting for approval. Many of the subscribers had requested the directors to publish a full and authentic report of the condition and prospects of the company, and afterward to convene a general meeting of the shareholders to take action as to what should be done; but all they had received was a circular giving a few loose details. Because of these conditions, those who were dissatisfied, including a number of the great landlords, sent a petition to the House of Commons requesting that they might be released from their obligations and not be considered as subseribers to the present undertaking ${ }^{1}$. Earlier in the year 1832 there had been a meeting of the owners and occupiers of land along the proposed course of the railway, at which there appeared to be agreement among those present that the railway as planned would depreciate the value of their property, and they, therefore, decided to protest against the granting of an Act of Parliament ${ }^{2}$. What was the outcome of this discord we need not trace; suffice it to say that by midsummer of that year the company issued its new prospectus, showing the public the advantages to be gained by this proposed railway, in opening up new sources of supplies of provisions for the metropolis, in facilitating and cheapening travel, in providing rapid and economical interchange of the great articles of consumption, and in connecting London with Liverpool and the great manufacturing sections of Lancashire and the Midlands ${ }^{3}$. Once more application was made to Parliament and Lord Wharneliffe, the chairman of the parliamentary committee to which this measure was submitted for examination and report, asserted that in his long experience in Parliament he had never seen a measure passed by either House that was supported by evidence of a more decisive character. But,

1 This petition is given in full in Manchester Guardian, April $7,1832, p .1$. It shows that the estimated expense of the railway was at first $\$ 1,500,000$, but in 1832 it was $£ 2,500,000$.

2 Manchester Courier, Fcb. 4, 1832, p. 3, on "London and Birmingham Railway."

3 This announcement or prospectus is given in full in Marichter Guardian, July 7, 1832, p. 1, and also in 'Collection of Prospectuses, etc.,' p. 61. It refers to the great success of the Liverpool and Manchester Railway. This line would connect with that to be constructed from Birmingham to Liverpool, and through the port of Liverpool it would furnish rapid connexion between Ircland and London. See also Brit. Mus. 1890. c. $9(5)$, and "Statement of the Case in support of the London and Birmingham Railway Bill," as given in 'Collection of Prospectuses, etc.,' p. $\mathbf{r 4}$. 
notwithstanding this, the Bill was thrown out, owing chicfly to the opposition of the landowners, who feared that their estates would be prejudiced or injured by the railway. This failure had resulted after $£ 32,000$ had been expended on the application, but still the company was not deterred in their efforts. Subsequent changes were made in the line in order to avoid the properties of two of the nobility who had strongly opposed it and to keep at a considerable distance from the town of Northampton ${ }^{1}$. With these alterations, the line was regarded favourably at the company's third application and the Act was passed in 1833. In 1837, the first section of the line was opened between London and Tring ${ }^{2}$, but it was not until the following year that the whole line was opened ${ }^{3}$. By this railway and what were later its north-western connexions, there was established a complete communication from London to Birmingham and from Birmingham to Liverpool; but we must remember that, at this time, these were entirely separate roads, not working in harmony, and, therefore, there was no through rate nor through traffic.

A few facts regarding the finances of this railway may be appropriately given. In 1830, when the line was being agitated, it was computed that the amount paid by passengers and pareels eonveyed by coaches between London and Birmingham exeeeded $£ 300,000$ a year, and that paid for the carriage of goods between the same places exceeded $£ 500,000$ a year. The expense of building the railway upon the best possible plan was estimated not to exceed $\$ 1,500,000$; so that one-fourth of the amount paid for the conveyance of passengers and goods would be ample remuneration on the capital to be spent on the construction of the railway ${ }^{4}$. But soon the plans were changed and the estimated cost was augmented, so that in the company's original

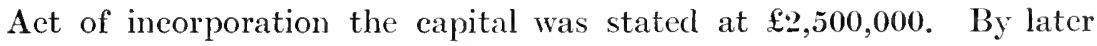
Acts, the company was empowered to raise a eapital in shares and on

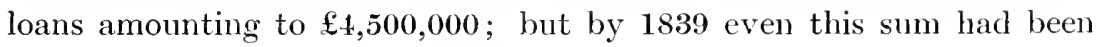

1 Stretton, History of the London and Birmingham Railway. The announcement of the directors of the railway in 1833 is given in 'Collection of l'rospectuses, etr.,' p. 65. It showed the advantage of the railway in regard to safety, expcdition and economy, and the benefits that would accrue to London and the public generally. The change of front of many landlords is apparent in the testimony that was given before the committee that had this Bill for consideration, and those who had formerly opposed railways were now favourable to them (sce 'Great Western Railway. Evidence on the London and Birmingham Railway Bill,' especially the evidence of Mr Earle, Mr .Joscph Pease, and Mr J. Moss).

2 The Times, Oct. 221, 1837, p. 2, on the London and Birmingham Railway Company.
3 stretton, op. cit.
4 Brit. Mus. 1890. c. 9 (5). 
exceeded by $£ 500,000$ on account of calls and loans, and the company proposed to go to Parliament again for authority to raise another $£ 1,000,000$, making the total capital $£ 5,500,000^{1}$, for it was admitted that the road would cost at least that sum. These vast amounts in excess of the estimated expenditures for the road caused disappointment and ealled forth some sharp eriticism; it was thought that the revenues of the company would not be sufficient to pay a reasonable return upon the great outlay ${ }^{2}$. But when it was shown that a large part of this increased expenditure was for the construction of additional lines of railway, so that new sources of income, which had developed subsequently to the origin of the railway, might yield to the company a good return after paying the interest on the eapital embarked in these accessories ${ }^{3}$, the sting was taken out of the adverse comment, and it was seen that the company was working with ultimate, rather than proximate, issues in view. The enormous amounts that were wasted in proceedings before Parliament and the extraordinary sums that were demanded to make complete settlement for their right of way will be apparent from the figures for this railway company, which show that the cost of obtaining the original Act of incorporation was $£ 72,868$. 18s. 10d., and the payments made for "land and com-

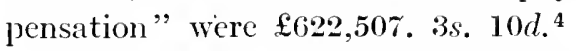

When London had been connected with the great centres in the Midlands and the north-west, the next project of most importance was to secure conncxion between the capital and Bristol, so as to give facility of access to the immense trade of the Severn valley. In reality, the agitation for this line did not wait even for the authorization of the London and Birmingham, but began after the suecess of the Liverpool and Manchester had been assured. Bristol had formerly been second only to London in its importance as a port, but Liverpool had risen into such prominence that it assumed the position which had been held so proudly by Bristol. As a consequence, the latter city had declined to third place, and its trade was languishing in the competition with its north-western competitor ${ }^{5}$. To some, it seemed as if this were

1 Herepath's Railway Magazine, N.S., v1, Pp. 16-17, letter of "A Friend to Railways and Truth," in regard to the London and Birmingham Railway.

2 Ilid., vi, pp. 17-18, 113-18, 235-6; The Times, May 9, 1837, p. 6.

3 The Times, May 23, 183\%, p. 6, letter from W. S. Moorsom.

4 Brit. Mus. 1890. c. 9 (21), 'Plans, Prospeetus, Reports, and Minutes of Evidence, in reference to the London and Birmingham Railway.'

5 A series of thirty letters from "A Burgess," relating to the trade of Bristol, showing the causes of its decline and the means by which its revival eould be effected, appeared in the Bristol Mercury, beginning with the issue of Feb. 2, 1833, p. 2, and ending with that of Jan. 4, 1834, p. 4. 
the acceptable time to restore the old eommercial prosperity and prestige of this ancient eity, and the railway question formed the nucleus of a conflict which helped to arouse Bristol from her lethargy. It will help us to understand the issue which confronted the people at this time if we look more closely at the conditions of transportation by land and water in 1832, when the problem as to the construction of a railway came into public attention.

The goods traffic along this route, especially the carriage of heavy commodities, was largely confined to the canals and conneeting waterways, namely, the River Avon Navigation, from Bristol to Bath, the Kennet and Avon Canal and River Kennet Navigation, from Bath to Reading, and the Thames Navigation, from Reading to London. The delay: and uncertainty of water carriage were becoming unbearable to the commereial interests, at a time when the mereantile practice was undergoing revision and the old system of keeping a large stock on hand was giving way to the method of keeping less stoek but more frequently replenished. The average time oceupied in the traffic by water from London to Bristol was from seven to ten days, but barges had been detained, on account of drought, flood, frost, or other stoppage, for weeks and even months on their journcys, and during these delays there was a great amount of pilferage carried on ${ }^{1}$. Such interruptions on account of natural conditions occurred several times a year, and the time when the canals were not in working order was increased by the necessity of stopping them for repairs. The vast volume of complaint concerning these obstaeles to trade was persistent, prolonged and almost universal ${ }^{2}$. In the case of articles of constant consumption, such as coal, groceries and other food-stuffs, the hindranee of the

1 Proceedings of the Great Western Railway Company, pp. 9, 28; 'Great Western Railway Bill. Minutes of Evidence before the Lords Committees,' evidence of Messrs Walker, Harley, Wilkins, Davis, Morris; Felix Farley's Bristol Joumal, April 19, 1834, pp. 3, 4, evidence of Messrs Hire and Stone; ibid., April 26, 1834, p. 2, evidence of Messrs Keys, Sheppard, Luscombe, Provis, Walker, Taylor, Moline, Wilson, Kendall, et alii.

2 It will help us to realize the situation more fully if we give a few instances of what actually took place, as taken from the evidence before the committee on this railway Bill (Felix Farley's Bristol Joumal, April 19, 1834, p. 3, and April 26, 1834, p. 2). Mr Hire, of Bristol, asserted that in one case several hogsheads of sugar were sent to him from London; but, instead of arriving in 13 days, they did not arrive for two months, so that he lost about $£ 300$ by this delay. Mr Davis, of Reading, in January, 1834, had his goods coming from London delayed a month all hut two days, which prevented him from executing his orders and thus caused him great loss. His goods, especially tobacco and sugar, were much injured by exposure to moisture. Butter was injured in hot weather by these delays and on onc occasion lic was glad to sell $£ 200$ worth at half-price. 
regular supply often produced most serious inconveniences; and it not infrequently happened that, by the stoppage of the canal, waggons had to be sent miles to procure necessaries from the barges which were unable to proceed on their voyages. This, of course, greatly increased the cost to the consumer, and, on such a necessary article as coal, was quite a burden ${ }^{1}$. Another inconvenience on the Thames was that vessels were of large capacity and would not set out on their voyage up the river until they had a full load. A merchant might, therefore, have ten tons of goods to be sent as quickly as possible by water in fulfilment of an order; but if the vessel that was to carry these goods was of eighty tons burden, she would not start until her cargo was complete. This compelled the tradesman to wait for the goods ${ }^{2}$. So absolutcly uncertain was the conveyance that not even an approximate calculation could be formed by the most experienced traders as to when their goods would arrive at the point of destination ${ }^{3}$; and merchants and manufacturers frequently received or sent their goods all the way by land carriage at twice the cost, or more, rather than send them by the navigations and not know that they would be certain to reach their destination at the required time ${ }^{4}$. In addition to the uncertainty of the navigation, its expense and the injuries which the commodities were likely to sustain, there was much annoyance on account of the losses by pilferage, which were considerable under ordinary conditions, but were very heavy when delays occurred to cause the barges to stand still.

1 Proceedings of the Great Western Railway Company, pp. 9, 28; 'Great Western Railway Bill. Minutes of Evidence before the Lords Committees,' evidence of Mr Davis; Felix Farley's Bristol Journal, April 26, 1834, p. 2, evidence before the conmittce on this railway Bill, given by Mr Ogden, Mr Ray, and others.

2 Proceedings of the Great Westcrn Railway Company, p. 28; 'Great Western Railway Bill. Minutes of Evidence before the Lords Committees,' evidence of Mr Davis, p. 396.

3 Felix Farley's Bristol Journal, April 19, 1834, p. 4, "Committee on the Great Western Railway Bill," statement of Mr Harrison. Sometimes on the Thames there would not be more than two "flash days" a week, and often barges were stranded on the shallows and could not move (ibid., April 28, 1834, p. 2, evidence of Robert Ray and others).

${ }^{4}$ Evidence of Messrs Walker, Stone, Shepherd, Provis, Ogden, Wilson, Harris, Mills, Davis, Pearman, et alii, given to Committee on the Great Western Railway Bill; also 'Great Western Railway Bill. Minutes of Evidence before the Lords Committees,' evidence of Mr Wilkins, Mr Marling, Mr Morris, and Mr Venables. Saxony wools, which were brought into the castern ports of England, were carried west principally by waggons to avoid the delay on the canal. Woollen goods manufactured in the west of England were sent to London by waggon paying 5s. per cwt., or sometimes by coach at $1 d$. per $\mathrm{lb}$., rather than by canal barge at $2 s .9 d$. per cwt. The goods were too valuable to risk sending them by canal, with the necessary transhipment, for they would become crushed and often wet before they were delivered. 
The passenger traffic, too, was not carried on as expeditiously as was desired, and the gross abuses, the inconveniences and the cost connected with coaching were impediments for which no adequate remedy had been devised. The insecurity of life had been the cause of continual complaint, and, as we have seen, measures had been taken to prevent the perpetual recurrence of those things which endangered the lives of travellers, but still the evils went on without serious check. Twentytwo coaches went up and down every day, and there were also four mail coaches a day, two up and two down. The great number of passengers who were carried by the coaches may be readily calculated from their returns, which showed that the average number of passengers by a four-horse coach was nine, by the mails five, and by a pair-horse coach six ${ }^{1}$. The average time taken by the stage coaches from London to Bristol, including stoppages, was fourteen hours, and by the mail thirteen hours. This was an average rate of speed of about nine miles per hour. But those who knew the speed attained on the Liverpool and Manchester Railway were eager to see the same twenty to twenty-five miles per hour accomplished on the way between Bristol and London, particularly when it could be secured at lower cost and with greater safety and comfort than by the coaches.

The above-mentioned reasons were by no means all that were adduced in support of the plan for a railway along this course. Much emphasis was laid upon the fact that Bristol, being the natural entrepot for Ireland, Wales and the West of England, would attract the trade from these sections, and their products could then be sent to London on a shorter haul and at a cheaper rate than if they were sent via Liverpool. In this way the metropolis would be furnished with quantities of food supplies from Ireland, with which Bristol had regular communication, and these could be greatly increased. Fish, also, instead of coming from the north, could be supplied in great abundance from that island ${ }^{2}$. The immense quantities of coal and iron in South

1 Felix Farley's Bristol Journal, May 3, 1834, p. 2, evidence of Thomas Cooper, coachmaster at Bath and Bristol, before the Committee of the House of Commons on the Great Western Railway Bill. See the returns of the passenger traffie as given by the records of the Stamp Office, a table of which is given in 'Great Western Railway Bill. Minutes of Evidence before the Lords Committees, evidence of R. J. Venables, p. 416. The same table is inserted in the Proceedings of the Great Western Raitway Company, and in the evidence given before the committee of the House of Commons on this Bill.

${ }^{2}$ Felix Farley's Bristol Journal, April 19, 1834, p. 4, "Committee on the Grea Western Railway Rill," statement of Mr Harrison; ibid., Sept. 28, 1833, p. 3, on the Great Western Railway; ibid., Oct. 5, 1833, p. 2, letter from John Weedon, on the Great Western Railway. 
Wales, with which Bristol had immediate connexion, and in the vicinity of the city of Bristol, would provide fuel for the increasing demands of London and the intervening places, at a reduced cost that would soon greatly increase the consumption of that commodity and the revenue to be derived from it ${ }^{1}$. The agricultural interests were appealed to by the possibility of opening up wider markets for their surplus produce, thus tending toward higher prices for everything they had to sell, and by the inevitable enhancement of the value of their lands should the railway be put into operation. For these claims they had the utmost justification from the results which had accrued along the two lines which were already carrying on their work as general carriers, namely, the Stockton and Darlington and the Liverpool and Manchester. The farmer could get supplies of manure from greater distances and at a cheaper rate than before, so that the land would be brought into a higher state of cultivation and the fertility of the soil improved. By the greater productiveness of the land and the better marketing facilities the rental value of the land would be increased, and consequently both owner and occupier would receive the benefit ${ }^{2}$. Farmers would also be able to send their cattle, sheep, etc., to the London markets at diminished expense, and at the same time the better means of conveyance would prevent any deterioration in the quality of the meat. This would make it possible for the butcher to pay the farmer higher prices for this meat supply, and to give the consumer a better quality of product. Encouragement was also given that, when the heavy road traffic had been transferred to the rails, the highways would be greatly improved and their maintenance would not involve such a heavy burden of expense. Lastly, the construction of such a great public work would give employment to a large number of men, and this would be a significant relief at the time when the pressure of distress was severely felt and the obligation of poor rates was being increasingly realized ${ }^{3}$.

Now, let us consider the nature of the opposition which was aroused against this scheme. As in the case of the other railways which were authorized before this, so in the case of the Great Western, the opposition of the landlords and of the inland waterway interests was the most powerful. On Nov. 19 and Dec. 9, 1833, there were

1 Felix Farley's Bristol Journal, Nov. 17, 1832, p. 3, "Railway from Bristol to London;" ibid., Oct. 12, 1833, p. 3, editorial under the eaption "Great Western Railway."

2 Felix Farley's Bristol Journal, April 26, 1834, p. 2, evidenee of Mr Geo. W. Hall and Mr.Joseph Pease, before the Commons Committee on the Great Western Railway Bill; also ibid., May 3, 1834, p. 2, evidence of Thomas Pearman and others.

${ }^{3}$ Bristol Mercury, Aug. 18, 1832, p. 3, letter from "Ignotus." 
mcetings of noblemen and gentlemen, owners and occupiers of lands through or near which it was proposed to make this railway, declaring that no case of public utility had been made out to justify or palliate such an uncalled-for encroachment upon the rights of private property; and that the projected railway would be repugnant to the feelings and injurious to the interests of the landed classes. They decided in eaeh case to enter into a subscription and appoint a committec who were to see that all possible legal measures were taken to counteract the activity of the promoters of the railway, and were to bring pressure upon their members of Parliament to induce the latter to oppose the sanctioning of such a baneful innovation ${ }^{1}$. But it must not be inferred from what we have said that all the landowners were opposed, for there were some who were sufficiently open-minded and public-spirited to see that their own personal predilections should be subordinated to the general good; and there were others, whose property would not be crossed by the railway, who were convinced that the proximity of that convenience would be of great value in the marketing of thcir products'. In the inland counties there were some who reeognized that in sending their products to London by railway at a lower expense they would come into competition with the south of Ireland, whieh would also be afforded great inducement to plaee its products on the same market; and if the market were thus taken away from the home producer the agriculture of these southern counties would suffer ${ }^{3}$. On the other hand, there were certain who could foresee that, with the lowering of the prices of food supplies, there would be a greater demand for them on account of greater consumption, and, consequently, there was little fear that Irish competition would be injurious to English interests. It is elear, however, that landlord opposition was active in preventing the favourable consideration of the Great Western Railway Bill.

The animosity of the waterway interests was likewise vigorous.

1 Felix Farley's Bristol Journal, Feb. 22, 1834, p. 1, gives the resolutions which were adopted at each of these meetings. Ibid., Mar. 15, 1834, p. 4, "Proeeedings in the House of Commons on the Great Western Railway Bill," showed many petitions for the measure, and some against, with very strong opposition from the landowners. Countess Berkeley petitioned against the Bill and said that her residence would be uninlabitable if the line marked ont by the company was seleeted.

2 Felix Farley's Bristol Journal, May 31, 1834, p. 3, evidenee of Lord Kensington on the Great Western Railway Bill.

3 Felix Farley's Bristol Journal, Oet. 5, 1832, p. 2, letter from John Weedon. Middlesex landowners and farmers opposed it beeause they thought it would bring produee to London from a distanee as eheaply as they eould send it there, and thus destroy their monopoly in that market. Buekingluamshire and Berkshire farmers opposed it beeause they feared Irish competition. (Procedings of the Cireat Western Railzay Company, pp. 10-11.) 
The Kennet and Avon Canal Company and the Commissioners of the River Thames Navigation were loud in their denunciation of a scheme which would take away their trade and nullify all that they had endeavoured to do. The canal company, through its special committee, unanimously resolved to oppose the railway ${ }^{1}$. They thought, from what they had already seen in other instances, that most of the traffic would leave the canal and go on the rails; that, thereforc, the money invested in the canal would be largely lost, and, as a rcsult, great numbers who were depending upon this undertaking for their income would be deprived of their maintenance ${ }^{2}$. But it was shown to them that the opposition evoked against other railways had been powerless to stem the tide of progress; that the principle of public good must prevail over that of private advantage, here as well as in the other cases, by the construction of a superior means of conveyance; and that the canal company should not blind themselves to the evidence of experience and throw away their money in useless legal contests ${ }^{3}$. The general committee of the Thames Navigation formed a more potent antagonist to the proposed railway than was the Kennet and Avon Canal Company, because they represented also the great majority of the owners of land adjacent to the river. In order to prevent the authorization of the railway, they endeavoured to enlist "the active assistance of the varions interests, threatened by this widely destructive speculation with inevitable ruin.". They sought to rouse public support to their side, by showing that the great body of commissioners, acting gratuitously, had, by judicious expenditure of over $£ 250,000$, made that navigation one of the most perfect in the kingdom; that anything which would lessen the amount of tolls they received would prevent the meeting of their obligations to their creditors and the maintenance of the navigation; and that, if the proposed railway were constructed, the river would fall into disuse and become silted up, the floods would increase in height and duration, many towns on the river would have their trade injured, and the lands along the river would deteriorate in value. The wide range and the nature of their appeal included the bondholders, whose security would be endangered by the railway; the landholder, the value of whose property would be affected; the great trading towns along the river, whose commercial prosperity was threatened; the owners of mills, wharfs, and other mercantile establishments, whose trade would be

1 Felix Farley's Bristol Journal, Mar. 1, 1834, p. 2, letter from "Aequus."

2 Bristol Mercury, Mar. 2, 1833, p. 2, letter from "Scrutator."

3 Felix Farley's Bristol Journal, Mar. 1, 1834, p. 2, letter entitled "Canals versus Railways."

${ }^{4}$ Ibid., Feb. 22, 1834, p. 1, "Thames and Isis Navigation in opposition to Great Western Railway." 
annihilated; and the owners of old locks whose revenues would be destroyed. To those who presided over, and those who were educated at, Eton College and Oxford University, appeal was made by the sanctity of their present trust and their former recollections and associations; and, lastly, it was requested that all those who resided upon the banks of this river, whether attracted there by its beauty, its salubrity, or its utility, would lend their aid to prevent the sanction of Parliament being given to "so useless a scheme" as that of the Great Western Railway'. With the great influence which the inland navigation companies exerted, it is little wonder that they were called the "fourth estate of the realm²."

Of the vehement opposition of the authorities of Eton College and the University of Oxford, we have already spoken in a former connexion. It was not until after repeated applications had been made that a branch line of the railway was sanctioned to Oxford, and then it was stipulated that the station should be built as far away from the city as it could conveniently be placed ${ }^{3}$. In the Act as first passed, there was also a clause forbidding the erection of any station at the important town of Windsor ${ }^{4}$.

While we have been impressed by the fact that the commercial classes, generally, were strongly in favour of the railway, we note in this case, what we have not observed in any of the foregoing, that some of the mercantile elements were averse to this railway. Some feared lest Bristol might become merely a way station between London and Wales and Ireland, and as such would be overshadowed by the metropolis to such an extent that it would cease to grow. Moreover, since there was always a prejudice in favour of the London market, the rapid transit by rail would enable purchasers in South Wales and the west of England to go directly to London for their supplies, and thereby Bristol's importance as a great entrepôt would probably decline $^{5}$. It would seem as if there were not a few people in Bristol who shared this apprehension that the railway, if constructed, might transfer part of the Bristol trade to London, and that the shipping and West India trade might also leave Bristol and follow the domestic trade to the metropolis ${ }^{6}$.

Of the other sources of opposition we shall merely mention a few; and of these the most important was the rivalry of other railways which

\& Felix Farley's Bristol Journal, Feb. 22, 1834, p. 1, "Thames and Isis Navigation in opposition to Great Western Railway."

2 Manchester Gazette, Jan. 15, 1825, p. 3, "Effect of Competition."

3 Shaen, Review of Raikeays and Raikway Legislation, p. 29 ; Sekon, Ilistory of the Great Western Railivay, p. 8.

4 Shaen, op. cit., p. 29.

5 Felix Farley's Bristol Journal, Jan. 19, 1833, p. 4, letter from "S.'T. C."

"Bristol Mercury, Mar. 2, 1833, p. 2, letter from "Scrutator." 
were projected at the time the Great Western was seeking incorporation, such as the line from Windsor to London ${ }^{1}$, the London and Southampton, and several others. Some trustees of turnpike roads did not favour the railway, on the ground that their revenues would be depleted because of the transference of the traffic from the roads to the rails ${ }^{2}$. Of a similar character was the opposition of the town of Maidenhead, on the plea that all the existing traffic which paid toll on the bridge over the Thames at that place would be diverted to the railway ${ }^{3}$. As in other instances, coachmasters and the representatives of the carrying trade on the highways presented feeble resistance to the movement in favour of the railway. But it would secm, from the records of the time, that one of the greatest factors with which the advocates of the line had to reckon was the inactivity of Bristol and its people to rouse themselves for the accomplishment of a great future good. We have not found the manifestation of any such shggish, self-satisfied spirit in the promotion of any other line. The Bristolians of that day, unlike those of the present, secmed to be in favour of the quiet enjoyment of the old, rather than of the reaching out after the new; they seemed to be rejoicing in the peaceful returns from their investments, rather than utilizing their wealth in channels which might greatly aid in restoring their former commercial ascendancy ${ }^{4}$. While the probability of good returns from the railway was indıcing eapitalists in Liverpool, Manchester, Birmingham, and other important towns in the north to subscribe largely for its shares, the wealthy classes in Bristol were, apparently, indifferent to the opportunity before them. Even after all the facts had been gathered and made public, and it had been conclusively proved before the parliamentary committee that the road would well repay the subscribers, it was with much difficulty and persuasion that they could be induced to support the railway by taking stock in it ${ }^{5}$.

1 The Times, Jan. 13, 1834, p. 3, and Jan. 20, 1834, p. 3.

2 Felix Farley's Bristol Journal, Mar. 15, 1834, p. 4; " Proceedings in the House of Commons on the Great Western Railway Bill ;" ibid., Mar. 15, 1834, p. 1, report of the meeting at Reading, statements of Mr Harris and Mr Law.

${ }^{3}$ Proecedings of the Great Western Raikay Company, pp. 10-11.

4 Felix Farley's Bristol Journal, Nov. 16, 1833, p. 4, letter from "R. R.;" ibid., Sept. 28, 1838, p. 3, on "Great Western Railway;" Bristol Mercury, June 30, 1832, p. 4, letter from John Ham; ibid., Aug. 11, 1832, p. 3, address of "G. R. C." to rouse the Bristolians from their apathy; ibid., Sept. 1, 1832, p. 2, emphasizing the same thing, and bemoaning the curse of "party spirit;" ibid., Sept. 29, 1832, p. 2, letter from "A Well-Wisher."

5 Felix Farley's Bristol Journal, Oct. 11, 1834, p. 3, letter from "R. R.;" ibid., Oct. 18, 1834, p. 4, and Nov. 8, 1834, p. 2, letters from Thomas Motley, "Good Speed," and E. Jones, urging the necessity of support. 
After more than a year had been spent by a committee of eitizens of Bristol in an elaborate investigation of the prospects for the railway and in ascertaining minute and aecurate information regarding the sourees of revenue and the amount of the returns from each souree, and after the survey by two enginecrs had shown that the line was very favourable ${ }^{1}$, the matter was brought before the publie with the object of enlisting popular support. Subseriptions did not eome in very rapidly, so that the company did not seeure enough money to warrant their applying to Parliament for permission to eonstruet the complete line between Bristol and London; but in the latter part of 1833 they gave notice that they intended to make applieation in the ensuing session for authority to construet the two end seetions of the line, that from London to Reading, with a branch to Windsor, and that between Bath and Bristol ${ }^{2}$. It was thought that the eompany was acting wisely in their determination to secure the two ends of their line, first, because if they had applied to Parliament for the whole line, and if for any eause they had failed to obtain their Act, it was highly probable, they thought, that the Windsor Railway Company might obtain the Aet they sought, to enable them to build a railway from Windsor to London. In that event, the most profitable part of the whole undertaking would have been lost to the Great Western Railway and the latter would have been at the mercy of its fortunate rival as to the terms of transit on that part of the line. The Bill was read in Parliament for the first time on Feb. 26, $1834^{3}$, and with the great support given it by London merehants it passed rapidly from stage to stage. At its seeond reading the vote stood 182 for and 92 against the measure, and the advantages of the railway as a national undertaking were beeoming firmly established ${ }^{4}$. After a debate of fifty-seven days in the committee of the House of Commons, during which there was strenuous exertion by the eontending parties-the one to preserve monopoly, the other to throw open the resourees of the kingdom for the general benefit

1 Felix Farley's Bristol Journal, Aug. 3, 1833, p. 4, gives the report of this committee. It is evident from the report that all possible care was taken to seeure faets that could be relied upon and to avoid any kind of exaggeration or false security.

2 Ibid., Nov. 2, 1833, p. 2, Great Western Railway Notice. The eommittce of promoters deeided that for the completion of the whole line $\$ 3,000,000$ would be needed; but they could not raise this amount in the two months that were left; and the Standing Orders of the House of Lords required that four-fifths of the proposed eapital should be actually subseribed before any railway Bill eould he read a third time. Henee the decision to get the two most important parts of the line first (Proceedings of the Great Western Railway Company, p. 7).

3 Felix Farley's Bristol Journal, Mar. 1, 1834, p. 3.

4 Ibid., Mar. 15, 1834, p. 3. 
-the Bill went to the House of Lords, but that body threw it out without even a hearing ${ }^{1}$. The reason for this failure was probably the fact that there was no security given for the completion of the whole line between these terminal sections ${ }^{2}$. A great public dinner was held by the opposition to celebrate the defeat, to secure which they had diligently and systematically arrayed all possible influence against the measure ${ }^{3}$. But the promoters of the railway set to work more vigorously than before to obtain the necessary amount of subscription to enable them to apply at the next session for authority to construct the whole line. The facts regarding the need and the advantage of such a railway were kept before the public, a new prospectus was issued ${ }^{4}$, opposition was allayed in some cases by seeing the real situation in a new light; and in the session of $\mathbf{1 8 3 5}$, despite much hostility which could not be placated, the Great Western Railway Act was passed. The road was opened in 1839-41.

In 1824 began the agitation for a railway to connect Newcastle and Carlisle, but it was not until 1829 that this line was authorized, and not before 1835 was it all open for traffic ${ }^{5}$. In 1834, the London and Southampton Railway Act was passed, with almost unanimous support, and the line was opened in $1838-40^{6}$. In 1825 the surveys for a railway between Leeds and Hull had been made and the work begun; but in 1826 the work was stopped on account of commercial difficulties, and also because of the increased water accommodation due to the opening of the new port of Goole, while at the same time many wanted, first of all, to know what would be the success of the railways then being formed before they should go on with additional construction?. In 1829 it was thought wise to construct only the part of the line between Leeds and Selby in the hope that the possible use of steam tugs on the

1 Shaen, Review of Railways and Railway Legislation, p. 29.

2 Proceedings of the Great Western Railway Company, p. 7.

2 For particular instances, see Felix Farley's Bristol Journal, Mar. 15, 1834, p. 3, editorial.

4 'Collection of Prospectuses, Maps, etc.,' p. 176, gives this prospectus in full! (1834).

5 Cumming, Rail and Tram Roads, p. 33.

${ }^{6}$ It would seem that few Iandowners petitioned against the formation of this railway (IIampshire Advertiser and Salisbury Guardian, Mar. 22, 1834, p. 2. petition of George Jones to the House of Commons) and that the amount of opposition to it was very insignificant. See the summary of the evidence upon this Bill as given in ibid., Mar. 29, 1834, p. 2 ; also Fay, $A$ Royal Road : being the History of the London and South Western Railicay, pp. 1-28. Yet, notwithstanding the slight opposition, the cost of obtaining the Act was $\$ 31,000$ (ibid., p. 17).

"Leeds Intelligeneer, Feb. 3, 1825, p. 3, on "Leeds and Hull Railway ;" ibid., Feb. 10, 1825, p. 3; ibid., Jan. 29, 1829, p. 3, on "Railroad from Leeds to Hull." 
river from Selby to Hull might furnish an aeceptable continuation of the railway service. The subscribers to the original undertaking were organized as the Leeds and Selby Railroad Company and application was made to Parliament for an Act to carry out their purpose. It was decided to make the railway available for either horse-power or locomotive engines, or, if thought desirable, to enable the company to use locomotive carriages ${ }^{1}$. The Act was passed in $1830^{2}$, and the work completed in 1834. It was the current testimony that, during the first year of operation, the increased speed and reduced expense had brought about an almost ninefold increase in the number of passengers travelling between these two centres ${ }^{3}$. In all probability, it was this rapidity, cheapness and safety of railway carriage, in contrast to the delay, uncertainty and danger of river navigation, that led to the design of

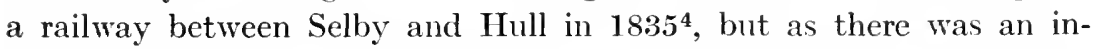
sufficient response for subseriptions to the latter railway at this time, the project could not be brought before Parliament for another year, and so the Act was not passed for the Hull and Selby Railway until $1836^{5}$.

Although direct rail connexion was thus secured between the manufacturing section of Yorkshire and the port of Hull, there was need of extending these facilities through the industrial sections of Yorkshire and Lancashire, so as to join this great seaport on the east with Manchester and Liverpool on the western sea. The authorization of the Leeds and Selby line was the signal for activity looking toward the junction of Leeds with the large centres of Lancashire. Here, two different routes were suggested: one following the general direction' of the Leeds and Liverpool Canal, and the other a more southerly course,

1 Leeds Intelligencer, Jan. 29, 1829, p. 3 ; ibid., Mar. 26, 1829, p. 3 ; ibid., Nov. 5 , 1829, p. 3. See report of James Walker, the engineer, concerning this line, as given in Macturk, History of Railways into Hull, pp. 18-32. He was decidedly in favour of the uniform line, without inclined planes, because the public could then, upon payment of the tolls, freely use the line to convey their own goods in either direction, and because there would be greater simplicity and certainty in its operation.

${ }^{2}$ Leeds Intelligencer, May 20, 1830, p. 3. Opposition was encountered from the Marchioness of Hertford and other landowners on the ground of the railway's interference with private property (ibid., Mar. 11, 1830, p. 3; April 1, 1830, p. 2; and May 13,1830, p. 3). The Aire and Calder Navigation Company at first opposed it, but afterwards withdrew their opposition (ibid., Mar. 18, 1830, p. 3; April 1, 1830, 1.2 ; and Iay 13,1830, p. 3). Slight opposition was also made by the watermen along the river and by the eaptains and owners of vessels there (ibid., Mir. 4, 1830, p. 3).

${ }^{3}$ Sheffield Iris, Sept. 29, 1835, p. 3, on Leeds and Selby Railway.

4 Macturk, op. eit., pp. 42-46, gives the prospectus of this railway, showing the reasons for its proposed eonstruetion.

5 Ibid., p. 46. 
from Manchester to Leeds. In the case of the proposed Liverpool and Leeds railway there were alternative routes suggested, but either of them would take the line through a region of productive industry of manufacturing and mining, and through a series of flourishing towns. So important did the railway appear that along its route some of the occupiers of land and the workers of the mines offered to pay an increase of rent in the event of its being established ${ }^{1}$. Application was made in 1831 for an Act to permit the construction of this railway but it was denied. The promoters, however, immediately set to work to remove the obstacles which had caused their defeat. In the agitation for the other railway between Manchester and Leeds, which also actively began in 1830 by a survey of the line ${ }^{2}$, there seemed to be more vigour than in the case of its rival. The citizens of both Manchester and Liverpool, as well as those of Leeds, were eager to see the line constructed ${ }^{3}$; and a report or prospectus of the undertaking was issued, detailing the necessity for the line and the objects to be secured by it ${ }^{4}$. The chief purposes to be served were the accelerating and cheapening of the transport of passengers and commoditics and the opening up of wider markets for the productions of the section through which it passed. In 1831 the measure was first brought before Parliament; but the Rochdale Canal Company and other opposing interests gave evidence to show that the existing means of conveyance were ample for all the traffic of the country, and the Bill failed, or else was abandoned for that session because it was too late to get it through ${ }^{5}$. For five years the project

1 Manehester Guardian, Dec. 11, 1830, p. 3, on "Liverpool and Leeds Railway." See also ibid., Jan. 1, 1831, p. 4, letter from "W. N. R.;" Liverpool Times, Nov. 16, 1830 , p. 365, letter from "Observer:" ibid., Nov. 23, 1830, p. 373, letter from a correspondent; Leeds Iutelligencer, Nov. 25, 1830, p. 3, on "Liverpool and Leeds Railway."

2 Manchester Guardian, Sept. 18, 1830, p. 2, on Railways; Leeds Intelligencer, Sept. 23,1830, p. 2. A company had been formed in 1825 for making this railway, but at that time of universal depression it was deemed advisable to postpone the measure (Leeds Intelligencer, Oct. 21. 1830, p. 2).

3 Manchester Guardian, Oct. 16, 1830, p. 2.

4 This report is given in ibid., Jan. 29, 1831, p. 1. The delays and inadequacy of the canals along this route were so strongly felt, according to this report, that by far the largest proportion of the merchandise was, with some difficulty, conveyed over the mountainous district by waggons and earts, at great expense and with the squandering of much time. The average time taken by the stage coaches between Manchester and Leeds was seven to eight hours and the time required for the carriage of goods was about twenty-four hours. But by the proposed railway there would be considerable reduction of cxpense and the time required for the carriage of goods or passengers would be three to four hours.

5 Manchester Guardian, April 2, 1831, p. 3; ibid., July 16, 1831, p. 3; ibid., July 30, 1831, p. 3 
slumbered, and then the promoters, with more spirit than before, began a campaign which, in spite of the opposition of the Aire and Calder Navigation, secured favourable consideration by Parliament and the passage of the Act authorizing the construction of the railway ${ }^{1}$. Another line connecting two important centres in this northern manufacturing area was the Manchester and Sheffield. An Act had early been obtained to make a railway here ${ }^{2}$; but, apparently, it was designed as a purely speeulative seheme, and when the shares would not bring a premium in the money market the whole thing was given up. But in 1835 the project was revived by those who were vitally interested in securing better facilities of carriage ${ }^{3}$. At that time the only means of conveyance between these places was by waggon over a rough country, and the time oceupied in performing the journey was about forty hours. There was neither existing nor prospective water carriage, so that nearly all the traffic would go by the railway, if constructed $^{4}$. No opposition was encountered from the landowners along the route, nor from any other interests; its advantages were indubitable; and the Act was passed for giving effect to the line in $1836^{5}$.

It is not our purpose to give a complete account of each railway that was formed; and we have traced in sufficient detail a few of the most important of the early undertakings, in order to see the various influences pro and con which were operative in laying down these roads. Many of the other lines are equally instructive, but we cannot follow their history here ${ }^{6}$. Among the railways for which surveys were made during the railway fever of 1825 , was one from London to

1 Leeds Intelligencer, Jan. 23, 1836, p. 3; ibid., April 23, 1836, p. 3.

${ }^{2}$ Manehester Guardian, Aug. 28, 1830, p. 2. The construction of the railway appeared to be considered as certain at that time.

3 Sheffield Iris, Oet. 13, 1835, p. 3, and Jan. 5, 1836, p. 3, on the Sheffield and Manchester Railway. When the measure was given up in 1830 , there seemed to be nothing more done about it until 1832, when at a meeting of the subscribers the whole undertaking was discussed. Some regarded it as useless and impracticable, and wanted it abandoned. Others thought nothing further should be done about it for three years. Finally, it was agreed that those who were friendly to it slould try to take up the shares of the dissentients: and if they were unsuccessful the concern should be abandoned. Evidently they were unable to meet the last condition.

4 See prospectus as given in Sheffield Iris, Nay 10, 1836, p. 2; also The Times, Oct. 28, 1837, p. 3, report of first general meeting of the Sheffield and Manchester Railway.

5 Shefficld Iris, Oct. 10. 1836, p. '2.

6 We would mention, among the shorter lines, the Sheffield and Rotherham Railway, the history of which is intensely interesting. The necessity of this line for the industrial development of Sheffield and its environs, the antagonism of a strong but unserviceable navigation monopoly, the hostility of the landlords, two of whom were implacable, are detailed in the columns of the Sheffield Iris, especially the following issues: July 29, 1834, p. 2; Oct. 7, 1834, p. 1; Oct. 14, 18is4, 1. 3; 
Cambridge. In 1827 the survey was extended north through Lincoln to York, but by that time the fever had stopped and nothing further was then done toward constructing this railway. In 1833 this Great Northern Railway line was again surveyed from London, via Cambridge, Lincoln and Gainsborough, to York, with several branches; but before the building of the road was authorized many years intervened, during which George Hudson, the "Railway Napoleon," was manipulating the railways of England through his control over the North Midland and the York and North Midland lines. It was not until the year $\mathbf{1 8 4 5}$ that an Act was passed to construct the Great Northern from London to a little north of Doncaster ${ }^{1}$. In 1834, the prospectus was issued for the Eastern Counties Railway, which was to run from London, via Colchester, to Norwich and Yarmouth ${ }^{2}$, and very glowing accounts were given of the great things which were to be accomplished by this railway. It was sanctioned by an Act passed in 1836; and at the company's first general meeting in that year, the Chairman showed what an "ample return" the stockholders would receive on their capital, and that the enterprise rested on "the broad and stable basis of national utility." But his optimism was eclipsed by the extravagant statements of some of the shareholders who thought that a dividend of at least twenty-two per cent. would be paid, and that this railway and other similar undertakings would provide such a social amelioration as to almost banish misery from the earth. But the perfidy of the Eastern Counties Railway Company, which, instead of building the road through to Yarmouth, stopped short at Colchester, and wanted to leave to another company the construction of the rest of the line, which would not pay so well but which would afterwards be used as a feeder for their more important part of the road, is a chapter upon which we shall not enter ${ }^{3}$. Notwithstanding the troublous days of its early history, the Eastern Counties Railway became an important

Mar. 17, 1835, p. 2; Mar. 31, 1835, pp. 2, 3, 4; April 7, 1835, pp. 2, 4; June 2, 1835, p. 2. Ibid., Sept. 15,1835 , p. 4, and Sept. 22, 1835, p. 4, gives a letter from W. Ibbotson which is very important.

1 Probably the best account of this railway is Grinling, IIstory of the Greal Northern Railway, which gives much detail also of Hudson's career. Acworth, The Railvalys of England, ch. v, may also be consulted. On Hudson's career, see also Railway Times, vi, pp. 1058, 1084, 1095-6, 1122, 1312-13; vir, pp. 62, 131 , $173-1,327-8$; vil, p. 2127.

2 Grinling, op. cit., p. 2. An earlier project had been brought forward during the railway fever of $\mathbf{1 8 2 6}$, for the construction of a line from Norwich to London; but it was apparently intended to be a spcculative venture and not to materialize (The Times, April 8, 1826, p. 3, letter from "A Shareholder").

3 On the Eastern Counties Railway see Acworth, The Ratilways of England, ch. x. Concerning the administrative fraud and financial corruption which made the name 
constituent in the Great Eastern, when this latter, in 1862, was formed by the amalgamation of five small lines.

Two other lines running out of London remain to be mentioned. From early days, Brighton had been noted as a fashionable resort, and along the three branches of this road there was a perpetual succession of coaches, each one vying with the others in speed and comfort. Along these lines of travel, too, large sums of money had been spent in cutting off curves, reducing or cutting through hills, and straightening, shortening and improving the road to the greatest extent, so that the numerous coaches which travelled it at all times of the day might not be impeded in their journeys. As soon as railways had demonstrated their many points of superiority over former means of communication, there was a movement for a line between London and Brighton, to provide for the constantly increasing passenger traffic which was overtaxing the coaches. The Bill was brought into the House of Commons in the early part of the year 1836, and ere long there were no fewer than five lines seeking authority to connect these termini, each line being the result of a survey by a different engineer. Then began the parliamentary contest, in which immense sums were spent, varying from $£ 16,500$ for the least expensive, to $£ 72,000$ for the most expensive. The fortunate line was completed and in operation before the critical period of $1843^{1}$. The movement for the railway between London and Dover, afterwards called the London and South Eastern, also began in the early months of $1836^{2}$. This road would be beneficial to the farmers, as, for example, in the quick conveyance of their stock to market; it would enable traders to carry on business with much less capital when they had easy access to London; and it would facilitate and encourage the passenger traffic between London and the Continent ${ }^{3}$. Authority was granted to construct the line, and it was in active use before the middle of the next decade ${ }^{4}$. With the completion of the above-mentioned lines, the chief arteries from the metropolis to the of this railway a by-word for treachery and deceit, see Railway Times, iv, pp. 6:3-64, and Herepath's Railway Magazine, N.S., 111, pp. 92-94, letter from "A Suffering Shareholder."

1 Railways as they Really Are: or Facts for the Serions Consideration of Railway Proprietors. No. 1, London, Brighton and South Coast Railteay. This gives the history and finances of this company in brief form, using almost exclusively the parliamentary documents, and citing minutely the references. The writer exposes the fraud practised by the company upon the public, showing the way in which the dividends paid were added to capital, etc. See also Acworth, The Rivilicays of England, ch. viii.

\footnotetext{
2 The Times, Mar. 16, 18:36, p. 7.

3 Ibid.
}

4 Consult Acworth, The Railways of England, ch. ix, for some interesting details not of an economic character. 
different parts of the kingdom were laid down in outline. It is beyond the scope of this work to enter into the minutiae of the construction of the railway net; we merely wish to present its general features in a series of great roads leading out from London ${ }^{1}$, with transverse roads where they were most required ${ }^{2}$.

The railway fever of 1825-6, as already noted, brought forward many projects which never materialized, and others which took form at a later time. But when the success of the Liverpool and Manchester was demonstrated, there were many who were eager to embark their capital in similar enterprises with the object of reaping corresponding rewards from analogous public services. Public attention was centred upon railways, and with the prospects that were held out by sanguine investors many were induced to put their earnings or capital where they would secure the largest returns. Since there was a disposition to readily devote funds to these particular channels, there came to be a prevailing mania in regard to railroads. Schemes were brought forward which were mere speculations, undertaken for purposes of indiviclual profit and without any thought that they would ever be carried through to completion. Every day new companies were announced, some of them very visionary and destined to end in ruin to those who put their money into them; but as the prices of the shares were advanced, speculation became rampant, and this in turn reacted to push the prices of shares still higher. Railway lines were planned along routes which could barely support a coach. Newspapers contained numerous prospectuses; and, on the basis of the statements made in these, millions were subscribed with eagerness and zeal. Railway Bills were coming before Parliament in great numbers, and in 1836 alone there were presented fifty-seven petitions involving an estimated outlay of over twenty-eight million pounds ${ }^{3}$. Many of these Bills were, of course, left without any action having been taken upon them. The grcat number of enterprises that were sanctioned during

1 For full statistics as to railway constrution up to 1844 , see Brit. Doc., 1844 (318), x1, 17, Appendix No. 2, pp. 4-5; also 'Report of Royal Commission of 1867,' pp. xxxiii-xxxiv. For descriptions of the various lincs, see Francis, Iistory of the Euglish Railway, I, chs. vii-ix, also Smiles, Lives of the Engineers, 111, pp. 346-96.

2 Such as the Newcastle and Carlisle, Manchester and Lceds, Leeds and Selby, Hull and Selby, Manchester and Sheflield, Leeds and Liverpool, Whitstable and Canterbury, etc.

3 Sheffield Iris, Niar. 22, 1836, p. 3, on "Railways." See also, in regard to this mania, ibid., Oct. 13, 18:35, p. 3, on "Railway Spcculations;" The Times, Feb. 13, 1836, p. 3, April 1, 1836 1.3, and June 17, 1836, p.3; Whishaw, Analysis of Railways, p. v; Grinling, History of the Great Northern Railway, 1. 3; Leeds Intelligencer, Oct. 31,1835 , p. 4 . 
this mania, from 1835 to 1837 , absorbed so much money that in the years from 1838 to 1844 very few new lines were anthorized ${ }^{1}$.

By the middle of this fourth decade of the eentury, it was obvious that railroads were no longer to be regarded as mere private enterprises, but as great public concerns, forming a new but most material element in the development of commeree, national wealth and national resources. Since they were in future to constitute the regular and established modes of communication between the different parts of the kingdom, and by their more rapid speed the value of time would be relatively enhanced, it became a matter of expediency that the lines should be planned according to some well-devised system, and that eare be taken not to saerifice public good to private advantage. If no supervision were to be exercised over the formation of these lines, they would be construeted in the same pieemeal fashion as the canal network, in consequence of which local and individual, rather than national and public, benefit would be considered. The railway mania of 1835-7 seems to have brought the issue more prominently before those who were looking beyond the temporary adjustment; and to them it was elear that to leave the railways to speculators, to be decided aceording to their judgment and interest, would be the greatest folly. The lines should be made to dovetail into one another; and to have sueh a preconcerted plan as a basis of action for the Legislature in sanctioning these undertakings, the eountry ought to be thoroughly examined and studied as to its needs and obstacles. One prime essential was that there should be ready communication between the capital and all parts of the kingdom; London was regarded as the heart from which, by the system of arteries and veins, the life of the whole organism should be maintained. How such a system was to be established and adjusted gave rise to differences of opinion. Some were agreed that the best plan would be to have a survey of the country made under the direetion of a Government commission, with a view to laying down the great trunk lines in the most favourable situations, from which branehes might be made according to the wants of different sections. In this way the country would avoid the evils of the parliamentary committee system of handling these Bills, under which it was not the best line, but the line whose personnel could exert the greatest influence in the committee, that received the reeognition

1 .Jeans, Jubilee Memorial of the Railway System, p. 141, says that up to and including 1836, Parliament had sanetioned 34 lines of railway, of a length of 994 miles, at an estimated cost of $£ 17,595,000$; and that in 1837 there were fourtecn new companies ineorporated, with power to construct 46.4 miles of railwiy at a cost of $£ 8,087,000$. Teisscrene, Etudes sur les zoies de communication, p. 19, says that in 1838-41 only 200 kilometres were authorized. 
sought ${ }^{1}$. Another advocated that cach of the great towns, like Manchester, Birmingham, Sheffield, etc., should, as far as possible, have its own direct railway connecting with London, so as to maintain the natural healthy condition of direct communication between the heart and the extremities ${ }^{2}$. It will be noted that this movement in the direction of systematization and correlation in the railway structure of the country was in harmony with the plan of Thomas Gray, more than ten years before, to have a consistent and effective development of the railway facilities; but in neither case did the proposals meet with favourable action from Parliament ${ }^{3}$, and lines continued to be treated as separate entities without regard to any organized relations with others.

Railway enterprise was something wholly new in the history of the world, and Parliament did not know what legislative principles to adopt so as not to stifle their development, but at the same time to safeguard the public interests. As laissez-faire doctrines were so predominant in every other aspect of the national life, and had proved to be productive of good in the case of the canals, the same policy was adopted at first regarding the railways. Each project was considered on its own merits; the conditions in that particular locality were expected to be carefully investigated by a parliamentary committee in regard to the need for the proposed line; and by the Act that was passed the railway company was allowed to charge a certain specified maximum of rates for different classes of goods, but otherwise it could conduct its business as it thought best ${ }^{4}$. This was the only restriction imposed upon the company in the operation of its road, for it was thought that other matters would be regulated by competition. The aim of the Legislature, at the outset, was to maintain the same freedom on the railways as on the old roads.

It was the avowed purpose, in the construction of the railway lines, that they should be open for the public use, on the payment of the tolls. This was enacted by Parliament to prevent monopoly, that is, to prevent the railway companies from getting exclusive control over

1 Parl. Papers, 1836 (0.96), xxi, 235, 'Minutes of Evidence before Select Committee on Railway Bills,' evidenee of James Walker, C.E., Q. 177-212; Mudge, Observations on Railicays, pp. 30-67.

2 Brit. Mus. 8235. ee. 12 (1), 'Reasons in favour of a Direct Line of Railroad from London to Manchester,' pp. 1-5.

${ }^{3}$ On this whole subject, in addition to the above references, see also The Imperial Railicay of Great Britain, by M. A., and IIansard's Parliamentary Debates, 1836, xxxiv, pp. 984-8.

4 'This maximum of rates was practically inoperative, for the companies found it convenient to lower their rates, in most cases, below this maximum. 
the conveyanee of passengers and goods along their respeetive lines; and even railway proprietors said that they wanted no monopoly: that they were merely toll-takers, and that it was neither their wish nor their intercst to undertake the work of a public carrier upon their own lines ${ }^{1}$. It was expected that merchants and others would put their own carriages on the line, and either furnish their own horse or steam-power, or pay the railway eompany for the use of their power. Even after the introduetion of steam-power this system in part prevailed in the case of goods traffie; for we find that in 1838 "engines belonging to different parties, eoach proprietors, and others," were running upon the Liverpool and Manehester line ${ }^{2}$, and so elosely assoeiated was the railway with the ordinary highways, in the public mind, that a seleet committee of the House of Commons, in 1837-8, recommended that the right enjoyed by private persons of running their own engines and trains upon any railway, should be extended to the Post Offiee ${ }^{3}$.

This system, of having divided responsibility on the same line, was not found to work well. In the first plaee, there was great danger in the running of rival trains over the same rails, on aeeount of the struggle for the greatest possible use of the railway facilities. In the second place, no provision had been made to ensure, for private trains and engines, aecess to stations, watering plaees and other equipment along the line. In the third place, the rate of toll limited by Act of Parliament was almost always so high as to make it impossible for other parties than the railway company to work at a profit, even if

1 'Report on Railway Communieation,' 1837-8, Q. 428, 495.

2 'Report of Seleet Committee on Railroads, 1837-8, Minutes of Evidenee, p. 133. See also 'Report of James Walker to the Committee of the Proposed Leeds and Selby Railway Company, given in Maeturk, History of the IIull Railways, pp. 18-32.

3 Brit. Doe. 1837-8 (257), xvi, 341, 'Report of Select Committee on Railroads,' p. iv. The Post Offiee had already been foreed to put the mail on the Manehester and Birmingham Railway, beeause, since the introduetion of the railway, the passenger $\operatorname{tr}$ ffie had left the mail coaches for a more speedy and eeonomieal eonveyance, and therefore there was no one who was willing to contraet for earrying the mail by mail eoaehes (ibirl., 'Minutes of Evidence,' p. 1).

The reacon why it was recommended that the Post Office should run its own cars, was beeause the railways eatrying the mails were often late and usuilly very irregular (ibid., 'Minutes of Evidenee,' pp. 12-1\%, 61-62). In 1833 the P'ost Office had entered into agreement with the Grand Junction Railway to earry the mails regularly between Birmingham and Liverpool and Iranehester. The regularity, however, was often affeeted by temporary imperfeetions in the maehinery, breaking down of waggons, taking too heavy traffie, station delays, ete. (ibid. 'Minutes of Evidenee,' p. 98). 
the other obstacles were removed ${ }^{x}$. Then, too, great difficulty arose from the fact that private parties were not willing to build engines and carriages under such regulations as were necessary to work well on the $\operatorname{road}^{2}$. Soon it became evident to the railway companies that, with due regard to the efficiency of their line and to the public convenience and safety, they could not allow rival parties to run engines and carriages on the same line; and it was eventually acknowledged that these lines of communication must be placed under undivided control and authority. Accordingly, a Parliamentary Committee of 1839 urged the necessity of prohibiting, as far as locomotive power was concerned, the rivalry of competing parties on the same line of railway ${ }^{3}$; and the Committee of 1840 decided that railway companies using locomotive power possessed a practical monopoly for the conveyance of passengers, and that under existing circumstances this monopoly was inseparable from the nature of their business ${ }^{4}$. It became imperative, therefore, that each railway company should take over the working of its own line. This difference between railway and other kinds of business was early recognized: that competition of rival interests on the same railway line is impracticable, and that the railway company is in essence a monopoly ${ }^{5}$.

But although the practice of traders or independent carriers running their own trains fell early into disuse, the theory of the railways being public highways is found in all the early Acts, and even in a great part of the modern railway legislation ${ }^{6}$. This privilege is preserved, indeed, to the present time, since it is conferred by the Railways Clauses

1 'Fifth Report of Seleet Committee of 1844 on Railways,' Appendix 2, p. 22.

2 Brit. Doe. 1840 (299), xin, 167, 'Third Report of Seleet Committee on Railway Communication.'

3 'Second Report of the Committee of 1839 on Railways;' also 'Third Report of Select Committee on Railway Comnunication,' 1840.

4 Brit. Doc. 1840 (299), xin, 16\%, "Third Report of Seleet Committee on Railway Communication; under heading "The Conveyance of Passengers by Railway."

5 As we have seen, this faet was fully recognized at least as early as 1839 (v. 'Second Report of Select Committee on Railways,' 1839).

As owners of the roads, railway companies were not intended by Parliament to have any monopoly or preferential use of the means of eommunieation on their lines; on the contrary, provision was made in all or most of the Aets of ineorporation, to enable all persons to use the road on payment of eertain tolls to the eompany, under such regulations as the eompany might make to seeure the proper and convenient use of the railway. But when railways began to be worked on a large scale with locomotive power, it was found that the necessities of the ease demanded the non-recognition of this Parliamentary safeguard.

6 See remarks of Wills, J.. in Hall vs. London and Brighton Railway Company, 90, in 1.5 Queen's Bench Deeisions, p. 536. 
Consolidation Act of $1845^{1}$; but the right is one to which it would be impossible to give practical effect, except in a very limited way. Almost the only remaining trace of the theory is found in the "running powers" exereised by one company over the lines of another; but these are usually arranged by agreement or by speeial statutory provision in each case.

Each railway Act, therefore, provided for the use of the railway by the public, subject to the company's approval of the engines and carriages to be used on it and to the payment of tolls not to exceed the maximum amounts stipulated in the Act. These tolls, in the case of animals and passengers, were on a mileage basis, and in the case of minerals and goods on a tonnage basis. The latter, of course, were divided into different classes ${ }^{2}$, according to the nature, bulk and value of the articles and their liability to damage. These tolls were payable merely for the right of passage along the railway. But after 1833 it became the practice to insert in railway Acts a clause allowing the eompany to charge for supplying the traction power also ${ }^{3}$. Here, then, were two tolls, the "road toll," for the use of the roadway, and the "locomotive toll," paid when the company supplied haulage.

It was not long before the eompanies took a third step. In two or three cases railway companies were required by their Acts to be carriers $^{4}$, but these were very exceptional. It soon became neessary for railways to provicle the whole equipment of rolling stock and a staff of officials for doing the carrying themselves, and from 1833-40 we find, in consequenee, that the railway Aets eontained not only toll clauses, but another elause authorizing the company, "if they shall think proper," not only to provide engines for use by other persons, but also to use and employ them themselves, in carrying the goods and passengers that might require that service performed ${ }^{5}$. The charges authorized by the Aets of that period, therefore, as pertaining to goods, fall into three elasses: first, the road toll, for the use of the roadway; seeond, the locomotive toll (without any specified linit) for the use of the engine; third, a "reasonable charge" for eonveyance, in addition to the above tolls, when the company provided everything

18 rict., c. 20 , sec. 92 .

2 The classification of goods for the railway traflic was borrowed directly from that of the canal Acts.

3 v. Great Western Railway Act, 1835, sec. 166.

4 Liverpool and Manchester Railway Act, 1827 (7 Geo. IV, c. 49. sec. 1:38); Newport and Pontypool Railway Act, ist5 (8 \& 9 Vict.. c. 159. sec. 12s): Monmouthshire Railway and Canal Act, 1852 (15 \& 16 Vict., c. 126, sec. 128).

- Sec, for instance, the Great Western laailway Act, of 1835 (5 \& 6 W. IV, c. 107 , sec. 167 ). 
and conveyed the traffie along their line. All three of these charges were paid by those who were engaged as earriers on the railways ${ }^{1}$. The reason for these payments is probably to be found in the traffic conditions of the railways at that time. As to the road-bed, the company had the monopoly and therefore Parliament thought best to limit and fix the rates of toll that might be taken for its use; but in regard to the other two eharges, it was expeeted that they would be determined by eompetition, sinee the carriers might legally employ their own engines and do their own earrying.

But experience soon taught that competitive earriers on the same line were an anomaly; that the work of conveyance had to be undertaken by the company; and from 1841 on, further restrietions were placed upon the eharges of the new eompanies that were authorized. A new form of clause began to prevail by whieh an inereased toll, of specified amount, was authorized when the company had to provide the rolling stoek and power and also had to do the actual work of earrying. Under this form of Act, which ineludes most of the railway Aets from 1841-4, the charges were: first, the road tolls, whieh even in early Aets had been of fixed amount; seeond, inereased tolls of fixed amount for the use of the company's earriages; and, third, a fixed additional eharge for locomotive power ${ }^{2}$. The fixing of the eharges for rolling stock probably shows that Parliament reeognized the futility of trying to regulate these charges by competition. It may be noted that neither railway company nor independent carrier was allowed to eharge more than the aggregate of these three tolls; for a clause in each Aet provided that "neither the eompany nor any other person using the railway as a earrier shall demand or take a greater amount of toll, or make any greater charge, for the earriage of passengers or goods than the company are by this Act authorized to demand ${ }^{3}$."

When eonveyance by the railway eompany had beeome the usual mode, another ehange was introduced, in the "Maximum Rates Clause," whieh limited a eompany's total eharge for conveyanee to something less than the aggregate of the three tolls; in other words, if the company

1 These three features of the charges that railways were allowed to make may be noted in the Acts of several large railway companies, e.g., Grand Junction Railway Act, 1833 (3 W. IV, c. 34); London and Birmingham Railway Act, 1833 (3 W. IV, c. 36); Great Western Railway Act, 1835 (5 \& 6 W. IV, c. 107); Bristol and Exeter Railway Act, 1836 ( 6 \& 7 W. IV, c. 36).

2 This form of charging clause may be seen in the Oxford Railway Act, 1843 (6 Vict., c. 10, sces. 281. 284); the Warwick and Leamington Union Railway Act, 18.12 (5 Vict., c. 81); the Yarmouth and Norwich Railway Act, 1842 (5 Vict., c. 82).

3 See Oxford Railway Act, 1843 (6 Vict., c. 10, sec. 288). 
had the advantage, as conveyers of traffic, of performing all three services, they were to be eontent with something less than the aggregate of the three sums which, as toll-takers, they were authorized to charge for each service separately. This gives us for the present-day railway Acts two sets of charging clauses: first, the toll clauses, inchuding the three charges spoken of above, and, second, the maximum rates elause, limiting the total charge for carrying $\mathbf{1}$. The maximum rates clause insured to the public cheap conveyance, while the toll elauses protected the companies against rival conveyers on their own lines, whether private earriers or other railway companies with running powers, by enabling them to levy tolls upon persons using the railway to such an amount as would prevent competition ${ }^{2}$.

When the railway companies had taken over the working of their lines and undivided control was accorded to each over its own line, eompetition became active between the different railways, and also between the railway companies and the canal companies, in the same territory. The natural effect of this competition was to cause the rates of carriage to be put down, sometimes to ruinously low figures, and when this could not be continued any longer, working agreements were entered into or amalgamations effected, without any Parliamentary sanetion ${ }^{3}$. Under these private arrangements, made for the mutual profit of the formerly competing companies, a higher scale of tolls and charges was usually established, sometimes in excess of even the original rates ${ }^{4}$. As soon as Parliament was aware that secret agreements were being made, it endeavoured to encourage those companies that wished to consolidate

1 The earliest Act in which this Maximum Rates Clause was inserted was probably the Kendal and Windermere Railway Aet, 1845 (8 \& 9 Viet., e. 32).

2 In regard to these statutory provisions of railway Aets, see Butterworth, Railway Rates and Traffie, p. 3 et seq.

3 Brit. Doe. 1846 (200), xul, 85, 'First Report of Select Committee on Railways and Canals Amalgamations.' This ealled attention to the legislative amalgamations, and also to the fact that some important lines of railway, originally formed by independent eompanies, and which had not proposed any legislative amalgamation, were at that time practieally under the same control and management; and so long as these parties felt it to be to their interest to combine, all the evils to be feared from amalgamation might be produced by private arrangements between them. Ibid., 'Minutes of Evidence,' p. 7 , shows a list of the railways and eanals that proposed amalgamation at this time.

4 Brit. Doc. 1846 (275), xu11, 93, 'Sccond Report of Select Committee on Railways and Canals Amalgamations ;' also 'Fifth Report of the Seleet Committee on Railways, 1844, Minutes of Evidenee,' p. 200 et seq. Evidence showed that several railway lines had formed working agreements, and had raised their eharges to keep up dividends as high as eight to eleven per cent. See also Brit. Doc. 1872 (364), xıI, 1, 'Minutes of Evidence,' p. 332. 
to come forward and obtain an Act authorizing this, for, by so doing, some method of general superintendence and control might be adopted, so that competition among lines might not be obliterated. In some cases, amalgamations had been sanctioned by Parliament from the first'.

While the most competent witnesses favoured amalgamation of competing lines, either of railways or canals, where competition might be destructive, they almost invariably favoured also the amalgamation of closely related lines which were not rivals. It was recognized that where two roads competed for the same traffic they had everything to gain and nothing to lose by amalgamation, or by an arrangement under which the traffic was divided. But the interests of the public must also be looked after, as well as those of the railways and canals. As early as the panic year of 1836 , when so many railway bills were being brought before Parliament, attention was called again and again to the fact that railway competition could not be relied upon to ensure the protection of the public from unjust charges ${ }^{2}$. The railway was essentially monopolistic, and even if another railway were formed as a rival it would be to their ultimate advantage to make some understanding to work together, and thus the possibility of competition would be further removed than ever. But there were a few who saw that it was not economical, nor would it prove effective, to construct two or three lines along a certain route, with the object of securing competition, when one company could carry all the traffic that was likely to be offered ${ }^{3}$. Even for the purpose of making competition effective, this would be a flagrant waste of capital; and the Legislature ought to prevent unnecessary waste of funds by seeing that lines were built only for necessities. But this cry for protection of the public, at the time of the panic, was different from that which came a few years later, after railways became more aggressive and formed closer working relations with one another. At the earlier time it was more spasmodic and individual; at the later time it was prolonged, profoundly and universally felt, and officially recognized. As early

1 Brit. Doc. 1846 (200), xm, 85, "First Report on Railways and Canals Amalgamations.'

2 The Times, June 17,1836, p. 3, statement of the Duke of Wellington; ibid., June 22, 1836, p. 4, cditorial, showing how the various concerns established to provide water for the city of London and its suburbs had finally combined and parcelled out the city for their own profit. This is also referred to by Mr Morrison in ibid., June 22, 1836, p. 4. See also IIarsard's Parliamentary Debates, 1836, xxxi1, pp. 977-94, and xxxiv, pp. 1-4.

3 The Times, June 17, 1836, p. 3, statement of the Duke of Wellington; Whishaw, Analysis of Railicays, p. v. 
as 1844, Parliament was strongly urged to retain within its power sufficient authority to curb the railways, should these tend to unduly increase their influence. It was impossible to foresee what turn affairs might take in the following years, and the public must be protected should the railways try to deal illiberally ${ }^{1}$. In the reports of various committees with reference to the railways and canals, we are impressed by the fact that the advantage to the public from competition between these two instrumentalities was fully recognized; but how to maintain that competition for the future was a subject which was constantly pressing for attention, and yet wholly unsolved ${ }^{2}$. They recognized that it would not be a wise policy to always refuse to sanction the amalgamation of railways and canals, for this was frequently for the public good; and the most fruitful suggestion they could make was that a searching inquiry should be made into the merits of each ease, and that Parliament should permit only those amalgamations which could be effected without prejudice to the public ${ }^{3}$. In the light of

1 Brit. Doc. 1844 (166), xr, 5, 'Third Report of Select Committee on Railways;' also the 'Fifth Report of Select Committee on Railways,' 1844, p. 82. The same caution was urged by the Board of Trade in the following year, v. Brit. Doc. 1845 (279), xxxix, 153, 'Report of the Railway Department of the Board of Trade on the Proposed Amalgamations of Railways.' They say: "If these extensive powers are to be granted to private companies, it becomes most important that they should be so controlled as to secure the public, so far as possible, from any abuse which might arise under this irresponsible authority." Then, after showing the complications that had recently arisen in railway operation, and the advantages to some railway companies of amalgamating with others, they say: "Accordingly we suggest for the consideration of Parliament that general and unlimited powers of granting or accepting a sale or lease of a railway or canal by another railway or canal company, or of otherwise merging the independence of one eompany in another, should not be allowed to be inserted in any Bill; and that when such powers are applied for in any specific instance, they should only be granted after a full consideration of the probable results as regards the interests of the public as well as of the parties."

2 Brit. Doc. 1844 (166), xr, 5, 'Third Report of Selcet Comnittee on Railways;' 1845 (279), xxxix, 153, 'Report of the Railway Department of the Board of Trade,' pp. 3-4; also $18+6$ (275), x111, 93, 'Second Report of sclect Committee on Railways and Canals Amalgamations;' etc. In the latter we find it stated that, "Therc are now few parts of the country which have not derived material advantage from the competition between railways and canals. It is obviously important that l'arliament should not sanction lightly any arrangements which would tend to deprive the public of this advantage; and it has been a subjeet of consideration with your committee whether, in order to maintain future competition, it might not be the duty of Parliament to refuse its assent to all bills uniting the interests of the railways and canals."

3 Brit. Doc. 1846 (275), xur, 98, "Second Report of the Seleet Committce on Railways and Canals Amalgamations,' under heading "Conclusion." 'This Committee recommended that, since the system of railways and eanals had hecome so complicated, some department of the Executive Government should be given full supervision over them, with power to enforce such regulations as were indispensable 
these facts, it is clear that in the various investigations of the railways and canals at that time, the interests of the people as a whole were regarded as paramount; and if these were not conserved it was not because they were not urged upon Parliament, but chiefly because of the lack of knowledge in that body of how to deal with the situation'.

While Parliament, without experience as a guide, was busy examining the eonditions under which railways were operating and endeavouring to seeure adequate legislation for their proper regulation as agents of the public service, the companies themselves were active in maturing plans for working agreements or consolidations. These were at first among lines that might be connected into a longer line of eommunication, and afterwards with parallel and competing roads. Experienee showed that lines of short length were generally worked at great disadvantage; and the saving of expense that would result from the eonsolidation of establishments was another reason why amalgamation was sought by those companies that wanted to add to their peeuniary prosperity ${ }^{2}$. For this reason, the amalgamation of short independent links or branches, and of umprofitable lines, with others of larger extent and in more prosperous eircumstances, was eagerly sought from purely economical eonsiderations. Another, and even more important, factor was that the full development of traffic upon a system of railways often depended very materially upon the existence of a uniform system of management and unity of interest over a considerable extent of line ${ }^{3}$. In regard to passengers also, serious inconveniences often resulted from the conflict of interests and lack of uniformity of system among independent companies. The more

for the interest of the public. See also Brit. Doc. 1845 (279), xxxix, 153, 'Report of the Railway Department of the Board of Trade on Proposed Amalgamations of Railways,' p. 4.

1 Even as early as 1840 (v. Brit. Doc. 1840 (299), xirl, 167, "Third Report of Select Committee on Railways'), a Conmittee of Parliament recommended that an authority be appointed to watch the carrying systems practised on different lines of railway, with a view to obtaining the best system "for the public welfare." See also the references under footnote 2 , p. 579 ; Brit. Doc. 1844 (166), xi, 5, "Third Report of Select Committee on Railways;' also 'Fifth Report' of same year, 'Minutes of Evidence,' p. 82; The Economist, Weekly Commereial Times, and Bamlers' Gazette, 1845, p. 1078, letter from Lawrence Heyworth, urging Parliament to insist that railways be undertaken on sueh principles of economy as to secure the greatest possible benefits to the public.

2 Brit. Doc. 1845 (279), xxxix, 153, 'Report of Railway Department of Board of 'Trade on Proposed Railway Amalgamations.' It was to put an end to the costly warfare of the London and Birmingham, the Grand Junction, and the Manchester and Birmingham, that they were amalgamated to form the London and North Western.

${ }^{3}$ Ibid., pp. 2-3, gives an example of this. 
obvious of these evils were those in which attempts were made, by companies holding one portion of a great line of communieation, to extort an undue charge by compelling passengers who had arrived at a terminus of one road in second or third-class carriages, either to wait, or to proceed on the adjoining road in carriages of a more expensive class ${ }^{1}$. Even first-class passengers were often subjected to delay and inconvenience in changing carriages and luggage upon a journey, owing to the same cause ${ }^{2}$. From such conditions, it would naturally be assumed that the more complete the unity of interest and management throughout the more satisfaetory and efficient would be the arrangements for traffic that had to pass over more than one line. It was these considerations of inter-railway operating economy, then, that led to the early working arrangements and consolidations ${ }^{3}$.

These began at an early stage in the history of the railways. By 1844, a number of Bills were being introdueed into Parliament to secure authority for consolidating certain lines, but we may be certain that this was by no means the beginning of such things ${ }^{4}$. Private working agreements were, doubtless, in existence for several years before this; for the railways had inereased their power so much that in that year a Committee of Parliament urged upon the House the necessity of seeing that the railways did not unduly extend their influence by destroying competition ${ }^{5}$. If there had not been sueh working agreements in force, there would have been no need for the strong appeal that was thus made to the Government, for there would have been no "illiberal" dealings of the railways toward the public to be guarded against. But we are not left in doubt upon this subject, for the evidence of witnesses is too conelusive to be discredited ${ }^{6}$.

1 See 'Fifth Report of Select Committee on Railways, 1844,' Appendix 2, pp. 2021. Here is given a good account of the "Nullity of Parliamentary Provisions for the Protection of the Public," and scveral "Instances of inconvenience to the public from the existence of so many independent railway eompanics."

2 Ibid., pp. 20-21 ; Brit. Doc. 1845 (279), xxxix, 153, 'Report of Railway Department of the Board of 'Trade on Proposed Railway Amalgamations,' p. 33.

${ }^{3}$ These, of course, were not the only reasons why railways sought eonsolidation. For instance, the Liverpool and Manchester wanted amalgamation with the Grand Junction Railway so that the two companies together might provide suflicient means to make their station commodious (v. Brit. Doc. 1846 (275), xir, 93, "Seeond Report of the Select Committee on Railways and Canals Amalgamations, p. 18).

4 'Fifth Report of Select Committee on Railways, 184.4, Minutes of Evidence, p. 82, where one witness said: "Now is the time for Parliament to proteet the public, when these Amalgamation Bills are being brought in."

5 Brit. Doc. 1844 (166), x1, 5, 'Third Report of Select Committce on Railways.' This Report is very explicit upon this point.

6 'Fifth Report of the Sclcet Committec on Railways, 1844, Minutes of Evidence,' p. 81. Here we are told that the London and Birmingham, and Birmingham and 
Whether we call these arrangements railway pools or not may be simply a matter of nomenclature; but the fact is that before 1844 there were quite a number of such agreements for division of traffic, or for adjustment and maintenance of rates. In addition to the amalgamations that were in force before 1845, many others were proposed in that year $^{1}$; and in 1846 there seems to have been a great number of such proposed mergers ${ }^{2}$. While many of these were not in that year sanctioned by Parliament, yet a considerable extent of both railways and canals came into the control of the powerful railway companies ${ }^{3}$;

Derby railways contemplated amalgamation, and they were to be amalgamated with the North Midland Company. lt would seem, therefore, as if working arrangements must have been in force for these roads before this, else such an extensive amalgamation would not have been projected, without knowing the benefits that would accrue from it. Further, the Birmingham and Derby and the Midland railways, after running a short time, made an arrangement that the Midland Company should take all passengers coming by certain trains by the North Midland line to London, and that the Birmingham and Derby should take all the passengers coming by other trains. This agreement was broken and the two companies quarrelled, after which they carried for almost nothing. Then a second agreement was made (ibid., p. 82).

The Bolton and Preston and the North Union railways which were competing lines for tralfic betwcen Preston and Manchester, after a short eontest, amalgamated, and in 1844 were applying to Parliament for this amalgamation to be eonfirmed.

The York and North Midland Railway and the Leeds and Selby Railway were competing lines for part of the trallic between Leeds and York and Hull. But the Leeds and Selby had been leased to, and later hought by, the York and North Midland Company (ibid., p. 83). Sce also the arrangement of the Manchester and Leeds Railway Company with the Calder and Heblele Navigation (ibid., p. 140). Other agrecments are mentionct on p. 169 et ser., pp. 384. 488; see also pp. 20-21 of Appendix No. 2 to this 'Fifth Report of the Select Committee on Railways, 1844.'

On pp. 20-21 of Appendix No. 2 of this 'Fifth Report of the Select Committee on Railways, 1844,' we learn that this movement of amalgamation or consolidation had "made rapid progress of late," and seven instances of this are there given.

1 For these, see Brit. Doc. 1845 (279), xxxix, 153, 'Report of Railway Department of Boart of Trade; p. 4.

2 Brit. Doc. 1846 (275), xur. 93. 'Second Report of Select Committee on Railways and Canals Amalgamations, Minutes of Evidence,' p.3. shows proposed amalgamations among existing railways, as stated in the titles of the Bills; pp. $3-6$ show proposed amalgamations of "new with existing railway companies," about 105 of which sought power to lease or sell to some other railway ; p. 7 shows a list of the railways and canals that proposed amalgamation. Some of these amalgamations were for filling up of old canals and building new railways instead, and often these railways were to be united with other railways.

3 For the canals and navigations acquired by the railway companies, by amalgamation. purehase, or lcase, from 1846-72, see Brit. Doe. 1872 (364), xiII, 1, Part 11, pl. 755-6. This is given in Appendix 9. See ibid., pp. 966- 11 (Appendix T), for 'Returns from Each Railway Company of the Names, Number, and Extent of the Canals and Navigations under their Control, and How Held.' This docs not give the railway amalgamation that had oecurred. 
and we may be certain that much of the amalgamation that failed to obtain the consent of Parliament became effective by secret agreements between the companies interested ${ }^{1}$.

When the time came that railways were allowed to take over canals, and to consolidate with other railways for the formation of great systems, we have a new epoch in the history of railway transportation. Instead of small, detached roads, having poor, if any, connexions with the next adjoining roads, long lines were formed and worked with a degree of economy and efficiency that was hitherto unknown. The times of arrival and departure of trains, instead of being a matter of caprice, and not made to suit the public convenience, were made to dovetail into a general scheme that grew to meet the needs of the public. Lines already constructed, by getting together, could save in the number of officers that were necessary to man them. The public also gained, because by uniting their interests the railways were better managed, their finances were put in better condition, and by thus putting an end to the wastes of competition the roads were able to deal more liberally with the public in the way of supplying conveniences 2 .

The completion of these great systems was not effected until after the railway mania of 1844-6 had done its work, and to that subject we must now give brief consideration. What was the cause of this third and greatest railway mania, we may be unable to determine, but it seems pretty certain that it was not brought on by the universal success of the railways which were then in existence. From the list of important railways which was published in 1841, we see that only eight out of twenty-two had their shares selling in the market above cost, while many were selling for prices that were much lower than the paid-up values of the shares ${ }^{3}$. The more probable cause was speenlation.

1 Brit. Doc. 1852-3 (796), xxxvin, 447, 'Fifth Report of Select Committce on Railway and Canal Bills, Minutes of Evidenee,' p. 187 where we are told that there were vast amounts of amalgamation that were not sanctioned by Parliament.

President Hadley, in his excellent work on Railroad Transportation, p. 159, after mentioning that the early history of English railway pools is obscure, says: "They first assumed importance some thirty years ago," whieh would make it about 1.855. We have shown in the foregoing that there were many working agreements before 1844, under which there was division of traflic among the lines interested; and from a careful study of this perior, I would place the time when they beame important at least ten years earlier than the date given by President Indley. The editor of the Railway Times characterized the year 1843 as the "year of amalgamation," and said that amalgamation was the order of the day (Railicay Times. v1, pp. 1128, 1387).

2 Brit. Doe. 1852-3 (736), xxxvir, 447, 'Fifth Report of Select Comnittee on Railway and Canal Bills, Minutes of Evidenee, p. 1.

3 Railway Times, iv (1841), p. 107, gives statistics of the more important railways. Those whose shares were sclling above cost were the Livcrpool and Manchester, 
The work of such a man as George Hudson, who rose from a position of obseurity until he eould eommand the poliey of several railroads, simply beeause of his gambling in railway shares and his ability to exereise undue influenee over railway directors, was, doubtless, an incentive to others to try the same method of piling up wealth ${ }^{1}$. The names he reecived as the "Railway King" and the "Railway Napoleon" are typical of his shrewd, grasping poliey, his work as a stoek-jobber, and his ability to lord it over railway offieials for his own material ends. Others were, doubtless, imitating his example; and the rage for speculation was fostered by the weekly reports and cireulars of the many brokers. In the latter part of the year 1844 railway projects were numerous, money was abundant, and its investment in railways was eneouraged by the prospeets of profit held out by scheming designers as bait to the unwary ${ }^{2}$. The editor of the most important railway journal of the time informs us that the fashionable phrase regarding the numerous railway undertakings that were daily making their appearance, was to say that a railway fever was raging ${ }^{3}$; and the editor of the London Times was urged to raise his voiee in warning against the mania which was then spreading rapidly over the land, and which promised a severe financial erisis that would shake the country ${ }^{4}$. By November 1844, a list of projected lines involving the aggregate capital of $£ 563,203,000$ was published, but many of these were abandoned ${ }^{5}$. The rage for shares continued and increased in intensity in 1845 , until it infeeted all classes from peer to peasant and from private individual to government officials ${ }^{6}$. The press was full of

Grand Junction, London and Birmingham, Great Western, Birmingham and Gloucester, London and South Western, Manchester and Leeds, and the York and North Midland.

1 For his career, sce the files of the Railway Times, vi (1843), pp. 1058, 1084, $1095-6,1122,1312-13$; VII $(1844)$, pp. 62, 131, 173-4, 327-8 (in which he is called the "Prince of Premium Hunters"), etc. Also the great detail given by Grinling, History of the Great Northern Railway.

2 Brit. Mus. 1396. g. 21, 'Railways and the Board of Trade', p. 7.

3 Railway Times, vil (1844), p. 485.

4 The Times, Nov. 20, 1844, p. 7, letter from "John Trot."

5 Jeans, Jubilee Memorial of the Railway System, p. 142, quoting from Spackman's published list.

6 Brit. Mus. 1396. e. 22 (4), 'Ruminations on Railways,' No. I, on "Railway Speculation," discussed the mania with sanity. The writer said (p. 6): "Such is the delirium in the share market, that many an honest, industrious tradesman withdraws from his more sober pursuits behind the counter, and dubs himself that delver into the mines of Golconda, a share-broker." In subsequent pages he goes on to deseribe how vehement was the fever for railroads. See also Brit. Mus. 8235 . d. 27, 'Railways and Shareholders,' p. 3. 
railway prospectuses ${ }^{1}$; and a large amount of the shares were in the hands of persons who were holding them, not for investment, but merely for speculation ${ }^{2}$. Share jobbing was rife ${ }^{3}$. Even such journals as the Railicay Times and The Economist were encouraging this vast expenditure of money and declaring that railway seeurities would constitute important means of investing capital ${ }^{4}$. On the other hand, the editor of the London Times was giving words of warning to the public against the time when blind confidenee would be displaeed by doubt and when the inevitable collapse would come ${ }^{5}$. All kinds of fraudulent methods were employed to delude the public and secure their funds ${ }^{6}$. The signifieance of the mania may be judged by the fact that, during the three years 1844-6, Parliament sanetioned Bills for the construction of 8470 miles of railway, which was just about three times the mileage then constructed; and the amount of eapital required for them, $£ 180,138,901$, was so great that the further growth of the railway system was eheeked for some years?. The financial panic which followed the railway mania, and which was probably in large measure due to the locking up of so much money in these temporarily

\footnotetext{
1 See, for example, the Raikway Times, The Economist, The Times, in their advertising columns.

2 The Times, Aug. 9, 1845, p. 6, on "Railway Speculation."

3 Ibid., July 11, 1845, p. 5 ; July 12, 1845, p. 5 ; July 14, 1845, p. 5 ; July 21, 1845, p. 7 ; July 25,1845 , p. 8 ; etc.

4 The Economist, 1845, p. 1013; Railway Times, v11, p. 485.

5 The Times, Aug. 9, 1845 , p. 6. It is interesting to contrast the editorial opinion of the Railway Times in 1844, when it was said that there was "neither fever nor lunacy in forming new railway schemes without end" (v11, p. 485), with that in 1845 , when his verdict was that those embarking in new railway schemes ought to exercise more caution (vili, Pt. I, p. 569).

6 Railway Times, vin, Pt. 1, p. 1013, letter from "Expositor;" "Railways as they Really Are,' No. 1, on the 'London, Brighton and South Coast Railway,' which exposes the frauds of this company, also Nos. 11 and vil ; Brit. Mus. 8235 . d. 27, 'Railways and Shareholders,' pp. 3-4; The Times, Oct. 18, 1845, p. 5, editorial ; ibid., Oct. 23, 1845, p. 7, letter on "Railway Speculation." 'This subject was continued in ibid., Oct. 25, 1845, p. 4 ; Oct. 27, 1845, p. 4 ; Nov. 8, 1845, p. 4; Nov. 14, 1845, p. 4 ; Dec. 2,1845, p. 4 ; in which the editor wrote strongly against the tide of speculation that was flooding the country. See also Brit. Mus. 1396. c. 22 (4), 'Ruminations on Railways,' No. 11, 'The Railway Board of 'Trade', and Brit. Mus. 1396. g. 21, 'Railways and the Board of 'Trade,' 3rd ed., pp. 20-28, showing the evils that attended the work of this body.

7 Jeans, op. cit., p. 142. In the year 1846 alone the length of railway authorized was almost double the total length of line authorized up to the end of 1843 . Brit. Doc. 1854-5 [1965], xuvil, 1, 'Report of the Railway Department of the Board of 'Trade' for 1854, p. xi. The amount of money authorized to be raised for the railways that were sanctioned in 1846 was $£ 132,617,368$; for those of 1847 ,

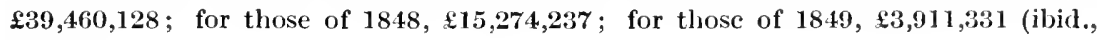
p. vii).
} 
unproductive enterprises, was severely felt in the spring of the year 1847, but we shall avoid any further reference to that subject. One outcome of the mania to which we may here allude was the great number of suits that were brought before the courts; some of these were instituted by railway companies against shareholders, because the latter refused to pay up the calls that were made upon then in connexion with their subseriptions; others were brought by individuals to recover deposits of money that they had advanced for the construction of railways which had not materialized. Some suits were started as a consequence of the winding up of undertakings that had proved abortive; and others were due to a variety of eauses, which we need not enumerate ${ }^{1}$.

We have already noted that up to and including the year 1843 there had been considerable amalgamation of railways ${ }^{2}$; in fact, it was asserted in 1843 that "amalgamation is the order of the day ${ }^{3} . "$ But after the cessation of the mania in 1846 there was a still greater agitation for amalgamation ${ }^{4}$. With the great amount of construction and reorganization which took place immediately following the mania, the weaker roads found it necessary to ally with the stronger, not only to reduce the expenses of management and operation, but to produce peaceful relations among the companies. Beginning with this epochmaking time in the history of the railways, a vast amount of consolidation was effected ${ }^{5}$, and the railways, instead of being left as independent units, were gradually becoming organized into a system which was beginning to take on its permanent form ${ }^{6}$. We may say that, by 1850 ,

1 Railway and Canal Cases, Vols. iv and v, give many of these.

2 Railiay Times, Vol. v1, gives much material on this suljeet, in addition to what we have already given.

3 Ibid., vi, p. 1128.

4 Ibid., Ix, p. 316.

5 Brit. Doc. $184-8$ (510), Lxil, 149 , gives very complete returns of all existing railway amalgamations in Great Britain and Ireland, aecompanying which is a map showing the amalwamation of railways that had taken place.

6 The tendeney in 1544 for railways to consolidate into a few great systems was beeming daily more manifest. The results that had already been realized showed conelusively that the probability was that the prineipal lines would be grouped into six or eight leading divisions. For the consolidations that had been made by 184t, see Brit. Doe. 1814 (:318), xy, 17. 'Tifth Report of Select Committee on Railways,' Appendix No. 2, 1. 21. For the probable results of the tendency toward amalgamation, see ibid., Ajpendix No. 2, p. 21 .

The leading systems, as developed in outline, by 1844 were as follows:

First. The Great North Western artery, extending for 2383 miles in a direct line from London to Laneaster and connecting Birmingham, Nanchester, Liverpool, and the manufaeturing distriets of Laneashire with the metropolis.

Secoud. The Great Midland and North Eastern system, beginning at Darlington, passing through York, within a few miles of Leeds and Sleffield, through Derby 
the present-day grouping of lines into the great arteries of eommunieation had been effected; and the ehanges sinee then have been the filling in of the network.

In eonnexion with the subjeet of amalgamation, there are one or two other features which require mention. The earlier railways had been formed by eompanies owning comparatively short lines; for example, the line from London to Liverpool belonged to three companies; and great loss of time and inconvenienee arose from the want of unity of management and from disputes between the companies. Therefore, partly for economy of management, and partly for the convenience of the traffie, some of these companies whose lines formed links in a through route obtained powers to amalgamate. But as time went on a further inerease in the number of railways led to eompetition of rival lines at many more points. This resulted in further amalgamation and buying up of rivals. Thus, amalgamation, which at first was a question of economy of management and publie convenience, beeame later a matter of offensive and

and Leicester, and meeting the Great North Western artery at Rugby. The length of this line was $201 \frac{3}{4}$ miles, and it was sonn to be extended to Neweastle.

Third. The Great Western system, from London to Bath, Bristol and Exeter. This when completed would give $194 \frac{1}{4}$ miles in a continuous line.

Fourth. The great transverse system, formed by the Liverpool and IIanchester, the Manehester and Leeds, the Leeds and Selby, and the Hull and Selby railways, conneeting the two leading ports of the east and west coasts, by a line of communication 132 miles long, and passing through the heart of the great manufacturing distriets of Lancashire and Yorkshire.

Fifth. The South Western system, from London to Southampton and Portsmouth.

Sixth. The South Eastern system, consisting of the Dover and Brighton Railways, which diverged from a eommon trunk at little south of Croydon.

Sezenth. The Eastern Counties system, intended to have eonnected Norwieh and the Eastern eounties with the metropolis, but only finished at that time from London to Colehester, 51 miles.

Eighth. The Northern and Eastern system, intended to conneet London with York by a line passing through Cambridge and Lineoln. and eompleted for only 32 miles out of London.

Among the minor and subsidiary lines may be mentioned:

First. The Neweastle and Carlisle Railway, connecting the North Eastern and North Western arteries.

Secoud. The Birmingham and Gloueester, Bristol and Gloueester, and Cheltenham and Great Western railways, connecting the North Western and Great Western arteries.

Thirl. The Birmingham and Derby Railway, eonneeting the Midland and the North Western arteries.

(v. Brit. Doc. 1844 (318), xi, I7, 'Report of Railway Department of Board of Trade,' Appendix No. 2, p. 6.) 
defensive policy, to enable the companies to fight one another more successfully.

The benefits from amalgamation were so apparent that many could foresee its eontinuance until all the railways of the eountry were united under the control of a few large corporations. Some went even further than that, and advoeated a general amalgamation of all the railways, not only from the standpoint of economy of operation, but to prevent a great deal of the jobbing and indiseretion that existed in some boards of directors ${ }^{1}$. As early as 1846 a seheme was proposed for merging the shares of all railway companies into one eommon stoek, under the management of a general proprietary board ${ }^{2}$; and this idea so occupied publie attention that in $\mathbf{1 8 5 2}$ the issue was investigated by a committee of Parliament ${ }^{3}$. That committee, however, reported adversely upon the plan, and it was never attempted. Another proposed solution of the railway problem, after the principle of monopoly had been reeognized, was that eertain distriets should be assigned to particular railway companies, and that in those distriets each should be protected from competition, in exehange for certain advantages that they were to give the public ${ }^{4}$. No definite plan was brought forward to carry this into execution and its futility soon became evident.

Another factor tending to the harmonious operation of railways, after the principle of amalgamation had been quite largely followed out, was the establishment in 1847 of the Railway Clearing House. In the earlier period of railways, the rolling stoek of one company did not generally pass from one line to another and the ineonvenienee and expense due to change of vehicles or transhipment were very great. But when the railway system had been developed to a considerable extent, it was neeessary for the companies to have a mutual understanding in regard to the sending of traffic over one another's lines. For this purpose, the ehief railway eompanies formed from among themselves an association, with a central office in London, to regulate certain questions of interehange of traffic as between the several companies, and to adjust the aeeounts arising out of the united aetion of the companies: to settle disputes as to the division of, and to

1 Brit. Doc. 1846 (489), xıI, 217, 'Report of Select Committee of House of Lords on Railways,' evidence of Mr W. Cubitt, p. 101, Q. 898; also 1852-3 (736), xxxvir, 447, 'Minutes of Evidence,' p. 32.

a Ibid.

3 Brit. Doc. 1852-3 (736), xxxvi1, 447, 'Fifth Report of Select Committee on Railway and Canal Bills.' It shows that such a general amalgamation would be undesirable, and why.

4 This view was taken by Gladstone's Committee of 1844 and by Lord Dalhousie's Railway Commission of 1845. See also Brit. Doc. 1852-3 (170), xxxviI, 5, 'Second Report of Sclect Committce on Railway and Canal Bills, Minutes of Evidence,' p. 30. 
apportion the receipts from, the traffic that might pass over more than one line, under agreements made by the several companies; and to keep the records of the movements of waggons and earriages when these might pass off the lines of the eompany to which they belonged, to the lines of other companies. This Railway Clearing House was a purely voluntary association at first, but in 1850 it was incorporated by Act of Parliament and had become a very important feature in preserving amieable relations among the various roads.

The width of gauge was another important problem which came up for consideration in 1846. When the Great Western Railway was constructed, the engineer, I. K. Brunel, constructed the road with the rails seven feet apart, while other roads generally had the rails only four feet eight and one-half inehes apart1. This diversity of gauge was a serious barrier to interehange of traffic, and in the above year, before the Committee of the House of Lords, railway engineers and others were in perfect agreement that the width of gauge should be uniform ${ }^{2}$. The settlement of this was important on account of the enormous number of lines that were then in progress and in prospect. In the session of 1846 the Gauge Act was passed, which enacted that unless it should be otherwise specified in the special Aets all future railways in Great Britain should be eonstrueted upon the gauge of four feet eight and one-half inehes, with the exeeptions of railways forming branches of the Great Western, or those situated in the counties of Somerset, Dorset, Devon and Cornwall ${ }^{3}$.

In a former connexion we spoke of the advantages whieh were anticipated from the development of railways, and we have referred to some of the results which were actually obtained in the cases of the Stockton and Darlington and the Liverpool and Manchester railways. A few words more as to the benefits that were definitely conferred by railways may not be out of place. Of course, the greatest results came

1 There were also mixed gauge lines, that is, roads with part of one gauge and part of another. In 1854, out of a total of 6114 miles of railway in England, there were 206 miles of mixed gauge, 647 miles of broad gauge, and 5261 miles of narrow gauge (i.e., 4 ft. $8 \frac{1}{2}$ in.). See Brit. Doe. 1854-5 [1965], xuviI, 1, 'Report of Railway Department of Board of Trade" for 1854, p. xii.

2 Brit. Doc. 1846 (483), xil, 21\%, 'Teport of Select Committee of the Housc of Lords on Railways, Minutes of Evidence; pp. 106-7. See also Brit. Doc. 1846 (3533), xxxvin, 3\%1, 'Copy of Minute of the Lords of the Committee of the Privy Council for Trade, on the Report of the Commissioners for inquiring into the Gaugc of Railways, June 6, 1846.' This has some good things on the subject of gatuge.

3 Brit. Doc. 1854 (139), Lxn, 441, 'Report of the Board of 'Trade to the General Committee on Railway and Canal Bills, on the Railway Bills of 1854, p. 26: also Brit. Doc. 1867 [3844], xxxvir, 1, 'Report of the Royal Commission on the Railways of the United Kingdom, Part 1, p. xv.

J. T. II. 
through the development of traffic, consequent upon the reduced cost and the increased speed of conveyance. Before the Stockton and Darlington was constructed, the number of passengers travelling between these two places was scarcely sufficient to pay for the running of a coach three or four times a week ${ }^{1}$. Between 1825 and 1832, when there were separate coaches running on the line, belonging to different individuals, the average number of passengers did not exceed 520 per week; so that the growth of the passenger traffic was slow but steady ${ }^{2}$. After that, the company took over the passenger business and so greatly increased the comfort and speed of their trains that, according to the statement of F. W. Cundy, a celebrated engineer, in 1834, 600 passengers per day were frequently conveyed along this line, where, formerly, by the coach, there were not more than ten passengers per day ${ }^{3}$. On the Liverpool and Manchester railway, in 1832, according to the evidence of the treasurer of the company, there were almost three times as many passengers conveyed as had been carried by the twenty-two regular coaches before the railway was opened ${ }^{4}$. In the case of the Leeds and Selby line, the number of passengers who travelled between these places during the first year of the operation of the railway increased, we are informed, from about 400 to about 3500 per week ${ }^{5}$. It is difficult to believe that there could have been as much as a nine-fold increase here in that short time, and yet we must remember that Leeds was flourishing as an industrial centre and Selby as a shipping centre. Perhaps some of this increase may have been merely experimental, indicative of the popular curiosity to try this new agency of travel, and may not have represented anything like as great a gain in the substantial, permanent increase of the business. But if passenger traffic increased so much there was a corresponding gain in the freight traffic and many a place was galvanized into new life by the advent of the railway. For example, during the first quarter of the nineteenth century the port of Stockton seemed to be subject to a gradual decline, but after the railway was built to connect with that port there was almost immediate reversal to a condition of steady progress. At the Tees ports the number of ships which cleared outwards in 1830 were three British ships of 262 tons and four foreign ships of 318 tons; but in 1841

1 Jeans, op. eit., p. 79.

${ }^{2}$ Ibid., p. 86. The details are given in pp. 85-86. See also Birmingham Journal, July 8,1826, p. 2.

3 Sheffield Iris, Oet. 14, 1834, p. 3.

4 'London and Birningham Railway Bill. Extraets from Minutes of Evidenee given before the Committee of the Lords,' evidenee of Henry Booth, pp. 53-55.

5 Sheffield Iris, Sept. 29,1835, p. 3 , editorial comment on the Leeds and Selby Railway. 
there were 454 British ships of 80,139 tons and 596 foreign ships of 44,392 tons ${ }^{1}$. The export figures for the coal trade are also instructive, since this railway was designed to tap the great coalfield behind Darlington. The total shipments of coal from Stockton, both coastwise and foreign, amounted to 1224 tons in $1822 ; 10,754$ tons in 1826 ; 66,051 tons in 1828 ; 704,781 tons in 1835 ; and $1,500,374$ tons in $1840^{2}$. Of course, it is possible that the railway was not the only cause of the great development of this traffic; but the fact that the great upward trend synchronized with the opening of the railway furnishes a strong presumption that the railway was the chicf cause of this development. The Liverpool and Manchester, in addition to saving cotton manufacturers and others large amounts on the conveyance of goods ${ }^{3}$, and increasing greatly the amount of business carried on in this locality, increased also the value and the extent of the traffic of the Lceds and Liverpool Canal, although the latter, fearing injury to their property, had opposed the railway at a very large expense ${ }^{4}$. The influence of the Manchester and Birmingham and the London and Birmingham lines in the development of traffic along that route was such that, in 1846, these lines were regarded as no longer capable of handling the immense amount of freight that was offered to them; and the manufacturers of both Manchester and Birminghan wanted to see a direct line constructed to connect them with London ${ }^{5}$. The great development of industry and agriculture which gave rise to the above-mentioned increase of traffic was one of the accompaniments of the railways.

Another of the immediate effects of the railway was the enhanced value that was given to land adjacent to it. The fact that by this means good markets could be brought nearer to the farmer made the land more valuable; and since the cultivator could secure a larger net return from

1 Jeans, op. cit., pp. 173-4, gives the statistics for each intervening year.

2 Ibid., pp. 174-5. Ibid., p. 176, gives comparative statistics of coal exports from Newcastle, Sunderland and Stockton, in the period before 1850, showing the extremely rapid growth of the exports from Stockton from 1821 to 1850 , as compared with the exports from the other two ports.

3 See evidence of many witnesses on the London and Birmingham Railway Bill before both Commons and Lords, 18:32.

4 'London and Birminghan Railway Bill. Extracts from Minutes of Evidence given before the Committee of the Lords,' evidence of James Forster, p. 4.

5 Brit. Mus. 8235. ee. 12 (1), 'Reasons in favour of a Direct Line of Railroad from London to Manchester,' pp. 8-11. The writer of this pamphlet says: "The trains are now frequently of such vast size as to render it impossible for the Company to keep time. These fucts can be abundantly established, even by the testimony of their own admissions and declarations." 
it he could pay a larger amount for his use of the land ${ }^{1}$. Land which formerly had been of little or no value, such as Chat Moss along the Liverpool and Manchester line, soon became veritable garden spots, and the proximity to large consuming eentres, effected by the railway, made the land valuable for gardening and other agricultural purposes ${ }^{2}$. Its value for building and industrial purposes also was soon recognized, and if the railway company, after its line was constructed, wished to purchase more land adjoining what they already had, they had to pay twice to five times as much for this subsequent purehase as for the first $^{3}$. When land was advertised as being for sale or to let, if it were at all possible the advertisement would stipulate that the railway either passed through the estate or near to it, for under these eonditions a higher price would be paid ${ }^{4}$. After railways had been carrying on their work for a few years, and it became known that they had paid at times large sums for the real estate they required, the eontemplated formation of railways in different parts was the signal to put up the price of land. In some instances exorbitant prices were asked by landowners, and, as the railway companies were not willing to aecede to these prices, juries were summoned to assess the value and decide between the two parties. In these cases the almost invariable result was that the jury assessed the value of the land at a lower figure than that offered by the railway

1 Manchester Guardian, Dee. 11, 1830, p. 3, showing that oceupiers of land and mines volunteered to pay higher rentals if the railway were put within easy reach of them. The Times, Scpt. 4, 1835, p. 2. This was also in accord with the testimony of Mir Pease, a director of the Stoekton and Darlington Railway, who said that not only had the value of his land along the line been inereased. but his rentals had likewise inereased, and that amid falling prices (The Times, Feb. 13, 1836, p. 3).

2 Birmingham Journal. May 19, 1832, p. 3, evidence of Messrs Moss, Earle, Lee and Pease; Shlefficld Iris, Oet. 7,1834, p. 1; Cundy, Obserzations on Raikways, 2nd ed., pp. 11-15, 17-21.

3 Shefficld Iris, Oet. 7, 1834, p. 1. Mr J. Moss, Deputy Chairman of the Liverpool and Manchester Railway Company, said that for the first eight miles outside of Liverpool his eompany paid 5s. 8d. a yard for the land they needed; but land all around the railway was sold before 1832 at $22 \mathrm{~s}$. a yard. The eompany also bought land at another part of their line for $\tau s$. a yard, but in 1831 , when more was wanted, $10 \mathrm{~s} .8 \mathrm{~d}$. a yari had to be paid. At another part of the line the eompany's subsequent purchase of land had to be made at doubie the price of the original purchase. Thomas Lee's testimony was that alter the eonstruction of the railway, land had been sold for building purposes at from three to five times the sum it would have brought before the establishment of the railway (Birmingham Journal, May 10, 1832, p. 3, evidenee of Messrs Mĩoss and Lee).

4 'London and Birmingham Railway Bill. Evidence before the Lords Committee,' p. 46, evidence of Joseph Pease; Birmingham Jourual, May 19, 1832, p. 3, evidence of Messrs Moss, Earle and Pease. 
company ${ }^{1}$. What we wish to impress is that either the prospective or the actual construction of a railway was accompanied by a movement toward higher prices for the land in the circumjacent territory.

Of the other immediate benefits secured by railways, we might enumerate a long list. Sometimes they conferred public benefits by reducing overgrown monopolies within reasonable bounds, as was done by the Liverpool and Manchester Railway when it entered the contest against the three navigation companies that opcrated between these two cities ${ }^{2}$. Sometimes they stimulated the more opulent eanal companies to make improvements in their canals and thus contribute to the public welfare instead of dividing among the proprietors the enormous profits that had been made by some of them ${ }^{3}$. They created an immediate and great demand for labour and thereby eased the burden of the labourers and of the community; they furnished in some cases good investments for English eapital, and thus kept these funds within the country for the development of the kingdom, rather than having them seek employment in foreign countries. But why need we go any further, for the history of the remainder of the nineteenth century is the record, in part, of the achievement of the railway.

With all the benefits which accrued from the construction of railways, there were also some evils which were a natural accompaniment of such a great change. In the first place, in railway initiation there were features which were decidedly objectionable. Some lines were formed for no other purpose than pure speculation; their promoters wanted to influence the market in such a way that the prices of their shares would reach a high figure, and then they would unload their holdings upon others who were innocent of the game that was being played. Values were given to shares purely on account of market manipulation, without any reference to the intrinsic value of the property upon which they were based, for in not a few instances they

I The Times, Oct. 28, 183\%, p. 3. gives a number of instances to show the relation of railways to the price of land. For example, in Bath a gentleman claimed firso for land taken by the Great Western Railway Company; the company offered him $£ 4500$ merely to save litigation, but this would not satisfy him, and the jury awarried him only £4223. Under similar cireumstances, Lord Manvers, in Bath, on his elaim of $£ 9000$, recejved from the company an offer of $\$ 4500$; but the jury awarded him only £3375. Many other cases are given in this reference. On five claims of $£ 16,067$, the jury gave only £2053. $7 s$.

2 The same outeome was the result of the Grand Junction and of the Lordon and Birningham Railway eompetition with the canals.

3 P., A Lelter to a Friend, containing Obsercations on the Comparative Merits of Canals and Railways, pp. 12-13, 29-30. Examples are given to conlirm this fact. 
had no material basis at all ${ }^{1}$. In other cases railways were projected, not with any idea of construction, but to induce existing railways to buy them off rather than have to meet the threatened competition ${ }^{2}$. Wilful misstatements of fact, in order to induce the public to come forward and invest in these undertakings, were not at all uncommon; and mere probable estimates were put forth with an assumption of confidence and reliability of aceuracy that were intended to deceive the unwary ${ }^{3}$. In some cases, impecunious individuals were able to reap considerable fortunes by bringing forward schemes for railways and having wealthy landowners along the proposed line pay large sums to cause the promoters to desist from what they regarded as a possible disfigurement of their estates. When we remember that many schemes projected at the times of the three manias were unworthy of being entertained, but were started for gambling purposes, we can faintly discern the expense and magnitude of such an evil ${ }^{4}$. Sometimes subscription lists were swollen by using the names of persons who had never given their consent, especially of those who would be influential in inducing others to signify their allegiance to the proposed scheme; and this moral turpitude must have been quite prevalent since there was the passage of an Act in 1844 for punishment of this offence ${ }^{5}$.

1 Sheffield Iris, Oet. 13, 1835, p. 3, on "Railway Speeulations," showing that the Manehester and Sheffield Railway: as first planned by some Liverpool people, was got i1 for this purpose, and that this view was probably present in the minds of those who went in for the North Midland Railway. See also Whishaw, Analysis of Raikays, p. v, who speaks of these sehemes as noxious weeds to be eradieated; Investigator (psend.), Bercare the Bubbles!!!. 2nd ed.. Pp. 1. 8; Herepath's Railway Magazine, N.S.. I pp. 32-35, where the editor shows up these frandulent methods that he had known: ibid., I pp. 72-78, letter of "Deteetor;" The Times, Oet. 18. 1845, p. 5, editorial; Miorrison, Defeets of English Railicay Legislation (1846), p 5.

2 See editorial in The Times, April 8. 1826. p. 3, expressing deep regret at the spirit of speenlation that had broken out among all ranks; also, on same page, letter from "A Shareholder" of the Norfolk, Suffolk and Essex Rail-Road Company, showing this nefarious scheme to have been only on paper, and not intended to be realized.

3 Herepath's Raikcay Magazine, N.S., I, pp. 72-78, letter of "Deteetor," eoncerning the South Eastern and Dover Railway; ibid., II, pp. 11t-17, false statements from the promoters of the Cheltenham. Oxford and Tring Railway, which they did not attempt to deny.

4 Martin, Raltwass, p. 3:3, quoting from 'Report of Parliamentary Committee on Railway Acts Enatments, Aug. 25. 1846. See also letter in Morning Chroniele, Nov. 17,1848 , on the results of eompetition.

5 The Times, Oct. 18, 1845. p. 5, editorial; Hansard's Parliamentary Debates, 1837, xxxvi pp. 855-63. See Aet 7 \& 8 Vict., e. 110, see. 65, which punished this offenee by a fine not exeeding $£ 10$. Compare the padding of the subseription list of the proposed London and Birmingham Canal, as given in Parl. Papers, 1830 (251), x, 719 . 
The construction of too many lines along eertain routes was another initial detriment. Following the accustomed policy, Parliament, thinking that competition would be desirable also in railways, sanctioned many competing lines, which swallowed up capital and seemed to waste the national wealth. It was not foreseen that competition, instead of causing low rates, might operate just the reverse. While this employment of the country's capital did produce results which were immediately injurious, it is open to question whether this supposed excess has not, in the long run, been of substantial benefit to the country. But even with all this expenditure, it seems clear that it was not always the best line, but the one which could command the greatest influence in Parliament, that secured recognition ${ }^{1}$; and this opened the way for political corruption and jobbing.

In the second place, in railway finance there were some things which were not for private welfare or public good. The enormous sums paid by the railway companies for lands and for compensation constituted a heavy preliminary obligation. An investigation of this matter in $\mathbf{1 8 4 5}$ showed that landowners frequently obtained for their lands a much larger amount than the land was really worth; and a landowner who was a member of Parliament, and who would otherwise be likely to oppose the Bill in Parliament, was sometimes given a higher price for his land than another who could not wield that influence. The companies recognized that it was often better to spend money in this way and stop opposition at the beginning, than to pay the higher expense of getting Bills through Parliament in the face of such opposition. In some cases, extravagant sums were paid in order to get rid of opposition, not only from landlords ${ }^{2}$, but from rival railway companies and other interests ${ }^{3}$. These expenses, along with the legal fees that

1 Parl. Papers, 1836 (0.96), xxi, 235, Mlinutes of Evidence before Select Conmittee on Railway Bills,' evidence of James Walker, C.E., Q. 178.

2 Parl. Papers, 1845 (420), x, 417, 'Report of Select Committee of the House of Lords on Compensation for Lands taken for or injured by Railways,' evidence of John Duncan, John Clutton, Edward Driver and John Cramp. Q. 289 shows that the gentleman who bought the land for the London and Brighton line testified that he paid fully ten times what the land was worth, simply to get rid of opposition.

3 Young, Steam on Common Roads, pp. 6r-6s. Shaen. Review of Railicays and Railzay Legislation, pp. 36-40, eitcs cases from the parliamentary reports showing that large sums had to be squandered to buy ofl opposition to certain Bills. Ibid., pp. 49-46, shows how much time and money was wasted before railway committecs of Parliament. Chattaway, Railways, pp. 23-24, said that "the sums paid by many of the railway companies for land and eompensation are almost fabulous;" and as he was an officia of the North British Railway, he should have known the facts. He referred to one property valued at $£ 5000$ that had been sold to a railway company for $\$ 120,000$. See also Marshall, Railzvay Legislation, p. 30 . 
had to be paid for competent solicitors who were experienced in the work of guiding measures through Parliament, and which were also excessive and sometimes extortionate ${ }^{1}$, made the cost of obtaining an Act of Parliament very burdensome. Another element in the situation that was to be deprecated was that rival roads endeavoured to outdo each other in the fineness of their equipment; and engineers, anxious to make a name for themselves, put into the construction of bridges and other works a large amount of money, which added to the aesthetic value, but not to the traffic value of the road. By these and other means the costs of the railways were often increased two or three times as much as the original estimate ${ }^{2}$.

Moreover, there was much financial manipulation that was derogatory to the welfare of the companies. When the shareholders elected their directors to look after the affairs of the company, they allowed them, in too many cases, to have full authority over the property and policy of the company, without keeping any oversight of the way in which the directors fulfilled the trust that was reposed in them. If one or two of the dircetors were particularly aggressive they sometimes got too large a share of the eontrol of the railway, and used it for their personal interests rather than for the bencfit of the owners of the

1 Young. op. cit., pp. $70-71$. He gives statistics as to these costs in particular cases. In one instance the expense was $£ 146,000$, and then the Bill was defeated; in another the solicitor’s fee was $£ 240,000$. See also Fay, A Royal Road, pp. 14, 17 . Chattaway, Kailways, p. 23 says that the parliamentary and legal expenses of the Great Northern were $£ 2400$ per mile, or a total of $£ 683053$; of the Cornwall, $£ 129,147$; of the Eastern Union, £242.385; of the South Western, £2r9,500; and of the Shropshire Union, £111.855. It is impossible for me to know how mueh confidence to plaee in the reliability of these figures. His figures for the London and South Western are widely different from those given in Fay, A Royal Road, p. 17, where the cost of obtaining the Act is given as $\$ 31,000$. Fay was a traffic official of the railway. Pratt, IIistory of Irland Transport and Communication in England, pp. 255-6, among other figures, gives $\$ 41,467$ for the London and South Western, but he is quoting from Porter's Progress of the Nation, and Porter gives no authority for his statement, but says that his figures do not include the same items of expense in each case. It was, doubtless, true that many of the companies did not know exactly how much these expenses were, but, in any case, they were high; and the wide differenees here noted may be explained by the inclusion of different elements of eost in each case. See also Martin, Railways, Past, Presem and Prospective, p. 32; The Times, Nov. 16, 1818, whieh shows that at a meeting of the shareholders of the Liverpool, Manchester and Newcastle Junction Railway, to dissolve the company, it was shown that they had already spent $\$ 100,000$ in law expenses.

2 Marshall, Railkay Legislation, p. 29; Chattaway, Railways, p. 24; Herepath's Railway Magazine, N.S., 11, Pp. 92-94, letter from "A Suffering Shareholder," to the shareholders of the Eastern Counties Railway; The Times, May 9, 1837, p. 6, letter from "T. G." on "Railways;" "A Few General Observations on the Principal Railways...," p. vi. 
property ${ }^{1}$. Wasteful expenditures were allowed to go on unnoticed and without any aecounting on the part of the offieials ${ }^{2}$. The most reckless extravagance had, in many instances, been shown, not alone in the actual construction of the main lines, but in the formation of seeondary lines at a cost that was unjustifiably high; and while all this was going on, shareholders remained singularly apathetic and only a small fraction of the total proprietary of a railway even attended the annual meeting of their company ${ }^{3}$. Sometimes a series of transaetions were carried throngh that were injurious to the revenues of the railways, such as leases, purchases and other eontracts that were paid for at too high a price ${ }^{4}$. Some railways sacrificed other considerations of great importance to the payment of dividends, and revenues which should have been put back into the property, or used for the liquidation of

1 As in the case of George Hudson and the York and North Midland Railway. Hudson had bought shares in the Hull and Selby Railway to the amount of $\$ 35,646$, and immediately sold these shares to the York and North Midland Railway Company for $£ 38,842$, thus netting himself $£ 3196$. He was able to do this because of the influence he had acquired over the directors of the York and North Midland. At a later time, after an investigation of the affairs of the York and North Midland by a committee of its directors, these shares were given back to Hudson, and he was required to pay back to the company the amount he had received through the salc of the shares ('York and North Midland Railway, First Report of the Committee of Investigation (1849),' pp. 6-7; ibid., 'Second Report,' p. 3, in which this committee reported that Hudson had become "almost sole and absolute manager" of the railroad, and that he had "abused the confidence which was placed in him, by wielding the power he obtained to forward his own interest." He had "lost his better judgement and moral rectitude when left with the entire control." See also Railway Times, 1v, p. 85; ibid., v, p. 1268 : ibid., v, pp. 1309 (letter of Charles Penfold), 1315-16; and ibid., v1, pp. 83, 84.

2 Marshall, Raitway Legislation, 2nd ed., p. 15; Merepath's Railway Magazine, N.S., II, pp. 92-94, letter from "A Suffering Shareholder ;" Railcay Times, Ir, p. 38, in which the editor says, in regard to railway management, that "extravagance is the rule, economy the exception." See also ibid., iv, pp. 38, 39, 42, 43, 61 et seq. ('Proceedings of the Meeting of the Manchester and Birmingham Railway Extension ') ; ibid., v, p. 1268.

${ }^{3}$ Railway Times, rr, pp. 13, 14, 38, 85 (editorial on the "necessity of observing the most rigid economy in the future management of railways"); ibid., r, p. 1220; Marshall, Railway Legislation, p. 18, said that the extraordinary disclosures of the affairs of some of the English companies had created so much suspicion among shareholders, that nothing short of a searching inquiry into the condition of every company would allay the prevailing alarm.

${ }^{4}$ Handyside, Review of the Manchester, Sheffield and Lincolnshire Railiculy, pp. 5-26. For example, this railway, he says, bonght for $\$ 21,000$ the Dearne and Dove Navigation, which cost but $\$ 6000$; and the Don Navigation which cust $£ 15.000$ they bought for $£ 450,000$. He gives many other examples. See also Chattaway, Railways, pp. 25-26, showing that branch lines which were intended to be feeders to the main line had often sucked the company dry, through guarantees, leases, etc. 
debt, were used for paying dividends of six, seven, or eight per cent. Had the directors furnished full statements of their affairs, there would have been sufficient light thrown upon the condition of the companies' affairs that it would be seen that dividends were not warranted. The payment of dividends out of capital; the charging of other expenditures improperly to capital, rather than to revenue; the neglect to provide properly for repairs, depreciation, renewals of permanent way and other essentials of good financing; these and similar methods enabled companies to pay good dividends and thus have their shares command a high price in the share market ${ }^{1}$. In one instance, at least, and probably in several others, the accounts were manipulated and falsified by those who were in charge of the road; one station agent was securing large amounts of money, through representing it as wages to be paid to the men; false statements were made wittingly; a general manager whose delusive methods and irregularities were known by the directors was kept at his post because he was capable; and all these things were going on while shareholders were ignorant or indifferent, more usually the former, in regard to their property ${ }^{2}$. It was not until well on in the fifth decade of the century that public opinion began to be aroused to really see what had been taking place; and the owners of the various properties were urged to take active interest thenceforward in the management of the companies' affairs, and to put in directors who would administer their trust for the public well-being ${ }^{3}$. Closely connected with the foregoing were the wide fluctuations in the prices of railway shares, by which some became wealthy and others imporerished. Many causes may be assigned for this, but the more important were the instability of the whole system of railways, the lack

1 Marshall, Railway Legislation, pp. 12-16. With the kind of statements that were issued, it was frequently impossible to know how much had been spent on rolling stock, how much on permanent way, how much on stations, etc. Langley, The Dangers of the North British Railivay Policy, 2nd ed., pp. 5-6, shows that the North British admitted in their reports that they were sacrificing other considerations, like the upkeep of rolling stock and permanent way, to the payment of dividends. In contrast with this, the North Eastern spent large sums on maintenance. See also 'Railways as they Really Are: or Facts for the Serious Consideration of Railway Proprietors,' Nos. 1 and II.

${ }^{2}$ A good illustration is furnished by the case of the York and North Midland under Hudson's régime (v. 'York and North Midland Railway, Report of the Committee of Investigation, first, second and third reports). This was, apparently, a one-man power, and the results of the investigation were terribly damaging to Hudson.

3 Ibid.; Marshall, Railzay Legislation, pp. 19-20; The Times, Jan. 16, 1843, p. 5; ibid., Jan. 23,1843 , p. 3, report of the committee on the Midland Counties Railway Company; ibid., Feb. 20, 1843, p. 5. 
of adequate reports as to the condition of the various companies, the decisions of the Railway Department of the Board of Trade, which, after 1844, had to sanction every new railway project before it was authorized by Parliament, and the gambling spirit which was prevalent in the early years of the establishment of railways ${ }^{1}$.

In the third place, there were some phases of railway operation which were objectionable from the standpoint of the companics and of the public. In the internal organization of the companies, there was for more than twenty years an imperfect definition of the authority of the various officials, so that responsibility for errors could not be fixed; reports were not rendered to the higher officials frequently enough for their guidance; there was lack of discipline in carrying out regulations and orders; the desire for economy went so far that the road was under-manned, or else the repairs and alterations were deficient in amount or defective in the quality of materials used; and in cases of accident or irregularity there was a lack of individual responsibility, since the heads of departments did not know to whom to look for instructions ${ }^{2}$. Competition brought some of the railways almost to the verge of ruin and entailed much loss to those whose funds were invested in these enterprises ${ }^{3}$; and even after different lines had entered into working agreements with one another, these agreements became so intricate and chaotic that constant disputes were inevitable. Nothing was more common than to see a company eagerly seeking authority to make a branch which could only bring it loss, but which, it was feared, would cause still greater loss if it fell into the hands of a rival ${ }^{4}$. In some cases the companies ran a greater number of trains than the traffic warranted, or carried traffic, for the time being, at unremunerative rates in order to take it away from their rivals. The time-tables show that, on the great routes, passenger trains moved about as regularly as the coaches had done formerly on the roads, the aim being to provide such conveniences of travel as would take the trade from the coaches. This excess of accommodation was neither warranted by public necessities nor remunerative to the railways, and through the

1 On the subject of price fluctuations of railway shares, see Marshall, Raikiay Legislation, pp. 10-12, 34-36; Brit. Mus. 1396. g. 21, 'Railways and the Board of 'Trade,' 3rd ed., pp. 24-40; The Times, Jan. 16, 1843, p. 5, giving a table of the fluctuations of railway shares during the year 1842 , which showed wide variations of prices.

2 McDonnell, Railway Management, pp. 1-23.

3 Cotterill, The Past, Present and Future Position of the London and North Western, and Great Western Railway Companies, p. 31 ; Civis (pseud.), The Railway Rnestion, p. 11.

4 Ibid., p. 11. 
formation of working agreements of one kind or another they gradually learned to reduce the unnecessary expenditure incurred in this way ${ }^{1}$. At first, too, there was the desire on the part of the companies to cater more carefully to the first-class passengers and to neglect to some extent the third-class passengers. The former were provided with good coaches; their trains were run at good speed, with as few delays as possible, and with the best connexions. On the other hand, the third-class passengers were poorly provided with coach accommodation; during the early years, the third-class coaches were open to all changes of weather; they were attached close to the engine, and the smoke and cinders from the engine were a source of great annoyance to the passengers; these cars were not run nearly as often as those of the higher classes along the same line and they were run at inconvenient hours; they were subjected to frequent and sometimes long delays, and it was aggravating for these passengers to lie on sidings while the first-class trains went speeding by. Not uncommonly the third and second-class passengers reached a junction point and then found that they would either have to stay there for some time or else pay the higher fares in order to proceed immediately in first-class coaches to their destination ${ }^{2}$. It would seem as if the object of the railway companies was to compel passengers to give up third-class and go first-class; for even second-class passengers received but meagre consideration on some lines. That the monopoly of the railway company was used to the detriment of the public is evident from the current testimony of the time ${ }^{3}$, and from the fact that Parliament was desirous of having working agreements, amalgamations, leases, etc., sanctioned by the authority of the legislature and subject to their jurisdiction and control. Many were in favour of giving up the principle of competition

1 Marshall, Railway Legislation, pp. 15, 50-51.

2 In addition to the references given on this subject when we were considering railway amalgamations and working agreements, see Galt, Railway Reform (1844), pp. 14-18 ; ibid. (1865), pp. xvii, 34-35 ; Brit. Mus. 8235.c. 72, 'Railway Management,' pp. 8-9; Young, Steam on Common Roads, pp. 71-84, showing the discomforts and indignities of third-elass passengers; The Times, Nov. 3, 1837, p. 5, letter from "A Passenger;" ibid., Scpt. 22, 1843, p. 6, letter from "A Second-class Traveller;" ibid., July 2, 1814, p. 6, letter from "A Commercial Man;" also other letters to the same effect in ibid., Aug. 22, 1844, p. 6; Aug. 27, 1844, p. 6; Aug. 28, 1844, p. 6; Sept. 26, 1844, p. 7. In ibid., Sept. 20, 1844, p. 6, a letter from .J. L. Ramsden, F.R.S., who held a great number of shares in the London and South Western, showed how little attention was paid to second and third-class passengers on his line.

${ }^{3}$ Galt, Railkay Reform (1865), pp. 34-36. On the abuse of railway monopoly, see also Parl. Papers, 1857-8 (0.77), xv, 11, 'Minutes of Evidence talien hefore the Select Committee on the Manchester, Sheffield and Lincolnshire, and Great Northern Railway Companies.' 
as applied to railways and of having agreements entered into wherever possible; but after seeing the early results of monopoly those who advoeated working agreements did so bccause they wanted to see greater unity of action, greater economy and improved accommodation, under some parliamentary supervision which would guard the public interests ${ }^{1}$. These, and other accompaniments of the extension of the railways, together with the political effects in seeuring what was called a "Railroad Parliament," were certainly fraught with a power for evil"; and yet many of them were imputable to the newness of the system, to the universal ignorance of its tendencies, and to the wonderful suddenness of its growth. Looked at from the distant point of view whieh the present affords, we can see that these evils were but incidents in the rapid expansion that was taking place.

From the foregoing, it is not diffieult to decide why many railways were unprofitable enterprises, so far as their owners were eoncerned. With the payment of very high charges in order to secure the act of incorporation, and often exorbitant priees for land and eompensation, followed by the great extravagance in the management of the companies' funds; the costly construction and equipment which greatly exeeeded the needs of traffic; the extraction of funds by dishonest officials, and the expenditures for ostentation rather than utilitythese, and the disastrous results of early competition, must have proved to be a burden, for some of the railways, that was hard to endure. For example, we learn that the Manchester, Sheffield and Lincolnshire Railway, during the first fourteen years of its activity, scarcely paid a fraction of a dividend on the amount of the original stock ${ }^{3}$. Even some of the main lines paid but low rates of interest upon the capital expended, for, in addition to the above-mentioned disabilities, they frequently had, in self defence, to link up with themselves certain branch lines of railway or canal, which, instcad of being feeders to the

1 Marshall, Railway Legislation, pp. 52-60; Galt, Railway Reform (1865), p. 56, showing that, under existing conditions, occasionally one company paid another a large sum of money if the latter would refrain from competition. Civis (psend.), The Railway Question, pp. 15-17, said that there was a feeling gaining ground that the roads of the country were properly the dominion of the state; and that to secure harmony of interests for the public good, the companies should admit a more regular and extensive exercise of state control.

2 Whitmore, Letter to Lord John Russell on Railzays (1847), pp. 9-10. We have not given a full account of all the evils that accompanied this period of great advanee, but have mentioned the most significant of them. Some others were almost entirely imaginary (P., Descant on Railroads); and others still were more or less unsubstantial (Jeans, op. cit., Ch. xul). See also Gordon, Observations on Railiculy Monopolies, pp. $1-55$.

3 Handyside, Review of the Manchester, Sheffield and Lincolnshire Railway, p. 4. 
main lines, proved rather to be suckers, withdrawing funds from the treasury of the main lines in order to pay interest to the claimants upon the branch lines'. Among the early railways in the north of England, there seems to have been quite a number that paid either no dividend at all or else but a very small return, and many of these were in the very centre of the industrial and mining section, especially in the county of Durham2. A writer, with intimate knowledge of the railways, has given us in $\mathbf{1 8 5 4}$ the dividends paid by the fifty-nine railway companies of England and Wales for the first half of that year; and working this out upon the annual basis, we find that, of this number, fifteen paid no dividend, thirty-four paid dividends from less than one per cent. to less than five per cent., five paid dividends of five to six per cent. inclusive, and five paid dividends of seven to ten per eent. inclusive ${ }^{3}$. There is no reason to suppose that the year 1854 was anything but an ordinary year, for by that time the country had recovered from the mania of 184t-6 and was again going on its normal way. With forty-nine out of fifty-nine railways, or eightythree per cent., paying less than five per cent. per annum, it would appear that the number of companies which secured reasonable remuneration on invested capital was small in comparison with the number of those which fell below the reasonable minimum. But although many of the railways were not profitable to their owners in yielding large financial returns they may still have been beneficial to the public in providing for the necessities and conveniences of traffic.

When considering the subject of roads, we noted the fact that, before 1830, the consolidation that had taken place in the turnpike trusts was not the consolidation of those which formed continuous lines of road, but of those that were found in particular counties, or parts of eounties, such as those in the vicinity of London or Bristol. But in the case of canals, the small amount of eonsolidation that had taken place was the merging of those which were parts of a continuous line of navigation. The amalgamation of the railways followed closely the type of that of the canals, not of the roads, by the formation of

1 Young, Steam on Common Roads, p. 67; Galt, Railway Reform (1865), p. 36 ; Civis (pseud.), The Railway Question, p. 11.

2 Jeans, op. cit., p. 171, mentions some of them.

${ }^{3}$ Chattaway, op. eit., p. 20. Here, also, he gives the average dividends that were paid during the period 1850-4.

4 Such as the consolidation of the Birmingham and Bilston Canal with the Birmingham and Tamworth, in 1783; the Trent and Hersey with the Oxford and Coventry canals, in 1785; the Chester and Ellesmere canals, in 1813; the Grand Junction and Regent's canals, in 1819; and the North Wilts Canal with the Berks and Wilts, in 1821 . 
adjoining railway lines into great through routes. Why should the roads have been different in this respect from the eanals and railways? The answer would seem to lie in the faet that the eontrol was different. The eanals and railways were in the hands of private companies, which, under their several Acts, were given authority to eonstruct and operate their transportation facilities in the several counties or distriets throngh which they passed; but the turnpikes were under the authority of the Justiees of the eounties, and it would have been almost impossible to get several sueeessive counties to work harmoniously in the proper maintenance of great through roads, such as that from London to Holyhead, or that from London to York.

From the foregoing outline of the railway systems of England we are impressed by the similarity of their position with that of the ancient Roman roads, and also with that of the turnpike and eanal systems which played so important a rôle. It was because of this juxtaposition of the turnpikes, canals and railways that the subjeet of competition between them assumed so conspieuous a place in the publie mind, and to this we now turn. 


\section{CHAPTER VIII}

\section{EFFECTS OF STEAU UPON ROAD TRANSPORTATION}

Following, probably, the example of the coaeh proprietors, who provided for both outside and inside passengers, the railway companies whieh undertook the conveyance of passengers provided two, and often three, different kinds of accommodation, at different prices ${ }^{1}$. The first-class were covered carriages, intended only for the well-to-do; the third-class earriages were at first open and exposed to all the changes of the atmosphere, and were for the poor; while the second-class aecommodation was intermediate in quality and eost, and was for the great middle class. The people who were expeeted to travel third-class were those who belonged to the working group; and it was thought that by providing this cheap means of eonverance the poor would be able to live out in the country where they could have agriculture or gardening as a by-employment, and have also better sanitary conditions, while they could go to and from their work every day. In making any comparison, therefore, between railway and stage coach charges, we must keep in mind this difference between first, second, and third-class rates on the railway, and must draw our analogies between first-elass rate and inside coach fare. and between second and third-class rates and outside coach fare.

Before the opening of the great trunk lines, about 1838-40, the coach fares on some roads werc very high ${ }^{2}$, while on others they were kept moderate by the influence of the competition of several coaches ${ }^{3}$.

1 Brit. Doc. 1844 (318), xi, 17, 'Fifth Report of Select Committee on Railways,' Appendix No. 2, pp. 12-13, showing that some railways rejected altogether or limited the third-class accommodation.

2 See Appendix $\tau$.

${ }^{3}$ See the great number of coaches licensed to run in $183 \%$ between London and other important places in the kingdom, as given in 'Collection of Prospectuses, Maps, etc., of Railways and Canals; p. 80. Between London and Birmingham, for example, there were 122 journey's wcekly and 1098 passengers carried; between London and Liverpool there were 68 journeys wcekly and 612 passengers carried; between $\mathrm{L}$. ndon and Manchester there were 119 journeys weekly and 107 ! passengers carried; etc. Of course these coaches werc not all engaged in competition; for all those which were under one management would not be rivals among themsclves. 
In our discussion of the cost of travel by coach during this period we found that, as a general thing, the inside fare was from two and one-half to four pence per mile; and more commonly the latter would come nearer to the actual truth than the former. This figure seems to be slightly lower than that given by one of the great coach proprietors, who said that before the introduction of railways the fares were about four and one-half pence per mile inside and two and one-half pence per mile outside 1 . But the Committee of 1844 , in speaking of this, said that upon most of the leading roads, where competition was effective, this rate of four and one-half pence per mile was somewhat higher than was customary. Probably, therefore, the coach rate which was prevalent on the great roads was three and one-half pence to four pence per mile, or in some cases a little more. The fares adopted by the leading railway companies were about three pence per mile for first-class passengers, two pence per mile for second-class, and one to one and one-half pence per mile for third-class ${ }^{2}$. These, it will be observed, were but little lower than the coach fares, probably just enough to be an additional inducement for passengers to travel by rail; but when we supplement the reduced rate by the combined incentives of greater comfort and speed ${ }^{3}$ of railway trains we can easily see why the railway would attract the passenger traffic away from the stage coaches.

After making the foregoing general statement, let us examine some particular instances of the results of this competition. In the investigation of 1844 , as to the effect of railways on the interests of the poorer classes, we have some very definite information given as to the relative cost of travelling by canal, stage coach and railway. The cost of passage from Manchester to London, for an ordinary family consisting of two adults and three children, was, by canal boat $£ 3$. 14 s., by coach

1 Testimony of Mr Chaplin before the Committee of the House of Commons on Railways, 1838. See also Brit. Doe. 1844 (318), xi, 17, 'Fifth Report of Seleet Committee on Railways,' Appendix No. 2, p. 9. Galt, Railicay Reform (1865), p. 71 , said that about 1830 the general average fares by mail coaches were $\tilde{5} d$. per mile inside and $3 d$. per mile outside, and by the stage coaches $3 d$. per mile inside and $2 d$. per mile outside. But we have formerly shown that the facilities by mail coaches were not better than those of the stage coaches at that time, and, therefore, the fares by the former could not be mueh, if any, in exeess of those by the latter means. It is clear from the evidence we have previously given that Galt's firures for stage eoaehes were too lww.

2 Brit. Doc. 1844 (318), xi, 17, 'Fifth Report of Select Committee on Railways,' Appendix No. 2. pp. 10-11, gives table of fares on leading roads. The average fares charged per mile were, for first-elass $2 \cdot 727 d$., for second-elass $1 \cdot 745 d$., and for thirdclass $1 \cdot 151 d$.

3 The average rate of travelling, stoppages ineluded, on the principal passenger railways was about twenty-four miles per hour (ibid., Appendix No. 2, p. 11).

J. T. Ir. 
$£ 6$. $2 s$, and by railway $\mathfrak{L} 4.15 s .{ }^{1}$ Thus, taking into consideration the necessary expenses incident to such a journey, we judge that travelling by railway cost only about three-fourths of that by coach. From London to Coventry, before the railway was opened, there was one stage waggon, charging nine shillings fare and taking thirty-six hours, and several stage coaches charging for outside fare seventeen shillings by night and twenty shillings by day, which took from ten to eleven hours; but in 1844, when the railway was in operation, there was no stage waggon on this route, and only one night stage coach, charging ten shillings and taking twelve hours, while by the railway the thirdclass fare was twelve shillings and the time occupied six and one-half hours $^{2}$. That is, the introduction of the railway brought a reduction of the fare and of the time required for this journey amounting to almost one-half. When we consider the greater expense for fees and meals when travelling by the stage coach, the cost of travelling by the latter vehicle must have been fully twice as much as by the railway. Again, before the cstablishment of the Liverpool and Manchester railway the coaches between these two places, at full capacity, could not carry more than 688 persons per day, and, on the average, probably

1 The following figures were given in detail as to this journey (Brit. Doc. 1844 (318), x1, 17, 'Fifth Report of Select Committec on Railways,' Appendix No.4) :

By Canal boat (Manchester to London).

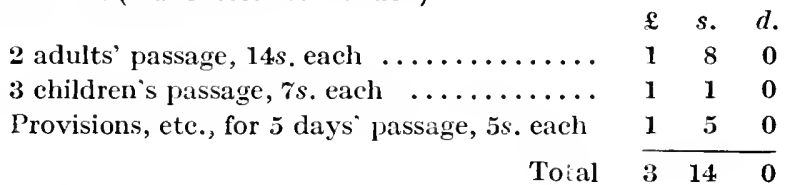

By Coach, Manchester to London, 186 miles.

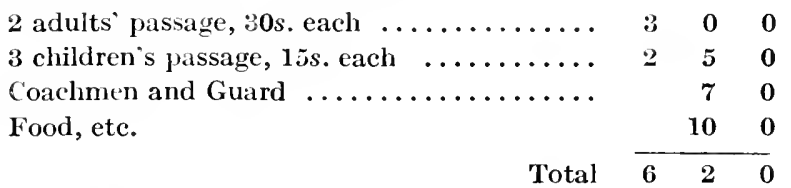

By Railway, Manchester to London, 212 miles.

'Third-class, Manchester to Birmingham,

2 adults' passage, $11 s$. each $\ldots \ldots \ldots \ldots \ldots$ 1. 20

3 children's passage, $5 s$. 6 d. each $\ldots \ldots \ldots \ldots .616 \quad 6$

Third-class, Birmingham to London,

2 adults' passage, $14 s$. each $\ldots \ldots \ldots \ldots \ldots$ 1 1 8 0

3 children's passage, $7 s$. each $\ldots \ldots \ldots \ldots \ldots$ 1 110

Food, etc., $1 s .6 d$. each $\ldots \ldots \ldots \ldots \ldots \ldots \ldots, \quad 7 \quad 6$

Total $\longdiv { 4 \quad 1 5 \quad 0 }$

2 Brit. Doc. 1844 (318), xı, 17, 'Fifth Report of Committee on Railways,' Appendix No. 4, p. 63. 
calried not more than 450 or 500. The railway at its commencement earried an average of $1070 \mathrm{per}$ day ${ }^{1}$. The fare by coach varied according to the scason and the amount of travel, but on the average it was ten shillings inside and five to six shillings outside; the fare by the railway in 1832 was five shillings for first-class and three shillings and six pence for third-class ${ }^{2}$. The time oceupied in making the journey by coach was four hours; the time occupied by the railway was but one and three-fourths hour ${ }^{3}$. It is evident that here, too, the establishment of the railway reduced by one-half the cost and the time of travelling. Before the advent of the railway, the twenty-four-hour journey by coach between London and Liverpool cost $\mathfrak{1 4 .} 4 s$, but, including the fees and the meals, the cost would approximatc $\mathfrak{E}$. After the railway had been opened some time, the cost by rail firstclass was $3 \pi s$. and second-class $27 s .^{4}$, showing the expense of travelling by railway to have been less than half that by road. Whilc, therefore, our general conclusion, above stated, that the railway fares, on the whole, were not much lower than those of the coaches, is probably close to accuracy, we must, nevertheless, realize that, in some instanees, there had been a reduction of as much as fifty per cent. in these charges. Similar results were secured in the conveyance of commodities. For example, before the opening of the Great Western, the waggon rate from London to Oxford was $£ 3$ to $£ 3.10 \mathrm{~s}$. per ton; but the railway charged only $30 s$. per ton, which was practically one-half the former charge ${ }^{5}$. The latter rate included rail carriage from London to Steventon and then waggon earriage for ten miles between Steventon and Oxford. Had there been rail carriage all the way, so as to avoid the necessity of a waggon haul and its attendant loading and unloading, the cost would have been still less than that mentioned, and probably would not have exceeded 25s. ${ }^{6}$ Before the opening of the railway to

1 In 1836 the average was 1200 daily. See Advantages of the Progressive Formation of Railkays, p. 23: 'London and Birmingham Railway Bill. Extracts from Minutes of Evidence before Lords Committee,' evidence of Henry Booth, treasurer of this railway company, pp. 53-55.

2 Ibid.

3 Annual Register, 1832. p. 445; also 'London and Birmingham Railway Bill. Extraets from the Minutes of Evidence before Lords Committee,' evidence of Henry Booth, pp. 53-55.

4 Shaen, Review of Railways and Railway Legislation, p. 32.

5 Brit. Mus. 8235. ee. 4 (1), 'Oxford and Dideot Railway Bill. Evidence taken before Commons Committee,' evidence of Mr Sadler, p. 3, and of Mr Sheard, p. 10.

${ }^{6}$ Ibid., evidence of Mr Clarke, p. 2r. The evidence of Messrs Sadler, Sheard, Underhill and Clarke gives much detail by way of comparison of rail with road carriage, both as to passengers and goods, showing the decreased cost and reduced time by the former. 
connect London and Manchester, the cost of carrying general goods by road was $70 s$. to $80 s$. per ton, but after the railway had been in operation for some time the charge by this faster conveyance was only $30 s$. to $40 s .{ }^{1}$, or one-half the former charge. We must not be understood, however, as implying that railway rates in general were only one-half as much as those charged by waggon.

In like mamer, the change in the amount of coaching and posting, after the coming of the railway, was almost immediate. Along the line of the Liverpool and Manchester Railway there had been each day twenty-two regular and seven occasional coaches for carrying passengers, but, within five months after the opening of the railway all these, with the exception of four, had disappeared. By 1832 all but one of these coaches had ceased running and that one was chiefly for carrying parcels ${ }^{2}$. On the road from London to Birmingham, before the railway was opened, one of the chief London coach proprietors had nine coaches; but after the opening of that line this number was gradually reduced until in 1839 he was working only two coaches and had difficulty in keeping them on. The fares charged by coach were only one pound inside and twche shillings outside; yet he got no inside passengers, because people could go by the railway for the same fare and they preferred that means of travelling ${ }^{3}$. The great number of coaches that travelled the road from London to the west of England was soon rednced after the railway was established in operation ${ }^{4}$; but it was not until after some years of rivalry, namely, about 1843, that

I Shaen, op. cit., p. 33.

2 Birmingham Journal, Feb. 5, 1831, p. 3, letter from "A Subscriber to the London and Birmingham Railway;" ibid., May 19, 1832, p. 3, evidence on the London and Birmingham Railway Bill; Ammal Register, 1832, p. 445. See also Shaw, Liverpools First Directory, p. 19.

3 Brit. Doc. 1839 (295), 1x, 369, 'Evidence of Mr Sherman,' p. 8. Others testified to like results. See also Brit. Doc. 1837 (456), xx, 291, 'Report of Committee on the Taxation of Internal Communication,' p. iv, and evidence of Messrs Horne (pp. 1-51), Gray (pp.5-10), Fage (p.15), Wimberley (pp. 35-38), Kemplay (pp. 38-39), etc. Slugg, Manchester Fifty Years Ago, p. 221, says that scores of posting houses were ruined by the introduction of railways; but he was speaking from memory. Stretton, in his IVistory of the London and Birmingham Railway, says that the result of the first run over this line was that the stage coach proprietors at once decided to raise their rates, and the following quotation appeared in several newspapers: "Coach Fare from Bimingham to London.- The coach proprietors on this line of road, aware that on even the partial opening of the London and Birmingham Railway, they may cry 'Othelo's occupation gone,' are making hay while sunshine is left them. The fare from Birmingham to London, which of late years has averaged from $18 s$. to $25 s$., has recently been trebied, the proprietors now modestly ask £3. 12s. fare from Birmingham to the metropolis."

4 To give some idlea of the amount of coaching on certain roads at the time railways were introduced, we give the following statistics from the records of the 
the last coach was driven off this road ${ }^{1}$. Before the railways could cause the coaches to give up the struggle they had to reduce their charges to a point almost equal to the fares of the coaches; and any slight excess of railway fares above that point was sufficient to bring back the coaches on some of the roads ${ }^{2}$. If railway companies had charged as much as the law allowed, their lines would have been comparatively deserted in most cases, for they would have been used almost exclusively by the opulent classes; but by putting down their charges to an approximate equality with those of the coaches they diverted to the rail all through traffic and most of the local coaching business along lines of road which were near to and parallel with the railways ${ }^{3}$. The decrease in the amount of coaching was accompanied by a corresponding reduction in the amount of posting along these roads.

Stage Coach Office (v. Proceedings of the Great Western Railway, evidence of Mr Sutherland, p. 39).

The number of coaches licensed and the number of journeys performed along the main western highway, in 1834, before the Great Western Railway was built, were as follows:

\begin{tabular}{|c|c|c|c|}
\hline $\begin{array}{l}\text { Number } \\
\text { of coaches }\end{array}$ & From & To & $\begin{array}{c}\text { No. of journeys } \\
\text { per week }\end{array}$ \\
\hline 6 & London & Bath & 40 \\
\hline 20 & , & Bristol & 136 \\
\hline 4 & $"$ & Cheltenham & 24 \\
\hline 3 & ", & Devonport & 14 \\
\hline 19 & , & Exeter & 81 \\
\hline 1 & $"$ & Farringdon & 6 \\
\hline 1 & 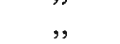 & Great Marlow & 12 \\
\hline 6 &, & Gloucester & 38 \\
\hline 1 &, & High Wycombe & 12 \\
\hline 1 & 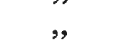 & Henley & 12 \\
\hline 1 & 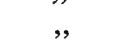 & Harlington & 16 \\
\hline 1 & , & Maidenhead & 12 \\
\hline 1 & , & Marlborough & 6 \\
\hline 4 & , & Newbury & 24 \\
\hline 10 & , & Oxford & 62 \\
\hline 11 & , & Reading & 80 \\
\hline 3 & 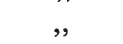 & Stroudwater & 20 \\
\hline 5 & , & Taunton & 24 \\
\hline 7 & , & Uxbridge & 82 \\
\hline 7 & 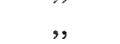 & Windsor & 96 \\
\hline 3 & , & Wallingford & 24 \\
\hline 1 & , & Wantage & 6 \\
\hline
\end{tabular}

1 Galt, Railway Reform (1844), p. 7 ; Brit. Mus. 8235. ee. 4 (1), 'Oxford and Didcot Railway Bill,' pp. 5-6.

2 Galt, Railway Reform (1844), p.7; Young, Steam on Common Roads, p. 84; The Times, Dee. $\mathrm{T}, 1843, \mathrm{p} .6$.

3 In Railway Times, v (1842), pp. 639-40, 711,973, we find a emparison of travel by railways and eoaches showing the vast change that had been effeeted by the 


\section{Effects of Steam upon Road Transportation [онар.}

We must bear in mind that this was a period of transition, and like all other similar periods was fraught with disaster to those upon whom the burden rested most heavily. Perhaps the classes that suffered most were the proprietors of coaching establishments and the innkeepers along the great roads. The latter class found their inn and posting business rapidly declining ${ }^{1}$; and the papers of the time contained the advertisements of whole coaching and carrying establishments that were selling out ${ }^{2}$. Through many years the coach-masters had endeavoured to provide facilities for a greatly increasing amount of travel and had, in some cases, many hundreds of horses; but when the railway came and took the passenger traffic from these great roads we can easily understand that ruin seemed to stare them in the face ${ }^{3}$. introduction of the railways. The last of the coaches between London and Cambridge made its final journey on Oct. 25, 1845 (The Times, Oct. 29, 1845, p. 5). The opening of the railway from Salisbury to Bishopstoke was the signal for the withdrawal of the coaches which went through Andover, which, but a few years before, numbered about forty daily (The Times, Mar. 12, 1847, p. 6).

1 The Times, Dec. 14, 1843, p. 5, "Turnpike $v$. Railway."

2 The Times, Sept. 28, 1837, p. 1, gives three such advertisements; ibid., Oct. 21, 1837 , p. 1, gives two advertisements; etc.

3 Some idea of the great traffic that centred in London may be gathered from a table (v. 'Collection of Prospectuses, Maps, etc., of Railways and Canals,' p. 80) showing the number of coaches licensed in 1837 to run between London and many other places, the number of passengers carried, and the wcekly receipts from these licenses. From the table we take the following data to show the extent of the coaching business between London and the north:

\begin{tabular}{|c|c|c|c|}
\hline & aces & $\begin{array}{c}\text { No. of journeys } \\
\text { weekly }\end{array}$ & $\begin{array}{c}\text { No. of passengers } \\
\text { weekly }\end{array}$ \\
\hline Lond & Birmingham & 122 & 1098 \\
\hline , & Liverpool & 68 & 612 \\
\hline ", & MIanchester & 119 & 1071 \\
\hline , & Glasgow & 14 & 70 \\
\hline , & Holyhead & 14 & 70 \\
\hline ," & Shrewsbury & 40 & 360 \\
\hline ", & Woodside & 14 & 126 \\
\hline , & Worcester & 51 & 459 \\
\hline 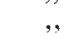 & Edinburgh & 14 & 70 \\
\hline ," & Halifax & 28 & 252 \\
\hline , & Leeds & 70 & 630 \\
\hline , & Leamington & 12 & 96 \\
\hline , & Leicester & 14 & 126 \\
\hline ", & Newcastlc-on-Tyne & 28 & 252 \\
\hline , & Nottingham & 28 & 252 \\
\hline ," & York & 14 & 126 \\
\hline ," & Barton & 12 & 96 \\
\hline , & Lincoln & 18 & 162 \\
\hline & Northampton & 14 & 126 \\
\hline$"$ & Aylesbury & 38 & 304 \\
\hline ," & Luton & 18 & 180 \\
\hline ," & Watford & 14 & 140 \\
\hline ," & Pinner & 26 & 260 \\
\hline
\end{tabular}

The traffic from London to the Eastern Counties is well represented by a diagram 
This was particularly true, of course, concerning those in the great centres, notably London. It would be erroncous, however, to suppose that the deeline or the disappearance of the comntry innkecpers on the important thoroughfares was due entirely to the advent of the railway; as a matter of fact, many of them wcre gradually climinated before this time, on account of the necessity of the coaches making fewer stops as they developed greater and greater speed ${ }^{1}$. Nor was the picture of the disappearance of the coaches entirely unrelieved by a brighter aspect. It is, doubtless, true that along the main roads, where they were in competition with the railways, the coaches were soon taken off; yet the increase of business brought by the railroads, not only at their stations but also on the country roads icading to the stations, caused a greater demand for the labour of horses in the carriage of passengers and goods ${ }^{2}$. We have ample proof of this from the increase in the number of such vehicles that were licensed ${ }^{3}$. We may, therefore, say that a decrease of coach traffic along roads that were adjacent and more or less parallel to the railway, which meant almost annihilation to some proprietors of coaches, was only the forerunner of greater business of this kind when once the readjustment

in the Appendix to Vol. Ix of the Brit. Doc. for 1839, showing the gradual diminution of the amount of passenger travel from London to the towns farther east:

The number of stage coaches from London to West Ham and Stratford was 62.

The number of stage coaches from West Ham and Stratford to Romford was

41 and 2 mails.

The number of stage coaches from Romford to Brentwood was 36 and 2 mails.

The number of stage coaches from Brentwood to Chelmsford was 32 and 2 mails.

Bearing in mind that some coach proprictors conducted the traffic on several of the chief roads where the density of travel was fully as great as the aforementioned, it is not hard to see what the sweeping away of all this business would mean to such establishments.

1 Herepath's Railway Magazine, N.S., vi, p. 463, letter of Joseph Lockwood.

2 Brit. Doc. 1839 (295), Ix, 369, 'Rcport of Select Committee on Railroads;' also ibid., Minutes of Evidence of Mr Macadam. Both of these references give us to understand that the increase on the lateral lines was not at all commensurate with the loss on the principal lines. This may have been the immediatc effect in some cases, but it certainly was not the ulterior effect. On the increase in the number of horses and vehicles that were used on the cross roads tributary to the Liverpool and Manchester Railway, sce Godwin, Appeal to the Public on Ratizays, p. 40; Hampshire Advertiser and Salisbury Guaddian, Mar. 29, 1834, p. 2, evidence of Mr Langston, of Manchester: Felix Farlcy's Bristol Journal, April 19, 1834, p. 4, Committee on the Great IVestern Railway Bill. See also Brit. Mus. 8235. ee. 4 (1), 'Oxford and Didcot Railway Bill,' evidence of Mr Sadler, p. 6, and IIerepath's Railkay Magazine, N.S., vi, p. 461.

3 Railway Times, vi (1843), p. 443, statement of the Earl of Ilardwicke, on the "Effect of Railways." He gives accurate statistics to substantiatc this fact. 
was effected ${ }^{1}$. Mention must also be made of the fact that one of the largest coaching establishments in London, and we cannot say how many more, became an ally of the railway to act as collectors and distributors of goods at the terminus ${ }^{2}$.

As a result, it was said, of the competition between the railways and the turnpike roads for the traffic of the country, which, in many cases, was accompanied by a great decrease or total decline of traffic on the turnpikes parallel with the railways, we find constant complaints from the turnpike trusts that thcir tolls were diminishing because of the diminution of posting and stage coach business ${ }^{3}$. It must be borne in mind that the trusts depended mainly upon the passenger traffic for their revenues. On account of this decrease of revenues, the debts of the trusts were constantly increasing, for it was the prevailing practice to convert the unpaid interest into principal, by the trustees giving interest-bearing bonds to cover the full amount. That there was a great increase in the debts of the trusts is beyond dispute ${ }^{4}$, as is also the fact that the debt was increased through the consolidation with it of interest that was in arrears ${ }^{5}$. The continuation of this practice, of

1 This is well exemplified in the Earl of Hardwicke's statement in the preceding reference.

2 Railway Times, Iv (1841), p. 209, showing that the Grand Junction Railway Co. had employed Chaplin and Horne for some time as their agents in London to unload and deliver goods. It is probable that few of the coaching firms were fortunate enough to attach themselves to the railways in this way.

${ }^{3}$ Brit. Doc. 1837 (456), xx, 291, Minutes of Evidence of Mr Hall. Also 1839 (295), 1x, 369, 'Report of Select Committee on Railroads,' and Minutes of Evidence of Messrs Bicknell, Levy and Mlacadam. On the reduction of traffic and tolls on particular roads, see Railican Times, v (1842), pp. 18, 21; but on the roads as a whole the tolls had apparently increased (ibid., vi, p. 443).

${ }^{4}$ Brit. Doc. 1833 (24), xv, 409, 'Second Report of Select Committee on Turnpike Trusts." The Committce "contemplate with alarm the results of the great and increasing debt on many roads." Statistics to prove this are given in ibid., 'Minutes of Evidence,' pp. 174-5.

From Brit. Doc. 1836 (547), xix, 335, 'Report of Select Committee on 'Turnpike Tolls and Trusts,' we learn that the trusts' debts at that time amounted to nearly $£ 9,000,000$, and that the probability was that they would constantly increase as in the past. See also 'Report of Select Committee of 1839 ' on the influence of railways on turnpike trusts, Brit. Doc. 1839 (295), 1x, 369, with evidence of Messrs Bicknell, Levy, and Macadam.

5 Brit. Doc. 1836 (54\%), xix, 335, 'Report of Select Committee on Turnpike Tolls and Trusts,' states that several trusts were at that time insolvent because the amount of interest due annually was more than the amount of the annual income. Also Brit. Doc. 1839 (295), ix, 369, 'Report of Select Committee on Railroads and Turnpike Trusts,' tells us that the debt then exceeded $£ 9,000,000$. Also ibid., evidence of Sir Jas. Macadam, who said that this policy prevailed very generally throughout the trusts of the kingdom, where interest payments could not be made. Hc said this was the chief cause for the increase of the bonded debt for some years 
course, increased both the prineipal and the interest of the debt. But when we come to consider the additional reasons why the trusts' revenues were insufficient to keep up their interest payments we meet with a problem which involves several other factors than that of railroad competition.

In a former chapter we have seen that, in the management of many of these trusts, the funds were squandered by injudicious expenditures and keeping up official parasites who were incapable of accomplishing anything for the good of the roads from which they drew their salaries. The same thing was, doubtless, still prevalent, although the accounts of the trusts did not show it ${ }^{1}$. Then, too, the statute duty, or statute labour, was abolished in $1835^{2}$, and also the composition in its place. This loss was estimated by Sir James Macadam, who had an intimate knowledge of the condition of the turnpikes, to amount to $£ 200,000$ a year ${ }^{3}$. But, notwithstanding the abolition of the statute labour, in the administration of which there was much frand, the finaneial eondition of many trusts became worse and worse ${ }^{4}$; and as a means toward obtaining economical and efficient management the consolidation of small trusts into larger trusts and of the larger trusts into unions of trusts was urged upon Parliament ${ }^{5}$. This suggestion, of eourse, eame

before that. This was very acceptable to creditors, in that it gave them additional security by a bond for the payment of their interest. His statement was that he knew some roads upon which there were sixty years' arrears of interest due.

1 Brit. Doc. 1836 (547), xix, 335, 'Report of Select Committee on Turnpike 'Tolls and Trusts.' The Committee put forth a plan that would be "useful in preventing any wasteful expenditure of funds in some trusts;" and although they do not expressly mention this form of extravagance, we are warranted, from what we have found hitherto, in saying that it still existed.

2 Act 5 \& 6 William IV, c. 50.

3 Brit. Doc. 1839 (295), Ix, 369, 'Report of Select Committee on Railroads and Turnpikes ;' also ibid., evidence of Mr Macadam. See also Brit. Doc. 1837 (457), xx, 343, 'Minutes of Evidence,' p. 9 et seq.

4 Brit. Doc. 1839 (295), ix, 369, 'Report of Committee on Railways and Turnpikes,' and evidence of Sir James Macadam.

5 The evidence was nearly unanimous that such consolidations would be desirable from many points of view: It would save the amounts now spent in salaries to officers of small trusts; it would give cheaper road materials by purchasing them in larger quantities; it would abolish the competition for such materials that was common among small trusts; and it would obtain an improved system of management by merging the small trusts into large trusts.

But there were also objections raised to the consolidation of such interests. Some trusts were in good cireumstances, and were opposed to allying with those that were in debt. Then, the creditors of those trusts that had given good security were averse to the adoption of any measure likely to lessen their security, by uniting the solvent trust, to which they had advaneed money, with one or more that were financially embarrassed. See Brit. Doc. $1836(547)$, xix, 335, 'Report of Selcct 
from the good results which were secured by the consolidation of the metropolitan turnpike trusts. It is not within the present plan to follow out the subsequent history of these roads ${ }^{1}$; but the point to be noted is that such recommendations were the ontcome of the reduction of revenues which accrued to the trusts.

Again, the competition of steam vessels on the rivers, and, more important still, in the coasting trade, drew away traffic, and consequently revenues, from the turnpike trusts. Wherever there was a route for steam vessels near the coast. and a more or less parallel coaching route on the land, whether near to or somewhat distant from the shore, the vessels almost invariably took the greater part of the passenger traffic, especially during the warmer part of the year. This rivalry of the two means of eonveyance was most noticeable along the east coast, and from London, around Kent, to the south-east coast. The preference that was shown by the public for the steam vessels was chiefly due to the fact that they were much more comfortable, and at the same time cheaper, than the coaches. For instance, a passenger

Committee on 'Turnpike Tolls and Trusts;' also 1839 (295), Ix, 369, 'Report of Select Committee on Railroads and Turnpike Trusts.'

1 A brief summary of the later history of the turnpike trusts will be à propos here. After 1830 many of the trusts were unable to maintain their roads in reasonable condition, and, according to the common law, the burden of maintenance devolved upon the parish. This liability was not enforced after the Highway Act of 1835 , but in 1841 an effort was made, in Aet 4 \& 5 Vict., e. 59, to restore it, by authorizing the Justices to demand a payment out of the highway rates toward the repair of turnpike roads where the tolls were insufficient. In this way, the parish had a double burden to bear, the payment of the tolls and the cost of repaining the road; and, while ineffective to improve the finanees of' the trusts, this system aroused hostility. The "Rebecea Riots" in 1842-3 were the ontcome; and the conditions in South Wales, where these riots were particularly vigorous, are told in the 'Report of the Royal Commission of Inquiry of 1844.' Finally, as a result. of this inquiry, an Act was passed to put an end to the administration of the trustees in South Wales, by merging all the trusts under "County Roads Boards," composed of Justices of the Peace. In England, no such centralization of control was possible, on account of the opposition of rival interests of one kind and another. But soon after the middle of the century there came to be a growing sentiment in favour of the abolition of the turnpikes and toll-gates. The committee of the House of Commons which, in 1864, investigated the subject reported that the tolls were "unequal in pressure, costly in collection, inconvenient to the public, and injurious as causing a serious impediment to intercourse and traffic," and advocated the union of the trusts in some such way as had been carried ont twenty years before in South Wales. Still the whole matter was left in abeyanee, so far as any general public policy was concerned; but from this time onward successive committees of the House of Commons began the gradual dissolution of the trusts, and their administration was handed over to the highway districts, or to the highway parishes, in which they were located. By 1887 only 15 trusts remained; by 1890 these had been reduced to two; and in 1895 the toll system ceased. 
could get by packet from London to Gravesend for $1 s$. $6 \mathrm{~d}$., and from Gravesend to Maidstone for $2 s .6 d$., making a total of $4 s$. from London to Maidstone; but the coaches charged 6. . for this distance ${ }^{1}$. From London to Neweastle the fares by coach were $\mathfrak{1} 4.10 \mathrm{~s}$. inside and $\mathfrak{E 2} .5 \mathrm{~s}$. outside; while by steamer the fares, including provisions and all expenses, were only $£ 3$ for the best cabin and $£ 2$ for the fore eabin ${ }^{2}$. Between London and Hull the fares by steamship were, for the best cabin $\mathfrak{f} 1.1 s$. and for the fore cabin $15 s^{3}$; and the fares between Hull and York, at these rates, could not exceed $5 s$. and $4 s$. respectively; so that the steamer fares between London and York could not have been

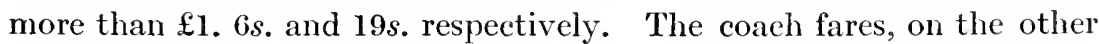

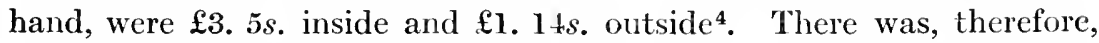
a decided advantage in travelling, where possible, by steamer. From the point of view of the coach proprietors, one vital element in their higher rates was that they had to pay duties and taxes from which steam navigation was free on account of the sea being an open highway that required nothing for its maintenanee ${ }^{5}$. It was recognized by the owners of coaches that they could not maintain their position in the face of this competition, and they were compelled to take of many of their coaches during the summer months, when the traffic was most

1 Brit. Doc. 1837 (456), xx, 291, 'Report of Committee on the Taxation of Internal Communication,' evidence of Mr Horne; also 'Report,' p. v.

2 Harris, The Coaching Age, p. 194.

${ }^{3}$ Macturk, History of the Railways into Hull, p. 11, advertisement of the "Enterprise" steamship. Harris, The Coaching Age, p. 194, gives the fares between London and York, not including expenses, as $8 s$. and $4 s .6 d$. for best cabin and fore cabin; but it is pretty certain that his figures are altogether too low, when we compare them with those which we have just given.

4 Harris, The Coaching Age, p. 194.

5 The conveyance of passengers by water was free of duty; but on making as close an approximation as possible to the truth, through a comparison of the rate of duty and the average number of passengers conveyed it was found that the duty paid by the stage coach was $\frac{1}{4} d$. per passenger per mile (Brit. Doc. 1837 (456), $\mathrm{xx}, 291$, 'Report of Committee'). On the road from London to Dover one coach proprietor had five coaches, on which he paid (in 1836) a mileage duty of £2273. 16s. 6d., from which his competitors by steam power were wholly free. The same conditions were found on the great north road (ibid., evidence of Mr Horne). In Harris, The Coaching Age, p. 193, we are given a statement of the duties and other expenditures of the "Wellington" coach from London to Neweastle for a year, drawn up by one who was thoroughly familiar with the accounts, which shows that the taxes paid by this coach to the Government were $22568.18 \mathrm{~s}$. 6 d. The tolls paid were extra, over and above this amount, and were annually ever $£ 2500$. From all of these expenses the vessels were frec. Steamship proprietors had another advantage over coaches in being allowed to retail wines and spirits without paying an excise license (Brit. Doc. 1837 (456), xx, 291, 'Report of Committee on 'Taxation of Internal Communication,' p. v). 
profitable, because there was not enough business for both rivals'. In the case of passengers who wished to reach any of the places on or near the great north road it was more congenial to them to take the vessel to the nearest point on the coast, and then reach their inland destination by coach, than to take the coach all the way ${ }^{2}$. Thus, people flocked to the steamboats and left the long coach roads wherever it was possible to do so conveniently. In some instances, the travelling on the lateral lines leading to these main roads was much increased, so that although steam navigation might interfere with the business on the roads that were parallel with it, it produced a considerable increase in the collateral trade ${ }^{3}$. Whether this increase of transverse trade made up inmediately for the loss of trade on the longer throngh routes it is impossible for us to determine.

But, in addition to the effect on the revenues of the roads due to the abolition of statute labour (or composition therefor) and to the competition of steam navigation, it is certain that the railways directly attracted the traffic from the adjacent thoroughfares that were parallel with them. This reduction of road carriage, by diminishing the tolls on the turnpikes, made it more difficult for the trusts to pay their interest obligations and maintain the roads. As it is impossible to make general statements on this subject with great accuracy, it will serve our purpose better to note the results in particular instances in which the great roads are involved.

One of the clearest cases of the influence of the railway in curtailing the revenues of the roads was that of the line from London to Birmingham. This road was practically parallel with the London and Birmingham Railway, and was one of the best constructed and managed roads in England. The railway was fully opened in 1838, and the tolls received on the various road trusts between these two cities, for the half-year ending Mar. 29, 1839, amounted to $£ 7899$, which when

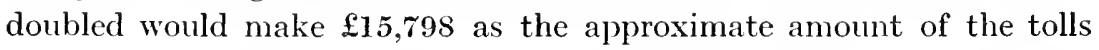

1 Brit. Doc. 1837 (456), xx, 291, 'Report of Committee;' also evidenee of Messrs Horne, Wheatley, Wimberley and Kemplay. These faets were evidenced by witnesses from almost every district of the kingdom. Baines, IIistory of Lizerpool, pp. 564-5, shows that when Bell put his first useful steamboat on the Clyde, plying between Glasgow and Greenock, four eoaches between these two plaees were immediately discontinued, on aeeount of the transfer of the passenger travel to the vessel, although the ordinary speed of the vessel was only four to four and one-half miles an hour, and less than that when the wind and tide were unfavourable. Buchanan, Pratieal Treaitise on Propelling Vessels by Steam, p. 13, says that in 1816, when he was writing, the vessels along the Clyde had largely superseded the coaches and that the steamers had greatly increased the amount of travelling.

2 Brit. Doe. 1837 ( 456$)$, xx, 291, evidence of Messrs Wimberley and Collins.

3 Ibid., evidenee of Mr Wimberley. 
for the first year after the opening of the railway. The tolls for the

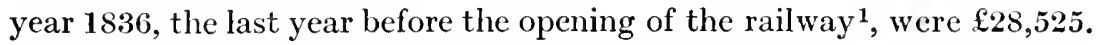
This shows a decrease of approximately $£ 12,727$ a year, or almost fifty per cent., on the tolls of $1836^{2}$. This could not have been due to canal competition, for the road traffic was derived largely from passengers and parcels while the canal traffic was that of heavy articles. It is evident, therefore, that the decrease of the road tolls was a direct accompaniment of, and caused by, the operation of the railway. A similar result may be noted in connexion with the Liverpool and Manchester Railway, which was opened in the latter part of the year 1830. Soon after its operation began, an attempt was made to let the tolls at two bars near the Manchester end of the turnpike road which followed the same direction as this railway. The Eceles bar, which had

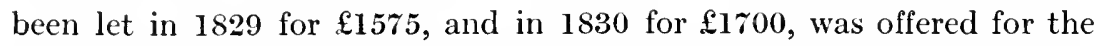
next year at $£ 800$; and the Irlam bar which had brought in 1829 a rental of $£ 1335$, and in 1830 of $£ 1300$, was ofiered for $£ 500$; but because of the reduction of revenue anticipated or experienced as a result of the railway, no one was found who wanted to farm these tolls, even at the immense reduction for which they were offered ${ }^{3}$.

At a ganglion like London, where great roads converge, the effect of a railway would necessarily be felt with great intensity. We would also expect considerable reductions of the tolls on roads that were parallel to railways but at short distances removed on either side. Taking those trusts which were parallel and close to, but not adjoining,

1 This railway was partly opened in 1837 and completely in 1838 .

2 Brit. Doc. 1839 (295), $\mathrm{Ix}, 369$, 'Minutes of Evidence,' p. 66. The details of this are as follows:

Turnpike Trusts between London and Birmingham

Whetstone Trust $\quad \ldots \quad$. $\quad \ldots \quad \ldots$

St Albans Trust $\quad \ldots \quad \ldots \quad \ldots \quad \ldots$

Dunstable Trust $\quad \ldots \quad \ldots \quad \ldots \quad \ldots$

Puddlehill Trust $\quad \ldots \quad$.. $\quad \ldots \quad$..

Hockliffe and Stratford Trust $\quad \ldots \quad \ldots$

Stratford and Dunchurch Trust .. ..

Dunchurch and Stonebridge Trust .. . .

Stonebridge and Birmingham Trust ..

$\therefore$ Tolls for half-year after the opening of the

London and Birmingham railway were

$\therefore$ Estimated toll for 1839 would be

3 Manchester Guardian, Feb. 12, 1831, p. 3.

\begin{tabular}{cc}
$\begin{array}{c}\text { Tolls received } \\
\text { for half- } \\
\text { year ending }\end{array}$ & $\begin{array}{c}\text { Tolls received } \\
\text { in year }\end{array}$ \\
Mar. 29, 1839 & 1836 \\
$£ 2,207$ & $£ 5,365$ \\
1,063 & 3,821 \\
720 & 2,770 \\
656 & 2,525 \\
735 & 3,507 \\
1,324 & 6,335 \\
466 & 1.707 \\
728 & 2,495 \\
\hline & \\
7,899 & \\
2 & \\
$£ 15,798$ & $£ 28,525$
\end{tabular}


the London and Birmingham Railway, we find that the tolls in $\mathbf{1 8 3 9}$ were only from one-half to two-thirds of what they were in $1834^{1}$; and, of course, those roads that were the more distant from the railway were less affected than those that were nearer ${ }^{2}$. So great were the reductions of the tolls in some cases, and the uncertainty of their amount, that it was becoming increasingly difficult to get anyone to farm them ${ }^{3}$. Sir James Macadam, who was the General Superintendent of the Metropolitan Roads, after speaking in 1839 of other factors which had caused some roads to go from bad to worse ${ }^{4}$, added the significant statement: "The calamity of railways has also fallen upon us, which, of course, has aggravated the evil ${ }^{5}$." It must not be understood from what we have said, and from the instances we have adduced, that wherever the railway went the roads fell into decay. The reduction of turnpike revenues noted above was an inevitable concomitant of the introduction of such a novel and effective instrument of transport as the railway; and there is no doubt that in some cases the financial embarrassment

1 The British Almanac and Companion for 1842, p. 119, gives us the following information regarding these roads:

\section{Names of the 'Trusts}

Amount of tolls

\begin{tabular}{|c|c|c|}
\hline \multicolumn{3}{|c|}{ Names of the 'Trusts } \\
\hline Metropolis Roads, North & $\cdots$ & $\cdots$ \\
\hline St Albans and Barnet & & \\
\hline Dunstable & . & \\
\hline Sparrows Herne & $\cdots$ & $\cdots$ \\
\hline Hocklifle and IVoburn & .. & .. \\
\hline \multicolumn{3}{|c|}{ Holyhead Road, Hockliffe district } \\
\hline \multicolumn{3}{|c|}{ Old Stratford and Dunchurch $\quad$. } \\
\hline \multicolumn{3}{|c|}{ Northampton and Newport Pagnell } \\
\hline \multicolumn{3}{|c|}{ Market Harborough and Welford } \\
\hline \multicolumn{3}{|l|}{ Dunchurch and Stonebridge } \\
\hline Market Harborough and & & \\
\hline Stone, Stafford and Penkri & & \\
\hline
\end{tabular}

\begin{tabular}{|c|c|}
\hline \multicolumn{2}{|c|}{ Amount of tolls } \\
\hline 1834 & 1839 \\
\hline$£ 86,676$ & $£ 77,944$ \\
\hline 3,472 & 1,896 \\
\hline 2,680 & 1,011 \\
\hline 3,458 & 2,613 \\
\hline 2,519 & 1,230 \\
\hline 3,250 & 1,198 \\
\hline 5,894 & 2,702 \\
\hline 2,260 & 1,505 \\
\hline 3,847 & 2,562 \\
\hline 1,525 & 1,027 \\
\hline 6,591 & 5,646 \\
\hline 1,536 & 901 \\
\hline
\end{tabular}

2 See above table. For other instances of similar reductions of tolls, see Brit. Doc. 1839 (295), Ix, 369, evidence of Mr Levy and others; also Railway Times, v (1842), pp. 18,21 .

3 Il)id.

4 In a communication from the Grand Junction Canal Company to the Board of Trade, in 1846, as to the desirability of keeping the Regent's Canal open and free from railway control, as a means of outlet for the inland canals, there are these words: "Now it is at once admitted that if this new power [i.e., locomotives and railways] can prove itself competent to under-carry canals, the Proprietors of the latter cannot reasonably expect to be shielded, either by Parliament or by Her Majesty's Government, from the ruin which has already befallen a considerable portion of our macadamized roads, with the various establishments... which are dependent thereon." This would seem to be good (because disinterested) testimony in regard to the decline of some of the best constructed roads.

5 Brit. Doc. 1839 (295), Ix, 369, evidence of Sir James Macadam. 
of the trusts was directly traceable to the railway. But we have already shown that before the iron road came into active use there were other factors which were eausing many of the trusts to be pecuniarily involved, and these, donbtless, still continued after the railway came into operation. If the railway did, along certain routes, exercise the most potent influence in cffecting an immediate dislocation of business from the road to the rail, it is evident that this transfer would leave the roads subject to less injury, and therefore they would not need so much expended upon them for maintenance and repair. It would seem, then, that if some other things had not been detrimental to the finances of the roads, the railways alone would not have brought about all the evils that were attributed to them.

Having now considered the effect of the railways in causing a decrease of the traffic and revenue of many of the turnpike trusts, we next inquire as to the reasons why the railways attained the ascendancy over the stage coaches. In the light of past experience, we to-day can see many reasons why they should have gained the pre-eminence, such as, their greater speed and comfort, greater acconmmodation and cheaper rates, to say nothing of the mental stimulus from railway travel ${ }^{1}$. But, beside these, at this early time there were some additional reasons for railway predominance whieh are not apparent to us to-day.

Railway companies had a much lighter burden of taxation than those who carried on the ordinary highways. In addition to the turnpike tolls, the chief taxes paid by regular stage coaches were:

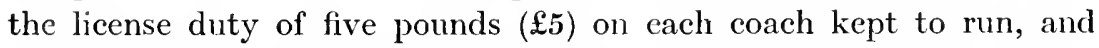
one shilling on each supplementary license; the assessed tax on coachmen and guards, which was £1. 5s. for each ${ }^{2}$; the stage coach duty, which was levied on a graduated scale according to the number of passengers which the coach would carry, but irrespective of the number of passengers actually carried or the number of horses used; and, finally, the assessed tax on all draught horses ${ }^{3}$. The license tax had to

1 See Railway Times, v (1842), pp. 639-40, 711, 973.

2 Brit. Doc. 1837 (456), $\mathrm{xx}, 291$, 'Report of Committee on 'Taxation of Internal Communication, Minutes of Evidence,' p. 3, Q. 31. Harris, The Coaching Age, p. 195, says that $\mathfrak{5}$ was assessed for every coachman and guard.

${ }^{3}$ Brit. Doc. 1837 (456), xx, 291, 'Report of Committee on Taxation of Internal Communication.' The stage coach, or passenger, duties were changed from time to time, but they were at best so burdensome that coach proprictors wanted them reduced to the minimum; and in order to accomplish this it was customary, with the approach of winter, to lessen the number for which the license was taken out at the Stamp Office. For example, a coach which was licensed to carry six inside and twelve outside during the summer when business was active might be licensed for the winter to carry only four inside and eight outside. In this way, the stage coach duty would be reduced about one penny a mile per single mile, or about thirty 
be paid whether the coach were run only a few days or for the whole year, and the same regulation was enforced concerning the assessed taxes. The stage coach rates were paid each way by the coach proprietors, the lowest amount being for a coach with a capacity of four passengers, which paid one penny per mile each way ${ }^{1}$; in other words, the lowest duty was one-fourth penny per passenger per mile. Beside the foregoing taxes, from which the railway company was exempted, the coaches had to pay a mileage duty, on the basis of the number of miles the coach travelled but without any reference to the number of passengers the coach was licensed to carry. Coach proprietors, in a few cases, bought their coaches outright; but in most instances they made an arrangement with the coach builder to pay him, for the use of the coaches that were required, a certain mileage rate, which varied from two to three pence per milc according to the contract they were able to make with the owner of the vehicles ${ }^{2}$.

On the other hand, the taxation of the railway, as an operating agent, consisted merely of a mileage duty of one-half penny per mile on every four passengers, that is, one-eighth penny per passenger per mile $^{3}$. It will be seen, therefore, that the mileage rate was the only one of the stage coach taxes that applied to railways, and it was only a small fraction of the amount charged on the coaches. But there was this further distinction to be carefully noted between the steam and the stage coaches, that while the railway was charged mileage rate

per cent., during the winter. It may be asked why a coach proprietor could not take out a license for a smaller number of passengers, paying therefore the lower duty, but carry the larger number of passengers on his coach. The answer is that penalties were heavy for the transgression of the law, and on the chief roads there were men who made their living by informing on persons who broke the law, since the informers got one-half of the penalty imposed on offenders. The number of passengers that a coach could carry had to be painted on it in a conspicuous place; and if a coach were found with more than its legal number of passengers the magistrate's fine made a considerable expense for the proprietor. See also Harris, The Coaching Age, pp. 196-8.

1 These stage coach duties, as given in the schedule to Act 2 \& 3 William IV, c. 120, were as follows:

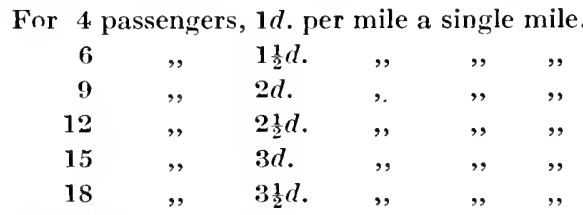

2 Harris, The Coaching Age, pp. 198-9.

3 Brit. Doc. 1837 (456), xx, 291, 'Report of Committee on Taxation of Internal Communication.' In 1842, this was changed to five per cent. of the receipts from passenger traffic. 
only on the passengers actually conveyed, the stage coaches were charged their rate on the number of passengers which the coaches were licensed to carry, whether they were full or empty. This was a detriment to the stage coaches; for if one of them was capable of carrying twelve passengers, only an average of eight passengers could be counted on; and, therefore, in paying both ways, they paid duty for twenty-four passengers, but carried and received payment for only sixteen ${ }^{1}$. Some advocated repealing the duties on stage coaches to enable them to compete with the railways, and a proposal had been made to take the tax off coaches rumning parallel with the railway, but neither of these was carried out ${ }^{2}$. This manifest unfairness could not but prove prejudicial to the proprietors of stagc coaches, many of whom expected that their business would be overwhelmed ${ }^{3}$. Some of them. however, saw clearly that, even if stage coaches were made free

1 Brit. Doc. 1837 (456), xx, 291, evidence of Mr Horne. He handed in the following computation to exemplify the difference between railway and road carriage in the matter of mileage duty alone:

Coaches to Birmingham, say 108 miles,-

If lieensed for 15 passengers, say average 10 , at $3 d$, a single mile,

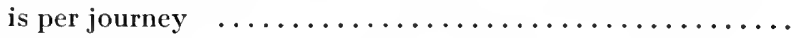

Railway at $\frac{1}{3} d$. per head, say 10 passengers, is per journey ....

Differcnce

\& s. d.

$\begin{array}{lll}1 & 7 & 0\end{array}$

\begin{tabular}{ll}
11 & 3 \\
\hline 15 & 9
\end{tabular}

The mileage duty, therefore, is $2 s .8 \frac{1}{2} d$. by coach, and $1 s .1 \frac{1}{2} d$. by railway, for each person actually carried.

Mr Horne had 3 Birmingham and 3 Liverpool and Manchester coaches.

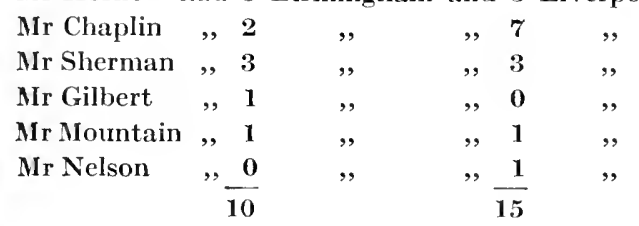

,

\& $s . d$.

On 10 Birmingham coaches, the difference between railway and coach $=\begin{array}{lll}7 & 17 & 6\end{array}$

On 15 Liverpool and Manchester eoaches, the difference between railway and coach $\ldots \ldots \ldots \ldots \ldots \ldots \ldots \ldots \ldots \ldots \ldots=2312 \quad 6$

On 6 eoaches between Liverpool, Manchester and Birmingham, the differenee between railway and coach $\ldots \ldots \ldots \ldots \ldots=4146$

Difference each way $=36 \quad 4 \quad 6$

Difference for journey $=72 \quad 9 \quad 0$

For a comparison of the mileage duties paid by stage and railway coaches, see also IIerepath's Railway Magazine, N.S., v, pp. 532-3, the figures of which are all right, but the editorial comment on them contains statements that cannot be accepted.

${ }^{2}$ IIerepath's Railway Magazine, N.S., vr, pp. 458-64; IIansard's Parliamentary Debates, xiv (1832), pp. 1300-2, statement of Lord Althorp.

3 Brit. Doe. 1837 (456), xx, 291, evidence of Mr Horne and Mr Gray.

J. T. II. 
of duty, they could not compete with the railways in the same direct line ${ }^{1}$, on account of the many other advantages which the railway had.

Another thing which tended to defeat the coaches in their competition with the railways was that the latter were frequently permitted by the Treasury to compound for their taxes at a very low and perfectly illusory rate: a privilege that was uniformly refused to the proprietors of stage coaches ${ }^{2}$. In the three years $1835-7$ the railways which were compounding for their mileage rate paid, in all, $£ 1519.10 s$., whereas the amount of mileage duty which would have been paid if no composition had been entered into would have been $25727.14 s$. 3d.; that is, they paicl about one-fourth of the statutory duty ${ }^{3}$. With such favouritism or protection to the younger and progressive means of communication it was inevitable that the railways should soon dominate in the carriage of passengers.

Enough has been said to show the effects of the introduction of railways, in particular cases, upon the previously existing means for the conveyance of passengers, and upon the roads. But it requires to be emphasized that the particular cases must not be taken as exemplifying or attempting to prove that the foregoing results were universally found to follow the construction of railways. On the other hand, we have the statements of some that the revenues of certain trusts which

1 Brit. Doc. 1837 (456), xx, 291, cvidence of Messrs Horne, Gray and Coilins.

2 Ibid., 'Report of Committee,' p. iii.

3 Brit. Doe. 1839 (517), x, 127, 'Appendix, No. 23,' pp. 406-7; also Brit. Doe. 1837 (456), xx, 291, 'Minutes of Evidence', p. 23.

This fact is more fully exemplified if we take the individual cascs of those railways which paid composition during the three years 1835-7, as follows:

\section{Railways}

Bolton and Leigh ..............

Canterbury and Whitstable ......

Hartleyburn and Brampton .......

Leicester and Swannington .......

Neweastle and Carlisle ..........

North Union (Wigan and Preston).

St Helens and Runeorn Gap .....

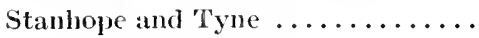

Stockton and Darlington .........

Stratford and Moreton ..........

Warrington and Newton ........

Total
Total amount of composition paid

$\begin{array}{rrr}£ & s . & d . \\ 30 & 0 & 0 \\ 51 & 0 & 0 \\ 6 & 0 & 0 \\ 60 & 0 & 0 \\ 255 & 0 & 0 \\ 360 & 0 & 0 \\ 25 & 0 & 0 \\ 2 & 10 & 0 \\ 600 & 0 & 0 \\ 20 & 0 & 0 \\ 110 & 0 & 0 \\ 1519 & 10 & 0\end{array}$

Amount of mileage duty that would have been paid, if not compounding

$\begin{array}{rrr}£ & s . & d . \\ 877 & 4 & 2 \\ 239 & 8 & 9 \\ 23 & 5 & 0 \\ 257 & 11 & 6 \\ 1294 & 3 & 7 \\ 1112 & 7 & 10 \\ 99 & 9 & 3 \\ 46 & 13 & 2 \\ 1301 & 5 & 11 \\ 51 & 13 & 8 \\ 424 & 11 & 5 \\ 5727 & 14 & 3\end{array}$


were paralleled by railways had inereased ${ }^{1}$. Whatever may have been the immediate results upon the revenues of the turnpike trusts, it is almost certain that the roads did not suffer any permanent set-back, nor did the number of coaches decrease; on the contrary, the number of licenses for coaches increased because of the necessities that accompanied the great stimulus given to travel'2.

1 Statements of Mr Pease and others before the Parliamentary Committee, as quoted in Adzantages of the Progressize Formation of Railicays, pp. 16-21; also Procecdings of the Great Western Railway Company, 'Minutes of Evidenee,' p. 49.

2 See Railiay Times, vi (1843), p. 443, giving statisties to prove these statements. 


\section{CHAPTER IX}

\section{COMPETITION OF RAILWAYS AND CANALS}

In a former chapter we have described the manner in which the carrying trade was effected on the canals; for before 1845 the canal companies themselves were not authorized to carry, but this work was done by private carriers and regularly chartered companies, who placed their own barges on the eanals and furnished the traction power, paying only the tolls demanded by each eanal company. We have also outlined the changes that were made in the organization of the carrying trade on the railways; but as it was in connexion with this that the first great railway struggle was precipitated we venture, even at the possible risk of repetition, to consider the three chief systems of railway operation with reference to the way in which goods were transported.

The system adopted by the London and Birmingham Railway Company allowed the carriers who chose to avail themselves of the terms offered by the railway company the opportunity of sending goods to any amount, the waggons and the locomotive power being provided by the railway company ${ }^{\mathbf{1}}$. The carrier collected and delivered

1 Brit. Doc. 1839 (517), x, 1, 'Second Report on Railways' pp. viii-ix; also Brit. Doc. 1840 (437), xis, 181, 'Fourth Report of Select Committee on Railway Conmunication, Minutes of Evidence,' p. 110, showing that the London and Birmingham Railway Company believed it was more advantageous to them to allow carriers to come on their line and pay the railway company tolls for the use of their road, than to be carriers themselves. The company thought that the public would also be better served, because the individual carrier who had charge of their goods would be more responsible. The railway company charged by weight only. They claimed all small parcels under 100 pounds, and transported them themselves (v. Brit. Doc. 1840 (437), xil1, 181, 'Minutes of Evidence,' p. 98). That the legislature intended to ensure the right of carriers to use the railways, upon payment of the tolls to the railway companies, is evident from the fact that every original railway Act, except that for the Liverpool and Manchester Railway, contained a clause to that effect. But since this right could not be exercised without great danger to the public, on account of the admission to the railway of steam-power that was not under the immediate control of the company, the provision was made in onc of the later Acts of the London and Birmingham Railway Company that the latter should provide the carriers with both waggons and power at a fair and reasonable charge (Railway Times, Iv, p. 366). See also Whitehead, Railway Management, 2nd ed., p. 6. 
the goods, took all risks, and paid the tolls and haulage charges, which were so regulated as to yield good profits to the railway company and a reasonable return to the carriers. This arrangement eould hardly be said to offer such competition as to secure the public against exorbitant charges, because the demand for carriage depended upon the terms and rates fixed by the company, and, consequently, the rivalry between the carriers was, in a great measure, restricted to the collection and delivery of the goods with which they were entrusted. This competition, therefore, afforded no guarantee that the service would be performed at the lowest remunerative charge. The profits of each carrier depended on the amount of his business, and this could only be maintained and increased be incessant attention to the wishes of his employers. This open system pursued by the London and Birmingham ceased when that line became merged with others in the London and North Western.

An entirely opposite system was that in force on the Liverpool and Manchester Railway. That company was required by its Aet to undertake the carriage of any goods that might be brought to its representatives for conveyance along the line; and thus private carriers were excluded from a share in the goods traffic. The company was limited as to the amount of charge which it might demand for the carriage; but, in reality, it did not charge the maximum rates specified in the Act. On the contrary, the rates were fixed with reference to the cost of water carriage between these places'.

The third system was a combination of the other two, and was found in operation on the Grand Junction Railway, from Birmingham to Manchester and Liverpool. The company could not prevent any private earrier using their line, but, at the same time, they themselves undertook the carriage of goods, and therefore competed at every point with the private carriers ${ }^{2}$. They retaincd for themselves the conveyance of all Birmingham and Lancashire goods coming from or going to London. Before admitting any earrier on their line, the railway

1 Brit. Doe. 1839 (517), x, 1, 'Second Report on Railways,' pp. viii-ix. It would seem, however, that the Liverpool and Ianchester, at a later date, found it wise to adopt a difierent plan from this which they had pursued for many years (Railvay Times, vi, p. 152). This railway company was different from any other in that it was made a carrier by its Act of incorporation. 'The Stoekton and Darlington, before that line was opened, had reeeived applieation requesting the privilege of carriage by loeomotive engine on its roadway, but had refused this; for the committee in charge, after eareful inquiries, were eonvinced that the eompany's welfare would be best served by being the prineipal earriers on its own line. Jeans, Jubilee Memorial of the Railicay System, p. 63.

2 Brit. Doe. 1839 (517), x, 1, 'Seeond Report on Railways; pp. viii-ix; also Brit. Doc. 1844 (318), xi, 17, 'Fifth Report of Select Committee on Railways,' Appendix No. 2, pp. 22-23. 
company bound him by agreement not to charge his patrons less for the carriage of goods than the rate demanded by the company for the same service ${ }^{1}$. Henee, the public could derive little or no benefit from this kind of competition. Moreover, we can readily see that when many carriers were allowed on the one line of railway. using the same track, stations, terminal facilities and other equipment, much confusion and no little strife would cnsue, not only among the carriers themselves but also between the railway company and the carriers, for the carriers were not always careful in their use of the appurtenances of the road. Then, when anything went wrong, or any injury was done, it was almost impossible for the company to know who had been the cause of the trouble. Besides, the safety and the convenience of passengers were endangered by the presence of so many rivals on the line. The jealousies and complaints that arose from such a confusion of interests on the same line had shown the railway company, as early as 1840 , the necessity of excluding private carriers altogether, and undertaking all the carrying trade themselves ${ }^{2}$.

The decision arrived at by the Grand Junction Railway Company was being reached by other railway companies also, as the only solution for the ills of the existing situation in regard to the goods traffic on railways ${ }^{3}$. In support of the contention that the railway companies should be the only carriers on their lines, it was urged that, as it was ncecssary for them to perform so much of the carriage as was equivalent

1 See Brit. Doc. 1840 (485), xin, 181, 'Minutes of Evidence,' pp. 88-89, for "Copy of an Agreement between the Grand Junetion Railway Company and Messrs Robins \& Co. (earriers) of Liverpool." The Grand Junetion Railway Company charged by the pareels, and these could not be boxed together by putting small ones inside of large ones (ibid., p. 98).

The Bolton and Leigh Railway, communicating with the Liverpool and Manehester, was let to a single carrier. The North Union Railway (from Wigan to Preston) professed to follow the example of the London and Birmingham, but up to 1839 only one earrier bad established himself upon the line, and as he was the lessee of the Bolton and Leigh it was thought that his wealth and influenee might exelude all other eompetition from these two lines. The Neweastle and Carlisle Railway Company was the only carrier on its line. The Stockton and Darlington was the prineipal carrier on this line; although there were also other parties, using horse-power, who were engaged in earrying goods. The Leeds and Selby Company was the sole carrier on that line. Brit. Doc. 1839 (517), x, 1, 'Seeond Report of' Committee on Railways.'

2 Brit. Doc. 1840 (299), xn1, 167, 'Third Report of Seleet Committee on Railway Communieation.' See also Railway and Canal Cases, 1, p. 592 et seq., Pickford et al. ws. The Grand Junetion Railway Company. This ease is fully discussed in Appendix 14.

3 Railzay and Canal Cases, 111, p. 563 et seq., Parker ws. Great Western Railway Company (1844), shows that this railway company was following the Grand Junction in trying to exclude the earriers from their line. 
to at least eighty per cent. of the whole cost, namely, the transport of the goods along the railway, the conditions were not such as to enable the public to benefit by the competition of private carriers, and the companies could perform the remaining twenty per cent. of the work more economically. Then, by the companies taking the carrying trade completely into their own hands, the shippers served by each line wonkl be assured the advantage of uniformity of charge. Finally, it was said that, in order to bring railway conveyance fairly into competition with the old canal monopoly that existed in many cases, it was essential that the railway companies should become carriers, since the great private carrying firms were generally interested in continuing the canal ${ }^{1}$.

On the other hand, it was asserted that it was neither so economical nor so convenicnt for the public that the railway company should step out of its legitimate sphere, by becoming collectors and distributors of goods; and that the competition of the private carriers, though confined to twenty per cent. of the total charge, was sure to reduce this portion of it to a minimum, and hence was worthy of a place in the public economy. Moreover, if the railway companies should become carriers, and the private carriers should be driven off the rails, the railways would then be in a position to combine with the canals and force the public to pay monopoly prices ${ }^{2}$.

1 Brit. Doc. 1844 (318), xi, 17, 'Fifth Report of Select Committee on Railways,' Appendix No. 2, also 'Minutes of Evidenee,' Q. 3938-6. Ibid., p. 290 et ser., gives much diseussion as to whether it was best to have private carriers on the railway lines or to have the railways act as carriers on their own lines.

The last argument, of course, has no weight. The railway could compete with the canal, by its having passenger traffic to add to its income, while the canal had none; so that, in order to meet the canal monopoly, it was not necessary to drive the private carriers off the railway.

2 Brit. Doc. 184t (31S), xi, 17, 'Fifth Report of Select Committee on Railways,' also 'Minutes of Evidence,' p. 290 et seq.

In the Raikeay Times, $\mathrm{F}, \mathrm{p} .366$, the editor of that journal in discussing the pamphlet of Henry Booth on the "Carrying Question," shows that Booth's arguments against admitting private carriers on the railway, though applicable to the Liverpool and Manchester Railway, did not bear upon the general question as it related to the vast and complicated interests over the whole kingdom. Then, when he had thus dismissed the consileration of that pamphlet, he reiterated his own views; and after showing that the carriers had a legal right to the use of the railways on payment of the tolls, he went on to exemplify low it was to the advantage of all parties that such competition should be encouraged. In addition to the reasons here suggested in the text, the editor says that the private carriers woulc compete also in the matter of attention and civility to the public, which was scarcely less important than the eeonomy of charges; whereas the railway companies as carrieus would show but slight moral responsibility. 'The carriers laad also well-established eollecting and distributing fucilities in all the important towns and cities, and were therefore prepared to look after the goods trallic at all places remote from the 
There certainly was a good deal of weight in some of the arguments advanced on each side. The effect of railway companies becoming carriers was undoubtedly, in many cases, beneficial, and led to a material reduction of the existing charges ${ }^{1}$; and, under certain circumstances, it might be as convenient for the public to employ the railway companies as carriers. This would be the case where the railway had a station at the point of destination of the shipment; for example, if a merchant in London were sending goods to Birmingham it would be just as convenient to have the railway take them there as to send them by a carrier on the canal, for as soon as they were unloaded at that railway station the Birmingham merchant would have no trouble in getting his goods. But, in regard to much of the traffic of the country, it would ccrtainly be felt as an inconvenience to be obliged to employ a railway company as the sole carrier. For example, if goods were to be sent from London to some place near Birmingham, and they were given into the hands of a private carrier in London, they would be taken by him or his agent from the station at Birmingham, when they had reached there, and delivered to the consignee; but, if the railway company were the only carrier, the freight would be left at Birmingham until removed by the consignee. To cite the instance of Coventry: if goods were sent by private carrier from London to Coventry, they would, if suitable, be taken by him on the railway to Birmingham (there being no station at Coventry), and then carted back by the carrier for the seventeen miles to Coventry and there delivered at the consignee's door. Eren this method of getting the goods to Coventry did not eost as much as to take them from London to Coventry by canal. But if the shipment were given to the railway company as the carrier it would be taken to Birmingham and left there to await the coming of the consignee or his agent who would ship the goods baek to Coventry by road or by canal as seemed most

railway termini. He regarded it as in the interest of the railways as well as the public to continue the earriers on their lines. For further discussion of the carrying question, sec Appendix 14.

1 Brit. Doc. 1840 (299), xur. 167, 'Third Report of Selcet Committee on Railways,' under heading II, "Carriage of Cattle and Goods by Railways."

Note what we have formerly said regarding the effect of the Liverpool and Manchester Railway in reducing the charges made by navigations between these places. Also Brit. Doc. 1840 (4:7), xi1, 181, 'Fourth Report on Railways, Minutes of Evidence,' pp. 82, 110 et seq.; and Brit. Doc. 181.1(318), xI, 17, 'Minutes of Evidence; p. 76 et seq., where we learn that when the Leeds and Selby Railway Company opened their line and did their carrying the rates on the Aire and Calder Navigation were very matcrially redueed. See also ibid., 'Minutes of Evidence.' p. 527 et seq. 
desirable ${ }^{1}$. The earriers who used both railway and canal conveniences carried the more valuable articles on the railway, and the eheaper freight, i.e., the more bulky and heavy commodities, by the canals, for the latter class generally did not require rapid transport. The private earriers who did nothing else than that work, and who had wellestablished facilities for the economical collection and distribution of traffic, assertcd that it was not possible for the railway company to perform these services as acceptably and cheaply as themselves: but, of course, the railway company could develop just as good facilities if it were thought best to put the performance of these duties in their hands. There was another advantage in employing private carriers, in that they were responsible for the goods from the time they left the consignor until they reached the consignee; but the raihway assumed no such responsibility ${ }^{2}$.

As we have seen, it was the intention of Parliament that railways should be on the same footing as canals and that railway proprictors should have similar rights to those of canal proprietors, that is, receiving tolls, but not carrying at all ${ }^{3}$. When this matter was under public discussion many of the earriers said that the only thing to do was to carry out the intention of Parliament and prescrve competition by excluding the railway companies from carrying on their own lines. Others were in favour of suppressing the private carricrs and giving all the work into the hands of the railways. ${ }^{4}$ Out of the mass of

${ }^{1}$ Brit. Doc. 1840 (437), xIII, 181, 'Fourth Report on Railways,' cvidence of Messrs Tibbits, Derham and Harnett (p. 24). The London and Birmingham Railway carried only through traffic.

2 Brit. Doe. 1844 (318), XI, 17, 'Fifth Report on Railways, Minutes of Evidence, Q. 3941. The personal relations of the private earriers with their patrons were a valued element in the conduet of business. Carriers allowed their customers from three to six months' eredit; and permitted them to warehouse their goods, withont charge, till they could conveniently send them to their destination. If any inconvenienee were suffered and a complaint made to the earrier, the latter was always amenable and an answer was obtained. Even though this redress was sometimes tardy and not entirely satisfactory to the shipper, it was better than to be treated with indifference. On the eontrary, it seens to have been the policy of the railways to be more overbearing. They required monthly settlements of bills. They did not allow goods to be left in their warehouses without the payment of storage charges. When complaints were made, the responsible railway official was so far removed from the complainant, and the company was so unresponsive, that unless the complainant had enough influence to enforee attention to his claim he could not deprend upon reeeiving justice. Boyle, IIope for the Camals, pp. 17-18.

${ }^{3}$ Brit. Doc. 1840 (299), xil, 167, 'Third Report of Select Committee on Railways;' also Brit. Doc.1840 (47.1), xin, 189, 'Fifth Report on Railways, Minutes of Fidenee, p. 40, Q. 959 ; ete.

4 On this whole question, see Brit. Doe. 1840 (299), xır, 16r, 'Report and Evidence,' which deals very fully with it; also Brit. Doe. 1814 (318). x1, 17, 'Minutes of Evidence,' p. 106 et seq. Sce also Appendix 14. 
conflicting testimony, the Parliamentary Committec of 1839 came to the conclusion that the intention of the Legislature in this respect could not be carried into effect in the way contemplated; for it was obvious that the payment of legal tolls was only a sery small part of the arrangements that were necessary to open railroads to public competition, and the rest of the arrangements were wholly disadvantageous to the private carriers on the line. They decided that, upon grounds of safety and economy, there should be upon every railway one system of management, under one superintending authority, which should have the power of making and enforeing all regulations necessary to the proper conduct and maintenance of the traffic. Because of this, it was essential that the railway company should possess a complete control over their line of road, even though they should thereby acquire an entire monopoly of the means of conveyanee.

We have entered thus fully into this subject because it is one of the pirotal points in the competition of railways and canals, and because it is interesting to see how early, after the introduction of railways, it was recognized and settled that they wcre unlike most other enterprises in being essentially monopolistic. Later reports from parliamentary and other public bodies reiterated and emplasized this charaeteristic feature, and also the need for some general supervision and control so that the public might derive the $u$ tmost benefit from this natural monopoly ${ }^{2}$; but into this latter phase, that of railway control, it is not our purpose to enter.

By what means did this monopoly power actually realize its monopoly, or, in other words, how did it drive the private carriers off the railway? In many cases the railway company gave no better terms to the carriers than to the occasional shipper, and so the carrying

1 Brit. Doc. 1839 (51 ) , x, 1, 'Second Report of Select Committee on Railways,' pp. vi-rii, xiii.

Another factor which contributed to the taking over of the carrying trade by the railway eompany was the sistematic efforts of the earriers to secure advantage over the railway company by making false declarations as to the weights and descriptions of the goods that they loaded for carriage on the company's waggons. The London and North Western had to appoint a detective to see that their interests with reference to this were protected. In $181 \%$, the next year after that company was formed, the system of toll carrying was abolished, and the raikwa company gradually becan to carry directly for the public (v. Stevensen, Fifty Years on the London and North Western Railaay, p. 17 et seq.). On this subject. see also Railica! Times, 1v. pp. 208-9, the affidavit of John Moss, and ibid.. vir, p. 21\%, on "Railway Companies and Railway Carricrs." Refer also to Appendix 14.

2 See, for instance, Brit. Doc. 1840 (299), xill, 167; ibid. 1844 (166), xi, 5; ibid. 1845 (279), xxxix, 153 ; ibid. 1846 (200), xill, 85. 
trade became unremunerative ${ }^{1}$. For cxample, the company charged the carriers for the mere transport of a certain weight of goods over the line, independently of the collection and distribution of these goods, the same rates as were charged the public for the carriage and the additional services of collection and distribution ${ }^{2}$. This was sometimes put into effect against all the carriers on the line at once, and in other cases the earriers, one at a time, were compelled to suspend operations on account of the imposition of these practically prohibitive rates. Sometimes lower rates were quoted to some carriers than to others ${ }^{3}$, and in at least one ease the railway company absolutely refused the use of its carriages to a eertain carricr. It appeared that the company had made arrangements to carry goods for another firm of carriers only, by which that firm obtained a monopoly of the conveyance of goods along that line of road ${ }^{4}$. A few ycars later, when this railway eompany allied its interests with others in the formation of the London and North Western, the latter company adopted the policy of being themselves the exclusive carriers on their line; but they retained an arrangement with Chaplin and Horne, who were probably the largest carriers into and out of London, to collect and distribute in London the goods going from and coming to that city by this railway ${ }^{5}$. During the tentative stages of

1 Brit. Doc. 1840 (437), xul, 181, 'Fourth Report on Railways, Minutes of Evidence,' p. 37, Q.918. 'This was done by the Grand Junction Railway Company, which was engaged in carrying on the London and Birmingham Railway, as well as on their own, and on the Liverpool and Manchester Railway.

${ }^{2}$ Brit. Doc. 1844 (318), xi, 17, 'Fifth Report of Select Committee on Railways, Minutes of Evidence,' pp. 138-9. Also Brit. Doc. 1852-3 (170), xxxvil, 5, 'Second Report on Railway and Canal Bills, Minutes of Evidence,' pp. 35-38, shows the means by which Kenworthy \& Co., carriers, were driven off the canals and railways by the railway companies that got control of these canals.

3 Brit. Doc. 1844 (318), xi, 17, 'Fifth Report on Railways, Minutes of Evidence,' pp. 384 ff.; ibid. 1852-3 (170), xxxv111, 5, 'Second Report of Select Committee on Railway and Canal Bills, Minutes of Evidence' of Mr Pixton.

4 Willmore, Wollaston and Hodges, Reports of Cases argued and determined in the Court of Queen's Bench, and upon Writs of Error from that Court to the Exchequer Chamber, and in the Bail Court, I, pp. 578 ff., ex parte Robins and others. Messrs Robins, general carriers, made application in 1838 for a mandanus to compel the London and Birmingham Railway Company to carry the goods of the applicants; but the Court decided that, under the Act of incorporation, the company could not be compelled to carry all goods sent for conveyance and the application was refused.

5 Parl. Papers, 1857-8 (0.77). xv, 11, 'Minutes of Evidence taken before the Select Committee on the Manchester, Shefficld and Lincolnshire, and Great Northern Railway Companies Bill,' Q. 4683-4, 4901-16. Chaplin and Horne would not state exactly what their relation was with the London and North Western Railway. They had also close business relations with the London and South Western. and finally invested a considerable sum in that railway. Fay, A Royal Road, p. 28. It would 
the development of the carrying trade, sometimes the railway company bought out the business of respectable carriers by payments that were much in excess of the real value; but even after the purchase was made some railways did not exclusively collect goods for themselves, but gave discounts and allowances for the collection and delivery of goods to and from the stations, and allowed a certain percentage for loading, unloading and invoicing, until it was discovered that frauds were being practised which tended to destroy the company's own carrying trade ${ }^{1}$. Under these conditions the tendency was for the company to eliminate the carriers entirely. But amid the variety of causes tending to take traffic from the carriers and give it to the railways was the growing conviction among the commercial classes that, because the railway company did not have to pay tolls on its own line, and the cost of locomotive power to it would be no greater than if furnished to a private carrier, therefore the railway company could do the earrying cheaper than any private carrier; and if either were to be stopped they would prefer to sec the company left as carrier ${ }^{2}$. The railway company had so many advantages over any other carrier fulfilling this office along their line, that gradually it beeame the universal practice for them to do all this work, including the eollection and distribution of the goods at their startingpoint and destination ${ }^{3}$.

It must not be concluded from what we have said that railway companies (execpt as regards passengers) superseded the old carriers at

seem that Chaplin and Horne were retained for this service on condition that they would cease carrying on the canals. Boyle, Ilope for the Canals, p. 5. See also Whitehead, Railway Management, p. $\%$.

I Nash, Railway Carrying and Carriers' Law, p. 75 ; also Railway Times, iv, pp. 208-9, and ibid., v11, p. $21 \%$.

2 Brit. Doc. 184. (318), xi, 17, 'Minutes of Evidence,' p. $52 \%$ et seq.; also Brit. Mus. S235. b. 5 \% (1), 'The Carriers' Case considered,' pp. 8-9. This was especially the case with the Grand Junction Railway Company, whose highest rate for the lightest articles of merchandise, up to April 184.4, had been 5s. a cwt., but after that was 4s. a cwt., from London to Liverpool. Other carricrs charged up to $6 s$. and 7s. a cwt. Note the two examples given in footnote 3. p. 631. See also Brit. Doc. 1840 (43\%), xm, 181, 'Fourtl Report on Railways, Minutes of Evidence,' p. 37.

This conviction, however, was long in being established, and we find strong opposition. up to the middle of the century, against the oppressive and unjust conduct of the railway companies toward the carriers. Pctitions were sent in by large and influential bodies of traders against the monopolistic policy of the railways to defeat fair competition. See Iterpath's Railicay and Commereial Journal, xi, pp. 585, 599. Also Appendix 14.

3 In all probability it is bccause the railways at this early time took over all the work of the carriers that to-day the English railways, unlike those of the United States and some other countries, do the collecting and distributing of the goods carried on their lines. Because of this, there is no need for such secondary concerns as Express Companies which we find in the Unitcd States. 
once. Few of the earriers tried the experiment of running their own trains along the railway, and these few, for reasons already giren, were forced to give up; but for some years a considerable part of the earrying business remained in the hands of the old firms ${ }^{1}$, who continued to collect goods from the public and to arrange for their safe delivery, employing: the railway companies, which would give them aecess, to convey them along their lines. On certain railways, as we have already shown, this practice prevailed for some years exclusively; on others, from the first, the companies seem to have undertaken the business of general earricrs for the public, as well as convcying for the carricrs².

Now that we have considered the organization of the carrying trade on the eanals and on the railways, we are able to appreciate more fully the effects of the competition which oceurred between these two rivals. In an earlier chapter of this work it was shown that before the introduction of the railways many canals had put up their rates, until, with their monopoly, some of them were making enormous profits. This fact is attested by the high market value of some shares, and by the large dividends obtained by the shareholders of certain canals ${ }^{3}$. In some cases, as soon as a railway was threatened and action taken toward that end, the adjacent canal, which had been deaf to all complaints, found it desirable to reduee its tonnage rates and to think

1 Pickford, Parker, Robins, Chaplin and Horne, etc. See the advertisement of Chaplin and Horne in Railway Times, vil (1844), p. 14.47, showing that they forwarded goods by the various railways, "on their own account or as Agents of the Companies." Then they mentioned the different railway lines they used and the places in England to which they shipped.

2 Brit. Doc. 1840 (299), xim, 167, 'Third Report on Railways,' p. 3 ; ibid. 1844 (318), xI, 17, 'Fifth Report on Railways,' Appendix No. 2, p. 22; ibid. 1881 (374), xiII, 1, 'Report of Select Committee on Railway Rates and Fares, Minutes of Evidence,' p. 573.

3 These large profits are reflected in the prices of some of the canal companies' shares; for example, the Staffordshire and Worcestershire Canal shares (of the par value of $£ 100$ ) sold in 1810 for $£ 735-50$, and in 1829 for $£ 810$; the Grand Junction Canal shares sold in 1810 for $£ 260-86$, in 1825 for $£ 330$, and in 1828 for $£ 315$; the Trent and Mersey shares sold in June 1825 for $\$ 2150$, in June 1828 for $£ 3280$, and in June 1829 for $\$ 3160$. See the quotations of the share market in the Gentleman's Magazine for these various dates.

The rates of dividend paid are also a good indication of the profits reaped by somc canals. In addition to those we have formerly noted, we may mention that in 1833 :

The annual dividend of the Coventry Canal was $\ldots \ldots \ldots \ldots .32 \%$

\begin{tabular}{|c|c|c|}
\hline & $"$ & Oxford Canal was \\
\hline &, & Stafford and Worcester Canal was . \\
\hline & ", & Trent and Mersey Canal was ..... \\
\hline & ," & Erewash Canal was ............ \\
\hline & , & Loughborough Canal was......... \\
\hline
\end{tabular}

(v. Martin, Railways-Past, Present, and Prospective, p. 27.) 
of the necessity of making improvements in its waterway in order to maintain the traffic ${ }^{1}$. But when a railway was actually constructed the first effect was to cause a reduction in the freight rates that had been in existence on the more or less parallel canals; and this cut in rates was almost immediate, for when the railway put a low rate into force the canals had to meet it or lose the traffic. With this diminution of freight rate, and the accompanying decrease of traffic due to a portion of the traffic being turned to the rails, it was inevitable that the railway should cause a decline in the revenues of the canals ${ }^{2}$. The amount of

1 Blewitt, New Monmouthshire Railway, pp. 11-15.

2 Teisserenc, Voies de communication, pp. 571-4, shows that, on aceount of the railway compctition, the revenue of the Wilts and Berks Canal was reduced from $482,500 \mathrm{fr}$. in 1839 to $212,500 \mathrm{fr}$. in 1843 , and the revenue of the Kennet and Avon Canal luring the same period deelined from $1,150,000 \mathrm{fr}$. to $800,000 \mathrm{fr}$. The opening of the London and Birmingham Railway in 1837-8 eaused a reduetion of the revenues of the Grand Junetion Canal from 4,957,500 fr. in 1838 to 2,700,000 fr. in 1844, and a eorresponding reduetion in the case of the Coventry Canal. The effeet of railway eompetition between Nanehester and Leeds is seen by the fact that the gross revenue of the Rochdale Canal from bulky eommodities declined from $1,473,250 \mathrm{fr}$. in 1840 , when the railway was opened, to $680.000 \mathrm{fr}$. in 1841 and 435,000 fr. in 184.4. These statisties are eorroborated by those given in the Appendix to a statement issued on behalf of the Grand Canal Co. of Ireland, as printed in The Times, July 20, 1844, p. 6.

On the route from Manchester to Hull, 99 miles by canal, the rates per ton before and after the opening of the railway (1840) were as follows:

\begin{tabular}{lcccccc} 
& \multicolumn{3}{c}{ Before } & \multicolumn{3}{c}{ After } \\
For corn, flour, ete...... & $£ 1$ & $4 s$. & $0 d$. & $£ 0$ & $13 s$. & $0 d$. \\
For cotton twist ....... & 1 & 12 & 6 & 1 & 0 & 0 \\
For manufactured goods & 2 & 5 & 0 & 1 & 4 & 0
\end{tabular}

Brit. Doe. 1845 (61), xxx1x, 293, p. 13. Beeause of railway competition, the Calder and Hebble Navigation, which was part of the through water-route betwcen Manchester and IIull, reduced their dividend from $18 \%$ in 1848 to $8 \%$ in 1849 . Herepath's Raitway and Commereial Journal, xi (1849), p. 1241.

The effeet of the opening of the Great Western Railway was also to reduee the eharges of carriage on the Thanes, as follows:

\begin{tabular}{|c|c|c|c|}
\hline \multirow{3}{*}{ London-Windsor. } & Date & Cost by water & Cost by railway \\
\hline & $\int 1829$ & $9 s$. per ton & - \\
\hline & 1846 & 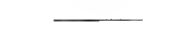 & $5 \frac{1}{2}-6 s$. perton \\
\hline \multirow{2}{*}{ London--Reading } & f1829 & 15s. perton & - \\
\hline & 11846 & & $7-8 s$. per ton \\
\hline London-Oxford & $\left\{\begin{array}{l}1829 \\
1846\end{array}\right.$ & £1. $2 s$. per ton & $10-121 \mathrm{~s}$. per ton \\
\hline
\end{tabular}

As soon as the I.iverpool and Manehester Railway was opened, the former insolence of the navigations eonneeting these two cities was inmediately abandoned, and under competition their rates had to be cut down. The rate on light goods earried on the canal was 15s. per ton; the railway redueed this to 10s. Ammual Register, 1832, p. 445. Sce also Boyle, Hope for the Canals, pp. 5-6; Shaen, Revierv of Railways and Railway Legislation, pp. 33-34. 
the reduction of the charge depended, of course, partly upon the conditions which prevailed before the railway came in; for if the canals had been charging unduly high rates the deerease was the greater, but if they had been contented with ample but not exorbitant profits the cut made in their rates was not so excessive. From these cireumstances it will be seen that it is wholly impossible to make any explicit general statement that will be a close approximation to the truth; but from material collected elsewhere in this volume, we may say that, putting it at the minimum, the reduetion in the rates was from one-third to one-half of the rates previously in effeet on the navigations. ${ }^{1}$. On those waterways which were adjacent to the railways the reduction wotld, of course, be greater than on those more remote. On the basis of the diminution of the freight rates alone, however, we would not get an adequate conception of the influenee of the railways; we must take into account also the entire change in the method of conducting business as a result of the more speedy conveyance. Orders given a long time in advance became more rare; retailers kept smaller stocks of goods; less capital was, therefore, tied up in unproductive forms; and, taking all things into consideration, there was probably a saving of at least seventy-five or eighty per cent. in the conduct of business.

The decreased revenues of the canals were reflected in the lower market values of some of the canal shares which had previously brought high prices; and the prices which ruled on the Exchange will be a corrective, if necessary, of the above-mentioned conclusion. For example, before the opening of the London and Birmingham Railway, the shares of the Grand Junction Canal were selling in 1833 for $£ 250$ and two or three years later for $£ 303$ to $£ 330$; but after the railway was in operation the shares of this canal fell to $£ 155$ in 1844 , to $£ 100$ in 1846 , and to $£ 60$ to $£ 70$ in $1853^{2}$. These were on the par value of $£ 100$. By 1844 the shares of the Warwick and Birmingham Canal had fallen from $£ 330$ to $£ 180$, the shares of the Worcester and Birningham from

1 In Appendix 10 there have been brought together some tables which will illustrate the reduction of rates that was brought about by competition, and for detailed information the material there collated may for the present suflice. In making the general statement that railway competition caused a reduction of at least one-third to one-half of the previous navigation rates, we have cndeavoured to keep well within the limits of aecuraey, as revealed by the statistics given in Appendix 10. This eonchusion is authentieated by the statement of a writer in the Railway Times, vil (1844), p. 21\%, who said that railways had eaused a reduction of over $50 \%$ in the east of carriage of goods, and also by Teisscrenc, op. cit., pp. 34$38,571-4$.

2 'Teisserene, op. eit., pl. 34-35; Brit. Doe. 1852-3 (246), xxxvm, 175, 'Third Report on Railway and Canal Bills, Minutes of Evidenee,' p. 14. 


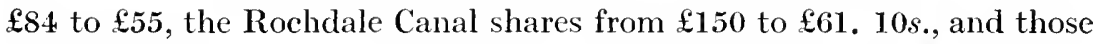
of the Kennet and Avon Canal from $£ 25$ to $£ 9$ per share ${ }^{1}$. We seem to be standing on firm ground, therefore, in saying that the revenues of canals which were paralle! with railways were reduced from one-third to one-half. In some instances we see still greater changes; for instance, Coventry Canal shares, which at one time were as high as $£ 1200$, fell as low as $£ 315^{2}$; and the shares of the Loughborough Canal, which before the opening of the railway sold as high as $£ 4300$ or $£ 4400$ each, had fallen to $£ 1200$ to $£ 1500$ in 1838 , and to $£ 180$ to $£ 200$ in $1872^{3}$.

Usually, however, when competition between a railway and a chain of canals had gone on for a little time, so that the profits of each had been considerably decreased by the reduction in the charges for conveyance, the competing concerns made a working agreement, which put an end to the competitive efforts of the canals. In all cases, the railway company was the aggressive rival of the canals. Sometimes these agreements were made secretly: at other times they were initiated in secret but afterwards ratified by Parliament; and there were other instances where they were entered into at first by consent of Parliament. The nature of these arrangements varied in different eases; some were really pooling agreements, others were simply a tacit understanding in regard to rates, while many forms of leasing the canal tolls to the railway were also found ${ }^{4}$. These working agreements were first formed in

1 The Times, July 20, 1844, p. 6. It would appear that the Rochdale Canal shares had been as high as five hundred guineas (£525). Brit. Doc. 1844 (318), xx, 17, 'Minutes of Evidence,' p. 488.

2 The Times, July 20, 1844, p. 6.

${ }^{3}$ Brit. Doe. 1872 (364), xil , 1, 'Report of Committee on Railway Amalgamations, Minutes of Evidence' of Mr Allport, Q. 4348, and A Few General Observations on Railways, p. 20. See also Brit. Doc. 1844 (318), xi, 17, 'Fifth Report on Railways, Minutes of Evidence, p. 76 .

4 As examples of these early working agreements, we give the following:

The Manchester and Leeds Railway had for a long time been competing with the Calder and Hebble Navigation, both charging very low rates; then they made an agrcement that the rates should be raised to a certain point, in consideration of which the railway company was to guarantee that the canal company's traffic should amount to a certain sum, and any cxcess beyond that sum was to be shared between them, the railway company having the right of putting inspectors on the canal to watch that the traffic that they had thus guaranteed was fairly conducted. This was done by consent of Parliament. Brit. Doc. 1844 (318), x1, 17, 'Fifth Report on Railways, Minutes of Evidence,' p. 140.

After the joining of Ianchester and Leeds by railway, the canal route along this course came into conflict with a powerful rival. The railway company, however, had a difficulty to meet, in that they did not know what the canal charged. They said they charged certain rates, but they used to let 50 tons go as 30 tons. By the competition, the revenue of the canal was reduced from $\$ 70,000$ to about $\$ 28,000$ a year; and this induced the canal company to come to terms. In order to put a 
the last years of the decade 1830-40, but they became much more numerous in the fifth decarle, during and after the railway mania. Sometimes the entire length of a canal, or some important link in it, was leased to, or purchased by, or otherwise amalgamated with the railway which was its strong competitor. In some cases arrangements were made for the conversion of canals into railways; and the initiative for this sometimes came from the side of the railway and sometimes from the canal company. In certain instances the canal companies, in their opposition to railways, and with the concurrence of their engineers, promoted Bills to convert their canals into railways, or to construct lines of railway parallel to or in connexion with their waterways. But as it was to the advantage of the railways to bring all conveyance under their control, they considered it necessary to prevent canal companies from obtaining powers to make railways. On the other hand, the canal companies probably exaggerated the power of the railways to destroy their profits, and opposed the railways in order to get the latter to come to some favourable terms for the protection of the canal shareholders. At times a company organized to construct a railway found a canal which followed the direction of the line they had projected, and negotiated for the acquisition of it, in order to be able to utilize its channel, lands and other equipment to save money and economize time ${ }^{1}$. In most cases, however, it was the canal

stop to such gross frauds and misrepresentation in regard to weights and rates, the Manchester and Leeds Railway Company, the Rochdale Canal Company, and the Calder and Hebble Navigation Company agreed that they should be fully informed of each other's rates, that these should not be changed without conference among themselves, and that the collection of dues should be more strictly attended to. Brit. Doc. 1844 (318), x1, 17, 'Ninutes of Evidence', p. 488.

In 1846, the London and North Western Railway Company made an agreement with the Birmingham Canal Company, eonsequent upon the following conditions: The Birmingham Canal Company were not only the owners of an important canal, but also of a good deal of adjacent land; and they were proposing to make a railway of their own very much in the course of the Stour Valley branch of the London and North Western Railway. That led to negotiations between the two concerns, and afterwards it was felt that if a railway were to be made and if the eanal company were not to make it, but an independent company were to make it, the canal conpany ought to be guaranteed from loss. This guarantec was dated 1846, and assured four per cent. to the eanal company if the canal did not earn that much. Brit. Doe. 1883 (252), xi11, 1, 'Minutes of Evidence' of Mr Evans, Q. 1493.

The North Staffordshire Railway, in applying for their Act, proposed to amalgamate with the Trent and Nersey Navigation. The railway company was to guarantee a certain percentage on the capital of the canal, on condition of their giving up the management of the canal to the railway company. Brit. Doc. 1846 (275), xn1, 93, 'Ninutes of Evidence,' p. $5 \pi$.

1 On the whole subject of the eonversion of canals into railways, see Teisserenc, Voies de communication, pp. 29-30, 477-86. He gives examples of canal companies

J T. II. 
companies, apparently, which were eager to have the railways take them over, either by purchase or by some form of working agreement.

By 1845 some of the possible evils of allowing railways to acquire too much control over canals had become evident: the railways had grown to be the predominant party in the contest, completely overshadowing most of the canals; and it was thought advisable that Parliament should give some eneouragement to eanals, as the weaker party in the competition. An Act was passed ${ }^{1}$, therefore, in that year, giving to canals a similar power to that possessed by railway companies, of varying their tolls or of leasing their tolls to eaeh other ${ }^{2}$. By having this privilege canal companies might be enabled to work together and quote through rates on the long lines of canals -rates that would be less than the aggregate of the rates eharged by each canal individually; or, one canal might take over the management of several adjoining canals, and, by reducing the rates of toll, make competition with the railways possible. This Aet was passed for the purpose of obtaining "greater competition for the public advantage"." In the Act passed in the same session to enable canal companies to become carriers of goods upon their canals, and to make working arrangements with, and to lease their canals to, other canal companics, we see the same object kept in view, namely, to place the canals more nearly on an equality with the railways, so as to permit even-handed competition 4 .

which were thinking of transforming their works into railways, and of railway companies that were plamning to take over and utilize the equipment of eanals. He shows that when the canal companies turned to the best cngineers for guidance the advice given was usually favourable to the alteration of the canals into railways. Sec also the examples given in Leed's Intelligencer, Nov. 25, 1830, p. 3 ; ibid., July 15, 1830, p. 4, and Oct. 7, 1830, p. 3: ibid., Oct. 21, 1830, p. 3, letter from "A Constant Reader," and note by editor; ibid., Nov. 4, 1830, 1. 3 ; Railivay Chronicle, Aug. 30, 1845, p. 1115, editorial; ibid., Aug. 2, 1845, pp. 981-2, on 'Railway and Canal Amalgamation;' The Economist, 1845, pp. 985, 994, 1015, and 1081. Sometimes canal proprictors were induced to convert their canals into railways because of lack of water to operate the canals. Sutclifle, Treatise on Canals, p. 73. For other examples of railway companies beconing owners of canals, and for two instances of canals that were controlled, but not absolutely owned by railways, see Report of Royal Commission on Canals and Waterways, vin (1909), pए. 9-11.

1 Act $8 \& 9$ Vict., e. 14.

2 By the Railway Clauses Consolidation Act of 1845, railways were allowed to vary their rates, so as to work together with other railways in hamonious agreement, especially as to through rates.

3 Brit. Doc. 1852-3 ( 736$)$, xxxvm, 447, 'Fifth Report of Committce on Railway and Canal Bills, Minutes of Evidence, p. 69 . Act 8 \& 9 Vict., c. 14.

4 Act 8 \& 9 Vict., c. 42 . In 1840 a Bill had been introduced into the House for this same purpose, of allowing canal companies to be carriers and to make traffic arrangements with other canal companies. Brit. Doc. 1840 (405), 1, 237.

Canal companies were not commonly carriers before this time, although a few 
How was this new legislation received by the railways? It was not long before the railway companies saw that the aim of the Canal Carricrs' Act was to keep them from securing monopoly, by allowing the canals to collaborate and thus obtain harmonious action in the contest against their rival. But acute minds soon recognized also that this Act gave power to railway companies that had become owners of canals to obtain a control over other canals, without coming under the notice of Parliament; and under such a plan no opportunity would be afforded to Parliament of taking the course usually taken when sanctioning arrangements between railway companies, of investigating the terms of the proposed arrangement before confirming it, or of subjecting it to the approval of the Board of Trade. If a railway company could obtain a controlling interest in a canal it would then be entitled to rank as a canal or navigation company, and claim the privileges of traffic arrangements that were allowed by this Act ${ }^{1}$. Accordingly, railways set to work to secure this standing, and thus make the statute that was intended for the benefit of their rivals, contribute to their own advancement. Having become in effect canal companies, through acquiring control over navigations, the railway companies were then

had been carriers for some time. The Bridgewater Trustees had been carriers on their canal, but, of course, it had been eonstrueted and operated under the control of a privatc individual. The Trent and Mersey Canal Company had also been carrying for the public on their line. Other canal companies had been engaged in this earrying trade, but not under their own names. Even where the work was done by the canal company there were always other carriers who were doing the same work, upon payment of the tolls; and on the Bridgewater Canal a small part of the traffie was carried by the Trustees, while the larger part was taken by other carriers. Brit. Doe. 1814 (318), xr, 17, 'Fifth Report on Railways, Minutes of Evidence,' p. 169 et seq.; Brit. Doc. 1840 (437), xıI, 181, 'Fourth Report on Railways, Minutes of Evidence,' Q. 960. But it was a very rare thing that the canal companies did the actual work of earrving, either before or after the passage of the Act of 1845. As late as the year 1883, several witnesses advoented the earrying business being taken up by the canal companies, as well as by the private carriers: and it was said that at that time the system of earrying goods on the intand waterways was almost exelusively in the hands of the trallie senders, who put their own boats on the canals and paid the toll to the eanal eompany (v. for example, Brit. Doc. 1883 (252), xum, 1, evidence of Mr Lloyd, p. 23; also Brit. Doe. 1868 [384.1], xxxin, 1, evidence of Mr Wilson, Q. 10,021, p. 483).

1 Brit. Doe. 1857-8 (411), xwy, 1, 'Report of Select Committee on Railway and Canal Legislation,' p. 40. The Aet authorized the owners of eanals and navigations to carry as common carriers on their own canals and navigations; to enter into arrangements with each other in the way that railway companies were authorized to do, so as to avoid the delays ineident to a diversity of interests; to cnter into agreements for the division and apportionment of tolls and charges; and to let the tolls and duties to be levied on any canal or navigation, or any railways or tramways belonging to them, to any other eanal or navigation companies for a period not exceeding 21 years. 
ready to enter into negotiations with other canal companies which were powerful rivals, and to make such agreements with them as would prevent their competing with the railways, so that the latter would have the whole field to themselves'. In this way, the aeumen of the railway managers or directors proved more than a match for the legislators, and the more powerful transportation rival was able to still further obtain the predominanee. So great was the influence that might be acquired by railway companies which were in a position to make use of the powers conferred by the Act of 1845 , that the Board of Trade suggested whether it might not be proper to place some restriction on the exercise by these companies of the power of entering into traffic arrangements with eanal companies ${ }^{2}$.

The impetus given to the anralgamation of railways and eanals before the beginning of the railway mania continued in the following years, and in 1846 there were over 200 Bills presented to Parliament

1 As an example of this strategy, we give some facts in the history of the Leeds and Liverpool Canal. Before the commencement of railway competition, the tolls on this canal for gencral merchandise varicd from $1 d$. to $1_{2}^{1} d$. per ton per mile. To meet railway competition, the canal tolls were reduced to $\frac{3}{4} d$. to $\frac{1}{2} d$. per ton per mile. As competitors for the traffic of the district traversed by this canal, there were three lines of railway, the London and North Western, the Mirland, and the Lancashire and Yorkshire. These railways, having under anthority of Parliament secured the property of certain navigations, and desiring to put down all competition for traffic in this district, engaged the Leeds and Liverpool Canal, in 1851, in consideration of an annuity of $\$ 41,860$, to give up all competition and to practically elose up their navigation by raising their tolls to a prohibitory figure, obtaining thereby for the united railways a complete monopoly of the traffic of that district. The arrangement was made to assume the appearance of a lease of the canal tolls, under the powers of the Act of 1845 . The lease, however, was a fiction: the $£ 41,860$ yearly was paid, not as a rent, but in consideration of a rise in the canal tolls, which shut up the navigation and compelled the traffic to go by rail. While the canal was charging the aforementioned reduced rates, these three railways, together with the East Lancashire Railway, offered the Leeds and Liverpool Canal this annuity, the counter condition being an increase of all the canal tolls to $1_{2}^{1} d$. per ton per mile, which was an advance of $100 \%$ to $200 \%$ on the existing tolls. The canal accepted the annuity offered, but refused to allow the East Lancashire Railway to appear as a party to the transaction, since the latter did not have any canal whereby to legalize the agrecment. The arrangement was therefore completed under the pretence of a lease of the Leeds and Liverpool Canal tolls, by the London and North Western Railway, as proprietors of the Huddersfield Canal. the Lancashire and Yorkshire Railway, as proprietors of the Bolton and Bury Canal, and the Midland Railway, as proprietors of the Ashby-de-la-Zouch Canal. The proportions in which the $\& 41,860$ was divided among the four railway companies were not publicly known. Brit. Doc. 1852-3 (736), xxxvin, 447, 'Fifth Report of Select Committee on Railway and Canal Bills, Minutes of Evidence' of Thomas Grahame, p. 69. For other instances, see Brit. Doc. 1857-8 (117), xxxr, 335, 'Report of Board of Trade on the Railway and Canal Bills of that Session,' p. 40.

2 Brit. Doc. $1857-8$ (117), xxxi, 335, p. 40. 
containing provisions for uniting canals with railways $\mathbf{1}$. The committce that was appointed to look into this subject recognized the growing tendency to union and extension, with its advantages of harmonious management and its accompanying evils of monopoly; and they recommended the appointment of a department of the Government to provide more effective supervision of railways and canals ${ }^{2}$. Still the amalgamations went on, with some effects that were detrimental to the public; and the committee of 1853 , that was appointed to report on the railway and canal bills of that year, urged that working agreements between different companies, for the regulation of traffic and division of profits, should be sanctioned under proper conditions and for limited periods, but that amalgamation of companies should not be sanctioned except in special cases, where its object was to secure public benefit through economy of management ${ }^{3}$. They also recommencled that the good results of such merging of interests should be retained, and the evils arising from them should be done away, by compelling every railway company to afford to the public, in regard to both goods and passengers, the full advantage of convenient intcrchange from one system to another ${ }^{4}$. Since competitors were able, in a great

1 Brit. Doc. 1872 (364), xıI, 1, 'Report of Select Committee on Railway Amalgamations,' under heading No. 8 .

2 Brit. Doc. 1846 (275), xuI, 98, 'Second Report of Select Committee on Railways and Canals Amalgamations.'

The recommendations of this, the first committee on railways and canals amalgamations, are important, and we give them as follows:

(1) The imposition of a low scale of tolls and charges upon all parties to the amalgamation. In the case of canals, the scales of tolls were of much greater importance than in that of railways, for, in most instances, the public were the carriers upon the canals.

(2) Strict regulations should be made for keeping the canals in effectual repair and with a proper supply of water.

(3) The public must have the right of carrying passengers and goods on the canals.

(4.) The privilege of making by-laws should be subjected to careful revision. By this means, many of the canal companies exereised much power and could prevent fair competition.

(5) Where a canal was converted into a railway, care should be taken that no district would be deprived of ellicient means of eommunication.

${ }^{3}$ Brit. Doc. 1852-3 (736), xxxvil, 447, 'Fifth Report of Select Comnittee on Railway and Canal Bills,' pp. 20-21. If working agreements were entered into and found to be injurious, they could easily be dissolved at any time; whereas if amalgamations were allowed they would be permanent and could not be subsequently broken. Brit. Doc. 1865 (:3), xLIX, 219, p. 23.

4 Brit. Doc. 1852-\$ (736), xxxvit, 447 , 'Fifth Report of Select Committee on Railway and Canal Bills,' pp. 20-21. Running powers were generally discouraged on the score of danger, and were to be conceded only in cases where free transit 
measure, to secure the benefits of eombination by agreements with each other, without anthority of Parliament, and there were many such private agreements ${ }^{1}$, it became necessary for Parliament to adopt some means of protecting the public by compelling proper arrangements for traffic between the companies. For this reason, the Legislature acted in aceordance with the rccommendation of the above-mentioned committee, and in the following year passed the "Railway and Canal Traffic Act, 1854." 'This Act enunciated two principles: that every company should afford, both for passengers and goods, proper facilities for forwarding traffic, and that no preferences should be given ${ }^{2}$. It was the first really important step in the direction of solving the difficulties that had arisen in connexion with the conduct of the traffic of railways whose interests were at variance with one another or with the interests of the public ${ }^{3}$. The Act also provided a summary remedy against

from one system to another could not be adcouately ensured by other means (ibid., pp. 20-21, No.6). The Board of Trade in 1865 also opposed the granting of running powers, that is, conceding to one company power to pass over the lines of another company without the consent of the latter, on the ground of its being questionable from considerations of publie safety (ibid., p. 24; also 'Fourth Report of Select Committee of 1853, p. 6).

1 Brit. Doc. 1852-3 (736), xxxyin, 447, 'Fifth Report of Select Committee on Railway and Canal Bills,' p. 6. Here it is stated that such combinations of interests under private agrcements were a matter of constant oceurrence.

2 Act 17 \& 18 Vict., c. 81. Under this Act, "every railway company, eanal company, and railway and canal company, shall afford all reasonable facilities for the receiving and forwarding and delivering of traffic upon and from the several railways and canals belonging to or worked by such companies respectively, and for the return of carriages, trucks, boats, and other vehicles, and no such company shall make or give any unduc or unreasonable preference or advantage to or in favour of any particular person or company, or any particular description of traffic, to any undue or unreasonable prejudice or disadvantage in any respect whatsoever." The rest of the Act gives provisions for its enforcement. Brit. Doe. 1854 (87), vi, 19 ; also Brit. Doc. 1854-5 [1965], xLvir, 1, 'Report of Raikway Department of the Board of Trade for 185t, $\mathrm{pp}$. $\mathrm{x}$, xi give the provisions of this Act.

The neeessity for this Aet may be further illustrated by the following instance: In 1853 there was a complaint sent to Parliament by the coal-owners in Lancashire, that the railway company did not provide locomotive power to meet their needs, and that their coal had bcen forwarded at the company's convenience, rather than their own. The company took higher elass traffic, which paid higher rates, and left the coal, which paid lower rates. Then, too, the railway left the coal-owners' rolling stock and coal on sidings along the line, which required the maintenance of a larger amount of rolling stock. The complaint also alleged that there was much delay in sending baek the empty waggons from London. Brit. Doc. 1852-3 (736), xxxvil, 447 , 'Fifth Report of Select Committee on Railway and Canal Bills, Minutes of Evidence,' p. 4.

3 The Railway Department of the Board of Trade, in 1865, observed that the necessity there might formerly have been for allowing running powers were, to some extent, obviated by the passage of the Railway and Canal Traffic Act, 1854, and 
railway companies for any violation of its enactments, by an application to the Court of Common Pleas ${ }^{1}$; but despite this it remained for many years practically a dead letter.

As soon as the Traflic Act of $\mathbf{1 8 5 4}$ had been passed, large numbers of Bills were laid before the House by railway companies, asking that authority be given to enter into various descriptions of agreements for working in eonnexion with other companies, or for forwarding or interchanging traffic with other eompanies. Out of a total number of 138 Bills introdueed in 1854, seventy-five were for making working arrangements and this movement for working agreements increased in importance during subsequent years ${ }^{2}$. Most of those that were authorized were for ten years, but the power of renewal at the expiration of that period was generally granted, subjeet, of course, to the approval of the Lords $^{3}$. The reason why there were so many of these agreements consummated about this time was because the trunk lines had been laid out, and the many short lines that were being eonstrueted had to be merged with them in order to acquire any stability of operation". To have attempted to remain apart from one of the main lines would have been to invite ruinous competition from the other roads in the same distriet; and, on the other hand, it was for the public good that new lines, whieh were extensions of, or feeders to, existing lines, should form part of one or other of the great systems and thus faeilitate intereommunication.

The amount of amalgamation that was effected between railways and canals we are unable to trace with minuteness through successive stages in the growth of the transportation system. Some had been aceomplished before the railway mania of $1844-6$; mueh more was

that they were necessary only where a company required to pass for a short distance over the line of another eompany to reach a station at which to deposit and receive traffic, or when such short piece of line was a link necessary for the completion of a special railway system. Brit. Doc. 1865 (3), xux. 219, p. 24.

1 See also Brit. Doc. 1867 [3844], xxxwm, 1, 'Report of Royal Commission,' p. xxi.

2 Out of 71 Bills introduced in the Session of 1858 , there were 46 seeking sanction for working and traffic agreements. Brit. Doe. 1857-8 (117), xxxı, 335, 'Gcneral Report of the Board of Trade upon the Railway and Canal Bills of the Session of 1858,' p. 11.

${ }^{3}$ Brit. Doc. 1854 (139), LxII, 441, 'Report of the Board of Trade on Railway Bills of 1854,' p. 14; also 1854-5 [1965]. xLvm, 1, 'Report of the Railway Department of the Board of Trade for 1854 ,' p. viii.

4 For the full text of the English and Scotch Traffic Agrecment, among seven great railway companies, for apportioning the receipts from the Scotch traffic, see Brit. Doc. 1856 [2114], L, , 1, 'Report of the Raikway Department of the Board of 'Trade for 1855.' Appendix No. 4. Some other traffic agreements are given in ibid., Appendix No. 5. 
completed during those years; and the subjeeting of canals to railway control went on more gradually subsequent to that time ${ }^{1}$. By $\mathbf{1 8 5 0}$ a considerable proportion of the eanals had passed into the hands of the railway companies ${ }^{2}$; and by about 1865 that proportion had been increased, until nearly one-third of the total length of the canals and navigations of Great Britain had gone over to the railways ${ }^{3}$. From the report of $\mathbf{1 8 7 2}$ we learn that there was a still greater extent of navigable waterways under railway eontrol, amounting to about three-eighths of the whole ${ }^{4}$; and in 1883, in Fingland and Wales alone, one-half of the total mileage of navigations had beeome allied with the railways and was no longer independent 5 .

1 The statisties of such amalgamations from 1846 to 1872 are given in Brit. Doe. 1872 (364), x11, 1, pp. 755-6, and are found in Appendix 9.

2 Brit. Doe. 1851 [1332], xxx, 1, 'Report of the Commissioners of Railways for the year 1850,' p. xix et seq.

3 Brit. Doc. 1867 [3844], xxxvir, 1, 'Report of the Royal Commission, Minutes of Evidence' of Mr Thomas Wilson, p. 428 et ser. Mr Wilson was hon. sec. of the Canal Association of Great Britain. The following summary is given (ibid., Q. 9902-4):

Extent of navigations in England and Seotland, in 1865 :

109 canals, total length

49 improved rivers, total length

$\overline{158}$ navigations, of a total length of

2552 miles

1339 ,

$\overline{3891}$,

Of these 3891 miles of navigation,

5 navigations have been converted into railways

37 navigations have been amalgamated with railways

2 navigations were wholly or partly leased to rail-

ways and virtually amalgamated with them

Total $\frac{177}{1271}$,

Therefore, about onc-third of all the mileage of navigations had gone into railway hands.

The particulars in regard to this 1026 miles of amalgamated canals and the railway companies that har absorbed them are given in Brit. Doc. 1867 [3844.], xxxvili, 1, 'Report of Royal Commission, Minutes of Evidence,' Q. 9906, pp. 428-9.

The extent to which the canals had passed under railway control, by 1872 , is shown on the map given in Appendix lis of the Report of the Select Committee (of 1872) on Railway Amalgamations,' Brit. Doe. 1872 (364), xıI, 1.

4 Brit. Doc. $18 \% 2$ (364), xnI, 1, 'Report of the Select Committee on Railway Amalgamations,' p. xx; also ihirl. pp. 755-6. We nay take the total length of navigable waterways of Great Britain in 1872 to be the same as that of 1865 . namely, 3891 miles. Aceording to the returns of that year (1872), there were then 1544 miles of canal in Great Britain held by railway eompanies, of which 1300 miles were held in perpetuity and the remaining 244 miles uncler temporary tenure. Therefore, at that time, there was about three-eighths of the total length of eanals under railway control.

5 Brit. Doc. 1883 (252), xıI, 1, 'Minutes of Evidence' of Mr Calcraft, Q. 3-6.

This subjecting of the inland waterways to the railways had its counterpart 
We have already observed that the first effeet of the introduction of a railway, as a competitor to a canal, was to cause the rates on the latter to be lowered; and by thus reducing the business and profits of the eanal the railway company hoped to bring the canal proprictors to terms ${ }^{1}$. But it sometimes oceurred that a canal was able to maintain competition with the railway; and where this was the case, the railway was compelled to eharge lower rates at competitive points, while it recouped itself by imposing higher rates at non-compctitive points ${ }^{2}$. On the passenger traffic the railways generally charged their maximum rates, because in that they had no competition; but on the goods traffic they charged much less than their maximum rates. In addition, the higher elass goods, for conveying which the railways offered specially good facilities as compared with canals, were charged rates very much

in the railways obtaining a strong foothold in the external trade. By 1847 the London and South Western Railway Company had nade a deed of settlement with a Steam Navigation and Packet Company connecting the channel ports with ports of the Continent, whieh gave the railway eontrol of much of the trade between England and Europe. Brit. Doe. 184\% (164. 1v), xxxi, 33 and 1847-8 (148 (30)), xxxi, 399, 'Reports of the Commissioners of Railways on the London and South Western Railway.' By 1858, the South Eastern Railway Company had obtained power to build, hire and work vessels for the purpose of affording communication between the ports of Folkestone, Dover, Hastings, Ramsgate, Hargate, Rye, Whitstable, or Gravesend, and any port in France or Belgium. Brit. Doe. 1857-8 (11\%), xxxi, 335, 'General Report of Board of Trade upon the Railway and Canal Bills of that Session,' p. 37.

1 See also Skey, Report to the Committee of the Birmingham and Liverpool Junction Canal, on the Present State of the Competition between the Canal Carriers using that Line and the Grand Junction Raikway Company, p. 4. He shows how the railways lowered freight rates to a point which was disastrous to the canals, while at the same time keeping up their passenger rates, so that no individual canal carrier could long compete against a rival armed with sueh powers. Refer also to Boyle, Ilope for the Canals, pp. 5-7, and Palmer, British Canals, pp. 19-20.

2 In 1853 the rate on second class goods between Liverpool and Birmingham was $15 \mathrm{~s}$, but the rate between Manchester and Birmingham was $17 \mathrm{~s}$. 6l. The distance was about the same in both cases; but between Liverpool and Birmingham there was the competition between the canal and the railways [the Grand Junetion Railway and the recently opened Shrewsbury line of railway], while between Manchester and Birmingham there was no such competition.

The following table of charges on, the Midland Railway between Birmingham and intermediate plaees to Gloueester, and between Birmingham and several other points, will illustrate still more fully the difference in the railway rates where canal competition existed and where it did not.

Note that the charge between Birmingham and Gloucester, 58 miles, was $7 s .6 d$. per ton, whereas the charge between Birmingham and Cheltenham, 46 miles. was 10s. At Gloueester, the competition of the waterways kept down the rate, but at Cheltenham there was no such competition. Similarly in other cases. Note also that the rates on first and second class articles were the same to Bromserove and to Gloueester, although the distance in the former ease was hardly one-third of that 
higher than lower class goods, for which the canals could enter into fair competition with them 1 .

After competition had proceeded to a eertain length, and canals found it advisable to merge their interests with the railways, this step was usually aceompanied by an inerease of rates, espeeially on the more valuable goods ${ }^{2}$, to a point higher than the competitive rates, and frequently higher than those which existed before competition became

in the latter (Brit. Doc. 1852-3 (246), xxxvin, 175, 'Third Report on Railway and Canal Bills,' p. 32).

Midland Railway rates between Pirmingham and the following places:

\begin{tabular}{|c|c|c|c|c|c|c|}
\hline $\begin{array}{c}\text { No. of } \\
\text { miles }\end{array}$ & $\begin{array}{l}\text { Ist } \\
\text { clas }\end{array}$ & $\begin{array}{l}\text { 2nd } \\
\text { class }\end{array}$ & $\begin{array}{l}3 \mathrm{rd} \\
\text { class }\end{array}$ & $\begin{array}{l}\text { 4th } \\
\text { class }\end{array}$ & $\begin{array}{l}\text { 5th } \\
\text { class }\end{array}$ & Smalls \\
\hline
\end{tabular}

Gloucester, in competition with Birmingham and Worcester Canal and Severn Navigation........

Cheltenham, no competition

Droitwich

$\left.\begin{array}{c}\text { and } \\ \text { Bromsgrove }\end{array}\right\}$ no competition

Worcester ...............

Hull, in competition with canals and Trent Navigation ................

Sheffield, no competition

York, no competition .....

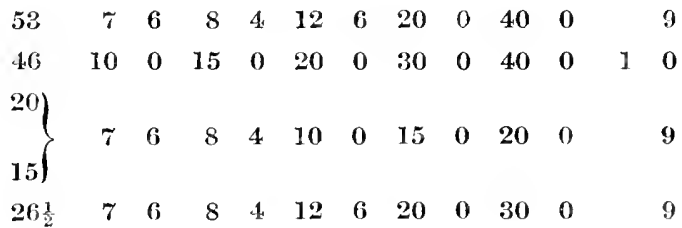

Newcastle, in compctition with navigations to Hull, and consters to Newcastle

$\begin{array}{rrrrrrrrrrrrr}134 & 20 & 0 & 20 & 0 & 25 & 0 & 30 & 0 & 40 & 0 & 1 & 3 \\ 86 & 20 & 0 & 25 & 0 & 35 & 0 & 40 & 0 & 60 & 0 & 1 & 0 \\ 129 & 26 & 8 & 30 & 0 & 33 & 4 & 40 & 0 & 60 & 0 & 1 & 6 \\ & & & & & & & & & & & & \\ 216 & 25 & 0 & 30 & 0 & 35 & 0 & 45 & 0 & 60 & 0 & 1 & 9\end{array}$

This same thing was observed by the Select Committee of 1872 , from the testimony of several witnesses who apneared before that body. Brit. Doe. 1872 (364), xin, 1. 'Report of Select Committee on Railway Amalgamations,' p. xxii ; also 'Minutes of Evidence' of Messrs Nicks and Clcgram, Q. 2919, 2987-8. See also ibid., p. xxi, and 'Evilenee' of Mr Wilson, p. 238 et seq.

1 In 1853, from Birmingham to Liverpool and Manchester, the rate on the lowest class of goods was $11 \mathrm{~s}$. a ton, but on the highest class it was 30s. a ton. Brit. Doc. i852-3 (246), xxxr11, 175, p. 32.

2 This was done when the Manchester and Leeds Railway made an agreement with the Rochdale Canal and the Calder and Hebble Navigation. Brit. Doc. 1844 (318), x1, 17, 'Fifth Report on Railways, Minutes of Evidence,' p. 488 . When the Birmingham Canal came under the control of the London and North Western Railway Company its tolls were raised; and the rate on iron going along that canal was $1 \frac{1}{2} d$. per ton per mile, while the rate on the Trent and Mersey, Bridgewater and Staffordshire and Worcestershire Canals was only $\frac{1}{2} d$. per ton per mile. Brit. Doc. 1852-3 (170), xxxvir, 5, 'Second Report of Committee on Railway and Canal Bills,' p. 70 . 
operative. In this way, independent canals began to find that their traffic was inconvenienced and injured by the high rates on the canals that were joined to railways, because by raising their rates to a point that was almost prohibitory to private carriers the railway-controlled canals not only drove the carriers off their own waterways but also materially aided in driving them off the independent canals. If carriers could not secure sufficiently favourable terms from all the canals in the chain, it was frequently useless for them to make any attempt at carrying; for to carry on a short stretch of canal, and then be compelled to transfer to a railway, or pay the high charges of the latter's canal, was wholly destructive of any advantages from water carriage ${ }^{1}$. This increase of railway and canal rates was but another phase of the general policy of the railways to realize the utmost results from their monopoly, and to secure ample returns for losses sustained during what were sometimes prolonged periods of competitive rate cutting.

The policy of the railways in regard to the canals was, in all cases, to drive the traffic from the water to the rails. From the earliest days of the competitive period this tendency was manifested and its dangers recognized; but the problem was, how to securc the canals from the interference and control of the railways, and to afford the former a good opportunity of testing their capabilities as a rival system². It would have been an easy matter for Parliament, had its members foreseen the outcome, to have passed legislation forbidding the railways doing anything that might prejudice canal interests, but that would not prevent private negotiations which looked toward a settlement of difficulties that would be acceptable to both the parties concerned. In contrast to this lack of knowledge on the part of the Legislature, there was the enterprise of the railway companies, which pursued their aim with steady and determined zeal. There were constant warnings given to Parliament against Bills which, if passed, would involve new or increased inducements to divert traffic from canals to railways; but in the face of these, the latter kept up the contest with their rivals.

1 Brit. Doc. 1852-3 (246), xxxvin, 175, 'Third Report of Select Committee on Railway and Canal Bills;' 'videnee of Mr Mellish and Mr Loch. p. 26. The committee of 1872 reported that "Where Railway Companies amalganate, or where Railway Companies acquire a navigation, the result is usually an increase of rates." Brit. Doc. 1872 (364), xill, 1, 'Ninutes of Evidence' p. 332. See also Brit. Doc. 1881 (374), xIII, 1, 'Report of Select Committee on Railway Rates and Farcs.' evidence of Mr Hingley, Q. 5489, 5659. In Appendix 11, we have brought together some tabular statements of freight rates, showing how much they were raised by the amalgamation of railways with eanals.

2 Brit. Doc. 1846 (275), xin, 93, 'Seeond Report of Scleet Committee on Railways and Canals Amalgamations.' 
Sometimes canals were purchased or leased by the railways, frequently at a loss so far as the revenue from the waterways was eoncerned, and then their free use was forbidden to the public, through the imposition of prohibitory tolls. In other cases the railway companies used their passenger traffic as a means by whieh they eould put down their freight. rates and thus appeal to shippers, from the standpoint of eeonomy, to patronize the railway. Then, when the canal companies or other carriers on the waterways had found it impossible to compete for traffic, and had sold their stock of horses, it would be hard for them ever again to get baek their traffic, since the public had become accustomed to having their goods carried by the faster conveyance of the railway ${ }^{2}$. In some instances. railways neglected or refused to repair the canals they held; and although the necessity for keeping them in good condition had been early shown to Parliament ${ }^{3}$, yet they

1 Brit. Doc. 1881 (374), xm1, 1, 'Report of Comnittee on Railway Rates and Fares, Evidence' of Mr Lloyd, Q. 10,181-2. In that year the Great Western had practically $£ 1,000,000$ invested in canals, and the net revenue was only $£ 276$ (in 1880 ). For some of these canals they had to pay rent charges of $£ 8243$, so that on the canals the company losi frg6r; but this closing of the canals was to bring the traffic on to the rails. Some of these canals the were forced by Parliament to purchase when they obtained power to construct their railways (v. Brit. Doc. 1881 (374), xiIr, 1, 'Minutes of Eridence,' Q. 13.720). See also Brit. Doc. 1846 (275), xi1. 93. 'Second Report of Committee on Railways and Canals Amalgamations, Evidence, p. 47. The oppressive policy of the Birmingham Canal Navigation, controlled by the London and Nortl Western Railway Company, was notorious (see example given in Brit. Doc. 1881 (374), xu, 1, 'Report of Committee on Railway Rates and Fares, Evidence' of Mr Spence).

As showing to what extent the Great Western Railway Company diverted the trafic from thrce of the most important of the canais of which it got control, note that on the Hercford and Gloucester Canal, in the thirty years following 1848, the gross receipts had decreased seventy per cent. During the same period, the receipts on the Stratford-upon-Avon Canal decreased seventy-seven per cent.; and in the same time the receipts of the Kennet and Avon Canal decreased eighty-seven per cent. That is, during that time, in the case of these three canais, seventy, seventy-seven and eighty-seven per cent. respectively of the traffic had been shunted on to the rails. Brit. Doc. $18 s 1$ (3r4), xi1r, 1, evidence of Mr Spence.

The tolls on the Leeds and Liverpool Canal. during the time it was under the control of the London and North Western Railway, were the maximum rates, and were as much as the through freight rate on the railway. This, of course, prevented the usc of the canal, and it was in reality closed up. Brit. Doc. 1872 (364), xm, 1. 'Report of Select Committee on Railway Amalgamations.' Q. 57r2.

2 Brit. Doc. 1846 (275), xı11, 93, 'Second Report of Committce on Railways and Canals Amalgamations, Evidence,' p. 35 ; also 1852-3 (246), xxxrif, 175, 'Third Report of Committee on Railway and Canal Bills, Evidence,' p. 16.

${ }^{3}$ Brit. Doc. $1846(275)$, xiı, 93, 'Second Report of Committee on Railways and Canals Amalgamations; Recommendations of the Committee,' among others that "strict regulations should be made for maintaining the canals in an efficient state of repair, and for securing a proper supply of water." 
were allowed to decline ${ }^{1}$. Notwithstanding the passage of the Aet of 1873, requiring railway-controlled eanals to be kept open and navigable for the publie without interruption and delay ${ }^{2}$, and that Parliament in many eases tried to annex conditions to the amalgamation, eompelling the companies to maintain the canals in an efficient working state ${ }^{3}$, many of these canals went from bad to worse; they became silted up, the locks became broken, and the navigation fell into disuse. From what we have just said, we ean easily see how the railways eould draw to themselves the traffic formerly earried on competing canals, and leave the latter in a state of hopeless decay.

An examination of the English canals to-day reveals the fact that the amount of traffie carried on them, tout ensemble, is comparatively insignificant. By way of summary, we shall now note some reasons for their failure to compete suceessfully with the railways. To diseuss this fully would require a more minute investigation of the poliey and management of each than we have the space here to deseribe; and so we shall endeavour to give only the salient factors whieh bear upon the problem.

In the first place, the disjointed state of the canals prevented their being used to advantage. Very few of them had the same dimensions ${ }^{5}$. They were constructed usually as short independent canals, and not as long through routes. Their dimensions were made to accord partly with the amount of money that had been subscribed or contributed

1 Brit. Doc. 1872 (364), xin, 1, 'Report of Select Committee on Railway Amalgamations,' p. xxii ; also ibid., 'Minutes of Evidence' of Messrs Clegram (Q. 2936) and Lloyd (Q. 5041). See also Brit. Doc. 1881 (374), xur, 1, 'Report of Conmittee on Railway Rates and Fares, Evidence,' Q. 10,184-8; and Brit. Doc. 1883 (252), XIII, 1, 'Report of Select Committee on Canals, Evidence,' Q. 564, 630, 632-3.

2 Brit. Doc. 1881 (374), xiII, 1, 'Report of Committee on Railway Rates and Fares, Evidence' of Mr Lloyd, Q. 10,194.

3 Brit. Doc. 1872 (364), xıI, 1, 'Report of Select Committee on Railway Amalgamations,' p. xxii ; also 'Evidence' of Mr Bartholomew, Q. 5779.

4 'The Act of 1873 was not enforced, because it would have cost the public too much to enforce it on account of the legal complications involved. Brit. Doc. 1883 (252), xiII, 1, 'IReport of Sclect Committee on Canals, Evidence' of Mr Lloyd, Q. 564. As to the manner in which that Act was evaded, see Brit. Doc. 1881 (374), xirr, 1, 'Report of Committee on Railway Rates and Fares, Evidence' of Mr Spence, Q. 10,435 et seq.

5 See Brit. Doc. 1872 (364), xm, 1, 'Report of Select Committee on Railway Amalgamations,' Part II, Appendix $\mathbf{X}$, which gives in detail the dimensions of all the navigations. With depths of water varying from $4 \frac{1}{2}$ feet to $14 \frac{1}{2}$ feet, widths varying from 7 to 22 feet, and corresponding variations in length of locks, it would be difficult to get any boats that could be used to good effect on a through route. See also Palmer, British Canals, pp. 19, 22; Boyle, IIope for the Canals, pp. 29-30. 
by the stockholders of the individual companies for the completion of their works, and partly with the difficulties that had to be overcome in the location of the canal, or the soil through which it had to pass. When a Bill was presented before Parliament, the proposed canal was considered solely on its own merits, and not in regard to any connexion that it might have in future with any other. Not only did the original dimensions of the eanals show wide diversity, but changes were sometimes made in these, at times when improvements were subsequently carried out ${ }^{1}$. Even on the same canal, there were sometimes differences in the size of the locks which had been constructed ${ }^{2}$. This lack of uniform gauge was utterly destructive of any economy of operation. If a barge were required to go along a through route, its carrying-power and dimensions had to be limited to suit the smallest locks on the route. If onc boat were not to be used throughout the course, there had to be frequent loading and unloading from one barge into another. Both these methods of carrying were wasteful: the former in the utilizing of the capacity of the boats and canals, and the latter in the employment of time and labour. So also, the canals with large locks often consumed a large portion of their water inefficiently without passing an effective cargo, while on the narrow eanals the carriers were greatly restricted as to the weight they could take. These discrepancies of gauge were wholly subrersive of the greatest usefulness of the canals ${ }^{3}$.

1 Brit. Doc. 1883 (252), xir, 1, 'Report of Select Committee on Canals, Minutes of Evidence,' p. 38, Q. 785-92.

On the Aire and Calder, for example, the locks were originally 60 feet $\times 15$ feet, with a depth of water of 3 fect 6 inches. Under the Act of $17 \tau 6$ the locks were made 66 fect $\times 15$ feet and the depth of water 5 feet. Under the Aet of 1828 , the locks were made 72 feet $\times 18$ feet and $\tau$ fcet depth of water. After 1860 , the locks were made 215 feet $\times 22$ feet and 9 feet depth of water.

2 Brit. Doc. 1883 (252), xill, 1, 'Evidence' of Mr Bartholomew, Q. 804. On the Leeds and Liverpool Canal, the locks on the Yorkshire side were 66 feet $\times 15$ feet 2 inches, and were capable of admitting boats 60 feet $\times 14$ feet 6 inches; but on the Lancashire side the locks were $r 6$ feet $\times 15$ feet 2 inches, and they would receive boats $i 0$ feet $\times 14$ feet 6 inches.

On the canal route connecting the river Severn at Saul with the Thames at Abingdon, the Stroudwater Navigation gauge was 75 fcet $\times 15$ fect, the Thames and Severn Canal gange 75 feet $\times 12$ feet 6 inches, and the Wilts and Berks Canal gauge 80 feet $\times \tau$ feet. The Thames alone had three gauges upon it, the gauge in every case being regulated by the size of the locks (ibid., 'Evidence,' Q. 107).

3 Canals eould not now be economicaily widened so as to make a uniform gauge, becanse of the fact that tunnels, stone bridges, etc., along the routes could not be widened except at vast expense. In one case, we are told. the canal runs under the houses in Manchester. This certainly could not be made wider. Brit. Doc. 1883 (252). xirI, 1, 'Report of Select Committee on Canals, Evidence,' Q. 1700-1. See also Boyle, Hope for the Canals, p. 23. 
Another reason for the failure of the eanals was the lack of unity of management, due to the great number of eompanies whieh controlled them. In 1883, between London and Liverpool there were three distinct routes: on the first there were nine different eanals and navigations, on the seeond route also there were nine different companies, and on the third there were ten separate companies ${ }^{1}$. From London to Bristol there were four routes: on the first, via the Kennet and Avon, there were three companies; on the seeond, via the Wilts and Berks Canal, there were five companies; on the third route, via the Stroudwater Canal, there were three companies; and on the fourth route, via the Warwick Canal, there were nine companies, and this was the oniy one in practical use 2 . From Birmingham to Bristol there were three routes $^{3}$. Between Hull and Liverpool there were four ways: on the first route, via the Leeds and Liverpool Canal, there were four separate companies; on the seeond, via the Rochdale Canal, there were seven eompanies; on the third, via the Huddersfield Canal, there were nine companies; and on the fourth route, via the Trent and Mersey Canal, there were at least five navigations. If', in 1883, there was such laek of unity, it could not have been less, but, possibly, more diverse in the period before the middle of the eentury; and these conditions have not been improved since $1883^{5}$.

1 Brit. Doc. 1883 (252), xu1, I, 'Report of Select Committee on Canals, Evidence,' Q. 231.

2 Ibid., 'Evidence,' Q. 232.

3 Ibid., 'Evidence,' Q. 233.

4 Ibid., 'Evidence,' Q. 234. In all these cases, the navigable tideways, such as the Mersey, Severn, Ouse, Humber, etc., are included as separate jurisdictions. Compare ibid., 'Evidence,' Q. T8:-4.

5 The 'Final Report of the Royal Commission on Canals and Waterways, 1909,' vil, p. 16, gives a few illustrations of this diversified control. For example: "Taking Birmingham as a centre, we will assume that it is proposed to despatch thence three eargo boats, one to the port of London, one to that of Liverpool, and one to Hull, by the most direct routes. The boat which went to London would have to traverse some portion of the Birmingham Canal system, next 22 miles of the Warwick and Birmingham Canal, next 14 miles of the Warwick and Napton Canal, then 5 miles of the Oxford Canal, then either 93를 miles of the Grand Junction Canal to Brentford, and finally the Thames, - or else $100 \frac{1}{2}$ miles of the Grand Junetion Canal to Paddington, and finally $8 \frac{1}{2}$ miles of the Regent's Canal to the Thames at Limelouse. All these waterways belong to different authorities. A cargo proceeding to the port of Liverpool would traverse first some part of the Birmingham Canal, then $2 \frac{1}{2}$ miles of the Birmingham and Warwick Junction Canal, then 17 miles of the Birmingham and Fazeley Canal, then $5 \frac{1}{2}$ miles of the Coventry Canal, then 60 miles of the Trent and Mersey Canal, and would then go, probably not without transhipment, by 12 miles of the Weaver Navigation and then by the Mersey to Liverpool, or, without going down the Weaver, proceed by the Trent and Mersey to its junction with the Bridgewater Canal at Preston Brook, and by that canal to the Manchester Ship 
In connexion with this want of unity of management along all the great through routes, some of the eanal eompanies, whose waterways formed eentral links in a longer ehain, took advantage of their peculiar position to raise their rates so as to seeure for themselves the largest possible return on their investment, even upon a small amount of traffie ${ }^{1}$. When the different eanals along a through route would not work in harmony, it was impossible to get a through rate that might enable the carrying to be eondueted at a profit to all, for the other companies that were not so advantageously situated would be obliged to reduce their rates below a reasonable minimum if the amount of the through rate were to be made aceeptable to the earrier. If the eanal companies, therefore, would not adopt eoneerted action, there certainly eould not be any fair eompetition with the railways ${ }^{2}$. The jealousy that existed between adjoining canals during the time preceding and immediately suceeding the introduetion of railways is well exemplified in the junetion or bar tolls. They were a sort of protective system, originally granted to the existing eanals, so that whenever any new canal formed a junetion with them the older canal could charge the amount of the bar toll merely as a gratuity for allowing traffic to enter

Canal, and thus to the Mersey; but as the narrow boat could not navigate the estuary, transhipment would be necessary. A cargo going to Hull would pass over some miles of the Birmingham Canal, $5 \frac{1}{2}$ miles of the Coventry Canal, 26 miles of the Trent and Mersey Canal, $9 \frac{1}{2}$ miles of the Trent Navigation, $2 \frac{1}{2}$ miles of the Nottingham Canal, 21 miles of the Trent Navigation, 4 miles of the Newark Navigation, 30 miles more of the Trent Navigation, 26 miles of the open Trent River, and then 18 miles of the Humber. Transhipment, probably at Nottingham, would be necessary." On this subject, for the earlier period before 1850, see Boyle, Hope for the Canals, pp. 23-24; Palmer, British Canals, pp. 19-23.

1 Brit. Doc. 1846 (275), xı1, 93, 'Second Report on Railways and Canals Amalgamations,' p. iv. As a special instance of a canal taking advantage of its position to raise its rates, we may mention the Grand Junetion Canal, which extends from Paddington to Braunston where it joins the Oxford Canal. The Grand Junction Canal was an important link between London and the great mining and manufacturing sections of Warwickshire, Cheshire, Staffordshire, ete. It was a monopoly without competitor; its exactions, excessive rates, discriminatory rates, and its supercilious conduct caused loud and general eomplaints even as late as 1836. Mercator, Tonnage Rates on Grand Junction Canal, pp. 8-24. The Oxford Canal had pursued a similar policy. See also Palmer, British Canals, p. 19.

2 About 1847 the Aire and Calder Navigation offered to lease the Calder and Hebble Navigation at a guaranteed net dividend of sixteen per cent, but the offer was refused. This high rate of dividend was surely a tempting offer, and why it was rejected we do not know; but it was not more than two years before railway competition had caused such a decrease of the revenues of this navigation that they were able to divide but eight per cent., or one-half of the dividend that had been guaranteed by the Aire and Calder. IIerepath's Railivay and Commercial Journal, $\mathrm{x} 1, \mathrm{p} .1241$. 
their canal at will ${ }^{1}$. These bar and compensation tolls were sometimes so extraordinarily high that they alone amounted to a sufficient ineome to pay a large dividend on the canal capital2. With such onerous charges upon the carriage of goods on the eanals, it is no wonder that the through traffic declined and that the railways came to have the upper hand. Of comse, when such canals passed into the control of the railways, these tolls were still continued; for it was the railway policy to divert all the trade from the canals to the rails, and this formed a useful auxiliary agency in the earrying out of this plan ${ }^{3}$.

1 Brit. Doc. 1881 (374), xıI, 1, 'Report of Committee on Railway Rates and Fares, Evidence' of Mir Lloyd, Q. 10,174. We must not confuse these bar tolls with the bars which were oecasionally allowed to remain between two canals that almost formed a junction end to end. For example, by Act of 1791 for making the canal from near Worcester to Birmingham it was provided that this canal should not eome within seven feet from the end of the Birmingham Canal without the consent of the proprietors of the Birmingham Canal in writing under their common seal. Up to 1815 this bar, of the width of seven feet, still remained to prevent any passage from one canal into the other or to prevent any waste of water ont of one canal into the other. Over that bar all the tralfie between the two canals had been eonveyed out of boats upon one canal into boats upon the other. In that year, the Worcester and Birmingluam Canal obtained the consent of Parliament to remove this bar, upon eondition that the Birmingham Canal might not be injured in any way, and this eanal agreed to the removal of the bar upon these conditions (v. Case in Support of the Bill for removing the Bar between the Birmingham, and the Worcester and Birmingham Canals, Birmingham Free Reference Library, No. 87,368). See also Itercpath's Railway Magazine, N.S., Iv, p. 373, address by "A Canal Proprietor."

2 Brit. Doe. 1881 (37.), xil , 1, "Report of Committee on Railway Rates and Fares, Evidence' of Mr Lloyd, Q. 10,174-6. See also the examples given in Shaen, Review of Roilways and Raikeay Legislation, p. 31.

The Oxford Canal Company, at the jumction of this eanal with the Warwick and Birmingham Canal at Napton, by authority of its Aet, was allowed to take a toll of $2 s .9 d$. per ton upon eoal, and $4 s$. $4 d$. per ton upon all other artieles. This was not for any service rendered, but merely for allowing traffie to pass from the other canal into the Oxford. In the first twenty years from the opening of the Warwick and Birmingham Canal, the Oxford Canal reeeived a quarter of a million in bar tolls at that jumetion, which was enough to pray a ten per cent. dividend on the entire cost of eonstruction.

The Grand Junetion was a still more extraordinary case. This eanal joined the Oxford Canal, seven miles from the junction of the latter with the Warwick and Birmingham Canal at Napton, and here there was a compensation toll of $6 \mathrm{~d}$. a ton leviable on all coal turning towards Oxford, which, in reality, never went within seven miles of the Grand Junction Canal, and in which they never could have any possible interest. Mereator, Tonnage Rates on Grand Jumetion Camal, p. 24, says: "The trade of the country at the present day (1836) groans under the excessive imposts and eomplicated system of the Grand Junction Canal and the abominable tolls." called eompensation tolls, paid to the Oxford Company.

3 That the railways took the full amont of these bar and compensation tolls on their eanals, is evident from Brit. Doe. 1872 (3(j4), xul. 1, 'Report of Seleet Committee on Railway Amalgamations,' p. xxi; also 'Evidence' of Mr Lloyd,

J. T. II. 
The railway companies, seizing upon this diversity of management in the canals, purehased or leased the important links of through routes, raised the tolls on these divisions to the utmost limit allowed by law, and thus made it impossible for the eompanies that owned the remainder of the lines of eanal and for the eommon earriers on a through route to maintain their traffic in competition with the railways. This was one of the earliest and most effective ways which the railways used for breaking up and paralyzing whole ehains of waterways ${ }^{1}$. The railway eompanies seldom, if ever, had possession of the whole of such a canal route, for that would require too mueh eapital to be tied up in unproductive business, espeeially when the control of a few miles would answer the purpose they had in view just as effectively. But besides putting up the tolls on their eanals, the railway eompanies, in some eases, eontrary to statute, neglected or refused to keep their eanals in repair ${ }^{2}$,

Q. 5031-32; also Brit. Doc. 1881 (37.4), xir, 1, ' Report of Select Committee on Railway Rates and Fares, Evidence,' Q. 10,180, 10,:09-10. The independent canals abolished their bar tolls (ibir., Q. 10,17\%).

1 Brit. Doc. 1846 (275), xn1, 93, 'Second Report of Committee on Railways and Canals Amalgamations, Hvidenee: p. 42; 1852-3 (170). xxxvir, 5, "Second Report of Committee on Railway and Canal Bills, Evidence' of Mr Pixton; also Brit. Doc. 1872 (364), xur, 1, 'Rcport of Committee on Railway Amaigamations,' pp. xxi-xxii. Mr Acwortl, who is, doubtless, the greatest railway eeonomist of England, in an article in the Ecomomic Jomrnal. June 1905, pp. 149-55, takes issue with the statement that railway companies "strangled" some of the canals which came into their posscssion or control. Whether we use the word "strangled" or not is a mere question of nomenelature: but it is undoubtedly true that when some of the important canal links came under railway dominanee their day as free-acting agents ceased. From that time onward, their policy was dictated by the railway companies into whose hands they had passed. This will be evident to those who consult the references I have here given for this paragraph. Sce also Palmer, British Canals, pp. 76-7\%. We are perfectly willing to admit that in many cases the canals were desirous of selling out to the railways, and in doing this they werc acting from the motive of self-intcrest. We may as wcll admit the application of the same legitimate principlc on the part of railways, which negotiated for the taking over of certain canals in order to further their own econonic interests.

2 Brit. Doc. 1872 (364), xur, 1, p. xxii; Brit. Doc. 1881 (374), xu1, 1; "Report of Committec on Railway Rates and Fares, Evidence' of Mr Lloyd, Q. 10,162. On the Stratford-upon-Avon Canal, owned by the Great Western Railway Company, Mr Lloyd said that a boat would make very good speed if it went one-and-a-quarter to one-anda-lualf miles per hour; and similarly for the trade on the Hereford and Gloucester Canal, owned by the same Company. See also London and Birmingham Railway Bill. Extraets from the Minutes of Evidence gizen before the Committee of the Lords on this Bill, pp. :3, 10; Palncr, British Camals, p. 28. Many of the canals had remained in ncarly the same condition as when they were first put into operation, thcir course was needlessly cireutous, their tunnels were small and inconvenient, they were inadequately supplied with water, and in the case of most companies no effort had becn made to progressively improve the canals so as to kcep them abreast of the development of the country and its expanding trade. Palmer, op. cit., 
and in other cases closed them at nights or stopped them for repairs just at the times when there would have been most traffic for eonveyance $^{1}$. Notwithstanding the reiterated recommendation by suceessive Parliamentary committees that every means should be adopted for the maintenance of cffective competition by the canals against the railways $^{2}$, the latter acquired possession of more and more of the strategic canal links, until the competition of the canals was stifled; or, in the words of Mr Conder, the canals were "struck with ereeping paralysis with all those obstructions ${ }^{3}$." The Joint Sclect Committee of $18 \% 2$, which inrestigated the railway and canal amalgamations, considered that "the most important method by which the railway companies have defeated the competition of canals has been the purchase of important links in the system of navigation and the discouragement of through traffic," and the great complaint against the railways still is that they tend to discourage traffic from going on the water routes ${ }^{4}$. Now it may be strictly true, although even this is open to question, that the railways did not acquire the canals with the deliberate intention of throwing obstacles in the way of their traffic development. It may not be just pp. 20-29; Herepath's Raikcay Magazine, N.S., Ir, p. 373, address to the canal navigation proprietors in Great Britain; Boyle, Hope for the Camals, p. 22; Reading Mercury, Nov. 25, 1793, p. 4, letter from "A Commissioner."

1 As much of the canal trafic was customarily carried at night, the railways would close their canals at night. Brit. Doc. 1872 (364), xıI 1, 'Report of Committee on Railway Amalgamations,' p. xxii, also evidence of Mr Clegram, Q. 2986-8, and Mr Lloyd, Q. 5041. In other cases, there would be a failure of the water supply, or the necessity of stopping for repairs at certain seasons when the canal would have been most used, and this would go on for weeks at a time.

2 See, for example, Brit. Doc. 1846 (275), xil, 93, 'Second Report of Committee on Railways and Canals Amalgamations,' under heading "Conehtision ;" Brit. Doe. 1872 (364), xıI, 1, 'Report of Committee on Railway Amalgamations,' p. xxiii, "Resolutions of the Committee."

${ }^{3}$ Brit. Doc. 1883 (252), xiI, ], 'Evidence before Select Committee on Canals,' p. 128, Q. 24.47.

Mr Grierson, the General Manager of the Great Western Raikway Company, in 1881, before a Committee of Parliament, testified that in many cases the railways were foreed to purchase the canals; that his company were possessors of several canals which Parliament forced them to purchase when they obtained the Act giving them power to construct their railway (v. Brit. Doc. 1881 (374), xil, 1. 'Report of Committee on Railway Rates and Fares, Evidence,' Q. 13,720). Mr Farrer, Secretary to the Board of Trade, also said that the purchase of eertain canals was made compulsory, in eonsequence of the terms Parliament imposed upon the railway companies when applying for their Aets. Furthermore, the railway companies sometimes found it a matter of poliey to buy off the opposition of the canal interests through the purchase of the canals. In the case of the Stratford-upon-Avon Canal, the eommittec would not allow the Bill to pass unless the railway company did absorb the canal (Brit. 1)oc. 1881 (374), xn, 1, 'Evidence,' Q. 16,466-7, 16.488-9).

4 'Final Report of Royal Commission on Canals and Waterways, 1909, Vn, p. 70, paragraph 381, and p. $7 \%$, paragraph 412 . 
to say with some that railway companies (cxcept perhaps in a few instances) acquired canals in order to strangle them. But it certainly is true to say that railway companies which have, in various ways, come into possession of canals feel, in most cases, little desire to do more than their barest legal duty in maintaining them. There seems no doubt but that they favour what they consider to be by far their most important business, that of placing all possible traffic on their lines of railway ${ }^{1}$. Where railway companies find it to their interest to maintain and improve their canals so as to promote trade on them they do so, though perhaps not always with successful results; but in the larger number of eases the railway companies seem to have neglected to promote, if not actually to have impeded by high tolls and otherwise, the traffic on the canals which they have acquired. The cases in which railway companies have a more or less strong interest in developing the trade upon canals which belong to them are cxceptions to the ruic ${ }^{2}$. But we must not suppose that it was the railway-owned canals alone which were allowed to fall into partial or total decay; as a matter of fact, many of the independent canals were fully as bad as those which were controlled by railways ${ }^{3}$.

Along with the foregoing physical factors leading to the relative decline of the canal traffic, we must include another clement which has becn alluded to incidentally in sevcral cases, namely, the fact that the canals were easily stopped or injured by frost, drought, and occasionally flood. This was one of the strong reasons put forward by the advocates of the railways, and there was ample justification for the desire to get rid of a system which entailed so much uncertainty and delay. To have goods stopped for weeks and sometimes months on account of the inability to narigate the canals, was subversive of all system in commcreial life 4 . The business community was coming to depend more and more upon regularity in the transportation of commodities, and as the waterways could not assure this they were gradually abandoned in favour of an improved means of conveyance which could provide this desideratum.

1 'Final Report of Royal Commission on Canals and Waterways,' 1909, v11, p. 77.

2 Ibid., pp. 74-76.

${ }^{3}$ Brit. Doe. 1883 (252), xi1, 1, 'Evidenee before Select Committee on Canals,' Q. 1343.

4 London and Birmingham Railway Bill. Eatrats from the Minutes of Evidence given before the Committee of the Lords on this Bill. PP. 3, 6, 9, 10; Great Western Railzay Bill. Minutes of Evidence taken before the Lords Commuttee to zehom the Bill was eommitted, pp. 7, 8, 11, 408; Mauchester Guardian, Jan. 29, 1831, p. 1, Report of the Manehester and Leeds Railway; Birmingham Journal, Sept. 9, 1826, p. 3, and Mar. 5, 1831, p. 3, statement of E. T. Moore: The Times, Jan. 30 , 1802 , p. 3 ; May 16,1826 , p. 2 ; Nov. 7,1826 , p. 2. 
The next adverse feature was the lack of tone and spirit in the system itself, and the failure, due partly to inability and partly to indifference, to adapt themselves to the changing eircumstances of the times. Barges were started on their journeys, not at definite times, but whenever the carriers had enough cargo to warrant their putting thcir horses on the tow-path. The arrival and departure of boats took place at all hours, and the horse with his feeding can attached to his month sauntered listlessly on his way, while those in charge of the boats systematically pillaged the goods and made frequent stops at the publichouses along the canals where time was squandered in drinking. In addition to this lack of punetuality in the delivery of goods and the frequent losses and delays, there was much difficulty in procuring rates and general information, since thesc were not publicly announced. The uncertainty, partiality and inconsistency of the carriers' charges, because of their being made without reference to any fixed rule; the want of promptness in rectifying errors and settling claims; and the general looseness of system and absence of unanimity or understanding among the various departments of the canal companies, conspired to perpetuate complaints against the whole system. The great number of independent carriers engaged upon the canals multiplied the number of transhipments, for besides having to tranship at the termini of the various canals, a similar transfer had to be made at each commencement and termination of a carrier's stage. In this way a loose, disjointed and uneconomical method of forwarding goods was imposed upon the shipper, and the number of hands through which the goods passed added needlessly to the cost and often preeluded the fixing of responsibility for injury or loss. Moreover, the earrier, instead of having his business divided naturally into three departments for attending to the receiving, the conveyance and the delivering of the goods, eaeh of which should have been in charge of a separate official and all joined under the supervision of one general head, sometimes required one person to attend to two or more things, in different places, at the same time. While the man was doing his work in one capacity, such as attending to the loading or moloading of a barge, he must have been neglecting it in another, such as receiving goods and making out an invoice for them; and it is no wonder, therefore, that disputes arose in regard to goods that went astray or that were not delivered. This laek of method, of system, of business acumen, in the conduct of the earriers' affairs must have been a potent reason of the decay of eanal traffic when railway aetivity began ${ }^{1}$.

1 Boyle, IIope for the Canals, pp. 19-29; Grahame, Treatise on Internal Intercourse and Communication (1834), pp. 28-29. 
Another reason for the failure of the canals to successfully compete with the railways was that they were at a great disadvantage on account of being unable to carry passengers. The large revenues from passenger traffic enabled the railways to lower their charges for the carriage of freight to such an extent that the canals, in meeting these lower freight rates, failed to makc sufficient profit, and were, therefore, compelled to reinquish their hold on the carrying trade, or else to amalgamate with the railways ${ }^{1}$. The latter, by charging the maximum fares for passengers, could make the receipts from this traffic pay all the fixed charges of the road, and allow the goods to be carried at so low a charge that the canals could not meet this rate for any length of time. The hope early expressed, that the canals could compete with the railways in the carriage of heavy freight, was not long in being deposed from the public mind; and the railways assumed the place of carriers par excellence ${ }^{2}$.

Finally, canal traffic declined because of a psychological reason. The discovery of railways as a means of transport, surpassing both in speed and economy any that were already in existence, so took the civilized world by surprise that the public were carried away with the thought of its possibilities. The canal traffic was carried on comparatively quietly and unseen, there was nothing fast about it. The sight of an occasional horse passing through the country, mounted or driven by a boy, and hauling an insignificant looking barge which was managed by one or two persons, excited no surprise on the part of anyone. In reality, most of the canal conveyance was effected at night, when it would be recognized by very few. On the other hand, the railway had an appearance of grandeur and ostentation that charmed the public. It seemed the embodiment of enterprise and boundless capabilities. The enormous trains conveyed across the country at a speed of twenty to thirty miles an hour contrasted strongly with even the best speed of the fly boats on the canals, going two and one-half to four miles an hour. The effectiveness of the engine and the substantial road-bed and rolling stock were all matters of wonder. The promptitude of train schedules was a radical reversal of the policy of the canal carriers, who, in the conduct of their business, had no schedule to which they adhered, but set out with their load whenever it was ready. When confronted with these

1 Brit. Doc. 1846 (275), xm, 93, 'Second Report of Committee on Railways and Canals Amalgamations,' p. iv; and 'Evidence' of Mr R. Scott, p. 60, Q. 555. See also Brit. Doc. 1852-3 (246), xxxvin, 175, 'Third Report on Railway and Canal Bills, Evidence,' p. 32, Q. 1700.

2 In treating of the effects of railway competition upon canals, we have toucherl upon the influence of the passenger traffic, but only slightly, because the central fact in that compctition was the relation of the carriers of goods to the canals and the railways. 
new conditions, the few who ventured to deprecate the total abandonment of all earlier means of transport, and especially those who advocated the retention and upkeep of waterways, found themselves a powerless minority. The reduction of freight rates elicited the support of the public, and writers for the railways industriously circulated the opinion that canals must ultimately give place to railways. As a result of these conditions the prices of canal shares went down ${ }^{1}$. In the fascination that the railways exercised from the outsct, the possibility of materially and effectively improving the waterways was lost sight of, while the economy which the former effected in the carriage of goods seemed so great as to lead to the idea that the limit of cheapness had been reached, and that it wonld be vain to suppose that the expense of carriage could be further reduced. Consequently any amount of money was placed at the disposal of railway schemes ${ }^{2}$ : while the canals, occupying the background of the public consciousness, were casily let go bccause they were thought to bc a declining property ${ }^{3}$. The railways lowered the rates of carriage on the canals to such an extent that the receipts and dividends of the canal proprietors werc greatly reduced; and the business of the railways, both in passenger and freight traffic, was on such a gigantic scale that the canals thought it would not be long before they would be driven out of business unless they could make an alliance or agreement with their over-powering rivals. This attitude of many canal proprietors toward their property was in great contrast to the enterprise exhibited by those younger men, usually of the trading and industrial classes, who were actively pushing the coustruction of railways ${ }^{4}$. The former often gave up the battle with the railway companies in despair, and perhaps at too early a period, before they had learned what strength they really had and how largely the traffic of the country would increase ${ }^{5}$.

1 Boyle, Hope for the Canals, pp. 5-6. 20; Palmer, British Canals, pp. 23, 25-26; Teisserene, Voies de communication, pp. 23-30.

2 Brit. Doc. 1883 (252), xu1, 1, 'Evidence before Select Committee on Canais, Appendix No. 18, pp. 25\%-61, statement of Lieutenant-General Rundall, R.F.

3 Brit. Doc. 1883 (252), xil, 1, 'Evidenee' of Mr Caleraft, Q. 61-62.

4 Ibid., 'Evidence' of Mr Abernethy, President of the Institution of Civil Engineers, Q. 1356-8.

5 Brit. Doc. 1872 (364), xm, 1, 'Report of Select Committee on Railway Amalgamations, Evidence,' Q. 5814.

In a recent work by Forbes and Ashford, entitled Our Waterzays, 1, 228, the authors say: "If, however, the canal eompanies must be regarded as in a great measure responsible for the rapid supersession of their undertakings by those of the railway companies, the predominant position of the latter is equally attributable to the failure of the Legislature to recognize the value of our waterways." From what we have already shown, when considering the subject of railways, it seems clear 
We have thus outlined the chief elements which entered into the decline of the canals; but we must not assume that this decline was always immediate, nor that all of them shared alike in the process of decay which we have just traced. We have scen that the carrying trade on the canals was the chief feature which gave them vitality in resisting the encroachments of the railways; and that the driving of the carriers off the canals was among the first of the railway tacties. But, in a few cases, the carriers were not to be so easily disposed of; they made arrangements with the independent canals as to the rates that would assuredly remain in foree for some time, and by securing favourable rates they were able to compete with the railways in the matter of local traffie. The through traffic, however, was dependent upon through rates, but as the railways had got eontrol of the important eanal links and had raised the tolls on these to a point that was usually prohibitory, the amount of goods carried on long through routes of waterway was comparatively insignifieant. We can, therefore, say that, for long distances, the competition of the canal with the railway was

that this statement is at least greatly exaggerated, if not wholly unfounded. In the 'Report of the Royal Commission on Canals and Waterways,' 1909, vir, p. 82, a similar implication is given, althongh not in the extreme form just noted; for it says: "But waterways in this country are also at a disadvantage, due not to the nature of things, but to a state of things which, in our opinion, has been to some extent brought about by errors in legislation, and by negleet on the part of Government and the Legislature." We question even this mild statement of so high an authority. From a close examination of the reports of committees in the decade 1840-50, we see that they invariably recommended that the eanal competition should be maintained, thus showing that they recognized the value of the canals, hut they were at a loss how to accomplish this; and if those who had so fully investigated the subject could not devise some suitable means of regulation, can we wonder that nothing was done by Parliament as a whole? Then, Parlianent was dominated by laissez faire principles: it was under this régime that the canais had brought so many benefits to Knglani, and it was but natural that the same policy should be allowed with the railways until it was cleariy seen how to change it for the better. Even the Committee of 18ty in their 'Third Report,' Brit. Doe. 1844 (166). xi, 5, and the Committee of 1846 in their 'First and Second Reports,' $18 \pm 6$ (200), xm, 85, and $1846(275)$. xill, 9:3, showed that great arvantages had come from the competition of the railways with the eanals; they said it was impossible for the Legislature to impose proper restrictions on the railway companies in this early stage: they showed that the public had derived great benefit from the cheaper earriage of goods, and urged that Parliament should not lightly sanetion any arrangements that would tend to de rive the public of this advantage. See also Brit. Doc. 1851 [1332], $\mathrm{xxx}, 1$, Report of the Conmissioners of Railways for the year 1850,' p. xix, on "Railway Tolls," third paragraph. The faet would seem to be that Parliament did not know what course to pursue, other than that taken, to regulate this new power; so far as Parliament was concerned, it was lack of knowledge, rather than lack of good intention, that allowed the canal competition to go on as it did until its elimination was assured. 
practically at an end by the middle of the century ${ }^{1}$. For short distanees, however, and especially where at least one terminus of the navigation communicates with the sea, canals have frequently held their own in competition with the railways ${ }^{2}$, and have in some cases paid good dividends to their proprietors ${ }^{3}$. We are, therefore, foreed to conclude, as we have already said, that the canals were probably handed over to the railways before their capabilities as a rival system were fully known.

Confronted with the fact that the railways were gradually abstracting the business from the canals, an oceasional advoeate ventured to devise a plan for keeping the watcrways competing with their formidable antagonist. One who had at first regarded the railway between Liverpool and Manchester as invineible was led soon after to a different conclusion; and, provided competition were properly conducted, he thought it possible for the private and independent canal carriers to not only recover all the earrying business that they had lost, but also to draw to themselves the carriage of passengers and light goods, which the railway had taken from the eoaehmasters and carriers on the turnpike roads. In order to accomplish these results, he proposed to get improved ressels to fit the navigation, with almost four times the carrying capaeity of those then in use, and employ steam haulage, so that, by the cooperation of the carriers and the navigation companies, the frcight on goods between these eities might be made as low as, or lower than, the actual cost incurred by the railway in earrying these goods. To get the passenger trade, he would put packet boats on

1 In Appendix 12 will be found one or two illustrations showing how the canals succeeded in holding their own against the railways.

Other examples of navigations which were successful in their competition against the railways were the Aire and Culder and the Weaver. These have been constantly improved, both as to the watcrway and the equipment for handling the traffic, and are even now active competitors of the railway for the earrying trade of their respective sections. Brit. Doc. 1872 (364), xill, 1, 'Report of Selcet Committee on Railway Amalgamations, Evidence,' Q. 3598 et seq.; Brit. Doc. 1883 (252), xıı, 1, 'Evidence before Select Committee on Canals,' evidenee of Mr Bartholomew, Q. $\%$ \% et seq.

2 Note, for instance, the Aire and Calder Navigation and the Weaver Navigation, above noted. See also Brit. Doc. 1872 (364), xill, 1, 'Evidencc,' Q. 3604 ct scy. Other examples are the Gloucester and Berkeley Canal, the Sevcrn Navigation, the Regent's Canal, and the Birmingham Canal Navigations.

The Leeds and Liverpool Canal, after getting free from railway control in 18.4, reduced its tolls by one-half and yet paid dividends of twenty-one per cent. Brit. Doc. 1883 (252), xm1, 1, 'Evidence' of Mr Bartholonew, Q. 827-32; 'Final Report of Royal Commission on Canals and Waterways, 1909. v11, p. 57.

${ }^{3}$ Brit. Doc. 1872 (364), xm, I, Appendix X, which gives full particulars of all the canals, including the dividends paid. 
the canal, each drawn by two horses and suitably built so as to attain a speed of ten miles per hour, the practicability of which, he said, had been established by more than two years' experience on the Paisley Canal in Scotland. By furnishing such facilities at less than half the fares charged by the railway, the canals and their carriers would be again favoured with public support, and would be able to retain their place as public servants. The diffieulties in trying to put such a plan into operation would have been insuperable at that time, on account of the fact that the various elements of the canal interest would not work together; neither do they operate in harmony to any extent even at the present day.

In 1841, after the Birmingham and Liverpool Junction Canal had lost half its tonnage and had been compelled to lower its rates by onehalf, its secretary brought forward a method by which he hoped to save the remainder of the tonnage from also going to the railway. His plan had much in common with that mentioned above. It was realized that, even if the canal companies gave up charging the full amount of their tonnage rates, this would not begin to make up for the amount by which the railway had reduced its freight rates; and, consequently, the essential thing was to save in the expense of transit. To do this, he would fasten a train of six boats closely together, one following the other, and draw the train by three horses in order to increase the speed of conveyance. The fast or "fly" trade he would treat in like manner, since it was in this that the opposition was severely felt; and it was by concentrating the traffic in large quantities, through having the carriers work together to make up full cargoes rather than a large number of boats with only a partial cargo, that the cost of conveyance would be reduced. In order to prevent the railway company from continuing to use the passenger and pareel trade as a weapon against the canal, he would introduce on the latter fast packet boats, like those which had been in successful use on the Scotch canals, and, by granting decreased fares and rates, would take much of the passenger and light goods traffic from the railway ${ }^{2}$. By disarming the railway of its most potent instruments of attack, it was hoped to place the canals on a more cven footing with their adversary. But here too, as in the former

1 Grahame, A Letter to the Traders and Carriers on the Navigations eonnecting Licerpool and Manchester, 2nd ed. (1834), pp. 6-36. A considerable amount of error is found in this pamphlet. See also his Treatise on Internal Intercourse and Communication, p. 159.

2 Skey, Report to the Committec of the Birmingham and Liverpool Junction Canal, on the Present Siate of the Competition betzeen the Canal Carriers using that Line and the Grand Junetion Railway Company, pp. 9-23. See also O'Brien, Prize Essay on Canals, pp. 15-21. 
case, the difficulty of getting the carriers to collaborate in carrying out such a plan would have been an almost insurmountable obstaele.

Another suggested method of enabling canals to withstand the opposition of the railways differed from the foregoing in detail, but fundamentally it involved the applieation of the same principle of pulling together. In the first place, systematic management should displace the existing confusion. Canal offices should be organized, where possible, with a responsible head for cach branch of the work, the receiving, the transporting and the distributing, and each of these heads should be acting under the supervision of one higher up. In this way, all immediate canses of inefficiency and error would be abolished, so far as the internal management was concerned. Then the various carrying establishments should be brought into accord witi one another so as to work upon an intelligible principle for the general good. The carriers alone could not work together in such a way as to adhere consistently to any comprehensive plan; and even if they eould, the tendency would be toward a monopoly, from which the public interests would probably suffer. The canal companies had no authority to enforce general regulations among the carriers in regard to eooperation; and, moreover, they greatly needed a much closer understanding among themselves. It seemed, therefore, as if the owners and shippers of goods were the only parties which could establish some body that wonld harmonize all interests; and it was therefore proposed that these should unite and appoint an agent to act for them, one who would hand over their products for transportation to that carrier who offered the greatest advantages ${ }^{1}$. The same barrier wonld have been found in any attempt to put this plan into effect as was noted in connexion with the other two suggested remedies, that is, the practical impossibility of securing sufficient united action to carry out such a contemplated project.

It would take too long to consider all the plans which have been brought forward to place the canals in a position to compete with railways and to be effective agents in the transportation of commodities. The Act of 1872, requiring railways to maintain their canals in working order, did something to arrest the decline of these waterways, although it was so meagrely obeyed that it had little constructive effeet. In the last two decades of the century, partly as a result of the agitation for lower freight rates, further efforts were made to work out a solution of the canal problem and these appear to have culminated, for the time being, in the labours of the rceent Royal Commission of 1906. After

1 Boyle, Hope for the Canals, pp. 29-43. See also Herepath's Railuay Magazine, N.S., 1v, pp. 373-4, address by "A Canal Proprietor." 
a thorough investigation of the entire subject, that body decided that if waterways, or certain main routes of waterways, were placed under a uniform administration and so improved as to provide the best system of meehanical traction, of transport, and of loading and unloading, the trade on these waterways would be largely inereased, provided that carriage upon them were substantially cheaper than that by railway'. They recommended that, as the first step in any comprehensive scheme of waterway development, it would be desirable to take in hand four main routes for analgamation and gradual but continuous improvement, namely, those which radiate as trunk lines from Birmingham, the canal centre of the Midlands, to the estuaries of the Humber, Thames, Severn and Nersey, and which have been ealled "the Cross'." These would tap the great mineral and manufacturing sections of the kingdom and give direct outlet to the four great ports of Liverpool, Bristol, London and Hull. These four routes should be amalgamated under a single control and should be so improved as to permit the use of larger barges for earrying an immense volume of long-distance traffic which did not require the highest speed. Sinee private eapital had not sufficient inducement to embark in this enterprise of improvement, the canals along "the Cross" should be taken over by the Government and paid for by the issnance of "waterway stock;" and the development of this four-branched water route should be effected by public funds. The final eontrol of the system should be put in the hands of a Waterway Board, created by the Government ${ }^{3}$. There are so many reasons why the Government should not subsidize inland waterways, that we think the half-hearted recommendation of the Majority Report should be adopted and acted upon only after much more convincing argument has been adduced in favour of it ${ }^{4}$.

But, to return to the period before the middle of the nineteenth century : to all the other carrying agencies of that time it seemed as if the railway would inevitably abstract their business from them. They seemed to be waging an unequal contest with a powerful antagonist. The proprietors of coaches, waggons and vans realized at the outset that the increased speed and better facilities of the railway would soon take most of the traffie off the road, where the two systems came into

1 - Final Report of Royal Commission on Canals and Waterways,' 1909, vir, p. 84.

2 Ibid., vIl, pp. 93-94, where the details are given, and pp. 188-9, where a summary of their recommendations is given.

3 Ibid., vir, pp. 165- 75 .

4 Ibid., v11, pp. 84-85, 17t-5. In the Traffic World(Chicago), xil (1913), pp.420-4, 419-53. I have dealt more fully with the present-day conditions and the recommendations of the Royal Commission of 1906 , to which article the reader is referred for more detailed consideration of this question. 
eompetition; and most of the eanals likewise soon found that their day of prosperity and independenee was hastening to its elose. Closely connected with the conditions of the internal trade was the welfare of the coasting trade; and it would be strange indeed if this too were not influenced by the activity of the railways. We have formerly observed that, when the Oxford Canal, for example, was being agitated, and a Bill therefor was before Parliament, the eastern coasting trade petitioned against it on the ground that when the metropolis reecived eal by means of this and other internal water connexions, the amount of coal that came from the north to London by the sea route would be greatly decreased, and this, in turn, would be detrimental to the maritime interests of the kingdom. In the same way, it was thought by some that the development of the railways would be prejudieial to the wellbeing of the marine; and in 1846 memorials of the shipping interests of Sunderland, Shields and the Tyne were presented to the Treasury, requesting that efficient measures might be devised for preserving the coal coasting trade from ruin through the conveyance of this northern coal southward by railway. It was admitted that coal eould be earried by railway from the Durham and Northumberland collieries to London at eharges lower than those for which ships could be navigated; and representation was made that to jeopardize or destroy this northern marine, while developing the railways, would be contrary to the best good of the kingdom, and would, in effect, be erippling "the right arm of England's strength ${ }^{1}$." But it is evident that if railways were allowed to earry coal from the mines to the interior portions of the country, they could not be prevented from earrying it to London. The point which we wish to emphasize, as a concluding thought, is that, within the first twenty years of the railway era, this young giant had overshadowed all other systems of earrying, some of which had taken centuries for development.

1 Railzay Chronicle, April 25, 1846, pp. 418-19, and June 13, 1846, p. 582. 


\section{APPENDIX 1}

\section{RIVER WEAVER NAVIGATION}

At the end of the seventeenth century and in the first two decades of the eighteenth century, the salt industry of Cheshire was coming to occupy an important place. Before 1699 , most of the coal that was used in the refining of the salt was brought from Staflordshire by land carriage, and the salt was taken, also by land carriage, to Frodsham Brilge near the mouth of the Weaver, and to Worcester and Bristol in the south, where it was loaded into vessels which carried it to other parts of England, to Ireland, and some to Northerı Europe.

The cost of carriage of salt seems to have varied greatly at different times of the year, and in some cases excessive charges were made for this service. This is evident from the following letter contained in the Brit. Mus., Add. MSS. 36,914, p. 3 :

"Sir, 'tis very observable how the rock-men have over-acted their part in conveying their rock (salt) from their pits...by giveing excessive rates, as some days 20s. per ton to Frodsham Bridge-the like for seven miles has not been known-and other days their wages were so great that pcople were so blinded with it, that they neglected their necessary duties at home, in plowing, sowing, etc. This hurry and charge is...vain, and labour and money near lost, for by it, they too greedily presumed to have the advantage of the surplusage weight, but they are nickt, as you'l finde in the Act, for all salt... after the 15th day of May (1699) shall be weighed wherever its landed at 75 lbs. the bu., which is a subject of lament among themselves...."

The great demand for horses to carry salt to Frodsham Bridge and Worcester was supposed to be the reason why the horses with which strangers came to Droitwich and other salt towns were taken from their pastures, were used for carrying salt to Worcester, and were then found near this latter place when they had been unloarled. So often was this the ease, that hotel landlords commonly advised their guests not to put their horses out in the pasture, but to keep them in the stables (v. Brit. Mus., Add. MSS. 36,914, p. 9).

On accomut of the difficulty in the matter of transportation of coal and salt. those manufacturers of salt which were more distant than others from the coal supplies and from the markets for the finished product found it difficult to compete with their rivals who enjoyed greater advantages than they in these respects. For example, the cost of coal at Northwich was greater than at Middlewich, because it had to be brought a longer distance by land carriage from the Staffordshire coal mines. On the other hand, those manufacturers who were nearer the supply of Staffordshire coal had a longer haul before they could bring their salt either to the Mersey or to the port of Worcester. A combination of the manufacturers had been 
formed at Droitwich (v. Brit. Mus., Add. MSS. 36,914, p. 10), and probably also at Middlewieh and Nantwich, to control the price of salt, and an attempt made by a private manufacturer to break up this monopoly had ended in failure. But a certain Mr Slyfford, and one or two associates, who owned salt deposits at Winnington Bridge on the Weaver, just below Northwich, saw that if they could get coal from Lancashire brought up the Weaver to their works, at a price that was lower than that for which their rivals could get it, and if they could have their finished product earried down from their works to Frodsham Bridge at a lower rate than their rivals, the trade in salt would be largely in their hands. For this reason, they proposed that the river earriage should be utilized rather than land carriage, and in order to make the Weaver, which in its original state was navigable only at high tides, an effective agent for their carrying business, a Bill was brought into Parliament asking authority to make this improvement.

Immediately the opposition was aroused. The other manufaeturers said that if the Weaver were made navigable only to Northwich it would advance the interests of only three or four proprietors of salt and salt rock, and would eertainly ruin the estates of several proprietors in other places, as at Middlewich, as well as some thousands of people adjacent, whose livelihood depended on the carrying of salt and coal (v. Brit. Mus., Add. MSS. 36,914, p. 10). The oplosition of the carriers found vent in many petitions to Parliament, of which the following is a fair sample (v. ibid., p. 16):

"The Iumble Petition of several Farmers \& Freeholders in Bucklow Hundred in the County Palatine of Cliester, in behalf of themselves and neighbors

Sheweth

That your petitioners having heard that there is a Bill presented to this Honorable House for making the River Weever navigable some few miles, which Bill should it pass would extremely impoverish your Pctitioners by depriving them of the Benefit they receive by earrying of coals to their own Houses at spare times in summer, and from thence to the Wiehes in Winter, whereby they are the better enabled to pay their rents and provide for the comfortable support of their families.

Wherefore

Your petitioners makc it their Humble Request that before the Bill be suffered to pass their objections against it may be heard from their Counsel or otherwise as this Honorable House shall be pleased to direct.

And your petitioners shall ever pray, ete."

Similar petitions to Parliament were sent by "the poorer sort of inhabitants of Bucklow Hundred" (ibid., p. 18), "the poorer sort of inhabitants of Northwich" (ibid., p. 18), "the poorer sort of inhabitants of Edesbury Hundred" (ibid., p. 19), "the farmers and freeholders in Northwich IIundred" (ibid., p. 20). These all presented the "ruin" which would ensue to the earriers should the Bill pass. But it is doubtful if these would have been eflective in defeating the Bill, had not the "prominent landlords and gentlemen of rank" taken the matter up. among whom were Lord Gerard, Thomas Cholmondeley, G. Warburton, and Sir Willoughby Aston. These men were presenting a petition to Parliament against the proposed improvement, and in order to give it more weight they sent around the following letter to get signatures to be attached to the petition (ibid., p. 20):

\section{"Gentlemen}

By intelligence from London and some practices in the country we find that the projectors concerning whom we have formerly troubled you, have renewed their desion and prepared a Bill now ready to be presented in Parliament, for making 
the Piver Weever navigable from Frodsham Bridge towards Northwich. We think it needless to represent to you how injurious this Bill would prove to those who have lands lying near the river; and Destructive to the trade of this County, especially of Middlewich and Nanıtwich and all the adjacent salt works; since the easy import of coals from Lancashire to Northwich and export of their salt would certainly enabie the proprietors there to undersell and ruin all the other salt works which are supplied with coais from Staffordshire or Wales; whereby about four thousand families, now subsisting by the land carriage of those coals, salt, and malt, would be utterly ruined and left to be maintained at the charges of their respective parishes; and the Rents of those lands which they inlabit, and of those near their Roalds would be impaired. After which some few proprietors of Salt Rock and Brine in and near to Northwich (who alone can be enriched by this project) having engrossed the trace, would impose the price of salt at their own pleasure, and raise their fortunes on the ruin of the country. We have prepared a petition to be heard by our counscl against the said Bill; and if ye approve it, we desirc your concurrence with us, believing your subscription will be as serviceable to the country, as obliging to

We send the like petition Gentlemen

$\left\{\begin{array}{l}\text { to other hundreds for expedition, } \\ \text { intending to unite them all in one Roll. }\end{array}\right.$

Yr humble servants."

(Here follow their names.)

Sinilar petitions were sent in by the "High Sheriff, Deputy Lieutenants, Justices of the Peace, Gentlemen, and other inhabitants of the County Palatine of Chester" (ibid., P. 24); by "the Inhabitants of Warrington, in the County of Lancaster" (ibick., p. 25), who protested because if the Bill should pass it "would subject the salt of Cheshire to a monopoly ;" and by "several gentlemen and others in that part of Staffordshire adjacent to Cheshire." who said that if the Bill should pass, it "would ruin most of the salt works in Cheshire; it would also greatly impoverish that part of Stalfordshire which the petitioncrs inhabit, by stopping the great vent of eoals thence to the Wiches and by destroying that commerce and carriage whereby the farmers are enabled to pay the greater rents and many of the poorer people wholly subsisted" (ibid., p. 28).

In Brit. Mus., Add. MISS. 36.914, p. 29, we have "A Short Aceount of a Design for making the river Weever in the County of Chester Navigable, from FrodshamBridge to Winnington-Bridge, heing about five or six Miles only." This is really a series of reasons against the projeet. It was intended for circulation among the members of the House of Commons, had the promoters proceeded in their purpose. Its substance follows:

This navigation is a design projected for engrossing the trade of selling salt and rock-salt into the hands of two persons only, whercby a great many families would be ruined and undone. As the trade now stands, all the proprietors of salt are upon equal terms throughout the whole county of Chester. (This, as we have already seen, was entirely wrong.)

Should the river Weaver be nade navigahle from Frodsham Bridge to Winnington Bridge, there will be the following evil consequences:

The two persons in this combination have salt works and rock salt adjoining Winnington Bridge where they intend to end the navigation. To there they can get coal cheap from Lancashire by water; hence, with no land carriage to trouble them, either for coal or salt, they will undersell all other salt works that have land carriage for both coal and salt. These two persons will drive out rivals, and therefore will be able to make their own prices for salt, "as formerly Northwitche did, till the erection of new salt-works in the county reduced the price of salt from 


\section{Appendix 1}

above $4 s$. to $2 s .6 d$. per barrel." Nothing but an abundance of salt will keep down its price.

The ruin of other salt works will be followed by adiditional evil results:

1. The collieries in Staffordshire and some in Wales will have their market reduced.

2. Those poor people who live by earriage of eoal and salt must starve or be a charge on the parishes. The same thing will happen to those who now carry malt to the Wiehes from Derbyshire and Nottinghamshire. 'The trade of malt for salt will be at an end by the destruetion of the salt-works, which will effectually and speedily be aceomplished, "should the monopolizing projeet of this self-ended navigation take effeet."

3. Continual overflowing and spoiling of the meadow grounds, which cannot be avoided because the river banks are low, and the water will be raised in the river by means of locks. The grazing lands along the river will also be injured; and this will cause reduetion of rents of these lower lands.

Many more mischiefs are so obvious, "that 'tis hoped this self-designed project shall never be eountenanced by Parliament, to the great prejudice and injury of the publick, for the sake of a private interest." (The feeling against this navigation was very strong; and the faet that we find no petitions in favour of it would seem to indieate that it had a selfish end.)

In 1709 , the question was revived apparently with more seriousness, and the people became alarmed at this pernicious self-ended project. Every man who had any influence with the members of Parliament used his position to show them, by letters, the terrible evils that would result from making the Weaver navigable. The great hostility against the Bill came from all sourees; and the vigorous opposition to it may be gathered from the letters of 1709, given in Brit. Mus., Add. MSS. 36,914 , pp. $34,40-45$.

This enterprise, though held off, could not be completely turned down, and by 1715 the promoters had "a great many friends" who were "very industrious" in behalf of the scheme. It had been so nuch talked about, that instead of losing ground it had gained inereased support (ibid., p. 54). A letter of May 16, 1715, shows the way in which the opponents of the Bill regarded it (ibid., p. 40):

"I was in hopes this ruinous project had been so often battled that we might have lived seeure from any further attempts of strangers to bring sure destruction upon so many poor families in this eounty, and so great damage to many other; but now to help forward their designs, they have got some assistants from Liverpool who no doubt have either our interest or their own very much at heart...." Then the writer goes on to give reasons against the measure.

In that year, on June 14, the Bill was read the second time, but it was finally accorded the same treatment as in former years, and was in effect thrown out (ibid., p. 58).

In order to make their ease stronger, the promoters of this navigation were supposed to have ordered to Frodsham Bridge such great numbers of ships that it was impossible to get enough white salt and rock salt to give them a full load, without keeping them lying there for many weeks, and some for months (ibid., p. 66). This would tend to show the need for vastly increased faeilities for transport. But, however this might be, in aceordance with another petition to them, the fouse of Commons, in January 1719, ordered a Bill to be hrought in for making the Weaver navlgable (ibid., p. 68).

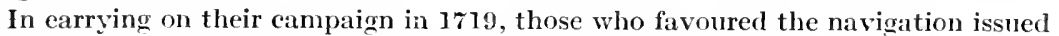
a pamphlet showing the 'Reasons for Making the River Weaver in the County of Chester Navigable;' and demonstrating that it would be of "very considerable national advantage," as well as of loeal benefit (ibid., pp. 86-90): 
The pamphlet begins by giving some account of the trade of those parts that will be affected by making this river navigable. The salt trade is the most important of all.

The mines of rock sali which supply all the salt refineries erected in Ireland, and in several parts of Great Britain, viz., Cheshire, Lancashire, North and South Wales, Bristol, ete., lie about one-quarter mile from Northwich. And the sall springs and salt works, which supply Ireland, Wales and several counties of England, with great quantities of white salt, are at Northwich and within three or four miles of that town.

This white salt and rock salt is brought by land carriage to the ships at Frodsham Bridge, and is mostly carried on horses' backs, by reason of the badness of the roads. The ships usually come in flcets, and henec the men and horses kept for carrying this salt have sometimes more than they can do, and at other times have scarcely any work. This difficulty is tending to ruin the salt trade. This winter, some ships have lain there three months before they could get fully laden; and such a thing spoils the trade and will eventually drive away the trade entirely, if not prevented.

The best, and perhaps the oniy, expedient that can preserve the trade is to make the river Weaver navigable. This wonld make carriage considerably cheaper, and give greater dispateh to the shipping.

Other Advantages of this Narigation:

It would allow England and Ireland to get their salt at home, and thus save buying foreign salt. But it might also enable Cheshire to supply salt to the nortluern parts of Europe.

Opening this navigation would make a way for attaining a good share of this trade with Northern Europe. Hence it would benefit both the kingdom and the county of Chester.

It will create new employment for much shipping. breed a great many seamen, cmploy many of our poor, and bring in considerable sums annually to our kingdom.

It wouk necessitate fewcr officers, and less charge and trouble of frequent weighing of the salt.

Then the pamphlet takes up what it calls some "weak but obstinate objections," namely :

1. That it would ruin the salt works at Middlewich and Nantwich.

This, if it were true, is not a reason why such a great public good should be declined, for fear of interfering with the private interests of a particular place or two. For by this navigation all those places that get salt from Cheslire would get it much cheaper than at present. But this will not ruin these two places, for as they are four miles ncarer the coal supply of Staflordshire they will be able to get their coal chcaper, and this will offset the extra four miles of land carriage necssary in bringing their salt to Northwich.

2. That it will overliow and spoil the adjacent lands.

This is refuted by the experience of other rivers; such lands are less liable to be overflowed than before the navigation was made. But, on the other hand, the adjacent lands are increased in value, because of the power of overflowing them on occasions of great drought or dry seasons.

3. That it will take away the livelihood of those who were formerly maintained by land carriage.

But particular employment must give way to the pullic good. Then, too, these carriers, because of the uncertain arrival of ships, have only a sorry livelihood, notwithstanding the great prices they get for carriage. Their horses, etc., have to be kept, whetlier there is work or not. Their present business is precarious and they would make a better living by going into dairying. Noreover, the increased 
trade brought by the navigation would give increased work for all classes of people.

By 1719 the opposition to the navigation lad assumed a somewhat different character from what it had been shortly before. Formerly the question was, whether Northwich should be allowed the advantage of this navigation, by which that town might be enabled to undersell, and consequently to ruin, all the other salt works, with the trade depending upon them, and then impose its own price of salt upon the nation. But sinee the diseovery of the rock salt, the projector of this design, being a proprietor of the rock, a considerable merehant, and naturally qualified for a great undertaking, might, by his rock salt, not only ruin all the brine trade of Northwich and the rest of Cheshire, and then impose his own price of salt upon the nation, but might also draw all the money in spccie to himsclf at London. So that, by 1719 , the question was, whether all the ancient Wiches and other brine salt works in Cheshire, and the trade depending on them, together with the landowners adjacent to the river, and the greater value of all the other lands in Cheshire by the land earriage, should be destroyed for the interest of a few men, without any public advantage (ibid., p. 95).

Other objections to the navigation were brought forward, as the project seemed nearer to obtaining Parliamentary sanction:

1. The boats would have to be towed up the river by loorses, and as this eountry was enclosed landowners would bc obliged to make gates at their own expense. The negligence of boatmen in elosing the gates would cause trouble in keeping each man's animals from his neighbour's lields. Hence there would arise quarrels, breaches of the peace, etc.

2. Several landowners had large estates along the river, "where their deer, sheep, rabbits, and other houschold provisions are kept." Boatmen were illdisposed persons, and as they would be compelled to pass through the grounds of these estate owners they would feed their horses on the landowners' hay and corn, at times when they would be waiting for the violence of the tides or floods to subside, or when awaiting the rassing of the water by the locks. Or the boatmen might steal their deer, shcep, wood, corn, fish, etc., and perhaps break open the houses of these gentlemen.

3. The farmers who lived along the river would not be able to use their fords to eross the river after it were made navigable, without wooden bridges that would obstruct the passage of the boats. Then, too, these bridges would be destroyed by the ice, as "often happens to the danger of the stone county bridges."

4. Higher than where the tides flowed, which was about thrce miles above Frodsham Bridge, the river was very narrow, full of roots of trees, and in many places, both above and where the tides flowed, so shallow that half the channel lay dry several months together in summer time when the tide was out, and in the other half the water would scarcely cover the stones in the rocky fords. This would prevent the river being made navigable, exeept at great cxpense. In cutting it wider, which would be made difficult by the roots of trees, there would be great loss and damage to the landowners, because some of their land would have to be used in making the towing paths also. In making it deeper, whieh could not be done but by eutting the bottom lower or by raising the water higher, there would be other difficulties; for if the river-bed were eut lower the rocky shallows must be cut at great expense, and the foundations of two stone eounty bridges across the river would be undermined; and if the water were raised higher, locks would have to be made, and these would cause the water to overlow the banks, especially in floods. They would also cause the water to be longer in passing off the ground, and thus this rich land would beeome bog or marsh land. 
5. This navigation would take away the living of those who were then carriers by land. The landowners were aceustomed to employ the tenants' teams in earrying, and so the tenants were enabled the better to pay their rents. If this carriage should cease, rents would fall, the tenants that have leases would be ruined, the landlords impoverished, the taxes on their lands would have to be abated, and henee the nation's revenue would be lessened. In reply to the question as to why these earriers could not turn to dairying, it was pointed out that some of them werc very poor people, and kept or hired horses for the purpose of carrying.

6. Northwich would, by this navigation, get sueh an advantage over all other salt works that she would be able to dictate the price for salt. Against this, it was shown that the Justices of the Peace had power to fix the price of salt; to whieh it was answered that if this Northwich projector should ruin the other salt works he would then be able to set his own price for salt.

In Brit. Nus. 35\%. b. $9(76)$, we are shown the desirability of the proposed navigation for the benefit of the salt trade of Cheshire, the opposition of Liverpool to the Bill, and the trouble with Mr Vernon, who had large salt works at Winsford. This difhieulty is very elearly stated in Brit. Mus. 35\% . b. 9 (78), 'Reasons Humbly Offered by the Trustees of Richard Vernon... against the Bill for Repealing Act 7 Geo. I for making River Weaver Navigable.' Other 'Proposals Humbly Offered for making River Weever Navigable from Frodsham Bridge to Northwich' are given in Brit. Mus. $35 \%$. b. $9(75)$. In spite of the endless repetition of the abovementioned objections (for which see also Brit. Mus., Add. MSS. 36,914, pp. 117-23), and the strong opposition encountered, the Bill passed into an Aet in 1720, under which this river was made navigable for nearly twenty miles from its mouth, that is, to Winsford Bridge. By this Act, the $\$ 9000$ subseribed to earry on and perfect the navigation could be increased by as much more, if necessary. In order to repay the cost of the improvement, a duty of $15 \mathrm{~d}$. per ton was to be taken on all goods carried on the river; and after payment of the eost the tonnage duty should be but 12d. per ton, the whole of whieh was to be applied for the public purposes of the county of Chester for ever. It was expected that, after the eost of the navigation had been defrayed, the county would get not less than $\$ 1500$ a year (Brit. Mus. 357. b. 9 (72), 'Reasons Humbiy Ollered against Bill for Repealing Aet 7 Geo. I for making River Weaver Navigable'). The merehants of Liverpool opposed this measure. Since the river was to be made navigable by three private undertakers at their own cost without any contribution from the eounty, it was thought unreasonable as well as unjust that the county should benefit financially from it, and that any money which would go to the county would be an overcharge on the navigation which would impede and burden trade (Brit. Mus. 357. b. 9 (73), "Reasons Humbly Offered against allowing County of Chester any part of the Tomnage Duty for making River Weaver Navigable'). An agitation was, therefore, started to repeal the Aet, but it was unsuecessful, and the work of eanalization began in 1721 . All revenues from tolls, in excess of the amount required to pay the eost of construction and maintenance, were to be devoted to repairing the roads and bridges of the county, and for any other purposes determined by the Justiees.

In 1759 the administration of the Weaver was entrusted to a body of selfperpetuating trustees, under whom the navigation works were extended and improved and made more enduring. About $180 \%$, the navigation was completed by a canal of four miles in length from Weston Point, where it joins the Mersey, to Sution loek; this was intended as a surer course than the lower part of the Weaver, so that boats could enter or leave at all conditions of the tide. For further improvements, see Minisière des tiazaux publics: Quatrième Congrès International de Navigation Intérieure, temu à Manchester en 1890, Rapports des délégués français sur les travaux du congrès. pp. 39-5.5. See also Hanshall, IIistory of Cheshire, p. 84. 


\section{APPENDIX 2}

\section{SHAPLEIGH ON HIGHWAYS (1749)}

He says (p. 4), "For, it must be granted, that there has been always, and now is, great reason to complain of the neglect of the repair of most roads within this kingdom; and that it has always bcen found by experienee, that the many laws, which have hitherto been made concerning their repairs, have never met with the desired success. Hence there must be some fundamental error in these laws, and there is need of further regulation."

He thinks the fundamental defect is in permitting parishes, towns, etc., to be presented or indieted for not repairing their roads (p. 5).

(p. 6) His method is:

1. To prove that the presenting or indicting of parishes, towns, ete., for not repairing their public roads is generally found to be hard and injurious to partieular persons; that it seldom, if ever, answers the intended design; and that it eauses the laws relating to the surveyors of the highways to be greatly neglected. Consequently, both these prosecutions should be entirely done away by law.

2 . To prove that the most just and most effeetual way to have the public roads kept in good and suffieient repair is to oblige the surveyors to do their duty.

3. To offer some amendments and additions to existing laws, which will more easily and more effectually oblige the surveyors to perform their offices, and the parishioners to do their six days' work.

To prove the first.

Act $3 \& 4$ W. \& M., c. 12 , see. 3 , allows the surveyors to be men in mean circumstances, men who have no property in the parish chargeable to the repair of the highways; sinee their qualification is $£ 10$ per annum of real estate, or $£ 100$ personal estate. But by the same Act a tenant of $£ 30$ a year may be appointed surveyor. If none so qualified can be found, then the Act directs that the most responsible persons within the parish are to be chosen. Under such mean persons for surveyors, it is not prudent nor safe for the rest of the parishioners to repair the roads, under their own direetions, lest their officiousness should hereafter be used as an argument of their obligation to repair them in their own right.

And, as laws now are, the parishioners have no eoercive power to oblige these mean persons to discharge their oflieial duties. Suppose the surveyor were too idle or obstinate to call out the parishioners to do their six days' work, or to oblige them to work honestly; would it not be unjust that the whole parish should be presented for negleet? The innocent would be punished with the guilty. Some parishioners, of course, would, and others would not, work voluntarily; hence the need of the surveyor to force them (p. 9).

It is unjust to punish the innoeent with the guilty. But Shapleigh says that the innoeent bear the burden of the surveyor's transgressions, while he goes free. (Evidently, therefore, the law which imposed a penalty upon neglect of either surveyor or parishioner to do his duty was found to be unenforced.) For in many places, especially in the Western eounties, the landlords of such tenants as are at rack-rent pay the rates, taxes, ete., for the tenants; and hence no proeess that ean issue upon any such presentment or indictment of the parish can in any way affect the surveyor's property. 
(p. 10) But suppose, again, that the parish surveyors should contribute some small matter only out of their own property toward the parish levies, or should happen to be sueh tenants as have all their rates, taxes, ete., paid by their landlords, and live in a parish where one or two persons own most of the property; suppose also that the landlords live at a great distance from the parish, and that the surveyors should be prejudieed against the stewards of the landlords (which is quite probable from their insolenee and imperiousness) and should refuse to do anything for repair of the parish roads; would it not be unjust that the innoeent landlord should be punished by sueh expensive proeeedings as presentments or indictments for an offenee which he could neither remedy nor prevent? This is no mere supposition, but actual fact.

(p. 12) Take the common ease: suppose the surveyors call ont the parishioners to their statute duty, and only two or three of the best houscholders and landholders obey the eall. Suppose that (beeanse of the surveyors' laziness, unwillingness, or probably from bribery or corruption) the surveyors do not foree the rest to come out to work, and thereby the parish is presented or indieted for not having its roads properly repaired: would it not be very unjust that those parishioners who have done the work required by law should still be punished ten or twenty times as mueh as the other householders, etc., who ought to have done their work, and as the surveyors who should have forced the work to be done?

(p. 13) This method is wholly ineonsistent with justice and reason. As the law now stands, every person having an estate within the parish is liable to be punished for not repairing the highways; and yet the law has not given him proper or suffieient power to compel the surveyors and defaulters to do their duty and contribute their part towards the repair of the public roads. So that the law in this particular instance punished persons for not doing that which it was not in their power to do.

Next, to show that notwithstanding these presentments and indictments are too often made against parishes, towns, etc., for not repairing their roads, yet such proceedings seldom, if ever, answer the end intendcd by them.

The faet is shown by experienee, for everyone observes that there are some parishes whieh have presentments or indictments almost perpetually hanging over their heads. This eould not possibly be the case if these proseentions were so effeetual for the repair of the roads, as some persons erroneously insist upon. The fact is beyond power of eontradiction.

(p. 15) From the nature and reason of such presentments and indictments, no good effect can possibly be expected from them, either to the publie or to individuals (exeept lawyers and others who attend the eourts of justice). For since the surveyors are mean persons, their payment toward the fine imposed on the parish is so small as to have very little effeet upon them; espeeially if it be considered that they are sure to have the laying out of this money-whieh they often do, more to their own benefit than to the improvement of the roads.

(p. 16) Besides, the presentment or indietment specifies particular parts of the road (those that are worse than the rest) to be repaired. This does not effeet a thorough reformation of all the roads of the parish.

(p. 17) Again, these proseeutions are often made against parishes, towns, etc., in the winter; and it costs the parish at that time of the year far more to repair its roads than if it were at a seasonable time of the year. If the road is complained of in the winter, and presented then, it has to be repaired then.

No result can be derived from such prosecutions, but the expensive repair of sueh places as happen just then to be out of repair; for these grievous prosecutions cannot reform the inclinations of the parishioners in general, nor make them more 
willing for the future to repair their roads. The power of repairing rests with the surveyors; and, therefore, as the parishioners, before the prosecution, could not safely repair the roads without the coneurrenee of the surveyors, so neither ean they do it after the prosecution is begun or ended. Can anyone think that such prosecutions will make the surveyors more diligent than they were before; when, as we have shown, they are seldon one penny out of poeket by all the presentments or indietments which the law ean throw upon the parishes, towns, etc., for which they are surveyors? They would rather be pleased than displeased with such prosecutions.

(p. 19) "This argument, I must own, earries great weight with me against the allowance of any sueh proseeutions; and I verily believe that all eonsiderate and disinterested persons must entertain the same opinion of it with myself."

But the vexation, oppression, expense and uselessness of these prosecutions are not the only reasons for laying them aside; Justiees of the Peaee would be more willing, earnest and ready to hear such complaints as are to be made against the surveyors and defaulters, and to enforce the laws against them, if they were restrained from exereising this favourite power of punishing all the parishioners promiscuously, by way of presentment, whieh most of them now are apt to think their safest and easiest remedy. Those interested would be more diligent in making such eomplaints of the surveyors and defaulters to the Justices of the Peaee, in case they found they had no other redress; and the Justices, in turn, would be more ready to give an attentive ear to sueh eomplaints.

To prove the sccond, viz., that the best zeay to have the roads repaired effectively is to oblige surveyors to do their duty.

(p. 20) If the six days' work were done faithfully, it would be sufficient in most eases for repairing the publie roads. Wherever it were otherwise, Aets $3 \& 4 \mathrm{~W}$. $\&$ M. and 1 Geo. I have given the General Sessions power to make a rate for that purpose, not exceeding fid. in the pound for any year. If, then, the due execution of the above methods would effectually repair most of our public roads, whenever they are out of repair, it must always happen (unless in ease of floods, great frosts. etc.) through the surveyors' default, or that of the parish, or of partieular individuals in the parish. And the laws have given. Justices of the Peaee and surveyors power to punish delinquents.

(p. 22) Under Aet 5 Eliz., e. 13, sec. 8, it is enacted that surveyors, under pain of $40 \mathrm{~s} .$, shall within one month after any person has omitted to do his statute duty, present the offence to the next Justiee of the Peaee, who shall certify that presentment at the next General Quarter Sessions, whieh Sessions shall immediately inquire of such default and assess sueh fine for it as they, or any two of them, shall think fit. With such authority, it is easy for Justices of the Peace to perform their duty; and when defaulters are found guilty, Aet 2 \& 3 P. \& M., e. 8, infliets a penalty on them that is double the value of their neglected labour. Under this Justices ean safely act, for they are simply earrying out their duties in eertifying the surveyors' presentment to the next General Quarter Sessions. The punishment is inflieted by the Court of Sessions upon the defaulter.

We have now shown that the laws have given power to the Justiees of the Peace to punish defaulters for non-repair of roads, and the surveyors for negleeting to present sueh offenders. Aet 5 Eliz., c. 13, has given the Justices an easy method of procedure.

Next, we show that this method of punishing the surveyors for negleeting to present defaulters for omitting to do their six days' zeork is just and equitable and the most effectual to obtain the end desired. For by this eaeh delinguent is punished according to the assistance which he ought, but negleeted, to give towards repair 
of the roads. By this way of proeeeding, the landowners and the rest of the parishioners are not all proniseuously punished, without making any distinetion between those who either have obeyed or else were willing to obey the directions of the law, from those who either have negleeted or else refused to observe its orders. By this way, the surveyors are not capable of triumpling, nor of benefiting themselves by their own neglect or open defiance of the law; but the innocent and faithful observers of the law are exenpted from that pumishment, which is, with a just and distinguishing hand, inflicted on each of the olfenders with equality and prudent distinéion.

(p. 26) But we have to show that this is not only the most just but also the most effeetual way to obtain the desired end.

Since the law has appointed proper officers to take eare of road repairing, that nethod must eertainly be the most effectual whieh has the greatest power and infiuence, and is the most eapable of eompelling these officers to do their duty, and effectually care for and suffieiently repair the roads. But presentments affect very few of sueh surveyors; and in general sueh proseeutions are rather beneficial than otherwise to them. Whereas, on the other hand, by Act 5 Eliz., e. 13, they are liable to be punished $40 \mathrm{~s}$. for not presenting defaulters; and, by Act 1 Geo. I, they are, for most cases of neglect of duty, liable to pay $\$ 5$. As this last method, therefore, is the most eoercive, and indeed the only effeetual one to foree the surveyors to do their duty, I think there cannot be the least doubt but that it is by much the most effeetual way to have the roads repaired and kept in repair. (Apparently, Shapleigh thought that the law which imposed the greatest punishment for neglect of duty was the most effectual for repairing the roads.)

Regarding the third-some amendments of and additions to the laws, in order the more effectually and easily to oblige surveyors to perform their duty, and the parishioners their six lays' work.

(p. 28) We have said that Act 5 Eliz., c. 13, sec. 8, gives a safe and easy method for Justiees of the Peace to proeeed in punishing surveyors or parishioners for neglect of duty; yet it is not so easy for there are later contradictions. Act 22 Car. II, c. 12, see. 9, says that complaint of defaulters to the publie roads is to be made to the next Justices of the Peace, who are requirerl, on the oath of one witness, to levy the penalties. By Aet 22 Car. II, c. 12, see. 12, the method authorized is the same as that of Act 5 Eliz., c. 13; and as Aet 22 Car. II is later than Aet 5 Eliz., and these two clauses seem diametrieally opposite to each other, it is hard to tell whieh is the best and safest method to be followed. Justices are rather unwilling to proeeed.

(p. 29) Again, by Act $3 \& 4$ W. \& MI., c. 12, sec. 9, all offences and neglects respeeting the publie roads are to be presented by the surveyor, on his oath, to the Justice of the Peace. But this Aet does not direet what the Justiee shall do with the presentment; it is inferred, however, that he ought to eertify it to the next General Quarter Sessions, because in the second seetion of the Aet it says that all former laws regarding the highways shall remain in elfeet. Besides (p. 30), Act 1 Geo. $I$ is so worded that it may seem doubtful whether the direetions given by the said former Acts, eoneerning these points, are not thereby repealed; and jurisdietion vested in the Speeial Sessions. Such vague laws weaken the hands of the Justices of the Peace, and beeatise the Justices do not care to act under them the surveyors and defaulters often go unpunished.

(p. 32) To proeeed on either of these statutes, however, is slow, for Special Sessions are only held every four months; but either method is preferable to presentments or indietments, for the latter are unjust and oppressive, as we have shown.

Then Shapleigh proceeds (p. 33 et seq.) to outline in full a law which he would 
recommend to the Legislature, to take the place of the old laws, so as to be clear and easily executed, and to give his reasons for particular clauses in the wording of his proposed new law.

(p. 56) "The six days' work have hitherto in most parishes been so much neglected, and so slightly performed, that I believe very few parishes can truly say, from their own experience, that the six days' work, duly and properly attended to, and performed by all the parishioners liable by law, to work in the amendment of the highways with due care and diligence, are not sufficient." [This seems to be strong testimony of the adequacy of the statute duty, if satisfactorily performed, to effect the improvement of the roads; but it also shows how poorly this work must have been done when the roads were in such a bad state.]

(p. 60) In speaking of the imposition of the assessment of $6 d$. in the pound, as authorized by Acts $3 \& 4$ W. \& M., c. 12, sec. 17, and 1 Geo. I, when the six days of statute labour were not sufficient to repair the roads, he says: "For such a rate does, in some parishes, raise by much too large a sum to be trusted in the hands of such persons as are generally chose surveyors." (The character of the surveyors, if they were at all like what is here implied, must have been such as would not command the respect and confidence of the parishioners.)

\section{APPENDIX 3}

\section{HAWKINS ON THE LAWS OF HIGHWAYS (1763)}

(p. ix) "But this the Public may be assured of, that every attempt to amend the Highway-Laws by additional or explanatory Acts, will produce great Confusion among those whose duty it is to execute them; and that nothing can remedy the evils at present complained of, but the consolidation into one Act of the most efficacious clauses contained in those now subsisting." (It was Hawkins' ehief purpose to get a consolidation of such Acts into one general Act.)

(p. 2) "It is too obvious to need insisting on that very little of the concern which has of late been shown about the roads in general has been directed to those that lead from parish to parish, and are not the ordinary channels of conveyance to cities and towns of great trade. The invention of turnpikes is manifestly calculated for great roads, which, as they are made in favour of commerce, produce a revenue sufficient to keep them in repair; but the former have been left to the care of the surveyors of the highways in their respective parishes, subject to the direction and controul of the Justices of the Peace."

Since the framing of Act $2 \& 3$ P. \& M., c. 8, and its successors under Elizabeth, coaches, chaises and post chaises had come in; and gentlemen who had these and drove on the road constantly got off with the same road work as the poor cottager who had no such things. These were not included under the term "draught" of the Act, and hence these nobles were mercly householders like the cottagers, so far as the statute labour was concerned. Hence there was great need for a change of the law.

(pp. 24-25) The statute $2 \& 3$ P. \& M., c. 8, is also indefensible. A law without a sanction is but a dead letter, and this is the case with this statute. Suppose a farmer, who occupies a plough-land or keeps a draught, is required by the law to send a team to work six days on the highways, and that he is averse to this duty. 
He does it only through fear of incurring the penalty. [Nelson, Justice of Peace, 6th ed., p. $332 \mathrm{n}$., says that a ploughland was formerly 100 acres, but at his time (1718) only 80 acres. By Act $7 \& 8$ W. III, c. 29, $\$ 50$ per annum was a ploughland. See also Burn, Justice of the Pcace (1755), I, p. 512.] But it may be to his interest to incur the penalty and not do his statute labour. For cxample, the labour of a cart, a team and a man is valued at 10s. a day in most places. He can get this if he lets them out to a ncighbour. But if he sends his cart and team and two men to work on the roads, the labour of all will excuse him from the payment of no larger a sum. So if he lets out his team and incurs the forfeiture he saves the labour of one man. Ilence the statute is pregnant with a motive for disobedience.

(pp. 25-26) In like manner the day labourer may argue that if he must either actually perform or forfeit the price of six days' labour, it is as well to choose the latter as the former. This defect, it must be confessed, is owing solely to the diminution in the valuc of money since this statute was enacted. Taking Bishop Fleetwood as authority, he says:

"In 1514, not long before the statutc was made, the wages of a labourer, from Easter to Michaelmas, except in harvest, were $4 d$. per day, and from Michaelmas to Easter, $3 d$. per day. The labour of a waggon, tcam, and two men, amounted to $2 s .8 d$. per day. But by the statute the penalty for default to send a team was $10 \mathrm{~s}$. and for default to send two men it was $1 \mathrm{~s}$. Therefore the penalty was $11 \mathrm{~s}$. for default in sending two men and a team. If these forfeitures be compared with the respective duties they were intended to enforce, we finc them to be sufficiently penal at the time the statute was made. But this is not so now."

But it is urged that whether the person charged does actually perform or pay the price of his duty, the case is the same to the public; inasmuch as the forfeiture will purchase just as much labour and assistance as was originally required of him; and if that is done, it is nothing to the public what hands were employed in it. But is it of no consequence to a state whether the laws are obeyed or not?

(p. 27) Lct us see how the law is observed in those few parishes where the people are disposed to yield obedience to the letter of it. The days for doing statute duty have long been lookcd upon as holidays, as a kind of recess from the accustomed labour, and have been devoted to idleness, and its concomitant indulgences of riot and drunkenness.

(p. 28) Further, those doing statute duty (which is to some extent voluntary) are less obedient to the directions of those whom the law has appointed to superintend it, than is consistent with the due discharge of their duty. The men are working at four or five different places in the parish and not under the oversight of an officer, and not executing a well thought out plan.

Again, cven if a surveyor were a good judge of roads, and of how to make and repair them, he has only six days to carry out his plan, and even then some may refuse to do their statute duty. How is the way to be amended under these conditions?

Some will say, let the surveyor apply the forfeitures incurred by the several defaults in the hire of teams and men and go on with his work. Very true, but first he is to get them. In order to do this, he is to enter on a new work, viz., to bring the defaulters to justice. And first he is to make out a list of their names, which, when completed, is to be returned to the Sessions, which may possibly be held cither in a week or in four months after the offence. The Justices upon this return, of course, issue summonses for the defaulters to show cause in a reasonable time why they will not pay; after this, if they do not comply, distresswarrants are issued, before the execution of which the wet weather sets in, and there is an end of road work for that year. The surveyor is then busied in making 
up his accounts against the Janury Sessions, or perhaps in defending actions grounded on some irregularity in the notice, the due publication of which, or of the respective defaults, not one in fifty of them is ever prepared to prove. When January comes, his account is passed and he pays the balance to the new surveyor, who will have just the same diffieultics to encounter as his predecessor.

(p. 30) Everyone knows that the highways shall be kcpt in repair by the screral parishes of which they are part. Act $2 \& 3$ P.\& M., c. 8, has established a form of proceeding by way of indictment against the parishioners, upon which. if the defendants are found guilty, they shall not be discharged by submitting to a fine, but a distraint shall go in infinitum till they repair.

(p. 31) Act 5 Eliz., c. 13, prescribes another method of proceeding-in effect much the same as that of an indictment-which is by a presentment of the surveyors to the next Justice, who is to certify the same at the next General Sessions, and the Sessions is immediately to inquire of the defaulters. But, despitc the word "immeriately," the general opinion on that clause of the statute is, that the certificate of the Justice in this case has not the effect of a presentment, but must be turned into an indictment, to which, by the Rules of Law, the offender may enter his traverse, and no trial can be had till the Sessions after.

Both these methods are objectionable. In the first, the law does not distinguish those who have done from those who have refused to do their statute work; but gives its judgment indiscriminately against the whole parish, and hence the innocent and the guilty are involved in the same punishment. By the second, there is not that expeditious justice which the statute gives reason to expcct.

(p. 33) The delay and expense of these methods of procceding are objections common to them both; and because of these reasons, as well as their ineflicacy, they should either be abolished or so regulated as to be more efiectual. Other complications have been introduced by Acts 22 Car. II, c. 12 (sces. 9 and 12) and 3 W. \& M., c. 12 (sec. 9) in regard to what should be the mode of procedure for offences and neglects respecting the public roads.

(p. 34) Besides all this, Act 1 Geo. I, stat. 2, c. 52, is so worded that it seems doubtful whether all the authority given by former Acts as to these matters is not taken away, and the jurisdiction vested in the Special Sessions.

(p. 36) A surveyor, if he is a farmer, or engaged in some other like occupation, is very often ignorant of how the roads should be amended. What effects can we expect to follow from ignorance combined with authority on the one side (i.e., the surveyor) and invincible obstinacy on the other (i.e., the parishioners)?

(p. 37) But the surveyors in general are not disposed to follow the lare in exccuting their offiee. One error they usually make is to consider the respective forfeitures for every day's default as a tax or rate; in consequence of whieh their practice is, as soon as they enter office, to assess (ex offieio) every inhabitant a sum proportional to the labour required of him, which they procecd to collect as soon as possible-like the proper officers do the poor rates. But these scveral sums are not due until there has been a default to perform the statute labour. In this way the surveyor is open to an action at law for the sums thus collected from the parishioners; and, further, when the notice has been so negligently given, as that its publication cannot be proved by an uninterested witness (i.e., one not liable for statute work in the parish), who can swear to the reading of it by the Clcrk. it is no blame if the parishioners do not go to the roads to work.

(p. 38) Surceyors also are corrupt, in commuting with parishioners for different amounts, receiving from some 5s., from others $4 s$., from others half-a-crown, cte., or what many of them like better, a bowl of punch. These things are punishable by a fine of $£ 5$, which the Justices in their Sessions have power to imposc. Such 
evils and many others of like nature are largely owing to the practice of electing tradesmen, and persons in a situation necessarily dependent and subject to influence, into parochial offices. Inferior inhabitants get the offices; while the gentlemen, perhaps from contempt of an employment which requires little more than to be able to write and keepl a year's accounts, or for other reasons, sit by and see the public defrauded and the law evaded.

Then Hawkins quotes from Burn on Justice (under title "Highways") saying that "Most of the books are remarkably confused under this title, occasioned by a multiplicity of statutes standing unrepealed, and yet altered perhaps five or six times or oftener, by succeeding statutes." Later, Burn says that there is no uniformity of action among the surveyors, and because each has the roads under his charge for at most six days, and his successor has other schemes and notions, the roads are never the better. Hence, it is but natural that the people have a picnic on statute labour days. Why should they not, when their work would be to no purpose?

District surveyors, he thinks, should be appointed, witl saiaries, to lay out the roads and attend and direct the work, and see that it is well done. He thinks this could be done with half the present legal maximum assessment of $6 d$. in the pound.

Burn's objections are two in number: first, the multiplicity of the laws, and second, the ill direction of the power given by them. The latter objection can be overcome by giving that power to those who have no temptation to abuse it; but the first objection he considers very serious.

(p. 43) Existing statutes relating to the amendment and repair of the highways are not fewer than twelve in number, made at different times as need required, and abounding in clauses which legal skill cannot rcconcile. Clauses in older statutes have been left unrepealed, though such clauses were altered and amended by subsequent Acts; different penalties have been inflicted for the same transgression by different statutes. Thus the highway laws have so accumulated as to be a subject of universal complaint.

(p. 47) Hawkins then pleads for modifying the highway laws so as to remove inconsistencies. He would reduce all into one law, so as to be efiective and easy in execution. In making such a law the following points at least should be looked to:

1. The burden on the public should be proportional to their circumstances and abilities to bear it.

2. Those who use the highways most should pay most.

3. The tax on gentlemen of large personal estates, who keep coaches, chariots, etc., should be adjusted in a compound ratio of their wealth and the use they are supposed to make of the highways.

4. Surveyors should be persons of greater property than are usually appointed to that office.

(p. 52) The advantages from the use of broad wheels, he says, are so apparent that it is needless to insist on them; "this is certain, that by means of them the price of carriage from York to London has been reduced forty per cent." He acknowledges that they do not sueceed so well on cross-roads as on the great roads, because the former are usually so narrow as to admit of only one track. These ways should be widened, and the use of broad wheels made universal.

(pp. 61-143) In these pages, he draws up a Bill to suit the ends he has in view; and if it were passed all the old laws would be repealed and their useful provisions alone embodied in the new law. 


\section{APPENDIX 4}

\section{ON LETTING THE TOLLS}

Usually the tolls were farmed out, and not managed by the trustees of the road on which they were to be eolleeted. Parliament laid down the conditions for letting the tolls, whieh inchuded the following: "To prevent fraud or any undue preference in the letting thereof, the Trustees are hereby required to provicle a Glass with so much sand in it as will run from One End of it to the other in One Minute; whieh Glass, at the Time of letting the said Tolls, shall be set upon a Table, and immediately after every Bidding the Glass shall be turned, and as soon as the Sand is run out it shall be turned again, and so for Three Times, unless some other Bidding intervenes: And if no other Person shall bid until the Sand shall have run through the Glass for Three Times, the last Bidder shall be the Farmer or Renter of the said Tolls" (IIills, IIistory of East Grinstead, p. 158, quoting from Aet 3 Geo. IV, e. 126, see. 55).

When the term for which the tolls had previously been let was near its expiration, the trustees of the turnpike trust usually announeed in the newspapers of that loeality that they would meet at a eertain place, on a eertain date, to again let the tolls of the turnpike gates whieh they eontrolled. This gave notiee to those who wanted to bid for them to appear at that time. The advertisement would read something like the following, which appeared in the Shrezstury Chronicle, Feb. 20, 1773 , p. 2:

Notiee is hereby given that "at a meeting of the Trustees, to be held at the Guildhall (Shrewsbury), on Tuesday the 23rd instant,...the Tolls arising on the Roads leading from Shrewsbury to Preston, Brockhurst, Shawbury, and Shreyhill, in the eounty of Salop, will be let to the best bidder, for the term of three years, eommeneing the seeond day of Mareh next.

John Warren, Clerk to the Trustees."

It was the usual rule that the man to whom the tolls were leased had to pay for the first month in advanee, as an evidenee of good faith on his part (v. Act 3 Geo. IV, e. 126 , see. 56). But the following advertisement shows that this was not always required, if the lessee could give other satisfaetory seeurity. In the IIereford Journal, April 20, 1803, p. 1, we find:

"Hereford Turnpike Trust.

Notice is hereby given, that the next Meeting of the Trustees will be held, at the City-Arms Hotel, in the City of Hereford, on Tuesday, the Third day of May next, when the tolls arising from the several Turnpike-Gates belonging to this Trust will be Let by Auetion to the best Bidder, who will be required to give security, to the satisfaction of the Trustees then present, for the performance of his or their contracts.

Partieulars by applying to Mr. J. Coren, Clerk to the Trustees.

N.B. New 'Trustees will then be appointed.

Apr. 2, I803."

Instead of leaving the notice in the above indefinite terms as to the price, it was eommon to stipulate what was the lowest amount for whieh the gates would be put up at auetion (v. IIereford Journal, Dec. 4, 1805, p. 22; Norfolk Chronicle and Norwich Gazette, Aug. 27,1814, p. 3); or else to give the anount for which they 
were let the preceding year (v. Newcastle Courant, April 16, 1774, pp. 2, 3); or, in some cases, in addition to the gross revenue, to give the amount which the toll realized, clear of the expenses of collection, during the last year or term of years (v. British Volunteer and Manchester Weckly Express, April 27, 1822, p. 1; Felix Farley's Bristol Journal, Feb. 10, 1787, p. 3). It is evident that, by these means, the tolls would tend to progressively increase from year to year. Sometimes the lease would be made for only one year, or two years, or three years, or the trustees might give the lessee an option on this (v. Ncwcastle Couramt, April 16, 1774, p. 3).

The method of letting the tolls, as told by one who had seen the process (v. Fowler, Records of Old Times, pp. 18-20), well illustrates why it was that the tolls did not continuously increase. The trustees, who were mostly country gentlemen of the district, gathered at the principal inn at the county town in considerable numbers. Usually the trustees gave a guinea for each gate let, to be expended in refreshments; and as there were generally six or eight gates, there would be that number of guineas spent among about forty or fifty "pikers," as they were called, who attended, but only about six or seven of these would be bialders and lessees; these were men of capital, who rarely collected their own tolls. Those who witnessed these meetings called them the "Whispering Society," as the company scattered about the inn yard in small groups were in full conclave, all in whispers; one would run ofi and whisper to another group and return again, when they would be approached by another envoy, while cireulating rapidly among them was one of the bona fide bidders, evidently making terms with several threatening opponents and promising from one to five pounds to the recipient who kept from bidding. At the appointed time, a rush was made to the auction room, where the trustees, with their clerks, treasurers. surveyors and other officers were assembled. After the conditions were read the letting commenced, but it sometimes happened that the whispering had been so effective, that not a single offer was made, to the astonishment of the trustees, who had not seen the manouvres that had been going on in the yard for more than an hour. As no bidclings were made, it was then announced that the upset price was (say) $₫ 200$ for each gate, and that unless that sum were obtained the gates would be withdrawn and the trustees would put in their own collectors and farn the gates themselves. When the sum was announced, a general groan of horror went round, and the trustecs were told that the offer was so outrageous it could not be listened to; that the last two years the gates had not produced more than $£ 180$ to $£ 190$, and that the lessees had lost all their wages and expenses, but if they would listen to reason a tenant could be found at 2150 . Suddenly some stranger to the "pikers," a decoy put up by the auctioneer, would bid $£ 180$, at which there would be a burst of indignation and outbreak of insulting by-play. By a continuous series of "card-playings," the bidders would keep down the prices of the gates to about the $\$ 200$; and very often the former lessee who had declared that he had lost so much by taking the gates for the last two years, was anxious to again have them since they had really been profitable to him. All the whispering that had taken place beforehand represented an endeavour to buy off every dangerous opponent. Many persons came down from London and elsewhere, under pretence of taking the gates, who earned a sovereign or even 23 , as payment for the day's work, from the lessee, who had probably held the gates for the past two or three years and was reluctant to lose them. Other evils connected with letting the tolls are given in Pagan, Road Reform, pl. 173-6, and by James and Willian Macadam in Parl. Papers, 1833 (703), xv, 409, pp. 497, 555.

The business of contracting to take leases of turnpikes was in many instances a very expensive one. The gentleman who took most of the gates in Buckinghamshire and some adjoining counties was a Mr Tongue, living at Manchester, and it was 
estimated that he had over $\$ 50,000$ annually embarked in gate holdings. He retained a regular staff of collcetors, who moved about from one part of the country to another as his confidential servants (Fowler, op. cit., pp. 18-20). Sometimes individuals, who were in the habit of hiring the tolls to a large amount, united into a company and leased a great number of gates, until they had from $\$ 100,000$ to $£ 200,000$ a year embarked in this kind of investment. Because of this monopoly of tolls, it often happened that upon two parallel lines of road in the control of the same lessee, the one paying the lower toll would be sacrificed to the other paying the higher toll; Parl. Papers, 1833 (703), xv, 409, 'Second Report of the Lords Committee on Turnpike Returns,' p. 497; IIansard's Parliamentary Debates, 1835, xxix, pp. 1183-92.

\section{- APPENDIX 5}

\section{RATE OF TRAVELLING, 1750-1880}

I HAve endeavoured to bring together in the following statistieal table only such data as are most authentic, and to indicate in each case the source of the information, so that it may be easily verified. It must not be thought that the matter here presented is absolutely accurate, for the writer makes no claim to such precision; as a matter of fact, it has been impossible to secure even correet distances between places, because we have no measurements of the roads which give us this information with guaranteed accuracy. Further, the changing and straightening of the roads, accompanied sometimes by slight changes in the coaehing routes, would vitiate any series of mileage figures which we might have. These things I have taken into account in the computation of the mileage and it will be seen that the distance sometimes varies; for between two places the length of the road differed, according to the route taken and the straightness or crookedness of the road. The same difficulties appear with reference to time, for a day at one part of the year or with one person, did not mean the same as at another part of the year or with another person; for example, days in summer were long, while the days in winter were short. It was not until the coaches were timed by hours and minutes that we get aceuracy in this particular. In some instances, the length of time required to perform a journey included the time spent at nights in the inns along the route; but we have no knowledge of how nuch time was thus consumed. With all these liabilities to error, and others which we need not here mention, it will be apparent that the best we can get is an approximation to the truth. The great amount of statistical material presented is intended to avoid any errors due to paucity of data upon which conclusions might be based; and, making all due allowance for these variations, it is claimed that the statistics are as reliable as the available information will permit. The inferences drawn from them will be found in the text. 


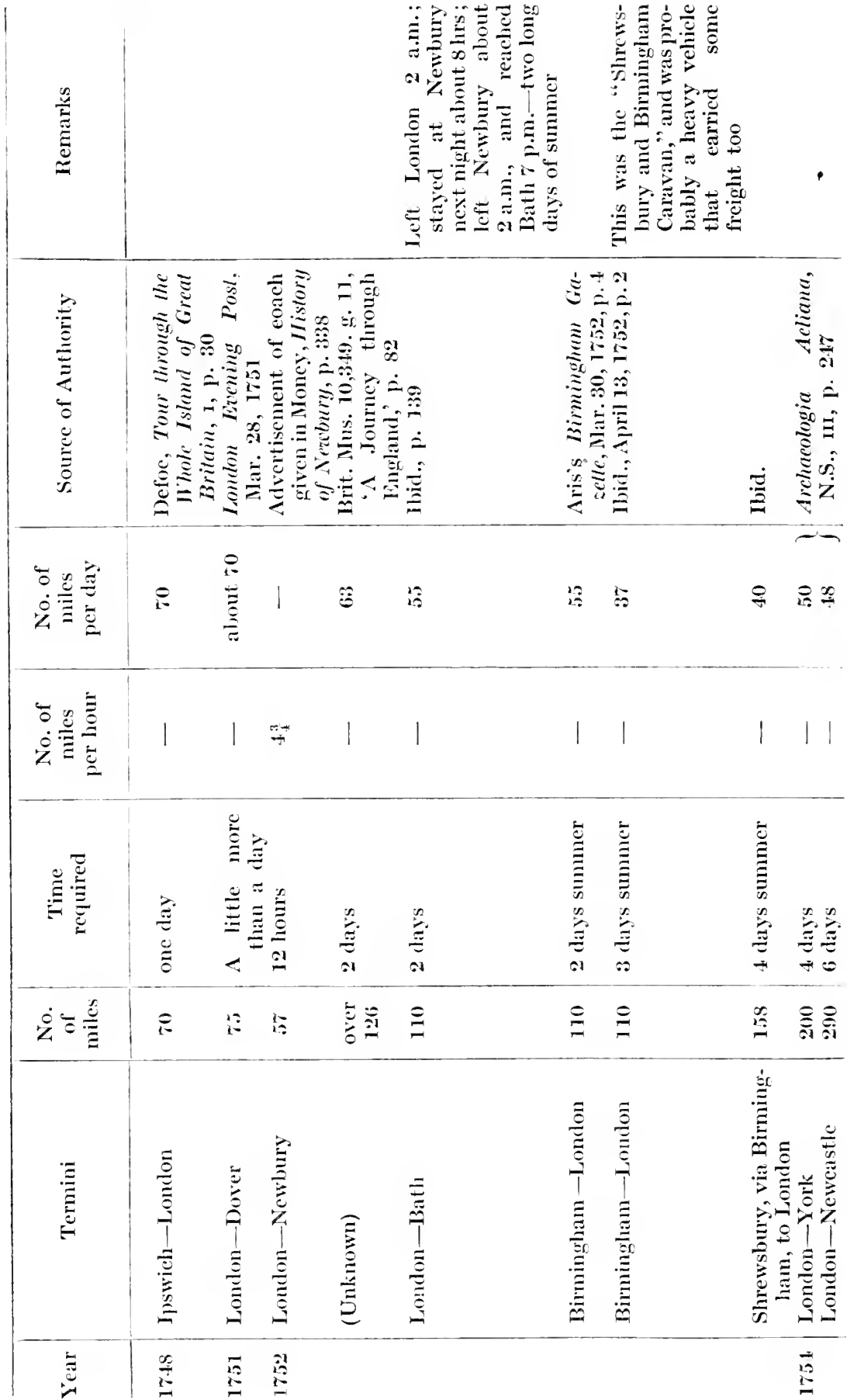




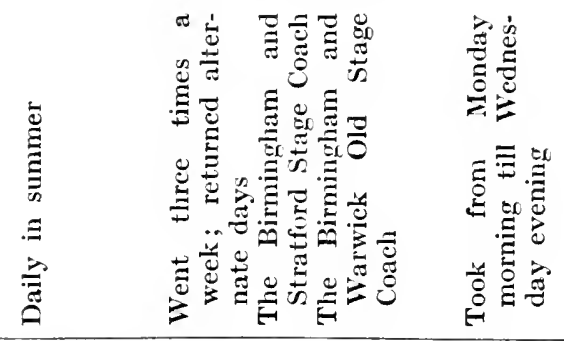

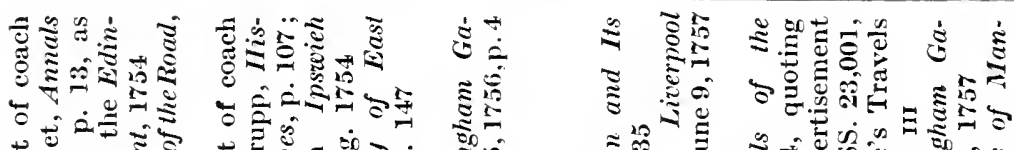

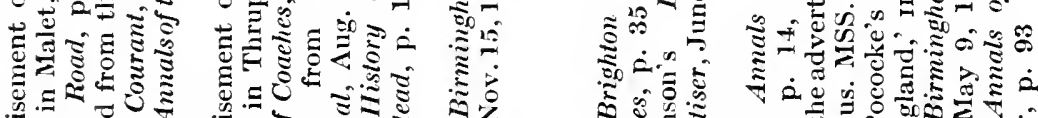

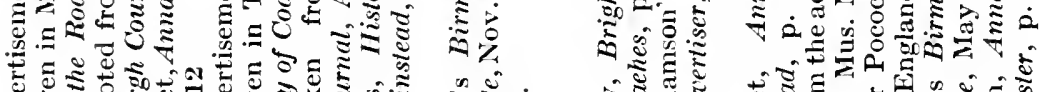

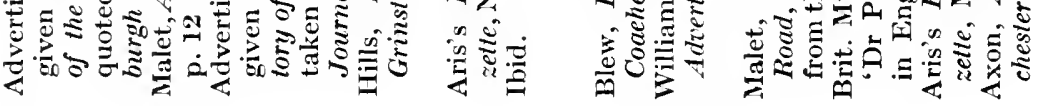

\begin{tabular}{|c|c|c|c|c|c|c|c|c|c|c|}
\hline 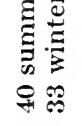 & $\frac{28}{7}$ & 1 & 年 & $\stackrel{\infty}{+}$ & 5 & $\ddot{8}$ & 5 & R & 8 & 8 \\
\hline 11 & 1 & 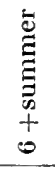 & 1 & 1 & 1 & 1 & 1 & 1 & 1 & 11 \\
\hline 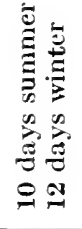 & 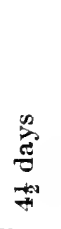 & 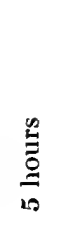 & 密 & 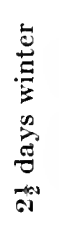 & 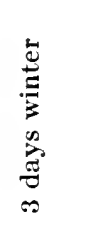 & 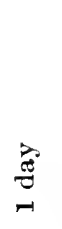 & $\stackrel{\infty}{\oplus}_{\infty}^{\infty}$ & $\underset{\infty}{\infty}$ & 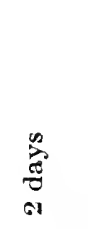 & 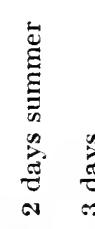 \\
\hline 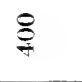 & $\underset{:}{0}$ & $\vec{\sigma}$ & 10 & @ి & $\cong$ & $\stackrel{\circ}{\circ}$ & $\stackrel{\leftrightarrow}{\circ}$ & $\stackrel{0}{91}$ & 吕 & $\stackrel{9}{\stackrel{9}{9}}$ \\
\hline 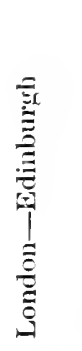 & 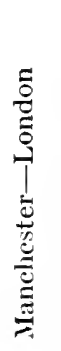 & 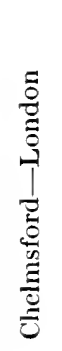 & 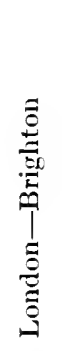 & 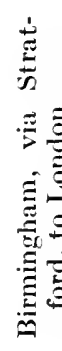 & 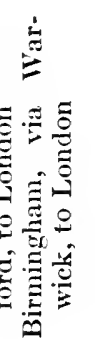 & & 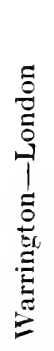 & 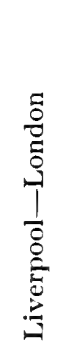 & 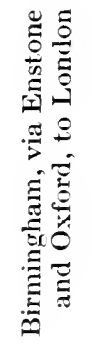 & 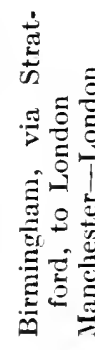 \\
\hline$\frac{\vec{B}}{5}$ & & & 足 & & & & $\begin{array}{l}3 \\
2\end{array}$ & & & \\
\hline
\end{tabular}




\begin{tabular}{|c|c|c|c|c|c|c|c|}
\hline & 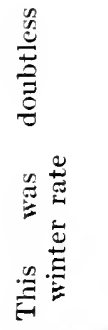 & & 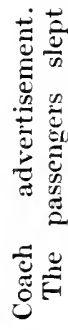 & & 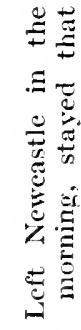 & & 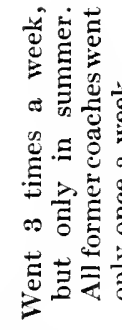 \\
\hline 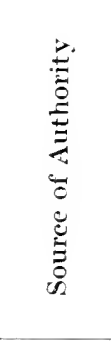 & \multicolumn{3}{|c|}{ 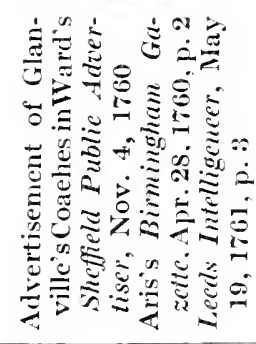 } & \multicolumn{2}{|c|}{ 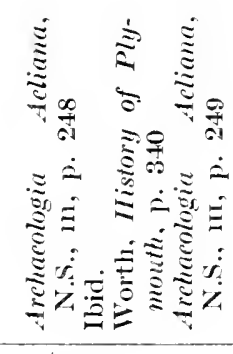 } & \multicolumn{2}{|c|}{ 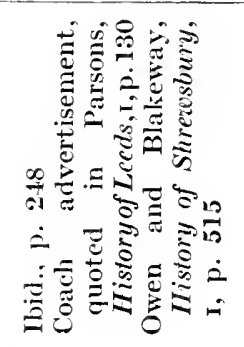 } \\
\hline 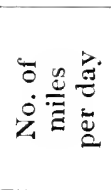 & 事居 & 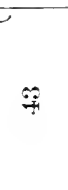 & 8 & 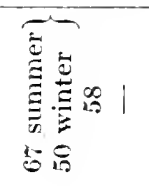 & 星 & 8 与 & 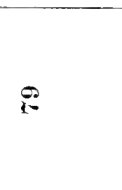 \\
\hline 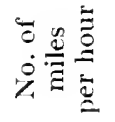 & 11 & 1 & 1 & $|1| \Leftrightarrow$ & & 11 & 1 \\
\hline$\stackrel{\Xi}{\Xi}$ & 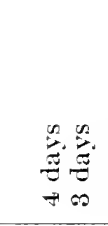 & 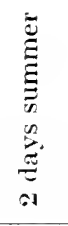 & 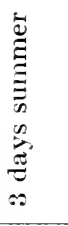 & 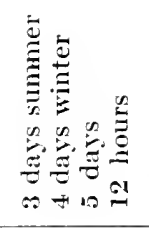 & 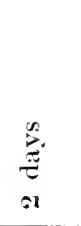 & 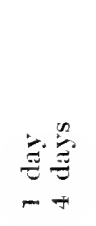 & 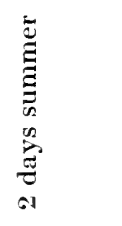 \\
\hline 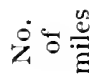 & פ日 & $\dot{\infty}$ & D & 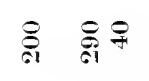 & $\stackrel{9}{\ominus}$ & $8 ̊$ & $\begin{array}{l}\infty \\
\stackrel{\infty}{2}\end{array}$ \\
\hline 莺 & 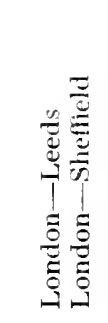 & 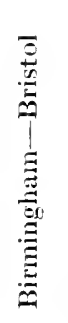 & 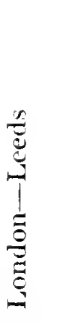 & 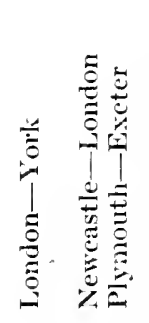 & 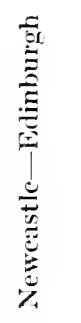 & 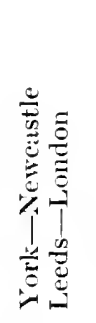 & 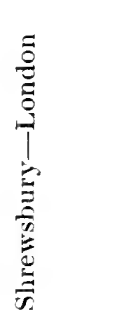 \\
\hline$\ddot{y}$ & 胥 & & $\Xi$ & 兽 & $\hat{0}$ & 总 & \\
\hline
\end{tabular}




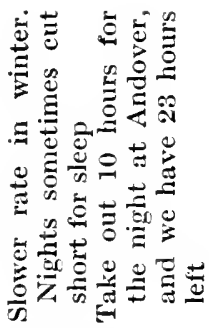

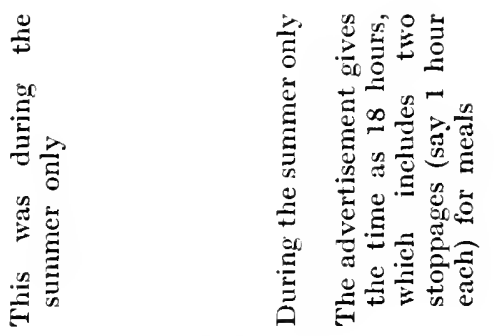

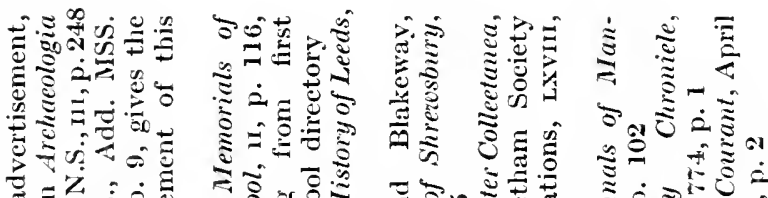

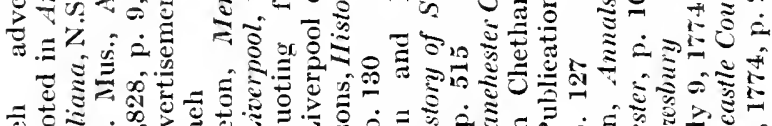

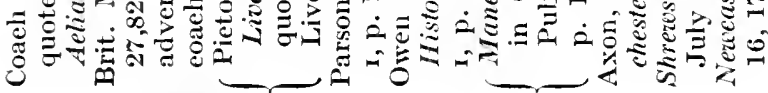

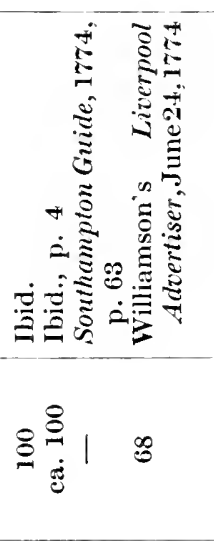
$1 \stackrel{20}{9}$
1 ) 1

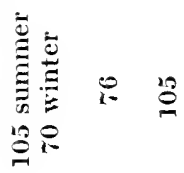

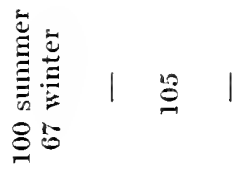

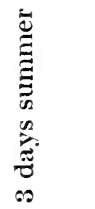

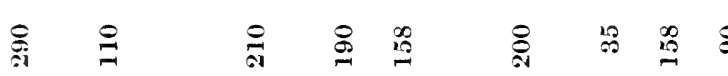

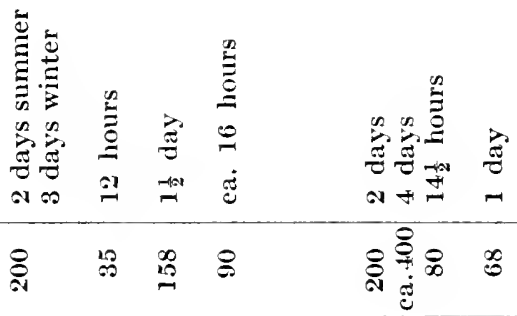

تี

:

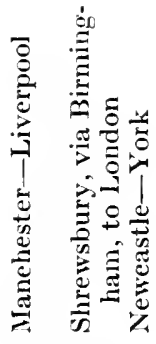

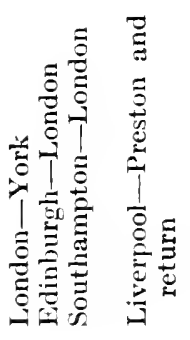

:

总总余

总茮 


\begin{tabular}{|c|c|c|c|c|c|c|c|c|c|c|}
\hline 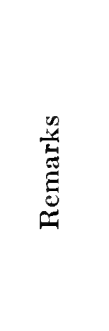 & 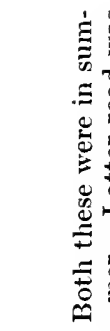 & 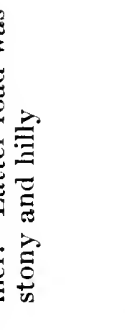 & 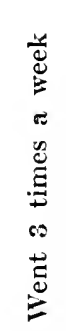 & 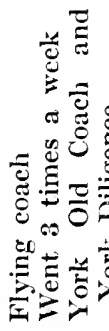 & 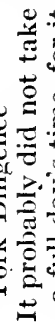 & 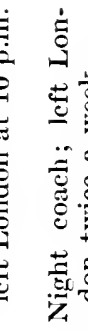 & 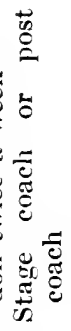 & & & \\
\hline 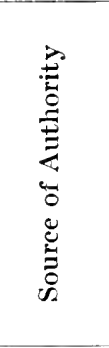 & 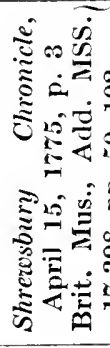 & 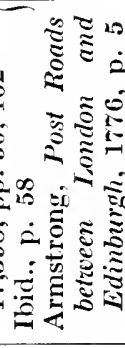 & 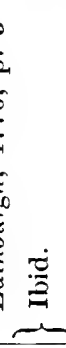 & 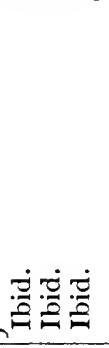 & $\begin{array}{l}0 \\
\dot{2} \\
\dot{0} \\
\ddot{\Xi}\end{array}$ & 苛: & 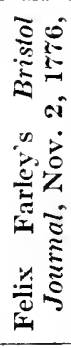 & 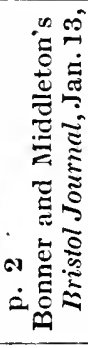 & 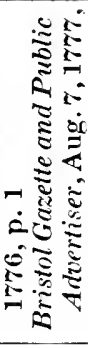 & $\begin{array}{l}0 \\
-\frac{0}{0}\end{array}$ \\
\hline 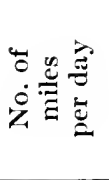 & 11 & 15 & 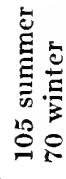 & 188 & 8 & 92 & $\begin{array}{l}\stackrel{\mathscr{E}}{\Xi} \\
\stackrel{\Xi}{E} \\
\mathscr{E}\end{array}$ & i & 1 & 1 \\
\hline 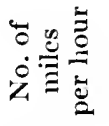 & ㄹ & $\Leftrightarrow 1$ & 11 & 21011 & 1 & 11 & 1 & 20 & ह & نُ \\
\hline 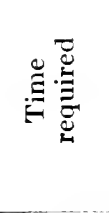 & 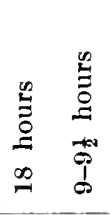 & 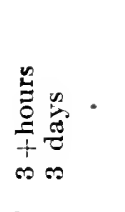 & 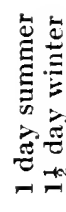 & 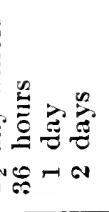 & $\vec{z}$ & $\begin{array}{l}0 \\
\tilde{E}= \\
\alpha-\end{array}$ & $\begin{array}{l}n \\
0 \\
0 \\
0\end{array}$ & $\underset{\stackrel{0}{g}}{\stackrel{\Xi}{g}}$ & $\begin{array}{l}\stackrel{\infty}{\Xi} \\
\stackrel{0}{\Xi} \\
\stackrel{\infty}{=}\end{array}$ & $\underset{\mathscr{\Xi}}{\stackrel{\infty}{\Xi}}$ \\
\hline$\dot{\bar{c}}$ & $\underset{\sim}{\stackrel{*}{*}} \&$ & 芯莡 & $\stackrel{20}{=}$ & $\bigotimes_{N} \& \bigotimes_{N}$ & $\&$ & 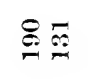 & $\stackrel{9}{9}$ & $\approx$ & $\stackrel{1}{0}$ & $\infty$ \\
\hline$\underset{E}{E}$ & 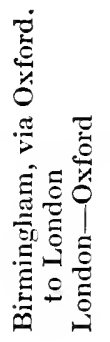 & 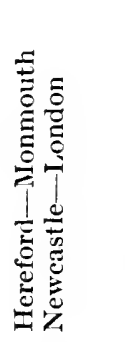 & 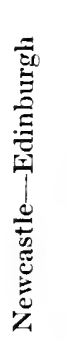 & 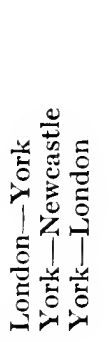 & 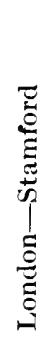 & 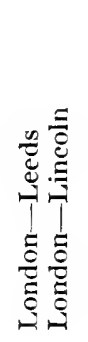 & 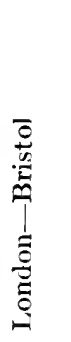 & 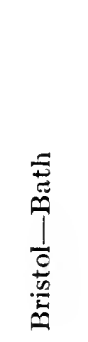 & & 吾 \\
\hline 总 & 量 & 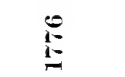 & & & & & & & $\frac{1}{2}$ & \\
\hline
\end{tabular}




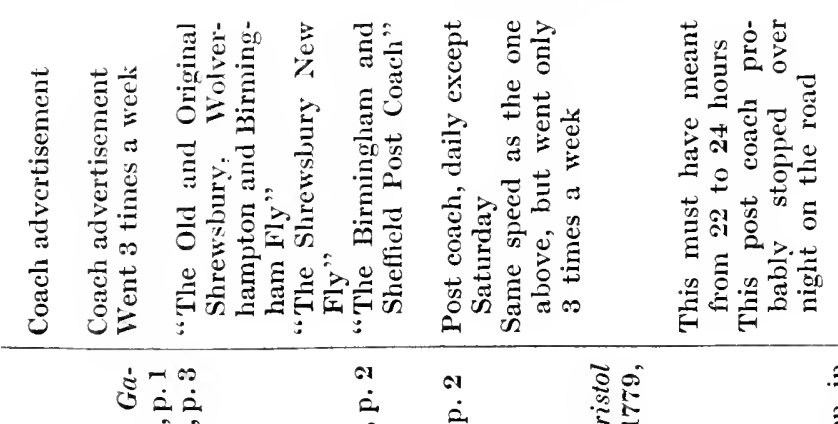

ร)

t⿹丁口

กิำ

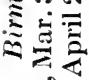

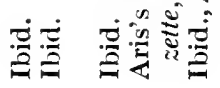

11108

요요

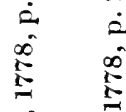

ลิ

这

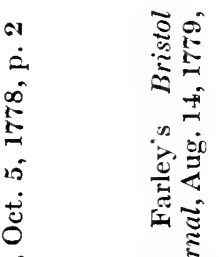

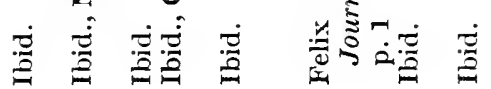

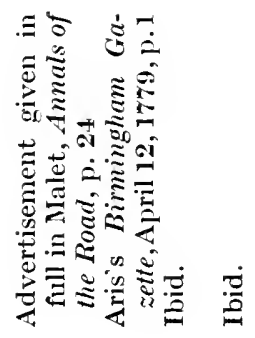

ฐ 8

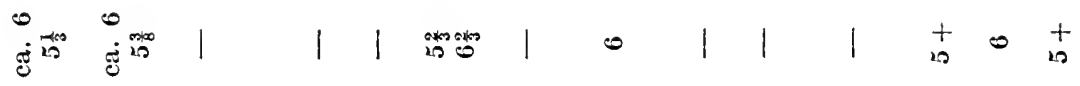

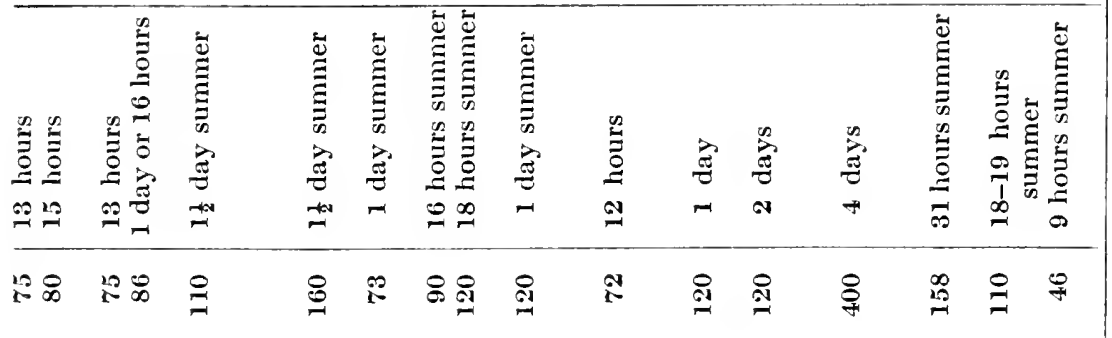

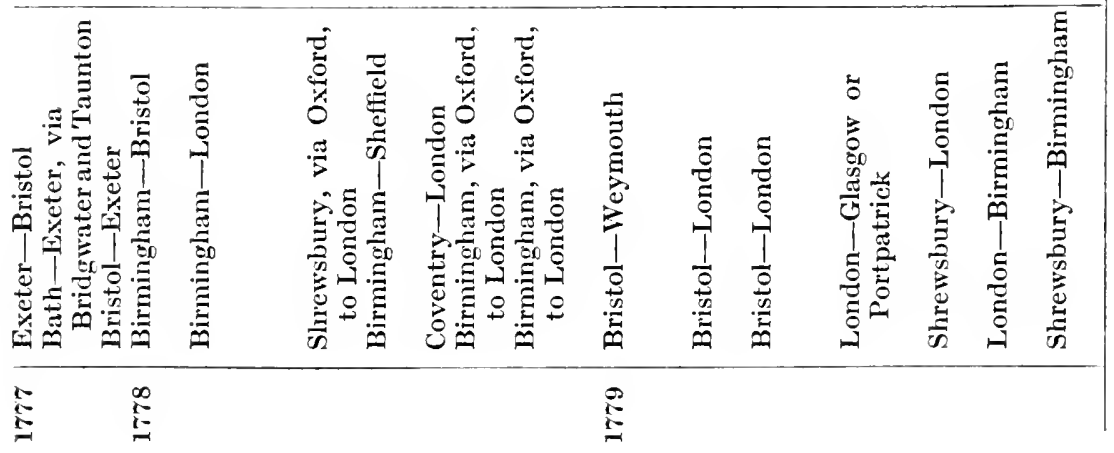




\begin{tabular}{|c|c|c|c|c|c|c|c|c|c|c|c|c|}
\hline 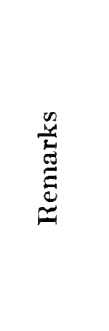 & 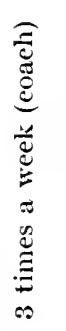 & 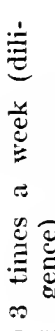 & 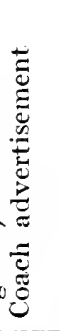 & $\begin{array}{l}\tilde{0} \\
\tilde{E} \\
\overrightarrow{0} \\
\overrightarrow{0} \\
0\end{array}$ & $\frac{2}{\bar{a}}$ & 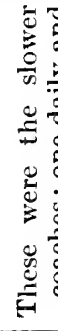 & & 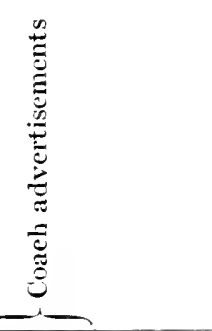 & & & & 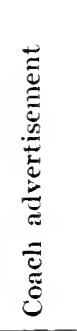 \\
\hline 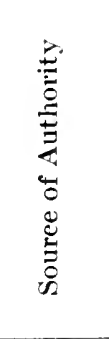 & 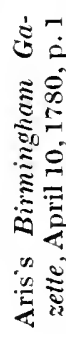 & 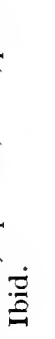 & 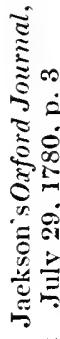 & 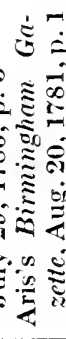 & 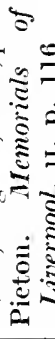 & $\frac{1}{\vdots}$ & & 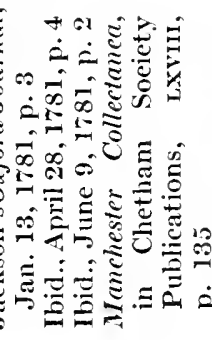 & 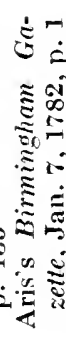 & 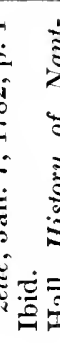 & 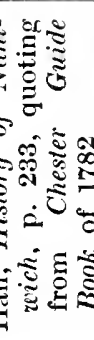 & 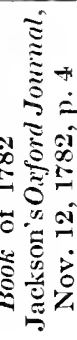 \\
\hline 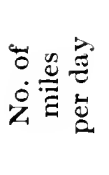 & 18 & 1 & $\stackrel{\varrho}{g}$ & 1 & $!$ & $\stackrel{20}{0}$ & 87 & 111 & 1 & 1 & 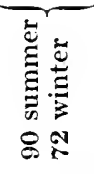 & 1 \\
\hline 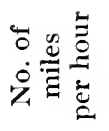 & 1 & 0 & 1 & 0 & 25 & 1 & 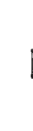 & $00 \stackrel{0}{0}$ & 0 & 20 & 11 & $\therefore$ \\
\hline 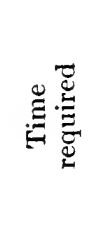 & 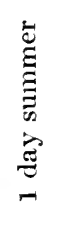 & 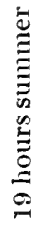 & $\underset{ت}{\vec{g}}$ & 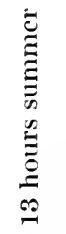 & $\begin{array}{l}\stackrel{n}{E} \\
\stackrel{0}{0} \\
\stackrel{9}{0}\end{array}$ & 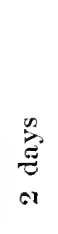 & 0 & 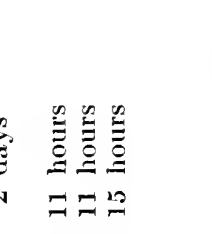 & 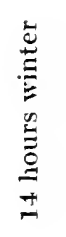 & 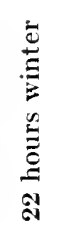 & 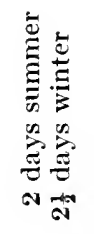 & 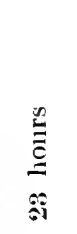 \\
\hline 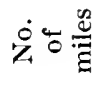 & 12 & $\stackrel{0}{=}$ & 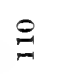 & $\infty 0$ & $\underset{a}{a}$ & $\underset{\sigma}{0}$ & 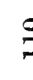 & 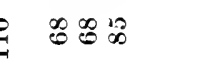 & $\stackrel{\infty}{\infty}$ & $\stackrel{\varrho}{\Xi}$ & $\underset{\infty}{\infty}$ & 8 \\
\hline 䔍 & 总 & 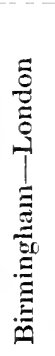 & 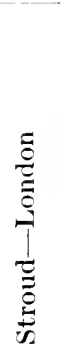 & 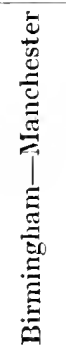 & 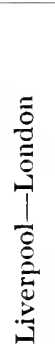 & 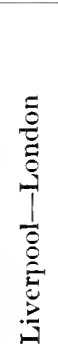 & 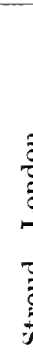 & 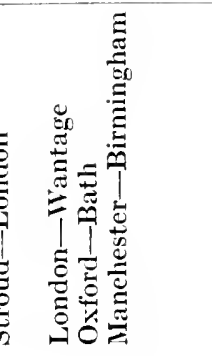 & 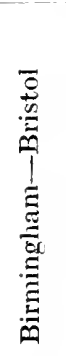 & 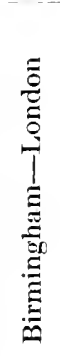 & 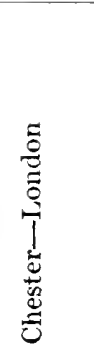 & 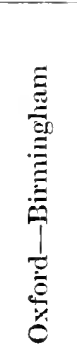 \\
\hline 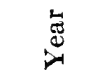 & $\begin{array}{l}\stackrel{D}{\infty} \\
\stackrel{\sim}{\Sigma}\end{array}$ & & & $\underset{\infty}{\infty}$ & & & & & $\begin{array}{l}0 \\
0 \\
1 \\
1\end{array}$ & & & \\
\hline
\end{tabular}



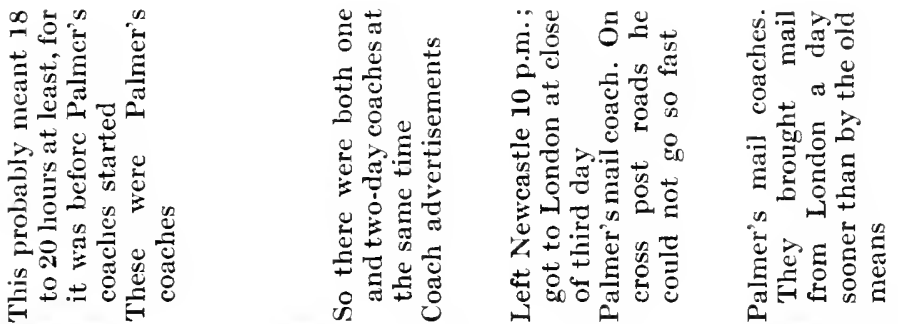

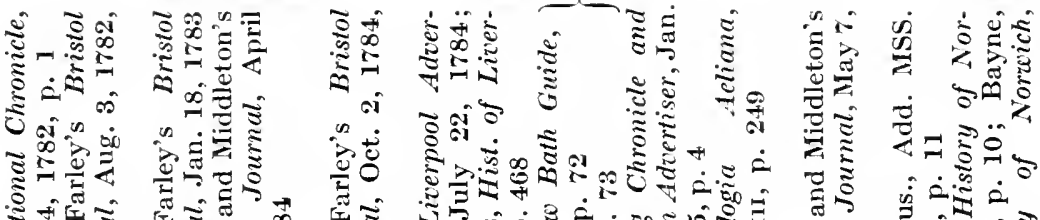

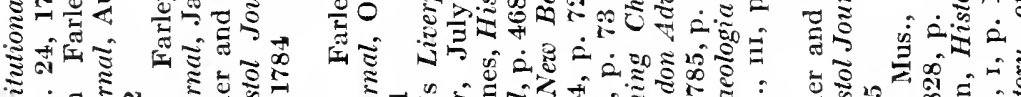

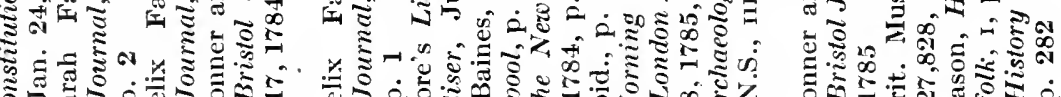

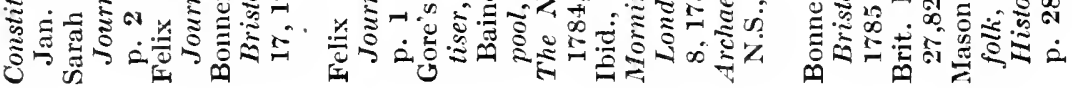

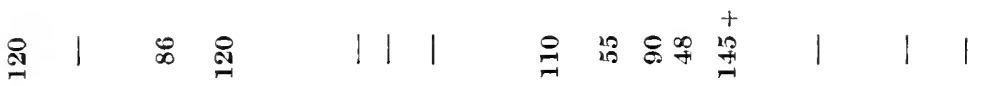

$1=1 \mid 1011110 \ldots$

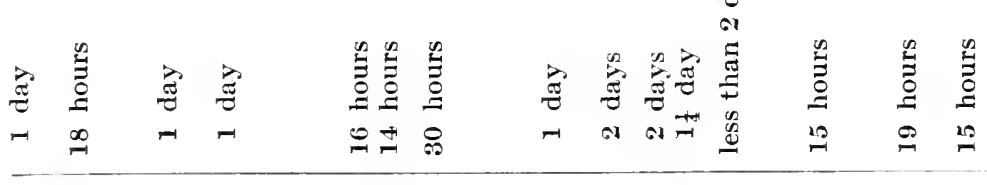

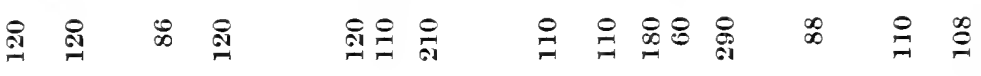

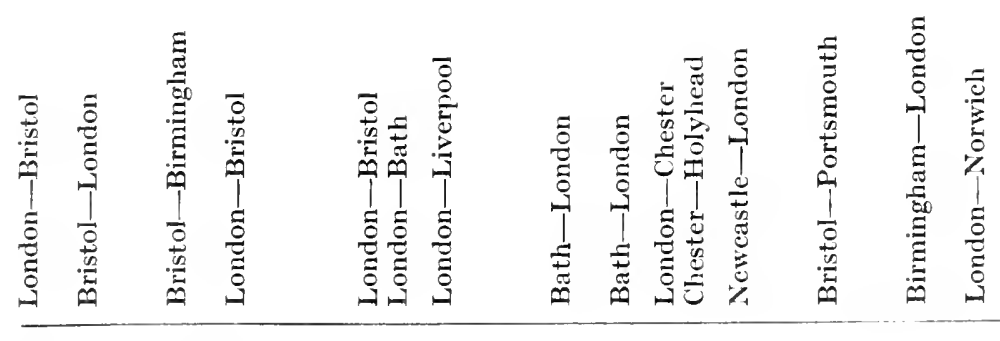

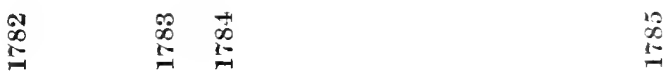




\begin{tabular}{|c|c|c|c|c|c|c|c|c|c|}
\hline 苞 & 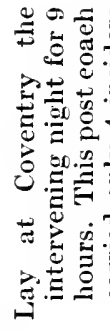 & 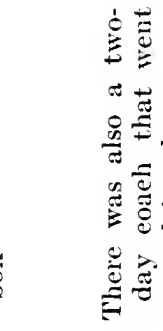 & 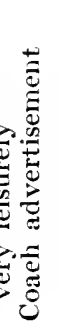 & 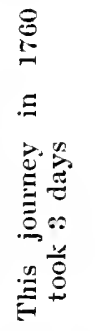 & & & 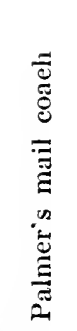 & & \\
\hline 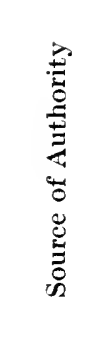 & 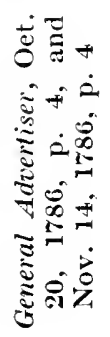 & 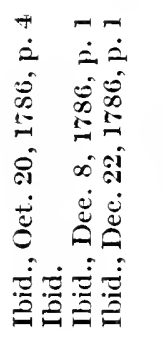 & 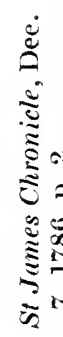 & 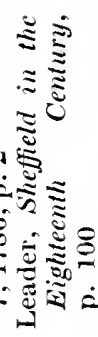 & 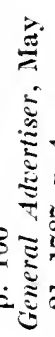 & 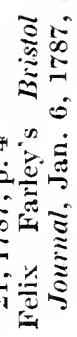 & 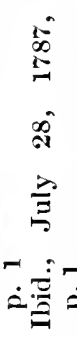 & 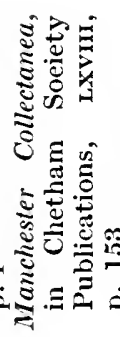 & 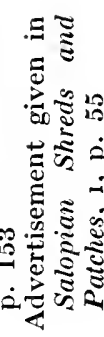 \\
\hline 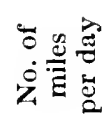 & 8 & $|8| 1$ & 1 & 1 & $\stackrel{19}{g}$ & 1 & 1 & 1 & 1 \\
\hline 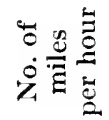 & 1 & $0 \mid 100$ & $x^{-1+}$ & 0 & 1 & हن & $\sin$ & $x$ & + \\
\hline$\stackrel{\Xi}{\Xi}$ & $\underset{0}{2}$ & 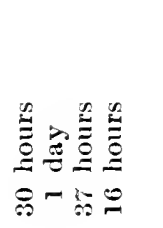 & 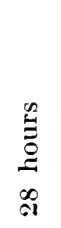 & $\underset{\vdots}{\stackrel{n}{\Xi}}$ & $\begin{array}{l}\dot{\tilde{\Xi}} \\
\tilde{\Xi} \\
\tilde{\Xi} \\
\vec{\Xi} \\
\vec{\Xi} \\
-\end{array}$ & 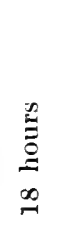 & 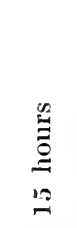 & 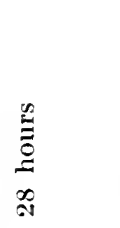 & 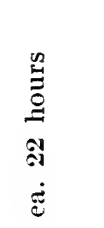 \\
\hline$\dot{0}+\frac{\infty}{Z}$ & $\stackrel{\mathscr{Q}}{\sim}$ & 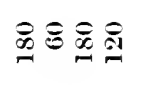 & $\frac{20}{61}$ & 8 & $\stackrel{19}{\mathscr{O}}$ & 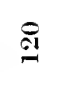 & $\mathscr{\infty}_{\infty}$ & $\stackrel{2}{9}$ & $\stackrel{\infty}{20}$ \\
\hline ב⿱艹 & 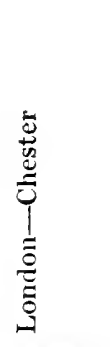 & 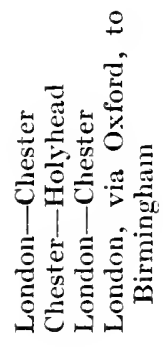 & 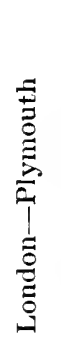 & 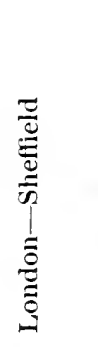 & 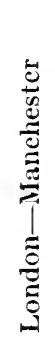 & $\underset{\frac{0}{0}}{\stackrel{0}{0}}$ & 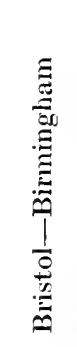 & 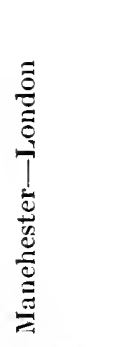 & 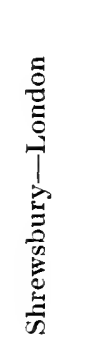 \\
\hline 苛 & $\stackrel{\infty}{0}$ & & & $\begin{array}{l}\infty \\
\infty \\
\infty\end{array}$ & & & & $\begin{array}{l}\infty \\
\infty \\
1 \\
1\end{array}$ & \\
\hline
\end{tabular}




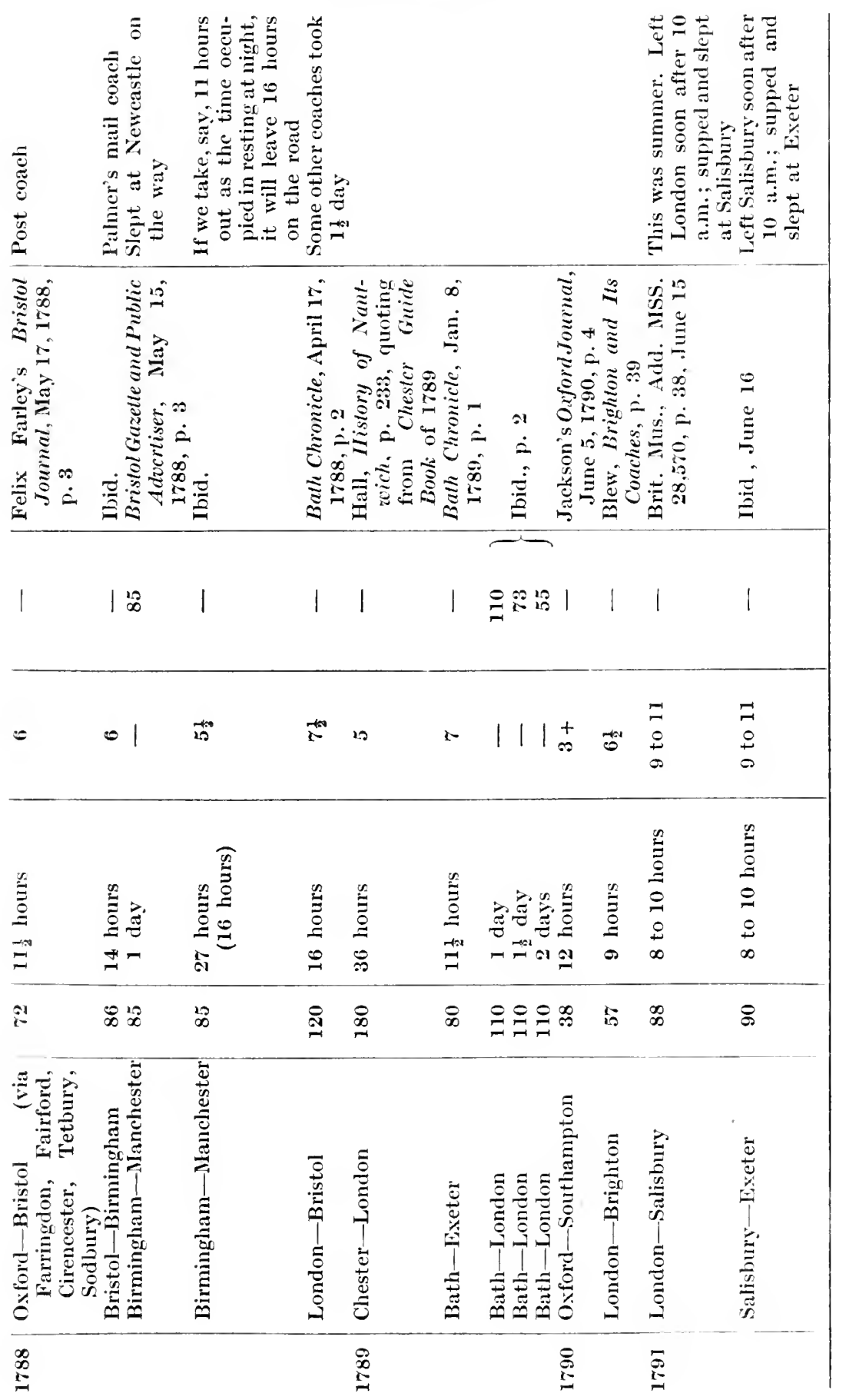




\begin{tabular}{|c|c|c|c|c|c|c|c|c|c|c|}
\hline 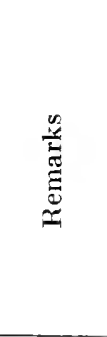 & 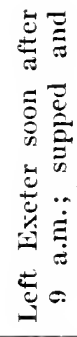 & & & 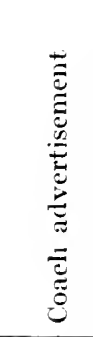 & 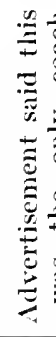 & & & & & 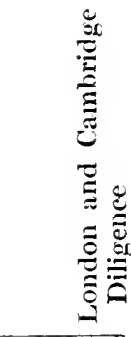 \\
\hline 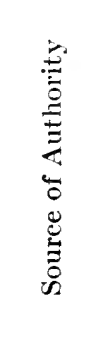 & 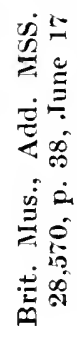 & 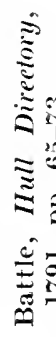 & 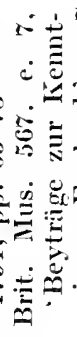 & 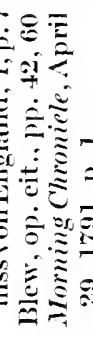 & 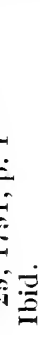 & 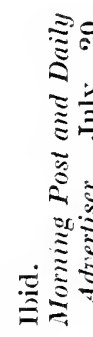 & 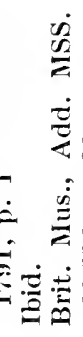 & 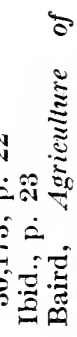 & 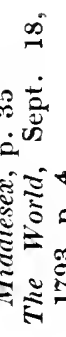 & 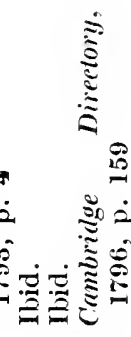 \\
\hline 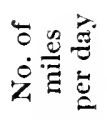 & 1 & $\hat{\theta}$ & 1 & 11 & 1 & 11 & 11 & 11 & 1 & 111 \\
\hline 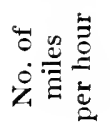 & $\begin{array}{l}\infty \\
0 \\
\infty\end{array}$ & 1 & $\stackrel{\infty}{\dot{E}}$ & 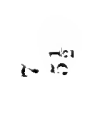 & $r$ & $x$ & $\dot{\mathrm{S}}^{20}$ & on & $=$ & $+\infty$ \\
\hline 总 & $\begin{array}{l}\stackrel{n}{\Xi} \\
\Xi \\
z \\
\stackrel{\Xi}{0} \\
0\end{array}$ & $\frac{n}{2}$ & 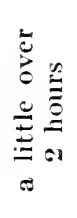 & 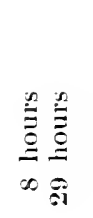 & 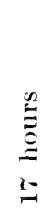 & 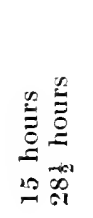 & 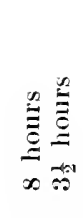 & 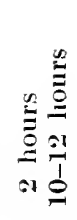 & 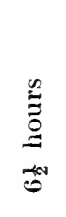 & 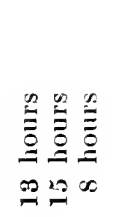 \\
\hline 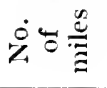 & 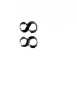 & $\stackrel{\mathscr{O}}{\mathscr{2}}$ & $\ddot{=}$ & 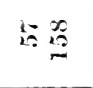 & 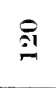 & $\stackrel{g}{g}$ & 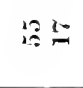 & $\stackrel{\infty}{\circ}$ & 18 & $\stackrel{\infty}{g} \stackrel{0}{=}$ \\
\hline : & $\stackrel{0}{\stackrel{0}{E}}$ & 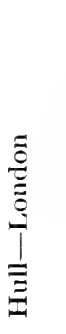 & 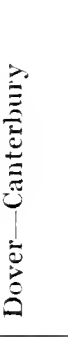 & 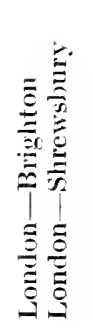 & 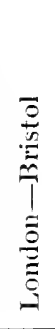 & 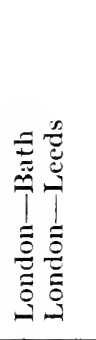 & 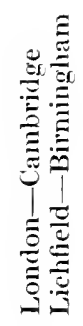 & 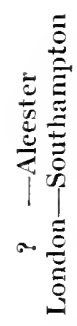 & 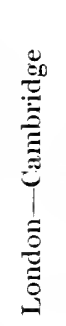 & 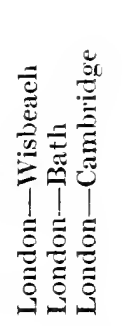 \\
\hline 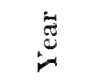 & $\vec{g}$ & & & & & & $\stackrel{a}{\stackrel{\theta}{E}}$ & 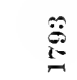 & & 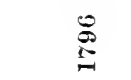 \\
\hline
\end{tabular}




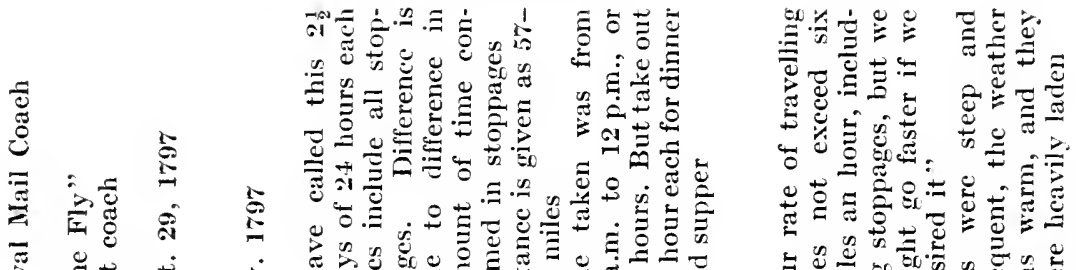

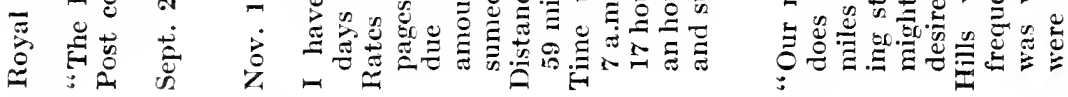

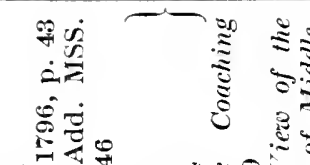

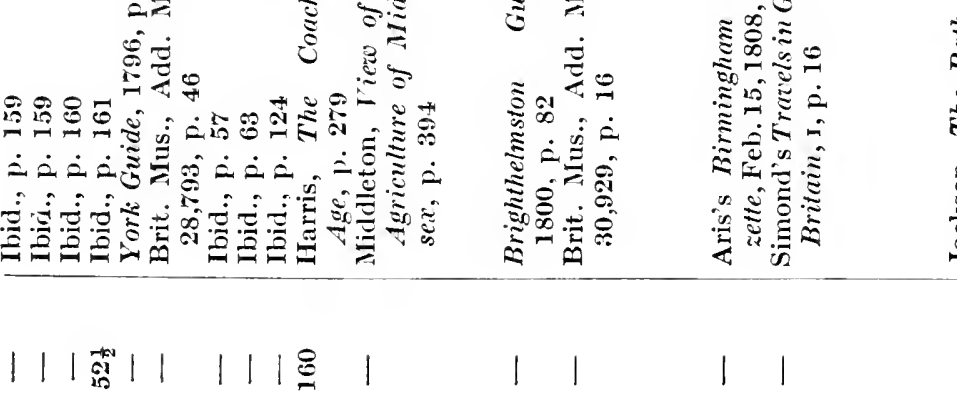

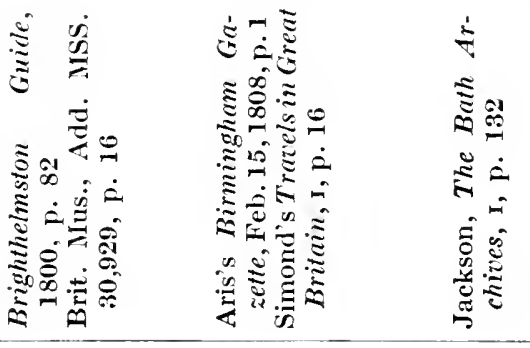

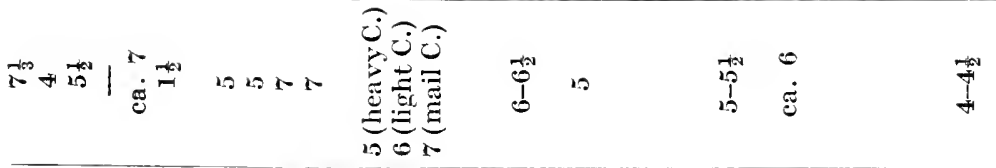

\begin{tabular}{|c|c|c|c|}
\hline 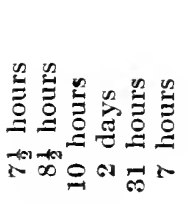 & 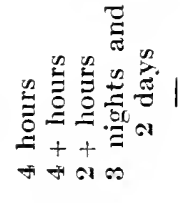 & 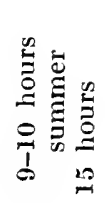 & 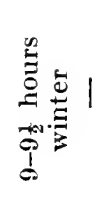 \\
\hline is 8 & 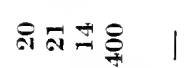 & 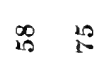 & 81 \\
\hline
\end{tabular}
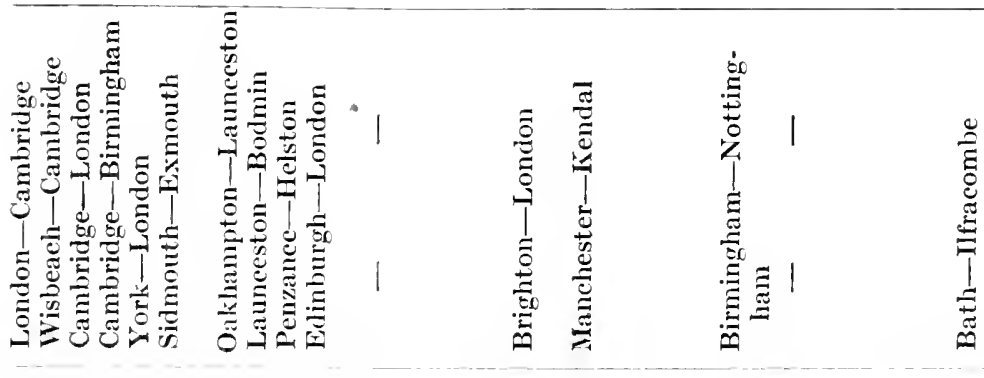

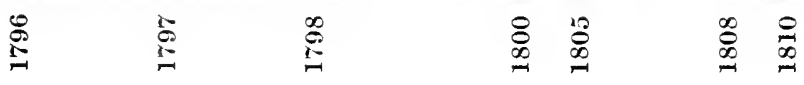




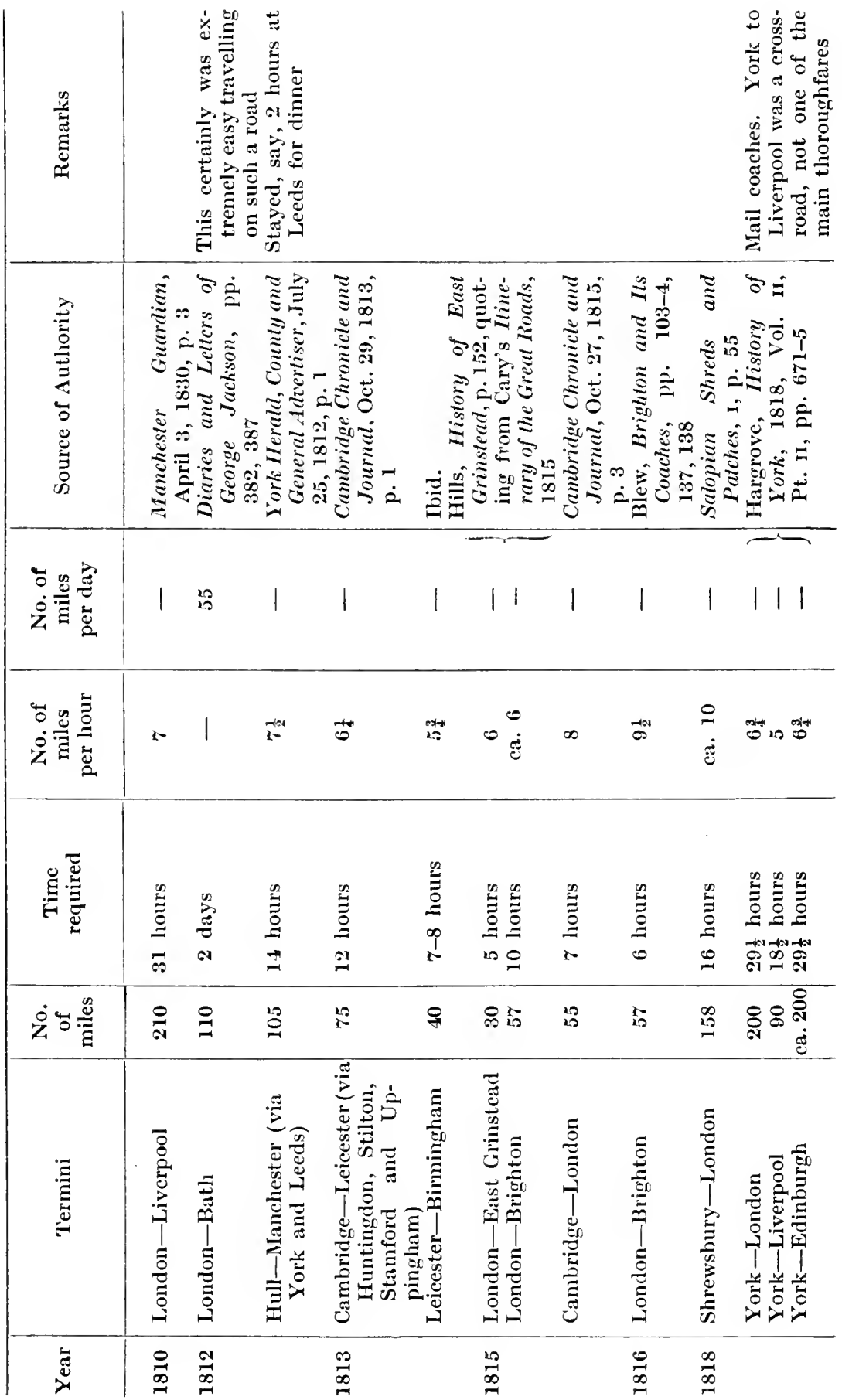




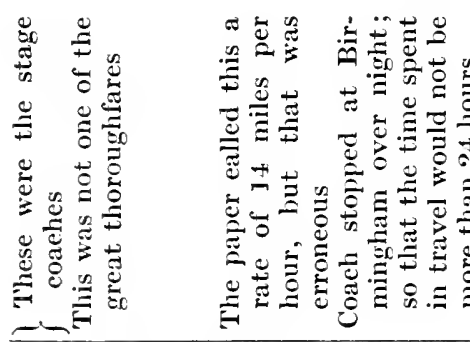

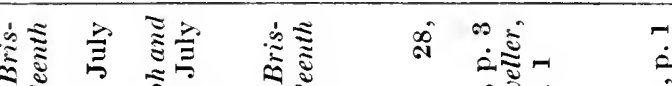

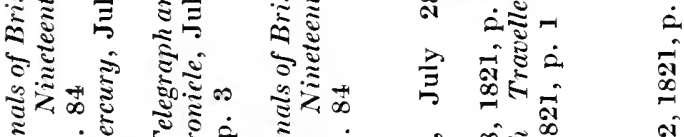

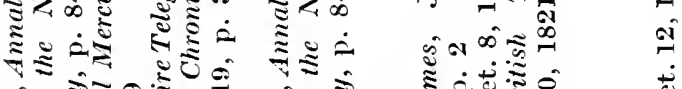

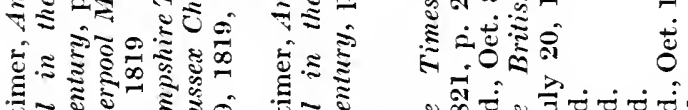

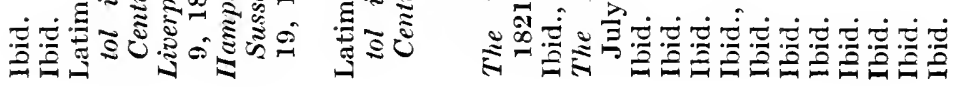

1111111111111111111

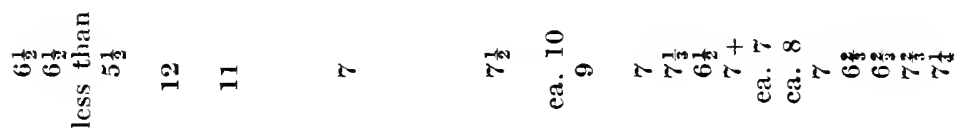

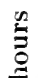

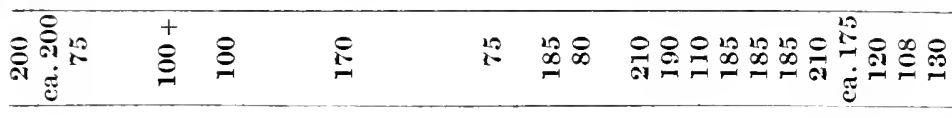

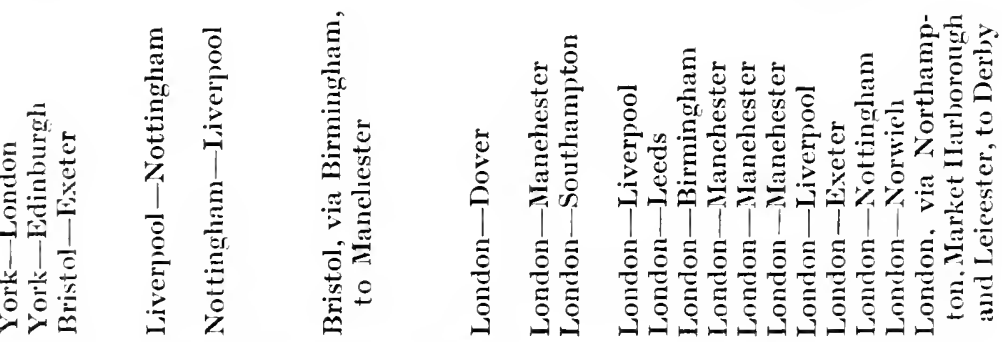

$\underset{\infty}{\infty} \stackrel{0}{\infty} \quad \stackrel{8}{\infty}$ 


\begin{tabular}{|c|c|c|c|c|c|c|}
\hline 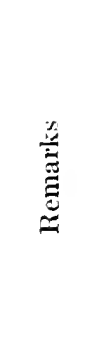 & & 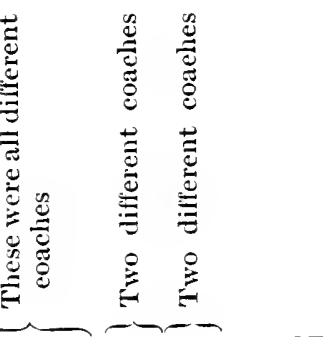 & & & & $\begin{array}{l}0 \\
0 \\
0\end{array}$ \\
\hline 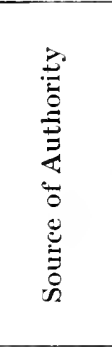 & 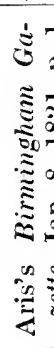 & 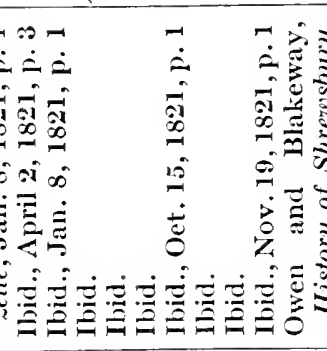 & 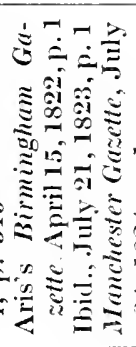 & b & 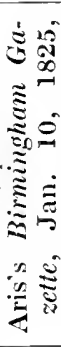 & 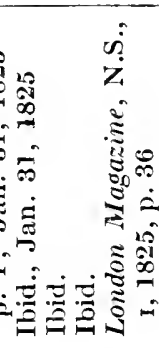 \\
\hline 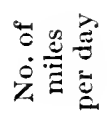 & 1 & 1111111111 & 111 & $1 \mid$ & | & 1111 \\
\hline 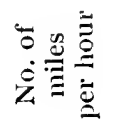 & & 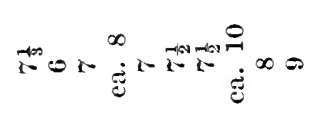 & 1- $\quad \infty$ & $\underbrace{\infty}$ & $\infty$ & $0 \cos _{\infty}^{+\infty} \infty$ \\
\hline$\stackrel{\mathscr{Z}}{\mathscr{Z}}$ & 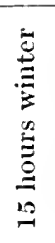 & 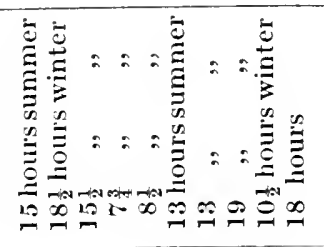 & 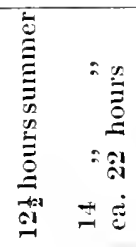 & 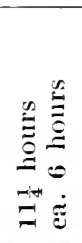 & 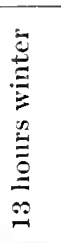 & 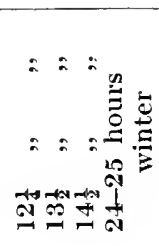 \\
\hline$\dot{\dot{z}}+\stackrel{\mathscr{E}}{\cong}$ & $\stackrel{\varrho}{\Xi}$ & 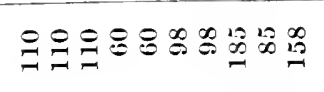 & 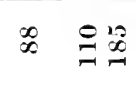 & $\ddot{\infty}$ & $\varrho$ & 을요용 \\
\hline 节 & 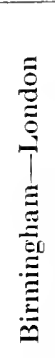 & 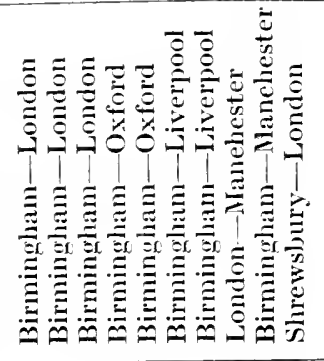 & 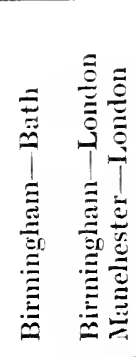 & 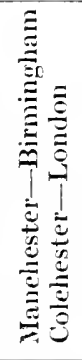 & 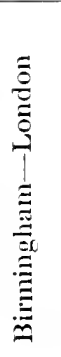 & 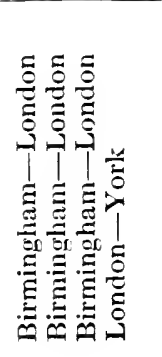 \\
\hline 节 & 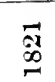 & $\stackrel{\infty}{\sim}$ & 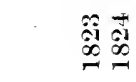 & 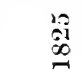 & & \\
\hline
\end{tabular}




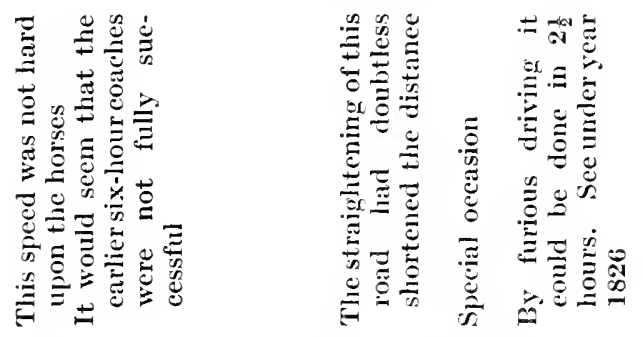

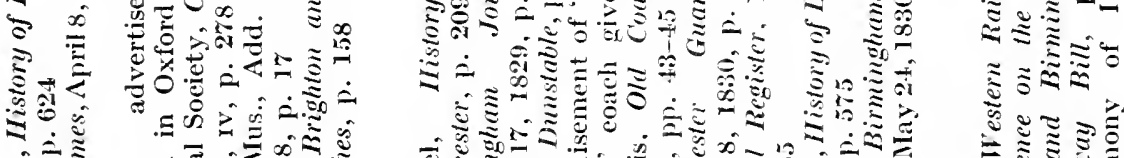

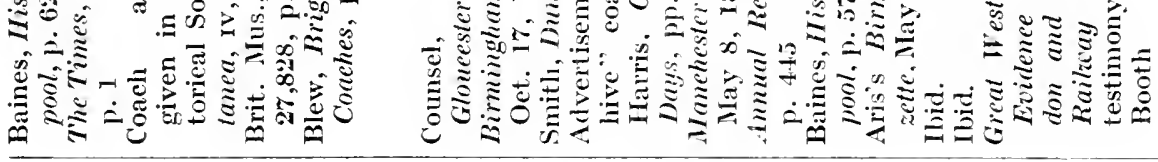

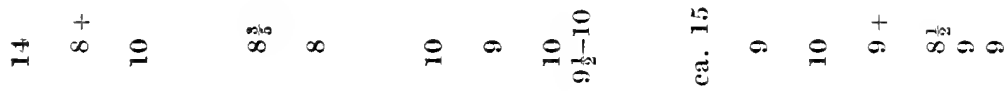

$\stackrel{\infty}{\Xi}$

के

a

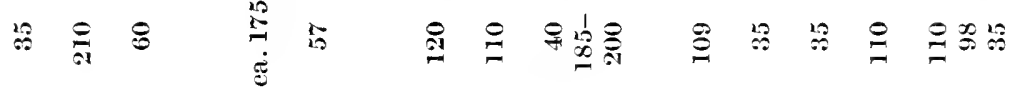

政

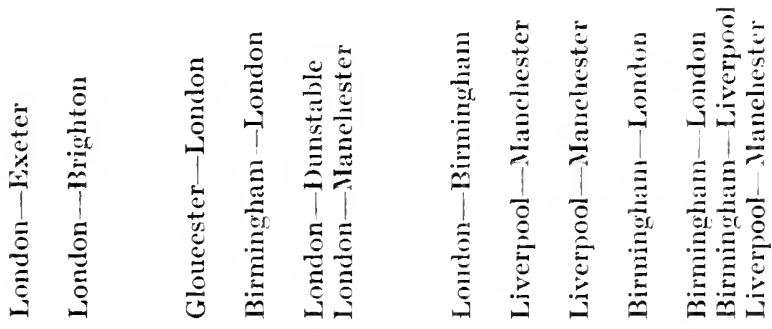

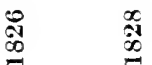

突 


\begin{tabular}{|c|c|c|c|c|c|}
\hline 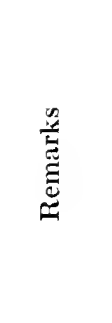 & \multicolumn{3}{|c|}{ 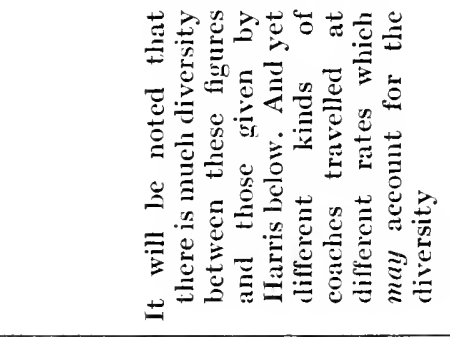 } & & \\
\hline 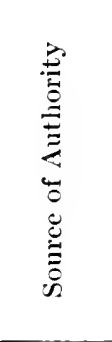 & 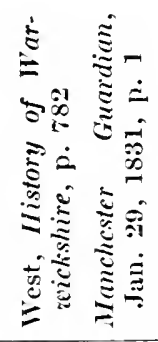 & 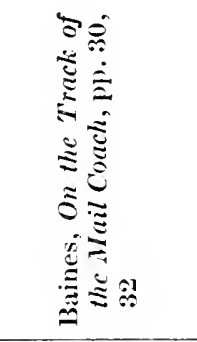 & 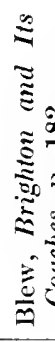 & 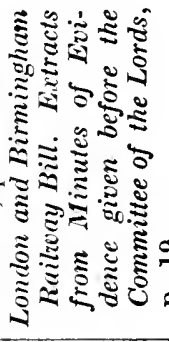 & 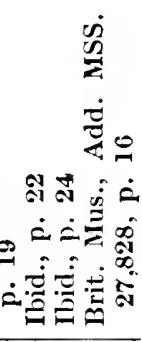 \\
\hline 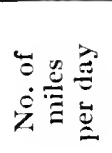 & $\overbrace{|\infty| \mid}^{-\infty}$ & 111111 & 1 & 1 & 111 \\
\hline 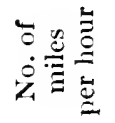 & om & 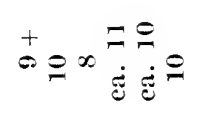 & $\vec{i}$ & $\underset{\infty}{-\infty}$ & $-\infty \theta$ \\
\hline$\stackrel{\Xi}{g}$ & 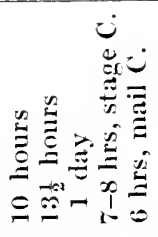 & 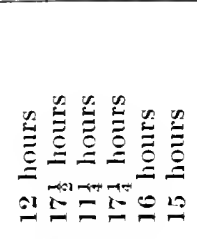 & 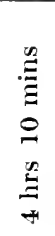 & $\begin{array}{l}\stackrel{n}{\Xi} \\
\stackrel{\Xi}{\Xi} \\
\stackrel{2}{2}\end{array}$ & 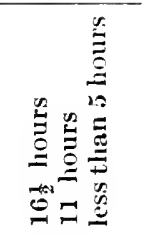 \\
\hline 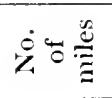 & 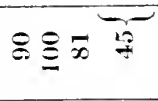 & $0 \begin{array}{l}0 \\
0 \\
0\end{array}$ & 5 & $\stackrel{8}{0}$ & $\stackrel{\infty}{=} \underset{0}{0}$ \\
\hline 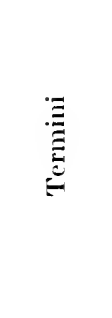 & 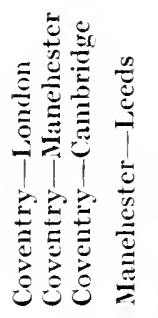 & 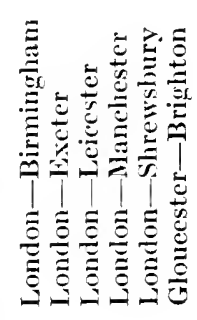 & 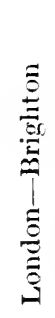 & 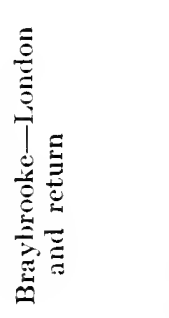 & 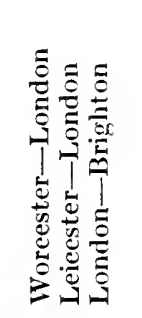 \\
\hline 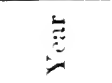 & $\overline{\ddot{\dot{x}}}$ & 兽 & & & \\
\hline
\end{tabular}




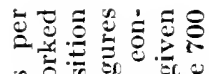

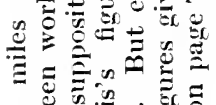

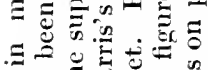

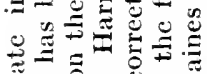

茫

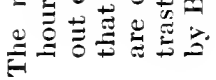

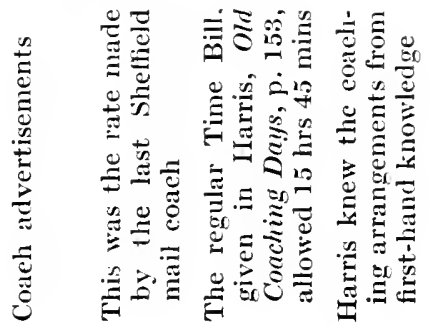

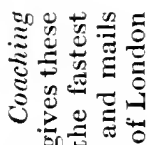

ङ

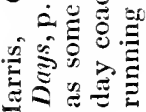

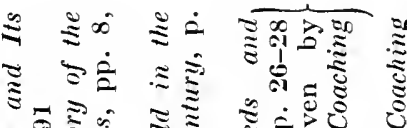

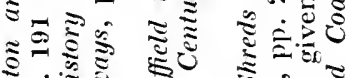

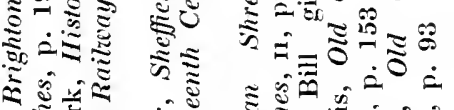

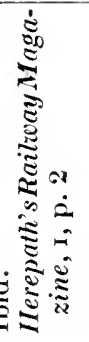

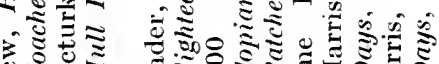
শิ

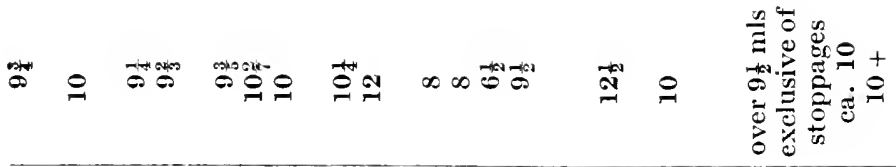

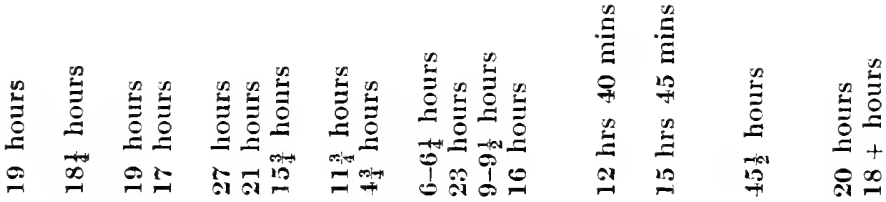

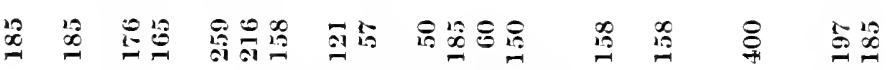

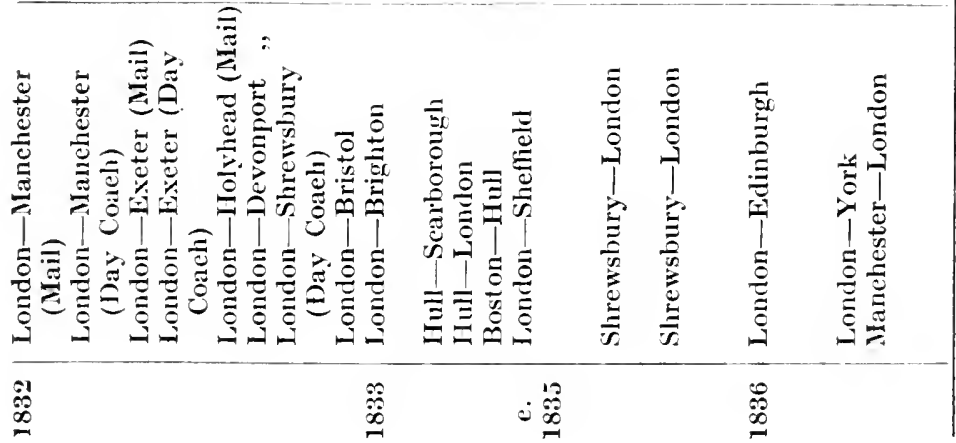

J. T. II. 


\title{
APPENDIX 6
}

\author{
COST OF TRAVEL, $1750-1830$
}

ThE following data upon this subject have been collected and arranged in tabular form; and it may here be said that this table is subjeet to the deviations from accuracy that were mentioned at the beginning of Appendix 5. For example, to those who would scrutinize these statistics closely it will be apparent that the distance between certain great termini is different in some cases from that in other cases. This is due in some instances to the fact that different routes were taken between these termini. For example, the road from London to Manchester might be through Dunstable, Northampton, Loughborough and Derby; or it might lead through Coventry, Birmingham, Newcastle and Iacelesfield. The improvement of the roads usually led also to the straightening of them, and consequently to the reduetion of the distances. In most of these cases we have considered the cost of travelling upon the great highways of communication of the kingdom, for the statisties of travel on the minor cross-roads have been difficult to secure, probably because the great majority of the travellers were destined for the great towns and cities on business, rather than for the smaller places on the cross-roads. Our conclusion from the statisties here presented will be found in the text. 


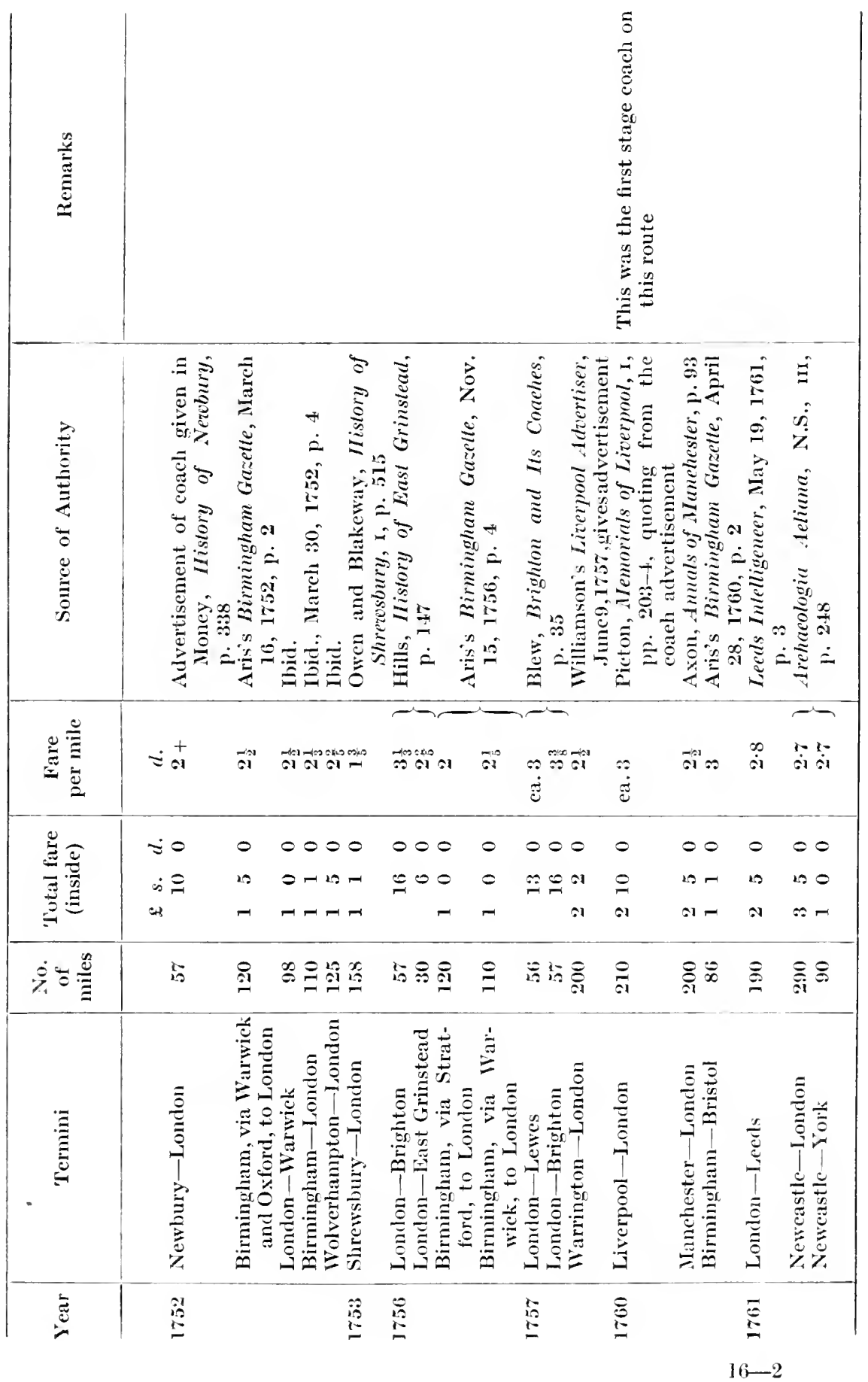




\begin{tabular}{|c|c|c|c|c|c|c|c|c|c|c|}
\hline تص & & & & & & & & 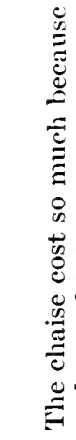 & & \\
\hline 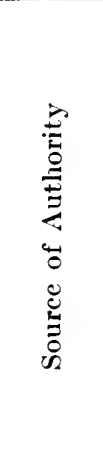 & 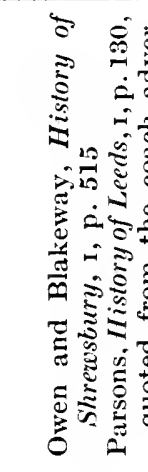 & 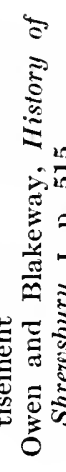 & 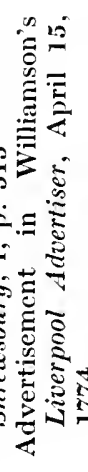 & 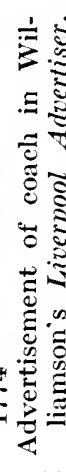 & 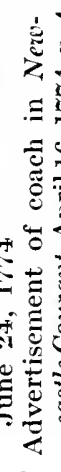 & 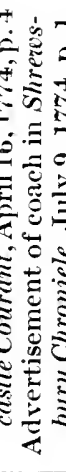 & 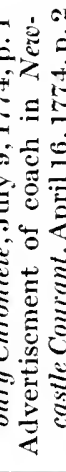 & 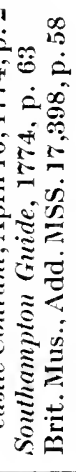 & 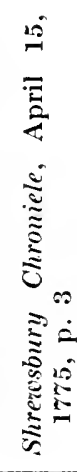 & 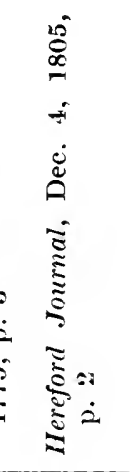 \\
\hline 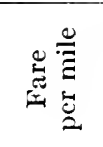 & व & N & ato & $\therefore$ & 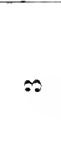 & הi & $\ddot{\dot{\sigma}}$ & No & $\stackrel{\leftrightarrow}{\dot{J}}$ & 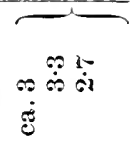 \\
\hline 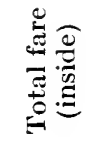 & 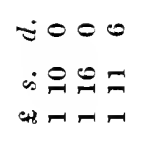 & $\begin{array}{l}0 \\
\pm \\
-1\end{array}$ & $\begin{array}{l}0 \\
\infty\end{array}$ & 0 & $\begin{array}{l}0 \\
0 \\
-1\end{array}$ & $\begin{array}{l}0 \\
\stackrel{2}{m}\end{array}$ & $\begin{array}{l}0 \\
\infty \\
\theta\end{array}$ & $\begin{array}{l}=0 \\
0\end{array}$ & $\begin{array}{l}= \\
x \\
m\end{array}$ & $\begin{array}{l}000 \\
0 N= \\
\pi\end{array}$ \\
\hline 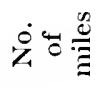 & 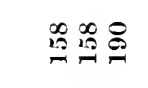 & 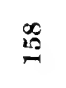 & $\stackrel{100}{\circ}$ & $\vec{\sigma}$ & 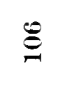 & $\stackrel{\infty}{2}$ & $\stackrel{\mathscr{G}}{i}$ & 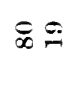 & $\stackrel{\Xi}{\beth}$ & $\stackrel{\mathrm{i}}{\mathrm{i}} \mathrm{N}$ \\
\hline$\stackrel{\Xi}{\Xi}$ & 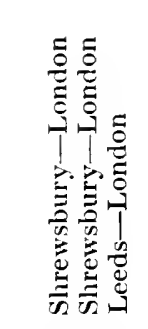 & 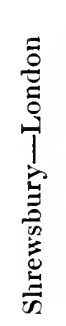 & 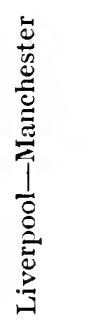 & 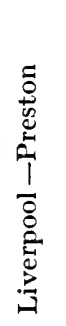 & 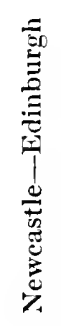 & 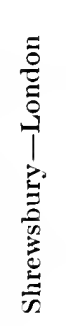 & 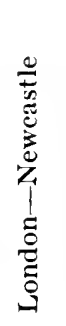 & 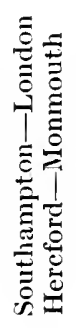 & 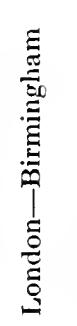 & 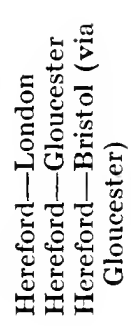 \\
\hline$\ddot{\Xi}$ & 总过道 & $\underset{N}{\mathbb{N}}$ & 壳 & & & & & $\frac{20}{1}$ & & \\
\hline
\end{tabular}




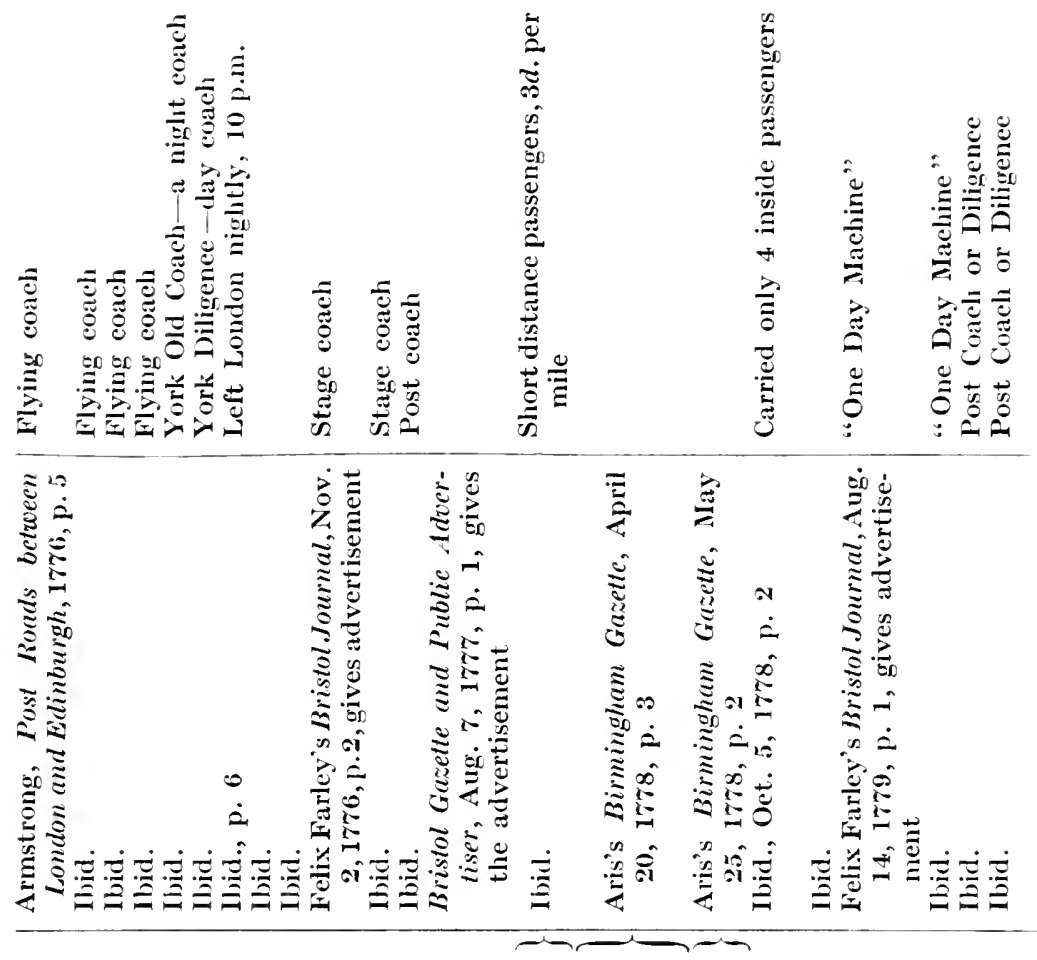

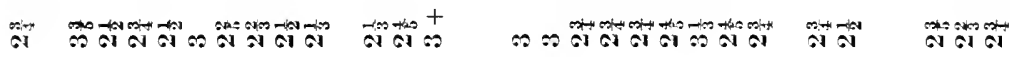

\begin{tabular}{|c|c|c|c|c|c|}
\hline$\theta$ & 100000000 & 000 & 000000000 & 00 & $\theta=0$ \\
\hline$\because$ & $=01-\infty) \infty 010$ & $-\infty=$ & $-\infty \infty \infty \mathrm{d}-0-0$ & 1028 & $\therefore \div 0$ \\
\hline$\therefore$ & 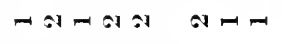 & 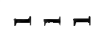 & 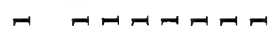 & $r r$ & $\sim-m$ \\
\hline 今. & 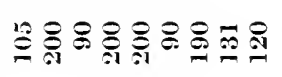 & 용용 & 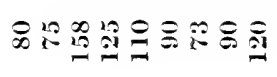 & $\cong \cong$ & 월 \\
\hline
\end{tabular}

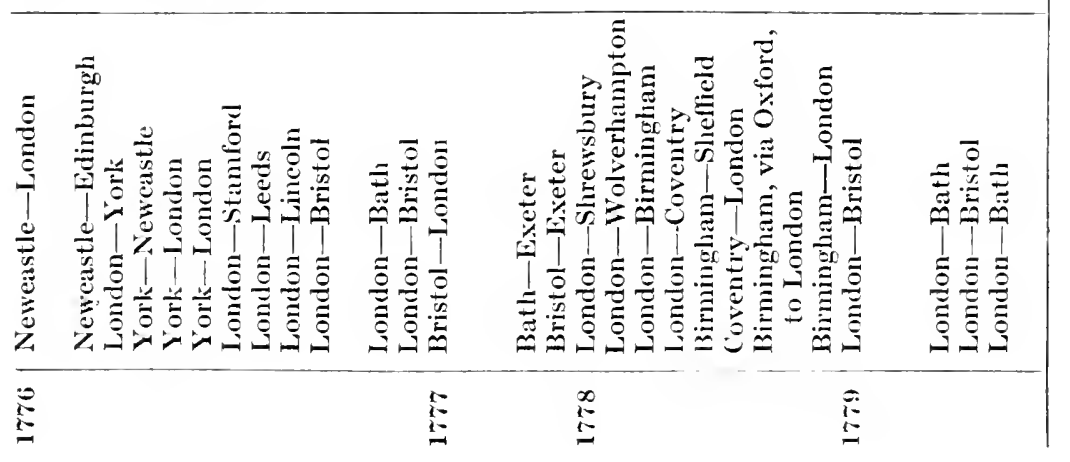




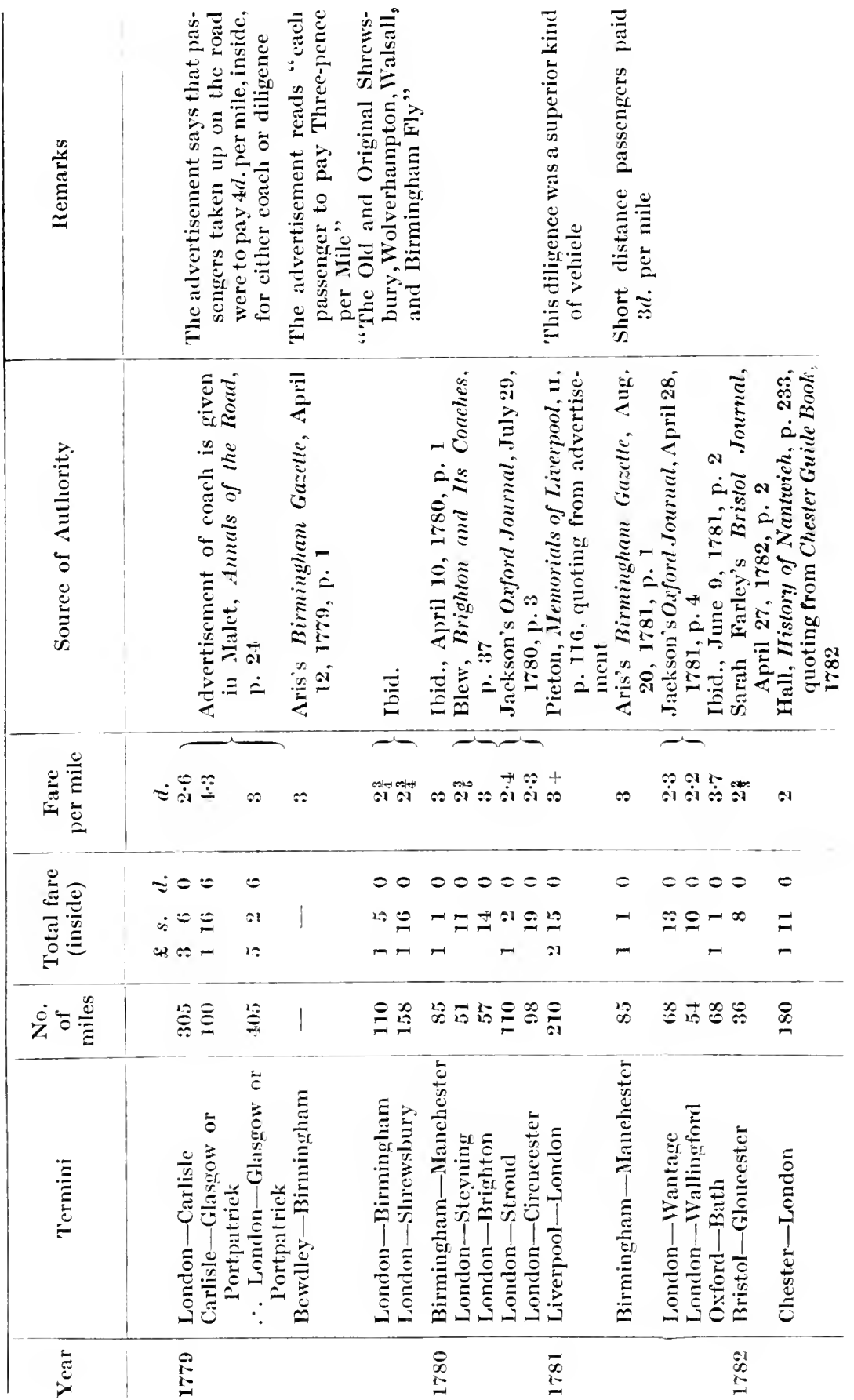



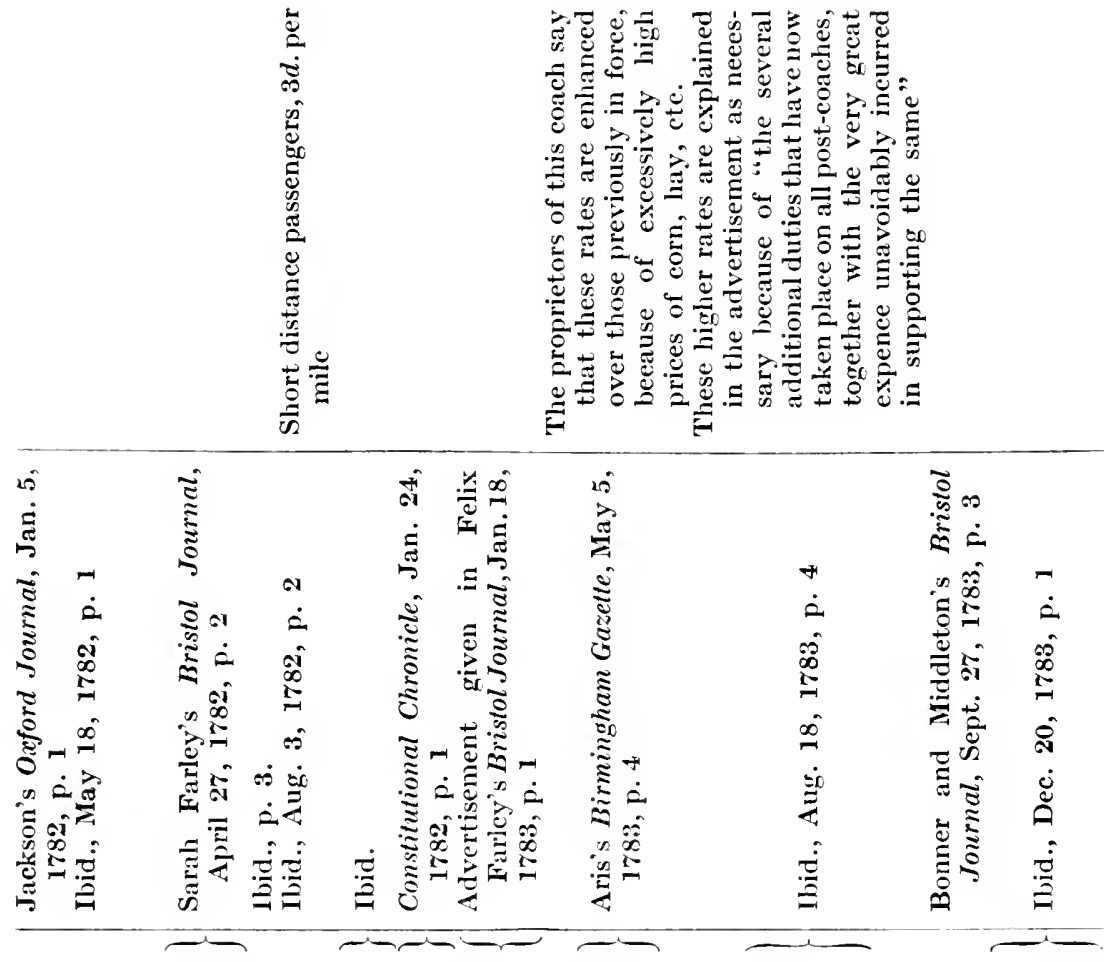

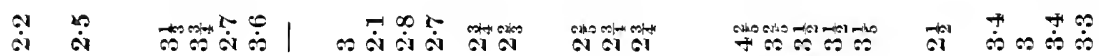

\begin{tabular}{|c|c|c|c|c|c|c|}
\hline 0 & 0000 & 000000 & 000 & 00000 & 0 & 0000 \\
\hline$\pi$ & $\infty 201$ & $\pi-\infty$ as 10 & $=\infty 2$ & $\ddot{\sim} \ddot{\sim} \approx 0$ & $\ddot{\theta}$ & $720+$ \\
\hline & $\pi$ & - & $\pi-1-1$ & $\therefore \sim \sim-\sim$ & & \\
\hline
\end{tabular}

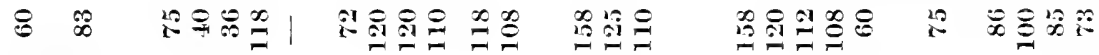

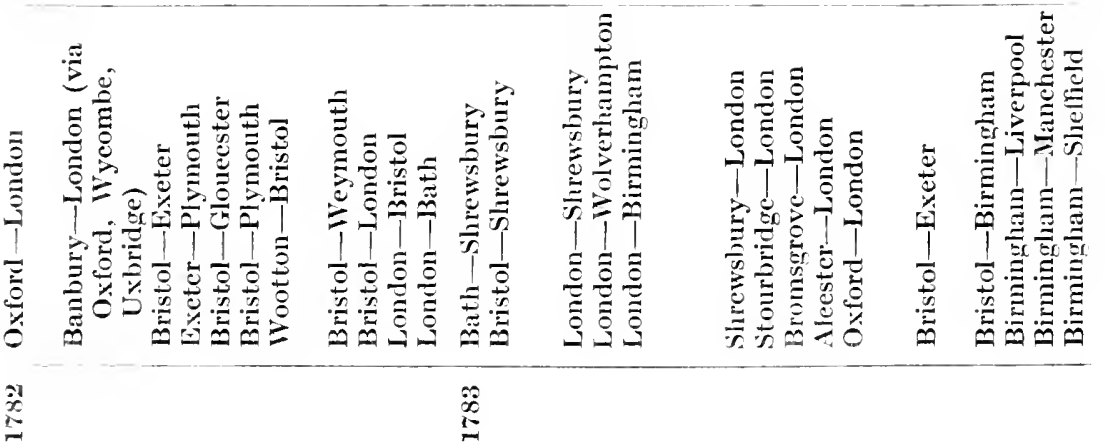




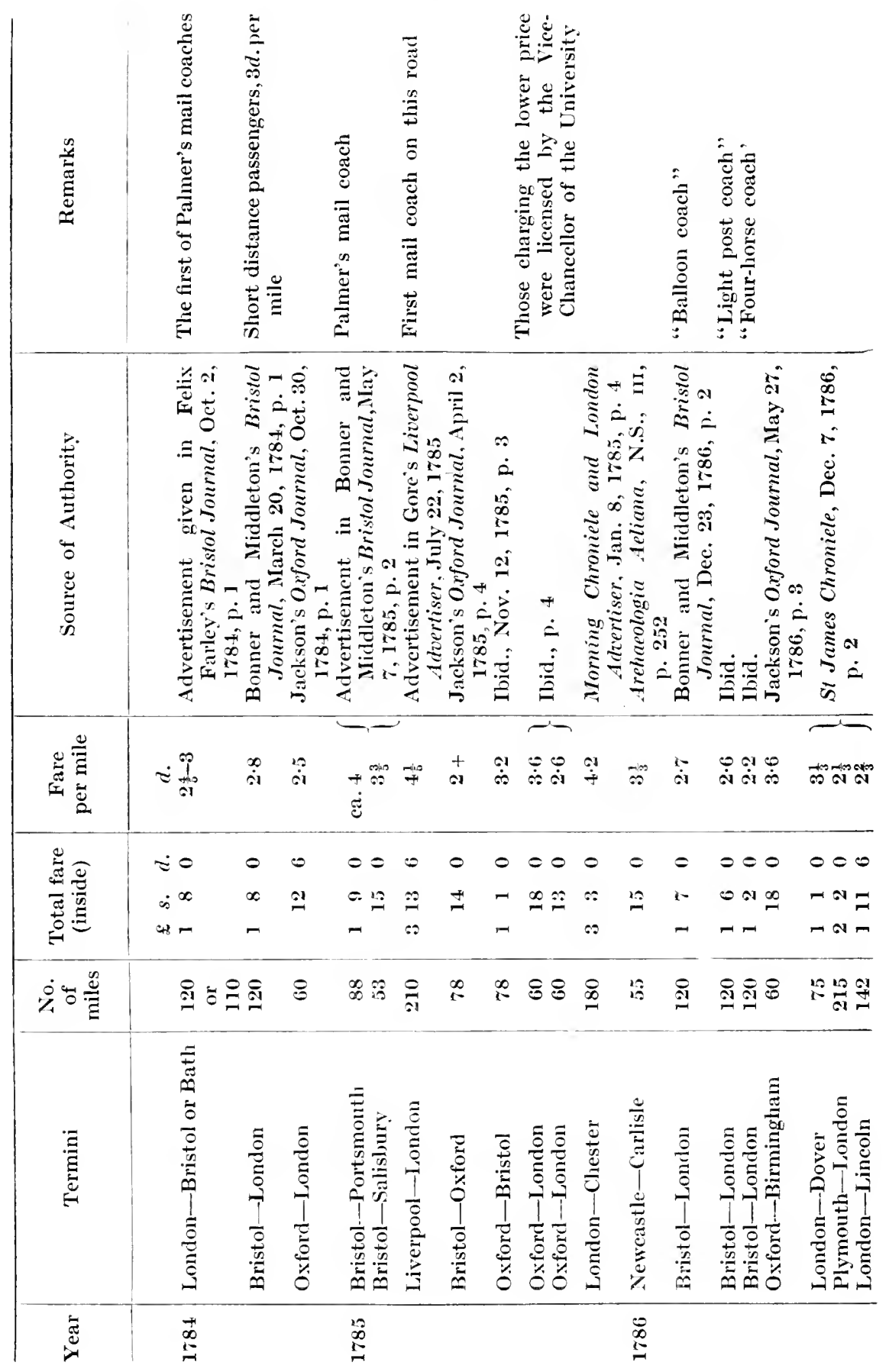



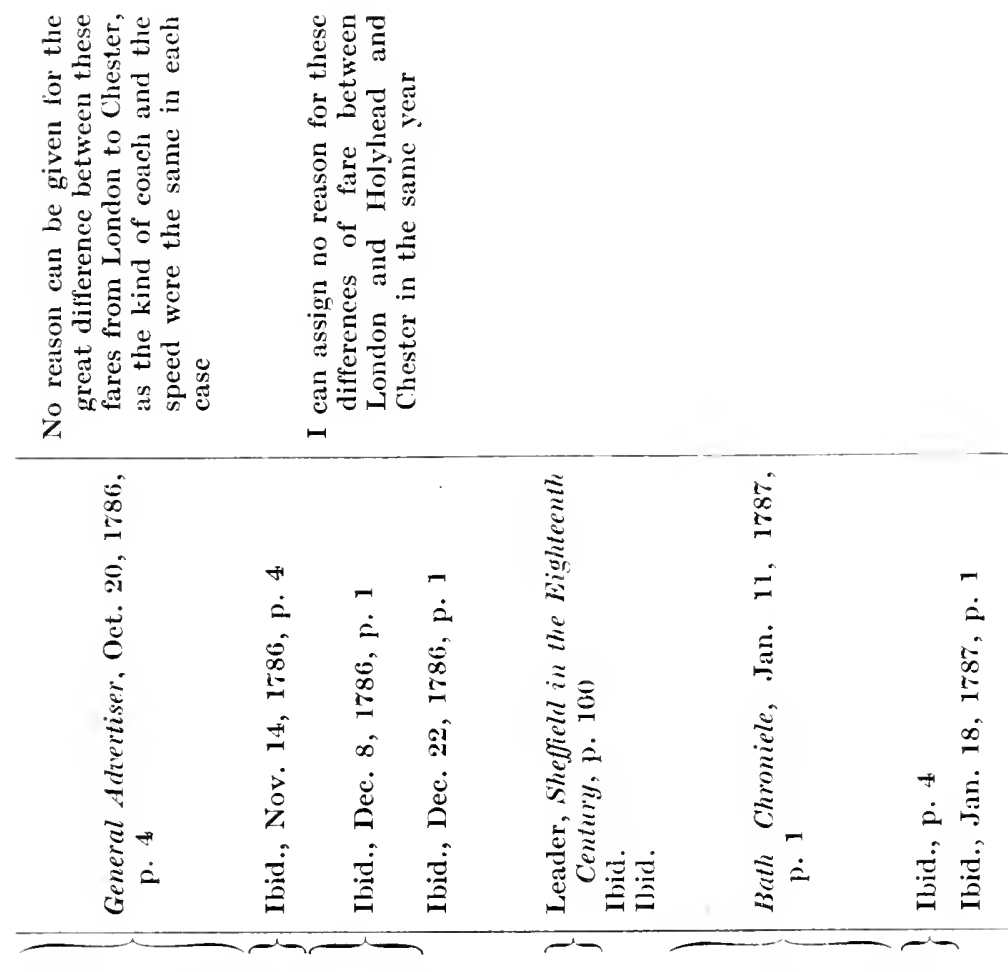

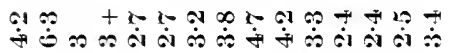

a हैं हं

$$
\begin{aligned}
& \text { - 00000000000000 } 000000000000000
\end{aligned}
$$

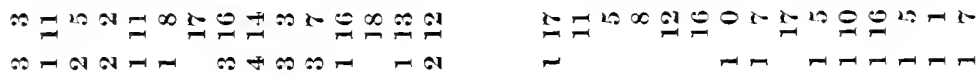

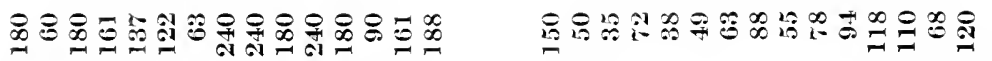

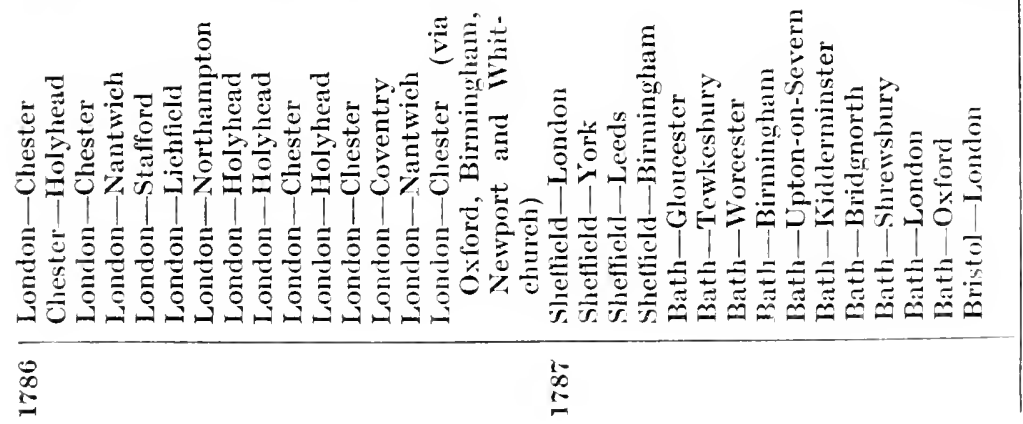




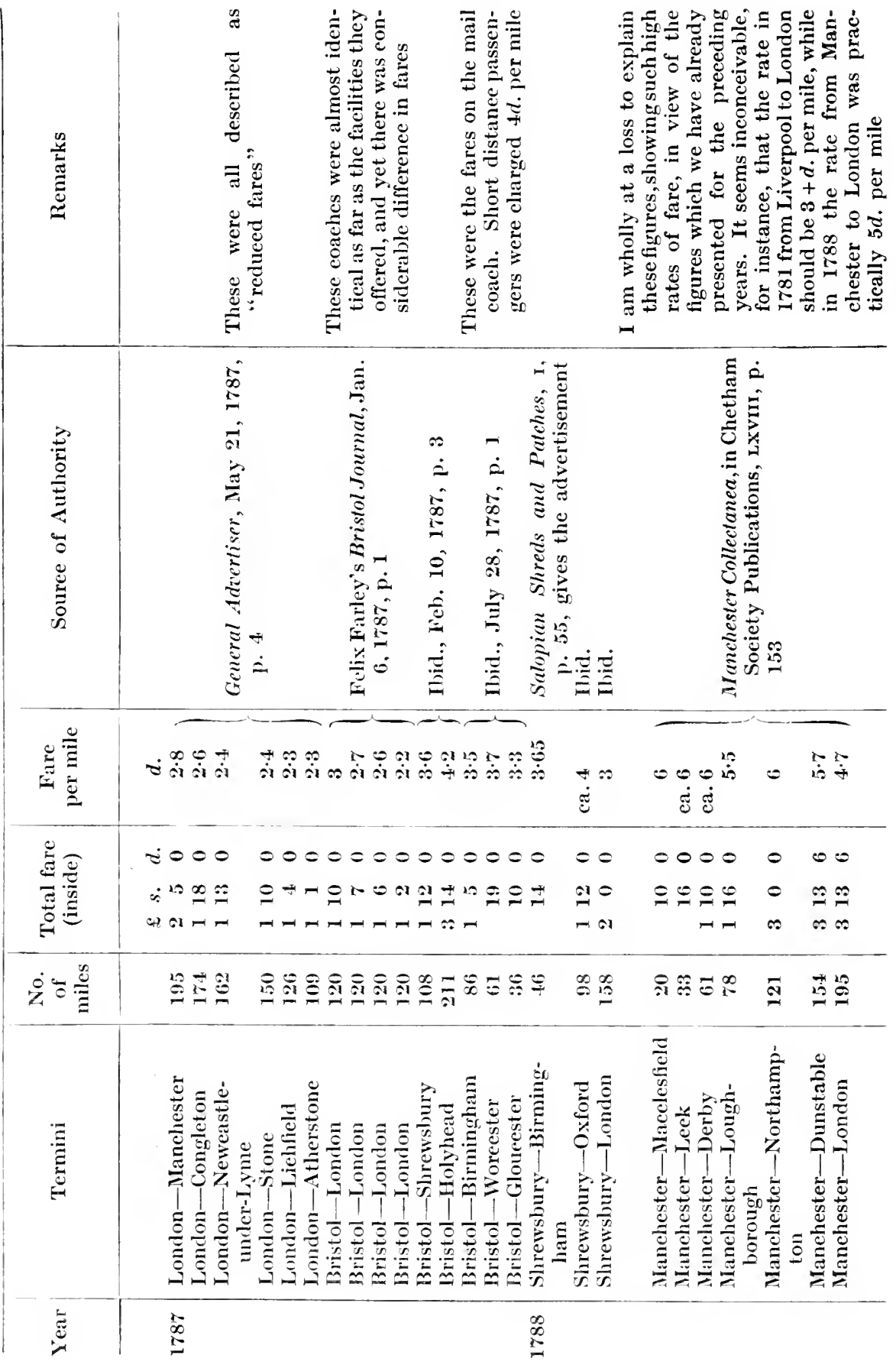




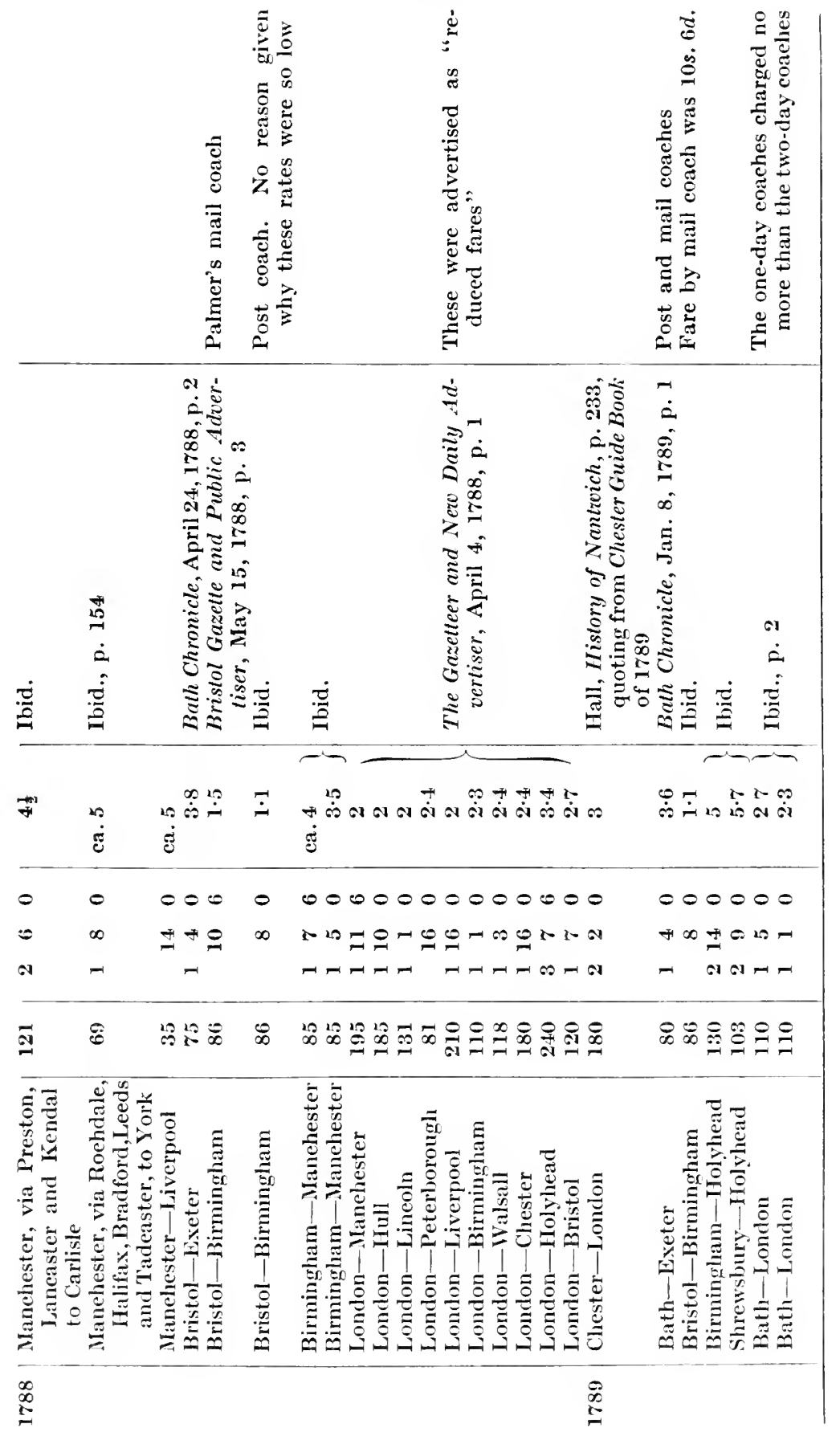




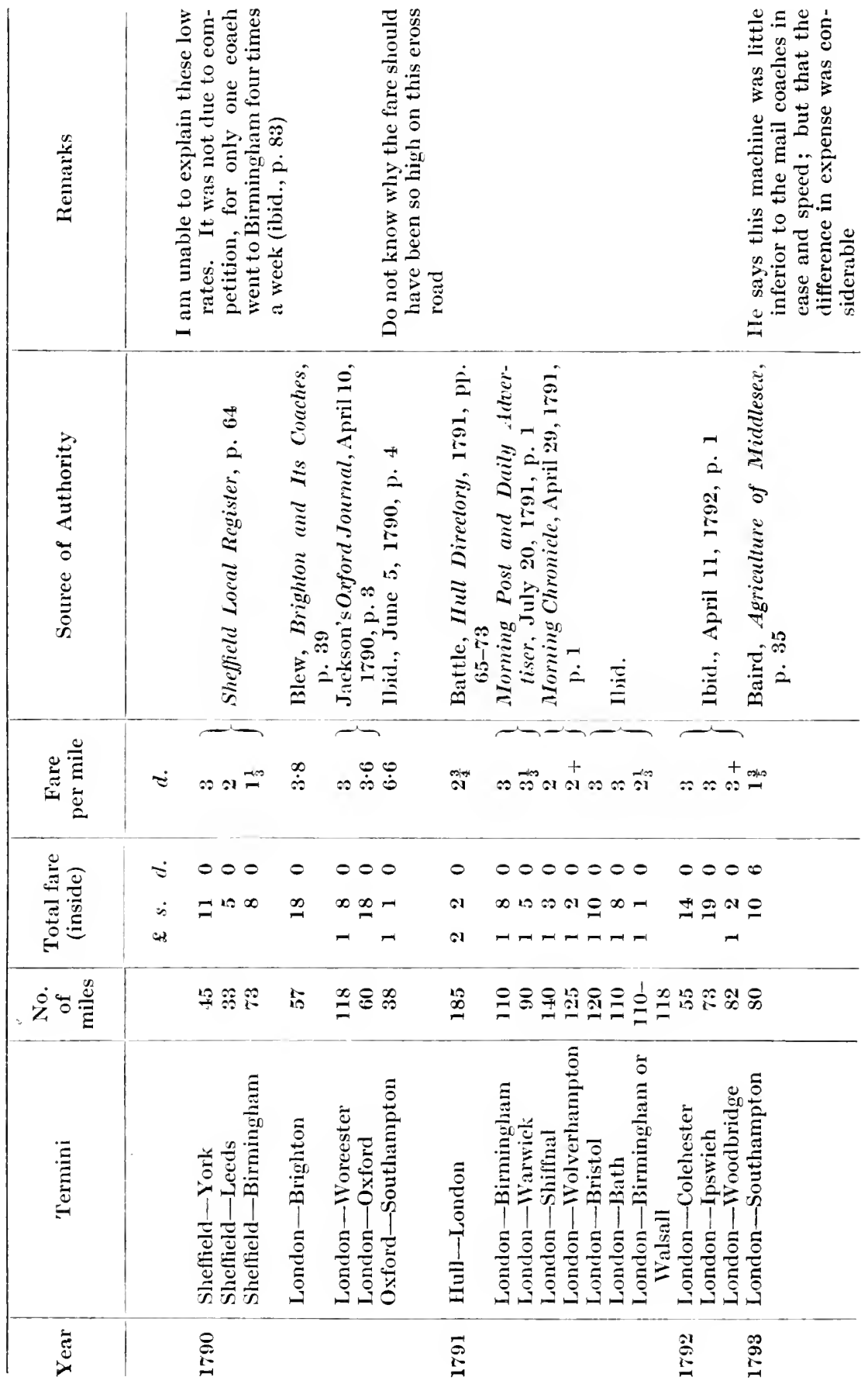




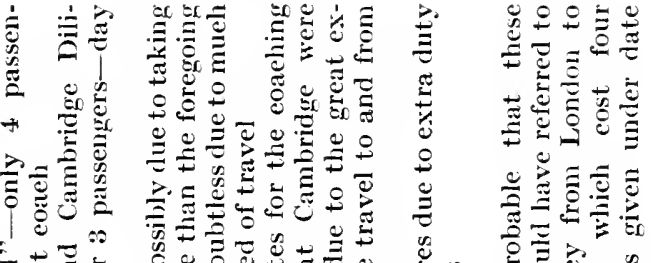

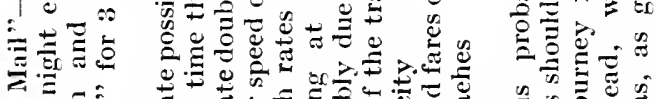

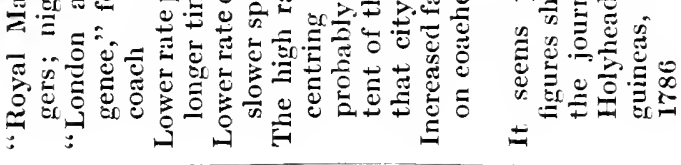

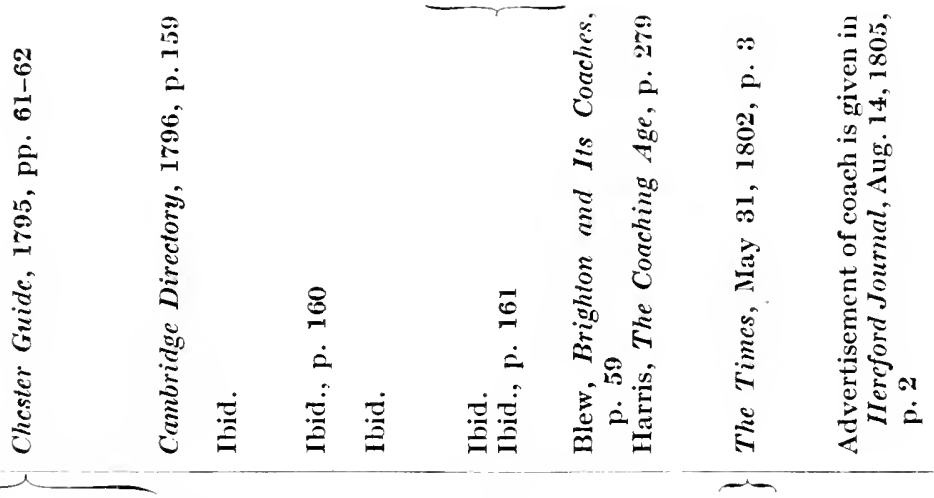

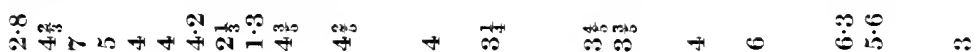
ฮึं

\begin{tabular}{|c|c|c|c|c|c|c|c|}
\hline 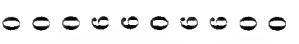 & 0 & 0 & 0 & $=0$ & 0 & 0 & $\Leftrightarrow 0$ \\
\hline 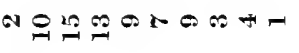 & 0 & $\stackrel{\infty}{\sim}$ & 20 & $\triangleq=$ & $\stackrel{9}{-}$ & 0 & $\Xi+$ \\
\hline 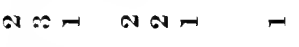 & $r$ & & & - & & $\varrho$ & $\nLeftarrow+$ \\
\hline
\end{tabular}

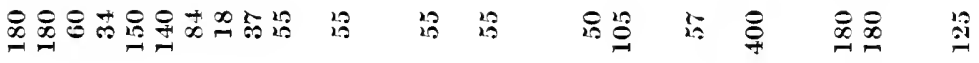

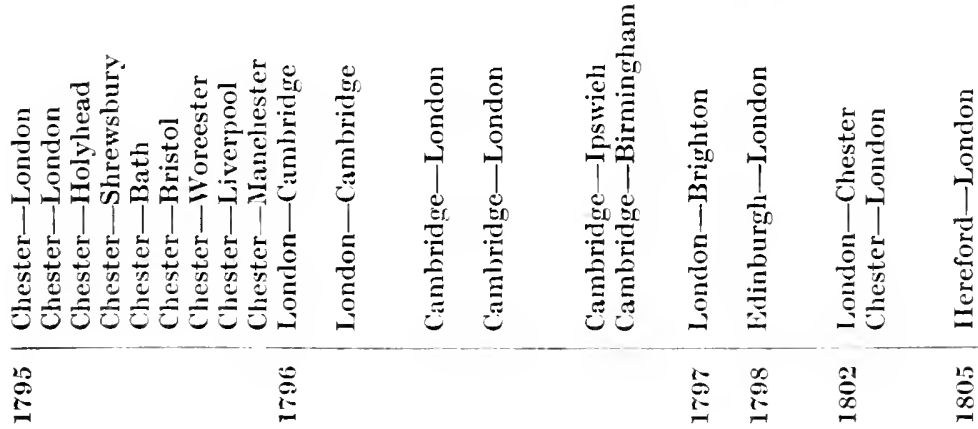




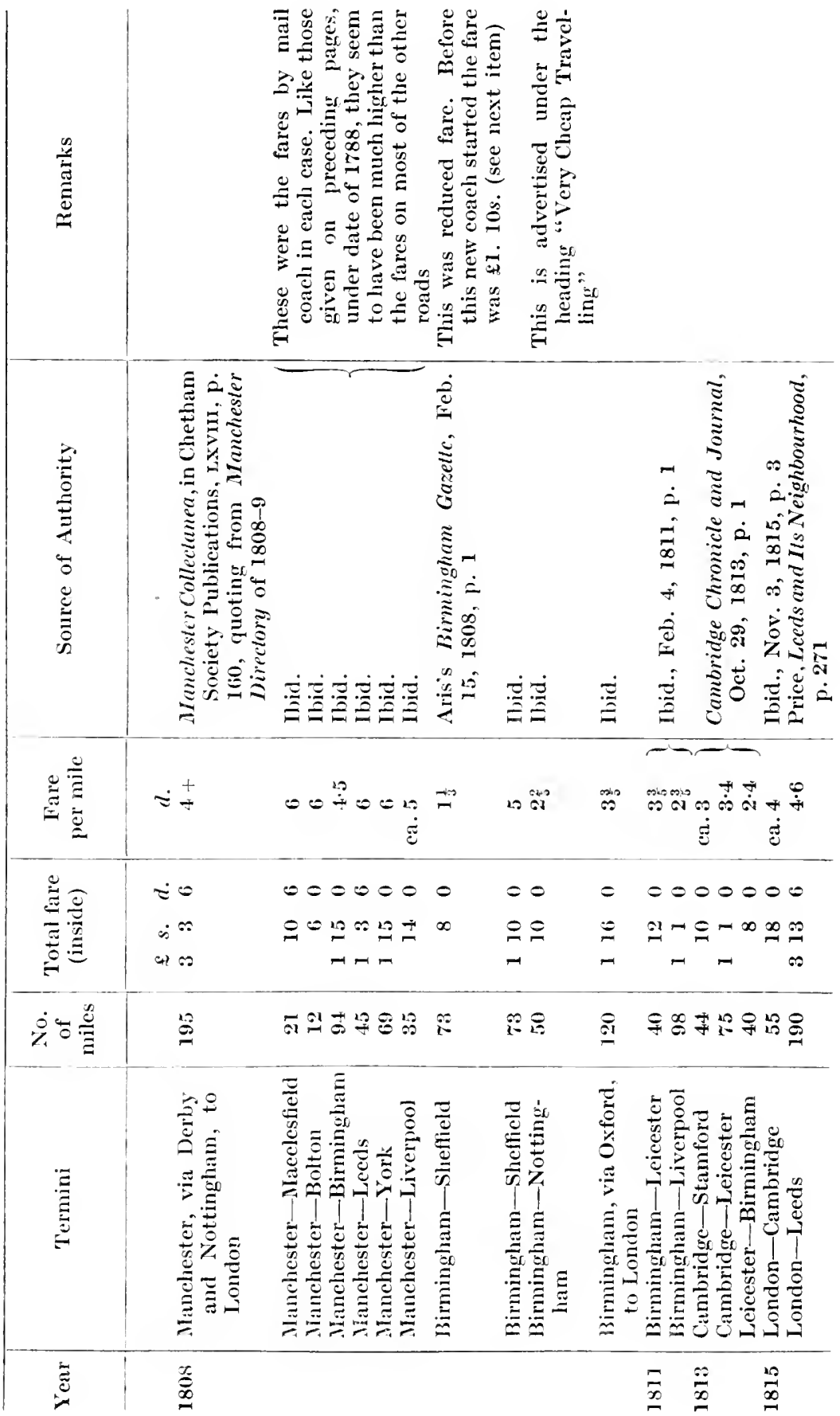




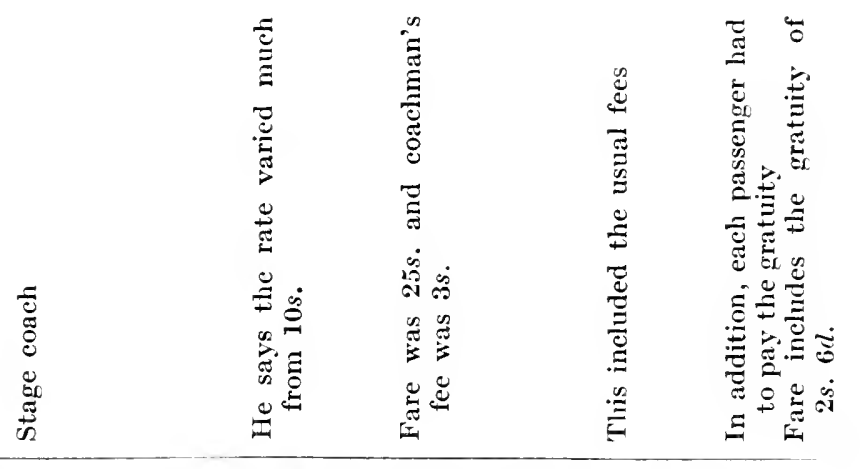

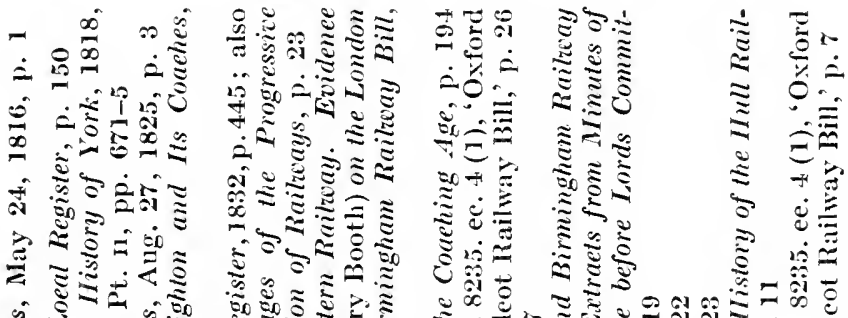

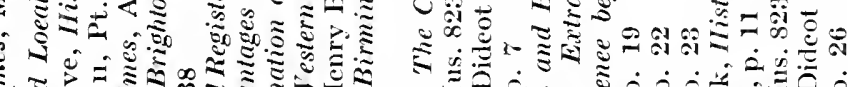
蛋

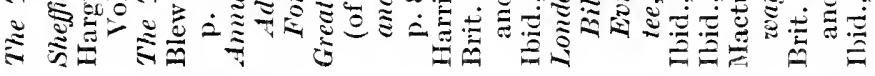

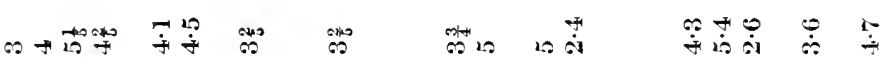

\begin{tabular}{|c|c|c|c|c|c|c|c|}
\hline $0=0$ & 00 & 0 & 0 & 00 & $=0$ & 000 & 0 \\
\hline $020 \%$ & $\stackrel{\infty}{\sim}-$ & $\varrho$ & 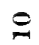 & $\varrho \infty$ & 209 & $a+x$ & $\because$ \\
\hline مه & $\pi$ & & & $\mp$ & $-m$ & 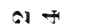 & \\
\hline
\end{tabular}

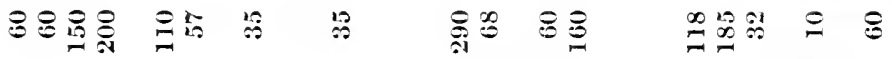

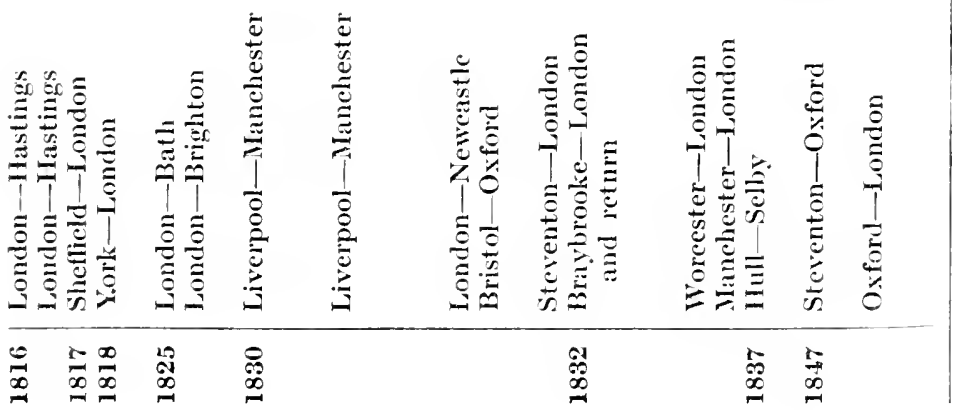




\section{APPENDIX 7}

\section{COST OF CARRIAGE OF GOODS BY LAND, 1750-1830}

The following details of the expense of conveyance by land have been brought together in this tabular form from sourees which are anong the most reliable. As in the preeeding tables, so here, the statisties have been made as aecurate as possible; but it is inevitable that some slight errors exist, on aecount of our inability to know exactly the length of the road from one place to another at these earlier times. But if absolute aecuraey is unattainable, we can at least say that the slight limit of error renders our figures relatively correct. The data here presented have been summarized, in order to arrive at some general conclusion as to the cost of earriage, and, at the same time, to enable the reader to see the variations from that general eonclusion, whieh is stated in the text. 


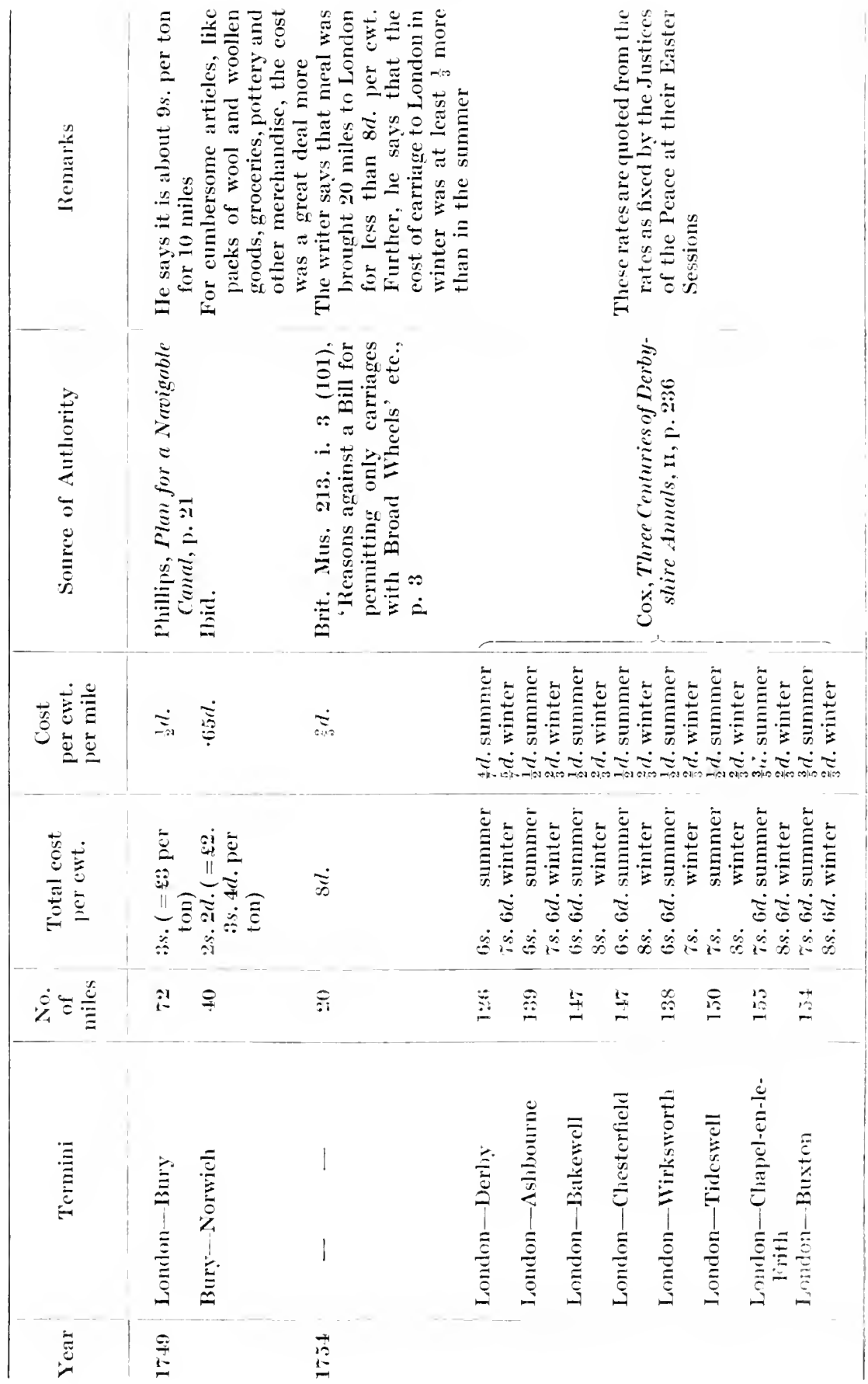

J. T. II. 


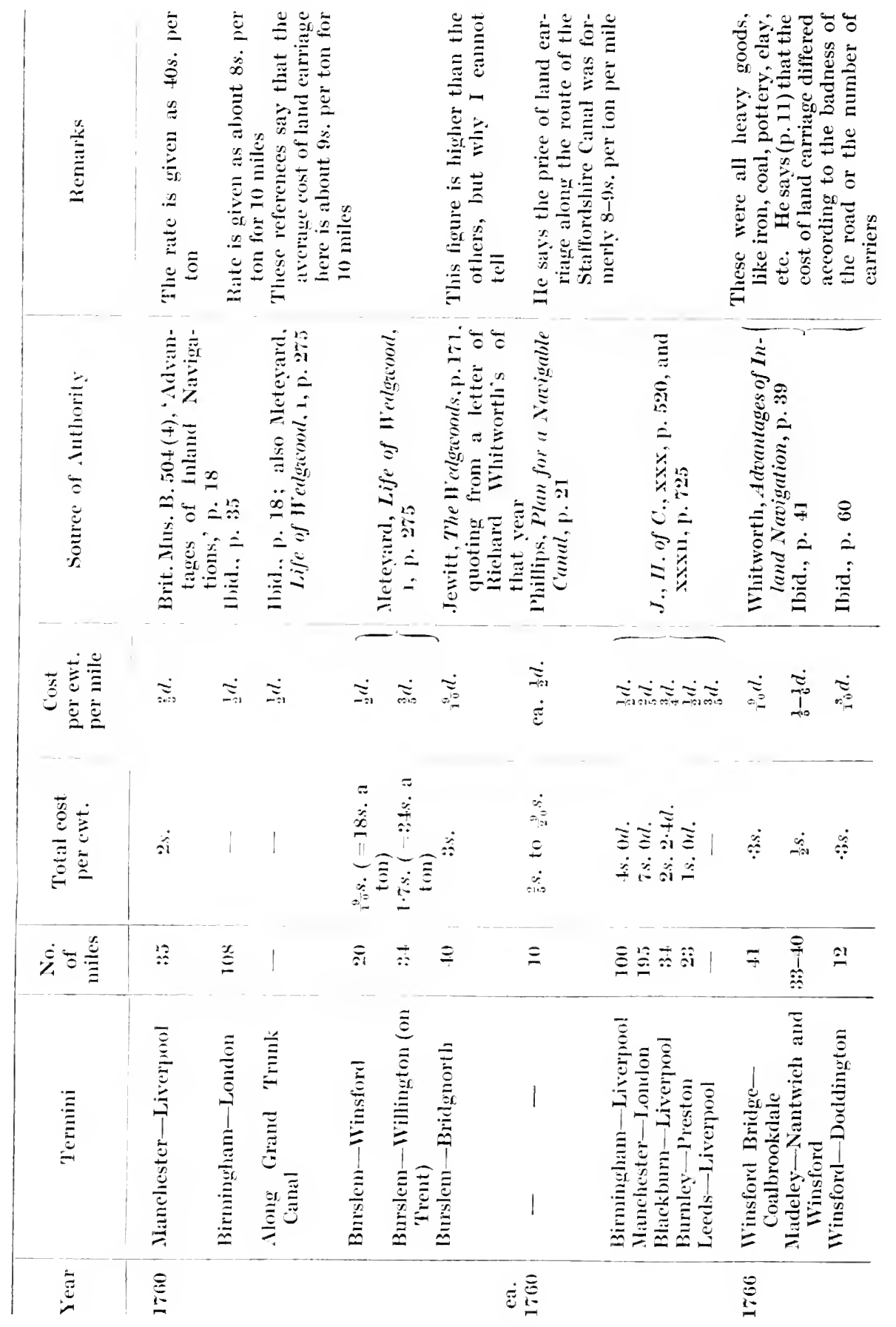




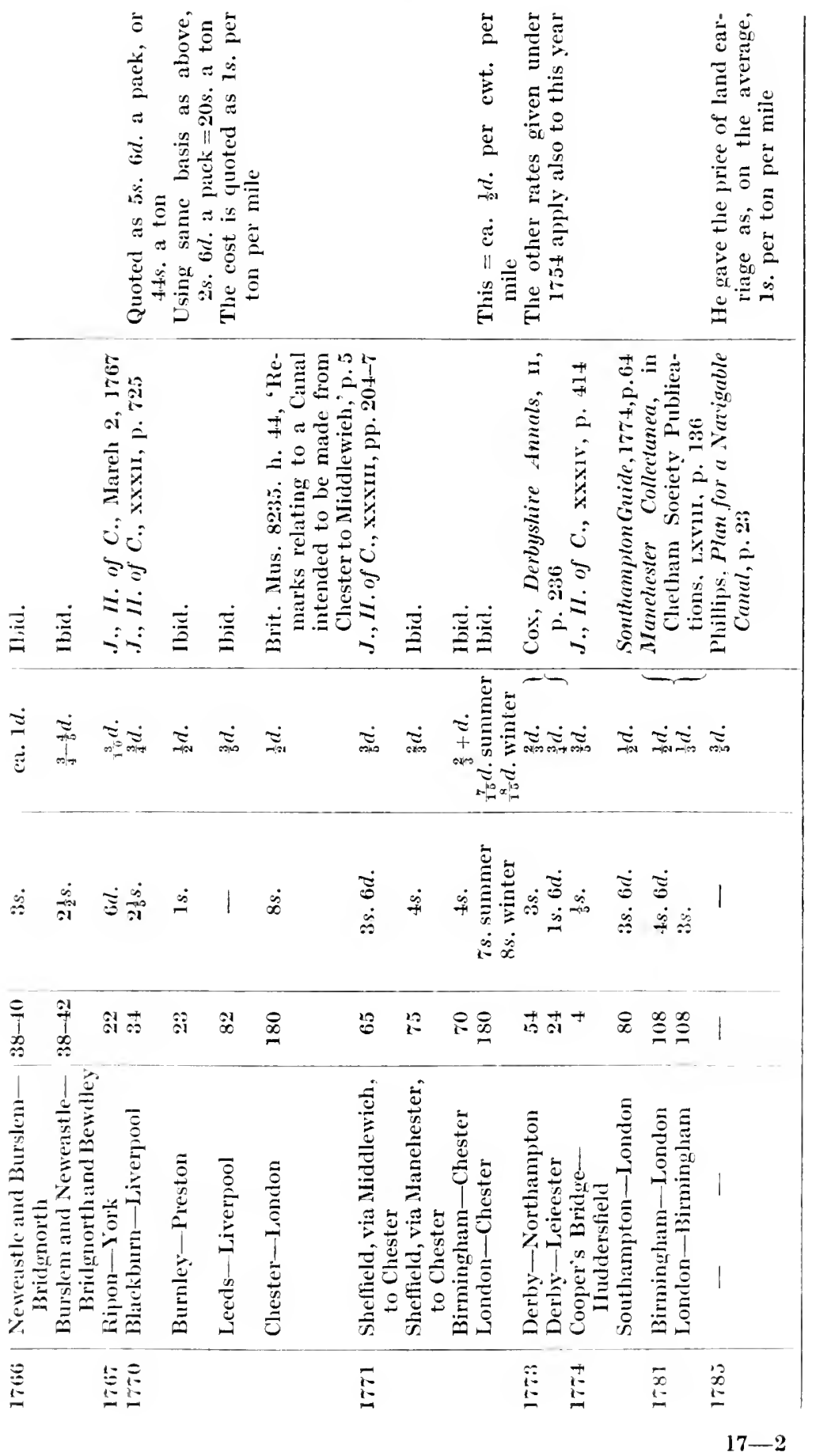


$\stackrel{\bar{\Xi}}{\stackrel{\Xi}{\Xi}}$

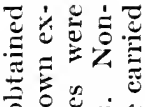

$\stackrel{\tau}{\Xi}$

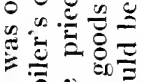

范

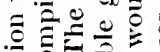

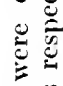

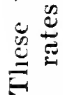
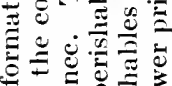

$\Xi \Xi$

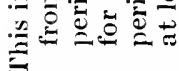

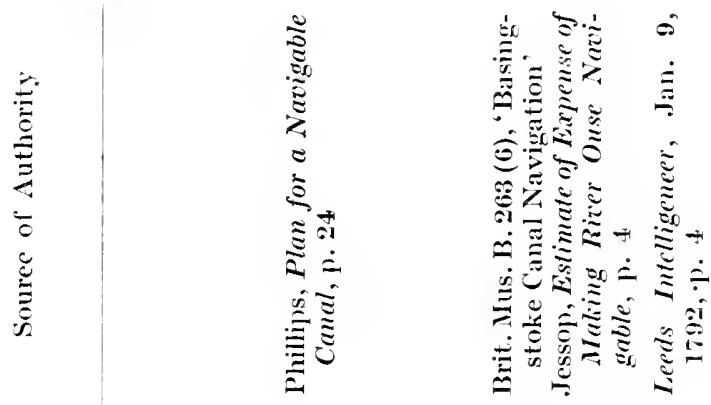

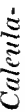

ฐ

$\therefore$ 这

完

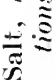

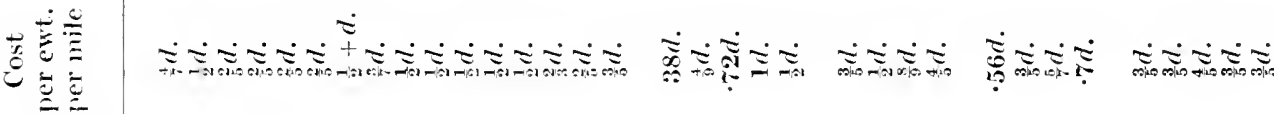

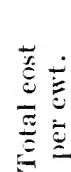

इ:: : : : : : :

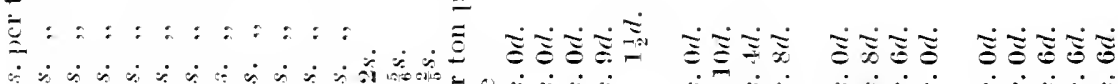

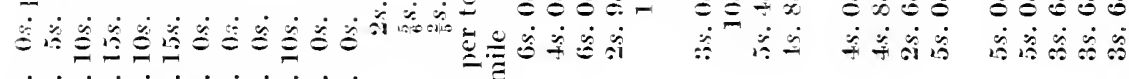

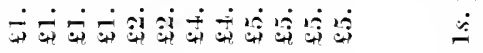

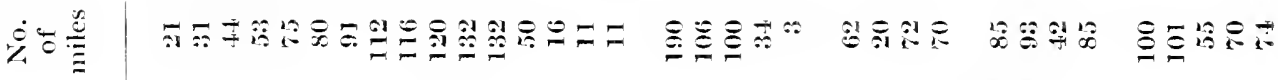

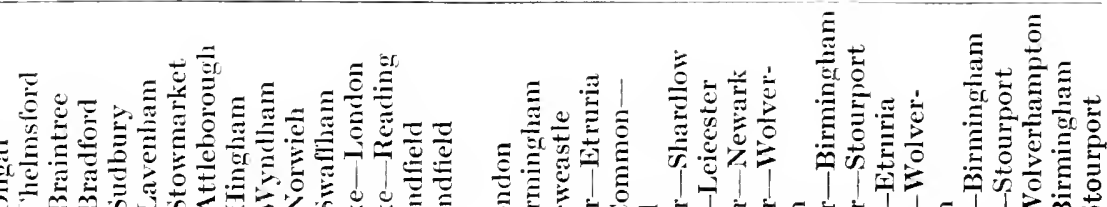

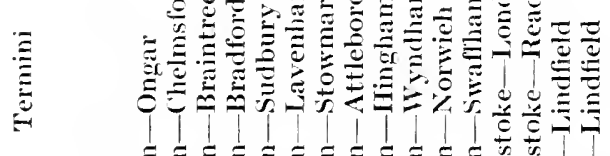
II

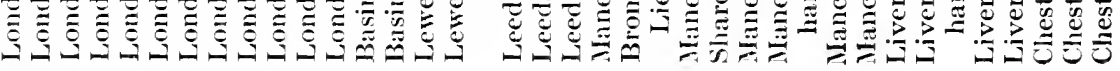

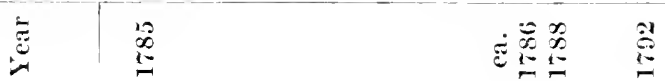




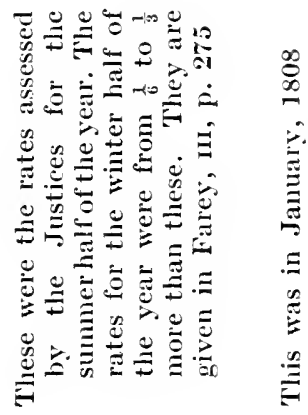

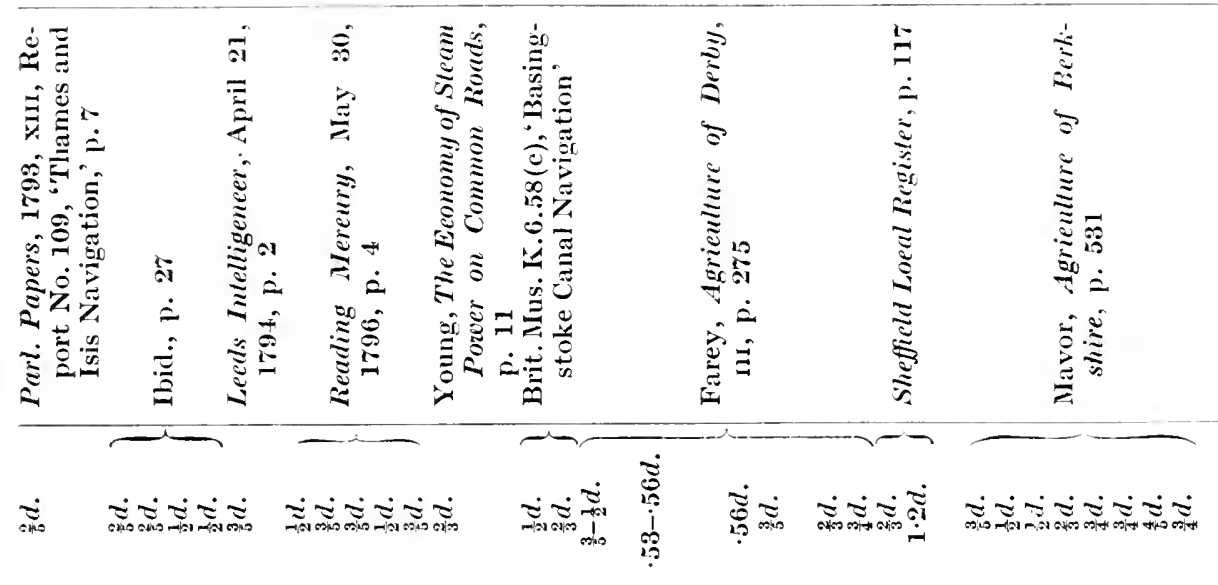

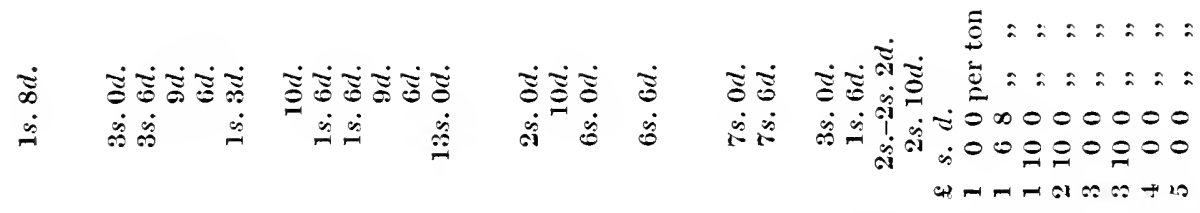

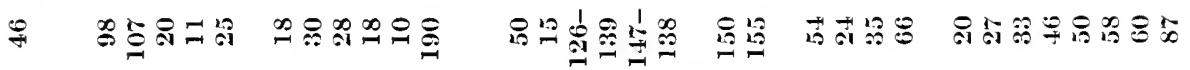

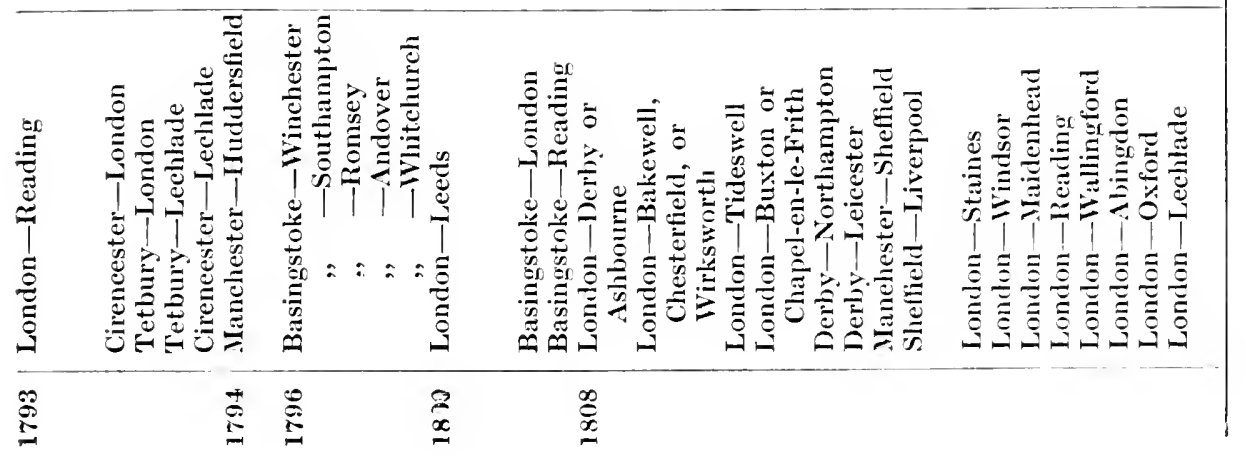




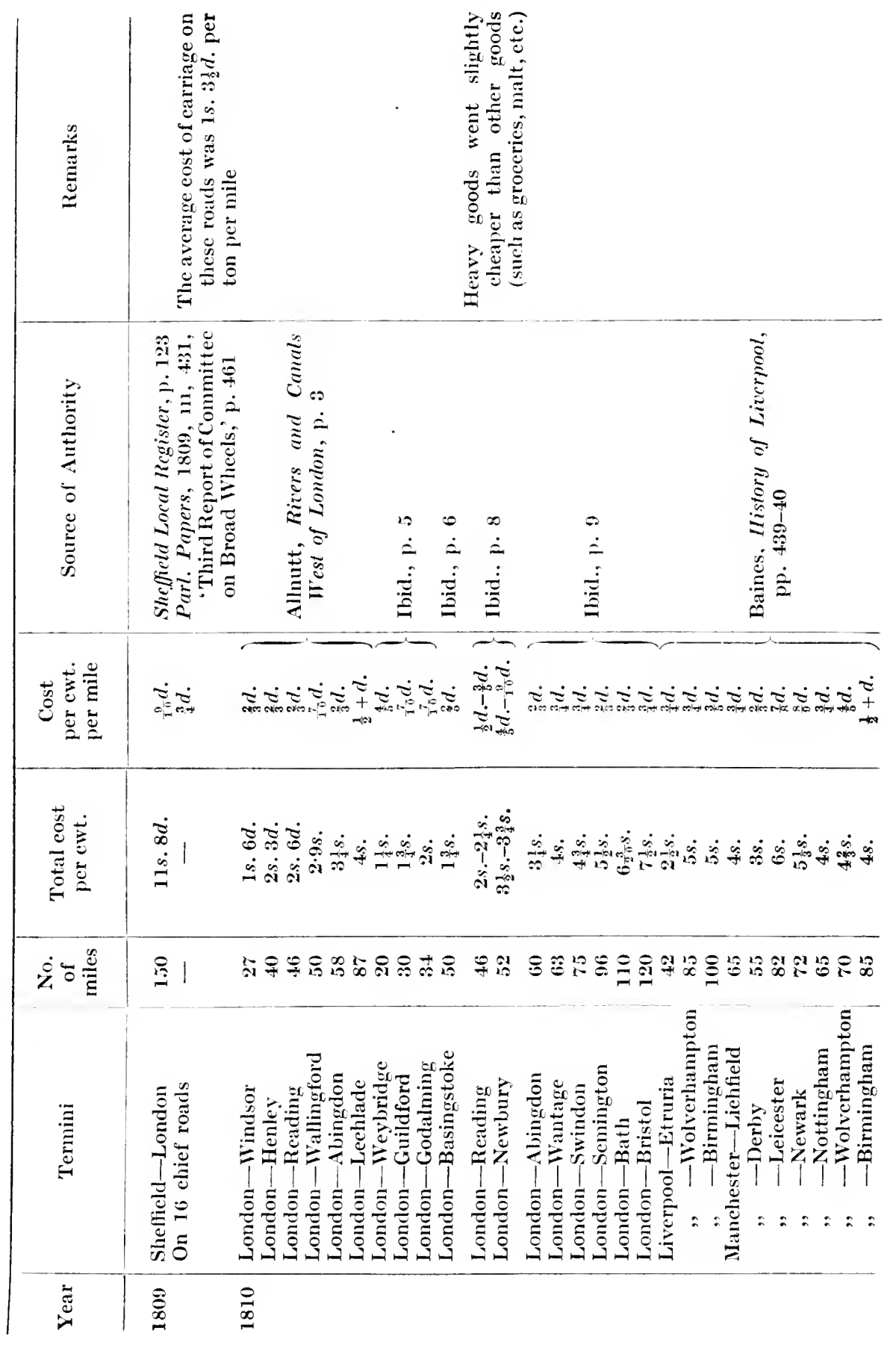




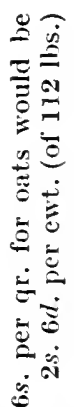
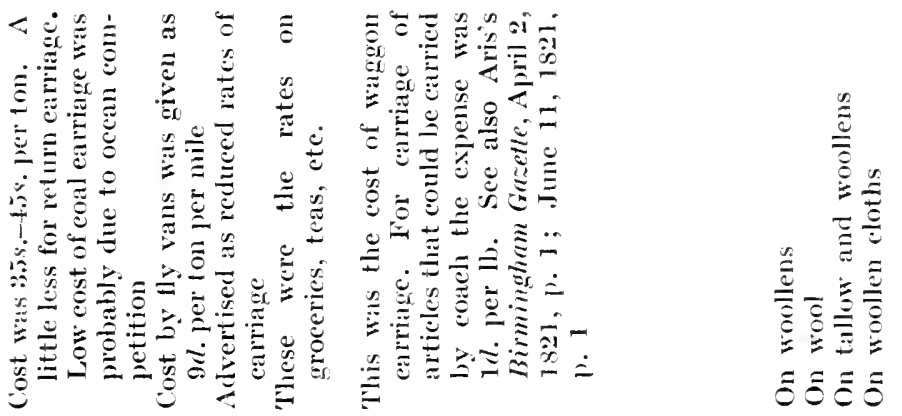

言 94 a

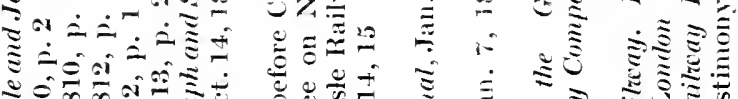

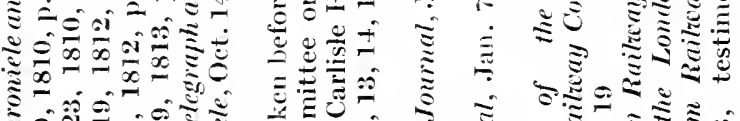

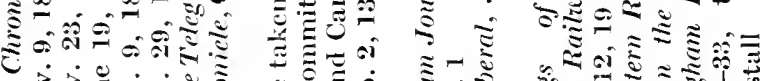

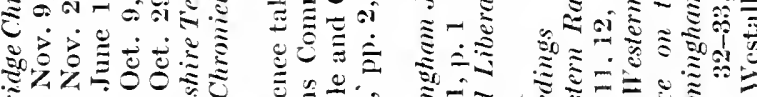

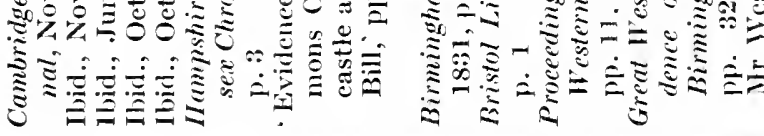

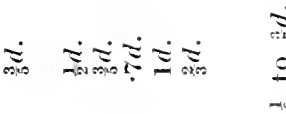

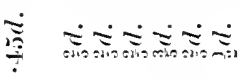

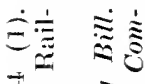

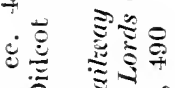

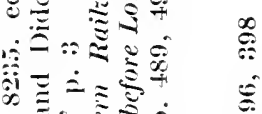

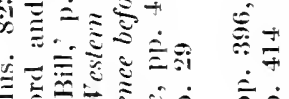

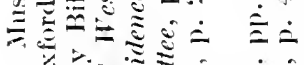

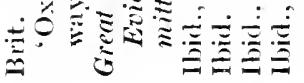
:

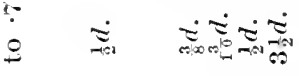
?

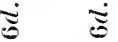

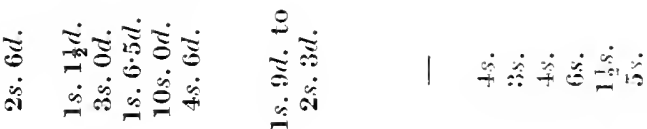

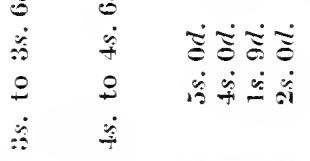

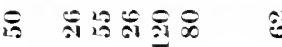

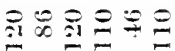

$\cong \quad \therefore \quad \equiv$

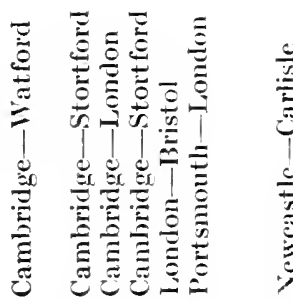

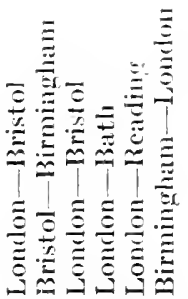

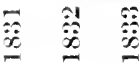

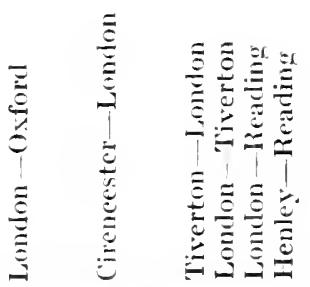

施

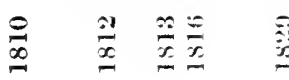




\section{APPENDIX 8}

\section{COST OF CARRLAGE BY INLAND NAVIGATIONS}

Is the following statistics. I have presented some available information regarding the expenses of conveyance by canal, and, where possible, have made a comparison of these with the costs of conveyance by the ordinary roads. It will be observed in the first table that the opening of the Grand Trunk Canal reduced the cost of carringe to an amount only one-third to one-fourth of that paid for land carriage. The following figures are taken from Baines, IIistory of Liverpool, pp. 439-40, into which, perhaps, they were incorporated from Salt, Statisties and Calculations, p. 71 :

\section{Canal carriage Land carriage per ton perton}

Fron Liverpool to Etruria

$\begin{array}{rrr}\text { \& } & s . & d . \\ & 1: 3 & 4 \\ 1 & 5 & 0 \\ 1 & 10 & 0 \\ 1 & 0 & 0 \\ 1 & 10 & 0 \\ 1 & 10 & 0 \\ 2 & 0 & 0 \\ 2 & 0 & 0 \\ 1 & 5 & 0 \\ 1 & 10 & 0 \\ 1 & 10 & 0\end{array}$

\& s. $d$.

$$
\begin{array}{ccccc}
, & , & \text { Wolverhampton } \ldots & \ldots \\
, & , & \text { Birmingham and stourport }
\end{array}
$$

From Manchester to Lichficld ... ... ...

$\begin{array}{llll}\text { Derby } & \cdots & \cdots & \cdots \\ \text { Leicester } & \cdots & \cdots & \cdots\end{array}$

$\ddot{n} \quad \ddot{ }$

I eicester ... $\quad \ldots \quad \ldots$

Newark $\ldots \quad \ldots \quad \ldots$

",

Nottingham $\quad \ldots \quad \ldots$

Wolverhampton ... ...

,$\quad$,

Biruingham

From Liverpool or Manehester to Shardlow ...

The freight rates on the navigations connecting Manchester with the Trent and Severn, and with the Birmingham Canal, in 1\%s1, were:
for perishable goods,
$3 d$. per ton per mile.
for non-perishable goods, $2 \frac{1}{2} l$.

The freight from Shardlow to Gainsborough (on Trent Navigation) was 10s. per ton (v. Manchester Collectanea, in Chetham Socicty Publications, Lxvir, p. 136).

The following table of freight rates, taken from Allnutt, Rizers and Canals West of London, p. 3, shows us what the rates of carriage were along the Thames, as compared with the rates for land carriage in the same sections:

Price of Carriage on rhe River Thames Navigation.

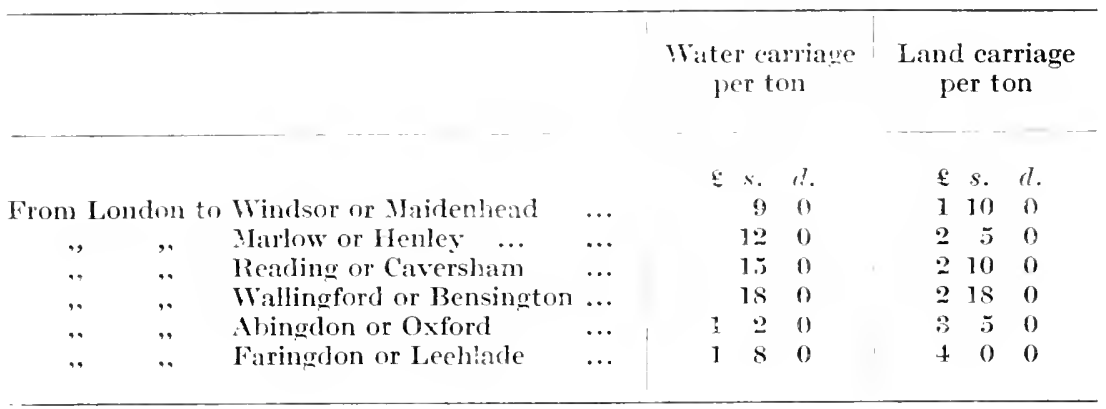


Therefore, according to Allnutt, the cost of land carriage along this route was from three to three and one-third times as much as water carriagc along the same route. But Mavor gives slightly different figures for practically the same year, and these we subjoin.

Mavor, Agriculture of Berlishire, 1808, p. 531, gives us the following Talle showing Prices of Carriage on the Thames and Isis Navigation, from Lcchlade to London and back, downward and upward: also Cost of Land Carriage to and from the Several Places undermentioned and London; and also the Time generally taken in navigating a Barge from such Places to London downward (with aid of stream) and upward (by horse-towing):

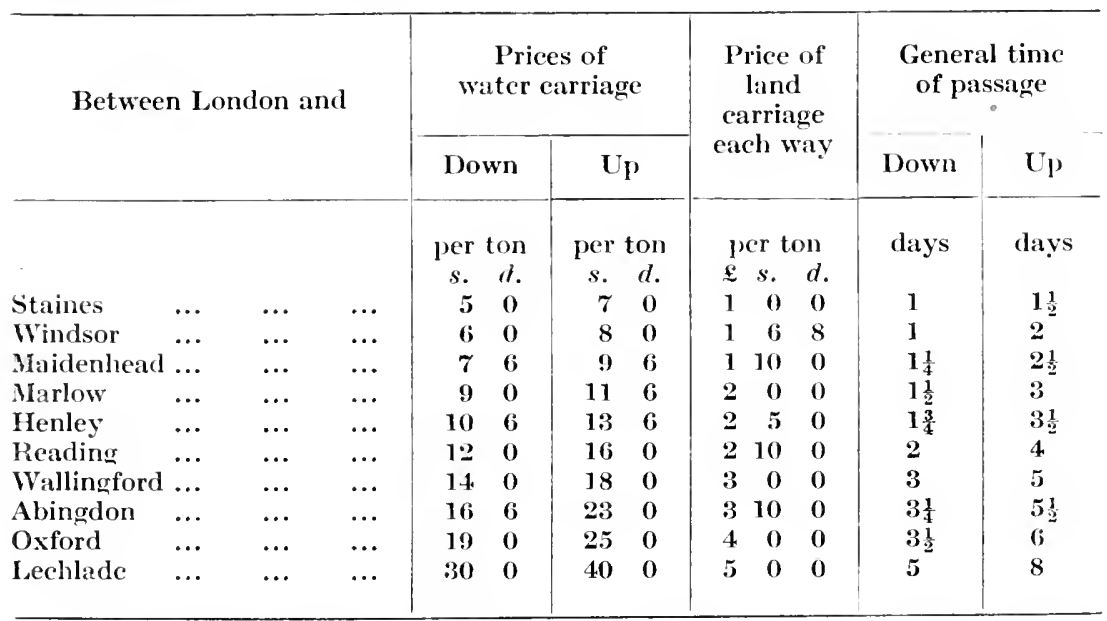

From this table, if we omit the last item, we learn that the cost of water carriage down-stream was roughly one-fourth, and the cost up-stream one-third, of the cost of carriage by land; or, in other words, the cost of land carriage was three to four times that of water carriage by the Thames Navigation.

Allnutt. p. 5. Prices of Carriage on the River Wey Navigation:

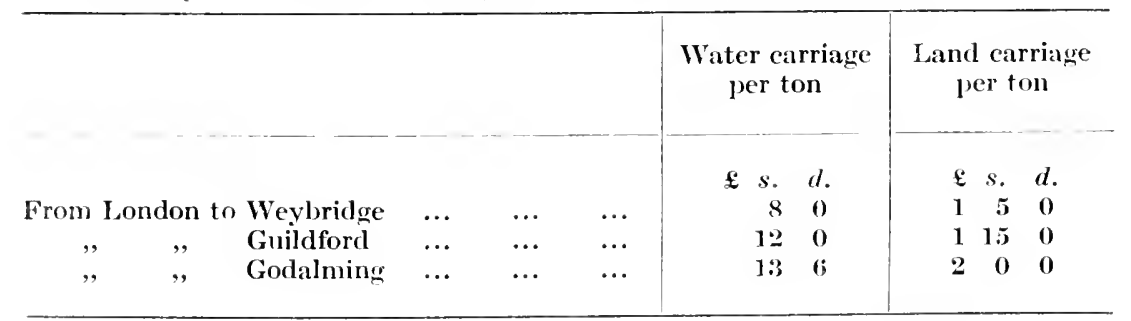

Therefore, land carriage cost three times as much as water carriagc.

Ibid., p. 6. Priecs of Carriage on the Basingstoke Canal:

\begin{tabular}{|c|c|c|c|}
\hline & & $\begin{array}{c}\text { Water carriage } \\
\text { per ton }\end{array}$ & $\begin{array}{c}\text { Land carriage } \\
\text { per ton }\end{array}$ \\
\hline From London to Basingstoke ... & ... & $\begin{array}{lll}\mathfrak{E} & s . & 1 . \\
& \text { is } & 0\end{array}$ & $\begin{array}{lll}£ & s . & l . \\
1 & 15 & 0\end{array}$ \\
\hline
\end{tabular}


Therefore, land carriage cost twice as much as water carriage. (The cost of land carriage about 1786 seems to have been slightly higher than at this time (1810), for it was then $£ 2$ per ton. Sce Brit. Mus. B. 263 (6). 'Basingstoke Canal Navigation.')

Allnutt, Rivers and Canals West of London, p. 8:

Prices of Carriage on River Kennet Navigation:

\begin{tabular}{|c|c|c|}
\hline & $\begin{array}{l}\text { Water carriage } \\
\text { per ton }\end{array}$ & $\begin{array}{c}\text { Land carriage } \\
\text { per ton }\end{array}$ \\
\hline & $\stackrel{s}{*} \quad d$. & $\mathfrak{E} s . \quad d$. \\
\hline From London to Reading (heavy goods, e.g.,coal) & 150 & 200 \\
\hline (other goods, e.g., grocerics) & 180 & 250 \\
\hline From London to Newbury (heavy goods) & 180 & $3 \quad 10 \quad 0$ \\
\hline (other goods) & 150 & $\begin{array}{lll}3 & 15 & 0\end{array}$ \\
\hline
\end{tabular}

Therefore, land carriage cost on the average three times as much as water carriage.

Ilbid., p. 9. Prices of Carriage on the Wilts and Berks Canal:

\begin{tabular}{|c|c|c|c|c|c|c|c|}
\hline \multirow[b]{3}{*}{ From } & \multirow[b]{3}{*}{ London to } & \multirow[b]{3}{*}{ Abingdon } & \multirow[b]{3}{*}{$\ldots$} & \multirow[b]{3}{*}{$\ldots$} & \multirow[b]{3}{*}{$\ldots$} & $\begin{array}{c}\text { Watcr carriage } \\
\text { per ton }\end{array}$ & $\begin{array}{c}\text { Land carriage } \\
\text { per ton }\end{array}$ \\
\hline & & & & & & $£ s . \quad d$. & $\&$ s. $\quad d$. \\
\hline & & & & & & $\begin{array}{lll}1 & 2 & 0\end{array}$ & $\begin{array}{lll}3 & 5 & 0\end{array}$ \\
\hline , & , & Wantage & $\ldots$ & $\ldots$ & $\ldots$ & $\begin{array}{lll}1 & 6 & 0\end{array}$ & $\begin{array}{lll}4 & 0 & 0\end{array}$ \\
\hline .. & , & Swindon & $\ldots$ & $\ldots$ & $\ldots$ & $\begin{array}{lll}1 & 13 & 0\end{array}$ & 4150 \\
\hline , &. & Semington & $\ldots$ & $\ldots$ & $\ldots$ & $\begin{array}{lll}2 & 5 & 0\end{array}$ & $\begin{array}{lll}5 & 10 & 0\end{array}$ \\
\hline, & .. & Bath ... & $\ldots$ & $\ldots$ & $\ldots$ & $\begin{array}{lll}2 & 12 & 6\end{array}$ & $\begin{array}{lll}6 & 3 & 0\end{array}$ \\
\hline , & , & Bristol & $\ldots$ & $\ldots$ & $\ldots$ & $\begin{array}{lll}2 & 15 & 0\end{array}$ & 7100 \\
\hline
\end{tabular}

Therefore, the cost of land carriage was about three times the cost of water carriage.

Ibid., p. 11. Prices of Carriage on the Kennet and Avon Canal:

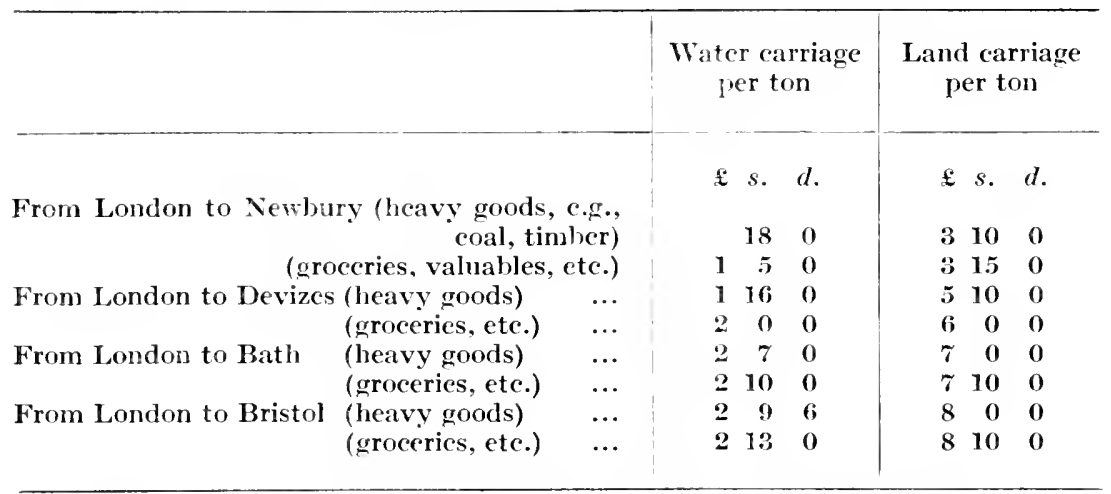

Thereforc, land carriagc cost thrce tinics as much as water carriage. 
From the tables given above, it would seem to be an almost universal rule that on the rivers and canals west of London the cost of water carriage was only about one-third of that by land.

On page 20 of Allnutt's work, he has shown the average ton-mile cost for the conveyanee of goods on the various navigations. This table is next alppended. A study of it will show that the price of carriage on river navigations was much less than on canal navigations. Where or how he obtained the data for this table. he does not say, and I have bcen unable to diseover; but it almost secms as if his object were partisan, namely, to show that river navigation was cheaper than canal navigation. I insert the table here for what it is worth; but $I$ warn the reader that my study of the subject does not warrant the above inference. The reduetion of the cost to a ton-mile basis is contrary to the way in which, according to my researches, the priees were stated or reckoned.

Average Price of Carriage (including tolls, etc.):

\begin{tabular}{|c|c|c|}
\hline Names of Navigations & $\begin{array}{c}\text { Valuable or } \\
\text { perishable goods } \\
\text { or goods liable } \\
\text { to risk } \\
\text { (per ton per mile) }\end{array}$ & $\begin{array}{l}\text { Other goods } \\
\text { coarse or } \\
\text { heavy } \\
\text { (per ton } \\
\text { per mile) }\end{array}$ \\
\hline $\begin{array}{l}\text { By Basingstoke, Kennet and Avon, Wilts and } \\
\text { Berks, Thames and Severn, and Stroud } \\
\text { canals } \quad \ldots . . . .\end{array}$ & $\begin{array}{c}d . \\
5-5\end{array}$ & $\begin{array}{l}d . \\
34-4\end{array}$ \\
\hline $\begin{array}{l}\text { By other canals, viz., Grand Junction, Oxford, } \\
\text { Fazeley, Birmingham, Staffordshire and } \\
\text { Woreestershire, and Grand Trunk }\end{array}$ & $5 \frac{1}{2}-6$ & $33_{4}^{3}-4_{4}^{1}$ \\
\hline 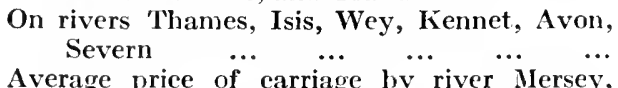 & $21-3$ & $2-2 \frac{1}{2}$ \\
\hline $\begin{array}{l}\text { Average price of carriage by river Mersey, } \\
\text { Runcorn to Liverpool } \ldots \\
\text { By river Trent, Gainsborough to Shardlow } \\
\text { By river Severn, Stourport to Bristol }\end{array}$ & $\begin{array}{l}3-3 \frac{1}{2} \\
23-3 \frac{3}{1} \\
2 \frac{1}{2}-3\end{array}$ & $\begin{array}{l}13-21 \\
2-21 \\
2-21 \\
2-2 \frac{1}{4}\end{array}$ \\
\hline
\end{tabular}

Before leaving this table, let me say that if any one will take the trouble to work out the ton-mile figures for the cost of carriage of goods, on the abovementioned eanals, as given in the foregoing tables, he will not find the figures in this last table to be eorrect, but will find them too high. Furthermore, we have faets from other sourees which confirm our opinion that Allnutt's ton-mile figures here given for canal navigations are altogether too high. In 'Collection of Prospectuses, Maps, etc., of Railways and Canals,' p. 19, we have the distances and tonmage rates between Birmingham and London, via the Birmingham. Warwiek and Birmingham, Warwiek and Napton, Oxford, and Grand Junetion canals, showing that the tonnage rate along this route for "gencral merehandise" was $29 s .8 d$. and the distance 146 miles. This, when redueed to the standard that Allnutt (unwisely) adopted, would give us the cost of carriage along these canals as $21 \%$. per ton per mile, which is praetieally the same figure as he has given for the cost of earriage on the great rivers. On the whole, thercfore, we are compelled to reject his inaceurate eomparison, as given in this table. It must not be assumed that in making the above computation on a ton-mile hasis we are giving any countenance to that basis of eomparison of rates; we have used it simply tentatively, to prove 
the erroneous nature of what Allnutt has brought forward. The fact is that water rates were not quoted on that basis.

In the 'Proceedings of the Great Western Railway Company,' in 1833, in the evidence of Mr Stone (tea dealer) of Bristol (p. 11), it was shown that, since 1827, the cost of land carriage from London to Bristol was $4 s$. per hundredweight, and the cost of water carriage from London to Bristol was $2 s .6 d$. per hundredweight.

On page 12 (ibid.), in the evidence of Mr Shepherd (grocer) of Bath, it was shown that the cost of land carriage, London to Batl, was $6 s$. per hundredweight, and the cost of water carriage, London to Bath, was $2 s .6 d$. per hundredweight.

On page 19 (ibid.), in the evidence of Mr Harris (grocer) of Reading, it was shown that the cost of carriage by land, London to Reading, was 30s. per ton, and the cost of carriage by water, London to Reading, was 15s. per ton.

In the Reports of the Commissioners on the Thames Navigation, in 1811, comparative freiglut rates on canals and rivers are given; but they were issued by those who would be favourable to the Thames. They are given here because they show Allnutt's figures of ton-mile rates, on the canals, for valuable and pcrishable goods, to be altogether too high. The rates they quoted were as follows:

\section{By Canals.}

London-Birmingham (143 miles),

Freight on valuable goods $=55 s$. per ton, or $4 \frac{1}{2} d$. per ton per mile.

$$
\text { , heavy , },=35 \mathrm{~s} \text {. , } 3 d \text {. , , }
$$

Birmingham-Manchester (116 miles).

Freight on valuable goods $=40 \mathrm{~s}$. per ton, or $4 \frac{1}{2} d$. per ton per mile.

$$
\text { , heary ", =26s. " } 3 d \text {. , , }
$$

Basingstoke-Weybridge (41 miles by canal and river),

Freight on valuable goods $=15 s .4 d$. per ton, or $4 \frac{3}{4} d$. per ton per mile.

$$
\text { , heavy }, "=13 s \text {. , } 44 \mathrm{~d} \text {. ,", }
$$

The mean of the rates on the three canals shows that valuable goods were carricd for $4 \frac{1}{2} d$. per ton per mile, and heavy goods were carried for $3 \frac{3}{8} d$. per ton per mile.

\section{By Rizer.}

Reading-London ( 78 miles),

Freight on valuable goods $=18 \mathrm{~s}$. per ton, or $2 \frac{3}{4} d$. per ton per mile.

$$
\text { , heavy ,. }=13 \mathrm{~s} \text {. , } 2 d \text {. , , }
$$

London-Abingdon (108 miles),

Freight on valuable goods $=26 s$. per ton, or $2 \frac{3}{4} d$. per ton per mile.

$$
\text { , heavy , =20s. , } 2 \frac{1}{4} d \text {. , , , }
$$

Taking the average of these rates, we would judge that, on the Thames river, valuable goods were earried for $2 \frac{3}{4} d$. per ton per mile, and heary goods were carried for $2 \frac{1}{8} d$. per ton per mile.

It will be noted from the above that the average rate here given on valuable goods carried by the canals was $4 \frac{1}{2} d$. per ton per mile, while Allnutt gives $5 d$. to $6 d$.; which seems to indicate that Allnutt's figures are very much overstated. Even the above figures given by the Thames Commissioners must not be accepted as authoritative, since they were given, doubtless for a purpose, by a body of men who wanted to present the Thames Navigation in as favourable a light as possible.

In the evidenec of Mr Westall, a linen draper of Birningham, before the Committee on the London and Birmingham Railway Bill, we learn that from London to Birminghan the rate on light goods carried by coach was $l d$. per lb.; on heavy 
goods earried by waggon it was 5s. per ewt.; and on the canal, linen goods and mereery paid 2s. $9 d$. per ewt., while extra heavy goods paid $2 s$. 6d. per ewt. (v. Great Western Railicay. Evidence on the London and Birmingham Railway Bill, pp. 32-33). Goods that came by coach from London were delivered in fifteen to sixteen hours from the time of leaving London. Goods that eame by waggon generally took four days. Goods that eame by canal took live to six diys. From these statements it would appear that the eost by canal was just half of the eost by waggon. This is in accordance with information eulled from other sonrces. For instance, that the cost of land carriage of Birmingham iron manufactures from Birmingham to London was 5s. per ewt., is confirmed by Brit. Mus. 214. i. 4 (120), 'Report of Committee on Oxford Canal, 1). 1 ; and the freight cost of the same goods by fly-boat on the canal from Birmingham to London, at a somewhat later period, was 45s. to 50s. per ton, or (say) $2 s$. 6d. per cwt. (Remarks upon Pamphlet by "Investigator" on the Proposed Birmingham and London Railway, 1. 13). It is evident, therefore, from this that the expense of carriage by canal was only one-half of that by land.

Again, from the 'Report of the Committee on the Oxford Canal' [Brit. Mus. 214. i. $4(120)$ ], p. 3 , we have the following statisties:

From Birmingham to Oxford, by canal, 160 miles, eost of $\mathfrak{f} s . d$.

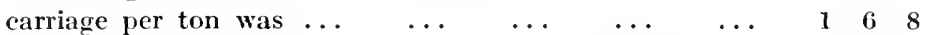

From Oxford to London, by Thames, eost per ton was ... $1+40$

$\therefore$ total charge by eanal and river from Birmingham to

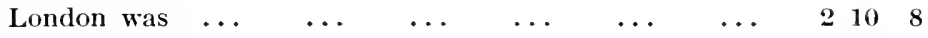

But total eharge by road from Birmingham to London was 5

Therefore the expense of water earriage was about one-half of that by road.

The great difference in cost between canal carriage and land carriage is also brought out in Phillips, Plan for a Navigable Canal, p. 21. Here he says that near the Staffordshire Canal the cost of road earriage was 8-9s. per ton for 10 miles, while the eost of water earriage by the canal was a half-erown per ton for 10 miles. This would indicate that canal carriage there was only about one-fourth the cost of carriage by road.

In the elaboration of this subject we find much diversity of statement as to the cost of carriage, and this is but natural, since the varions waterways were very much unlike one another and also because different elasses of goods could only be moved at different costs of transportation [see, for instance. Communications to the Board of Agriculture, I, p. 179; Observations on the Comparative Merits of Navigations and Railroads, p. 40; Gooeh, Agriculure of Cambridge, p. 28]. But from what we have here presented, we may broadly generalize by saying that the eost of canal conveyance was from one-fourth to one-half of the cost of carriage by roal. 


\section{APPENDIX 9}

\section{RAILWAY AND CANAL AMALGAMATIONS UP' TO 1866}

From Brit. Doc. 1872 (364), xm, 1 (Part 2), pp. 75.5-6, we take the following table as to the canals and navigations acquired by railway companies by amalgamation, purchase, or lease:

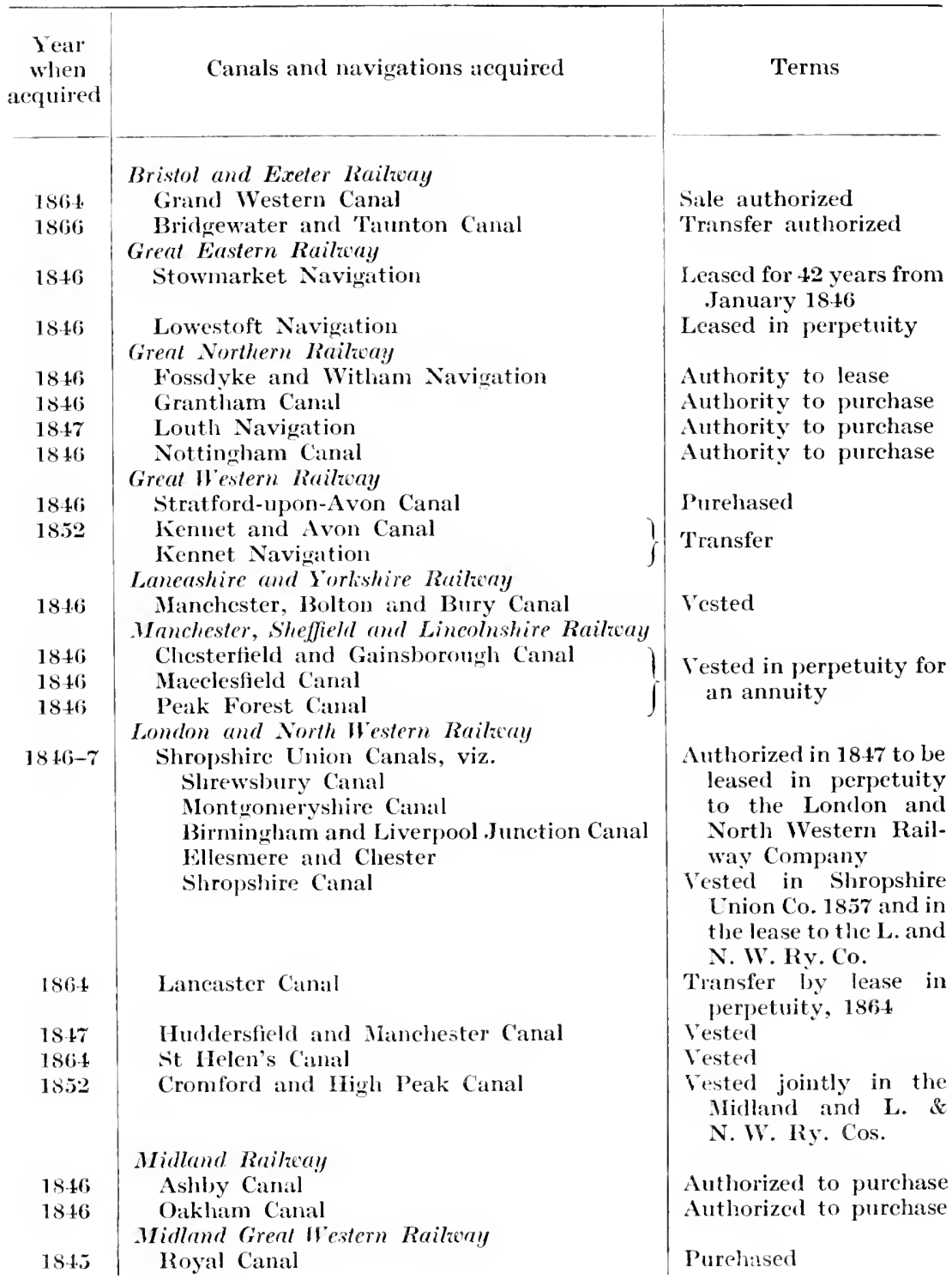




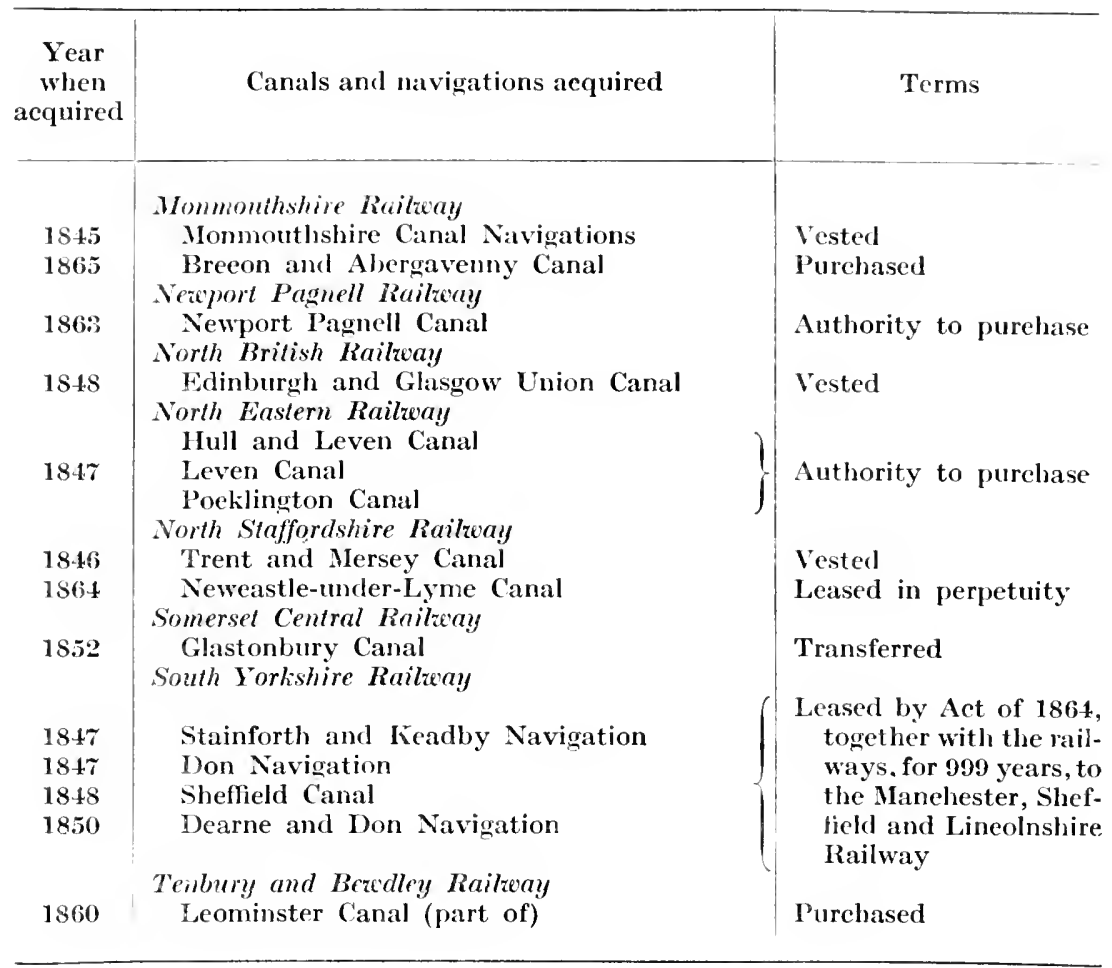

\section{APPENDIX 10}

\section{EFFECT OF RAILWAY COMPETITION ON CANAL CHARGES}

IN the following tables. I have brought together sueh information of a statistieal character as could be found, in the hope that it might make more definite the results that acerued from the competition of railways with the previonsly existing eanals. It will be seen that the variations which are found in these rates are too widc to base any general statement upon them, and have it reflect with mathematical precision the reductions whieh were made. The only eonelusion whieh we may reach from the facts as presented is that the minimum reduction was ahout one-sixtl of the former rates and the maximum reduetion was about six-sevenths of those rates. These limits, bowever, are of little practieal value; and to generalize somewhat further and still be within the truth, we may say that, on the whole, the minimum reduction of rates was from one-third to one-half of the former rates.

The following table shows a statement of the reduction which took place in the rates on the Grand Junction and Leicester lines of canal since the introduction of 
railways in that section (1836). The Grand Junction Canal forms the main trunk of ranal communication between London and the North. It extends from Paddington to Braunston, where it runs into the Oxford Canal, which conmunicates by other canals with Liverpool, Manchester and Birmingham. Five miles short of its entrance to the Oxfort Canal it is joined by the Leicester lines. The lines here included werc amalgamated with the Grand Junction Canal.

Table A. Tomage rates on undermemtioned lines of canal.

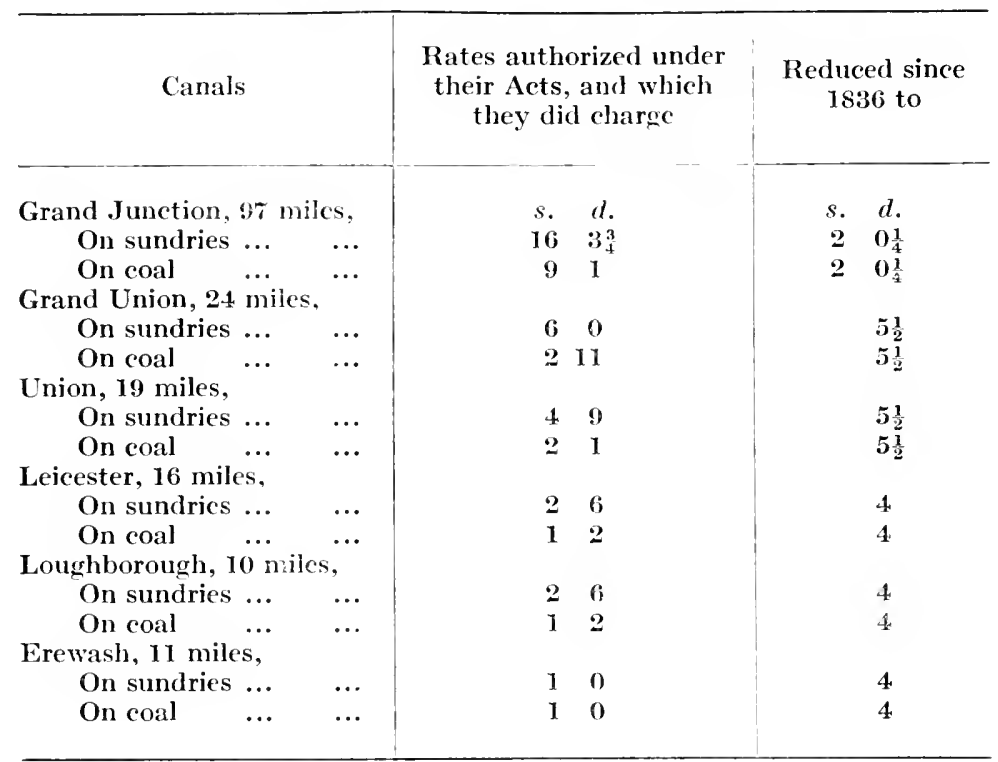

Here the reduction was very great; so great as to make the competitive rates only one-third to one-cighth of the former canal rates (v. Brit. Doc. 1846 (275), xil, 93, 'Minutes of Evidence,' p. 43).

From the Report of the Royal Commission of 1867, Brit. Doc. 1867 [3844], xxxyu, 1, p. lxv, we take the following information:

TABLE B. Rates per ton, Bristol to London.

\begin{tabular}{|c|c|c|c|c|c|c|}
\hline \multirow{2}{*}{\multicolumn{3}{|c|}{ Articles }} & \multicolumn{3}{|c|}{ Rates charged by Carriers } & \multirow{2}{*}{$\begin{array}{c}\text { Rates charged } \\
\text { by Railway } \\
1866\end{array}$} \\
\hline & & & 1820 & 1830 & 1840 & \\
\hline Drapery & $\ldots$ & $\ldots$ & $\begin{array}{cc}s . & d . \\
66 & 0\end{array}$ & $\begin{array}{cc}s . & d . \\
60 & 6\end{array}$ & $\begin{array}{cc}s . & d . \\
47 & 6\end{array}$ & $\begin{array}{lr}s . & d . \\
40 & 0\end{array}$ \\
\hline Hops ... & $\ldots$ & $\ldots$ & $68 \quad 0$ & 630 & $49 \quad 6$ & $40 \quad 0$ \\
\hline Oil & $\ldots$ & $\ldots$ & $60 \quad 6$ & 470 & 420 & $20 \quad 0$ \\
\hline 'Tobaeco & $\ldots$ & $\ldots$ & 660 & 660 & 476 & $26 \quad 8$ \\
\hline
\end{tabular}


TABle C. Rates per ton, Birmingham to London.

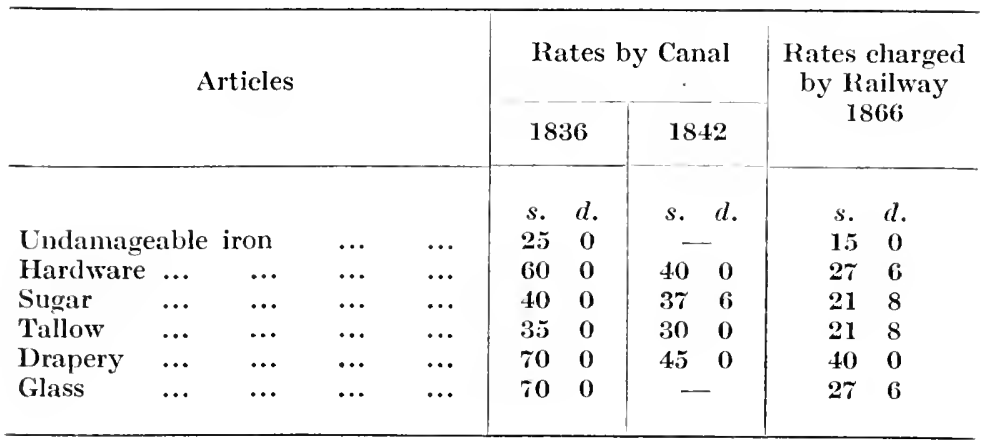

This road was opened in $1837-8$, and therefore the difference between the rates of 1836 and 18.42 would show the eflect of the railway. The canal rates of 1842 were only from two-thirds to six-sevenths of those of 1836 ; that is, there had been a reduetion of from one-seventh to one-third of the former canal rates.

From Manchester to London, bales and grain were earried:

in 1833 , by quick vans, at £20 per ton.
,, 1834, by eanal
, \&4 , ,
"1840, by railway
", $3.4 s .8 d$. per ton.? This was before the railway
,, 1866, by railway
„£1. 15s.
, $\int$ eompany aeted as carrier.

The railway rate of 1840 was, therefore, only three-fourths of the former eanal rate of 1834 .

Tables D, E, F, G are taken from Brit. Doe. 1881 (374), xim, 1, 'Report of the Seleet Committee on Railway Rates and Fares,' Appendix No. 59.

TABle D. Tonnage rates, London to Birmingham. By canal in 1836; by railway and canal in 1842; by raitwoys in 1866 and 1880 .

\begin{tabular}{|c|c|c|c|c|c|c|c|c|c|c|}
\hline \multirow{3}{*}{\multicolumn{2}{|c|}{ Articles }} & \multicolumn{3}{|c|}{$\begin{array}{c}\text { Rates by Canal, Collected } \\
\text { and Delivered }\end{array}$} & \multirow{2}{*}{\multicolumn{4}{|c|}{$\begin{array}{l}\text { Rates by Rail- } \\
\text { ways, Collected } \\
\text { and Delivered }\end{array}$}} & \multirow{2}{*}{\multicolumn{2}{|c|}{$\begin{array}{c}\text { Rates by } \\
\text { Railways, } \\
\text { Colleeted } \\
\text { and } \\
\text { Delivered }\end{array}$}} \\
\hline & & \multirow{2}{*}{\multicolumn{2}{|c|}{$\begin{array}{c}\begin{array}{c}\text { Before Rail- } \\
\text { way opened }\end{array} \\
1836\end{array}$}} & \multirow{2}{*}{$\begin{array}{c}\begin{array}{c}\text { After Rail- } \\
\text { way opened }\end{array} \\
\mathbf{1 8 4 2}\end{array}$} & & & & & & \\
\hline & & & & & \multicolumn{2}{|c|}{1842} & \multicolumn{2}{|c|}{1866} & \multicolumn{2}{|c|}{1880} \\
\hline \multirow{3}{*}{\multicolumn{2}{|c|}{$\begin{array}{l}\text { Undamageable iron } \\
\text { Damageable iron }\end{array}$}} & & $d$. & s. $\quad d$. & & $d$. & & & & \\
\hline & & & 0 & - & - & & 15 & & 15 & \\
\hline & & 27 & 6 & - & - & & 17 & & 17 & \\
\hline Hardware & $\ldots$ & 60 & 0 & 350 & & & 27 & & - & \\
\hline Nails $\quad \ldots$ & $\ldots$ & 40 & 0 & 326 & & & 21 & & - & \\
\hline Raw Sugar & $\ldots$ & 40 & 0 & 376 & 37 & 6 & 21 & & 20 & \\
\hline Lump Sugar & $\ldots$ & 50 & 0 & $37 \quad 6$ & 40 & & 27 & & - & \\
\hline Tallow ... & ... & 35 & 0 & 350 & 30 & & 21 & & - & \\
\hline Tea & $\ldots$ & 50 & 0 & $37 \quad 6$ & 40 & & 32 & 6 & 34 & \\
\hline Drapery & $\ldots$ & 70 & 0 & - & 45 & & 40 & 0 & 40 & \\
\hline Spelter ... & $\ldots$ & - & & 180 & 20 & 0 & 17 & & 15 & \\
\hline Glass $\quad \ldots$ & $\ldots$ & 70 & 0 & $\cdots$ & - & & 27 & & - & \\
\hline
\end{tabular}


During the stoppage of the canal by frost, etc., before the opening of the railway, goods had to be sent by road waggon at these charges:

$$
\begin{aligned}
& \text { Glass, 140s. per ton. } \\
& \text { Other goods, 120s. , }
\end{aligned}
$$

From the above figures for the canal rates of 1836 and 1842, it appears that, on account of the railway competition, the canal rates of 1842 were only from twothirds to three-fourths of the canal rates of 1836 .

TABle E. Tonnage rates, London to Manchester. By quick vans in 1833-4; by canal in 1834; by raikways in 1840, 1866 and 1880.

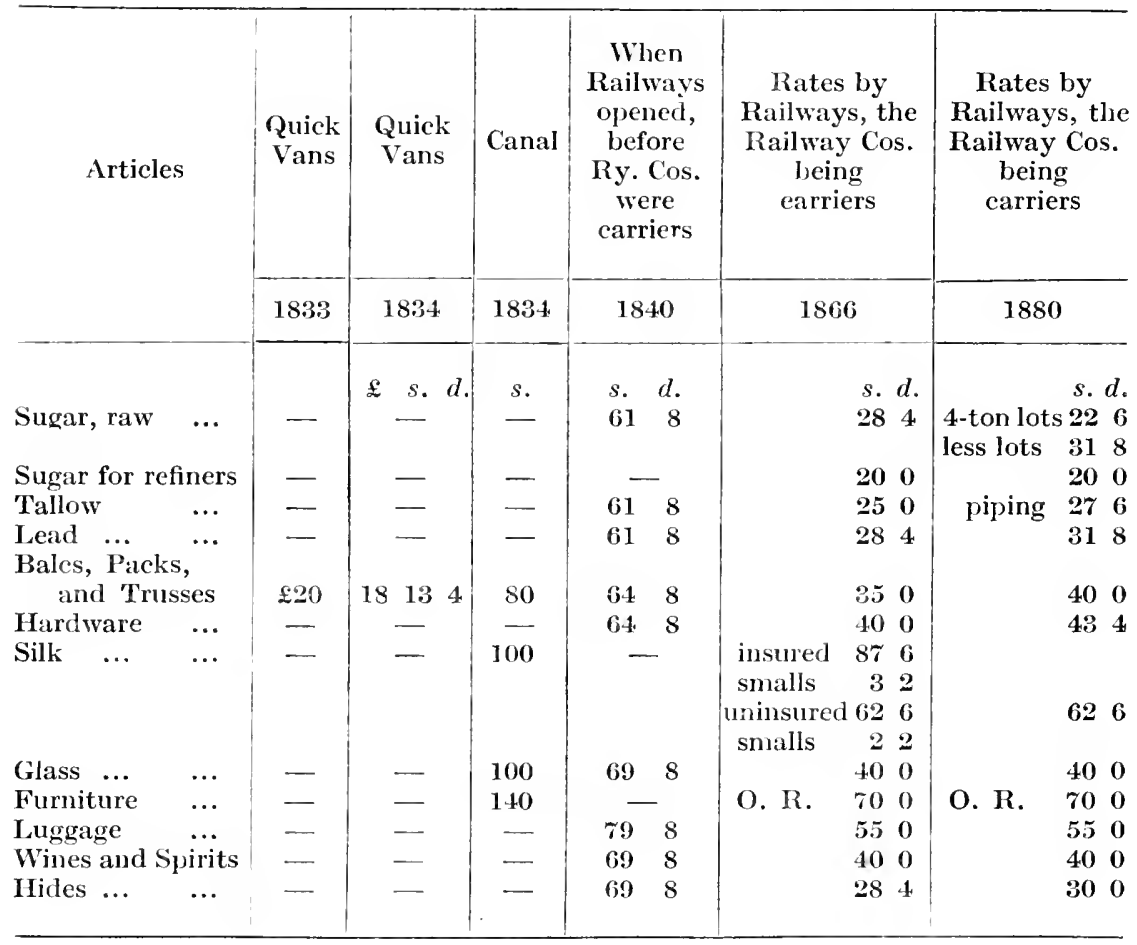

From the above tabie, nothing very definite can be learned as to the effect of railways in reducing the rates formerly charged by canals; for in a comparison of the rates of 1834 and 1840 there are only two articles for which the rates are given in both of these years, namely. "Bales, Paeks, and Trusses," and "Glass." The table is more valuable in showing the reduction of rates between 1840 and 1866, after the railway companies became carriers.

The following table is much more valuable in showing the effect of railways in reducing the rates charged by the canals (q.v.).

From this table, the rates by canal, before and after the railway was opened, are easily compared, without any disturbing elements; and it is apparent that the reduced rates after the railway was opened were only from one-half to two-thirds of those in effect before the railway was opened; or, in other words, there was a reduction of one-third to one-half of the former cost of carriage. 
TABle F. Tonnage rates, Birmingham to Manchester. By canal in 1836; by raitways and canal in 1842; by raitways in 1866 and 1880.

\begin{tabular}{|c|c|c|c|c|c|}
\hline \multirow{3}{*}{ Articles } & \multicolumn{2}{|c|}{$\begin{array}{l}\text { Rates by Canal, Col- } \\
\text { leeted and Delivered }\end{array}$} & \multirow{2}{*}{\multicolumn{2}{|c|}{$\begin{array}{c}\text { Rates by Railways, } \\
\text { Colleeted and Delivered }\end{array}$}} & \multirow{2}{*}{$\begin{array}{c}\text { Rates by } \\
\text { Railways, } \\
\text { Colleeted } \\
\text { and } \\
\text { Delivered }\end{array}$} \\
\hline & \multirow{2}{*}{$\begin{array}{c}\begin{array}{c}\text { Before } \\
\text { Railways } \\
\text { opened }\end{array} \\
1836\end{array}$} & \multirow{2}{*}{$\begin{array}{c}\begin{array}{c}\text { After } \\
\text { Railways } \\
\text { opened }\end{array} \\
1842\end{array}$} & & & \\
\hline & & & 1842 & 1866 & 1380 \\
\hline Undamageable iron & $\begin{array}{cc}s . & d . \\
22 & 6\end{array}$ & s. $\quad d$. & s.d. & $\begin{array}{ccccc}s . & d . & s . & d . \\
10 & 0 & \text { to } & 11 & 6\end{array}$ & $\begin{array}{ll}s . & d . \\
12 & 0\end{array}$ \\
\hline Damageable iron & 250 & - & - & $\begin{array}{c}116 \text { to } 130 \\
s . \quad d .\end{array}$ & 136 \\
\hline Hardware & 400 & 200 & 250 & $20)$ & 218 \\
\hline Nails $\quad \ldots$ & 300 & $17 \quad 6$ & 200 & 168 & 176 \\
\hline Iron wire & - & & 200 & 168 & 176 \\
\hline Pareels and bales & 300 & 200 & 250 & 226 & $24 \quad 2$ \\
\hline Flint Glass $\quad \ldots$ & $40 \quad 0$ & - & - & O.R. 226 & A. 2010 \\
\hline
\end{tabular}

TABLe G. Tommage rates, South Staffordshire to Liverpool. By canal in 1831, and by railways in 1866 and 1880.

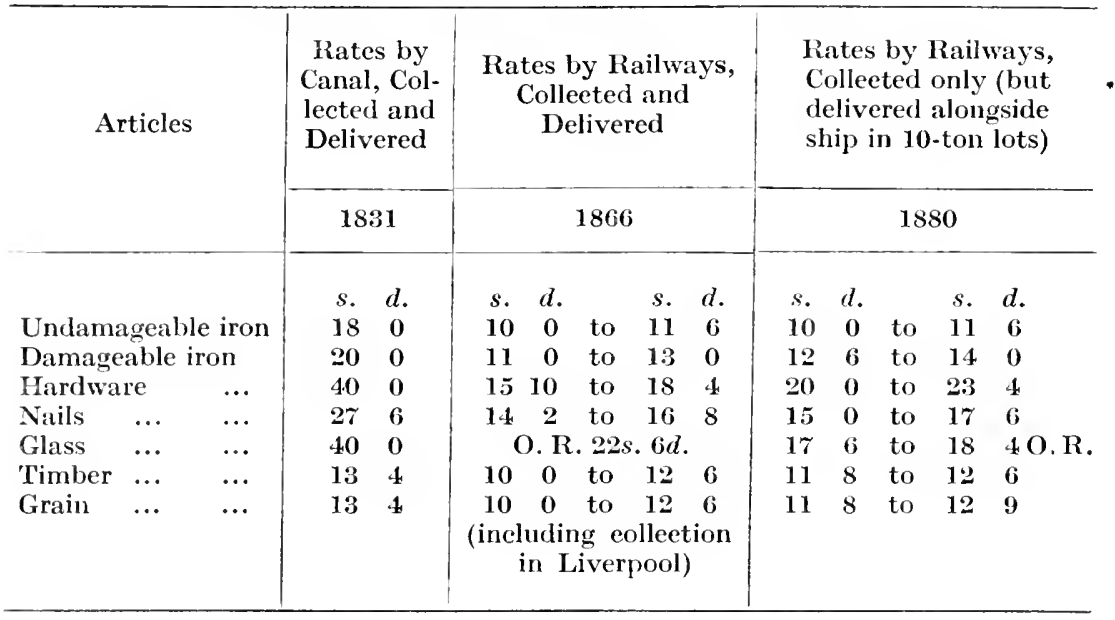

These figures do not show the immediate effeet of the railways, but ouly the ultimate reduction of rates which they brought about, a reduetion whieh amounted to one-sixth to one-half of the former canal rates. 


\section{APPENDIX 11}

\section{STATISTICS SHOWING EXTENT TO WHICH FREIGHT RATES WERE RAISED THROUGH AMALGAMATIONS OF CANALS AND RAILWAYS}

IN the following tables we give some authoritative information as to the extent to which railway and canal rates were raised, through the amalgamation of the canals with the railways. From the nature of the case, it is impossible to generalize, since each instance had no connexion with any other but was arranged solely on its own merits.

About the middle of the century, pig iron was brought in large amounts to Runcorn (chiefly from Scotland), because that was a great depot and distributing centre. From there it was sent along the Bridgewater Canal to Leigh, thence along the Leeds and Liverpool Canal and the Lancaster Canal into the country northward. The following table contrasts the tolls that were charged before and after the formation of the working arrangement between the railways and canals in that section.

Illustration of the Operation of the Advanced Toll on Pig Iron from Runcorn to the following places:

\begin{tabular}{|c|c|c|c|c|c|c|c|c|c|c|c|c|}
\hline \multirow{3}{*}{ To } & \multirow{2}{*}{\multicolumn{2}{|c|}{$\begin{array}{l}\text { Total Railway } \\
\text { charges with } \\
\text { which the Canal } \\
\text { from Runcorn } \\
\text { must compete }\end{array}$}} & \multicolumn{10}{|c|}{ Canal Tolls } \\
\hline & & & \multicolumn{5}{|c|}{ Previous to the Lease } & \multicolumn{5}{|c|}{ After the Lease } \\
\hline & $\begin{array}{l}\text { From } \\
\text { Fleet- } \\
\text { wood }\end{array}$ & $\begin{array}{c}\text { From } \\
\text { Poul- } \\
\text { ton }\end{array}$ & $\begin{array}{r}\text { Lanca } \\
\text { Canal, 1 } \\
\text { ton per }\end{array}$ & $\begin{array}{l}\text { ter } \\
\text { mile }\end{array}$ & $\begin{array}{c}\text { Leeds a } \\
\text { pool C } \\
\text { per ton }\end{array}$ & $\begin{array}{l}\text { Id Liver- } \\
\text { nal, } \frac{1}{2} d . \\
\text { per nile }\end{array}$ & $\left|\begin{array}{c}\text { Total } \\
\text { Toll } \\
\text { formerly }\end{array}\right|$ & $\begin{array}{c}\text { Lanca } \\
\text { Canal, } \\
\text { ton per }\end{array}$ & $\begin{array}{l}\text { per } \\
\text { ile }\end{array}$ & $\begin{array}{l}\text { Leeds a } \\
\text { pool Ca } \\
\text { per ton }\end{array}$ & $\begin{array}{l}\text { Liver- } \\
\text { Litd. } \\
\text { : mile }\end{array}$ & $\begin{array}{l}\text { Total } \\
\text { Toll } \\
\text { now }\end{array}$ \\
\hline & s. $d$. & s. $d$. & miles & $d$. & miles & s. $\quad d$. & s. $\quad d$. & miles & d. & $\begin{array}{c}\text { miles } \\
8\end{array}$ & s. $d$. & $\begin{array}{ll}s . & d . \\
1 & 0\end{array}$ \\
\hline $\begin{array}{l}\text { Wigan } \\
\text { Blackburn }\end{array}$ & $\begin{array}{ll}4 & 0 \\
5 & 6\end{array}$ & 50 & $\overline{11}$ & $\overline{11}$ & 19 & $9 \frac{1}{2}$ & $1 \quad 8 \frac{1}{2}$ & $\overline{11}$ & $\overline{11}$ & $\begin{array}{r}0 \\
19\end{array}$ & $\begin{array}{ll}1 & 0 \\
2 & 4 \frac{1}{2}\end{array}$ & $\begin{array}{ll}1 & 0 \\
3 & 3 \frac{1}{2}\end{array}$ \\
\hline Accrington & - & 56 & 11 & 11 & 25 & I $0 \frac{1}{2}$ & $111 \frac{1}{2}$ & 11 & 11 & 25 & $31 \frac{1}{2}$ & \\
\hline Burnley & 70 & 56 & 11 & 11 & 35 & & & 11 & 11 & 35 & $4 \quad 4 \frac{1}{2}$ & $53 \frac{1}{2}$ \\
\hline Marsden & - & 56 & 11 & 11 & 40 & 18 & 27 & 11 & 11 & 40 & 50 & 511 \\
\hline Colne & 一 & 56 & 11 & 11 & 45 & $110 \frac{1}{2}$ & $2 \quad 9 \frac{1}{2}$ & 11 & 11 & 45 & $57 \frac{1}{2}$ & $\begin{array}{ll}6 & 6 \frac{1}{2}\end{array}$ \\
\hline
\end{tabular}

It will be observed from these figures that the total tolls charged after the leasing of the canals by the railways were twice or three times as much as before the lease was effected. Brit. Doc. 1852-3 (246), xxxvin, 175, 'Evidence of IIr Loch.'

In the case of the Bolton and Bury Canal, great changes were made in the rate of tolls after its amalgamation with the Lancashire and Yorkshire Railway, as indicated by the following schedule, from which we see that in some cases the railway freight rate was slightly more than the canal tolls, and in other cases slightly less; so that, on the whole, we may say that the average railway freight mileage rate was probably about the same as the average canal tolls. In other words, independent carriers sending goods by the canal would pay as much in tolls only as the railway would charge for the whole service, including haulage. Brit. Doc. 1852-3 (246), xxxviII, 175, 'Evidence of Mr Loch.' 


\section{Bolton and Bury Canal.}

Comparison of the Relative Charges per ton per mile made by the Lancashire and Yorkshire Railway Co., for freight on their railway, and for Toll on their Canal.

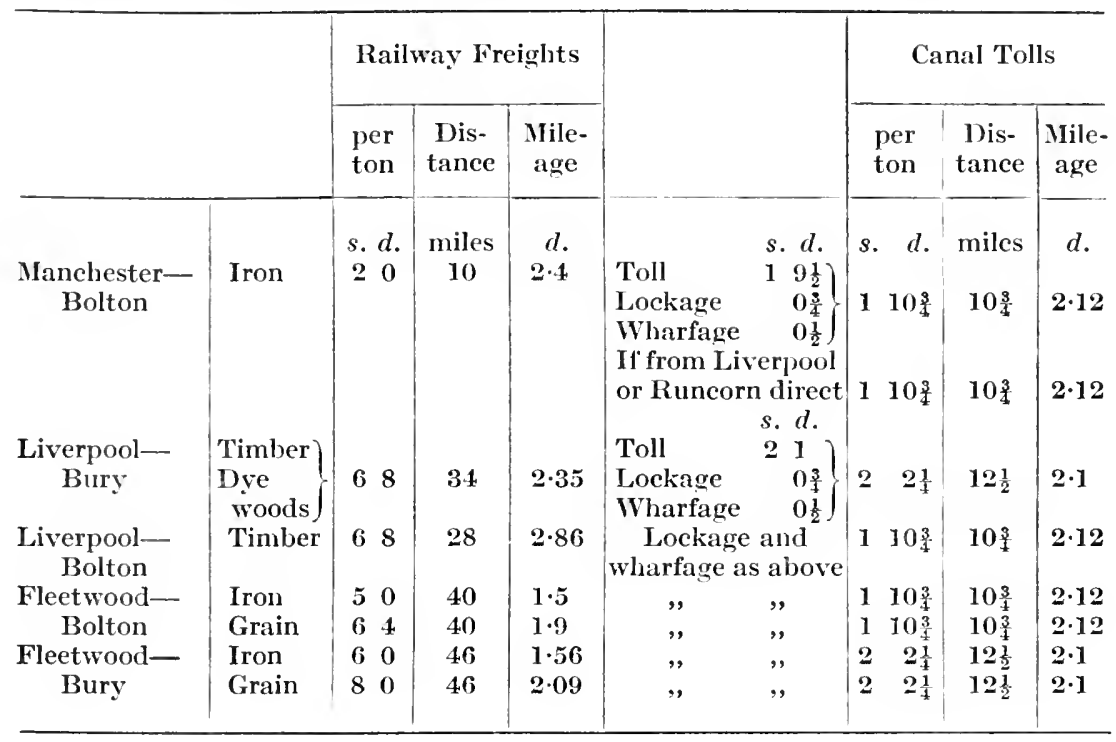

The following comparison is made of the Charges on the Huddersfield Canal, before and after amalgamation with the London and North Western Railway:

\section{IIuddersfield Canal.}

\begin{tabular}{l|l}
\hline Charges before Amalgamation & Charges subsequent to Amalgamation \\
\hline Toll of 1d. per ton per mile & $\begin{array}{l}\text { Toll, 1d. per ton per mile } \\
\text { Tunnel dues, } 1 s .6 d \text {. per boat each way } \\
\text { Light dues, equal to } 10 \text { to } 15 \text { tons } \\
\text { Wharfage, 1d. per ton }\end{array}$ \\
\hline
\end{tabular}

\section{Illustration.}

Formerly, a boat with a cargo of 20 tons, and returning light, $\quad\{s . d$. $\begin{array}{llllllll}\text { would pay for } 20 \text { miles } & \ldots & \ldots & \ldots & \ldots & & 13 & 4\end{array}$

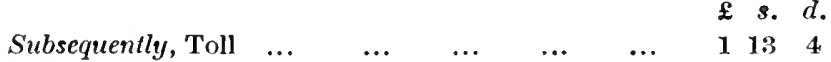

Tunnel dues, 1s.6d. each way $\quad \ldots \quad 3 \quad 30$

Light dues, say for 15 tons $\quad \ldots \quad 10 \quad 1 \quad 50$

Wharfage, on 20 tons $\quad \ldots \quad \ldots \quad \frac{1}{2} \quad \begin{array}{llll}3 & 3 & 0 \\ \text { Difference }= & 1 & 9 & 8\end{array}$

Brit. Doc. 1852-3 (216), xxxvin, 175, 'Evidence of Mr Loch.' Sec also ibid., p. 34, showing how, after a prolonged contest, the Bridgewater Canal Trustees werc forced to put up their rates in obedience to the demand of the railways. 
Two other cases are here quoted from the 'Report of the Committee of 1872 on Railway Amalgamations,' Brit. Doc. 1872 (364), xill, 1, 'Minutes of Evidence,' p. 332 :

Between Leeds and Manchester, there were three navigations, namely, the Aire and Calder, the Calder and Hebble, and the Rochdale Canal. Manchester packs were being conveyed along these waterways at a rate with which the railways could not compete; and in order to destroy this competition the London and North Western, the Lancashire and Yorkshire, the North Midland, and the Manchester, Sheffield and Lincolnshire Railways jointly obtained a lease of the Rochdale Canal for a term of years, and raised the tonnage upon Manchester packs to a rate prohibiting their conveyance upon the water any longer.

Another instance is that of the London and North Western Railway Company in dealing with the food supply from Liverpool and from Gloucester to the mining districts of Staffordshire. Distance was all in favour of Gloucester, and the rate from that port to the Staffordshire collieries was originally $7 s$. a ton. The London and North Western, luaving obtained practical control over the old Birmingham Canal, by which the food supplies were conveyed from the terminus of the Birmingham and Worcester Canal at Birmingham to the collieries, an average distance of ten miles, raised the rate on that canal so as to increase the total rate from $7 \mathrm{~s}$, to $10 \mathrm{~s}$. per ton, and by so doing turned the supply of corn for that district from Gloucester to Liverpool, in order that this supply should be conveyed over seventy-five miles of their railway. By 1865 the bankers, merchants, etc., of Liverpool were loud in their complaints against the excessive rates charged by "that leviathan monopolist," the London and North Western. Brit. Mus. C. T. 309 (7), 'Rates of Carriage to and from Liverpool,' pp. 1-10.

We have elsewhere noted the extortionate prices charged for carriage by the navigations connecting Liverpool and Manchester, before the opening of the railway there in 1830; and the strong protests of those who were the projectors of the railway. With reference to this subject, there is an interesting remark by Mr Francis R. Conder, C.E., in a paper read before the Manchester Statistical Society, on Nov. 30, 1882. He says: "The statement might well be regarded as incredible, were it not supported by indisputable evidence, that fifty years after the opening of the Liverpool and Manchester Railway, it costs more to convey a bale of cotton from the one city to the other than it did in 1829." Brit. Doc. 1883 (252), xirr, 1, Appendix, p. 239. Within half a century, one monopoly was displaced by a more progressive but equally exacting one.

\section{APPENDIX 12}

\section{ILLUSTRATIONS OF THE WAY IN WHICH CANALS SOMETIMES MAINTAINED COMPETITION AGAINST THE RAILWAYS}

It may serve to exemplify more fully how any competition between the canals and the railways was possible, if we take one or two illustrations:

About 1850, the Grand Junction Canal Company was the largest of the carriers by canal. In 1847 the canal companies generally were afraid that the carriers would be forced to leave the waterways. They had been driven off the London and North Western road and forced to give up some of their most important traffic. The Trent and Mersey Canal had allied its interests with, and was under the control of, the Nortl Staffordshire Railway Company, and therefore the canal route from Birmingham to Liverpool and Manchester was practically closed to private carriers. 
Under these circumstances, the Grand Junction Canal Company determined to fight for their right to carry between London and Birmingham. They entered into negotiations with other independent canals, asking them to share in starting a carrying establishment. They all refused; and the Grand Junction Company, before entering upon a carrying business, made agrecments with almost all the other independent canals between the end of their line and Birmingham, so as to make sure what tolls these canals would charge them. Under these arrangements, the Grand Junction Company was able for years to keep the traffic on the canal and even to increase the absolute amount of it. The statisties of this trade we append below: Brit. Doc. 1852-3 (246), xxxvi1, 175, 'Evidence of Mr Mellish,' pp. 14-15:

Amount of Trade on Grand Junction Canal.

\begin{tabular}{l|c|c|c}
\hline Year & $\begin{array}{c}\text { Through } \\
\text { Trade }\end{array}$ & $\begin{array}{c}\text { Local } \\
\text { Trade }\end{array}$ & $\begin{array}{c}\text { Total } \\
\text { Trade }\end{array}$ \\
& & & \\
\hline & tons & tons & tons \\
\hline 1833 & 186,029 & 522,228 & 708,257 \\
1834 & 192,253 & 527,528 & 719,781 \\
1835 & 192,859 & 631,786 & 824,645 \\
1836 & 191,043 & 826,518 & $1,017,561$ \\
1837 & 216,706 & 890,251 & $1,106,957$ \\
1838 & 202,134 & 746,354 & 948,488 \\
1839 & 231.953 & 712,169 & 944,122 \\
1840 & 224,819 & 729,430 & 954,249 \\
1841 & 235,511 & 851,954 & $1,087,465$ \\
1842 & 227,782 & 714,053 & 941,835 \\
1843 & 239,116 & 749,386 & 988,502 \\
1844 & 295,100 & 794,421 & $1,089,521$ \\
1845 & 294,257 & 847,616 & $1,141,873$ \\
1846 & 229,282 & 858,689 & $1,087,971$ \\
1847 & 253,141 & 910,325 & $1,163,466$ \\
1848 & 227,736 & 803,548 & $1,031,284$ \\
1849 & 206,390 & 771,865 & 978,255 \\
1850 & 221,853 & 804,879 & $1,026,732$ \\
1851 & 219,886 & 879,988 & $1,099,874$ \\
1852 & 228,925 & 915,644 & $1,144,579$ \\
& & & \\
\hline & & & \\
\hline
\end{tabular}

The foregoing statistics begin with 1833, the year the London and Birmingham Railway Act was passed, so that the figures for the first years were not affected by railway competition.

The total trade on the canal had increased, therefore, 25 per cent. in twenty years. To show how large this tradc was, compare the following figures:

1852, London and North Western Railway 639 miles
," Grand Junction Canal $\ldots .398,622$ tons.

That is, with a length of line about five times as great as that of the canal, the railway carried only three times the amount of freight that was carried by the canal. Of course, we must remember that the heavy and bulky freight that went by the canal paid a much lower carriage rate than the goods that were sent by rail, so that, ton for ton, the revenue on the railway was much greater than that on the freight carried by the canal. Consequently, from the standpoint of the operating revenue, the above comparison may mean very little. 
Note, that much the larger part of the above traffic was local. We have said that the absolute amount of traffic on the canal increased, but, of course, the relative amount did not keep pace with that on the railway.

Another case which shows us the way in which, by the aid of the carriers, a canal was able to keep its traffic, at least for some time, from going over to the railway, was that of the Bridgewater Canal. When the Liverpool and Bury Railway was opened, which was another line between Liverpool and Nanchester, it had to be satisfied with some part of the traffic to commence with. At that time, the Bridgewater Trustees were carrying about twice as much traffic between these two places as the Liverpool and Manchester Railway ( $v$. table at end of this Appendix). The railway companies proposed to the Bridgewater Trustees that instead of continuing to carry what they could collect, and what they conceived themselves to be entitled to, they should be content with only half the traffic, and the other half should be divided between the two railway companies. The Trustees objected to this, but the railway companies insisted on the division; and at the same time they required the Trustees to exclude the private carriers from the canals, for it was felt that the success of the Trustees in collecting so large a traffic was due very much to the exertions and independent energy of the carriers. The Trustees declined both proposals: either to yield up the trade which was their own, or to exchude the carriers from their canals. (They had bought up the Mersey and Irwell Navigation, in 1844, as almost a bankrupt concern.) The railway companies persevered in their demands, and as a result the rates between Liverpool and Manchester were reduced from an average of $7 s$. and $9 s$. a ton, to $2 s .6 d$. a ton, for six months or so. The 'Trustees, to avert the railway companies' intention, made arrangements with the private carriers that they would carry them through safely and that they would bear their losses from the beginning to the close of the contest. In return for this, they required the carriers to act almost as their agents and to charge the freight rates that the Trustees might direct. It answered the purpose; the carriers were thus able to pass through the contest and aid the trade on the canal: and the final result was that the proportion of traffic on the canals was as large as, if not larger than, it had been previously.

The railway companies again applied for a division of traffic, and it was agreed to, with the stipulation that the Trustees should pay over to the railway companies 5s. per ton on the excess which the Trustees might carry above their one-half. This went on for about nine montbs, but it was a losing game for the Trustees, and they put an end to it about the close of the year 1850, after which there was no division of traffic, but a tariff of rates for the three parties.

Under previous arrangement, the canal charged $8 s .4 d$. a ton on manufactured goods from Manchester to Liverpool, while the railway charged $10 \mathrm{~s}$. for the same service, the difference being regarded as an equivalent for the faster carriage on the railway. But, later, the railway company forced the canals, after long-continued resistance, to put their rates up to 10s. Brit. Doc. 1852-3 (246), xxxvirI, 175, 'Minutes of Evidence,' pp. 23, 34.

The tonnage of freight carried on these navigations, during these critical years, is given in the following table. It shows what an important factor the private carriers were in the maintenance of the traffic, as compared with the amount carried by the owners of the navigations : 


\begin{tabular}{|c|c|c|c|}
\hline & & 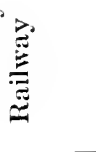 & 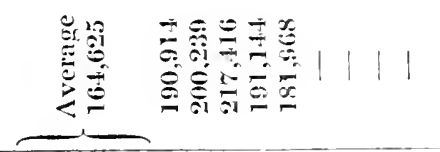 \\
\hline & 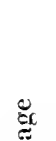 & 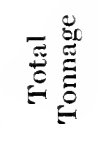 & 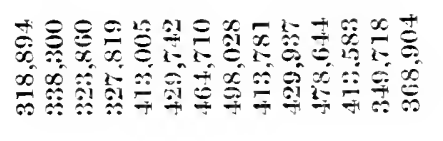 \\
\hline 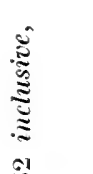 & 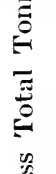 & 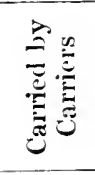 & 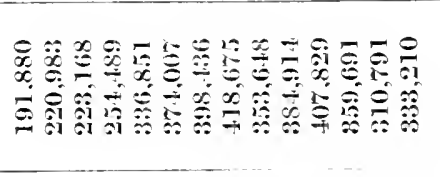 \\
\hline 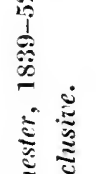 & $\overbrace{3}^{3}$ & 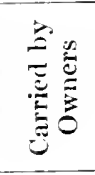 & 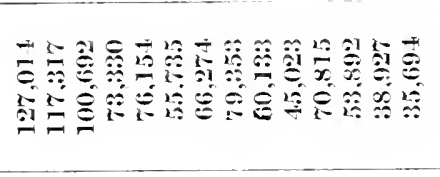 \\
\hline 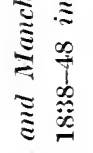 & 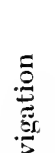 & 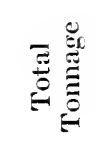 & 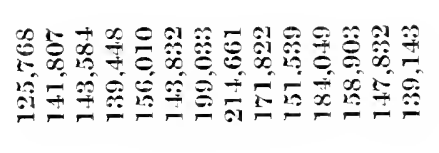 \\
\hline 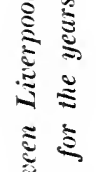 & $\begin{array}{l}\vec{Z} \\
\bar{D} \\
\bar{\Xi} \\
\Xi \\
\Xi\end{array}$ & 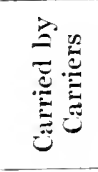 & 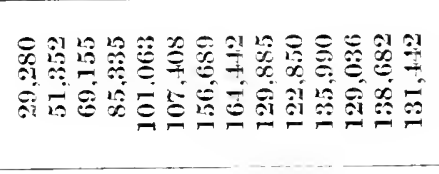 \\
\hline 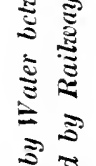 & 它 & 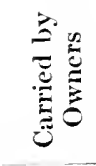 & 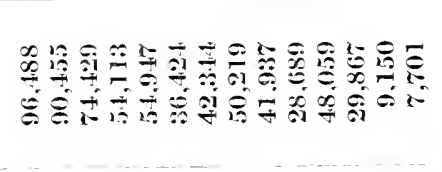 \\
\hline$\underbrace{3}$ & $\bar{\Xi}$ & 总 & 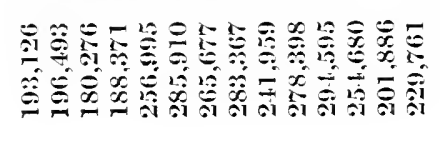 \\
\hline 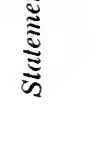 & 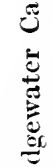 & 光 & 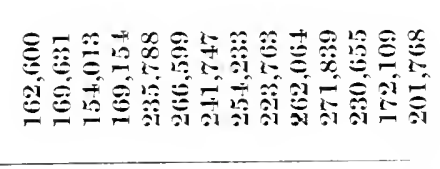 \\
\hline & Фี & 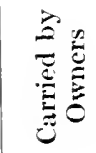 & 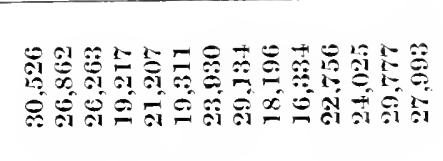 \\
\hline & & 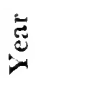 & 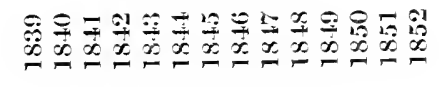 \\
\hline
\end{tabular}




\section{APPENDIX 13}

\section{STATISTICAL VIEW OF HIGHWAY AND CANAL LEGISLATION}

THE accompanying tabular view of the Road Acts and Canal Acts must not be understood to be reduced to the most careful mathematical exactness of absolute accuracy; but within the limits of accuracy which are at all possible in the application of statistics to the subject in hand, we venture to assert that no defects will be found, and that the presentation here given will show concisely the relative importance which the roads and canals assumed at the different periods and in the different sections of England. It has been the endeavour to group the counties by natural divisions, according to the great industrial characteristics which have been predominant in each group, and not according to any artificial geographical arrangement.

What, then, are the limits within which we may expect accuracy? In the first place, a road or a canal which extended into two or more counties has been noted under each county; so that if one road were built through three counties, it would be made to appear as three roads. But since this has been done consistently through the whole time between 1700 and 1830 , the relative accuracy of our statistics will not be affected.

We must not suppose, however, that all these Acts represent actual road construction immediately after the passing of the Acts. Sometimes roads authorized to be made at a certain time were not made until years afterwards; and this would seem to vitiate any conclusions we might draw; but when we remember that this dilatoriness in constructing roads after they were sanctioned would not be much different at one period from another, we can easily see that our results are still quite comparable at all the periods during this epoch.

Again, all the Acts here enumerated were not for construction of new roads. A great many terms are uscd in the statutes in describing the purposes of the Acts, such as "building," "constructing," "amending," "repairing," "widening," "altering," etc., the roads; and in many other cases the Acts were passed for continuing the provisions of former Acts. While, thercfore, our figures do not give us exact information as to ncw construction, they give us a very accurate guide as to the relative importance which the roads assumed at the different periods and in different sections of the kingdom. What we have said in this connexion regarding the roads is not so pertinent concerning the canals, for in connexion with them there was comparatively little legislation that was not followed by actual construction.

Another reservation we must make as to the roads, namcly, that these Acts do not include the general road or turnpike Acts which were intended to apply to all the roads alike. As we have secn, these general Acts were scarce during the last half of the eightecnth century, because legislation was passed for each road separately according as the claim of each was presented. The number of these general Acts was so small in comparison with the number of separate road Acts (there being only four of any great consequence), that we may safely neglect them, as being insignificant for statistical purposes.

Now, what do our statistics, as thus defined, show in regard to the development of the means of communication? That there was a great increase in the attention given to road improvement beginning about 1750 , is evident from the average road Acts per decade in the period given, the number per decade from 1751-90 being five 


\begin{tabular}{|c|c|c|c|c|c|c|c|c|c|c|c|}
\hline \multirow{3}{*}{ 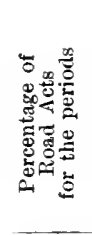 } & 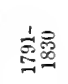 & : & $\stackrel{\leftrightarrow}{9}$ & ثं & $\dot{\bar{y}}$ & $\ddot{\infty}$ & 管 & $i$ & 暗 & 20 & \\
\hline & 实产 & $\infty$ & 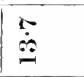 & 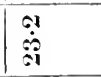 & $\therefore$ & $\stackrel{\stackrel{9}{g}}{\stackrel{g}{g}}$ & $\dot{\infty}$ & I: & $\stackrel{\ddot{g}}{\dot{\theta}}$ & $\mid \overline{0}$ & \\
\hline & 定通 & مُ & $\stackrel{\hat{i}}{i}$ & $\stackrel{9}{\stackrel{9}{0}}$ & $\stackrel{\infty}{+\infty}$ & $\stackrel{\hat{\vdots}}{\vdots \vdots}$ & $\stackrel{\stackrel{9}{g}}{g}$ & $\dot{\dot{\dot{g}}}$ & $\ddot{B}$ & 10 & \\
\hline \multicolumn{2}{|c|}{ 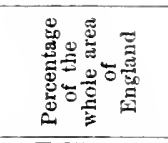 } & $\stackrel{2}{\Leftrightarrow}$ & E & $\stackrel{\Re}{\stackrel{\oplus}{ \pm}}$ & $\stackrel{9}{\dot{H}}$ & $\ddot{\dot{\theta}}$ & $\stackrel{P}{i}$ & $\stackrel{9}{\stackrel{\Xi}{Z}}$ & $\overrightarrow{\dot{D}}$ & $\stackrel{\infty}{\infty}$ & \\
\hline \multirow{2}{*}{ 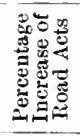 } & 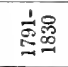 & in & $\exists$ & $\%$ & 120 & â & 品 & \% & $\bar{\sigma}$ & $\hat{B}$ & F \\
\hline & 항요 & 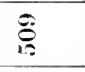 & 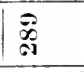 & 6 & !章 & $\vec{\oplus}$ & | & 䉁 & | & & 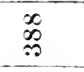 \\
\hline \multirow{3}{*}{ 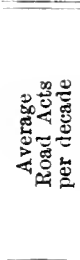 } & 密总漹 & 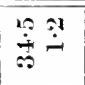 & 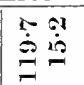 & 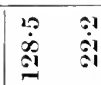 & 突题 & 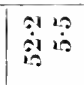 & & 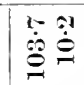 & 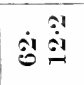 & 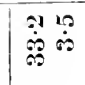 & $\dot{\dot{\theta}}$ \\
\hline & 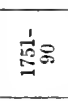 & 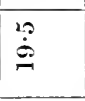 & 安 & $\begin{array}{ll}10 \\
\dot{a}\end{array}$ & 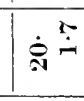 & $\frac{40}{4}$ & 今. & $1 \dot{B}^{\circ}$ & ${ }^{\circ}$ & $\dot{s i n}^{20}$ & 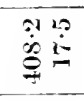 \\
\hline & 这品 & $\hat{\circ}$ & 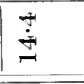 & $\dot{\Xi}$ & $\dot{4}$ & $\mid \begin{array}{l}\infty \\
i \\
i\end{array}$ & $\mid \begin{array}{l}\infty \\
\infty \\
\infty\end{array}$ & $1 \overrightarrow{0}$ & $\dot{\infty}$ & 10 & 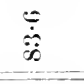 \\
\hline \multirow{3}{*}{ 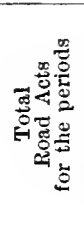 } & 通兑 & $\infty_{0}^{\infty}$ & 80 & $\frac{7}{13} 8$ & छ잉 & 89 & \%ิ & $\frac{12}{77}=$ & 㛚 9 & 管 & $\underset{P}{P}$ \\
\hline & 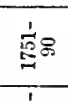 & $\infty$ & 萂 & 要 & $\infty^{x}$ & $5^{301}$ & $0 \approx$ & $\left.\right|_{\substack{+\infty \\
\text { s. }}}$ & $E_{0}^{\circ 1}$ & $8^{\circ 1}$ & 簿是 \\
\hline & 童品 & $\Leftrightarrow$ & $\hat{i}$ & 18 & si & $\infty$ & 1 & के & 9 & 10 & $\stackrel{\infty}{7}$ \\
\hline \multirow{4}{*}{ 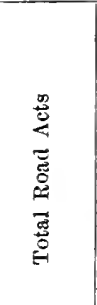 } & 家启 & $8-$ & $\mid$\begin{tabular}{l}
0 \\
\hdashline
\end{tabular} & 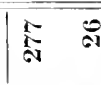 & $1 \operatorname{lig}^{2}$ & $\Xi^{\infty}$ & $\stackrel{\infty}{=}$ & 獸 & $\overrightarrow{0}$ & $x^{\prime \prime}$ & 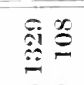 \\
\hline & 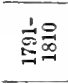 & $2 \pi$ & $\sigma_{3}^{\infty}$ & 葪 & 920 & $\mid \stackrel{8}{\&}$ & 192 & 芯: & 志 & 号家 & $\Xi 2$ \\
\hline & हं & 8 & $\vec{\Xi}=$ & 盖 & $H^{*}$ & $\left.\right|_{i=1} ^{\infty}$ & 吕 & |식 & $\infty_{0}^{\infty}$ & 利 1 & 鮎早 \\
\hline & 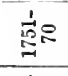 & 80 & $g^{x}$ & 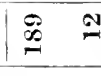 & $10 \%$ & $\left.\right|^{2}$ & 107 & $10_{0}^{\circ}$ & 90 & $b^{\infty} 0$ & 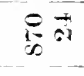 \\
\hline
\end{tabular}


times, and from 1791-1830 between seven and eight times, greater than those of 1701-50. The immediate ehange at the decade 1751-60 is very marked from the number of Acts of that period as compared with those of the period 1r41-50, namely 340 in the latter decade and 403 in the former, which is almost 200 per cent. increase. This change would seem to point very strongly to the belief that the Industrial Revolution was already in progress in the deeade from 1751-60. The pereentage of increase of the road Acts in 1751-90 over the preceding fifty years is markedly eharacteristie of England's progress.

Another feature of the table which will be at once discerned, is the way in which certain sections increased their road Acts, as a sign of the industrial advance in these localities. Perhaps this is best brought out by considering the average road Aets per decade in the three periods given. Two divisions are very prominent in this respect, namely, the North Midland counties in one group, and the counties of Lancaster, York and Chester in the other. These were the great manufacturing sections, which were much in need of improved means of carriage and communication. But the causes for these changes we have dwelt upon fully in the chapter dealing with the roads after $\mathbf{1 7 5 0}$.

It is needless for us to follow out in detail al! the information obtainable from sueh a view of the legislation; but one other fact deserves to be mentioned, that is, the enormous change in the number of eanal Aets in the period 1791-1800 over any previous period. In that period there were almost exactly six times as many Aets as in the preceding deeade; and the figures we have here given for twenty-year periods show the ehange at a glanee. Had we the opportunity to give the figures for the year 1793, and compare them with the corresponding figures for any previous year, we should at once discover that the thirty-third year of the reign of George III was the year of the "canal mania." There were exactly three times as many Acts passed that year as in the preceding. With the opening of the railway era in $\mathbf{1 8 3 0}$, we come to a time when there were very few, almost no, Acts passed for the eonstruetion of eanals, and the break at this year was very abrupt.

\section{APPENDIX 14}

\section{PICKFORD ET AL. v. THE GRAND JUNCTION RAILIVAY CO.}

An important chapter in the history of railways is that which deals with their relation to the carriers, and shows us the way in which the latter were driven off the lines of railway and their trade came into the hands of the railway companies. We must not give the impression, however, that all the firms of carriers were driven off the rails, nor that those which were ousted from their trade had their business overthrown and their connexions despoiled immediately. Some lines dealt more liberally with the carriers, and even eneouraged their trade as a means of increasing the revenues of their roads; while others were opposed to the carriers from the first and did all they could to take the trade away from them. We have elsewhere examined this subject in general, and therefore do not need to revert to it here; but, instead, we wish to present the history of a particular ease, which throws much light upon the general subject, a ease which was unique in the history of railway traffie development, and which made the earrying trade the topie of vigorous and sometimes aerimonious diseussion. The ease of Pickford et al. $v$. The Grand 
Junction Railway Co. is all the more important from the fact that at the present time Pickfords are probably the chief survivors of the early carriers who began their work on the canals and have had a continuous activity as forwarders of goods ever since.

For some years after the establishment of the steam railway as a common earrier, it was thought by many that the public interest could best be safeguarded by allowing competition on the railway lines; and, with this object in view, the private carriers were in most cases admitted to these lines. As we have already seen, there were several different systems under which the carriers were allowed to work. On the London and Birmingham Railway all carriers were admitted under certain regulations; but the Grand Junction Railway Co., while they allowed private carriers engaged in the London trade upon their line, retained to themselves the conveyance of all Birmingham and Lancashire goods.

The presence of the carriers upon their line was irksome to the Grand Junction Railway Co., for the latter were anxious to secure a regulated monopoly; and, while seeming to give more frcedom to the carriers and the public, the railway company, in 1839 , invited the carriers to enter into arrangements with them, by which the Birmingham and Lancashire traffic was to be opened to competition among the carriers, and the charges to the public were to be reduced. But the condition was imposed that the carriers were "not to charge less than" the railway company. The rates were reduced to the public, subject to this reservation. It would seem as if this were but a cloak to cover up a deeper design. In 1838 the railway company found that, even with their monopoly of the carriage between Lancashire and Birmingham, their business as general carriers was very small; for the public had become accustomed to their former carriers, whose established connexions gave them facilities for safe and economical carriage. It would, therefore, be advantagcous for the railway company to have the old carriers supplanted and their connexions appropriated. Hence, while the carrier was, apparently, freely admitted upon the line, in reality he was admitted as a mere servant of the railway company. By the agreement, Pickfords got but a small percentage of the traffic receipts from the goods that were tumed over to the railway company. Then, when the railway rates were reduced, ostensibly to benefit the public, the returns of the Pickfords became so small as to be unremunerative. The railway company did not stop here, however, but compelled Pickfords, under an ingenious arrangement, to contributc, out of their small percentagc, a certain amount in payment of railway services at terminals (J. Moss, Railways, p. 386; Railway Times, Iv, p. 186).

In 1840 a crisis was finally reached in the relation of the carrier to the railway company. By their Acts of Parliament the Grand Junction Railway Co. were authorized to make reasonable charges for the carriage of goods, and to fix what they regarded as proper charges for carrying small parcels, not exceeding $500 \mathrm{lbs}$. cach. The railway company became carriers of goods for hire between Manchester and London, using for that purpose their own line and the lines of the Liverpool and Manchester and London and Birmingham Railway Cos. They published a list of charges, which divided the "rates by merchandize trains" into seven classes, from 16s. to 60s. a ton; and then followed "boxes, bales, hampers, or other packages," when they contained parcels, etc., under $112 \mathrm{lbs}$. weight each, directed, consigned, or intended for different persons, or for more than one person, on which the rate was made 1d. per lb. weight. On Nov, 24, 1840, Pickford \& Co. packed several parcels (consisting of teas, books, and hardware, which had been delivered to them by various persons to be carried from Birmingham to Manchester) in a hamper, the gross weight of which, including the parcels, was 8 ewt. 3 qrs., although cach parcel 
separately was less than $112 \mathrm{lbs}$. weight, and would, if delivered separately, havc been a small pareel and thus have fallen under the titlc "smalls" according to the sevenfold elassification above-named. This hamper was tendered to the Grand Junction Railway Co., and they were asked to carry it to its destination, for which service Pickfords olfered to pay all that the railway company could legally eharge, namely, 60s. per ton or a total of $£ 1.6 \mathrm{~s} .6 \mathrm{~d}$. The railway company's agent at Birmingham refused to receive the hamper unless the senders allowed him to open it, so that the number of parcels might be known, and each parcel might be charged and paid for separately at the rate fixed in the railway company's list, or unless they would pay the railway company $1 d$. per $\mathrm{lb}$. upon the total weight of 8 ewt. 3 qrs., which would have amounted to $£ 4.1 \mathrm{~s} .8 \mathrm{~d}$. Piekfords refused to pay the latter, and the railway company refused to earry the hamper (Railway and Canal Cases, III, pp.198-5. A similar case is given in ibid., 111, pp.197-8). This case was tried in 1841 and was decided in favour of Pickford \& Co. (Railway and Canal Cases, II, p. 592 et seq.).

It will present the situation more elearly if we give briefly the two sides of the case, without attempting to weigh the merits of either; and if the reader will remember that there were other eases similar to this (e.g., Parker $v$. Great Western Railway Co., as given in Railway and Camal Cases, 11, p1'.563-87), he will understand that the arguments in this ease were applicable in the others. The evidence and allidavits in favour of the Grand Junction Railway Co. are found in Railway Times, Iv (1841), pp. 208-9, 236-8, 289-92; v (1842), pp. 739-41 ; vI, pp. 176, 206; vil, pp. 217-18; and those in favour of Pickford \& Co. are given in Railway Times,

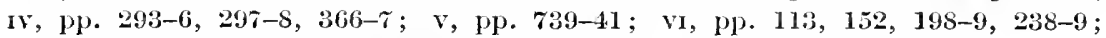
vil, p. 328; and in Railway and Canal Cases, 11, pp. 203-4, 538, 551-5.

The central dilliculty, as we noted above, turned upon the carrying of "smalis" in hampers. It was said that Pickford \& Co. had sent small pareels for different persons packed together in hampers, for the carriage of which they had paid the railway a certain rate per ton, the same as for goods, and afterwards, in distributing these parcels, charged each person the full amount of carriage that would have been paid had each pareel been earried separately. This was represented as having been done in order that the carriers might pocket the difference and thus swell their profits from the carrying trade. Pickford \& Co. denied this allegation, and the court did not find any truth in it. On the other hand, the court decided that it was illegal for a railway company to charge for a hamper of small parcels for delivery to one consignee, the same as if they had had the trouble of collecting and delivering each separate article.

The statement was made that Pickford \& Co.'s charges were not uniform to all persons under like cireumstances, and thus there was introduced upon the railway a system which the publie had found very objectionable on the canals. Not only were they accused of discrimination between eustomers, but it was also said that they commonly made insufficient, and, in some cases, untruc declarations of the description or quantity of the goods they delivered to the railway company for earriage, and thus deprived the railway company of their just and normal charges for earrying. The Grand Junetion Railway Co. also believed it true that, because they did not charge anything for packages returning empty, Pickford \& Co. declared as empty certain packages which were actually discovered to contain goods that Piek fords knew to be liable to charge like all other goods. 'To remedy these injuries that were believed to exist, and to benefit both the publie and themselves, the Grand Junction Railway Co. determined to put an end to certain special agreements between them and the common carriers, and so some of the carriers continued their business and others ceased to earry on the Grand Junction Railway.

The Grand Junction Railway Co. had acquired the right to carry goods on the 
lines of the London and Birningham Railway Co. and the Liverpool and Manehester Railway Co. In Liverpool and Manchester the Grand Junction Railway Co. had no arrangements for collecting and distributing their traflic and so cmployed the Liverpool and Manchester Railway Co. as their forwarding and delivering agent in these cities. They were in the same position with regard to London, and for some tine they had employed the old carrying firm of Chaplin and Horne to be their agents in the metropolis, to unload and deliver in London all goods brought thither by the Grand Jumction Railway Co., and to collect and load in London all goods that could be sent by that railway conpany. (The arrangements by which Chaplin and Horne acted as agents of the Grand Junction Railway Co. in London are given in Railicay and Canal Cases, I1I, pp. 199-201; see also the advertisement of Chaplin and Horne in Railicay Times, vil, p. 1447.) For this work Chaplin and Horne got $10 \mathrm{~s}$. per ton. The Grand Junction Railway Co. had been accustomed to charge 65s. per ton for goods sent from Manchester to London, and to pay 10s. per ton to Chaplin and Horne for their work. Pickford \& Co. wanted the railway company to give them the same favourable rate as had been given Chaplin and Horne; and they tendered the railway company 55s. per ton for the carriage of the goods, they doing the work of distributing their own goods in London. But the railway company said 65s. per ton was their charge to all persons for carrying goods, and thus Pickford \& Co. were refused any concessions. The court held that it was unreasonable for the Grand Junction Railway Co. to discriminate between the two carrying firms, and their decision was that the railway company should make their rates for carriage to all parties, under like circumstances, the same (Railway and Canal Cases, III, pp. 203-4).

In addition to the foregoing, another of the great points in dispute was the desirability of having the common carriers on the railway line. We have elsewhere shown that practically all the early railway acts contemplated the competition of the carriers on the linc and made provision therefor according to the varying circumstances. Of course, subsequent expcrience had clearly shown that this right could not be cxercised without great danger to the public, and therefore some dcemed it wise either to regulate this competition, or else to have the railway companies cooperate with the carricrs so that the latter, with their well-equipped establishments, might be valuable adjuncts of the railways in extending their traffic. The question, therefore, was, as to whether it was the interest of the public and the railways to overthrow or to encourage the carriers upon the lines. It was evident that if the railways could get all the carriers driven off their lines and could obtain a monopoly of the traffic, the public would have little security as to economy of clrarge and cfficiency of management in connexion with the operation of the railways; and concerning this matter Piekford \& Co., while opposing the Grand Junction Railway Co. in their monopolistic policy, appealed to the public to support them in their efforts to prevent this monopoly (sce their letter addressed to "The Merchants and Trade of Liverpool," as given in Raitway Times, v1, p. 152). The railway company, in their turn, pointed out that it would be more conomical to eliminate all middlemen and their profits, as thereby rates would be lower for the public, and also referred with much satisfaction to the fact that their rates were much lower than the rates charged by the carriers on their line (v. Railicay Times, vi, p. 206). Consequently, they urged that the public interests would be best scrved by giving them, rather than the common earriers, all the traffic. Pickford \& Co., on the other hand, reminded the public that it was their competition that caused the railway company to put down the rates, and that if the public allowed them to be driven off the line, the Grand Junction Railway Co. would then be in a position to unduly increase the rates and recoup themselves for their present competitive loss. 
The foregoing were the chief points in the controversy, but there were many minor elements which also cntered into it (see digest of the essential points of the dispute in Railivay Times, v, pp. 739-41). As we have already noted, the decision of the court (rendered July 7,1842 ) and of the Vice-Chancellor was in favour of Pickford \& Co., and the Grand Junction Railway Co. were required to live up to the law in the application of rates and to desist from discrimination against Pickford \& Co. (Railway and Caral Cases, I1I, pp. 203-4).

As a matter of fact, however, the Grand Junction Railway Co. did not obey the decision of the court, but continued their existing policy. A long and desultory correspondence was kept up between these two parties, ostensibly, from the railway company's point of view, to arrive at some satisfactory arrangement as to the legal principles to be observed, but, really, it would seem, to prevent the carrier from getting any hold upon trafic to be carried on the railway. Pickford \& Co., by letter, appealed to the railway company, and urged the latter to deal fairly with their shareholders and the carriers by obedience to the. law (v. letter in Railway Times, v1, p. 113); but the railway company refused to accept the court's decision. Pickfords then addressed the traders of Liverpool, and, doubtless, those of other places also, showing the determination of the Grand Junction Railway Co. to secure a monopoly of the carrying trade, and earnestly soliciting the support of the merchants in their efforts to prevent this (Railzay Times, vi, p. 152). Their claims were upheld by some of the most infuential of those who were closely in touch with traffic affairs, and were also supported by the experience of some roads which had found it desirable to change their former plan of exclusion of the carriers (Railway Times, vi, p. 152): but the Grand Junction Railway Co. continued their system (although slightly altered) with singular pertinacity and in almost entire disregard of the court, notwithstanding the statement of their Secretary that they were living up to the court's decree ( $v$. Letter of Mark Huish, in Railway Times, vi, p. 206).

During the two years which followed the first decision, Pickford \& Co. had been unable to get the railway company to grant them reasonable charges for carriage in accordance with the law. The Grand Junction Railway Co. took an appeal against the decision of the Vice-Chancellor, and reopened the case before the Lord Chancellor (Railway and Canal Cases, I11, p. 538); but upon the evidence showing the unreasonable and discriminating way in which the railway company had treated the carriers on their line (ibid., pp. 551-5), the Lord Chancellor upheld the decision of the Vice-Chancellor against the railway company.

It is almost impossible to ascertain exactly the attitude taken by the Grand Junction Railway Co. in regard to this decision, but it seems fairly certain that they practically ignored the decrce of the court. We arrive at this conclusion from the action that was taken by the mcrchants of Liverpool in 1849 , when they presented to the Railway Commissioners a memorial with reference to the carriage of parcels by railway. After citing the decision of the court that the sending of hampers packed with small parcels was legally and morally justifiable, they referred to the oppressive regulations issucd by the railway companies calculated to put a stop to that privilege altogether, and then asked that an investigation be made into this course of procedure and the remedy be applied, so that shippers might be protected and that railways might be prevented from securing a monopoly of the carrying trade (v. 'Nemorial' given in Railkay Times, xis, p. 624. Memorials of like nature were presented from the merchants of Birmingham, Leeds, ete., as shown in IIerepath's Railtway and Commercial Journal, xi, p. 585). These complaints against the railway companies became loud and persistent; and in the same year (1849) a deputation, consisting of the most influential carriers, appeared before the Railway Commission, and presented petitions from Liverpool, Birmingham, Leeds, Edinburgh, 
Sheffield, Newcastle, Bristol, and other large plaees, praying that the railway companies might be prevented from resorting to illegal and improper means in order to defeat fair eompetition (IIerepath's Railway and Commercial Journal, xi, p. 599). With all this testimony, the eonelusion is almost inevitable that the Grand Junetion Railway Co. paid little attention to the verdiet of the eourt; but continued the policy which was considered as most effeetive for driving the private earriers olf their line.

On the whole subjeet of the relations of the railways to the earriers, see Nash, Railway Carrying and Carriers' Law (1846), Pt. 11, Chap. $\mathrm{x}$, whieh takes up the two great cases, Pickfords $v$. Grand Junetion Railway Co., and Parker $v$. Great Western Railway Co. Hodges, The Lawe relating to Railways and Railway Companies (1847), Chap. II, also treats the whole question fully from the legal side, and goes exhaustively into the two great cases. See also the public diseussion of it in the Railicay Chronicle, 1844, pp. 110-11, 134-5, 159-60, 184-5, and ibid., 1845, pp. 173 and 379, in which the railway side is taken; as it is also in Brit. Mus. 8235. b. 57 (1), "The Carriers' Case considered in Reference to Railways' (1841), a small pamphlet written in a very biased vein. Both sides are presented in The Times, Mar. 5, 1844, p. 5; June 10, 1844, p. 6; Sept. 27, 1844, p. 6; April 21, 1845, p. 6; Mar. 21, 1846, p. 5; July 24, 1846, p. 4; Aug. 3, 1846, p. 3. Refer also to Whitehead, Railicay Management, pp. 6-8, and Boyle, Hope for the Canals, pp. 5-6, 14-18. 


\section{BIBLIOGRAPHY}

It is necessary to say that the following references do not comprise more than a majority of the works that have been consulted, but they are those from which material has been chiefly obtained for the discussion of the subject in hand. Occasionally others are mentioned in the text, but it has been essential to limit the voluminous bibliography to include only the most important sources of information.

\section{OFFICIAL PUBLICATIONS}

British Documents to 1911, including Journals of the House of Commons and House of Lords, Statutes of the Realm, Reports of Committees and Commissions, etc. Rotuli Parliamentorum and Rotuli Hundredorum.

IIansard's Parliamentary Debates.

Mirror of Parliament.

Calendar of State Papers, Domestic.

Calendar of Treasury Papers.

Rymer's Foedera, Conventiones, Literae, et cujuscunque generis Acta Publica inter reges Angliae, ete.

Harnes, S. A Collection of State Papers relating to Affairs in the Reigns of King Henry VIII, King Edward VI, Queen Mary, and Queen Elizabeth, from the year 1542 to $1570 \ldots$...ft by William Cecil, Lord Burghley.

Acts of the Privy Council of England, 1429-1601.

Rusnwonth, Jonn. Historical Collections of Private Passages of State, etc., $1618-49$.

Fintu, C. H., and Tait, R. S. Acts and Ordinances of the Interregnum, 1642-1660. 3 vols. London, 1911.

Railway and Canal Cases. Vols. I-vı. London, 1835-54.

\section{GENERAL WORKS}

A., M. The Imperial Railway of Great Britain. London, 1865.

Aсworth, Willias M. The Railways of England. London, 1889.

Adnys, Williay Bridges. Practical Remarks on Railways and Permanent Way; as adapted to the Various Requirements of Transit. London, 1854.

- Roads and Rails and their Sequences, Physical and Moral. London, 1862.

English Pleasure Carriages: their Origin, History, Varieties, Material, Construction, etc. London, 1837.

Agriculture, Board of. Communications to the Board of Agriculture; on Subjects relative to the Husbandry and Internal Improvement of the Country, 1797-1811. 7 vols. London, 1797-1811. Ditto for year 1819. London, 1819.

Alexander, Joln. The Two Stephensons. Pioneers of the Railway System. London, [1903]. 
Alles, John. History of the Borough of Liskeard and its Vicinity. London, 1856.

Allen, Lake. The History of Portsmouth ; containing a full and enlarged Account of its Ancient and Present State, etc. London, 1817.

[Allen, Thomas.] A History of the County of Lincoln, from the Earliest Period to the Present Time; by the Author of the Histories of London, Yorkshire, Lambeth, Surrey, Essex, etc. Assisted by Several Gentlemen residing in the County. 2 vols. London, 1834.

Allnutt, Zichariah. Considerations on the Best Mode of Improving the Present imperfect State of the Navigation of the River Thames from Richmond to Staines, showing the Advantages to the Public, the Navigator, and the Owners and Occupicrs of Houses, Mills, etc....in preference to the making any Canal. Maps, etc. Henley, 1805.

- Uscful and Correct Accounts of the Navigation of the Rivers and Canals West of London. Map. 2nd ed. Henley, [ca. 1810].

Anderson, Jayes, LL.D. Recreations in Agriculture, Natural History, Arts, and Miscellaneous Literature. 6 vols. London, 1799-1802.

Anderson, Johs. History of Edinburgh. Edinburgh, 1856.

Anversos, T. An Historical and Chronological Deduction of the Origin of Commerce. 4 vols. London, 1764 .

Anonymons. A Cursory View of a Proposed Canal: from Kendal to the Duke of Bridgewater's Canal, leading to the great Manufacturing Town of Manchester, etc. (Birmingham Free Reference Library, No. 90,319.) [N.P.] [1769.]

- Case in Support of the Bill now depending in Parliament for removing the Bar between the Birmingham, and the Birmingham and Worcester Canals. (1815.) (Birmingham Free Reference Library, No. 87,368.)

- Obscrvation on the General Comparative Merits of Inland Communication by Navigations or Rail-Roads, with particular Reference to those projected or existing between Bath, Bristol, and London: In a Letter to Charles Dundas, Esq., M.P., Chairman of the Kennet and Avon Canal Company. London, 1825.

- Statement by a Subscriber to the London and Birmingham Railway, to the Proprietors and Occupiers of Estates on the Line of the proposed...Railway. Dated, London, 27 Jan., 1831. (Birmingham Free Reference Library, No. 88,482 .)

Observations on Railways particularly on the Proposed London and Birmingham Railway. London, 1831.

- Railways; their Uses and Management. London, 1842.

An Account of the Proceedings of the Great Western Railway Company, with Extracts from the Evidence given in Support of the Bill, before the Committee of the House of Commons, in the Session of 1834. London, 1834.

- Copy of the Wearmouth Bridge Acts of Parliament, viz., 32 Geo. III. c. 90, for building the Bridge, and 54 Geo. III. e. 117, to authorize the Disposal of Certain Securities on the Tolls by way of Lottery... Bishopwearmouth, 1830.

- Two Reports of the Commissioners of the Thames Navigation, on the Objects and Consequences of the Several Projected Canals, which interfere with the Interests of that River; and on the present sufficient and still improving State of its Navigation. Oxford, 1811.

The Qucen's Famous Progress, or Her Majesty`s Royal Journcy to the Bath, and IIappy Return. London, 1702.

Observations on a General Iron Railway: Showing its great superiority over all the Present Methods of Conveyance, and claiming the particular attention of Merchants, Manufacturers, Farmers, and, indeed, every class of 
Society. 2nd ed. (Author was Thomas Gray.) London, 1821. Brit. Museum 1029. e. 19.

Anonymous. The Parish of Ashburton in the Fifteenth and Sixteenth Centuries; as it appears from Extracts from the Churchwardens' Accounts, A.D. 14791580. With Notes and Comments. London, 1870.

A Compleat History of Somersetshire. Sherborne, 1742.

The History of Cheshire: Containing King's Vale-Royal entire, together with considerable Extracts from Sir Peter Leycester's Antiquities of Cheshire; and the Observations of Later Writers, particularly Pennant, Grose, etc. 2 vols. Chester, 1778.

- Railway Competition. A Letter to George Carr Glyn, Esq., M.P., Chairman of the London and North Western Railway. London, 1849.

The History of Guildford, the County-Town of Surrey. Containing its Ancient and Present State, civil and ecclesiastical, Collected from Public Records and other Authorities, etc. Guildford, 1801.

- The History of Inland Navigations, particularly those of the Duke of Bridgewater in Lancashire and Cheshirc. Folding Map of the Bridgewater Canal. London, 1766. 2nd ed., 1799.

The Monthly Chronicle of North-Country Lore and Legend. 5 vols. Newcastle-on-Tyne, 1887-91.

- Salopian Shreds aud Patches (reprinted from "Eddowes's Shrewsbury Jourual'•). 10 vols. Shrewsbury, 1875-92.

Anstice, Robert. Remarks on the Comparative Advantages of Wheel Carriages of different Structure and Irauglit. Bridgewater and London, 1790.

Archer, Mark. Willian Hedley, the Inventor of Railway Locomotion on the Present Principle. 3rd ed. Newcastle-npon-Tyue, [1885].

Asuron, John. 'The Dawn of the XIXth Century in England. 2 vols. London, 1886.

Astle, Thomas. The Will of Henry VII. London, 1775.

Aston, Josepin. A Picture of Manchester. Manchester, [1816].

Atrinson, D. H. Talph 'Thoresby, the Topographer; His Town and Times. 2 vols. Leeds, $1885-87$.

Atrinson, Thomas Dinham, and Clark, John Willis. Cambridge Described and Illustrated, being a short History of the Town and University. London, 1897.

Atkyss, Sir Robert. The Aneient and Present State of Glocestershire. London, 1712. (Reprinted in 1768.)

Avon, River. A Reply to the Answer to the Objections usually raised against the Embankment of the River Avon within the Port of Bristol...in a Letter to George Gibbs, Esq.,.... Bristol, 1791.

Orders in Council, His Majesty's Commission, and Certificate of the Commissioners, in the Year 1636, relative to the Navigation of the River Avon, in the Counties of Gloucester, Worcester and Warwick. (Birmingham Free Reference Library, No. 90,318.) Tewkesbury, 1826.

Axon, Ernest (editor). Manchester Quarter Sessions. Notes of Procecdings, Vol. I, 1616-23. Edited from the Manuscript in the Reference Library, Manchester. [Manchester], 1901.

Axon, William Edward Armitage. The Aunals of Manchester: A Chronological Record from the Earliest Times to the end of 1885. Manchester and London, 1886.

Bacon, Nathaniell. The Anualls of Ipswehe. The Lawes, Customes and Governmt of the same. Collected out of $\mathrm{Y}^{\mathrm{e}}$ Records Bookes and Writings of that Towne. Edited by Willian H. Richardson, M.A.; with a Memoir by Sterling Westhorp, Mayor of Ipswich, 1884-85. Ipswich, 1884 . 
Badeslade, Thomas. The History of the Ancient and Present State of the Navigation of the Port of King's-Lyn, and of Cambridge, and the rest of the TradingTowns in those Parts: And of the Navigable Rivers that have their Course through the Great-Level of the Fens, ealled Bedford Level. Also The IIistory of the Ancient and Present State of Draining in that Level.... From Authentick Records, and Ancient Manuscripts; and from Observations and Surveys.... London, 1725.

- Reasons humbly offered to the Consideration of the Publick; shewing how the Works now executing by Virtuc of an Act of Parliament to Recover and Preserve the Navigation of the River Dee, will destroy the Navigation; and occasion the Drowning of all the Low Lands adjacent to the said River, etc. Chester, [1735].

- The New Cut Canal, intended for Improving the Navigation of the City of Chester, with the Low Lands adjacent to the River Dee, compared with the Welland, alias Spalding River, now silted up, and Deeping-Fens adjacent, now Drowned, etc. Chester, [1736].

- The Ancient and Present State of the Navigation of the Towns of Lyn, Wisbeach, Spalding, and Boston ; of the Rivers that pass through those Places.... ?nd ed. London, 1751. [This is, in substance, the same as Badeslade's "Account of the Present State, etc." with additions from MSS. in possession of the Corporation of Adventurers.]

Baigent, Francis Joseph, and Millard, James Elwin. A History of the Ancient Town and Manor of Basingstoke in the County of Southampton. Basingstoke and London, 1889.

Bailex, John, and Culley, George. General View of the Agriculture of the County of Northumberland.... London, 1794.

- General View of the Agriculture of the County of Cumberland. With Observations on the Means of Improvement. Drawn up for the Consideration of the Board of Agriculture and Internal Improvement. London, 1794.

Balley, Thowas. Annals of Nottinghamshire. History of the County of Nottingham, including the Borough. 4 vols. in 2. London and Nottingham, [1852-55].

Baines, Edward. The History of the County Palatine and Duchy of Lancaster. 2 vols. London and Manchester, 1868.

- The History of the County Palatine and Duchy of Lancaster. New edition, revised and edited by John Harland; continued and completed by Brooke Herford. 2 vols. London, 1868.

Baines, F.E. On the Track of the Mail Coach ; being a Volume of Reminiscences, personal and otherwise. London, 1895. (Author was sometime InspectorGeneral of Mails, and author of "Forty Years at the Post Office.")

Baines, Tiromas, and Fairbainn, William. Lancashire and Cheshire, Past and Present. London, 1867.

Baines, Tromas. History of the Commerce and Town of Liverpool, and of the Rise of Manufacturing Industry in the Adjoining Counties. London and Liverpool, 1852.

Baird, Thomas. General View of the Agriculture of the County of Middlesex, With Observations on the Means of its Improvement.... London, 1793.

Barrett, C. R. B. Somersetshire: Highways, Byways, and Waterways. London, 1894.

Barteetr, Willian A. The History and Antiquities of the Parish of Wimbledon, Surrey. London and Wimbledon, 1865.

Bateman, Josepil. The General Turnpike Road Act, 3 Geo. IV. cap. 126; with an Appendix of Forms...to which are added an Index and Notes. London, 1822. 
Bateman, Joseph. A Second Supplement to the Gencral Turnpike Road Acts for 1827. Containing the Amended Acts 5 Geo. IV. c. 69 and 8 Geo. IV. c. 24, etc. London, 1827 .

The General Highway Act, $5 \& 6$ W. IV. c. 50, with Notes and an Index. London, 1835.

Bateson, Mary. Records of the Borough of Leicester, being a series of Extracts from the Archives of the Corporation of Leicester. 3 vols. London, 1899-1905.

Bayley, Thouas Butterworth. Observations on the General Highway and Turnpike Acts passed in the Seventh Year of His Prcsent Majesty, etc. London, 1773.

BAYNe, A. D. A Comprehensive History of Norwich (including municipal, political, rcligious, and commercial History). London and Norwich, 1869.

Bearcroft, Philip, D.D. An Historical Account of Thomas Sutton, Esq.; and of his Foundation in Charter-House. London, 1737.

Beckmann, Join. A History of Inventions and Discoveries. 3 vols. London, 1797. Bennett, Jalies. The History of Tewkesbury. Tewkesbury, 1830.

Bergier, Nicolas. The General History of the Highways, in all Parts of the World, more particularly in Great Britain. London, 1712. (Good on Roman administration of the highways.)

Buhingsley, Jolin. General View of the Agriculture of the County of Somerset, with Observations on the Means of its Improvement.... Bath and London, 1797.

Bird, James Barry. The Laws Respecting Travellers and Travelling, comprising all the Cases and Statutes relative to that Subject, ete. London, 1801.

- The Laws respecting Highways and Turnpike Roads, comprising the Common Law relating to Highways...the Statutc Law relating to Highways and Turnpike Roads, etc. London, 1801.

Bisuton, J. General View of the Agriculture of the County of Salop.... Brentford, 1794.

Blacklock, F. Gainsford. The Suppressed Benedictine Minster, and other Ancient and Modern Institutions, of the Borough of Leominster. Leominster, [1900].

Blackner, John. The History of Nottingham, embracing its Antiquities, Trade, and Manufactures, from the Earliest Authentic Records to the Present Period. Nottingham, 1815.

Blew, Willian C. A. Brighton and Its Coaches. A History of the London and Brighton Road, with some Account of the Provincial Coaches that have run from Brighton. London, 1894.

Blewtt, Reginald Janes. New Monmouthshire Railway from Newport to Nanty-glo and Blaenafon through Pontypool. [Newport, 1844.]

Blomefield, Francis. An Essay towards a Topographical History of the County of Norfolk. 2nd ed. 11 vols. London, 1805-10.

Blomfield, J[as]. C[marles]. History of the Present Deanery of Bicester, Oxon. 8 vols. Oxford and London, 1882-94.

Booth, Henry. An Account of the Liverpool and Manchester Railway, comprising a History of the Parliamentary Proceedings, preparatory to the Passing of the Act, a Description of the Railway, in an Excursion from Liverpool to Manchester....Liverpool, [1830].

Bourn, Daniel. A Treatise upon Wheel Carriages; shewing their Present Defects : with a Plan and Description of a New Constructed Waggon: which will effectually preserve and improve the Public Roads, and be more useful, cheap, and handy to the Proprietor. London, 1763.

- Some Brief Remarks upon Mr Jacob's Treatise on Wheel Carriages. London, 1773. 
Bowes, I. Gcorge Stephenson and M. Ferdinand de Lesseps. The Men and their Work: the First Public Railway in the World: and the Suez and Panama Canals. London, 1893.

Boyle, EDward, and WAghorn, Thomas. The Law relating to Traffic on Railways and Canals. 3 vols. London, 1901 .

Boyle, J. R. The Early History of the Town and Port of Hedon, in the East Riding of the County of York. Hull and York, 1895.

The County of Durham. London, 1892.

Boyle, Thonas. Hope for the Canals! showing the Evil of Amalgamations with Railways to Public and Private Interests, and the Means for the Complete and Permanent Restoration of Canal Property to a Position of Prosperity, upon its Present Basis of Original and Independent Enterprise. London, '1848.

Boyman, Boyman. Steam Navigation, its Rise and Progress. London, 1840.

Boys, Joun. General View of the Agriculture of the County of Kent... Brentford, 1794.

Boys, William. Collections for an History of Sandwich in Kent. Canterbury, 1892.

Brand, Jonn. The History and Antiquities of the Town and County of the Town of Newcastle upon Tyne. 2 vols. London, 1789.

Brasbridge, Josepit. The Fruits of Experience; or Memoir of Joseph Brasbridge, written in his 80th year. London, 1824.

Brassington, W. Salt. Historic Worcestershire. London, 1895. (Pp. 21-30 deal with Roman, British and Saxon Roads.)

Bray, William. Sketch of a Tour into Derbyshire and Yorkshire. 2nd ed., 1783. (In Pinkertion's Voyages and Travels, Vol. 11, pp. 336-464.)

Brayley, Edward W. A Topographical History of Surrey. 5 vols. London, 1850.

Brent, John. Canterbury in the Olden Time, From the Municipal Archives and other Sources. Canterbury and London, 1860.

Brewer, J. S., and Bullen, Wiljian. Calendar of the Carew Manuscripts, preserved in the Archiepiscopal Library at Lambeth, 1515-1574. London, 1867-73.

Brindeley, James. Queries proposed by the Committee of the Common-Council of the City of London, about the intended Canal from Monkey Island to Isleworth, answered. Also, An Estimate of the Expence of making a Navigable Canal from Monkey Island to Isleworth, upon the Lower Line laid down in the Plan, by the Way of Stanes, etc. London, $17 \% 0$.

- [Report] to the Committee of the Common-Council of the City of London [regarding the improvement of the river Thames]. [London], 1770.

Briscoe, Join Potter. History of the Trent Bridges at Nottingham. (A Paper read before the Royal Historical Society, Apr. 22, 1873.)

Brome, James. Travels over England, Scotland, and Wales. Giving a True and Exact Description of the Chiefest Cities, Towns, etc. London, 1700.

Brown, Thomas. General View of the Agriculture of the County of Derby.... London, 1794.

Browne, Sir Thomas (1605-82). Works: including his Life and Correspondence. Edited by Simon Wilkin. 4 vols. Norwich and London, 1836.

Buchanan, Robertson (C.E.). A Practical Treatise on Propclling Vessels by Steam, etc. Glasgow, 1816 .

Bull, Frederick William. A History of Newport Pagnell. Kettering, 1900.

[Bult, Hen ry.] A History, Military and Municipal, of the Ancient Borough of the Devizes, and subordinately of the entire Hundred of Potterne and Cannings in which it is included. London and Devizes, 1859 . 
Buller, E. C. A Compendious History and Description of the North Union Railway. Preston, 1838.

Bunce, John Thackray. History of the Corporation of Birmingham, with a Sketch of the Earlier Government of the Town. 2 vols. Birmingham, 1878-85.

Bunn, J. W. Wricis (compiler and editor). Worcestershire County Records. Division I, Documents relating to Quarter Sessions. Calendar of the Quarter Sessions Papers. Vol. I, 1591-1643. Worcester, 1900.

Burn, Richard. The Justice of the Peace, and Parish Officer. 2 vols. London, 1755. (Burn was a J.P. for Westmorland County.)

- A New and Aceurate Description of the Present Great Roads and the Principal Cross Roads of England and Wales. London, 1756.

- The History of the Poor Laws : with Observations. London, 1764. (Pp. 236238 refer to the highways.)

Burton, Robert. A New View, and Observations on the Ancient and Present State of London and Westminster (continued by an Able Hand). London, 1730 .

Burton, Thomas. Diary of Thomas Burton, Esq., Member in the Parliaments of Oliver and Richard Cromwell, from 1656 to 1659 ....Edited and ilhustrated with notes historical and biographical by John Towill Rutt. 4 vols. London, 1828.

Burton, William. The Description of Leicestershire, Containing Matters of Antiquitye, Historye, Armorye and Genealogy. (MS. notes by Peter Le Neve.) London, 1622.

Buscir, Dr Wilinela. England under the Tudors. Vol. x, King Henry VII (14851509). Translated under the supervision of Rev. A. H. Johnson, M.A., by Alice Todd. With Introduction and some comments by James Gairdner. London, 1895.

Butterworth, A. Kaye. A Treatise on the Law relating to Rates and Traffic on Railways and Canals, with speeial referenee to The Railway and Canal Traffic Aet, 1888, and the Practice of the Railway and Canal Commission. 2nd ed. London, 1889.

Calderwood, Mrs. Letters and Journals of Mrs Calderwood of Polton, from England, Holland, and the Low Countries in 1756. Edited by Alexander Fergusson. Edinburgh, 1884.

[Canning, Richard.] The Principal Charters Which have been Granted to the Corporation of Ipswich in Suffolk. London, 1754.

Capper, Charles Henry. Observations on "Investigator's" Pámphlet relative to Railways. London, 1831.

Capper, Robert. Proposed Birmingham Ship Canal. Birmingham, 1886.

Caröe, W. D., and Gordon, E. J. A. Sefton: A Descriptive and Historical Account, comprising the Collected Notes and Researches of the late Rev. Engelbert Horley; Together with the Records of the Mock Corporation. London and New York, 1893.

Carter, N. H. Letters from Europe, comprising the Journal of a Tour through Ireland, England, Scotland, France, Italy, and Switzerland in the years 1825, '26, and '27. 2 vols. New York, 1827.

Cartwrigit, James J[oel]. Chapters in the History of Yorkshire; being a collection of Original Letters, Papers, and Public Documents, illustrating the State of that County in the Reigns of Elizabeth, James I, and Charles I. Wakefield, 1872.

(editor). The Memoirs of Sir John Reresby, of Thrybergh, Bart., M.P. for York, etc., 1634-1689, written by Himself. London, 1875. 
CAny, Jonn. Cary's new Itinerary, or an Accurate Delineation of the Great Roads, both direct and cross, throughout England and Wales. London, 1798.

- Inland Navigation; or Select Plans of the Several Navigable Canals throughout Great Britain, ete. London, 1795.

Cary, Robert. Memoirs of the Life of Robert Cary, Baron of Leppington, and Earl of IIonmouth. Written by Himself, and now published from an Original IS. in the Custody of John Earl of Corke and Orrery,.... London, 1759.

Catirall, Willia. The History of Oswestry. eomprising the British, Saxon, Norman, and English Eras; the Topography of the Borough, ete. Oswestry, [1855].

Challenor, Bronley. Selections from the Munieipal Chronicles of the Borough of Abingdon from A.D. 1555 to A.D. 1897. Abingdon, 1898.

Chaluers, George. Caledonia: or a Historical and Topographical Account of North Britain from the most aneient to the present Times. New edition. 8 vols. Paisley, 1887-1902.

Cinambertain, Henry. A New and Compleat History and Survey of the Cities of London and Westminster, the Borough of Southwark, and Parts adjacent; from the Earliest Aecounts to the Beginning of the Year 17r0....By a Soeiety of Gentlemen; Revised, Corrected and Improved, by Henry Chamberlain. London, 17\%0.

Chamberlaye, Edward. Angliae Notitia, or the Present State of England: Together with Divers Reflections upon the Antient State thereof. 1st, 2nd and 3rd editions. London, 1669.

Chaubers, A. H. Observations on the Formation, State and Condition of Turnpike Roads, and other Highways, with Suggestions for their Permanent Improvenent on Seientific Principles.... London, 1820.

Chanter, J. R., and Wainwright, Thos. Reprint of the Barnstaple Records. 2 vols. Barnstaple, 1900.

Chantreau, M. Voyage dans les trois Royaumes d'Angleterre. d'Écosse et d'Irlande, fait en 1788 et 1789 . 3 vols. Paris, 1792 .

Chapman, William. Report on the Proposed Navigation between the East and West Seas, so far as extends from Newcastle to Haydon-Bridge,.... Neweastle, 1795. - Observations on the Various Systems of Canal Navigation, with Inferenees practical and mathematical; in whieh Mr Fulton's Plan of Wheel-Boats, and the Utility of Subterraneous and of small Canals, are partieularly investigated. London, 1797.

Chatraway, E. D. Railways: Their Capital and Dividends, with Statisties of their Working in Great Britain and Ireland. London, 1855-56.

Citizen, A (pseud.). A Short Historical Aceount of Bristol Bridge; with a Proposition for a new Stone Bridge, from Temple Side to the Opposite shore. As also An Account of some remarkable stone Bridges abroad....Likewise An Account of some Bridges of Note in England. Bristol, 1759.

- A Reply to A most Partial Pamphlet, entitled A Letter from a IBY-Stander, to the Commissioners for Re-building the Bridge at Bristol. Bath. 1762.

Crvis (pseud.). The Railway Question. Praetical Suggestions for a Fundamental Reform of the Railway System, on a Prineiple combining National Benelits with the Permanent Interests of Shareholders. London, 18.56.

Claridge, John. General View of the Agrieulture in the Couniy of Dorset.... London, 1793.

Clark, Andrew. The Life and Times of Anthony Wood, Antiquary, of Oxford, 1632-1695, described by himself. Collected from his Diaries and other Papers. 5 vols. Oxford, 1891-1900. 
Clark, Andrew. Survey of the Antiquities of the City of Oxford, composed in 1661-66 by Anthony Wood; edited by Andrew Clark. 3 vols. Oxford, 1889, $1890,1899$.

Clark, Jonn. General View of the Agriculture of the County of Hereford. London, 1794.

Clarke, Leonard W. The History of Birmingham. 7 vols. in MS. Birmingham, [N.D.].

Cleland, James. Enumeration of the Inhabitants of the City of Glasgow and County of Lanark. For the Government Census of M.DCCC.XXXI. with Population, and Statistical Tables relative to England and Scotland. 2nd ed. Glasgow, 1832.

Cliffond, Frederick. History of Private Bill Legislation. 2 vols. London, 1885-87.

Clubee, John. History and Antiquities of the Ancient Villa of Wheatfield, in the County of Suffolk. (Contained in "Fugitive Pieces on Various Subjects," Brit. Mus, 12.352. ee. 21. London, 1761.)

Clutrerbuck, Robert. The History and Antiquities of the County of Hertford, compiled from the best authorities and Original Records. 2 vols. London, 1815.

Clutterbuck, Rev. R. H. The Archives of the Corporation of Andover. Reprinted from the "Andover Advertiser," 1891 (?).

Cobbetr, Ricuard Stutely. Memorials of Twickenham. London, 1872.

Conbett, Willian, Jr. The Law of Turnpikes; or an Analytical Arrangement of, and Illustrative Commentaries on, all the General Acts relative to the Turnpike Roads of England: ete. London, $\mathbf{3} 824$.

Cobbett, Williau, M.P. Tour in Scotland; and in the Four Northern Counties of England in the Autumn of the Year 1832. London, 1833.

Codnington, Thonas. Roman Roads in Britain. London and Brighton, 1903.

Colbonne, Jonn. Report on a View taken in Pursuanee of an Order of the Bedford Level Corporation, in the Months of June and July last, of the Middle and South Levels, and their Outfalls to sea; with a Plan for the effectual Draining the said Levels. [Chester], 17\%7.

Conborne, Thonss. The Monmouthshire Railways and the Monmouthshire Freighters. Newport, 1890.

[Collins, B. C.] A Treatise on Inland Navigation. Salisbury: Printed for B. C. Collins, 1788.

Colquiloun, Patrick. A Treatise on the Commerce and Police of the River Thames.

Colville, Mrs Arther. Duchess Sarah: being the Social History of the Times of Sarah Jennings Duchess of Marlborongh, with Glimpses of her Life and Aneedotes of her Contemporaries in the Seventeenth and Eighteenth Centuries. London, New York, ctc., 1904.

Conybeare, Rev. Enward. A History of Cambridgeshire. London, 1897.

Cooke, Geo. Alexander. A Topographical and Statistical Description of the County of Lancaster; containing an Account of its Situation, Extent, Towns, Rivers, Canals, ete. London, [N.D.].

- Topographical and Statistical Description of the County of York. London, [N.D., but about 1812].

Cordier, J. Considérations sur les chemins de fer. Paris, 1830.

[Corry, Jonn.] The History of Liverpool, from the Earliest Authenticated Period down to the Present Time.... Liverpool, 1810.

Corry, Jonn, and Evans, Rev. Jolis. The History of Bristol, Civil and Ecelesiastical; including Biographical Notices of Eminent and Distinguished Natives. (Vol. I by John Corry and Vol. if by Rev. John Evans.) Bristol, 1816. 


\section{Bibliography}

Corry, John. The History of Lancashire. 2 vols. London, 1825.

Cont, R. Rail-road Impositions Detected: or Facts and Arguments to prove that the Liverpool and Manchester Railway has not paid One per cent. Nett Profit; and that the Birmingham, Bristol, Southampton, Windsor, and other Railways arc, and must forever bc, only Bubble Speculations. London, 1834.

Cotrerill, Cimarles Forster. The Past, Present and Future Position of the London and North Western, and Great Western Railway Companies...with an Inquiry how far the Principle of Competing Lines, in Reference to Railway Undertakings, is sound and defensible. London, 1849.

Coulson, H. J. W., and Fonres, Urquhart A. The Law relating to Waters, Sea, Tidal and Inland, Including Rights and Duties of Riparian Owncrs, Canals, Fishery, Navigation, Ferries, Bridges, and Tolls and Rates thercon. 2nd edition. London, 1902.

Court, M. H. A Digest of the Realities of the Great Western Railway. London, 1848.

Cowper, Edward Alfred. The Steam Engine. (In "Heat and Its Mechanical Applications." A series of Lectures delivered at the Institution of Civil Engineers, session 1883-84, pp. 55-100.) London, 1885.

Cowper, J. M. Notes from the Records of Faversham, 1560-1600. (In Trans. Royal Historical Society, 1872, pp. 324-343.)

Cox, Rev. J. Chas. Thrce Centuries of Derbyshire Annals, as illustrated by the Records of the Quarter Sessions of the County of Derby, from Queen Elizabeth to Queen Victoria. 2 vols. London, 1890.

Coxe, Wildrayl. A Historical Tour Through Monmouthshire. (First published in 1801.) Brecon, 1904.

Croker, John Wilson. The Croker Papers. The Correspondence and Diaries of the late Right Honourable John Wilson Croker, LL.D., F.R.S., Sceretary to the Admiralty from 1809-1830. Edited by Louis J. Jennings, in 3 vols. London, 1885.

Cromwell, Thomas. History and Description of the Ancient Town and Borough of Colchester, in Essex. 2 vols. London, 1825.

Croston, James. The History of the County Palatine and Duchy of Lancaster, by the late Edward Baines, with additions of the late John Harland and Rev. Brooke Herford. A New, Revised, and Enlarged Edition, edited by .James Croston. 5 vols. Manchester and London, 1888.

Cruden, Robert Peirce. The History of the Town of Gravesend in the County of Kent and of the Port of London. London, 1843.

Crutchley, John. General View of the Agriculture of the County of Rutland.... London, 1794.

Cumuing, Alexander. Observations on the Effects which Carriage Wheels with Rims of different Shapes have on the Roads; respectfully offered to the Consideration of the Legislature. (Birmingham Free Reference Library, No. 210,445.) Pentonville, 1797.

- A Supplement to the Observations on the Contrary Effects of Cylindrical and Conical Carriage Wheels. London, 1809. (Discusses mechanical features.)

Cuming, T. G. Description of the Iron Bridges of Suspension now Lrecting over the Strait of Menai, at Bangor, and over the River Conway, in North Wales.... Also some Account of the Different Bridges of Suspension in England and Scotland, ctc. London, 1824.

- Illustrations of the Origin and Progress of Rail and Tram Roads, and Stcam Carriages, or Locomotive Engines; also Interesting Descriptive I'articulars of the Formation...Extent, and Mode of Working some of the Principal Railways now in Use within the United Kingdom. Denbigh, 1824. 
Cundy, N[ıcholas] W. Inland Transit. The Practieability, Utility, and Benefit of Railroads; the Comparative Attraetion and Speed of Steam Engines, on a Railroad, Navigation, and Turnpike Road.... 2nd ed. London, 1834.

Observations on Railways, addressed to the Nobility, Gentry, Clergy, Agriculturists, Merehants, Manufacturers, Ship Owners, and Traders, particularly to those situate on the Line and connected with the Grand Northern and Eastern Railroad. 2nd ed. Yarmouth, 1835.

Cunninghan, W. The Growth of English Industry and Commeree. 3 vols. 4th ed. Cambridge, 1903-05. (5th ed., 1910-12.)

Danieli. Rev. J. J. The History of Chippenham. Compiled from Researches by the Author, and from the Collections of the Latc Rev. Canon Jaekson, F.S.A. Chippenham, Bath, and London, 1894.

Davies, Rev. Jonn Silvester. A History of Southampton. Partly from the Manuscript of Dr Speed, in the Southampton Arehives. Southampton and London, 1883.

Davies, Rev. Rowland. Journal of the Very Rev. Rowland Davies, LL.D., Dean of Ross (and afterwards Dean of Cork), from Mar. 8, 1688-89, to September 29, 1690. Edited by Richard Caulfield, B.A. Printed for the Camden Soeiety, 1857.

Davis, Henry George. The Memorials of the Hamlet of Knightsbridge. (Edited by Chas. Davis.) London, 1859.

Davis, Richard. General View of the Agriculture of the County of Oxford.... London, 1794.

Davis, Tionas. General View of the Agriculture of the County of Wilts.... London, 1794.

Deacon. Wiblialu. Observations on Stage Waggons, Stage Coaches, TurnpikeRoads, Toll-Bars, Weighing Machines, \&c. Occasioned by a Committee of the House of Commons being appointed to inquire into the Principles and Effects of Broad and Narrow Wheels. London. 1807.

Dechesne, Laurent. L'Évolution économique et sociale de l'industrie de la laine en Angleterre. Paris, 1900.

Dee, Johs. The Private Diary of Dr John Dee, and the Catalogue of his Library of Manuseripts, from the Original MSS. in the Ashmolean Museum at Oxford, and Trinity College Library, Cambridge. Edited by James Orehard Halliwell, Esq., F.R.S. London, 1842.

Deering, Charles, M.D. Nottinghamia Vetus et Nova, or an Historical Aceount of the Ancient and Present State of the Town of Nottingham. Gathered from the Remains of Antiquity and Collected from Authentic Manuscripts and Ancient as well as Modern Historians. Nottingham, 1751.

[Defoe, Daniel.] An Essay upon Projeets (pp. 68-112). London, 1697. Brit. Mus. 1029. b. 24.

A Tour through the Whole Island of Great Britain. By a Gentleman. 4th edition. 4 vols. London, 1748.

A Tour Through the Whole Island of Great Britain. 4th edition, with very great Additions, Improvements, and Corrections; whieh bring it down to the year 1748. 4 vols. London. 1748.

Dehany, Wildiay Knight. The General Turnpike Aets, 3 Geo. IV. c. 126 and 4 Geo. IV. c. 95, with the Reasons for Passing the Explanatory Act, and for the Alterations introduced into it, etc. London, 1823.

Dekner, Thonas. A Knight's Conjuring. Done in earnest: Discovered in jest. London, [1607].

Delane, W. F. A. The Present General Laws for Regulating Highways in England : eonsisting of the 41 Geo. III. c. $109 ; 41$ Geo. III. c. 22; and the Last General 
Highway Act 5 \& 6 W. IV.c. 50. Arranged Alpluabetically as one Act. London, 1835.

Delaune, Thomas. Angliae Metropolis: or, The Present State of London: with Memorials comprehending a Full and Succinct Account of the Ancicnt and Modern State thereof...continued by a careful hand. London, 1690.

[Dense, Samuel.] The History and Antiquities of Roclsester and its Environs, cte. Rochester, 17\%2.

Dent, Roвert K. The Making of Bimingham: being a History of the Rise and Growtl of the Midland Metropolis. Birmingham and London, 1894.

D“Ewes, Sir Sinonos. The Journals of all the Parliaments During the Reign of Queen Elizabeth, both of the House of Lords and House of Commons. London, 1682.

D'Haussez, Baron. Great Britain in 1833. 2 vols. Philadelphia, 1833. (French edition, 2 vols. Bruxelles, 1833.)

Dibdin, Thomas Frognall. A Bibliographical, Antiquarian and Picturesque Tour in the Northern Counties of England and in Scotland. 2 vols. London, 1838.

Dicksox, R. W. General View of the Agriculture of Lancashire....By R. W. Dickson. Revised and prepared for the Press by W. Stevenson. London, 1815.

Dodv, Ralpu. Report on the First Part of the Line of Inland Navigation from the East to the West Sea by way of Newcastle and Carlisle, as originally projected, and lately surveyed. With Map. Newcastle, 1795.

- Report on the Proposed Canal Navigation, forming a Junction of the Rivers Thames and Medway: with General Estimates, etc. London, 1799.

- A Short Historical Account of the Greater Part of the Principal Canals in the Known World; with some Reflections upon the General Utility of Canals. Newcastle-upon-Tyne, 1795.

Report on the Intended Grand Surrey Canal Navigation. London, 1800.

Doons, Joнn. Railway Reform A Public Necessity, with Practical Suggestions. Belfast, 1868.

Donaldoson, Javies. General View of the Agriculture of the County of Northampton.... Edinburgh, 1794.

Donisin, Bryan. A Paper read before the Institution of Civil Engineers, on the Construction of Carriage-way Pavements. London, 1824.

Drake, Francis. Eboracum: or the History and Antiquities of the City of York. London, 1736.

Driver, Abrahay and William. General View of the Agriculture of the County of Hants.... London, 1794.

Dugdale, Sir Wrllian. The Life, Diary, and Correspondence of Sir William Dugdale, edited by William Hamper. London, 1827.

Duncuni, John. Collections towards the History and Antiquities of the County of Hereford. 3 vols. (Vol. III is by W. H. Cooke; and the continuations are by W. H. Cooke, in 1892, and M. G. Watkins, in 1897.) Hereford and London, 1804-82.

- General View of the Agriculture of the County of Hereford.... London, 1805.

Dundas, Criarles. Observations on the General Comparative Merits of Inland Communication by navigations or railroads. Bath, 1825 .

Dussford, Martix. Historical Menoirs of the Town and Parish of Tiverton in County of Devon. Collected from the Best Authorities. Exctcr, 1790.

- Miscellaneous Observations in the Course of Two Tours, through several Parts of the West of England. Tiverton, 1800.

Dupin, (Baron) Chables. Mémoires sur la Marine et les ponts ct chaussécs de France et d'Angleterre. Paris, 1818. 
Dupin, (Baron) Charles. Voyages dans la Grande-Bretagne, entrepris relativement aux Services Publics de la Guerre, de la Marine, et des Ponts et Chaussées en 1816, 1817, 1818 et 1819. 3 Parties. [Part III deals with roads and canals.] Paris, 1820-24.

The Commercial Power of Great Britain; exhibiting a Complete View of the Public Works of this Country....Translated from the French. 2 vols. London, 1825. [This is a translation of part of Part III of "Voyages dans la GrandeBretagne.")

Dutens, J. Mémoires sur les travaux publics de l'Angleterre. Paris, 1819.

Earwaker, John Parsons (cditor). The Court Lcet Records of the Manor of Manchester from the year 1552 to the year 1686, and from the year 1731 to the year 1846. 12 vols. Manchester, 1884-90.

East, Robert. Extracts from Records in the Possession of the Municipal Corporation of the Borough of Portsmouth and from Other Documents relating thereto. New and enlarged edition. Portsmouth, 1891.

Eckersley, Peter. Railway Management. Observations on Two Letters to George Carr Glyn, Esq., M.P., by John Whitehead...and Mark Huish. London, 1848.

Edgewortil, Richard Lovell. An Essay on the Construction of Roads and Carriages. 2nd edition. London, 1817.

Egerton, Francis Henry. The Second Part of a Letter to the Parisians, and the French Nation, upon Inland Navigation, containing a Defence of the Public Character of His Grace, Francis Egerton, late Duke of Bridgewater, etc. By the Honorable Francis Henry Egerton....And including some Notices and Anecdotes concerning Mr James Brindley. [Paris, 1820.]

Egremont, Jomn. The Law relating to Highways, Turnpike-Roads, Public Bridges, and Navigable Rivers. Vol. I. (No other was published.) London, 1830.

Elstobi, Whllan, Jr. The Pernicious Consequences of Replacing Denver-Dam and Sluices, etc., considered; in a Letter to Mr .John Leaford. Wherein his Arguments (concerning the same) contained in a Pamphlet entitled, Observations, etc., are fairly and candidly examined. Cambridge, 1745.

ENfield, Willian. An Essay towards the History of Leverpool, drawn up from Papers left by the late Mr George Perry, and from other Materials since collected. Warrington, 1773.

Englefield, Sir Henry C. Observations on the Probable Consequences of the Demolition of London Bridge. London, 1821.

Escott, Thos. Hay Sweet. England: Its People, Polity, and Pursuits. 2 vols. London, Paris, and New York, 1879.

Espriella, Don Manuel Alyarez [pseudonym for Robert Southey]. Letters from England (translated from the Spanish). 1st American edition, Boston, 1807. and American edition, New York, 180 s.

[Evelyn, Joun.] A Character of England. As it was lately presented in a Letter to a Noble Man of France. London, 1659. Brit. Mus. 292. a. 43.

Fairbairn, Hevry. A Treatise on the Political Economy of Railroads; in which the New Mode of Locomotion is considered in its Influence upon the Affairs of Nations. London, 1836.

Fairbairn, William. Remarks on Canal Navigation, illustrative of the Advantages of the Use of Steam as a Moving Power on Canals. London, 1831.

Falkner, Jolin Meade. A History of Oxfordshire. London, 1899.

Farex, Jonx, Sr. General View of the Agriculture and Minerals of Derbyshire. 3 vols. London, 1811.

Farrer, Willian. The Court Rolls of the Honor of Clitheroe in the County of Lancaster, Vol. I. Manchester and Burnley, 1897. 
Faujas de Saint-Fond, Barthelémy. Travels in England, Seotland, and the Hebrides. Translated from the Freneh. 2 vols. London, 1799.

Faulkner, Thomas. An Historical and Topographical Deseription of Chelsea and its Environs. 2 vols. Chelsea, 1829.

The llistory and Antiquities of the Parish of Hammersmith. London, 1839.

FAY, SAll. A Royal Road: being the Ilistory of the London and South Western Railway, from 1825 to the present Time. Kingston-on-Thames, 1883.

Ferguson, Richard Saul. Cumberland and Westmorland M.P.s from the Restoration to the Reform Bill of 1867. London, 1871.

- A History of Cumberland. London, 1890.

A Boke of Recorde or Register, containing all the acts and doings in or concerning the Corporation within the 'Town of Kirkbiekendall beginning (1575), ete. Kendal and Carlisle, 1892.

Ferguson, R.S., and Nanson, W. Some Munieipal Records of the City of Carlisle. Carlisle and London, 1887.

Fievnes, Celia. Through England on a Side Saddle in the time of William and Nary. With an introduction by Hon. Mrs Griffiths. London and New York, 1888.

Fishwick, Lieut.-Col. Henry. The History of the Parish of Preston in Amounderness in the County of Lancaster. Rochdale and London, 1900.

Fletcher, Willian. The History and Development of Steam Locomotion on Common Roads. London, 1891.

Foot, Peter. General View of the Agriculture of the County of Middlesex.... London, 1794.

Fowler, John Kersiey. Echoes of Old Country Life. London and New York, 1892. - Reeords of Old Times: Historieal, Soeial, Political, Sporting and Agricultural. London, 1898.

Fox, Jons. General View of the Agriculture of the County of Monmouth.... Brentford, 1794.

Fraser, Robert. General View of the County of Devon.... London, 1794.

General View of the County of Cornwall.... London, 1794.

Freenan, Edward A. Exeter (in Historie Towns Series). London, 1887.

Fry, Joseph Storrs. An Essay on the Construction of Wheel Carriages....With Suggestions relating to the Prineiples on whieh Tolls onght to be imposed, etc. London, 1820.

Fultox, Robert. A Treatise on the Improvement of Canal Navigation; exhibiting the numerous Advantages to be derived from small eanals and boats from two to five feet wide, etc. London, 1796.

[Galt, William.] Railway Reform; its Expediency and Praeticability considered. 3rd ed. London, 1844.

Galt, Wildian. Railway Reform: its Importance and Praeticability eonsidered as affecting the Nation, the Shareholders and the Government. London, 1865.

Gasquet, Аввот. Parish Life in Mediaeval England. London, [1906].

Gasquet, Francis Aidan. Ienry VIII and the English Monasteries. London, 1906.

Gatty, Aifred. Sheffield: Past and Present. London, 1873.

Gaussev, Alice C. G. A Later Pepys. The Correspondenee of Sir William Weller Pepys, Bart., Master in Chancery 1758-1825, with Mrs Chapone, Mrs Iartley, ete. Edited with an introduetion and notes by Aliee C. G. Gaussen. 2 vols. London and New York, 1904.

Gentleman (pseud.). Proposals at large for the Easy and Effectual Amendment of the Roads, by some further neeessary Laws and Regulations coneerning the Wheels of all Carriages; and the Methods or Rules of Travelling;...To which 
are added, Brief Remarks and Considerations on the foregoing Proposals; tending to prove the Necessity and Utility thereof. By a Gentleman. London, 1753.

Gentleman (pseud.). A Tour from London to the Lakes: containing Natural, Economical, and Literary Observations. London, 1792.

— A Tour in Monmouthshire and Part of Glamorganshire in July 1806. Halesworth, 1807. Brit. Mus. 578. b. 41 (1).

George, C. M. The National Waggon-Post; to travel at the Rate of twenty miles per hour, carrying One Thousand Ton Weight, all over the kingdom of England, with Passengers, Goods, and Stock. Paris, 1825.

Gerstner, F. De. Mémoire sur les grandes routes, les chemins de fer et les canaux de navigation; traduit de l'Allemand de M. F. de Gerstner...et précédé d'une introduction, par M. P. S. Girard. Paris, 1827.

Gibrs, A. E. The Corporation Records of St Albans. St Albans, 1890.

Gilbert, C. S. An Historical Survey of the County of Cornwall: to which is added a Complete Heraldry of the same. 2 vols. Plymouth and London, 1817-20.

Gilbert, Davies. The Parochial History of Cornwall, founded on the Manuscript Histories of Mr Hals and Mr Tonkin. 4 vols. London, 1838.

Gilbey, Sir Walter. Early Carriages and Roads. London, 1903.

Godwin, George, Jr. An Appeal to the Public on the Subject of Railways. London, 1837.

Gonzales, Don Manoel. The Voyage of Don Manoel Gonzales (late Merchant) of the City of Lisbon in Portugal, to Great Britain (1731)....Translated from the Portuguese Manuscript. London, 1808.

Gooch, Rev. Williay. General View of the Agriculture of the County of Cambridge.... London, 1813.

Goomman, Williay. The Social History of Great Britain during the Reigns of the Stuarts, beginning with the Seventeenth Century. New York, 1843.

Gordon, Alexander. An Historical and Practical Treatise upon Elemental Locomotion, by Means of Stcam Carriages on Common Roads: showing the Commercial, Political, and Moral Advantages, etc. London, 1832.

- The Fitness of Turnpike Roads and Highways for the most Expeditious, Safe, Convenient, and Economical Internal Communication. London, 1835.

- Observations addressed to Those Interested in either Rail-ways or Turnpike-

Roads; showing the Comparative Expedition, Safety, Convenience, and Public and Private Economy of these two Kinds of Road for Internal Communication. London, 1837.

Observations on Railway Monopolies, and Remedial Measures. London, 1841.

Gordon, W. J. Our Home Railways: How they began and How they are worked. 2 vols. London, [1910].

Gosson, Stephex. Pleasant Quippes for Upstart Newfangled Gentlewomen. London, 1595. Reprinted, 1847.

Grahame, Thomas. Treatise on Internal Intercourse and Communication in Civilized States and particularly in Great Britain. London, 1834.

- Essays and Letters on Subjects conducive to the Improvement and Extension of Inland Communication and Transport. Westminster, 1835.

- A Letter to the Traders and Carriers on the Navigations connecting Liverpool and Manchester. 2nd ed. Glasgow, 1834.

Granger, Joseph. General View of the Agriculture of the County of Durham.... London, 1794.

Gray, Tionis. Observations on a General Iron Railway, or Land Steam-Conveyance; to supersede the Nceessity of Horses in all Public Vehicles; showing its vast Superiority in every Respect, etc. 5th ed. London, 1825. (1st ed., 1821.) 
[GRAY, W.] Clorographia, or a Survey of Newcastle upon 'Tine. London, 1649.

Great Western Railway. Extracts from the Minutes of Evidence on the London and Birmingham Railway Bill, together with Abstracts from Acts of Parliament, ete. (Birmingham Free Reference Library, No. 63,041.) London, 1833.

Great Western Railway Bill. Minutes of Evidence taken before the Lords Committees to whom the Bill was committed. 1835.

Great Western Railway. Speech of Counsel on the 30th May, 1848, before A Select Committee of the House of Commons, on behalf of the Head, Lower and Assistant Masters of Eton against the Great Western Railway Extension from Slough to Windsor. (Printed for private circulation only.)

[Green, Jonn Richard.] Oxford during the Last Century, being two Series of Papers published in the Oxford Chronicle and Berks and Bucks Gazette during the Year 1859. Oxford, 1859.

Green, Jolln Ricitard, and Roberson, Rev. George. Studies in Oxford History, chiefly in the Eighteenth Century. Edited by C. L. Stainer. Oxford, 1901.

Green, John Richard. Oxford Studies. (Edited by Mrs J. R. Green and Miss K. Norgate.) London, 1901.

Green, Valentine. The History and Antiquities of the City and Suburbs of Worcester. Two volumes in one. London, 1796.

Griffitu, Edward. A Collection of Ancient Records, relating to the Borough of Huntingdon, with Observations illustrative of the History of Parliamentary Boroughs in General. London, 1727.

Griggs, Messrs. General View of the Agriculture of the County of Essex.... London, 1794.

Grinling, Charles H. The History of the Great Northern Railway, 1845-1902. London, 1903.

Grundy, John. Philosophical and Mathematical Reasons, Humbly offered to the Consideration of the Publick, To prove that the Present Works, executing at Chester, to recover and preserve the Navigation of the River Dee, must intirely destroy the same. With some Remarks on Mr Badeslade's Reasons, etc., thereon. Chester, [1735 or 1736].

Guilding, Rev. John Melville (editor). Reading Records. Diary of the Corporation, 1431-1654. 4 vols. London, 1892-96.

Gurney, Goldsworthy. Observations on Steam Carriages on Turnpike Roads. With Returns of the Daily Practical Results of Working; the Cause of the Stoppage of the Carriage at Gloucester: and the consequent Official Report of the House of Commons.... London, 1832.

Guthrie, James. The River Tyne: its History and Resources. (Guthrie was late Secretary to the R. Tyne Commission.) Newcastle-upon-Tync, 1880.

H., W. The Infallible Guide to Travellers, or Direct Independants. Giving a most Exact Account of the Four Principal Roads of England, beginning at the Standard in Cornhill, and extending to the Sea-Shore, and branching to most of the Cities... with their true distance... according to Mr Oglesby's Dimensuration. By W. H. Gent. London, 1682.

Hadley, George. A New and Complete History of the Town and County of the Town of Kingston-upon-Hull. Kingston-upon-Hull, 1788.

HaLl, JAves. A History of the Town and Parish of Nantwich,... in the County Palatine of Chester. Nantwich, 1883.

Halliwell, Janes Orchard (editor). The Autobiography and Correspondence of Sir Simonds D'Ewes, during the reigns of James I and Charles I. 2 vols. London, 1845.

J. T. II. 
Hancock, Walter. Narrative of Twelve Years' Experiments (1824-36) Demonstrative of the Practicability and Advantage of Enploying Steam-Carriages on Common Roads.... London, 1838.

Handyside, George. Review of the Manchester, Sheffield and Lincolnshire Railway. Newcastle-upon-Tyne, 1863.

Hansiall, J. H. The History of the County Palatine of Chester. Chester, 1817.

Harcourt, Leveson Francis Vernon. Rivers and Canals. The Flow, Control, and Improvement of Rivers, and the Design, Construction and Development of Canals both for Navigation and Irrigation, etc. 2 vols. 2nd edition, rewritten and enlarged. Oxford, 1896.

Hardwick, Charles. History of the Borough of Preston and its Environs, in the County of Lancaster. Preston and London, 1857.

Harny and Page. Bedfordshire County Records. Notes and Extracts from the County Records comprised in the Quarter Sessions Rolls (1714-1832) and Sessions Minute Books (1651-1660). [N.P., N.D. (1907?).]

Handy, William John (editor). A Calendar to the Records of the Borough of Doncaster. 4 vols. Doncaster, 1899-1903.

Hargrove, William. History and Description of the Ancient City of York; comprising all the most interesting Information, already published in Drake's Eboracum; enriched with much Entirely New Matter, from other Authentic Sources. 2 vols. York, 1818.

Harper, Cinarles G. The Holyhead Road: the Mail Coach Road to Dublin. 2 vols. London, 1902.

The Exeter Road: the Story of the West of England Highway. London, 1899.

The Bath Road : History, Fashion and Frivolity on an old Highway. London, 1899.

The Cambridge, Ely, and King's Lynn Road: the great Fenland Highway. London, 1902.

The Norwich Road: an East Anglian Highway. London, 1901.

-The Grcat North Road: the Old Mail Road to Scotland. 2 vols. London, [N.1.].

- The Newnarket, Bury, Thetford, and Cromer Road: Sport and History on an East Anglian Turnpike. London, 1904.

- The Brighton Road: Old Times and New on a Classic Highway. London, 1892.

- The Dover Road: Annals of an Ancient Turnpike. London, 1895.

The Portsmouth Road, and Its Tributaries: To-day and in Days of Old. London, 1895.

Harmis, George. Materials for a Domestic History of England. (In Trans. Royal Historical Society, 1873, pp. 142-57.)

Harris, Stanlfy. Old Coaching Days. London, 1882.

The Coaching Age. London, 1885.

[Wm.] Harrison's Description of England in Shakspere's Youth. Being the Second and Third Books of his Description of Britainc and England. Edited from the first two Editions of Holinshed's Chronicle, A.D. 1577, 1587. By Frederick J. Furnivall. 3 vols. London, 1877-1908.

Hassall, Cundes. Gencral View of the Agriculture of the County of Monmouth.... London, 1812.

Hawkins, Joun. Observations on the State of the Highways, and on the Laws for Amending and Keeping them in Repair, etc. London, 1763.

— Tyburn's Worthies. London, 1722. 
Hawkins, William. A Full True and Impartial Account of all the Robberies committed in City, Town, and Country, for several Years past by William Hawkins, in Company with Wilson, Wright, Butler, Fox, and others not yet Taken, ete. London, 1722. Brit. Mus. G. 19,418 (1).

Hawrswoor, Nicholas. A Short Historical Account of London-Bridge; with a Proposition for a New Stone-Bridge at Westminster....In a Letter to the Right Honourable the Members of Parliament for the City and Liberty of Westminster. London, 1736.

Head, Sir George. A Home Tour Through the Manufacturing Districts of England in the summer of 1835 . New York, 1836.

Healey, Charles E. H. Cinadwick. The History of the Part of West Somerset comprising the Parishes of Luccombe, Selworthy, Stoke Pero, Porlock, Culbone and Oare. London, 1901.

Hearne, Thomas. Remarks and Collections. 6 vols. Edited by C. E. Doble, D. W. Rannie, and others. Oxford, 1885-1902.

Hearnshaw, F. J. C., and D. M. (editors). Southampton Court Leet Records. Vol. I, Parts I and II, 1550-1602. Southampton, 1905-06.

Hedges, John Kirby. The History of Wallingford, in the County of Berks, from the Invasion of Julius Caesar to the Present Time. 2 vols. London, 1881.

Heir, Juyes. Representation of the Benefits and Advantages of making the River Avon Navigable from Christ-Church to the City of New Sarum; \&c. London, 1672 .

Hemingway, Joseph. History of the City of Chester, from its Folndation to the Present Time. 2 vols. Chester, 1831.

Henmeon, J. C. The History of the British Post Office. London, 1912. (An excellent piece of work.)

Hervey, John, First Earl of Bristol. The Diary of John Hervey, First Earl of Bristol. With Extracts from his Book of Expenses, 1688-1742. With Appendices and Notes. Wells, 1894.

Hervey, John, Lord. Memoirs of the Reign of George the Second, from his Accession to the Death of Queen Caroline. Edited from the Original Manuscript at Ickworth, by the Right Hon. Joln Wilson Croker, LL.D., F.R.S. 2 vols. London, 1848.

Hervey, John. Letter Books of John Hervey, First Earl of Bristol...1651-1750. 3 vols. Wells, 1894 .

Hibbard, Johs. Statements on the Great Utility of a Circular and other Inland, etc., Canal Navigation, and Drainage; with the great Interest locally arising therefrom to the Improvement of Agriculture, Cattle, Manufacture, Commerce, and Fisheries, of Great Britain and Ireland, ete. London, 1796.

Hills, Wallace Henry. The History of East Grinstead. East Grinstead, 1906.

Hrtchins, Fontescue. The History of Cornwall, from the Earliest Records and Traditions to the Present Time. Edited by Mr Samuel Drew of St Austell. 2 vols. Helston, 1824.

Hobnouse, Right Rev. Bishop. Churchwardens' Accounts of Croscombe, Pilton, Yatton, Tintinhull, Morebath and St Michael's Bath, ranging from A.D. 1349 to 1560 . [London], 1890.

Hodges, Whlinar. The Law relating to Railways and Railway Companies. London, 1847 .

Hodgson, Jollx. A History of Northumberland, in three Parts. (Pt III, Vol. I, 1820; Pt i by J. Hodgson Hinde, 1858.) 6 vols. Newcastle-upon-Tync, 1820-58.

Höfкen, GustaF. Englands Zustände, Politik, und Machtentwickelung mit Bczichung auf Dentschland. Theilc I, II. Lcipzig, 1846. 
Holinshed, Raphael. Description of Britaine. London, 1585.

Chronicles of England, Scotland, and Ireland. 6 vols. London, 1807-08.

Holland, Henry. General View of the Agriculture of Cheshire.... London, 1808.

[Holland, John.] The Tour of the Don. A Series of Extempore Sketches made during a pedestrian Ramble along the Banks of that River, and its principal Tributaries. Originally published in the "Sheffield Mercury" during the Year 1836. 2 vols. London, 1837.

Holloway, Williay. The History and Antiquities of the Ancient Town and Port of Rye, in the County of Sussex. London, 1847.

Holmes, Richard. The Booke of Entries of the Pontefract Corporation, 1653-1726. Pontefract, 1882.

Holt, John. General View of the Agriculture of the County of Lancaster... London, 1794.

Homer, Henry. An Inquiry into the means of Preserving and Improving the Publick Roads of this Kingdom. London, 1767 .

Hopkis, Evax. An Abstract of the Particulars contained in a Perambulatory Survey of above Two Hundred Miles of Turnpike Road, through the Counties of Carmarthen, Brecknock, Monmouth, and Floucester. Swansea, 1805.

Horsfield, Thomas Walker. The History, Antiquities, and Topography of the County of Sussex. 2 vols. Lewes and London, 1835.

Hougiton, John. A Collection of Letters for the Improvement of Husbandry and Trade. 2 vols. London, 1681.

- A Collection [of Letters] for the Improvement of Husbandry and Trade, etc. Revised, corrected, and published by...Richard Bradley, F.R.S. 4 vols. London, 1727.

Howard, Hon. Sir Robert. The Committee, a Comedy. London, 1665.

Huddeston, Lawsox. Method of Conveying Boats or Barges from a higher to a lower Level and the contrary on Canals; by means of a Plunger, instead of loosing Water by Locks. (Nicholson's Journal, rv, p. 236, anno 1703.)

Hudson, Rev. Willian, and Tingey, John Cottinglian. The Records of the City of Norwich. 2 vols. (I have examined only Vol. I.) Norwich and London, 1906.

Huerne de Ponneuse, M. Des Canaux Navigables considérés d'une manière générale, avec des recherches comparatives sur la navigation intérieure de la France et celle de l'Angleterre. Tome deuxième. Paris, 1822. (Vol. I unpublished.)

Hulls, Jonathav. A Description and Draught of a new-invented Machine for carrying Vessels or Ships out of, or into any Harbour, Port, or River, against Wind and Tide, or in a calm. London, 1737.

Humphreys, Artuun L. The Materials for the History of the Town of Wellington, County of Somerset. London and Wellington, 1889.

Hunter, Rev. Josepir. South Yorkshire: The History and Topography of the Deanery of Doncaster. 2 vols. London, 1828, 1831.

Hunter, Joseph. Hallamshire. The History and Topography of the Parish of Sheffield in the County of York...A new and enlarged edition, by the Rev. Alfred Gatty, D.D. London, 1869.

Hutchiss, John. The History and Antiquities of the County of Dorset, compiled from the best and most Ancient Historians, Inquisitiones post mortem, and other Valuable Records and Manuseripts in the Public Offices, and Libraries, and in Private Hands, ete. 2 vols. London, 1774.

Hutchinsox, W. The History of the County of Cumberland, and some Places Adjacent. 2 vols. Carłisle, 1794.

Hutron, W. An History of Birmingham. 3rd edition, 4 vols., with MS. Notes by Hamper. Birmingham, 1795. 
Hutton, W[illiam]. The Scarborough Tour in 1803. London, 1804.

Investigator (pseud.). Beware the Bubbles!!! Remarks on Proposed Railways, more particularly on that between Birmingham and London. 2nd ed. London, 1831.

InviNg, Joseph. The Annals of Our Time, 1837-71. London and New York, 1871.

Jackson, Sir Geonge. The Bath Archives. A further Selection from the Diaries and Letters of Sir George Jackson, K.C.H., from 1809 to 1816. Edited by Lady Jaekson. 2 vols. London, 1873.

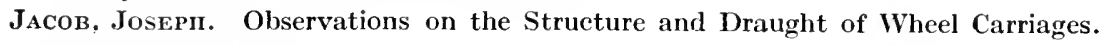
London, 1773.

Jeaffreson, J. Cordy. The Life of Robert Stephenson, F.R.S. (witl Descriptive Chapters on some of his most Important Professional Works, by Prof. Wm. Pole, F.R.S.). 2 vols. London, 1864.

Jfans, J. S. Jubilee Memorial of the Railway System. A History of the Stockton and Darlington Railway and a Record of its Results. London, 1875.

Jeboult, Enward. A General Account of West Somerset, Description of the Valley of the Tone, and the History of the Town of Taunton. Taunton, 1873.

Jessop, William. Report to the Committee of the Subscribers to the Grand Junction Canal. Northampton, 1792.

[Jessop, William.] Estimate [by Wm. Jessop] of the Expence of making Navigable the River Ouse, from Lewes into Barcomb Mill-Pond, at the High Water of Neap Tides, for Vessels of $45 \mathrm{ft}$. in Length, $12 \mathrm{ft}$. in Breadth, and drawing $3 \mathrm{ft} .6 \mathrm{in}$. of Water; so as to carry 30 Tons. (It is accompanied by other papers in MS. regarding the Navigation and Drainage Works along this route near Lewes.)

Jewitt, Llewellyns. The Wedgwoods: being a Life of Josiah Wedgwood; with Notices of his Works and their Productions, Nemoirs,...and a History of the Early Potteries of Staffordshire. London, 1865.

Johnson, Cinarles. A General History of the Lives and Adventures of the Most Famous Highwaymen, Murderers, Street-Robbers, etc. London, 1734.

Johnson, Cuthbert W. The Advantages of Railways to Agriculture. [Lewes, 1837.] Jordax, Rev. John. A Parochial History of Enstone, in the County of Oxford. . London and Oxford, 1857.

Joyce, Henbert. The History of the Post Office from its Establishment down to 1836. London, 1893.

Jusserand, J. J. Les Anglais au moyen âge: la vie nomade et les routes d'Angleterre au XIVe siècle. Paris, 1884. (Translated by L. T. Smith under the title "English Wayfaring Life in the Middle Ages." London. 1889. 4th ed., 1892.)

Kemp, Thomas. A History of Warwick and its People. Warwick, 1905 (?).

Kenvedy, Jonn. The History of Steam Navigation. Liverpool, 1903.

Kent, Natifaniel. General View of the Agriculture of the County of Norfolk.... London, 1794.

King, Austin J., and Watts, B. H. The Municipal Records of Bath, 1189-1604. London, [1885].

King, Lieut.-Col. Cooper. A History of Berkshire. London, 1887.

Kitchin, Thovas. The Traveller's Guide through England and Wales. London, 1783.

[Labelye, Cimarles.] The Present State of Westminster Bridge. Containing a Deseription of the said Bridge, as it has been ordered into Execution by the Right Honourable, etc., the Commissioners appointed by Parliament, etc. 2nd edition. London, 1743 .

Laeelyf, Charles. The Result of a View of the Great Level of the Fens, taken at the Desire of His Grace the Duke of Bedford, ete., Governor, and the Gentlemen of the Corporation of the Fens, in July 1745. London, 1745. 
Labelye, Charles. An Abstract of Mr Charles Labelye's Report, Relating to the Improvement of the River Wear, and Port of Sunderland. Newcastle-uponTyne, 1748 .

- A Description of Westminster Bridge. To which are added, An Account of the Methods made use of in laying the Foundations of its Piers. And an Answer to the Chief Objections that have been made thereto. With an Appendix, containing Several Particulars relating to the said Bridge, or to the History of the Building thereof, etc. London, 1751 .

LAMBERT, B. The History and Survey of London and its Environs. 4 vols. London, 1806.

Langford, John Alfred. A Century of Birmingham Life: or a Chronicle of Local Events from 1741 to 1841. 2 vols. Birmingham and London, 1868.

- Modern Birmingham and its Institutions : a Chronicle of Local Events, from 1841 to 1871. 2 vols. Birmingham (1873-77).

Langley, J. Baxter. The Dangers of the North British Railway Policy, or a Question for the Consideration of the Inhabitants of Newcastle and the Surrounding Towns. 2nd ed. Newcastle, [1861].

Lardner, Dionysius. Railway Economy: A Treatise on the New Art of Transport, its Management, Prospects and Rclations,... London, 1850.

— Railway Economy: A Treatise on the New Art of Transport....With an Exposition of the Practical Results of the Railways in Operation in the United Kingdom, on the Continent, and in America. London, 1850.

Latimer, John. The Corporation of Bristol in the Sixteenth Century. 1531-1600 (from original sources). Bristol, 1903.

- The Annals of Bristol in the Seventeenth Century. Bristol, 1900. The Annals of Bristol in the Eighteenth Century. Bristol, 1893. The Annals of Bristol in the Nineteenth Century. Bristol, 1887.

Larson, Jonn F. George Stephenson; The Locomotive and the Railway. London, 1881.

Leach, Fomund. A Treatise of Universal Inland Navigations, and the Use of All Sorts of Mines. A Work entirely New. Recommended to the Inhabitants of Great Britain and Ireland. Plainly demonstrating the Possibility of making any River and Stream of Running Water in the World Navigable, by Canals of a New Construction, without Locks and Dams, etc. London, [1790].

Leader, John Daniel. Extracts from the Earliest Book of Accounts belonging to the Town Trustees of Sheffield, dating from 1566 to 1707, with Explanatory Notes. Sheffield, 1879 .

- The Records of the Burgery of Sheffield, commonly called the Town Trust. London, 1897.

Leader, Robert Eadon. History of the Company of Cutlers in Hallamshire in the County of York. 2 vols. Sheffield, 1905.

- Sheffield in the Eighteenth Century. Sheffield, 1901.

Leatham, Isaac. General View of the Agriculture of the East Riding of Yorkshire.... London, 1794.

Lecky, William Edward Hartpole. A History of England in the Eighteenth Century. 8 vols. London, 1878-90.

Lee, Lancelot J., and Venables, R. G. Shropshire County Records. Issued in fourteen numbers.

Leland, John. The Itinerary of John Leland, the Antiquary. 9 vols. 2nd edition; collected and improved from the Original Manuscript. With the addition also of a General Index. Oxford, 1745.

[Le SAGe, G. L.] Brit. Mus. 10,348, aa. 12. Remarques sur l'état present 
d'Angleterre, faites par un voyageur inconnu [G. L. Le Sage] dans les années 1713 et 1714. Amsterdam, 1715.

Leslie, James. Description of an Inclined Plane for conveying Boats from Onc Level to another on the Monkland Canal, at Blackhill, near Glasgow. Edinburgh, 1852.

Ley Land, Jomn. The Yorkshire Coast, and the Cleveland Hills and Dales. London, 1892.

Lindsay, W. S. History of Merchant Shipping and Ancient Commerce. 4 vols. London, 1874-76.

Lipsconb, George. A Journey into Cornwall, tlirough the Counties of Southampton, Wilts, Dorset, Somerset and Devon. Warwick, 1799.

Litrleton, E. Proposal for Maintaining and Repairing the Highways. London, 1692.

Lloyd, Jonx, Jr. Papers relating to the History and Navigation of the Rivers Wye and Lug. Hereford, [1873].

Lloyd, SAriuel. A National Canal between the Four Rivers a National Necessity. London, 1888.

Loftie, W. J. A History of London. 2 vols. London, 1883.

— Old and New London. 5 vols. London, [N.D.]. Vols. I and II are by Walter Thornbury.

London and Birmingham Railway Bill. Extracts from the Minutes of Evidence given before the Committee of the Lords on this Bill. London, 1832.

Loveday, John Edward Taylor. Diary of a Tour in 1732 through Parts of England, Wales, Ireland and Scotland. Edinburgh, 1890.

Lowe, Robert. General View of the Agriculture of the County of Nottingham.... London, 1794.

Macadam, John Loudon. Remarks on the Present System of Road-making, with Observations deduced from Practice and Experience with a view to the Revision of the Existing Laws and the Introduction of Improvements in the Method of Making, Repairing, and Preserving Roads. and defending the Road Trusts from Misapplication of Funds. Bristol, 1816; 2nd edition, Bristol, 1819; 3rd and 4th editions, London, 1821 ; 5th edition, London, 1822.

Observations on the Management of Trusts for the care of Turnpike Roads, as regards the Repair of the Road, the expenditure of the Revenue, and the appointment and Quality of Executive Officers, etc. London, 1825.

Mace, Thonas. Profit, Conveniency, and Pleasure, to the Whole Nation. Being a short Rational Discourse, lately presented to His Majesty concerning the Highways of England: Their Badness, the Causes thereof, the Reasons of those Causes, the impossibility of ever having them well-mended according to the old way of mending But may....according to This New Way.... London, 1675.

Maceroni, Francis. A Few Facts conceming Elementary Locomotion. 2nd ed. London, 1834.

—_ Maceroni versus Mechanics' Magazine. London, 1834.

- Memoirs of the Life and Adventures of Colonel Maceroni... 2 vols. London, 1838.

Macgregor, J. Observations on the River Tyne, with a View to the Improvement of the Navigation;.... Newcastle, 1832.

Mackenzie, E. A Descriptive and Historical Account of the Town and County of Newcastle-upon-'Tyne, including the Borough of Gateshead. 2 vols. in one. Newcastle-upon-'Tyne, 1827.

[MaCky, J.] A Journey through England. In Faniliar Letters from a Gentleman Herc, to His Friend Abroad. 3 vols. London, 1714-29. 
Maclaren, C. Railways compared with Canals and Common Roads, and their Uses and Advantages explained. Edinburgh, 1825. (Contained in the "Pamphleteer," Vol. xxvi. London, 1826.)

Macpherson, David. Annals of Commerce, Manufactures, Fishery and Navigation. 4 vols. London, 1805 (?).

MacRitchie, Rev. William. Diary of a Tour Through Great Britain in 1795. (With introduction and notes by David MacRitchie.) London, 1897.

Macturk, G. G. A History of the Hull Railways. Hull, [1879].

Maitland, Willian. The History and Survey of London from its Foundation to the Present Tinc. 2 vols. London, 1760.

Malconi, Wrlitan, Janes and JACOB. General Vicw of the Agriculture of the County of Surrey.... London, 1794.

- General View of the Agriculture of the County of Buckingham.... London, 1794. Maldien, H. Elliot. A History of Surrey. London, 1900.

Malet, Captain [Haroln Esdaile]. Annals of the Road or Notes on Mail and Stage Coaching in Great Britain. To which are added Essays on the Road, by Nimrod. London, 1876.

Manning, Owen. The History and Antiquities of the County of Surrey. 3 vols. London, 1804.

Mantoux, Paur. La Révolution industrielle au xvin ${ }^{\mathrm{e}}$ siècle. Paris, 1906.

Markinam, Christopher Alexander. The Liber Custumarum: the Book of the Ancient Usages and Customs of the Town of Northampton, from the Earliest Record to 1448. Northampton, 1895.

Markiam, Christopiter A., and Cox, Rev. Jonn Charles. The Records of the Borough of Northampton. 2 vols. Northampton, 1898.

MArsu, A. E. W. A History of the Borough and Town of Calne, and some Account of the Villages, etc., in its Vicinity. Calne and London, 1904.

Marsuall, Wilitam. The Rural Economy of Norfolk: conprising the Management of Landed Estates, and the Present Practice of Husbandry in that County. 2 vols. London, 1787.

The Rural Economy of Yorkshire. Conprising the Management of Landed Estates, and the Present Practice of Husbandry in the Agricultural Districts of that County. 2 vols. London, 1788.

The Rural Economy of Glocestershire; including its Dairy, etc. 2 vols. Glocester, 1789.

The Rural Economy of the Midland Counties; including the Management of Live Stock \&c. 2nd edition. 2 vols. London, 1796.

- The Rural Economy of the West of England: including Devonshire, and parts of Somersetshirc, Dorsetshire and Cornwall... 2 vols. London, 1796.

The Rural Economy of the Southern Counties; comprising Kent, Surrey, Sussex; the Isle of Wight; the Chalk Hills of Wiltshire, Hampshire, etc. 2 vols. London, 1798.

- Minutes, Experiments, Observations, and General Remarks on Agriculture in the Southern Counties; a new Edition. To which is prefixed a sketch of the Vale of London, and an Outline of its Rural Economy now first published. 2 vols. Loudon, 1799.

A Review of the Reports to the Board of Agriculture; from the Northern Department of England. York, 1808.

- A Review (and Complete Abstract) of the Reports to the Board of Agriculture; from the Midland Department of England :.... York, 1815.

- A Review (and Complete Abstract) of the Reports to the Board of Agriculture; from the Southern and Peninsular Departments of England :.... York, 1817. 
Marsmall, William. Railway Legislation and Railway Reform eonsidered with Special Reference to Scottish Lines. 2nd edition. Edinburgh, 1853.

Martin, R. M. Railways-Past, Present, and Prospective. London, 1849.

Mason, Robert Hindry. The History of Norfolk: from Original Records and other Authoritative Sources preserved in public and private collections. London, 1884.

Massingbero, Rev. W. O. History of the Parish of Ormsby-cum-Ketsly, in the Hundred of Hill and County of Lincoln, compiled from Original Sources. Lincoln, [1893].

_ Court Rolls of the Manor of Ingoldmells in the County of Lincoln. London, 1902.

Mather, Wirliam. Of Repairing and Mending the Highways. London, 1696.

Mathew, Francis. Of the Opening of Rivers for Navigation, The Benefit exemplified by The Two Avons of Salisbury and Bristol. With a Meditcrancan Passage by Water for Billanders of Thirty Tun between Bristol and London. With the Results. London, 1655.

- A Mediterranean Passage by Water between the Two Sea Towns Lynn and Yarmouth, upon the Two Rivers The Little Owse, and Waveney. With farther Results. Producing the Passage from Yarmouth to York. London, 1656.

- A Mediterranean Passage by Water from London to Bristol \&c. And from Lynne to Yarmouth, and so consequently to the City of York: for the great Advancement of 'Trade and Traffique. London, 1670.

Matnews, J. Remarks on the Cause and Progress of the Scarcity and Dearness. London, 1797.

Mavor, William. General View of the Agriculture of Berkshire... London, 1808.

Maxweld, George. General View of the Agriculture of the County of Huntingdon.... London, 1793.

Maxwelu, Rt. Hon. Sir Herbert. The Crecvey Papers: A Selection from the correspondence and Diaries of the late Thomas Creevey, M.P. 2 vols. J Jondon, 1904.

May, George. A Descriptive History of the Town of Evesham, from the foundation of its Saxon Monastery. Evesham and London, 1845.

McDonnell, G. Railway Management, with and without Railway Statistics. London, [1854?].

MeIge, Guy. The Present State of Great Britain and Ireland. 11th edition, revised and completed by Solomon Bolton. London, 1757.

Mercator (pseud.). Remarks on the Tonnage Rates and Drawbacks of the Grand Junction Canal, with Observations on the proposed London and Birmingham Canal, by Mercator. London, 1836.

Meriton, George. A Guide to Surveyors of the Highways, shewing the Duty of Such Surveyors...collected and gathered out of Public Acts of Parliament, etc., now in force. London, 1694.

Metcalfe, Joun. The Life of John Metcalfe, commonly called Blind Jack of Knaresborough. With many entertaining aneedotes...and also a suceinct Account of his various Contracts for Making Roads, Erecting Bridges, and other Undertakings,.... York, 1795.

Meteyard, Eliza. The Life of Josiah Wedgwood from his Private Correspondence and Family Papers...and other Original Sources. 2 vols. London, 1865-66.

Middeton, Joms. View of the Agriculture of Middlesex; with Observations on the Means of its Improvement.... London, 1798.

Misson, Henry de Vaudroy. Mémoires et observations faites par un voyageur en Angleterre. [Paris], 1698. (This book was translated into English by John 
Ozell and published in London, 1719, under the title "M. Misson's Memoirs and Observations in his Travels over England etc.")

Molyedx, William. Burton-on-Trent: its History, its Waters, and its Breweries. London, [1869].

Monsen, Dr P. Einiges über die öffentlichen Arbeiten in England,.... Kiel, 1838.

Money, Walter. The History of the Ancient Town and Borough of Newbury in the County of Berks. Oxford and London, 1887.

Monk, Johx. General View of the Agriculture of the County of Leicester.... London, 1794.

Moore, Henry Charles. Omnibuses and Cabs: Their Origin and History. London, 1902.

Moore, Thomas. The History of Devonshire, from the Earliest Period to the Present. London, 1829.

Morant, Philıp. The History and Antiquities of the County of Essex, compiled from the best and most ancient historians; from Domesday-Book, etc.; the whole digested, improved, perfected, and brought down to the present time. 2 vols. London, 1768. (Reprinted at Chelmsford, 1816.)

Moreau, P. Description of the Railroad from Liverpool to Manchester. Together with a History of Railroads, and matters connected therewith, compiled by A. Notré,....Translated from the French by J. C. Stocker, Jr., Civil Engineer. Boston (Mass.), 1833.

Moritz, Rev. Charles P. Travels, chiefly on foot, through Several Parts of England, in 1782, described in Letters to a Friend. Translated from the German by a Lady. (In Pinkerton's Voyages and Travels, Vol. 11, pp. 489-573.) The German text is entitled "Reisen eines Deutschen in England im Jahr 1782," by Carl Philip Moriz. Berlin. 1785.

Morris, Rupert Hugh. Chester in the Plantagenet and Tudor Reigns. [Chester, 1893.]

Morrison, James. Observations illustrative of the Defects of the English System of Railway Legislation, and of its injurious Operation on the Public Interests; with Suggestions for its Improvement. London, 1846.

Morton, Joln. The Natural History of Northamptonshire; with Some Account of the Antiquities. To which is Annexed A Transcript of Doomsday-Book, so far as it relates to That County. London, 1712.

Moryson, Frnes. An Itinerary written by Fynes Moryson Gent. First in the Latine Tongue, and then translated by him into English. Containing His Ten Yeeres Travell through the Twelve Dominions of Germany, Bohmerland, Sweitzerland, Netherland, Denmarke, Poland, Italy, Turkey, France, England, Scotland, and Ireland. London, 1617.

Moule, H[EnRx ] J[osepir]. Descriptive Catalogue of the Charters, Minute Books and Other Documents of the Borough of Weymouth and Melcombe Regis, A.D. 1252-1800. Weymouth, 1883.

Mudge, Richard Z. Observations on Railways, with Reference to Utility, Profit, and the Obvious Necessity for a National System. London, 1837.

Muir, Ranisey. A History of Liverpool. London, 1907.

Murray, Adan. General View of the Agriculture of the County of Warwick.... London, 1813.

Nash, Charles. Railway Carrying and Carriers' Law ; the Liabilities and NonLiabilities of Railways, Carricrs, and others,...the Dispute between Railways and Carriers; Extracts from Judgments; with the Law, and Cases illustrating the Reasoning on those Subjects; etc. London, 1846. 
Nelson, W. The Office and Authority of a Justice of Peace: Collected out of all the Books, whether of Common or Statute Law, hitherto written on that subject, etc. 6th edition. London, 1718.

Newball, John. A Concern for Trade, and the Various Consequences; relating to the Encrease and Decrease....Also Remarks on the Bill, intitl'd A Bill to amend and render more effectual the Laws in Being for the Preservation of the publick Roads, \&c. Stamford [1745-6(?)].

Newcastle. An Account of the Great Flood in the River Tyne, on Saturday Morning, Dec. 30, 1815. To which is added, A Narrative of the Great Flood in the Rivers Tyne, Tease, and Wear, \&c. on the 16th and 17th Nov., 1771. Newcastle, 1816.

- Copy of the Evidence taken before a Committee of the House of Commons on the Newcastlc and Carlisle Railway Bill. Taken from the shorthand notes of Mr Gurney. To which is added the Report of Mr Leather, on the Projected Line of Railway. Newcastle-upon-Tyne, 1829.

[Nichols, Jonv.] Illustrations of the Manners and Expences of Antient Times in England, in the Fifteenth, Sixteenth, and Scventeenth Centuries, deduced from the Accompts of Church-wardens, and other Authentic Documents, collected from Various Parts of the kingdom, with explanatory Notes. London, 1797.

Nichols, Jons. The Progresses and Public Processions of Queen Elizabetlı...now first printed from Original Manuscripts of the Times; or collected from scarce Pamphlets, etc. 3 vols. London, 1788-1805.

Nicholson, Connelius. 'The Annals of Kendal: being a Historical and Descriptive Account of Kendal and the Neighbourhood. London and Kendal, 1861.

Nicholson, Joseph, and Burn, Richard. The History and Antiquities of the Counties of Westmorland and Cumberland. 2 vols. London, 1777.

Norden, John. Notes on London and Westminster. 1592. [Brit. Mus. 010347. m. 16.]

— Speculi Britanniae Pars. A Description of Hartfordshire. 1598. (Reprinted) London, 1903.

The Surveyors Dialogue. London, 1607.

- Speculi Britanniae Pars Altera: or a Delineation of Northamptonshire (in 1610). London, 1720.

- Speculi Britanniae Pars: An Historical and Chorographical Description of the County of Essex. London, 1840.

- An Intended Guyde for English Travailers. London, 1625.

- Speculum Britanniae: An Historical and Chorographical Description of Middlesex and Hartfordshire. London, 1723.

- Speculi Britanniae Pars: A Description of Hartfordshire, by John Norden, 1598. Reprinted with portrait and biography of John Norden by W. B. Gerish. Ware and London, 1903.

North, Roger. The Life of the Right Honourable Francis North, Baron of Guilford, Lord Keeper of the Great Seal, under King Charles II and King James II.... London, 1742.

Northumberland County History Committee. A History of Northumberland. 7 vols. Vols. I and II, by Edward Bateson, London, 1893-95. Vol. 111, by Allen B. Hinds, London, 1896. Vols. Iv-vir, by John C. Hodgson, London, 1897-1904.

O'Brien, IV. The Prize Essay on Canals and Canal Conveyance, for which a Premium of $\$ 100$ was awarded by the Canal Association. London, 1858.

Observer, An (pseud.). Brief Remarks on the Proposed Regent's Canal. London, 1812.

Ogilby, Jons. [Brit. Mus. G. 4697.] Britannia Depicta: or, Ogilby Improved. Being an Actual Survey of all the Direct and Principal Cross Roads of England 
and Wales....Engraved by Emanuel Bowen, Geographer....Compiled from the Best Authorities, by John Owen, Gent.

Ogilby, John. Britannia, Volume the First: or, an Illustration of the Kingdom of England and Dominion of Wales: by a Geographical and Historical Description of the Principal Roads thereof. Actually Admeasured and Delineated.... London, 1675.

An Actual Survey of all the Principal Roads of England and Wales; described by One Hundred Maps from Copper Plates,...now improved, very much corrected, and made portable by Joln Senex. 2 vols. London, 1719.

Oginvie, A. M. Ralph Allen's Bye, Way, and Cross-Road Posts (from Documents in the Home Office Papers in the Record Office). London, 1897.

Oriver, Rev. George. The History of the City of Exeter. Exeter and London, 1861.

Ormenod, George. The History of the County Palatine and City of Chester. (2nd edition, revised and enlarged, by Thomas Helsby.) 3 vols. London, 1882.

[Owen, Hugh.] Some Account of the Ancient and Present State of Shrewsbury. Shrewsbury, 1808.

Owen, Hugh, and Blaleway, John Brickdale. A History of Shrewsbury. 2 vols. London, 1825.

Owen, Williar. New Book of Roads; or a Description of the Roads of Great Britain. London, 1805.

P., E. M. S. The Two James's and the Two Stephensons; or, the Earliest History of Passenger Transit on Railways. London, 1861.

P., F. A Letter to a Friend, containing Observations on the Comparative Merits of Canals and Railways, occasioned by the Reports of the Committee of the Liverpool and Manchester Railway. London, 1832.

P., J. For Mending the Roads of England: its proposed. Signed J. P. Brit. Mus. T. 1816 (13). [1715 (?).]

P., X. A. A Descant upon Railroads. London, 1842.

Pagan, Willian. Road Reform: A Plan for abolishing Turnpike Tolls and Statute Labour Assessments, and for providing the Funds necessary for maintaining the P'ublic Roads by an Annual Rate to be levied on Horses. Edinburgh, 1845.

Page, William (editor). The Victoria History of the Counties of England. (We omit the complete list of these volumes, but many of them have excellent material.)

Palmer, Henry R. Report on the Improvement of the Rivers Mersey and Irwell, between Liverpool and Manchester, describing the Means of adapting them for the Navigation of Sea-going Vessels. London, 1840.

-.. Description of a Railway on a New Principle; with Observations on those litherto constructed. London, 1824.

Palier, J. E. British Canals. Problems and Possibilities. London, 1910.

Paluer, John. Papers relative to the Agreement made by Government with Mr Palmer, for the Reform and Improvement of the Posts. London, 1797.

_. Mr Palmer's Case Explained. By C. Bonnor. London, 1797.

- Debates in Both Houses of Parliament in the Months of May and June 1808, relative to the Agreement made by Government with Mr Palmer for the Reform and Improvement of the Post Office and its Revenue. London, 1809. Brit. Mus. 8244. ce. 37 .

Park, Thous (compiler). The Harleian Miscellany: A Collection of Scarce, Curious, and Entertaining Pamphlets and Tracts, as well in Manuseript as in Print: Selected from the Library of Edward Harley, Second Earl of Oxford, etc. 10 vols. London, 1808-13.

Parkes, W. Claim of the Subscribers to the Birmingham and Liverpool Railroad. London, 1824. 
Parkinson, R. General View of the Agriculture of the Connty of Huntingdon.... London, 1813.

Parnele, Rt. Hon. Sir Henry. A Treatise on Roads. London, 1834.

Parsloe, Josern. Our Railways. Sketches Historical and Descriptive, with Practical Information as to Fares and Rates, etc., and a Chapter on Railway Reform. London, 1878.

Parsons, Enward. The Civil, Ecclesiastical, Literary, Commercial and Miscellaneous History of Leeds, Halifax, Huddersfield, Bradford, Wakefield, Dewsbury, Otley, and the Manufacturing District of Yorkshire. 2 vols. Leeds, 1834.

[Patching or Patchen, Resta.] Four Topographical Letters, written in .July 1755, upon a Journey through Bedfordshire, Northamptonshire, Leicestershire, Nottinghamshire, Derbyshire, Warwickshire, etc. from a Gentleman in London to his Brother and Sister in Town, etc. Neweastle-upon-Tyne, 1757.

Paterson, James. A Practieal Treatise on the Making and Upholding of Public Roads,...And a Dissertation on the Utility of Broad Wheels, and other Improvements. NIontrose, 1819.

Pearce, Willialy. General View of the Agriculture of Berkshire... London, 1794.

Pease, Sir Alfred E. The Diaries of Edward Pease, the Father of English Railways. London, 1907.

Pegge, Sanuel. Curialia Miscellanea, or Aneedotes of Old Times; Regal, Noble, Gentilitial, and Miscellaneous. London, 1818.

Pemberton, T. Engar. James Watt, of Soho and Heathfield, Annals of Industry and Genius. Birmingham, 1905.

Pennant, Thomas. The Journey from Chester to London. London, 1782.

A Tour from Downing to Alston Moor (1773). London, 1801.

A Tour from Alston Moor to Harrogate (1773). London, 1804.

A Journey from London to the Isle of Wight (1787). London, 1801.

Peprs, Samuel. Diary and Correspondence of Samuel Pepys, Esq., F.R.S., from his Manuscript Cypher in the Pepysian Library, with a Life and Notes by Richard Lord Braybrooke. Deciphered, with additional notes, by Rev. Mynors Bright. 6 vols. London, 1875-79.

Percy, H. A. [Brit. Mus. 684. e. 27.] Northumberland Household Book (edited by T. Percy, Bishop of Dromore). The more correct and full title is, " The Regulations and Establishment of the Household of H. A. Perey...at his Castles of Wresill and Lekinfield in Yorkshire [at 1512 and after]." 1770.

Phelps, Rev. Wrlliam. The History and Antiquities of Somersetshire. 2 vols. London, 1839.

Phrl'Anglus (pseud.). 'The Contrast: also Further Considerations on the Concern for Trade. With Proposals how to amend and render more effectual the Laws in Being for the Preservation of the Public Roads, and to preserve Trade. In Two Letters to a Member. London, [1746]. Br. Mus. 1139. 1. 11 (2).

Philips, Fravcis. Analysis of the Defective State of Turnpike Roads and Turnpike Securities, with Suggestions for their Improvement. London, 1834 .

Phildips, J. A General History of Inlaud Navigation, Foreign and Domestic; containing a Complete Account of the Canals already exeeuted in England; with Considerations on those projected. 4th ed. London, 1803.

Phillips, Jонn. A Treatise on Inland Navigation; illustrated with a Whole-Sheet Plan, delineating the Course of an Intended Navigable Canal from London to Norwich and Lynn, through the Counties of Essex, Suffolk and Norfolk... With Two Other Plans, to prove the Practicability of executing the Whole with Success :.... London, 1785. 
Phillips, Sir Richard. A Personal Tour through the United Kingdom; describing living objects and contemporaneous interests. Nos. 1 and 2. London, 1828.

Phillips, Robert. A Dissertation concerning the Present State of the High Roads of England, especially of those near London. Wherein is proposed a new Method of Repairing and Maintaining Them. London, 1737.

Picton, J. Allanson. Memorials of Liverpool, Historical and Topographical, including a History of the Dock Estate. 2nd ed. 2 vols. London and Liverpool, 1875.

L_Liverpool Municipal Records. 2 vols. London and Liverpool, 1883, 1886.

Prlkington, Jalies. A View of the Present State of Derbyshire; with an Account of its most remarkable Antiquities. 2 vols. Derby, 1789.

Pitr, W. General View of the Agriculture of the County of Stafford.... London, 1794.

Pitt, Wilinam. General View of the Agriculture of the County of Leicester.... London, 1809.

- General View of the Agriculture of the County of Northampton.... London, 1809.

- General View of the Agriculture of the County of Worcester... London, 1813.

Plymley, Joseph. General View of the Agriculture of Shropshire... London, 1803.

Poneroy, Willian Thomas. General Vicw of the Agriculture of the County of Worcester.... London, $\mathbf{1 7 9 4 .}$

Poole, Benjanin. Coventry : its History and Antiquities. London and Coventry, 1870.

Poole, Braithwatte. The Conimerce of Liverpool. London and Liverpool, 1854.

Pratt, Enwin A. British Canals: Is their Resuscitation Practicable? London, 1906.

A History of Inland Transport and Communication in England. New York, 1912.

Price, A[ubrey] C[harles]. Leeds and its Neighbourhood: an Illustration of English History. Oxford, 1909.

Priest, Rev. St John. Gencral View of the Agriculture of Buckinghamshire.... London, 1813.

Priestley, Joseph. Historical Account of the Navigable Rivers, Canals, and Railways throughout Great Britain (to refer to the Map of Inland Navigation). London, 1831.

Pringle, Andrew. General View of the Agriculture of the County of Westmorland.... Edinburgh, 1794.

Procter, Thonas. A Profitable Worke to this whole Kingdome. Concerning the mending of all High-ways as also for Waters and Iron Workes. London, 1610.

Progress, Peter (pseud.). The Rail, its Origin and Progress. London, 1847.

The Locomotive, or the Steam Engine applied to Railways, Common Roads, and Water. And an Account of the Atmospheric Railway. London, 1848.

Proprietor, A (pseud.). The Advantages of Railways with Locomotive Engines, especially the London and Greenwich Railway or Viaduct...to the Public, the Proprietors of Property along and near the Line of Road, and the shareholders, explained. 2nd ed. London, 1833.

Provis, W. A. Suggestions for Improving the Canal Communication between Birmingham, Wolverhampton, Shropshire, Cheshirc, North Wales, and Manchester, by means of a New Canal from Middlewich to Altringham. London, 1837.

Publicus (pscud.). Observations on Bridge Building, and the Several Plans offered for a New Bridge. In a Letter addressed to the Gentlemen of the Committee, 
appointed by the Common Council of the City of London, for putting in Execution a Scheme of Building a New Bridge across the Thames, at or near Black Friars. London, 1760.

[Quncer, Thomas.] A Short Tour in the Midland Counties of England; performed in the summer of 17r2. Together with an Account of a similar Excursion undertaken September 1774 [by Thomas Quincey]. London, 1775.

Radcliffe, Sir George. The Life and Original Correspondence of Sir George Radeliffe,....By Thomas Dunham Whitaker. London, 1810.

Railways. A Few General Observations on the Principal Railways executed, in progress, and projected, in the Midland Counties and North of England, with the Author's Opinion upon them as Investments. London, 1838.

Railways as they Really Are: or Facts for the Serious Consideration of Railway Proprietors. No. I. London, Brighton and South Coast Railway. London, 1847. No. II. The Dover, or South-Eastern Company. London, 1848. No. vit. The Lancashire and Yorkshire Railway. London, 1847.

Raumer, Frederick von. England in 1841 : being a series of letters written to friends in Germany. Translated from the German by H. Evans Lloyd. 2 vols. London, 1842.

Rendel, G[race] Daphne. Neweastle-on-Tyne: its Municipal Origin and Growth. London, 1898.

Renne, Broun, and Shirreff, Messrs. General View of the Agriculture of the West Riding of Yorkshire.... London, 1794.

Rennie, John. Report of a Survey of the River Thames, between Reading and Isleworth, and of Several Lines of Canals projected to be made between those Places; with Observations on their Comparative Eligibility. London, 1794.

- Report and Estimate of the Grand Southern Canal, proposed to be made between Tunbridge and Portsmouth : by means of which and the River Medway, an Inland Navigation will be opened between the River Thames and Portsmouth. [With large Plan of the Canal.] London, 1810.

- Autobiography of Sir John Rennie, F.R.S. Comprising the History of his Professional Life, together with Reminiscences dating from the Commencement of the Century to the Present Time. London, 1875.

Richardson, M. A. The Borderer's Table Book. 8 vols. Newcastle-upon-Tyne, 1846.

- Reprints of Rare Tracts, Imprints of Antient Manuscripts, \&c., chiefly illustrative of the History of the Northern Counties. Vol. 1II, Historical. Newcastle, 1849.

Roberson, George, and Green, Join Richard. Oxford during the last Century. Oxford, [N.D.].

Roberts. George. The Social History of the People of the Southern Counties of England in past Centuries. London, 1856.

Roberts, Sauvel. Autobiography and Select Remains of the late Samuel Roberts (of Sheffield). London, 1849.

Robertsox, Arcimbald. A Topographical Survey of the Great Road from London to Bath and Bristol, etc., in 2 Parts. London, 1792.

Robertson, Rev. David. Diary of Franeis Evans, Secretary to Bishop Lloyd, 1699-1706. Printed for the Worcestershire Historical Society, by James Parker \& Co. Oxford, 1903.

Rogers, Janes E. Thonold. A History of Agriculture and Prices in England. 6 vols. London, 1886-8\%.

[Runder, S.] The History of the Ancient Town of Cirencester, in two Parts : Pt IThe Ancient State; Pt II-- the Modern and Present State. Cireneester, 1814. 
Rudge, Thomas. General View of the Agriculture of the County of Gloucester.... London, 1807.

Rusuworth, John. Historical Collections of Private Passages of Statc, Weighty Matters in Law, Remarkable Proceedings in Five Parliaments (1618-1629). 8 vols. London, 1721.

Rydock, Willian. The Lil'e and Notorious Practices of William Rydock, alias Wreathocke. Who was condemned for Felony in Robbing the Reverend Dr Lancaster on the Highway. June 11, 1735. London, 1736.

Rye, W. B. Collections for the History of Rochester. 3 vols. Rochester, 1817-87. Rye, Williau Brenchley. England as Seen by Foreigners in the Days of Elizabeth and James the First....Extracts from the Travels of Foreign Princes and Others. London, 1865.

_- England as seen by Foreigners in the days of Elizabeth and James I. Comprising translations of the Journals of the two Dukes of Wirtemberg in 1592 and 1610. London, 1865.

Ryuer, James. The Practice of Navigation upon a New Plan. Bath, 1 rr8.

Rymer, Thoma. Foedera, Conventiones, Literae, et Cujuscunque Generis Acta Publica, inter Reges Angliae et Alios quosvis Imperatores, Reges, Pontifices, Principes, vel Communitates, ab ineunte Saeculo Duodecimo, viz., ab anno 1101, ad nostra usque Tempora, Habita aut Tractata, etc. Editio secunda. Tomi I-Xx. Londini, 1726-1735.

S., E. The Discoverie of the Knights of the Poste: Or the Knightes of the Post, or comon common baylers newly Deseried.... London, 1597.

S., R. (pseud.). [Br. Mus. 1028. a. 3.] Avona; or a Transient View of the Benefit of making Rivers of this Kingdom Navigable. Occasioned by observing the Scituation of the City of Salisbury, upon the Avon, and the Consequence of opening that River to that City. Communicated by Letter to a Friend at London. By R. S. London, 1675.

SAlis, Henry Rodolphe de. A Chronology of Inland Navigation in Great Britain. London, 1897.

Salt, Samuel. Statistics and Calculations essentially necessary to Persons connected with Railways or Canals, containing a Variety of Information not to be found elsewhere. Manchester, 1845 .

Salzinann, L. F. The History of the Parish of Hailsham, the Abbey of Otham and the Priory of Michelham. Lewes, 1901.

Sandars, Josepin. A Letter on the Subject of the Projected Rail Road between Liverpool and Manchester, pointing out the Necessity for its Adoption and the Manifest Advantages it offers to the Public, with an Exposure of the exorbitant and unjust Charges of the Water Carriers. 3rd edition. Liverpool, 1824.

Saussure, Cesar de. A Foreign View of England in the Reigns of George I and George II. Translated and edited by Madame Van Muyden. London, 1902.

Scotcher, Richard. The Origin of the River Wey Navigation. Being an Account of the Canalization of the River, from a Manuseript written by Richard Scotcher in 1657. Now first published. Edited with an Introduction by Thomas J. Lacy. Guildford, 1895.

Scott, Benjanin. The Progress of Locomotion; being Two Lectures on the Advances made in Artificial Locomotion in Great Britain. London, 1854.

Scotr, Joun. Digests of the General Highway and Turnpike Laws, with the Schedule of Forms,... and Remarks. Also an Appendix on the Construction and Preservation of Roads. London, $17 \% 8$.

- Berwiek-upon-Tweed. The History of the Town and Guild. London, 1888. 
Scrivenor, Harry. The Railways of the United Kingdom Statistically considered in relation to their Extent, Capital, Amalgamation, ete. From authentic documents. London, 1849 .

Sekon, G. A. (psend. for G. A. Nokes). A History of the Great Western Railway, being the Story of the Broad Gange. London, 1895.

SEYER, SAllUEL. Memoirs Historical and Topographical of Bristol and its Neighbourhood. 2 vols. Bristol, ]821, 1823.

Shaten, Sanuel, Jr. A Review of Railways and Railway Legislation at Home and Abroad. London, $184 \%$.

Shapleigir, John. Highways: a Treatise shewing the Hardships, and Inconveniences of Presenting, or indicting Parishes, Towns, etc., for not repairing the Highways. And offering several material Additions, and Amendments to the Laws now in being, for the better, and more effectual Repairing of the same. London, 1749 .

Shareholder, A. (psend.). Railroads. Statements and Reflections thereon: particularly with Reference to the Proposed Railroad without a Tunnel, and the competition for the Line between London and Brighton. By a Shareholder, at the Request of Other Shareholders. London, 1836.

Suaw, George T. and Isabelua. Liverpool's First Directory. A Reprint of the Names and Addresses from Gore's Directory for 1766....Also a History of the Liverpool Directories from 1766 to 1907 . Liverpool, 1907.

Shaw, Rev. S. A Tour to the West of England in 1788 (in Pinkerton's Voyages and Travels, Vol. 1I, pp. 172-335). London, 1789.

Shaw, Simeon. History of the Stafordshire Potteries; and the Rise and Progress of the Manufacture of Pottery and Porcelain. First published in Hanley, 1829, and Reissued at London, 1900.

Sheardown, Willian. The Great North Road and the Great Northern Railway; or, Roads and Rails. Doncaster, [1363].

Shelford, Leonard. The Gencral Highway Act of the 5 \& 6 W. IV.c. 50 . With Notes Explaining the Alterations in the Law of Highways, etc. London, 1835.

Simond, Lours. Journal of a Tour and Residence in Great Britain, during the years 1810 and 1811, by a French Traveller. 2 vols. New York, 1815. (2nd ed., corrected and enlarged : to which is added an Appendix on France, written in December 1815, and October 1816. 2 vols. Edinburgh, 1817.)

Sinipson, Robert. A Collection of Fragments Illustrative of the History and Antiquities of Derby, compiled from authentic sources. 2 vols. Derby, 1826.

Sinclair, Rev. J. S. Memoirs of Sir John Sinclair, Bart. 2 vols. London, 1837.

Skey, Robert S. Report to the Committee of the Birmingham and Liverpool Junction Canal, on the Present State of the Compctition between the Canal Carriers using that Line and the Grand Junction Railway Company, with Suggestions for a more economieal and effective working of the Canal. Westminster, 1841 .

Stelgh, John. A History of the Ancient Parish of Lcek, in Staflordshire; ineluding Horton, Cheddleton and Ipstones. 2nd ed. London, [1883].

SlugG, J. T. Reminiscences of Manchester Fifty Years Ago. Manchester and London, 1881.

Sueaton, John. Begin, From a Survey of the River Calder, from Wakefield to Brooksmouth, and from thence to Salter-Hebble Bridge, near Halifax, taken in the Months of October and November 1757, by John Smeaton, it appears as follows:- Halifax, 1757.

- Reports of the late John Smeaton, F.R.S., made on Various Occasions, in the Course of his Employment as a Civil Engincer. 3 vols. London, 1812. 
Smiles, Samuel. Lives of the Engineers. 4 vols. London, 1861-62.

- Industrial Biography. Iron Workers and Tool Makers. London, 1879.

Smitu, Arthur. The Bubble of the Age; or the Fallacies of Railway Investments, Railway Accounts, and Railway Dividends. 3rd ed. London, 1848.

Surm, Worthington G. Dunstable: Its History and Surroundings. London, 1904.

Sorbière, SAliuei.. A Voyage to England, containing many Things relating to the State of Learning, Religion, and other Curiosities of that Kingdom (English translation). London, 1709.

Steunat, Henry. Account of a Plan for the better supplying the City of Edinburgh with Coal; together with an Examination of the Merits of the Two Principal Lines pointed out for the Intended Canal between Edinburgh and Glasgow. Edinburgh, 1800.

Stevenson, Davin. Fifty Years on the London and North Western Railway, and other Memoranda in the Life of David Stevenson. Edited by Leopold Turner. London, 1891.

Stevenson, W. Henry. Records of the Borough of Nottingham; being a series of extracts from the Archives of the Corporation of Nottingham, 5 vols., 11551702. (Vol. v edited by W. T. Baker.) London and Nottingham, 1882-90.

- Calendar of the Records of the Corporation of Gloucester. Gloucester, 1893.

Stevenson, William. General View of the Agriculture of the County of Dorset.... London, 1812.

- General View of the Agriculture of the County of Surrey.... London, 1813.

Stewart, Cirarles S. Sketches of Society in Great Britain and Ireland. 2nd ed. 2 vols. Philadelphia, 1835 .

Stocks, John Edward, and Bragg, W. B. Market Harborough Parish Records to A.D. 1530. London, 1890.

Stone, Thоmas. General View of the Agriculture of the County of Huntingdon.... London, 1793.

General View of the Agriculture of the County of Bedford.... London, 1794.

- General View of the Agriculture of the County of Lincoln.... London, 1794.

Srow, John. The Abridgement of the English Chronicle, First Collected by M. John Stow, and after hin augmented with very many memorable Antiquities, and continued...unto the beginning of the Yeare 1618. By E. H. Gentleman. London, 1618.

- Annales, or a Generall Chronicle of England. Begun by John Stow: Continued and augmented...unto the end of this present yeerc, 1631. By Edmund Howes, Gent. London, 1631.

- A Survey of London, written in the year 1598. New Edition edited by William .J. Thoms, F.S.A. London, 18.42. (Another edition, London, 1876.) A Summarie of the Chronicles of England to 1590. London, [N.D.].

Stretton, Clement E. Early Tramroads and Railways in Leicestershire. Burtonon-Trent, 1900.

- History of Various English Railways (The Stretton Collection for the Chicago Exhibition, 1893).

A Few Notes on Early Railway History. London, 1884.

- History of the South Staffordshire Railway. Wolverhampton, 1885.

- The Stour Valley Railway and Great Western. Shrewsbury, 1886.

- History of the Manchester and Birmingham Railway. Manchester, 1886.

The Grand Junction Railway. [N.P.], 1887.

The History of the Birmingham and Derby Junction Railway. Birmingham, 1892. 
Stretton, Clenent E. The History of the Birmingham, Wolverhampton, and Stour Valley Railway. Printed for Chicago Exhibition, 1893.

The History of the Railways of Birmingham. Birmingham, 1897 (?).

The History of the London and Birmingham Railway. Leeds, 1901.

The History of the Amalgamation and the Formation of the London and

North Western Railway Company. Leeds, 1901.

- History of the London and North Western Railway. Leeds, 1902.

- The History of the Birmingham and Gloucester, and Bristol and Gloucester

Railways. Leeds, 1902.

— The Stone Roads, Canals, Edge-Rail-Ways, Outram-Ways, and Elcetric Rail-

Ways in the County of Leicester. Leicester, [1907].

Strickland, H. E. General View of the Agriculture of the East Riding of Yorkshire.... York, 1812.

Subscriber (pseud.). Remarks upon the Pamphlet by "Investigator," on the Proposed Railway between Birmingham and London. By a Subscriber to the Railway. London, 1831.

Summers, Jeremah Wildiam. The History and Antiquities of Sunderland, Bishopwearmouth, etc., from the earliest Authentic Records down to the Present Time. Vol. I. Sunderland, 1858.

Surtees, Robert. The History and Antiquities of the County Palatine of Durham : compiled from original records preserved in public repositories and private collections. 4 vols. London, 1816-40.

Surtees Society Publications. Vols. Lxv and Lxxvir, for the years 1875 and 1883, entitled "Yorkshire Diaries and Autobiographies in the Seventeenth and Eighteenth Centuries." Durham, London, etc., 1877 and 1886.

Sutchiffe, Johs. Report on the Line of Navigation from Hexham to HaydonBridge,....And A Report on the Line from Newcastlc to Haydon-Bridge.... Newcastle, [1797].

- A Treatise on Canals and Reservoirs, and the best Mode of Designing and Executing them; with Observations on the Rochdale, Leeds and Liverpool, and Huddersfield Canals, \&c. Rochdale, 1816.

Swinden, Henry. The History and Antiquities of the Ancient Burgh of Great Yarmouth in the County of Norfolk. Norwich, 1772.

Sydenham, John. The History of the Town and County of Poole; collected and arranged from Ancient Records and other authentic documents, etc. Poole, 1839.

Sydney, William Connor. England and the English in the Eighteenth Century. 2 vols. London, 1891.

- The Early Days of the Nineteenth Century, in England. 2 vols. London, 1898.

Sykes, Jons. Local Records : or Historical Register of Remarkable Events which have occurred in Northumberland and Durham, Newcastle-upon-Tyne, and Berwick-upon-Tweed. 2 vols. Newcastle, 1833. (Reprinted and a third volume added by T. Fordyce, Newcastle, 1866-67.)

Sylvester, Сharles. Report on Rail Roads, and Locomotive Engines, addressed to the Chairman of the Committee of the Liverpool and Manchester projected Railroad. 2nd ed. Liverpool, 1825.

Sympson, E. Mansel. Lincoln: A Historical and Topographical Account of the City. London, 1906.

TA1T, JAses. Mediaeval Manchester and the Beginnings of Lancashire. Manchester, 1904.

Tate, George. The History of the Borough, Castle and Barony of Alnwick. 2 vols. London, 1866-69. 
Tatham, William. Remarks on Inland Canals, the small System of interior Navigation, Various Uses of the Inclined Plane, ete. London, 1798.

The Political Economy of Inland Navigation, Irrigation and Drainage.... London, 1799.

Taylor, Javies. A Brief Account of the Rise and Early Progress of Steam Navigation: intended to demonstrate that it originated in the Suggestions and Experiments of the late Mr James Taylor of Cumnock, in connection with the late Mr Miller of Dalswinton. Ayr, 1844 .

Taylor, John ("Water Poet"). The Old, Old, Very Old Man; or The Age and long Life of Thomas Par, the Son of John Parr of Winnington in the Parish of Alberbury, in the County of Salopp (or Shropshire) who was Borne in the Raigne of King Edward the 4th being aged 152 yeares and odd Monethes etc. London, 1635.

The Coaches Overthrow. Or A Joviall Exaltation of Divers Tradesmen, and Others, for the Suppression of Troublesome Hackney Coaches. London, [1635?].

— All the Workes of John 'Taylor the Water Poet being 63 in number Collected into one Volume by the Author. London, 1530.

- The Carriers' Cosmography: or A Brief Relation of the Inns, Ordinaries, Hostelries, and other Lodgings in and near London; where the Carriers, Waggons, Foot-posts and Higglers do usually come from any parts, towns, shires,...with nomination of what days of the week they do come to London, and on what days they return; etc. London, 1637 .

— John Taylor's Last Voyage, and Adventure, Performed from the twentieth of July last 1641 to the tenth of September following. In which time he past, with a seullers Boate from the Citie of London, to the Cities and I'ownes of Oxford, Gloucester, Shrewesbury, Bristoll, Bathe, Monmouth, and Hereford, ete. London, 1641 .

Taylor, Joseph. A Journcy to Edenborough in Seotland (in 1705). Printed from the MS. with Notes, by William Cowan. Edinburgh, 1903.

Teissernac, Ednond. Études sur les voies de communication perfectionnées et sur les lois économiques de la production du transport. Paris, 1847.

[Tellord, Thonas, and Douglass, L.] An Account of the improvements of the Port of London, and more particularly of the Intended Iron Bridge, consisting of one Arch, of Six Hundred Feet Span. London, 1801.

Telforn, Thouas, and Nicholls, Capt. Ship Canal for the Junction of the English and Bristol Channels. Reports by these two men. London, [1824].

Telford, Thomas. Life of Thomas Telford, Civil Engineer, written by himself; containing a Deseriptive Narrative of his Professional Labours: with a Folio Atlas of Copper Plates. Edited by John Rickman, one of his Executors.... London, 1838.

[Tronss, Jonn.] The Local Register and Chronologieal Aecount of Occurrences and Faets connected with the Town and Neighbourhood of Sheffield. Sheffield, 1830.

Tronas, Willian. Observations on Canals and Railways, illustrative of the... Advantages to be derived from an Iron Rail-Way, adapted to Common Carriages, between Neweastle, Hexham and Carlisle;...also second erition, Report of Robert Dodd...on a Proposed Navigable Canal between Neweastle and Hexham. Newcastle-upon-Tyne, 1825.

Trompson, Pishey. The History and Antiquities of Boston, and the Villages of Skirbeek, Fishtoft, ete. Boston (Eng. and Mass.) and London, 1856.

[Thorpe, J.] A Collection of Statutes eoneerning Rochester Bridge. London, 1733. 


\section{Bibliography}

Thrupp, Gronge A. The History of Coaches. London, 1877.

Timmins, Sanver. William Murdock. (In Birmingham Miscellaneous Pamphlets, Vol. 11. 2. Birmingham Free Central Library, No. 145,025.)

Tomss, R. C. The King's Post. Being a volume of historical facts relating to the Posts, Mail Coaches, Coach Roads, and Railway Mail Services of and connected with the Ancient City of Bristol from 1580 to the Present time. Bristol, 1905.

— The Bristol Royal Mail, Post, Telegraph, and Telephone. Bristol, [N.D.].

Tounsix, Josiuna. The History of the Town of Taunton, in the County of Somerset. Taunton, 1791.

Tredgold, Thonas. A Practical Treatise on Railroads and Carriages, slowing the Principles of estimating their strength, Proportions, Expense, and Annual Produce, etc. London, 1825.

Trevituck, Francis. Life of Richard Trevithick, with an Account of his Inventions. 2 vols. London, 1872.

Tristram, William Outram. Coaching Days and Coaching Ways. London, 1888. Trusler, Jonn. Description of the Road from London to Batl.. London, 1797.

- A Delineation of the Roads of the West and South of England. Bath, 1800.

Tuke, Mr, Jr. General View of the Agriculture of the North Riding of Yorkshire.... London, 1794.

Turner, Geonge. General View of the Agriculture of the County of Gloucester.... London, 1794.

Turner, Williay H[enry]. Selections from the Records of the City of Oxford, with Extracts from Other Documents illustrating the Municipal History, 15091583. Oxford and London, 1880.

Twiniva, Rev. Thovas. Recreations and Studies of a Country Clergyman of the Eighteenth Century. London, 1882.

Vallance, John. Considerations on the Expedience of Sinking Capital in Railways. London, 1825.

Vancouver, Charles. General View of the Agriculture of the County of Cambridge.... London, 1794.

General View of the Agriculture of the County of Essex.... London, 1795.

General View of the Agriculture of the County of Devon.... London, 1808.

- General View of the Agriculture of Hampshire.... London, 1813.

Vanderstegen, Willian. The Present State of the Thames Considered; and a Comparative View of Canal and River Navigation. London, 1794.

Vatke, Theodor. Culturbilder aus Alt-England. Berlin, 1887.

Vowell, John, alias Hoker, Jorn. The Antique Description and Account of the City of Exeter: in three Parts. Exon, 1765.

Wagner, Carl A. Über die wirthsehaftliche Lage der Binnenschiffahrtsunternehmungen in Grosbritannien und Irland. 2 Pts. Berlin, 1901. (Reprinted from Archiv für Eisenbahnwesen.)

Wake, Bernard John. Turnpike Roads: Lenders of Money on Mortgage of 'Tolls, \&c. cannot, under the Present Acts, have any Legal Security:-A Reply, in Support of this Doctrine to William Knight Dehany, Esq.... the avowed Dranghtsman of the Recent Turnpike Road Aets, and who has attempted to refute it, in Answer to a Former Publication by the Author of this. London, 1823.

Walfond, Connelius. Fairs, Past and Present: A Chapter in the History of Commerce. London, 1883.

Walfond, Edwand. Old and New London. 6 vols. London, [N.I.].

Walker, D. General View of the Agriculture of the County of Hertford.... London, 1795. 
WaLker, Janes, and Rastrick, John Úpeth. Liverpool and Manchester Railway. Report to the Directors on the Comparative Merits of Loco-motive \& Fixed Engines, as a Moving Power. Liverpool, 1829.

Walker, Janes Scott. An Accurate Description of the Liverpool and Manchester Railway, and the Branch Railways to St Helen's, Warrington, Wigan and Bolton; with an Account of the Opening of the Railway, and of the Melancholy Accident which occurred to the late Rt. Hon. William Huskisson, etc. 3rd edition. Liverpool, 1832.

Wallis, Johs. The Natural History and Antiquities of Northumberland: and so much of the County of Durham as lies between the Rivers Tyne and Tweed; commonly called North Bishoprick. 2 vols. London, 1769.

Walpole, Horace. Paul Hentzner's Travels in England, during the Reign of Queen Elizabeth (1598), translated by Horace, late Earl of Orford, etc. London, 1797.

- Journal of the Reign of King George the Third, from the year 1771 to 1783. Now first published from the Original Manuscripts. Edited, with notes, by Dr Doran. 2 vols. London, 1859.

- The Letters of Horace Walpole...edited by Mrs Paget Toynbee. 16 vols. London, 1903.

Ward, Jolis. The Borough of Stoke-upon-Trent, in the Commencement of the Reign of Her Most Gracious Majesty Queen Victoria, etc. London, 1843.

Ward, Thomas HumpIny. The Reign of Quecn Victoria: A Survey of Fifty Years of Progress. 2 vols. London, 1887.

Wardell, James. The Municipal History of the Borough of Leeds, in the County of York, including numerous extracts from the Court Books of the Corporation, and an Appendix, containing copies and translations of Charters, and other Documents relating to the Borough. London and Leeds, 1846.

WARner, Rev. Ricinad. A Walk through some of the Western Counties of England. Bath, 1800.

- The History of Bath. Bath, 1801.

- A Tour through the Northern Counties of England and the Borders of Scotland. 2 vols. Bath, 1802.

- A Tour through Cornwall in the Autumn of 1808. Bath, 1809.

Watkins, John. An Essay towards a History of Bideford, in the County of Devon. Exeter, 1792.

Webr, Sidney and Beatrice. English Local Government: The Story of the King's Highway. London: Longmans, Green \& Co., 1913.

WEDEL, LUPOLD von. Journey through England and Scotland, made by Lupold von Wedel in the years 1584 and 1585. Translated from the Original Manuscript by Dr Gottfried von Bülow, Supt. of the Royal Archives in Stettin. (In Trans. Royal Historical Society, N.S., Vol. Ix, 1895, pp. 223-70.)

Wedge, John. Gencral View of the Agriculture of the County of Warwick.... London, 1794.

Wedge, Thomas. General View of the Agriculture of the County Palatine of Chester.... London, 1794.

Welford, Ricilalid. A History of the Parish of Gosforth, in the County of Northumberland. Newcastle-upon-Tyne (1879).

- History of Newcastle and Gateshead in the Fourteenth and Fifteenth Centuries. London and Newcastle-upon-Tyne, [N.D.; probably about 1884].

Welibeloved, Robert. A Treatise on the Law relating to Highways; comprehending Turnpike Roads, Public Bridges, and Public Foot-paths, etc. London, 1829. 
[Wendebons, F. A.] Beyträge Zur Kentniss Grosbritanniens vom Jahr 1779. Aus der Handschrift eines Ungenanten [F. A. Wendeborn] herausgegeben von Georg Forster, Professor am Carolino in Cassel. Lemgo, 1780.

Wendeborn, Fred. Aug. A View of England towards the Close of the Eightecnth Century. Translated from the Original German, by the Author himself. 2 vols. London, 1791.

Wentwonth, Thonas, Earl of Strafford. The Earl of Strafford's Letters and Dispatches, with an Essay towards his Life by Sir George Radeliffe....By W. Knowler. 2 vols. London, 1739.

The Wentworth Papers (1705-39). Selected from the Private and Family Correspondence of Thomas IVentworth, Lord Raby, created, in 1711, Earl of Strafford, of Stainborough, co. York. With a Memoir and Notes by James J. Cartwright, M.A. London, 1883.

West, WilliaM. The History, Topography and Directory of Warwickshire, etc. Birmingham, 1830.

Westall, Geonge. Inland Cruising on the Rivers and Canals of England and Wales. London, 1908.

Wheeler, Janes. Manchester, its Political, Social, and Commercial History, Ancient and Modern. Manchester and London, 1836.

Wheeler, William Henry. A History of the Fens of South Lincolnshire, being a Description of the Rivers Witlam and Welland and their Estuary, etc. 2nd edition. Boston and London, 1896.

Whishaw, Francis. Analysis of Railways: consisting of a Series of Reports on the Twelve Hundred Miles of Projected Railways in England and Wales, now before Parliament; together with those which have been abandoned for the present Session, etc. London, 1837.

Whitaker, Thomas Dunham. The History and Antiquities of the Deanery of Craven, in the County of York. 2nd edition. London, 1812.

_ Loidis and Elmete; or an attempt to illustrate the District described in those Words by Bede; and supposed to embrace the Lower Portions of Aredale and Wharfdale, together with the Entire Vale of Calder, in the County of York. Leeds, 1816.

- The History and Antiquities of the Deanery of Craven, in the County of York, 3rd edition with many Additions and Corrections, edited by A. W. Morant. London, 1878.

White, J. Some Account of the Proposed Improvements of the Western Part of London, by the Formation of the Regent's Park.... 2nd edition. London, 1815.

Whitehead, John. Railway Management, Letter to George Carr Glyn, Esq., M.P., Chairman of the London and North Western Railway Company. 2nd edition. London, 1848.

Whitmore, W. W. Letter to Lord John Russell on Railways. London, 1847.

Whitwortir, Richard. The Advantages of Inland Navigation; or some Observations offered to the Public to shew that an Inland Navigation may be easily effected between the three great ports of Bristol, Liverpool, and Hull; together with a Plan for executing the same. London, 1766 .

Wnitworth, Robert. A Report and Survey of the Canal proposed to be made on one Level from Waltham-Abbey to Moorfields. Also of a line which may be continued from Mary-bone to the said proposed Canal, etc. With an Address on the Importance and great Utility of Canals in General. London, 1773.

Wild, Rev, J. Tetney, Lincolnshire. A History. (Printed for the Author by Albert Gait.) Grimsby, 1901. 
Wilkinson, W. A. The Toll Question on Railways exemplified in the case of the Croydon and Greenwich Companies. London, 1841.

Williamson, Captain James. The Clyde Passenger Steamer: Its Rise and Progress during the Nineteenth Century. Glasgow, 1904.

Willmore, Frederic William. A History of Walsall and its Neighbourhood. Walsall and London, 1887.

- Records of Rushall, County Stafford, with a Transcript of the Old Parish Register and Extracts from the Churchwardens' Accounts. Walsall, 1892.

Willumore, Grainam, Wollaston, F. L., and Hodges, W. Reports of Cases argued and determined in the Court of Queen's Bench and upon Writs of Error from that Court to the Exchequer Chamber, and in the Bail Court. London, 1840.

Wilson, Henri. Hints to Road Speculators, together with the Influence Railroads will have upon Society, in promoting Agriculture, Commerce, and Manufactures. London, 1845.

Wilson, Thomas. The Railway System and its Author, Thomas Gray, now of Exeter. A Letter to the Right Hon. Sir Robert Peel, Bart. London, 1845.

Wonderspoon, John. Memorial of the Ancient Town of Ipswich, in the county of Suffolk. Ipswich and London, 1850.

Wood, Nicholas. A Practical Treatise on Railroads, and Interior Communication in General; with Original Experiments and Tables of the Comparative Value of Canals and Rail-Roads. London, 1825.

Wooncroft, Bennet. A Sketch of the Origin and Progress of Steam Navigation from Authentic Documents. London, 1848.

Woodnuff, Chas. Eveleigu. A History of the Town and Port of Fordwich, with a Transeription of the XVth Century Copy of the Custumal. Canterbury, [1895].

Woodward, B. B., Wilks, T. C., and Lockhart, Charles. A General History of Hampshire, or the County of Southampton, Including the Isle of Wight. 3 vols. London, [1861-69].

Woolrych, Humphrey W. A Treatise on the Law of Ways, including Highways, Turnpike Roads and Tolls, Private Rights of Way, Bridges, and Ferries. London, 1829.

- A Treatise on the Law of Waters and of Sewers; including the Law relating to Rights in the Sea, and Rights in Rivers, Canals, Dock Companies, Fisheries, Mills, etc. London, 1830.

Wordsworth, Christopher. The Fifteenth Century Cartulary of St Nicholas Hospital, Salisbury, with Other Records. Salisbury, 1902.

Wongan, G. B. General View of the Agriculture of the County of Cornwall.... London, 1811.

Wortin, Richard Nicholls. History of Plymouth, from the Earliest Period to the Present Time. Plymouth, 1890.

Calendar of the Plymouth Municipal Records. Plymouth, 1893.

Wylie, James Hamlton. History of England under Henry the Fourth. 4 vols. London, 1884-98.

Yonge, Walter. Diary of Walter Yonge, edited by George Roberts for the Camden Society. London, 1848.

York and North Midland Railway Reports of the Committee of Investigation. York, 1849.

Young, Arthur. The Farmer's Tour Throngh the East of England. London, 1771.

— A Six Weeks' Tour Through the Southern Counties of England and Wales. London, 1768.

— A Six Months' Tour Through the Nortlı of England. London, 1771. 
Young, Arthur. The Farmer's Letters to the People of England. London, 1768. - General View of the Agriculture of the County of Lincoln; Drawn up for the Consideration of the Board of Agriculture and Internal Improvement, by the Secretary to the Board. London, 1799 .

- General View of the Agriculture of Hertfordshire; Drawn up for the Consideration of the Board of Agriculture and Internal Improvement, by the Secretary to the Board. London, 1804.

- General View of the Agriculture of the County of Suffolk; Drawn up for the Consideration of the Board of Agriculture and Internal Improvement, by the Secretary to the Board. 3rd edition. London, 1804.

_ The Farmer's Letters to the People of England...to which is added Sylvae: or, Occasional Tracts on Husbandry and Rural Economies. London, 1767. General View of the Agriculture of the County of Sussex.... London, 1793.

- General View of the Agriculture of the County of Suffolk.... London, 1794.

- General View of the Agriculture of the County of Norfolk.... London, 1804.

- General View of the Agriculture of the County of Essex.... 2 vols. London, 1807 .

View of the Agriculture of Oxfordshire.... London, 1809.

Young, Charles Frederick T. (C.E.) The Economy of Steam Power on Common Roads, in Relation to Agriculturists, Railway Companies, Mine and Coal Owners,...with its History and Practice in Great Britain....And its Progress in the United States, by Alex. L. Holly, C.E., and J. K. Fisher. London, 1860.

Young, Rev. George. A History of Whitby, and Streoneshalh Abbey; with a Statistical Survey of the Vicinity to the Distance of Twenty-five Miles. 2 vols. Whitby, 1817.

\section{BRITISH MUSEUM MANUSCRIPTS}

No. 5,489, pp. 108-21. Papers concerning the River Stour in County of Kent. $1774-75$.

No. 5,865 , p. 183 . Petition for leave to bring in a Bill into Parliament to recover the Navigation of River Cam. 1r01-02.

No. 5,866, p. 222 b. Memoranda regarding Coaches.

No. 5,957, pp. 1-48. Tour in England, July 20 to Oct. 19, 1735.

No. 6,668, pp. 909-14. Itinerary from Winster, co. Derby, to Ormskirk, co. Lancaster.

No. 6,70\%. Reynolds' Derbyshire Collection.

No. 6,767. Notes of a Tour in Nottinghamshire and Derbyshirc, etc., in 1766.

No. 11,052, pp. 80-136. Papers regarding River Wye Navigation. [1619-51.]

No. 11,302. (Scudamore Papers, Vol. x11.) Papers and Accounts on the County of Hereford. Bridges, Iron Works, and River Wye.

No. 11,394, pp. 28-44. Papers on the Dee Navigation, 1733 .

No.11,571. Journey through Surrey and Sussex by John Burton, 1752.

No. 12,496, pp. 263-91. Orders and Directions, Together with a Commission for the better Administration of Justice, and more perfect Information of His Majestic, etc. (Printed.) London, 1630.

No. 12,497, p. 360. The Presentment of the Jury touching Mordon (Wandle) River (co. Surrey). 
No. 14,256-259. Dr Richard Pococke's Journey Round Scotland to the Orkneys, 1760. 4 vols.

No. 14,260-261. Travels of Dr Pococke in England in 1764. 2 vols.

No. 14.823. Journal of Tours by Craven Ord in the Counties of Norfolk and Suffolk, 1781-97.

No. 15,776. Journals of Rev. Jeremiah Milles, and of his Travels in different Parts of England and Wales, 1735-43.

No. 15,800. Plut. Clxxxir. B. Dr Richard Pococke's Journey into England from Dublin, by way of the Isle of Man, also his Journey into Cornwall and Devonshire, the Original Manuscripts, 1750.

No. 16,179. Extracts from the Registers and other Documents of the City of Chester from the time of Edward II to the year 1701 .

No. 21,550. Tour Through the Counties of Suffolk, Norfolk, Cambridge, and Essex, Sept. 10 to Dec. 19, 1777, by Captain (Francis) Grose.

No. 21,567, p. 2. A Survey of the Rivers of Wye and Lugg, in reference to portation and fishing.

No. 22,926. Some Observations made in a Journey begun June 7 , and finished July $9,1742$.

No. 22,999-23,001. Dr Richard Pococke's Travels in England. Original MSS. Vols. I-IiI.

No. 23,087. Tours of Mr Vertue through the Counties of Essex, Suffolk, Norfolk, Hants, Wilts, Warwick, Gloucester and Oxford, 1739-40.

No. 23,089. Journals of Tours in Sussex and Surrey, 1747 .

No. 23,749. A few Notes about the River Nene.

No. 24,809. Papers relating to the City of London, the Thames, and Middlesex.

No. 28,566. Iter Boreale: anno salutis 1639, \&......inter Anglos \& Scotos, etc. Journal with the King's Army, 1639, by John Aston.

No. 32,442, 1p. 1-76. Sketch of a Tour from London to the Lakes, made in the Summer of the Year 1799.

No. 32,443, pp. 240-64. Fragment of a Description of a Tour from London through Oxford to Southampton, 1829.

No.34,754. A Relation of a Short Survey of 26 Counties, briefly describing the Citties and their Scytuations, and the Corporate Towns and Castles Herein. Observed in a Seven Weekes Journey begun at the City of Norwich, (1634)....... By a Captaine, a Lieutenn ${ }^{t}$, and an Ancient, All three of the Military Company at Norwich. Also A Relation of a Short Survey of the Westerne Counties, in which is hriefely described the Citties, Corporations, Castles, and some other Remarkables in them. Observed in a seven Weekes Journey begun at Norwich, ......Aug. 4, 1635. By the same Lieutennant, that with the Captaine, and Ancient of the Military Company in Norwich Made a Journey into the North the yeere before.

No. 35,686, pp. 27, 53-54, 61 ff., 68-69, 71-165. Papers on the River Ouze Navigation. 1793-94.

\section{BRITISH MUSEUM ADDITIONAL MANUSCRIPTS}

Add. 5,842, pp. 244-71. A Tour through Part of England in 1735 (by John Whaley). Various other memoranda, e.g., pp. 103, 359, etc.

Add. 6,693, p. 305. The State of the Rivers of Wye and Lugg in Herefordshire. (Printed.)

Add. 11,395. Memorandum Book and Diary of Thomas Warton, 1780-84. 
Add. 15,662, p. 225. License granted by Edward III (21 Ed. III, 1347) to Newcastle-upon-Tyne to levy customs for repair of the Bridge across the river in that town.

Add. 17,398. The Original Itinerary of Grose the Antiquary. Journeys in England in 1775 and 1777 .

Add. 18,003. A Journal of the Proceedings of the Trustees appointed for putting in Execution an Act of Parliament passed in the Twelfth Year of the Reign of Queen Anne, Intituled An Act for the Speedy and Effectual Preserving the Navigation of the River of Thames....

Add. 18,047. Official Returns of the Public Revenue, from 1699 to 1745.

Add. 18,054. A Particular State of the Receipts and Issues of the Public Revenue, from 1688 to 1702 .

Add. 19,200. The History and Antiquities of the Ancient Villa of Wheatfield in the County of Suffolk (by the Rev. William Myers). London, 1758.

Add. 19,942. Dr J[eremiah] Milles's Sketches of Horse Panniers, Pack Saddles, etc. (ca. 1755).

Add. 24,466. Tours in Nottinghamshire and Derbyshire, 1801-02.

Add. 24,933. An Account of the Antient Wooden and present Stoned Bridge at Rochester and of the Lands proper and Contributary thereto.

Add. 27,587. Letter-Book of A. Jelfe, relating to Westminster Bridge, 1734-44 (showing accounts also).

Add. 27,951. Journals of Visits to England by an Irish Clergyman in 1761 and 1772 .

Add. 28,570, p. 37 et seq. Tour to the West, 1791 .

Add. 28,648, pp. 2-28. Rochester Bridge.

Add. 28,649. The Description of Devonshire by Sir William Pole, of Shute, Kt. Transcribed by J. Prince.

Add. 28,793. Journal of Rev. John Skinner during his Tour in Cornwall, ete. $1797,1798$.

Add. 28,802. Llewelyn Meyrick's Journal of a Tour through Part of England and North Wales in the summer of 1821 .

Add. 30,172. Journal of Tours in the Midland and Western Counties of England and Wales 1794, and in Devonshire in 1803.

Add.30,173. Journey made by William Phillipps from Broadway (County Worcester) to Manchester and Liverpool, and back, 1792 .

Add. 30,302. Remarks upon Wayside Chapels with Observations on the Architecture and Present State of the Chantry on Wakefield Bridge, by John Chessell Buckler and Charles Alban Buckler, architects. London and Oxford, 1870 .

Add. 30,929. Diary of Charles Danvers, of 'Tours in the West of England and in the Lake District, 1795-1812.

Add. 31,337. Journal of a Tour from Brighton to Weymouth in 1816.

Add. 31,857. William Cobbett's Eastern Tour, 1830.

Add. 32,442, pp. 1-76. Sketch of a Tour from London to the Lakes made in the Summer of the Year 1799.

Add. 33,576, p. 63. Suit concerning the Lock near Waltham Abbey on the River Lea, 1683.

Add. 33,640. Sketehes in Wales, Derbyshire, etc.; 1803. By Rev. J[ohn] Skinner. Add. 33,683-685. Journal of a Northern Tour (by Rev. John Skinner) from Camerton, to London, to Peterborough, and Lincoln, to York and Furbam, and thence to Edinburgh and Linlithgow in the year 1825. 3 vols.

Add. 34,105, pp. 188-95. On the Medway Navigation, 1627. 
Add. 34,218, pp. 37-58. Statements, Arguments and Correspondence concerning the Navigation and Overflowing of the River Medway between Maidstone and Yalding. 1600.

Add. 34,727. West Papers, Vol. 1, pp. 14, 16.

Add. 35,154; 35,142-1 47 (6 vols.); 27,825-830-Place Manuscripts-Biography of

Francis Place, and articles on Social and Industrial Conditions.

Add. 35,649, pp. 222 and 224. Papers on the Tolls charged on several Navigations. Add. 35,679, pp. 316-23. Papers showing troubles with a certain lock-keeper on River Cam. 1759-60.

Add. 35,689, p]. 21-22. Papers concerning the River Cam Navigation. [1811.] Add. 35,691, pp. 67-89, 94, 116. Papers relating to the Turnpike from Arrington to Biggleswade. $\mathrm{P}_{\mathrm{P}}$. 169-74, 275, 315, Papers regarding the Navigation of the Rivers Cam and Ouze.

Add. 36,663, p. 558, gives 'A List of Coaches passing through and coming into Neweastle-under-Lyme, Nov. 1830 (by Mr T. P. Platt).'

Add. 36,767, pp. 1-4, give an Order of Privy Council in regard to the Conservation of River Thames. Page 146, a paper entitled, 'The State of the Cause concerning the Milles and Causey at Chester.' 27 Feb., 1607.

Add. 36,914. River Weaver Navigation and Cheshire Salt Works, 1699-1720.

\section{BRITISH MUSEUM, EGERTON MANUSCRIPTS}

Eger. 784. Diary of Mr (William) Whiteway of Dorchester, co, Dorset, from Nov. 1618 to March 1634.

Bibl. Eg. 926. Original Letters from the Rev. S. Denne, Rector of Wilmington,

Kent, and others, on Kentish Topography and Antiquities, 1771-84.

Eger. 2235, pp. 84-93. Tours of the Rev. Joseph Spence to Kimbolton and Ormesby in 1743 , and to Kirkby and the Peak in 1752 .

\section{BRITISH MUSEUM, S'TOWE MANUSCRIPTS}

Stowe $\mathbf{7 4}$, p. 84. Letter from (Sir) A. Copley, dated Saturday, Jan. 1, 1697, to Thomas Kirke, Leedes, regarding a Bill to make river Dun navigable.

Stowe 818, pp. 83-87. Memoranda on making Derwent river Navigable.

Stowe 8r7. Sampson Erdeswicke's Staffordshire. MS. additions by E. Vernon. Pp. 13-22 contain 'A Scheme or Proposal for making a Navigable Comnunication between the Rivers of Trent and Severn, in the County of Stafford. By Dr Thomas Congreve of Wolverhampton.' Printed in London, 1717.

\section{BRITISH MUSEUI, LANSDOWN MANUSCRIPTS}

Lansd. 32. Papers regarding the River Lee Navigation.

Lansd. 38, pp. 84-85. An Answer to the Complaint of the Inhabitants of Enfield against the earrying of grain from Ware to London by the River of Ley (Lea), Oct. 29, 1583. P. 88, A Petition of the Inhabitants of Ware to Lord Burghley, for a Commission to hinder damage done to the River Lea, 1583. Pp. 91-95, The Defects of the Water of the River Lea from Waltham Holy Cross to the mills bencath Stratford at Bow, 1583.

Lansd. 41, p. 44. Orders issued for the Conservation of the River Thames, Sept. 1584; pp. 169-76, Ordinances, Laws and Decrees of Oct. 1, 6 Elizabeth, of the Commissioners of Sewers of Lincolnshire.

Lansd. 49, pp. 74-75. An Order for the Repair of the Bridge at Walmesford. [1586] 
Lansd. 55, pp. 109, 114. Complaint to Lord Burghley as to the impassability of Christmas Lane in Suffolk. Jan. 8, 1587.

Lansd. 60, p. 96. The Inhabitants of Enfield complain to the Queen that they are impoverished by the Navigation of the River Lea, and ask redress or relief. 1589.

Lansd. 76 , No. 55, pp. 125-28. Order of the Star Chamber concerning the Right of Navigation on River Lea, June 20, 1594.

Lansd. 84, pp. 55-57. Papers concerning the exactions made by the people of King's Lynn on goods carried to or from Cambridge. 1597.

Lansd. 142. Several Papers concerning the Watermen of the River Thames.

Lansd. 166, pp. 84-93. Papers regarding the repairing of Berwick Bridge. [1607-13]

Lansd. 328. A Volume containing extracts from Ancient Records concerning the Repairing of bridges in various Counties of England.

Lansd. 561. Trial in Court of Kring's Bench, 1754, regarding the Ancient Highway from Richmond, through Richmond Park, to Croydon.

Lansd. 688. Tour in the Midland Counties, 1710.

Lansd. 722, pp. 29-40. Sir William Dugdale's Journal of his Itinerary to the Fens of Ely, begun from London, May 19, 1657.

Lansd. 896, pp. 162-67. Papers on the Navigation of Beverley Beck.

\section{BRITISH MUSEUM, HARLEY MANUSCRIPTS}

Harl. 368, p. 7 ff. A Paper giving Reasons [in favor of Bristol] against the Continuance of the Port of Gloucester. May 25, 1584.

Harl. 2003. This whole Volume deals with the River Dee and its Mills and Causey, etc. Harl. 2022, p. 66. Papers regarding River Dee.

Harl. 2046, p. 1. Indenture made April 28, anno 12 Eliz., for repairing a highway $2 \frac{1}{2}$ miles long adjoining to Chester.

Harl. 2057, p. 116. An Order of the Assembly at Chester, July 17, 1612, for cleansing etc. Horne Lane.

Harl. 20\%7, p. 21. Regarding the maintenance of Huntington Lane, near the City of Chester, in repair.

Harl. 2081. Law Papers Concerning Dee Mills. Ca. 1607.

Harl.2082. Cheshire Collections of Manuscripts on Chester and Dee Mills, etc.

Harl. 2084. This Volume deals almost wholly with the River Dee and the Mills and Causey at Chester.

Harl. 2150, p. 182. Indenture under which Thomas Bennett of Chester was to keep the Streets of that city in good repair. Dated Oct. 8, 12 Eliz.

Harl. 2263, p. 323. A Lieense for inclosing a certain horse way through private ground. Dated Dec. 23, 1708.

Harl. 2264, p. 272. Docquet of a License for the enclosure of a certain common. 24 Jan., 1710 .

Harl. 6166, p. $229 \mathrm{ff}$. The defaults and common Nuisance of Bridges and of Causeys and of Ways at every end of the Bridges within the Inundreds of Tandridge and Ryegate and Divers Other Places within the said County [Surrey] to be inquired of by the .Justices of Peace of the same County at their General Sessions to be held at Croyden the Tuesday next aftcr Twelfth day in the 25th Year of our Sovereign Lord King Henry VIII.

Harl. 6211. An Account of my Travels from Venice throngh Germany into England [temp. Charles I], Vol. II, pp. 132-206. [By John Lawson (?).]

Harl. 6494, p. $129 \mathrm{ff}$. Journey into the West of England, 1637. 


\section{BRITISH MUSEUM, SLOANE MANUSCRIPTS}

Sloane 1156. Relation du voyage de Monsieur de la Villeauxcleres en Angleterre faict en l'année 1624 .

Sloane 1731 b. Journal du voyage de mon frère Jean de Cardonnel en Irlande etc. [including West England]. 1649-50.

Sloane 1899. Dr Thomas Browne's Journal of a Tour in Kent. 1693.

Sloane 1900, pp. 36-60. Dr Edward Browne's Memorandum Book, 1662; Diary of a Journey in England, begun Sept. 8, 1662.

Sloane 1983 A \& B. Memoranda made in a Journey from London to Oxford. Sloane 3323, pp. 267-69. Papers concerning the River Dee Navigation.

\section{WYATT MANUSCRIPTS}

Nos. 93,189 and 93,190, 2 vols., in Birmingham Free Reference Library. Deal with a variety of subjects.

\section{BRITISH MUSEUM, PAMPHLETS AND TRACTS}

012314. e. 88. Coach and Sedan Pleasantly Disputing for Place and Precedence, the Brewers-Cart being Moderator. London, [1636].

08226. aaa. 29. Reasons humbly offered to the Consideration of Parliament, for the suppressing such of the Stage-Coaches and Caravans now travelling upon the Roads of England, as are unnecessary, and Regulating such as shall be thought fit to be continued. [1700?]

08235. f. 18. Seasonablc Considerations on a Navigable Canal Intended to be cut from the River Trent, at Wilden Ferry, in the County of Derby, to the River Mersey, in the County of Chester. [1766]

08235. f. 77. Observations on the General Comparative Merits of Inland Communication by Navigations or Railroads, with particular Reference to those projected or existing between Bath, Bristol, and London : in a Letter to Charles Dundas, Esq., M.P., Chairman of the Kennet and Avon Canal Company. London, 1825.

08235. h. 12. Reports and Pamphlets on the Subject of Norwich a Port, from the Year 1818 to the passing of the Norwich and Lowestoft Navigation Act in 1827. Norwich, [1818-27].

21. h. 5 (2). By the Maior. Orders set down by the right Honorable, Sir John Watts, Knight, Lord Maior of this Citty of London with the Co[n]sent of the Aldermen his brethren concerning the rates of Carriages with Cartes within this Cittie and Borough of Southwarke. At the Guild Hall the xxv day of November, 1606. London, [1606].

21. h. 5 (36). Ad Session Oier' \& 'Terminer \& Gaolae Domini Regis de Newgate Deliberation' tent' pro Civitat' London apud Justice-Hall in le Old Baily in Paroch' S. Sepulchri in Ward' de Faringdon extra London praed', die Mercurii, scilicet decimo septimo die Junii, Anno Regni Regis Caroli Secundi nunc Angliae \&c. vicesimo, etc. [London, 1666 or 1667?]

21. h. 5 (52). Ad General' Quarterial' Session' Pacis Dom' Regis tent' pro Civitat' London...die Mercurii, scilicet sexto decimo die Octobris, Anno Regni Dom' nostri Caroli Secundi...vicesimo quarto, etc. [London, 1672]

101. i. 59. Plan for Raising Three Hundred Thousand Pounds, for the Purpose of compleating the Bridge at Black-Friars, and Redeeming the Toll thereon; Embanking the North Side of the River Thames...; Redeeming the Antient Toll upon London Bridge.... London, 1767. 
102. k. 52. An Act of Common Council for the better Regulation of HackneyCoaches. London, 1683.

191. e. 9. A New Description of England and Wales, with the Adjacent Islands. Wherein are contained Diverse useful Observations and Discoveries, in respect to Natural History, Antiquitics, Customs...with a Particular Account of the Products, Trade, and Manufactures...to which is added a new and correct Set of Maps of each County, their Roads and Distances;...by Hermann Moll, Geographer. London, 1724.

213. i. 1 (44). A Bill for Enlarging the Term and Powers granted by an Act passed in the Twentieth Year of the Reign of His present Majesty [Geo. II] for repairing the High-Road leading from...Stockton-upon-Tees, to Darlington, and from thence through Winston to Barnard Castle, etc.

213. i. 1 (45). A Bill for Continuing, and making more Effectual, Two Acts of Parliament, one passed in the Tenth Year of the Reign of Her late Majesty Queen Anne, and the other in the Eighth Year of the Reign of His late Majesty King George the First, for Repairing the Highway between a certain Place called Kilburn Bridge in the County of Middlesex, and Sparrows Herne in the County of Hertford.

213. i. 1 (86). The Case of the Deputy Postmasters [as to keeping horses for supplying those riding post]. [London, $1748(?)]$

213. i. 1 (87). The Case of the Innkeepers and Keepers of Livery Stables, and also of the several Owners and Proprietors of Inns and Livery-Stables, and of Lands lett therewith. [London, 1748]

213. i. 1 (91). The Case of the Land-Owners interested in the Banks on each Side of the River Ouze, in the County of Norfolk, between Stowbridge and the Port of Lynn.

213. i. 2 (60). A State of the Road from Keighley to Kendall; and of the Expence the Country will be put to, by paying Interest and Salaries, in case the Bill for a Turnpike-Road should pass; with an estimate of what may be yearly raised by the Laws now in being.

213. i. $2(61)$. The Reasons published against the Bill for a Turnpike between Keighley and Kirkby Kendal, Answered.

213. i. 2 (62). Reasons against the Bill for an intended 'Turnpike between Keighley, in the County of York, and Kendall, in the County of Westmorland.

213. i. 2 (76). A Bill for Confirming an Agreement entered into between the Company of Proprietors of the Undertaking for recovering and preserving the Navigation of the River Dee, and Sir John Glynne, Baronet, Lord of the Manor of Hawarden, and several Freeholders and Occupiers of Land within the said Manor; and for Explaining and Amending Three several Acts of Parliament, of the Sixth, Fourteenth, and Seventeenth Years of His present Majesty's Reign, for recovering and preserving the Navigation of the said River Dee.

213. i. 3 (100). Considerations about the Method of Preserving the Public Roads.

213. i. 3 (101). Reasons against a Bill for Permitting only Carriages with broad Wheels, and those drawn by two Horses, to pass on Turnpike Roads, with regard to the Countries within Twenty-five or Thirty Miles of London. [About 1754-55.]

213. i. $5(94)$. A State of the Case, relating to the several Navigations made, or proposed to be made in or adjoining to the North-Eastern Parts of the County of Chester.

213. i. 5 (94). Remarks upon the Observations on the intended Navigation from Witton Bridge, to the Towns of Knutsford, Macclesfield, Stockport, and Manchester. [Ca. 1766] 
213. i. 5 (95). A State of Facts tending to shew the Utility of the Proposed Canal from Witton near Northwich to Knutsford and Macclesfield, and by Stockport to Manchester. [Ca. 1766]

213. i. $5(96)$. Navigation. Some Observations relative to Navigation: Humbly submitted to the Consideration of the Legislature. [Ca. 1766]

213. i. 5(97). Observations on the Intended Navigation from Witton Bridge to Knutsford; and from thence through Macelesfield and Stockport to the Town of Manchester. [Ca. 1766]

214. i. 4 (103). Observations on the Effects of the Intended Oxford Canal Navigation, with respect to the Diminution or Increase of Seamen. [1769]

214. i. 4. (104). Begin, As a Bill is now depending in Parliament before the Right Honourable the House of Commons, for making a Canal, from the City of Coventry, to the City of Oxford, the following Queries are humbly submitted to the Consideration of both Houses of Parliament, before the said Bill passes into a Law. [1769]

214. i. 4 (119). A Letter (dated Mar. 4, 1769) from Yarmouth to the Representatives in Parliament for Yarmouth and Lynn, on the Subject of the Canal Navigation from Coventry to Oxford, now depending in Parliament.

214. i. 4. (120). Report from the Committee appointed by the Chamber of London to consider the Bill for extending the Coventry Canal to Oxford; with Facts and Observations subjoined respecting the Coal and Coasting Trade. [1769?]

214. i. 4 (124). The Case of the Petitioner, George Perrott, Esquire, on the Bill for Making a Canal from the Coventry Canal-Navigation, at or near Coventry, to the City of Oxford. [1769?]

215. i. 1 (105). Thames Navigation. (Reply to a printed Bill lately handed about, entitled, Some few of the many Objections that occur to the Bill now depending in Parliament for making a Navigable Cut from Sunning...to Monkey Island, Sc.) $[1771$ ?]

215. i. 4.(117). Case and Reasons for Disusing Weighing Engines on the Turnpike Roads. $17 r 4$.

290. c. 30. A New and Compleat Survey of London. By a Citizen and Native of London. 2 vols. Loudon, 1742.

356. m. 1 (26). An Act for making the River Stour Navigable from the Town of Maningtree in the County of Essex, to the Town of Sudbury in the County of Suffolk. (Act 4 \& 5 Anne, c. 15, Public.)

356. m. 1 (34). A Bill to make the River Darwent, in the County of Derby, Navigable (Act 6 Geo. I-Public-c. 27).

356. m. 1 (66). The Case of the Carriers and Waggoners who carry Goods to hire. [1720?]

357. b. 7 (39 or 99). Reasons against the Navigable Scheme.

357. b. 7 (109). An Answer to the Reasons against the Navigable Scheme.

357. b. 9 (2). A Particular State of the Receipts and Issues of the Publick Revenue Taxes and Loanes during the Reigne of his late Majesty King William. That is to say, From the 5th day of November 1688 from which Day the Parliament appointed the said Accounts should comence to the 25th day of March 1702 being the ffirst Determinacon of the Accompts since the Demise of his said late Majestye which happened on the 8 th day of March preceeding. The same reduced to one Generall Accompt or State for the whole time above menconned. [This is all in MS.]

357. b. 9 (72). Reasons Humbly Offercd by John Daniel and William Blackburn, Esquires, for themselves, and on Behalf of Charles Duckenfield, Thomas Butterworth, and John Reddish, Esquires, and others, Gentlemen and Freeholders of 
the County of Chester, against a Bill for Repealing an Aet made in the Seventh Year of His Majesty's Reign, for making the River Weaver Navigable from Frodsham Bridge to Winsford Bridge in the County of Chester. [1726?]

357. b. 9 (73). Reasons Humbly Offered Against allowing the County of Chester any part of the Tonnage Duty for making the River Weaver Navigable; and that the same may be made Navigable on the Easiest Terms.

357. b. 9 (74). Reasons Humbly Offered Against a Bill passed the Honourable House of Commons and now Depending before Your Lordships, Entitled, A Bill for Repealing an Aet passed in the Seventh Year of His present Majesty's Reign, for making the River Weaver Navigable, from Frodsham Bridge to Winsford Bridge in the County of Chester, and for the more speedy and effeetual earrying on and perfeeting the Navigation of the said River, from Frodsham Bridge to Northwyeh in the said County.

357. b. 9 (75). Proposals Humbly Offered for Making the River Weever Navigable from Frodsham Bridge, to Northwieh in the County of Chester.

357. b. 9 (76). Reasons Humbly Offered for passing the Bill for making the River Weaver Navigable from Frodsham Bridge to Northwieh in the County of Chester : With Remarks upon the Proposals from Liverpool.

357. b. 9 (77). The Case of the Barge-Nasters and others, Navigating on the Rivers of Isis and Thames, from Oxford to London; showing the Hardships they labour under, by the exorbitant Sums they pay for passing through the several Loeks, Wears, Bucks, Gates and for the Use of Boats belonging to the same, and going over Towing-Paths on the Banks of the said Rivers.

357. b. 9 (78). Reasons Humbly Ofiered by the Trustees of Riehard Vernon, Esq., deeeased, against the Bill for Repealing an Aet made in the Seventh Year of His Majesty's Reign, For making the River Weaver Navigable from Frodshan Bridge to Winsford Bridge, in the County of Chester.

35\%. e. 1 (28). The Case of the Cheesemongers, in and about the Cities of London and Westminster, relating to the Bill to recover and preserve the Navigation of the River Dee, in the County of Chester. [1732]

357. e. 1 (37). The Case of the Inhabitants of the County and City of Chester, Petitioners for the Bill to Reeover and Preserve the Navigation of the River Dee; In Answer to the Petition of the Cheesemongers in and about the City of London against the said Bill. [1732]

357. e. 3 (69). Reasons against building a Bridge over the Thames at Westminster. 357. e. 4 (32). An Aet for making Navigable the River or Brook, ealled Worsley Brook, from Worsley Mill, in the Township of Worsley, in the County Palatine of Laneaster, to the River Irwell in the said County. (Aet 10 Geo. II-Publie -c. 9.)

35\%. e. $13(54)$. The Case of the Undertakers for making Navigable the Rivers Aire and Calder, in the County of York, and of their Lessees. [31 Geo. II?]

358. b. $3(41)$. Reasons for extending the Navigation of the River Calder from Wakefield to Halifax. (This would be about 1757 or 1758, for Smeaton's Survey was made 1757.)

358. 1). 4 (36). An Aet for Explaining and Amending an Aet passed in the Sixth Year of His present Majesty's Reign, intitled, An Aet to Recover and Preserve the Navigation of the River Dee, in the County Palatine of Chester ; and another Aet passed in the Fourteenth Year of his present Majesty's Reign, intituled, An Act for Ineorporating the Undertakers of the Navigation of the River Dee; and for Repealing the Tonnage-Rates payable to the said Indertakers; and for granting to them other Tonage or Keelage-Rates in lieu thereof; and for other Purposes therein mentioned. (Aet 17 Geo. II, e. 28, Publie.)

J. T. II. 
517. b. 31. The Statute 7 Geo. IV, cap. cxlii, for Consolidating the Trusts of the Turnpike Roads, in the Neighbourhood of the Netropolis, north of the Thames.... London, 1826.

517. k. 16 (3). England's Wants: or several Proposals probably beneficial for England, Humbly offered to the Consideration of all Good Patriots in both Houses of Parliament. By a true lover of his Country [Edward Chamberlayne]. London, 1667 .

567. c. 7. Beyträge Zur Kenntniss vorzüglich des Innern von England und seiner Einwohner. Aus den Briefen eines Freundes gezogen von der Herausgeber. 4. Bde. Leipzig, 1791.

5r7.b. 6-10. A Description of England and Wales. Containing a particular Account of each County...and the Lives of the illustrious Men each County has produced, \&c. 10 vols. London, 1769.

578. k. 30. Observations made during a Tour through Parts of England, Scotland, and Wales, in a Series of Letters [by Richard Joseph Sulivan, F.R.S.]. London, 1780 .

579. c. 41 (3). A Description of the Ancient and Present State of the Town and Abbey of Bury St Edmund's, in the Courty of Suffolk. 3rd edition. Bury St Edmunds, 1782.

579. с. 42 (4). A Description of Janchester: giving a Historical Account of those Limits in which the Town was formerly included....By a Native of the Town. Manchester, 1783.

712. a. 4. The Traveller's Companion. Containing Variety of Useful yet Pleasant Natters relating to Commerce.... London, 1702. Pp. 51-58 give an outline of the Post Roads (at that time) from London, with their several stages and branches.

712. g. 15. A Few General Observations on the Principal Railways Executed, in Progress, and Projected, in the Midland Counties and North of England, with the Author's Opinion upon them as Investments. Maps. London, 1838.

712. g. 16(17). A Treatise of Wool and Cattel. In a Letter written to a Friend, Occasioned upon a Discourse eoncerning the great Abatements of Rents, and the Low Value of Lands, \&c. London, 167\%.

712. g. 16 (20). The Trade of England Revived: and the Abuses thereof Rectified, in Relation to Wool and Woollen-Cloth, Silk and Silk-Weavers, Hawkers, Bankrupts, Stage-Coaches, Shop-Keepers, Companies, Markets, Linnen-Cloth. Also What Statutes in force may be injurious to Trade and Tradesmen, with several Proposals. London, 1681.

725. c. 40. News from the Fens, or An Answer to a Pamphlet entituled, Navigation Prejudieed by the Fen-Drainers.... Wherein is set forth the Vanitie and Falshood of that Discourse, and it is Proved, That Navigation is meliorated by the Fen-Drainers, \&c. London, 1654 .

796. c. 36. A Brief Director for those that would send their Letters to any Parts of England, Seotland or Ireland. Or a List of all the Carriers, Waggoners, Coaches...that come to London, from the most parts and places, by Land and Sea. [1710?]

816. 1. 4. (21). Rohinson, Mayor. Commune Concilium tentum in Camera Guihaldae Civitatis London. decimo die Octobris, Anno Domini 1663. Annoque Regni Domini nostri Caroli Secundi, nunc Regis Angliae, etc. Decimo quinto. [London, 1663]

816. m. 7 (131). A Proposal [for regulating Cars, Carts, etc., in London].

816. m. 8 (4). The Case of the Town and Port of King's-Lynn in Norfolk, as to their Navigation. 
816. m. 8 (5). The Case of the Corporation of the Great Level of the Fenns; relating to a Bill depending in Parliament, for the better Preservation of the Navigation of the Port of King's-Lynn;....

816. m. 8 (6). The State of the Adventurers Case, in Answer to a Petition exhibited against them by the Inhabitants of the Soake of Peterburgh.

816. m. S (11). A Short Demonstration, That Navigation to Bedford, is for the Benefit of Bedfordshire.

816. m. 8 (38). The Case of the Citizens of Chester in Answer to several Petitions from Leverpool, Parkgate, and the Cheesemongers ; and also to Printed Reasons [by 'Thomas Badeslade] against the Aet to Recover and Preserve the Navigation of the River Dee. 1735 .

816. m. s (39). Reasons for making the River Dunn in the West Riding of the County of Xork navigable, and the great advantages which will aeerue to the Nation in general by it.

816. m. $8(49)$. The Case of the Barge-Masters and others, Navigating on the Rivers of Isis and Thames, from Oxford to London, shewing the Hardships they labour under, by the exorbitant sums they pay for passing through the several Loeks, ete. [1720?]

816. m. 8 (50). Reasons for making Navigable the Rivers of Stower and Salwerp, and the Rivulets and Brooks running into the same, in the Counties of Woreester and Stafford. [1720?]

816. m. 8 (51). An Answer, as well to a Paper, intituled Reasons wherefore the making Navigable of the Rivers of Stower and Salwerp in the County of Worcester, will be of great advantage to the County of Salop, and espeeially to the Towns of Shrewsbury, Bridge-North, Wenlocke, Wellington, and Towns adjoyning to the River of Severn. As also to another Paper, intituled, An Answer to some partiall pretenees, ealled, Reasons dispersed by some Shropshire Coal Masters. [1720?]

816. m. 8 (52). The Case of making the River Avon, in the County of Somerset and Gloueester, Navigable, from Bristol to Bath....

816. m. 8 (53). The Case for Making the Rivers Aire and Calder, in the County of York, Navigable to Leeds and Wakefield.

816. m. 8 (5t). Reasons against the Bill for making the Rivers Ayre and Calder, in the West Riding of the County of York, Navigable.

816. m. 8 (55). Reasons humbly offered to the Consideration of the Parliament, for the making Navigable the River Derwent, from the Town of Derby to River Trent.

816. m. $8(56)$. The Case of the Navigation of the River Wye, in the County of Surry. [London (?), 1670.]

816. m. 8 (57). A Reply to a Paper Intituled: An Answer to the Pretended Case Printed eoneerning the Navigation of the River Wye, in the County of Surrey, by shewing the true state thereof. [1670?]

816. m. 8(58). The Proposals for making the River Chelmer navigable, from Malden to Chelmsford, are as follow. Also, Objeetions against these Proposals.

816. m. 9 (13). An Abstraet of the Forfeitures and Penalties set and imposed on Offences done contrary to the Aet of Parliament for Paving and Cleansing the Streets.

816. m. 12 (79). An Aet of Common Couneil for the Government of Cars, Carts, Carrooms, Carters, and Carmen; and for the Prevention of Frauds in the Buying and Selling of Coals.

816. m. 12 (151). To the Honourable the Commons of England in Parliament Assembled. The Humble Petition of a great Number of the Licensed Haekney Coachmen. 
816. m. 12 (152). The Case of the Antient Hackney-Coachmen...Humbly Presented to the Honourable House of Commons.

816. m. 12 (153). The Case of John Nicholson, Walter Storey, (and others) in Behalf of themselves and the First 400 Ancient Hackney-Coachmen, and their Widows.

816. m. 12 (154). The Case of the Hackncy Coachmen.

816. m. 12 (155). The Hackney Coachmen's Case, Humbly presented to the Honourable House of Commons; with a Proposal to Raise for Her Majesty $£ 200,000$ per annum.

816. m. 12 (156). The Case of Thomas Blunt...and the Rest of the Eight Hundred Licens'd Hackney Coach-men....

816. m. 12 (157). To the Honourable the House of Commons, The Humble Petition of Charles Sewell, Thomas Holland, and George Garrett, on behalf of themselves, and the rest of the Eight Hundred Licensed Hackney Coach-men, and their Widows.

816. m. 12 (158). To this Honourable House, The Case of the Coachmen; of divers Coachmakers, Harnessmakers... and other Traders depending upon them,... in relation to the Bill for cncreasing the Number of Hackney Coaches.

816. m. 12 (159). The Case of Divers Tradesmen, Creditors of the Hackney Coachmen, in London and Westminster, and Stagemen to several Places of England.

816. n. 12 (161*). The Humble Proposals of James Lord Mordington, and Martin Laycock, Esq.; for the Farming of the Hackney-Coaches.

816. m. 12 (162). Stage-Coaches Vindicated: or Certain Animadversions and Reflections upon several Papers writ by J. C. of the Inner Temple, Gent., against Stage Coaches.

816. m. 12 (163). A Copy of a Printed Letter from J. C. to a Post-Naster in the Country, with Directions about the Management of his Designe for Putting down Stage Coaches.

816. m. 14 (26). Reasons Humbly Offered to the Honourable House of Commons, why the Waggoners ought not to be obliged to any certain Weight.

816. m. 14(27). The Case of Richard Fielder, in Relation to the Petition of the Waggoners.

816. m.14(28). The Case of John Littlehales, against the pretended Petition of the Waggoners travelling the Northern Roads of England, etc.

883. h. 16. The Laws of Sewers; or the Office and Authority of Commissioners of Sewers. 2nd edition. London, 1732.

982. b. 22. A Description of the River Thames, etc., with the City of London's Jurisdiction and Conservacy thereof proved, both in point of Right and Usage, by Prescription, Charters, etc....to which is added... Observations...also of the Water Carriage on the River Thames.... London, 1758.

1028. h. 24. The Methods proposed for making River Dunn Navigable, and the Objections to it answered. With an Account of the Petitioner's Behaviour to the Landowners. 'To which is annexed, a Mapp of the River, and the Reasons lately Printed for making it Navigable, with the Advantages of it. London, 1723. 1130. c. 43 (2). Statement of the General Laws respecting Highways, and Turnpike Roads; including the Substance of the New Acts. London, [1825?].

1138. b. 11. The Ancient Trades Decayed, Repaired Again: Wherein are declared the several Abuses that have utterly impaired all the Ancient Trades in the Kingdom;.... Written by a Countrey Tradesman. London, $16 \pi 8$.

1246. 1. 16 (1). Act 7 Geo. I, Stat. 1, c. 15. An Act for making the Rivers Mercy and Irwell navigable from Liverpool to Manchester, in the County Palatine of Lancaster. 
1246. 1. 16 (3). An Act for making a Navigable Cut, or Canal, from the River Trent, at or near Willen Ferry in the County of Derby, to the River Mersey, at or near Runeorn Gap.

1302. g. 8 (3). Canal between the Eastern and the Western Seas. Newcastleupon-Tyne, 181\%. [A series of reports of various meetings, regarding better communication between Newcastle and Carlisle, taken from local newspapers of that year.]

1396. e. 22 (4). Ruminations on Railways. No. I, Railway Speculation; No. II, The Railway Board of Trade. London, 1845.

1396. g. 13. Railways; their Uses and Management. London, 1842.

1396. g. 21. Railways and the Board of Trade. 3rd edition. London, 1845.

1396. 9.49 (13). The Amalgamation of Railways considered as affecting the Internal Commeree of the Country. London, 1846.

1851. b. 2(15). Begin: Pilkington, Mayor. [A Proclamation of the London Common Council.] [London, 1691]

1865. c. 17 (28). The Case of many Coaehmen in London and Westminster, and within the Weekly Bills of Mortality, Lieensed according to the Act for Licensing Hackney-Coaches, but yet turned out by the present Commissioners. [London, 1670 ?]

1879. e. 4 (28). The Case of the Waggoners of England, Humbly presented to the Consideration of Parliament. [1700?]

1890. e.9. Plans, Prospectus, Reports, and Minutes of Evidence, in reference to the London and Birmingham Railway. London, 1832-65.

1890. e.4 (5\%). Proposals for Raising by Subscription the Sum of $£ 400,000$ in Shares of $£ 100$ for the Purpose of building and maintaining a Briclge over the River Thames, from the South side of the said River, at or near...Horse Shoe Alley,...to the Bottom of Queen Street, Cheapside, in the city of London. London, 1810.

2064. a. A General History of the County of Norfolk, intended to eonvey all the Information of a Norfolk Tour, with the more extended Details... 2 vols. Norwieh, 1829.

2099 (5). An Essay to shew the Advantages that will follow the Progressive Formation of Railways throughout the Kingdom. By E. P. London, 1836.

2390. Traets on the Proposed Stamford Junction Navigation. Stamford, [1810-11].

63r6. b. 28 (2). Bye Laws marle by the Trustees of the River Lee Navigation; and Penal Clauses in the Acts of Parliament, passed for improving, extending, and preserving the Navigation of the River Lee; from the Town of Hertford to the River Thames. Hertford, 1827.

6426. de. 13. An Act for better Regulating the Poor; Maintaining a Nightly Wateh; Lighting, Paving, and Cleansing the Streets, Rows, and Passages; Providing Fire-Engines and Firemen, and Regulating the Haekney-Coaelimen, Chairmen, Carmen, and Porters, within the City of Chester. London, 1772.

6485. c. 11. A Brief Aceount of Wilkinson and Hetherington, two Notorious Highwaymen, who were executed at Morpeth...1821. Neweastle-upon-Tyne, 1821.

8223. e. 9 (12). The Case of the Unlieensed Hackney-Chairmen, usually Imploy'd within the Cities of London and Westminster and the Suburbs and Liberties thereof.

8223. e. $10(70)$. Prospectus of the Kentish Railway Company.

8223. e. 10 (101). l'rospectus of the Norfolk, Suffolk, and Essex Rail-Road Company. 1825. 
8223. e. 10 (116). Prospectus of the Patent Steam Carriage Company, for England and Wales. [1825]

8223. e. $10(14 \tau)$. Prospectus of the Surrey, Sussex, and Iants Railroad Company. London, 1825.

8223. e. $10(148)$. Prospectus of the Surrey, Sussex, Hants, Wilts, and Somerset Rail-Road Company. Lothbury, 1825.

8223. e. 10 (149). Taunton Great Western Rail-Road Company. [Resolutions drawn up] At a Meeting of Land-Owners and Others, resident in Taunton and its Neighbourhood the Expediency of forming a Rail-Road from...Taunton to Bristol, and from Taunton to Exeter, with a Branch to Tiverton. Taunton, 1825.

8223. e. 10 (151). Proposed Tontine Bridge across the Swale, at or near King's Ferry, Islc of Sheppy.

8229. bbb. 60. Considerations on the Probable Commerce and Revenue that may arise on the Proposed Canal bctween Newcastle and Maryport. Carlisle, 1807.

8235. a. 71. The Railways of England; containing an Account of their Origin, Progress, and Present State...together with a Map. London, 1839.

8235. aaa. 5. History of the Darlington and Barnard Castle Railway : with Notices of the Stockton and Darlington, Clarence, West Hartlepool, and other Railways and Companies in the District. By an Inhabitant of Barnard Castle. London, 1877.

8235. b. 57 (1). The Carriers' Case Considered in Reference to Railways. London, 1841.

8235. c. 72. Railway Management; or how to make Ten Per Cent. London, 1860.

8235. cc. 41 (1). An Authentic Description of the Kennet and Avon Canal. To which are added, Observations upon the Present State of the Inland Navigation of the South-Western Counties of England; and of the Counties of Monmouth, Glamorgan, and Brecon, in South Wales. London, 1811.

8235. d. 27. Railways and Shareholders; with Glances at Railway TransactionsShareholders' Powers-Accounts and Audits-Railway Meetings-Defective Legislation, etc. By an Edinbro' Reviewer. 2nd edition. London, 1849.

8235. ee. 4 (1). Oxford and Didcot Railway Bill. Copy of the Evidence taken before a Committce of the House of Commons. Oxford, [1848].

823.5. ee. 12 (1). Reasons in favour of a Direct Line of Railroad from London to Manchester. London, 1846.

8235. h. 4.4. Remarks relating to a Canal intended to be made from the City of Chester, to join the Navigation from the Trent to the Mersey, at or near Middlewich. Chester, 1770.

8245. bb. 14. A Letter to the Inhabitants of Hertford [as to the desirability of Turnpike Trusts working together to secure the best results]. [1771?]

87r5. b. 49 (1). Reasons against the Bill now depending in Parliament, for the Scouring out and Deepening of the River Nene.... Cambridge, 1754.

87r5. c. 66. Extracts from the Book of Minutes of the Commissioners, and from Reports of Engineers; with other matters relating to the Wear Navigation Act. Sunderland, 1819.

8775. f. 20. Considerations on the Idea of Uniting the Rivers Thames and Severn through Cirencester, with some Observations on other intended Canals. London 1782.

8776. a. 17. A Short Narrative of the Proceedings of the Gentlemen, concerned in obtaining the Act, for building a Bridge at Westminster... London, 1738.

8776. a. 45. Reflections on the Gencral Utility of Inland Navigation to the 
Commercial and Landed Interests of England; with Observations, by Publicola, on the Intended Canal from Bimingham to Worcester, etc. London, [N.D.]. 8776. aaa. 33. Facts and Arguments respecting the Great Utility of an Extensive Plan of Inland Navigation in Ireland. Dublin, 1800.

8776. b. 40. Considerations on the Proposed Cut from the Medway to the Thames, ....and its probable Effects on the Navigation of the Medway. London, 1827.

8r76. c. 14. Thames Navigation. Observations upon the Evidence adduced before the Committee of the House of Commons, upon the late Application to Parliament for a Bill for making a Navigable Canal from the River Kennet...to join the Basingstoke Canal, etc. Maidenhead, 1825.

8776. c. 21. Proposals at Large for the casy and effectual Amendment of the Roads, by some further Necessary Laws and Regulations, concerning the Wheels of all Carriages;....By a Gentleman. London, 1753.

8776. ee. 17 (6). A Treatise on Inland Navigation. Salisbury: Printed by B. C. Collins, 17s8. [Probably Collins was also the author.]

10,347. e. 13. Tables for the Calculation of Lock Dues, payable upon the Calder and Hebble Navigation by virtue of an Act of Parl. (5 Geo. IV). Halifax: Printed for the use only of the Company of Proprietors of the Calder and Hebble Navigation, 1825.

10,348. a. 5. Meine Fussreise durch die drey brittischen Königreiche. Voran einige Nachrichten von dem Feldzuge in Champagne. Von einem französischen Offizier. Riga, 1797.

10,348. cce. 56. North of England and Scotland in 1704 [A Journal published from the Original MS. of an unknown author]. Edinburgh, 1818.

10,349. a. 1. A Brief Description of England and Wales; containing a Particular Account of each County.... London, [1780?].

10,349. bb. 17. A New and Accurate Description of the Present Great Roads and the Principal Cross Roads of England and Wales commencing at London, and continued to the farthest Parts of the Kingdom, with the several Branches.... London, 1756.

10,349. g. 11. Narrative of the Journey of an Irish Gentleman through England in the Year 1752. Edited (by Henry Huth) from a Contemporary Manuscript, with a few illustrative Notes. London, 1869.

10,815. c. 35. Will of the Duke of Bridgewater. London, 1836.

B. 263. (4). Facts and Reasons Tending to shew, that the Proposed Canal, from the Trent to the Mersey, ought not to terminate at Northwich and Burton; and to prove, That this Plan hath been well digested and hath not wanted public Notoriety.

B. 263. (5) and (7). An (engraved) Plan of the Intended Navigable Canal from Basingstoke to the River Wey; and a List of Landowners through whose Grounds the Basingstoke Canal is intended to pass.

B. 263. (6). Basingstoke Canal Navigation. Supposed Annual Carriage on the said Canal, \&c. [1786 or 1787]

B. 503. (5) and (6). Reports of the Engineers appointed by the Commissioners of the Navigation of the Rivers Thames and Isis to survey the State of the said Navigation from Lechlade to Days Lock.... Printed 1791.

B. 503. (7). A Report of the Committee of Commissioners of the Navigation of the Thames and Isis, appointed to Survey the Rivers from Lechlade to Whitchurch, 1791. Printed at Oxford, 1791.

B. 504. (2). An Address to the Public on the New Intended Canal from Stourbridge to Worcester; with the Case of the Staflordshire and Worcestershirc Canal Company. 1786 . 
B. 504. (3). Reflections on the General Utility of Inland Navigation to the Commercial and Landed Interests of England; with Observations on the Intended Canal from Birmingham to Woreester, and some Strictures upon the Opposition given to it by the Proprietors of the Staffordshire and Worcestershire Canal. It is signed "Publicola."

B. 504. (4). A Vicw of the Advantages of Inland Navigations: with a Plan of a Navigable Canal, intended for a Communieation between the Ports of Liverpool and Hull. London, 1765. [The author was probably R. Bentley, partner of Josiah Wedgwood.]

C. 32. d. 8. A Direetion for the English Traviller, by which he shal be inabled to Coast abont all England and Wales åc. [London, 1643] It contains 'A Brief Direetor for those That would send their Letters to any parts of England, Scotland, or Ireland. Or, a List of ail the Carriers, Waggoners, Coaches, Posts, Ships, Barks, Hoys, and Passage Boats that come to London, from the most parts and places, by Land and Sea.'

C.T. 217. Letter [of W. W. Whitmore] to Lord John Russell on Railways. London, 1847.

C.T. 309. (7). Report of the Proeeedings of a Public Neeting of the Inhabitants of...Liverpool... [to consider the Rates of Carriage to and from Liverpool].

E. 856. (4). An Aet of Common-Councell made the eleventh day of September, in the Yeare of our Lord 1655. For the better avoiding and prevention of Annoyances within the City of London, and Liberties of the same. [London], 1655.

E. 927. (4). The Devil's Cabinet Broke Open: or a New Discovery of the Highway Thieves. Being a Seasonable Adviee of a Gentleman lately converted from them, to Gentlemen and Travellers to avoyd their Villanies.... London, 1657.

E. 1063. (59). An Ordinanee for Better Amending and Keeping in Repair the Common Highwaies within this Nation. London (Mar. 31), 1654.

E. 1064. (5). An Ordinance of Explanation of a Former Ordinanee, Entituled, An Ordinance for Better Amending and Keeping in Repair the Common Highwaies within this Nation. May $16,1654$.

E. 1064. (18). An Ordinanee for the Regulation of Hackney Coachmen in London and the Places Adjaeent.

E. 1064. (38). An Ordinanee for the Giving Libertie for the Carrying of Millstones, Stone, Timber, ete. Sept. 2, 1654.

G. 6463. (228). Articles set down by the Right Worshipfull Thomas Randolph Esquier, Master and Comptroller generall of all her Majesties Posts, and straightly by him commanded to be kept by the Postes from London, to the Northerne borders against Scotland.... London, 1583.

G. 6463. (232). Orders set downe and allowed by the Lordes of her Majesties Privie Counsell, and appoynted to be put in print for the Postes betweene London and the borders of Scotland. [At Westminster, Jan. 14, 1583] [1583]

K. 6. 58 (e). Basingstoke Canal Navigation.

Maps 46. b. 23. A Book of the Names of all Parishes, Market Towns, Villages, Hamlets, and smallest Plaees, in England and Wales... London, 1657.

Maps 46. b. 26. A Book of the Names of all Parishes, Market Towns, Villages, Hamlets, and smallest Places, in England and Wales. London, 1677.

Maps 88. d. 13. Doeuments and Plans relating to Canals of England.

T. 100*(14). 'The Case of the River Derwent, in respect of Navigation, and of the Bill now in Parliament coneerning the same. [1705 (?)] 
T. 115\%. (2). The Fingerpost; or Direct Road from John-o'-Groat's to the Land's End: being a Discussion of the Railway Question. London, [1825?].

T. 1157. (4). Highways Improved. A Letter to a Menber of Parliament on the Expedieney of Appointing County or District Surveyors of Highways. London, 1825.

T. 1371. (18). The Probable Effects of the Proposed Railway from Birningham to London Considered. London, 1831.

T. 1860. (3). A Journey to England. With some Account of the Manners and Customs of that Nation. London, 1700.

\section{SERIAL PUBLICATIONS}

Annual Register.

Antiquary, 'The.

Archaeologia: or Miscellancous Tracts relating to Antiquity. Published by the London Society of Antiquaries. London, 1770-present time.

Archaeologia Aeliana: or Miscellaneous Tracts relating to Antiquity. Published by the Society of Antiquaries, of Newcastle-upon-Tyne, New Series.

British Almanac and Companion. London, 1829-46.

Camden Society. Annals of the First Four Years of the Reign of Quecn Elizabeth by Sir John Hayward, Knt. Edited from Harl. MS. 6021, by John Bruce. London, 1840.

Camden Society. Wills and Inventories from the Registers of the Commissary of Bury St Edmunds and the Archdeacon of Sudbury. Edited by Samuel Tymms. London, 1850.

Camden Society. Letters and Papers of the Verney Family down to the End of the Year 1639. Printed from the Original MSS. in the possession of Sir Harry Verney, Bart. Edited by John Bruce. London, 1853.

Chetham Society Publications. Vol. xuvi contains The Portmote or Court Lcet Records of the Borough or Town and Royal Manor of Salford, from 1597 to 1669 inclusive. Transcribed and edited by J. G. de T. Mandley. 1902.

Vol. xxy contains the Continuation of the Court Leet Records of the Manor of Manchester, A.D. 1586-1602. Compiled and edited by John Harland, 1865.

Chetham Society Publications. Vols. Lxvin and Lxxı, Collectanea relating to Manchester and its Neighbourhood at Various Periods. Compiled, arranged, and edited by John Harland, F.S.A. Printed for the Society, 1866 and 1867.

The Commercial and Agricultural Magazine, 1799-1802, continucd as The Agricultural Magazine, 1802- .

Edinburgh Review. Vol. xxxil (1819), pp. 477-87; Vol. cxix (1864), pp. 340-68.

Gentleman's Magazine.

The Grand Magazine of Universal Intelligence, and Monthly Chronicle of Our Own Times. 3 vols. London, 1758-60.

Highland Society of Scotland. Prize Essays and Transactions of the Highland Society of Scotland. Vol. vi (Edinburgh, 1824), pp. 1-146, deals with Railroads in a series of Essays edited by Robert Stephenson.

Local Notes and Queries. 7 vols. (Birmingham Free Reference Library, No. 144,953.)

The London Magazine; Or, Gentleman's Monthly Intelligencer. 27 vols. London, 1732-58.

The London Magazine. Vol. I, N.S., 1825.

Memoirs and Procecdings of the Literary and Philosophical Socicty of Manchester. 2nd series, Vol. III (1819), and 4tll series, Vol. vill (1894). 
Monthly Magazine.

Oxford Historical Socicty. Collectanea. 4 vols. Oxford, 1885-1905.

Quarterly Review, The. Vols. xxxil and xcvil. London, 1825 and 1855.

Quatrième Congrès International de Navigation Intérieure, tenu à Manchester en 1890. Rapports des délégués Français sur les travaux du Congrès. Paris, 1892.

Railway Chronicle, 1844-49. London, 1844-49.

Railway and Commercial Journal, Herepath's. Vols. IX-XI. London, 1847-49.

Railway Magazine, The, and Annals of Science, by John Herepath: containing copious accounts of all Railways at Home and Abroad, N.S., Vols. I-vi. London, 1836-39.

Railway Times. Vols. I-XiI (1838-49). London, 1838-49.

Repertory of Arts and Manufactures, The. 16 vols. London, 1794-1802; continued as The Repertory of Arts, Manufactures, and Agriculture, consisting of Original Communications, etc. 2nd series, 46 vols. London, 1802-25.

Royal Statistical Society, Journal of the. London, 1839-present time.

Transactions of the Cumberland and Westmorland Antiquarian and Archaeological Society, N.S., Vols. I-Iv. Kendal, 1901-04.

Transactions of the Lancashire and Cheshire Antiquarian Society. Manchester, 1883-present time.

\section{NEWSPAPERS}

The Bath Chronicle. Jan. 11, 1787-Jan. 8, 1789.

Birmingham Advertiser, 1833. Birmingham, 1833.

Aris's Birmingham Gazette. (Birmingham), 1740-1833.

The Birmingham Journal, 1825-34. Birmingham, 1825-34.

Bonner and Niddleton's Bristol Journal. (Bristol), Jan. 14, 1775-Dec. 23, 1786.

The Bristol Gazette and Public Advertiser. (Bristol), Aug. 7, 1777-May, 15, 1788.

The Bristol Liberal. Jan. $7,1832$.

The Bristol Mercury. June 30, 1832-Oct. 5, 1833.

The Constitutional Chronicle. (Bristol), 1780-82 (irregular numbers only).

Felix Farley's Bristol Journal. (Bristol), Nov. 2, 1776-May 17, 1788; Nov. 17, 1832-

Dec. 13, 1834.

Sarah Farley's Bristol Journal. (Bristol), April 27, 1782-August 3, 1782.

The Chronicle of Bristol. Aug. 1, 1829-Jan. 1, 1830.

The Cambridge Chronicle and Journal, from Nov. 2, 1810-Nov. 3, 1815.

Glocester Journal, 1789-91. Gloucester, 1789-91 (irregular numbers only).

Hampshire Advertiser and Salisbury Guardian. Southampton, 1832-34.

The IIampshire Telegraph and Sussex Chronicle. 1814-19.

Hereford Journal. April 20, 1803-Dcc. 4, 1805 (irregular numbers only).

Hull Advertiser. 1834-35.

Leeds Intelligencer, 1758-1836. Leeds, 1758-1836.

Billinge's Liverpool Advertiser, 1823-28; continued as The Liverpool Times, 182932. Liverpool, 1823-32.

The City Mercury: or, Advertisements concerning Trade. London, Nov. 4, 1675; July 4, 1692; March 13, 1693; March 20, 1693; March 27, 1693; June 11, 1694; Dec. 10, 1694.

The County Chronicle and Weekly Advertiser, for Essex, Herts, Kent, Surrey, Middlesex, Berks, etc. London, 1818-36.

Domestic Intelligence, or News both from City and Country. London, Oct. 24, 1679- ; continued as The Protestant (Domestick) Intelligence, or News both from City and Country, from Jan. 16, 1680, ou. London, 16r9-82. 


\section{Bibliograply}

The Economist, Weekly Commercial Times, and Bankers' Gazette, 1844-47. London, 184t-47.

The London Evening Post. (London), Jan. 20-22, 1732-36.

The Gazetteer and Ncw Daily Advertiser. (London), Feb. 27, 1787-April 4, 1788.

The General Advertiser. (London), Feb. 26, 1785-May 21, 1787.

The Morning Chroniele and London Advertiser. Jan. 8, 1785-April 1, 1786.

The Morning Chronicle. (London), April 1, 1791-April 11, 1792.

The Morning Post and Daily Advertiser. (London), July 20, 1791.

The Oracle. (London), March 22, 1792-Sept. 22, 1792.

The Public Advertiser. (London), April 8, 1786-Oct. 22, 1793.

The St James Chronicle. (London), Dec. 7, 1786-Aug. 29, 1793.

The London Times. Mareh 3, 1794-Nov. 8, 1847 .

The Manehester Advertiser. (Manehester), Aug. 30, 1825 to end of 1826.

Wheeler's Manehestcr Chroniele, 1831-32. Manehester, 1831-32.

Manchester Courier, 1825-2\%. Manehester, 1825-27.

Manchester Gazette, 1824-31. Manchester, 1824-31.

Manchester Guardian, 1825-46. Manchester, 1825-46.

The Neweastle Courant. (Newcastle), April 16, 17r4-Dec. 4, 1794; 1821-32.

Oxford Gazette and Reading Mereury, 1767-71. Reading, 1767-71.

Jackson's Oxford Journal. July 29, 1780-Nov. 2, 1793.

The Reading Mercury and Oxford Gazette. Reading, 1792-96.

Sheffield Iris, 1828-37. Sheffield, 1828-37.

Ward's Sheffield Public Advertiser. (Sheffield), 1760-65.

The Shrewsbury Chronicle or Wood's British Gazette. (Shrewsbury), Feb. 20, 1773-April 15, 1775.

The York Herald, County and General Advertiser. York, 1812-14.

\section{GUIDE BOOKS}

Bath. The New Bath Guide, or useful Poeket Companion for the Year 1784.

The New Birmingham Directory, and Gentleman and Tradesman's Compleat Memorandum Book. (Printed by and for M. Swinney.) Birmingham, 1774 (?).

The Birmingham Directory; or Merchant and Tradesman's Useful Companion. Birmingham, $17 \% 7$.

Chapman's Birmingham Directory. Birmingham, 1803.

Brit. Mus. 579. e. 41 (1). Brighton New Guide; or a Deseription of Brighthelmston and the Adjacent Country. London, 1800.

The Tradesman's and Traveller's Poeket Companion: or the Bath and Bristol Guide.... Bath, [1750?)].

Matthews, William. Matthews New Bristol Directory, for the Year 1793-94, etc. Bristol, [1793-94].

Bristol. The New History, Survey and Deseription of the City and Suburbs of Bristol, or Complete Guide, and informing and useful Companion for the Residents and Visitants of this ancient, extensive and inereasing City, etc. Bristol, 1794.

A Description of the University, Town, and County of Cambridgc...Direetions coneerning the Posts, Roads, Stage Coaches, Waggons, ete., to and from Cambridge. Cambridge, 1796.

The Chester Guide. Chester, 1795.

Battle's Hull Direetory for the Year 1791. IIull, [1791].

A Complete Guide to All Persons who have any Trade or Coneern with the City of London, and Parts adjacent; containing the Names of all streets...An 
Account of all the Stage-Coaches, Carriers, \&c. (for the years 1740, 1772, 1774, 1783). London, 1740, 1772, 1774, 1783.

(W.) Holden's Annual List of Coaches, Waggons, Carts, Vessels, \&c., from London, to all parts of England, Wales, Scotland, and Parts of Ireland, including the villages near the Metropolis. London, 1802, 1809.

Brit. Mus. 579. c. 43 (3). The Ancient and Modern History of Portesmouth, Portsca, Gosport and their Environs. Gosport, [N.D.]

Southampton. The Southampton Guide for 1774 and 1797 .

The York Guide (1796): Containing a Description of the Cathedral and other Public Buildings...to which is added...Times of the Posts coming in and going out; Mail and other Coaches, etc. 2nd edition. York, 1796.

\section{MAPS}

Ogilby, John. Itinerarium Angliae, or, A Book of Roads, wherein are contained the Principal Road-Ways of His Majesty's Kingdom of England and Dominion of Wales. London: Printed by the Author at his House in White-Fryers, M.DC.LXXv.

Brit. Mus. Maps 86. d. 10 (33). A New Map containing all the Cities, Market Townes...Roads, etc. London, 1696.

England Exactly Described, or a Guide to Travellers : in a Complcat Sett of Mapps of all the County's of England. London, 1715.

Brit. Mus. B. 264. (3). A Set of Fifty New and Correct Maps of England and Wales, \&c. with the Great Roads and Principal Cross-Roads, \&c. Shewing the Computed Miles from Town to Town. A Work long wanted, and very useful for all Gentlemen that travel to any Part of England. All, except two, composed and done by Hermann Moll, Geographer. London, 1724.

Badeslade, Thomas. Chorographia Britanniae, or a set of Maps of all the Counties in England and Wales. (Comprises a Map for showing the great roads from London and a Map of all the cross roads.) London, 1742.

Bowles's New Traveller's Guide, throngh the Principal Direct and Cross Roads of England and Wales. London, [ca. 1750].

Armstrong, Mostyn John. An Actual Survey of the Great Post-Roads between London and Edinburgh. London, 1r76.

Paterson, Daniel. A New and Accurate Description of all the Direct and Principal Cross Roads in Great Britain. 4th edition. London, 1778. Fifth edition, corrected, and improved, with Additions, London, 1781. Fifteenth edition of same, London, 1811.

Kitchin, Thomas. The Roads in England and Wales. Engraved from the latest Surveys, by Thomas Kitchin, Hydrographer to His Majesty. 1783.

Brit. Mus. 1190.7. A Map of England, shewing the Lines of all the Navigable Canals, with those which have been proposed.... 1795.

A Collcction of Prospectuses, Maps, and other Documents relating to Early Railways, Canals, etc., 1793-1846. Birmingham Free Central Library, Iron Room, Box No. I11. (Some fine material.)

Enouy, Joseph. A New Map of England and Wales, compiled from Actual Surveys of the Counties...with the Turnpike Roads according to the New Admeasurements, Navigable Rivers and Canals. London, 1801.

Brit. Mus. Maps 30. a. 47. Map of England and Wales with Part of Scotland [showing clearly the navigable canals and rivers]. 1802. 
Smith's New Map of England and Wales, with Part of Scotland, including the Turnpike and principal Cross Roads, the Course of the Rivers and Navigable Canals, \&c. London, 1806. Ibid., for the year 1818, and for 1827.

Owens, William. New Book of Roads, or a Description of the Roads of Great Britain. New cdition. London, 1814.

Mogg, Edward. A Survey of the Highroads of England and Wales, with Part of Scotland...exhibiting at one View...the various Branches of Roads and Towns to which they lead, together with the actual Distance of the sanc from the Main IRoad, Rivers, Navigable Canals, Railways...\&c. London, 1814-15. Brit. Mus. Maps 47. c. 14.

Cary, John. Cary's New Itinerary : or an Accurate Delineation of the Great Roads, both Direct and Cross, throughout England and Wales: with many of the principal roads, in Scotland, from an Actual Admeasurement. Fth edition, with Improvements. London, 1817.

(Huerne de Pommeuse.) Des Canaux Navigables. Atlas de la Navigation Intérieure de l'Angleterre et de la France. 1819. Paris, 1822.

Cheffins's Official Maps of the London and Birmingham, and the Grand Junction Railways. London, 1839.

Brit. Mus. Maps 92. d. 29. Wyld's Railroad Map of England and Wales [showing also those in progress and those projected, and outlining the high roads]. London, 1840.

A Map of England, Wales, and Scotland, describing all the Direct and Principal Cross Roads in Great Britain, and showing the Railroads, Great Rivers and Navigable Canals. London, 1841.

Bradshaw's Railway Companion, containing the Times of Departure, Fares, etc., of the Railways of England, etc. Nanchester and London, 1842.

Cary's Reduction of his Large Map of England and Wales, with Part of Scotland; comprehending the whole of the Turnpike Roads, with the Great Rivers and the Course of the different Navigable Canals. London, [1850?].

Collins' Railway Map of England and Wales and Part of Scotland, shewing the Inland Navigation by means of Rivers and Canals, together with the Rail and Principal Turnpike Roads, from the most recent surveys. London, [1852?].

England and Wales showing the Railroads, completed, proposed, and in Progress. London, [1853].

Bett's New Map of England and Wales compiled from the latest Parliamentary Documents, showing the Roads, and Railroads. London, [ca. 1853].

Stanford's Railway and Road Map of England and Wales. London, 1862.

Brit. Mus. Maps 29. a. 37. A Pocket-Gnide to the English Traveller: Being a Compleat Survey and Admeasurement of all the Principal Roads and most considerable Cross-Roads in England and Wales. In One Hundred Copper Plates. London, 1719.

Brit. Mus. 1175. (106). A New Map of England and Wales, comprehending the whole of the Turnpike Roads, with the Great Rivers and Navigable Canals. London, 1804. Very complete in its details.

Brit. Mus. C. 32. d. 8. A New Map of the Kingdome of England and Principality of Wales, taken out of I. S. (i.e., John Speed). London, 1673. It is contained in 'A Dircction for the English 'Traviller.' London, 1643.

Brit. Mus. 1205. (9). A New Travelling Map of England, Wales and Scotland; Drawn from all the Surveys which have hitherto been made of particular Counties, describing the Direct and principal Cross Roads, Cities, Boroughs, Market Towns and Villages, to which is added the actual distance from one 
Market Town to another, and exact admeasurement of each place from London. By Edward Mogg. London, 1810. Excellent map.

Brit. Mus. 577. e. 2. The Traveller's Guide: or, a Most Exact Deseription of the Roads of England. Being Mr Ogilby's Actual Survey, and Mensuration by the Wheel, of the Great Roads from London...together with the Cross Roads. London, 1699. 'This is simply a pocket edition of Ogilby's 'Itinerarium Angliae.'

Brit. Mus. 1175. (45). A New Map of England and Wales, describing all the Turnpike and principal Bye Roads, the Great Rivers and Navigable Canals. By Robcrt Rowe. London, 1819. Great detail.

Brit. Mus. 1205. (10). Wallis's New Travelling Map of England and Wales, with Part of Scotland, on which are delineated the Direct and Principal Cross Roads,... Also the Course of the Great Rivers.... London, 1815. Clear representation of the roads because avoiding a mass of other details.

Brit. Mus. 1175. (17). 'The Post Roads through England and Wales; by T. Jefferys, Gcographer to His Majesty. [London, 1792] Omits all other roads except post roads.

Brit. Mus. K. 5. 68. Bowles's New Pocket Map of England and Wales, Revised and corrected from the best Authorities; with the Addition of New Roads, and other Improvements. By D. Paterson. London, 1773.

Brit. Mus. K. 191. g. 13. Nouveau Théâtre de la Grande Bretagne, Vol. Iv. After the first two plates, there is 'A New Map of South Britain or England and Wales. Containing all the Cities and Market Towns with the Roads from Town to Town...' London, 1720. Does not show London as the centre of a series of great roads to all parts of the kingdom; but shows many smaller places than London which were greater road centres than it.

Brit. Mus. K. 5. 52. A New Map of England. Containing the Adjacent Parts of Scotland, Ireland, France, Flanders and Holland. Shewing the true Scituation and Distance of London from Edinburgh, Dublin,.... With a Description of the Post Roads, and their several Branches from Town to Town,....By R. Greene. London, [1690]. Does not show such a vast network of roads as some other maps of this time.

Brit. Mus. K. 5. 60. The South Part of Great Britain, called England and Wales. Containing all $y^{\mathrm{e}}$ Cities, Market Towns, Boroughs,...with $\mathrm{y}^{\mathrm{e}}$ Names of ye Rivers,...Great or Post Roads, and principal Cross Roads \&c. By Hermann Moll, Geographer. London, 1710.

Brit. Mus. K. 5. 61. A New and Accurate Map of England and Wales. Describing in a more distinct and correct manner than any other Map Extant, all the Cities, Boroughs, \& Market Towns \&c. also all the direct and principal Cross Roads, with the post Towns and computed distances between Town and Town....By E. Bowen, Geographer. London, 1734. Roads clearly delineated.

Brit. Mus. K. 5. 62. Le Royaume d’Angleterre. Divisé en Comtez et Baronies. Dressé sur les dernières Observations par et chez le $\mathrm{S}^{\mathrm{r}}$ le Rouge Ingénieur Géographe du Roi. Paris, 1745. Gives the great roads only.

Brit. Mus. 1205. (4). The Traveller's Guide or Ogilby's Roads Epitomized. A Sett of Tables in which are described all the grand Roads \& several of the Cross Roads of England and Wales....By I. V. Kircher. London, [1706]. Shows a vast network of roads at that time, as does also

Brit. Mus. Maps 86. d. 10 (33). A New Map Containing all the Citties, Market Townes, Rivers, Bridges, \& other considerable Places in England and Wales. Wherein are delineated $y^{\mathrm{e}}$ Roads from Towne to Towne,... London, [1696]. 
Brit. Mus. K. 5. 88. The Traveller's Companion or the Post Roads of England and Wales; with Distanees in Measured Miles. By the late John Rocque, Chorographer to the King. London, 1771.

Brit. Mus. K. 5. 84. The Roads of England according to Mr Ogilby's Survey. London, [1712]. Cireular map of the great roads.

Brit. Mus. Maps 89. e. 3 (50). $\Lambda$ New Mapp of the Kingdome of England, representing the Prineedome of Wales, and other Provinces, Cities, Market Towns, with the Roads from Town to Town. Amsterdam, [1590]. This volume gives also a complete series of county maps.

Brit. Mus. 1220.4. Smith's New Map of the Railways and Canals of England, Wales and Scotland. Containing also the prineipal Roads, and the distanees of the plaees from London. London, 1838. Gives dates of Canal Aets.

N.B. The foregoing are only a few of the large number of maps consulted in order to secure the greatest degree of aceuracy in this work. 


\section{INDEX}

Accommodations of trains, excessive, 599

Accounts, of railways, falsified, 598

Acts of Parliament, great cost of securing, $428-9$

Agriculture, advance of, in eighteenth century, 212-3 ; eflect of, upon roads, 213 ; profited much from canals, 4134 , and from railways, $487-8,534,591$

Aire and Calder Navigation, improvements of, 371, 377; opposed to Manchester and Leeds Railway, 567

Allen, Ralph, improvements by, in postal facilities, $323-1$

Amalgamation, of railwars, and its effects, $577,586-7,588$; fivoured when for the public good, 579,600 ; initial stages of , 581-2: progress of, 586-7, $640-1,643$; of all railways, advocated, 588 ; system of, 602-3 : supervision of, recommended, 640-3; incrcase of, after passage of Railway and Canal Traffic Act, 1854, 643, and reason therefor, 6.13

Assessment, provided for repair of roads, $52,56-7,59,61,78-9,105-6$; recommended, 216

Avon, river, navigation of, 181, 183

Barnsley Canal, construction of, 371

Bar tolls, 652-3

Basingstoke Canal, effect of, in reducing cost of carriage of goods, 4.5

Bell, Henry, connexion of, with steam navigation, 454

Berks and Wilts Canal, construction of, 375

Birmingham, connexion of, witl t London, 97 ; centre of llidiand canals, 370

Birmingham Canal, construction of, 370 ; consolidation of, with Birmingham and Fazeley Canal, 371; junction of, with Coventry Canal, $3 \sigma_{2}$

Birmingham and Fazeley Canal, construction of, 370 ; consolidation of, with Birmingham Canal, 371

Birmingham and Warwick Canal, construction of, 370

Birmingham and Worcester Canal, construction of, 370 ; opposition of, to rival canal, 398

Boston bridge, history of, 20-21

Bridges, responsibility for, $4,6,15,21-2$,
144; early, 14-15; repair and maintenance of, by piety and bequests, 15 , 17,30 , by returns from indulgences, $16,30,144$, by contributions at bridge chapels, 16, 144, by gilds, 18, 144, by receipts from tolls, 18-21; constantly in decay, 21; divided responsibility for, 22, 148, 153; tendency to making county responsible for, $22,151,350-3$; customary liabilities for, $147 \mathrm{ff}$.; royal aid to, 152-3; widening of, 154-5, 350,353 ; "gratuity bridges," 351 ; Glasburne Bridge case, 351; Lord Ellenborough's Act concerning, 352; administration of, 353-4

Bridgewardens, 19,149

Bridge, Westminster, construction of, $146-7$

Brindley, James, 361, 364, 366, 379, 384

Bristol, antagonism of, to rival market at Bath, 184; apathy of, toward Great Western Railway, 562 ff.

Calder Navigation, see Aire and Calder Navigation

Canal companies, organization of, 432-6 ; not usually public carriers, 435-6

Canal, pound-lock, first, 165

Canals, first suggested, 185-90; suggestion of, came from Holland and other countrics, 356; projection of first modern, 356; Bridgewater, 360-3 ; Trent and Mersey, 364-7; Staffordshire and Worcestershire, 367-8; Coventry, 368; Oxford, 368-9; in the Midlands, 370-3; in the north, 370-1; consolidation of, 371-2; Stroudwater, 373-4; Thames and Severn, 373-5; Kennet and Avon, 375; Berks and Wilts, 375; small, agitation for, 38991; inclined planes on, 391-2; "circular canal," suggested, 392 ; success of, 394; "canal mania" of 1792-3, 391-6; reasons for opposition to, 396404, 543-5; new, to safeguard older competitors from loss of revenue, 4001 ; opposition to, from coasting trade, 101 ; benefits anticipated from, 40410 ; benefits actually realized from, 410-16; advantages of, over river navigations, 415-6; operation of, financial results from, 416-21, 536, 545; some unprofitable, 416-8; 
proportion of successful and unsuccessful, 418-20; some profitable, 421-7; reasons for lack of success of, $427-32$, 536-7; carrying service on, organization of, 436-12; carrying service on, complaints against, 440-2, 536-8, 5435 , 555-6; introduction of steam on, 442-4; eflect of, on cost of carriage, 44.1-9; supposed advantages of, over railways, 494-5; constantly pleaded the claim of vested interests in opposing prospective railways, 495-6, 500-1, 536-40, 548-9, 551, 560; stimulated to improvement by railways, 593; revenues of, reduction of, due to railway competition, 634-5; decreased value of shares of, due to railway competition, 635-6 ; competition compcls them to make working agreements with railways, $636-8$; taken over by railways, $637-8$; legislative aid given to, to enable them to compete with railways, 638 , but this was nullified by railway aggression, 639-40; Railway and Canal Traffic Act, 1854, 642-3; progress of amalgamation of railways with, 643-4; some results of competition of railways with, 645-7; railway-controlled canals drove private carriers off the independent canals, 647 ; traffic of, drawn to railways, $647-9$; methods used by railways to take the traffic from, $647-8$; reasons for decline of, 647-59; disjointed state of, $649-50$; lack of unity of management of, 651; jealousy between, 652-3; chain of, broken up by railways purchasing strategic links, 654-6; easily hampered by drought, frost and flood, 656; failed to adapt themselves to progressive changes and to adopt business methods, 657 ; handicapped because unable to carry passengers, 658; psychological reason for decline of, 658-9; plans devised to maintain competition of, 661-3; present-day suggestions for waterway improvement, 663-4

Canal shares, unprofitable, 416-20, valuable, 421-7

Capital, required in business, saving of, by railways, $490,544,547$; waste of, by too much railway construction, 595

Caravans, 123

Carmen, in London, regulation of, 131-2

Carriage of goods, early, 8-9; during Tudor period, 43-5; early organization for, 44-5; charges for, to be assessed by Justices, 65 ; cost of, 91-3, 139-40; later organization for, 141-2; by river, cost of, compared with cost of land carriage, 206-9; by packhorse, 304; waggon carriagc substituted for pack-horse, 305-7; desire for regularity of, $208-9$; speed of, by stage waggons, 346-7; cost of, by stage waggons, $347-9$; cost of, decreased by canals, 410-11, 441-9; organization for, on canals, 436-42; defects of the service for, on eanals, 440-2; rate of speed in, by canals, 450-1; cost of, expected reduction by railways, $485-7,543-5$; speed of, incrcased by railways, $487-9,543$, $590 \mathrm{fl}$; certainty and regularity of, by railways, $489-90$; wholly inadequatc and too costly by canals, 543-5; cost of, reduced by railways, $590 \mathrm{tf}$.; systems of, on different railways, 624-6; by privatc carriers on railways, cessation of, 630-3

Carriers, combination among, increased prices, 64-5; their tratlic on western roads, 93 ; rates of, settled by .Justices, 140 ; organization of tralfic of, 141-2; methods employed by waggon carriers, 305-10; organization of, on canals, $435-46$; opposed construction of railways, 549; could not be allowed on railways, 574 ; how driven off railways, 630-3

Cast iron, wheels of, for early railways, 464; rails of, introduced, $464-5$; rails of, displaced by matleable iron, 467

Chairs, Sedan, introduced into England, 116-7; cost of, 128

Chapman, William, favoured small canals, 391

Chelmer, river, proposed navigation of, 183

"Circuiar canal," suggested, 392

Clergy interested in good roads, 8

Coaches, introduction of, 110 ; increasing use of, 103, 112 lf.; lackney, introduction of, 112-8; restrictions upon, 116-8; stagc, intreduced, 119-21; private, in London, 130; hackney, prolitable licenses of, 131; intense compctition among stage coaches after $1750,312-3$; coaching schedules harmonized with those of other conveyances, 313-5; organization of coaching business, 315-6; financial operation of stage, 316- 7 ; evils conneeted with operation of stage, $317-20$, 343,557 ; busincss sometimes increased by railways, 550-1, 611 , and sometimes reduced, 608-9; competition of, with steam vessels, 614 lf.; more heavily taxed than railways, $619-2]$, lience unable to successfully compete with railways, 619-22

Coaching establishments, opposed the construction of railways, 501-2, 549, 551 ; ruined by railways, 610-11; sometimes allied with railways, 612, 631

Coachmen and guards, inpositions of, 318

Coal, cost of carriage of, to Manchester and Liverpool, 359 
Coasting trade, antagonism of, to inland navigations, 401 ; competition of railways with, 665

Commissioners of navigations, their duties and authority, 194-6

Commissions of Sewers, purpose and authority of, 24

Compensation, of older canals by newer, $400-1,652-3$; paid by railways, 499 , 595

Competition, in coaching, 312-3, not always effective, 322-3; effect of, on fares, 343-4; on canals, 441-2; of carriers on same railway, impossibility of, 574; inter-railway, 577, 599; of railways, reduction of rates by, 577; of railways, efforts to maintain, 57780, Parliament knew not how to maintain, 580-1, 647; too much railway construction due to desire to maintain, 595; of railways with coaches, 605 ff.; of canals with railways, encouraged by special legislation, 638, but nullified by railway aggression, 639-40; some results of, between railways and canals, 645-6

Composition for tolls, 227, 230, 259-60 ; abolished, 233, 613

Consolidation of railways, encouraged by Parliament, 57 $7-8$; effect of, on rates and fares, $57 \%$; activity in securing, 580; why desired. 580-1; with canals and other railways, $583 \mathrm{ff}$; ; advantages of, 583; progress of, 586-7

Consolidation of trusts, advantages of, 280-3

Constables, with Churchwardens, to appoint statute duty days, 33

Construction of canals, extravagant cost of, 428-9; unwise, 429-31

Construction of roads, mechanical improvement of, suggestions for, 106-7, 264-5; bad methods of, 251-6

Cost of carriage of goods, see Carriage of goods

Court Leet, settled obligations of lord and tenant, 4 ; decay of its authority, 14 ; presentments for bridges before, 21

Court of Common Pleas, 643

Coventry Canal, construction of, 368 ; financial difficulties of, 372 ; consolidation of, with Oxford and Grand Trunk Canals, 372 ; junction of, with Birmingham Canal, 372; opposition of, to rival canal, 399

Custom, cflect of, in settling coach fares, 343

Dance, Sir Charles, and the steam carriage, 332

Dangers of coaching, $317-8$

Debts of turnpike trusts, 612-6 ; increased by railway competition, $616-9$

Dee, river, navigation of, 196-200; its early importance, 196; proposals for recovery of, 197-8; opposition to improvement of, 199 ; river turned into new channel, 199-200

Defects of canal carriage, 440-2

Direction of roads, frequently unfortunate,250-1 ; recommended improvement of, 265

Discrimination of railways as to passenger facilities, 600

Diversion of trathic by canals, 415

Diverting highways, 221

Dividends, railway, other considerations sacrificed to, 597-8

Don, river, navigation of, 202-6 ; opposition to improvement of, 202-3; financial dilficulties connected with, 203-5; discordant interests concerned witl, 205-6

Draining of the Fens, 190-3

Eastern Counties Railway, 568-9

Edge-rail and flanged wheel introduced, 465

Engineers, road, 84; introduction of, $266 \mathrm{ff}$.; Metcalfe, John, work of, 266-8; Telford, Thomas, work of, 268-76; Macadam, John Loudon, work of, 276-81

Eton College, opposition of, to Great Western Railway, 503, 561

Exe, river, navigation of, 164-5

Extraordinary tolls, 73-5

Fairs, 43, 44

Fares, passenger, determination of, 343; by steam vessels and coaches, $614 \mathrm{ff}$.

Farmers, attitude of, toward canals, 404-7, and toward railways, 503-4, 551 ; would derive advantages from railways, 534, 544, 558-9; benefits to, obtained from railways, 591-3

Fens, draining of the, 190-3

Financial manipulation, 596; see also Fraud and misrepresentation

Flasluing, 162, 431

Fraud and misrepresentation, in canal promotion, 427-8, 545; in railway promotion, 594; in railway accounts, 598 ; in railway finance, 601

Freight landling in quantity, cheaper by railway, 493

Fulton, Robert, agitation of, for small canals, 389-9]; work of, in steam navigation, 454

Gauge Act, $\mathbf{5 8 9}$

General Highway Act, provisions of, 218-23, 232-3

General Turnjike Act, provisions of, $218,223-7$; amended, 232

Gild of the Holy Cross, its work in repairing roads and bridges, 31

Gilds, interested in repairing roads and bridges, $6,30,31$

Glasburne Bridge case, 351

Grain trade, monopoly of, 167, 408 
Grand Junction Canai, construction of, 376-7

Grand Iunction Railway, formed, 542; system of carriage on, 625-6

Grand Trunk Canal, see Trent and Mersey Canal

Gray, Thomas, contribution of, to railways, 507-9

Great Eastern Railway, 569

Great Northern Railway, 567-8

Great Western Railway, 554 ff.; need of, 555-8; opposition to, 558-62; elforts toward securing, 563-4; broad gauge of, 589

Gurney, Goldsworthy, and the steam carriage, 330-2

Hackney coaches, introduction of, 112-8; opposition to, 113-4, 115-6; difficulties in licensing, $125 \mathrm{ff}$.

Hackney coachmen, difficulties of, 12530 ; evasion of the law by, 125-30; licenses of, very profitable, 131

Hadley, President A. T., quoted, $583 \mathrm{n}$.

Hancock, Walter, and the steam carriage, 330-1

Highway Act, General, provisions of, 218-23; amended, 232 ; provisions as aniended, 2:32-3

Highwaymen, 143

Holyhead road, condition of, 95-7, 2712 ; Telford's improvement of, 271-4

Horses, number used on waggons, 66-7, 68 ; number of, relation to amount of statute duty, 105; cost of kecping supply of, 320 ; coaching caused great destruction of, 320 ; employment of, anticipated decrease of, due to canals, 405, did not materialize, 413; anticipated decrease of employment of, due to railways, 493; employment of, on railways, 511 ; increased employment of, due to railways, 550-1

Huddersfield Canal, construction of, 371, 4.30

Hudson, George, 568, 584

Hull and Selby Railway, 564-5

Hulls, Jonathan, first applied steam to navigation, 452

Inclined planes, on canals, favoured, $391-2$; on railways, favoured, 510-11

Indulgences, granted for repairing roads or bridges, 6

Industrial Revolution, demanded greater transportation facilities, 357; aided by canals, 410-11

Industry, advance of, in eighteenth century, 211-2; an antieipated result of canals, 407 ; progress of, due to railways, 591

Informers, evils arising from, 67 n., $68-9$

Inland navigation, see Navigation, inland

Innkeepers, impositions of, on travellers, 319 ; ruined by railways, $610-11$
James, William, contribution of, to railways, 507, 509-10

Justices of the Peace, authority of, over roads, 34, 64, 221, over strcets of towns, 37 , over river carriage, 209

Kendal and Lancaster Canal, construction of, 371

Kennet and Avon Canal, construction of, 375

Laissez-faire doctrines, applicd to canals and railways, 572

Landed proprictors, interested in good roads, 7 ; refused the best line of road, 83-4; opposed construction of canals, 396, 403; opposed construction of railways, 497-500, 546-8, 551, 553, $558-9$; greatly benefited by railways, $527,534,558,591-3$

Law, of highways, evaded because not clear, 104-5; caused burdensome inequalities, 105; suggested changes in, 105-6

Lea, river, navigation of, improvement of, $26,165-8$

Lee, river, see Lea, river

Leeds and Liverpool Canal, construction of, 370,430

Leeds and Selby Railway, 564-5

Legal fees to secure Acts of Parliament, extortionate, 595-6

Legislation for coaching, infraction of, 319

Legislation for roads, $51 \mathrm{ff} ., 216 \mathrm{ff} ., 227-$ 33 ; contained gross inconsistencies, 218; agitation for simplification of, $218,227-32$; significance of amount of, 2:3-5; encouraged its own infraction, 242; evasion of, 245

Liverpool, growth of, 357-8, 514-5; poorly supplied with necessaries of life, 358-9

Liverpool and Birmingham Railway, $535 \mathrm{ff}$; need of, $535-8$; reasons for and advantages of the proposed line, 538-9; efforts toward sccuring, 5:3843; absorbed by Grand Junction Railway, 542

Liverpool and Manchester Railway, nced of, 514-21; plans for, 521-2; opposition to, 522-4; question of motive power for, 524-6: the first public general railway, 526 ; success of, 526-9; effects of, 527-8, 548, 589, 591 ; later financing of, 529-31; caused reduced revenues to adjacent turnpike trusts, 617

Liverpool and Wigan Canal, eonstruction of, 370

Loads carried on roads, too heavy, evils of, 243-4, 249-50

Location of canals, frequently unfortunate, 429-30

Location of roads, frequently bad, 
250-1; recommended improvement of, 265

London, streets of, in Tudor times, 36-7, in eighteenth century, 98-9, $103 \mathrm{n}$.; hackney coaches in, 125-31; regulation of carmen in, 131-2

London and Birmingham Railway, 543 ff.; need of, 543-5; early efforts to obtain, 545-6; opposition to, 546-9; advantages of the proposed, 549-51; later efforts to obtain, 551-3 ; finances of, 553-4.

London and Brighton Railway, 569

London and Dover Railway, 569

London and Southampton Railway, 564

London and South Eastern Railway, 569

Lug, river, navigation of, 183

Macadam, James, 280, 283, 618

Macadam, John Loudon, work of, as road engineer, 268-9, 276-81

Maceroni, Col. Francis, connexion of, with steam carriage, 330

Nalleable iron, used for rails, 466-7; displaced east iron rails, 467

Manchester, growth of, 357-8, 514-5; poorly supplied with necessaries of life, $358-9$

Manchester and Ashton - under - Lyne Canal, construction of, 371

Manchester and Bolton Canal, construction of, 371

Manchester and Leeds Railway, 566-7

Manchester and Sheflield Railway, 567, 601

Manufactures, new, established along eanals, 411

Markets, wider, their relation to roads, 211-2, 235; result from canals, 404-7, 411-2

Nathew, Francis, urged great use of inland waterways, 186-7; suggested canal between Isis and Avon rivers, $188-9$

"Maximum Rates Clause," 5r6-7

Nedway, river, navigation of, 169-71; opposition to navigation of, 170-1

Mersey, river, proposed improvenent of navigation of, $18:$

Mersey and Irwell Navigation Company, rates charged by, 208; monopolistic conditions of, raised freight rates, 516-9; inadequate facilities for the traffie, 519-20; great profits of $520-21$

Metcalfe, John, work of, as first road engineer, 266-8

Mileage duty, 317

Mills, on rivers, destroyed navigations, $162-3,170$; owners of, opposition to navigations by, 174, 176-80, 184, 397

Monasteries, obligation for road repair, 4: interested in having good roads, 8,29 ; elfect of their dissolution on roads, 29

Money, misapplication of, $67-8,80-2$,
240-1; methods of preventing, 257-9, 349

Monmouthshire Canal, bad construction of, 430; monopoly of, broken up by railway, 491

Monopoly, expected to be broken up by construction of new canals, 407-8; canal, broken up by railway, 490-2, 543,593 ; of farmers, broken up by railway, 503-4; of railways, essential to their business, 574; of railways, different from all others, 574; of railways, detrimental to the public, 600

Monorail system, of Henry R. Palmer, 513

Murdock, William, experiments of, with steam carriage, 328

Navigation, inland, see River navigation

Nen, river, navigation of, 180-1

Nene, river, see Nen, river

Newcastle and Carlisle Railway, 564

North Road, Great, condition of, 89-92

Norwich, to Yarmouth, navigation from, 25 ; to London, condition of roads from, 98

Ogle, connexion of, with steam carriage, 330

Operation of railways, defective, 599600

Ostentation in railway construction, 596

Outram, Benjanin, work of, in tramway construction, 465

Oxford Canal, construction of, 368-9; financial difficulties of, 372 ; consolidation of, with Coventry and Grand Trunk Canals, 372; proposed junction of, with London, 376

Oxford University, opposition of, to Great Western Railway, 503, 561

Pack-horses, organization of carrying trade by, 141-2

Palmer, John, established mail coaches, 324; improved transmission of mail, 325; his trouble in the General Post Office, 326-7

Parisli, responsibility of, for roads, 34; negligent of duty, $57-8$

Passenger travelling, see Travelling

Pauper labour, employed on roads, 242-3; discontinuance of, recommended, 260

Paving, Acts for, 12, evaded by householders, 13. 39

Paviour, appointment of, 13; his importance, $13,39,40$

Plateways, 463,464

Plough land, meaning of, 104-6

Pontage, 18-21

Pooling by railways, 582

Postal facilities, improvements of, 323-7

Post-cliaises, infraction of the law by, 319 ; expense of travelling by, 321-3 
Posting, organization for, $46-8,50,110$; cost of, $47-8,110,321-3$; increase in amount of , 320-1; extortionate charges for, 322-3; decrease of, due to railways, $608-9$

"Railroad Parliament," 601

Railway and Canal Traffic Act, 1854, 642-3

Railway Clearing House, 588-9

Railways Clauses Consolidation Act, $574-5$

Railways, early, 465-6; early, construction of, 467-8; different from tramways, 469-70; regarded as accessories to canals and turnpikes, 469-70; roads vs., as to facility of carriage of goods; 472-3; development of locomotive steam engine on, 473-6; Stockton and Darlington, $477 \mathrm{ff}$; anticipated benefits from and reasons for construction of, 485-94, 496-7,

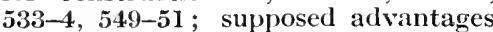
of canals over, $494-5$; opposition to, $497-507,522-4,536-40$, 595; contribution of Thomas Gray to, 507-9; contribution of William James to, 509-10; suggestions as to construction and operation of, 510-13; Liverpool and Manchester, 514-31; railway fever of $1825-6,532-3$, 5\%0; Liverpool and Birmingham, 535-43; London and Birmingham, 54:3-54; Grand Junction, 542; Great Western, 55464; opposed other railways, 561-2; Newcastle and Carlisle, 564; London and Southampton, 561; Hull and Selby, 564-5; Leeds and Selby, 564-5; Manchester and Leeds, 566- $\tilde{7}$; Manchester and Sheflield, 567; Sheffield and Rotherham, 567 n.; Great Northern, 567-8; Eastern Counties, 568-9; Great Fastern, 569; London and Brighton, 569; London and Dover (London and South Eastern), 569 ; mania of $188.5-7,570-1$; system in construction of, reeommended, 571-2; considered at first according to laissez-faire policy, 572; parliamentary opposition to monopoly of, $572 ;$ cssentially monnpolistic, 573-4, $5 \% 6,578$; impossibility of having divided responsibility on same line of, 573 ; as carriers, progressive legislation concerning, 574-7: charges of, how fixed, 574-7; classification of articles carried by, 575; tolls on, .75-7; "Maximum Rates Clause," 576-7 ; competition between different, 577.599 : working agreements formed among. $57 \tau, 640-1$; efforts to maintain competition of, 577-80; amalgamation of, favoured, 578. 579, 580-1; impossibility of having compctition of, 578 ; reasons for consolidation of, $580-1, \quad 586-8$; pooling by, 582; advantages of consolidation of, 583; "railway mania" of 1844-6, 583-6, 640 ; completion of the great systems of, 586-7 ; general amalgamation of, advocated, 588: plan for divisional monopoly of, 588; Clearing House established, 588-9; interchange of traffic, arrangements for, 588-9, 6.42-3; question of gauge, 589 ; benefits resulting from, 589-93, 656; evils accompanying, 593-601 ; unprofitable, reasons for, 601-2; systems of amalgamation of, $602-3$; closely followed the lines of Roman roads, turnpikes and canals, 603; classes of passenger accommodation on, 604; caused decrease of coaching and posting on adjacent highways, 608-9, 616: absorbed most of the passenger traffic, 609-12; helped to inerease debts of turnpike trusts, 612-1, 616-9; their ascendancy over stage coaches, reasons for, 619-23; taxation of, lighter than that of coaches, 619-21; systems of carriage on, 624 ff.; as carriers, reasons for and against, $626-9$; claims of the private carriers on, $62(i-9 ;$ as carriers, decision in favour of, 629-30 ; how the private carriers were driven off the lines of, 630-3; competition, effect on canals, $633 \mathrm{ff}$.; canal revenues declined because of competition by, 634-5, 64.5; use of, reduced amount of capital necessary to conduct business, 635 ; competition, caused deeline of value of canal shares, $6.35-6$; competition, forced the canals to make working agrecments, 636-8: took over canals, 637-8; legislative aid to enable canals to compete with, 638 , was nullified by railway aggression, 639-40; amalgamation of, should be carefully supervised for the public good, 641-3; Railway and Cinal 'Traffic Act, 1854, 64:-3; progress of amalgamation of, with canals, (it:3-1; canals sometimes caused reduetion of freight rates at competitive points on, 645 ; some results of competition of canals with, $645-\tau$; carriers driven off ranals by, 647; aim of, to drive traffic from waterways to the rails, $647-9$; methods they used to take traffic from canals, 647-8; competition of, with the coasting trade, 665

Railway shares, values of, $528-9,58: 3-6$; manipulation of, 59:3-4

Responsibility for bridges, divided, 22

River navigation, 22-8; much used in early days, 22; complaints against obstructions in, 23, 158, 16\%, 176, 378-9; heavy penalties for olsstructions in, 28, 158, 176; efforts to preserve, 24-5; forees tendling to destroy, 25, 160-4, 185, 388-9; ; examples of improvement of, 25 ff.; 
efforts to maintain freedom of the Severn, 26-7, 158-60; explains cheapness of land carriage, 27-8; Exe navigation, 164-5; Lee navigation, 165-8; antagonism to, 167-8; Medway navigation, 169-71; Wye navigation, 171-6; making rivers navigable, 180-5; improvement of, under Cromwell, 182; benefits of making, 183-4; new, opposition to, 184 ; improvement of, chiefly in manufacturing sections, 194; administration of, 194-6; Dee, river, navigation of, $196-200$; Trent, river, navigation of, 200-2; Don, river, navigation of, 202-6; Mersey and Irwell, rivers, navigation of, 355 ; Worsley Brook, navigation of, 355-6; Sankey Brook, navigation of, 355-6; need of increased facilities of, 359-60; improvements of Aire and Calder, 371, 377: improvements of Weaver, 377 ; general improvements of, 377; 'Thames, difficulty of securing improvement of, $378-85$; efforts toward improvement of Severn, 386-7; agitation for iniprovement of Tyne, 387-8; claimed less attention than canals after 1750,388 ; agitation for system in iniprovement of, 393-4; improvement of, expected from canals, 409 , 414; inferiority of, to canals, 415-6; barriers to suceess of, 431-2, 555-6; speed of carriage of goods by, 450-1; opposition of, to railways, 559-61

Rivers, public and private, 157-8

Roads, Roman, 1-4, and their decay, 4; British, 2-3; early English, nature of, 5; obligation for repair of, 4; Act passed to secure safety upon, 5; metlods of repair, by charity, 5, 30, by gilds, 6,3$]$, by voluntary gifts. 6 , 30, by landed proprietors, 7 ; condition of. $8 \mathrm{n} ., 14$; rcasons for their decline before sixteenth century, 14. Later roads, repair of, from corporate and private sources, 30-2, and by individual benevolence, 32 ; how repaired over open-field area, 32-3; Higluway Act of 1555 and its provisions, 33-4; condition during Tudor period, 43, 48-9; legislation for repair of, 1586-1750, $51 \mathrm{ff}$.; repair of, by assessment, 52; liability for repair of, difficult to determine, 53-4; responsibility for, not taken serionsly, 53, 80 ; legislation for, nullified, 54-8, 66-9, 82, 215-7, 237 ff., 245; provision for widening, $60,61,65-6$; establishment of turnpikes, 61 ; bad, reasons for, $66-9,80-84,237-56$; private, $77-8$; after 1745 , attertion to, 80 ; not always along best course, 83-4, 239-40; condition down to 1750, 85-101; in Yorkshire, 88-9, 281-8; between York and London, 89-92, 284-8; in southern counties, 92-3,
295-7; from London to the west, 93-5, 293-4; from London to the north-west, 95-7, 288-93; in eastern counties, 97-8, 298-300 ; near London, 98-100; mechanical construction of, suggestions for improving, 106-7; parish responsibility for, suggested change of, 107-8; improvement of, 136-7; need for greater improvement of, 211-3; benefits of good, 213, 235; greater interest in, after 1750,213 , 227 ; improvement of, many suggestions for, 101-9, 213-6; legislation for, after 1750, 216 ff., 227-33; remedies for improvement of, 256-66, 409 ; improvement of, by road engineers, 266 ff.; improvement of Great North Road, 284-8; general nature of improvement of, 300-2, $335 \mathrm{ff}$; improvement of, as result of canals, 414; improvement of, due to railways, 493-4

Rochciale Canal, construction of, 371, 430; opposed to Manchester and Leeds Railway, 566

Rochester bridge, responsibility for, 22

Royal visits, preparations for, 132-4

Salwerp, river, navigation of, 183

Sankey Brook, navigation of, 355-6

Sedan chairs, introduced, 116-8; cost of, 128

Severn river navigation, history and obstruction of, $26-7$; efforts to maintain the freedom of, $26 \mathrm{f}$., 158-60; later history of improvements of, 386-7

Sewers, Commissions of, purpose and authority of, 24 .

Shareholders, often indifferent as to railway management, 597-8; urged to take active interest in their properties, 598

Sheffield and Rotherham Railway, 56r n.

Sign posts ordered, 66

Smith, Adam, 213, 240, 493

Soar, river, navigation of, 181

Speculation, in canals (1792-3), 394-6 ; in railway shares $(1825-6), 532-3$; in railways $(1835-7), 570-1$; in railways $(1841-6), 583-5$; in railway initiation, 593-5

Staffordshire and Worcestershire Canal, $367-8$

Stage coaches, introluced, 119-21; increased speed of, 121-2, 335-9; opposition to, 12:3-5; attempt to suppress, 122-5; made time schedules to harmonize with packet boats, 125; infraction of the law by, 319; evils of travelling by, $317-20,557$; rate of travelling, 5.57

Stage coach duty, 316

Stage waggons, their importance, 122-3; rate of travelling of, 346-7; cost of carriage by, $347-9$ 
Stainforth and Keadby Canal, authorized, 371

Star Chamber, Court of, decrec of, 159-60

Statute duty, on roads, established, 33 ; penalty for non-fulfilment of, 34 ; became fixed, 35-6; its purpose largely defeated, $49,215,241-2$; dilficultics in its execution, 54-8, 214-6, 241-2; misunderstandings as to amount of, 55-6; evils connceted with, 215-6, 241-2; its abolition urged, 216, 259-60; made morc equitable, 220 ; system was obsoletc, 232 ; abolislıcd, 233, 613

Steam carriage on common roads, efforts to establish, $327-35$; reasons for failure of, 333-5

Steam engine, development of, on railways, 473-6

Stean navigation, its development, $452 \mathrm{ff}$; on the Clyde, 454; in British waters, 4.54-9; rapid progress of, after 1814, 458; little used on canals, 459

Steam packet service, 456-9

Stean vessels, attracted traffic from the roads, 611 , by cheaper fares, 615 , and better travelling facilities, 616 ; competition of, with coaches, 614 ff.

Stephenson, George, 475, 476, 507; appointed engineer of Stockton and Darlington Railway, 479

Stephenson, Robert, 466, 478, 507

Stockton and Darlington Railway, 477 ff.; agitation for, 477-8; difficulty of securing the Act for, 478-9; the question of power to be used on, 480-1, 484-5; success of, 481, 514, 589; organization of the carrying trade on, 481-3; method of operation of, $482-4$

Stopping up roads, 221, 275

Stour, river, navigation of, 183

Straightening of roads, 275

Strcets, of mediaeval towns, how maintained, 9-14; in many cases bad, 12; paving Acts evaded, 12-13 ; establishment of paviours, 13; condition of, in Tudor times, 36-7; liability for repair of, $37-40$; specially cleaned before a royal visit, $39:$ special methods of repairing, 40; obstructions in, 40-2, 101-4; unsanitary condition of, 42-3, 98-9, 102; nature of, as highways, 101-4; of towns and cities, 1750-1830, condition of, 302-3

Stroudwater Canal, benefits of, 373; connexion of, with Thames and Severn Canal, 374

Subscription lists, fraud in compiling, 594

Summers, connexion of, with steam carriage, 330

Surrey Iron Railway, 465-6, 472

Surveyor-gcneral, need of, 215 ; alppointment of, recommended, 256-7
Surveyors, for roads, appointed, 33 ; duties of, $33-4,51-2,59,64$; given increased powers, 34,60 ; ncglectful of duty, 54-5, 64, 67, 82-3, 214-5, $237-9,256$; authorized to levy assessments, 60; changed inctlod of appointing, 64; increased penalty for negligence of, 64; dilficulties of, 67 , 238-9; bad metlod of appointment, 237-9; recommended qualified and paid surveyors, 256-7

Symington, William, and steam navigation, 453-4

Tatham, William, wanted small eanals and inclined planes, 391

Taylor, James, conncxion of, with steam navigation, 453

Taylor, John, the IVater Poct, 114, 121

Telford, Thomas, work of, as road cngineer, 268-76; comparison of his and Macadam's methods of road construction, 278 ; opposition of, to railways, 507

Thames, river, navigation of, 176-80; navigation of, obstructions to, 176-7, 179-80; exactions of lock and weir owners on, 178 ; later history of, 37885; opposition of Commissioners of, to railway, 560-1

Thames and Severn Canal, construction of, 373-5

Tide, influence of, upon river navigation, 26,163

Toll-gates, opposition to, 65 ; farming of, 71,227 ; destruction of, 71-3; additional tolls at, 73; much fraud in administration of, 260-1 ; more equitable method recomniended, 261 ; annoyance from multiplication of, 321 , 341

Tolls, murage, 9 ; pontage, 10, 18-21 ; pavage, 10; traverse, passage or through, 11; on Great Nortlı Road, agitation for reduction of, 92 ; heavy expense of, 316 ; bar and compensation, 652-3

Towns, streets of, condition in Tudor times, 36-7; opposition of, to railways, 502-3, 560

Trade, extension of, over wider areas in sixteenth century, 43-4

Tralfic, freight and passenger, increased by railways, $590 \mathrm{ff}$. See also Carriage of goods

Trains, number of, too great, 599

Tramroad, see Tramway

Tramway, early use of, 461; development in construction of early, $463 \mathrm{ff}$.; method of constructing, $467-8$; different from present-day railways, $469-70$; location of, $470-2$

Travelling, early, 5; mostly on foot or horseback, 8, $9 \mathrm{n.}$; speed of. 9; during Tudor jeriod, 45-8; rate of, during Tudor period, 50-1 ; aided 
by sign posts, 66; on Great North Koad, rate of, 89-92; in eastern counties, rate of , 97-8; from Oxford to London, rate of, 100: general conditions of, in seventeenth and eighteentl centuries, $109 \mathrm{ff}$.; rate of, 1600-1750, 134-8; cost of, 1600-1750, 138-9, 605; inereased amount of, 1750-1830, 310-2; intense competition in coaching after $1750,312-3$; coaching schedules harmonized with those of other conveyances, 313-5; increased rate of, 1750-1830, 335-9; ; cost of, 1750-1830, 340-6; increased speed of, by railway, $487-9,53 t-5$, 590 ; inconveniences of, by railway, 580-1; increase of, due to railways, $590-1$; cost of, on railways, compared with canals and roads, 605-8; decrease of, on turnpikes, due to railways, 612-3

Trent, river, navigation of, 200-2 ; reasons for improvement of, 201 ; opposition to improvement of, 201

Trent and Mersey Canal, first contemplated, 357; asitation for, 364-5; construction of, 366 ; benefits from, 366-7 ; consolidation of, with Coventry and Oxford Canals, 372; effect of, in redueing cost of carriage, $\mathbf{1 4 6}$

Trevithick, Richard, experiments of, with steam carriages, 328-30, and steam engine on railway, 475-6

Trinoda necessitas, 4, 21

Turnpike Aet, General, provisions of, 218, 223-7

Turnjikes, first legislation for, 61, how received, 63; establislied first on great roads, 65; Acts, expense of securing, 65, 236-7; trustces established, 70 ; administration of, by trustees, 70-1; piecemeal administration of, $70-1,242$; opposition to, 80; put under Sessional control, 223; trusts, eonsolidation of, 227 ; trustees of, opposed canal construction, 397-8, 403 , and railway construetion, 502, $5.51,562 ;$ proposed construction of railways at sides of, 511-3

Turnpike trusts, consolidation of, 227, 257-9; finances of, 281, 240-1; deeply in debt, 231, 241, 257-9; remedies to improve finances of, 257-9; gradual reduction in number of, 261 ; metropolitan, consolidation of, 280-3; general consolidation of, recommended, 283 ; debt of, increased by railway competition, $616-9$

Tyne, river, navigation of, 387-8
Undertakers of navigations, their duties and authority, 194-6

Vested interests, opposition of, to canal construction, 398-401; canals used plea of, in opposing railways, 495-6; opposition of, to railways, $504,506,560$

Warwick and Napton Canal, construction of, 370

Watermen, Thames, complaints against coaches by, 113; high charges of, 160

Water Poet, the, John Taylor, 114, 121, 185

Weaver, river, proposed improvement of the navigation of, 183; improvements in navigation of, 377

Weighing engines (or machines), established, 73 ; additional tolls taken at, $73,74-5,223$; evils of, 73 n.-75, 223-1, 230, 249-50; abolition of, recommended, 263-4; abolition of, 232

Weirs in rivers, advantages of, $23 \mathbf{n}$.

Wey, river, navigation of, 181-2

Wheels, narrow, restriction of, 68-9, 229 ; bore heavier burden of tolls, $76-7,217$; evils of, $84,214,244$; opposition to, 261-3

Wheels, wide, provided for, 60; not compulsory, 61; made compulsory, 75 ; complaint against demand for, 76 ; use of, encouraged, $76-7,261-2$; desirability of, for road maintenance, 214,217 ; legislative encouragement of , 217, 219, 224-6; evils of carrying heavy weights on, 245-7

Wheels, cylindrical and conical, investigation of, 227; evils of bad construction of, $247-9$; cylindrical, recommended adoption of, 262

Whirlicotes, 109

Winchester, Statute of, 5

Wood, Nicholas, connexion of, with railways, $466,467,507$

Working agreements, various forms of, 636-7. See also Consolidation of railways and Amalgamation

Worsley Brook, navigation of, 355-6

Wye, river, navigation of, $171-6,183$

Yarmouth, to Norwich, navigation from, 25; connexion of, with London, 97-8

Yarranton, Andrew, urged great development of interior waterways and cutting canals, 189,373 ; aided in improving Dee navigation, 197

York to London, condition of roads from, 89-92

Yorkshire, roads in, condition of, $87-9$ 
This book is DUE on the last

date stamped below

WHEPRET

LUS 


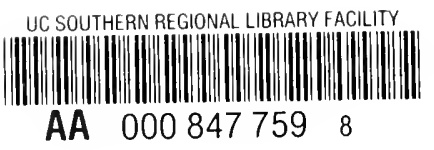




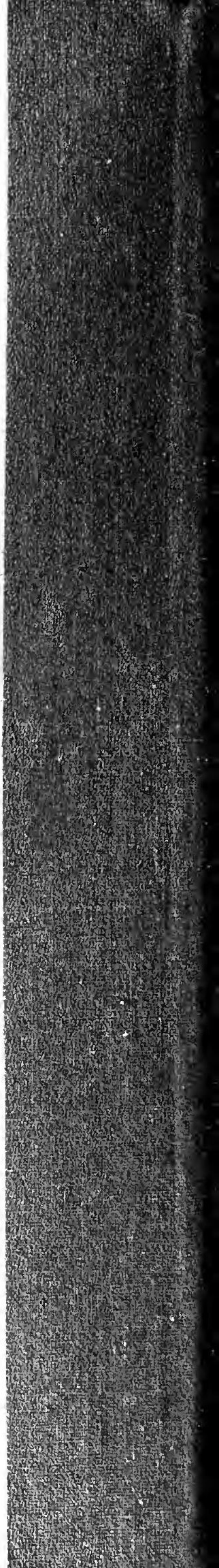

